\title{
UICN
}

\section{Estado das áreas \\ protegidas e de conservação na África Oriental e Austral}

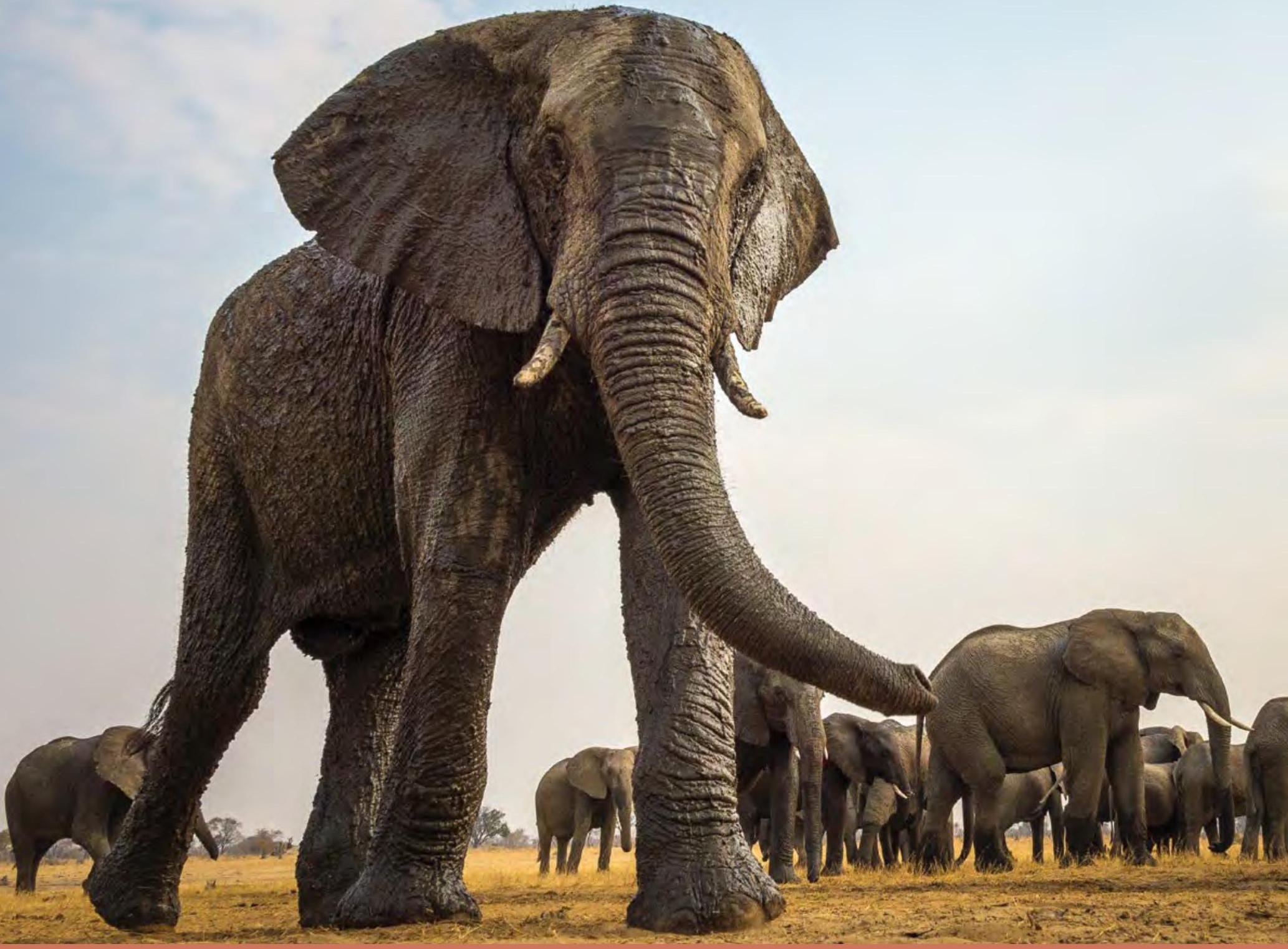

RELATÓRIOS SOBRE O ESTADO DAS ÁREAS PROTEGIDAS E DE CONSERVAÇÃO SÉRIE N 1

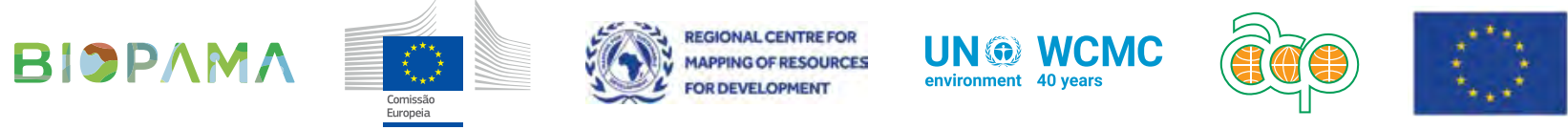





\section{Estado das áreas}

protegidas e de conservação na África Oriental e Austral 
A designação de entidades geográficas neste livro, e a apresentação do material, não implicam a expressão de qualquer opinião por parte da UICN ou outras organizações participantes relativamente ao estatuto legal de qualquer país, território ou área, ou das suas autoridades, ou relativamente à delimitação das suas fronteiras ou limites.

As opiniões expressas nas presentes directrizes não reflectem necessariamente as da UICN ou de outras organizações participantes.

A UICN tem o prazer de reconhecer o apoio dos seus parceiros-quadro que fornecem o financiamento de base: Ministério dos Negócios Estrangeiros da Dinamarca; Ministério dos Negócios Estrangeiros da Finlândia; Governo de França e Agência Francesa de Desenvolvimento (AFD); Ministério do Ambiente, República da Coreia; Agência Norueguesa de Cooperação para o Desenvolvimento (Norad); Agência Sueca de Cooperação Internacional para o Desenvolvimento (Sida); Agência Suíça para o Desenvolvimento e Cooperação (SDC); e o Departamento de Estado dos Estados Unidos.

O conteúdo desta publicação é da exclusiva responsabilidade dos seus autores e não pode, de forma alguma, ser considerado como reflectindo a opinião da União Europeia nem do Grupo de Estados ACP.

Esta publicação foi produzida com o apoio do $11^{\circ}$ Fundo Europeu de Desenvolvimento.

A UICN afirma não possuir qualquer responsabilidade por erros ou omissões que possam ocorrer nesta tradução ou em desvios relativos à versão no idioma original da publicação. No caso de discrepâncias, por favor consulte a edição original. Título da publicação original: The state of protected and conserved areas in Eastern and Southern Africa. State of Protected and Conserved Areas Report Series No. 1. (2020). Nairobi, Quénia: UICN ESARO. DOI: https://doi.org/10.2305/IUCN.CH.2020.15.en

Publicado por: $\quad$ UICN, Escritório Regional para a África Oriental e Austral, através do Programa BIOPAMA

Direitos de Autor: @ 2020 UICN, União Internacional para a Conservação da Natureza e Recursos Naturais (C) 2021 UICN, União Internacional para a Conservação da Natureza e Recursos Naturais, para a tradução em português. A reprodução desta publicação para fins educativos ou outros fins não comerciais é autorizada sem autorização prévia por escrito do detentor dos direitos de autor, desde que a fonte seja plenamente reconhecida. A reprodução desta publicação para fins de revenda ou outros fins comerciais é proibida sem autorização prévia por escrito do detentor dos direitos de autor.

Citação: $\quad$ UICN ESARO (2021). Estado das áreas protegidas e de conservação na África Oriental e Austral. Relatórios sobre o estado das áreas protegidas e de conservação série $n^{\circ} 1$. Nairobi, Quénia: UICN ESARO.

ISBN: $\quad 978-2-8317-2137-8$ (PDF)

978-2-8317-2138-5 (impresso)

DOI:

https://doi.org/10.2305/IUCN.CH.2020.15.pt

Foto da capa: $\quad$ Elefantes, Parque Nacional de Hwange, Zimbabué. @ Wilderness Safaris

Foto do verso: Reserva Natural lle aux Aigrettes, Maurícias. @ G Gina Bonne IOC

Layout por: Mary-Anne van der Byl

Traduzido por: DMME Translation Services

Produção do

layout português: Jimena M. Vila

Impresso por: Minuteman Press

Disponível em: UICN África do Sul

333 Grosvenor Street

Hatfield Gardens, Block A

Pretória, África do Sul

+27 (0)12 342 8304/6

info.esaro@iucn.org

https://www.biopama.org/

www.iucn.org/resources/publications

O texto deste livro é impresso em papel feito de fibra de madeira proveniente de florestas bem geridas e certificadas em conformidade com as regras do Forest Stewardship Council (FSC). 
UICN

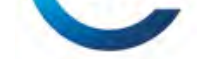

\section{BIOPAMA}

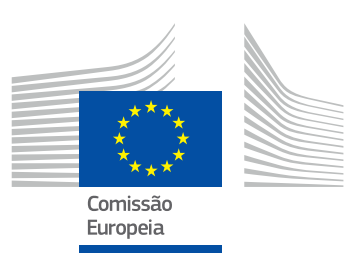

REGIONAL CENTRE FOR MAPPING OFRESOURCES FORDEVELOPMENT
União Internacional para a Conservação da Natureza (UICN)

A UICN é uma União de membros composta tanto pelo governo como por organizações da sociedade civil. Aproveita a experiência, os recursos e o alcance das suas [mais de] 1,400 organizações membros e a contribuição de mais de 18,000 peritos. A UICN é a autoridade mundial sobre o estatuto do mundo natural e as medidas necessárias para o salvaguardar. www.iucn.org

\section{Gestão de Biodiversidade e Áreas Protegidas}

O programa Gestão de Biodiversidade e Áreas Protegidas (BIOPAMA) visa melhorar a conservação a longo prazo e a utilização sustentável dos recursos naturais nos países de África, Caraíbas e Pacífico (ACP), em áreas protegidas e comunidades circundantes. É uma iniciativa do Grupo de Estados ACP financiada pelo $11^{\circ}$ Fundo Europeu de Desenvolvimento (FED) da União Europeia, implementado conjuntamente pela União Internacional para a Conservação da Natureza (UICN) e pelo Centro Comum de Investigação da Comissão Europeia (JRC). Com base nos primeiros cinco anos de actividades financiadas pelo $10^{\circ} \mathrm{FED}$, a segunda fase do BIOPAMA fornece ferramentas para a gestão de dados e informação, serviços para melhorar os conhecimentos e a capacidade de planeamento e tomada de decisões sobre áreas protegidas, e oportunidades de financiamento para acções específicas baseadas em sítios.

www.biopama.org

\section{Centro Comum de Investigação e a Comissão Europeia}

A Comissão Europeia (EC) é o órgão executivo da União Europeia (UE), que é o maior doador mundial de ajuda oficial ao desenvolvimento. Como serviço científico interno da EC, o Centro Comum de Investigação (JRC) fornece às políticas da UE apoio científico e técnico independente e baseado em provas, incluindo políticas e programas ao nível global e especificamente os que se concentram no Grupo de Estados de África, Caraíbas e Pacífico (ACP).

www.ec.europa.eu/jrc/en

\section{Centro Regional de Cartografia de Recursos para o Desenvolvimento}

O Centro Regional de Cartografia de Recursos para o Desenvolvimento (RCMRD) é uma organização intergovernamental composta actualmente por 20 Estados Membros da África Oriental e Austral, tendo sido criada em 1975 pela União Africana (AU) e pela Comissão Económica das Nações Unidas para África. O RCMRD promove o desenvolvimento sustentável através da Geração, Aplicação e Divulgação de Geo-informação e Tecnologias Aliadas entre os seus Estados Membros e partes interessadas. O nosso mandato é executado através de áreas temáticas tais como Gestão de Recursos Naturais; Gestão Ambiental; Acção Climática; Segurança Alimentar e Agricultura Sustentável; Gestão do Conhecimento e Desenvolvimento de Capacidades; Gestão de Terras; e Desenvolvimento Urbano.

www.rcmrd.org

\section{UN WCMC environment 40 years}

\section{Centro Mundial de Monitorização da Conservação do Ambiente da ONU}

O Centro de Monitorização da Conservação Mundial do Programa das Nações Unidas para o Ambiente (UNEP-WCMC) é um centro global de excelência em biodiversidade. O Centro funciona como uma colaboração entre o Programa das Nações Unidas para o Ambiente e a instituição de caridade WCMC registada no Reino Unido. Juntos estamos a enfrentar a crise global que a natureza enfrenta. www.unep-wcmc.org

\section{Organização dos Estados de África, Caraíbas e Pacífico}

A Organização dos Estados de África, Caraíbas e Pacífico (OACPS), anteriormente conhecida como o Grupo de Estados ACP, é uma organização criada pelo Acordo original de Georgetown em 1975, e subsequentemente revista em 2019. Os principais objectivos da OACPS centram-se no desenvolvimento sustentável dos seus membros e na sua integração gradual na economia global; coordenação das actividades da OACPS no quadro da implementação do Acordo de Parceria existente com a União Europeia; consolidação da unidade e solidariedade entre os membros da OACPS; e estabelecimento e reforço da paz, segurança e estabilidade em sociedades livres e democráticas.

www.acp.int 


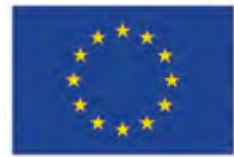

União Europeia

Os Estados Membros da União Europeia decidiram ligar o seu know-how, os seus recursos e os seus destinos. Juntos, construíram uma zona de estabilidade, democracia e desenvolvimento sustentável, mantendo simultaneamente a diversidade cultural, a tolerância e as liberdades individuais. A União Europeia está empenhada em partilhar as suas realizações e os seus valores com países e povos para além das suas fronteiras.

www.europa.eu

Esta publicação foi produzida com o apoio do $11^{\circ} \mathrm{FED}$. O conteúdo desta publicação é da exclusiva responsabilidade dos seus autores e não pode, de forma alguma, ser considerado como reflectindo a opinião da União Europeia ou do Grupo de Estados ACP.

\section{As Comunidades Económicas Regionais da África Oriental e Austral (RECs)}
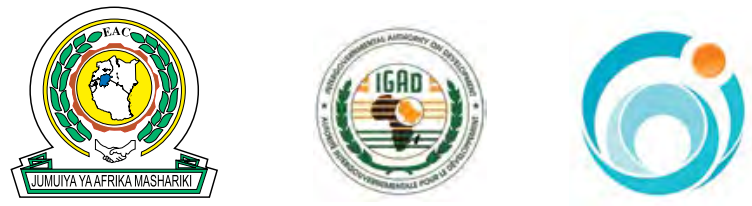

INDIAN OCEAN

COMMISSION

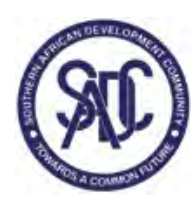

\section{Países representados no presente relatório}

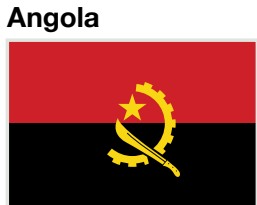

Etiópia

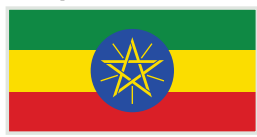

Quénia
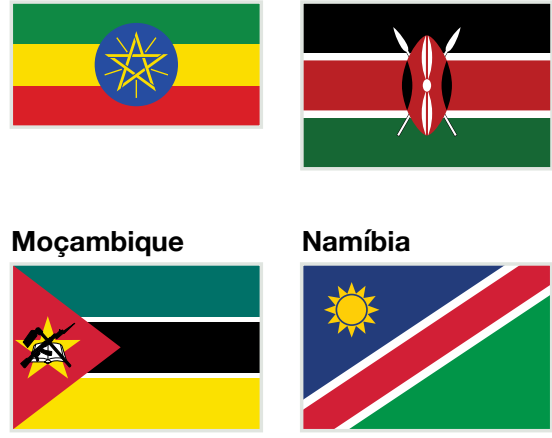

Sudão do Sul
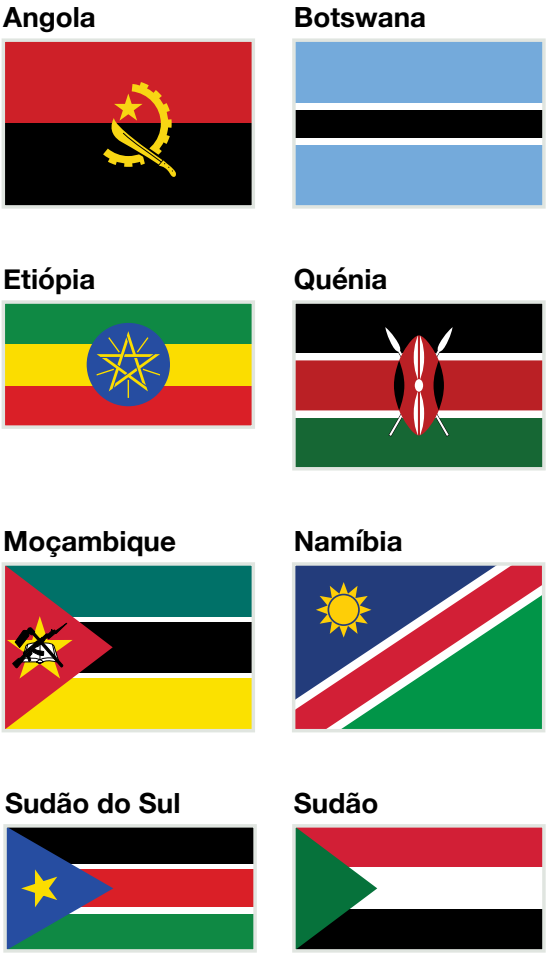
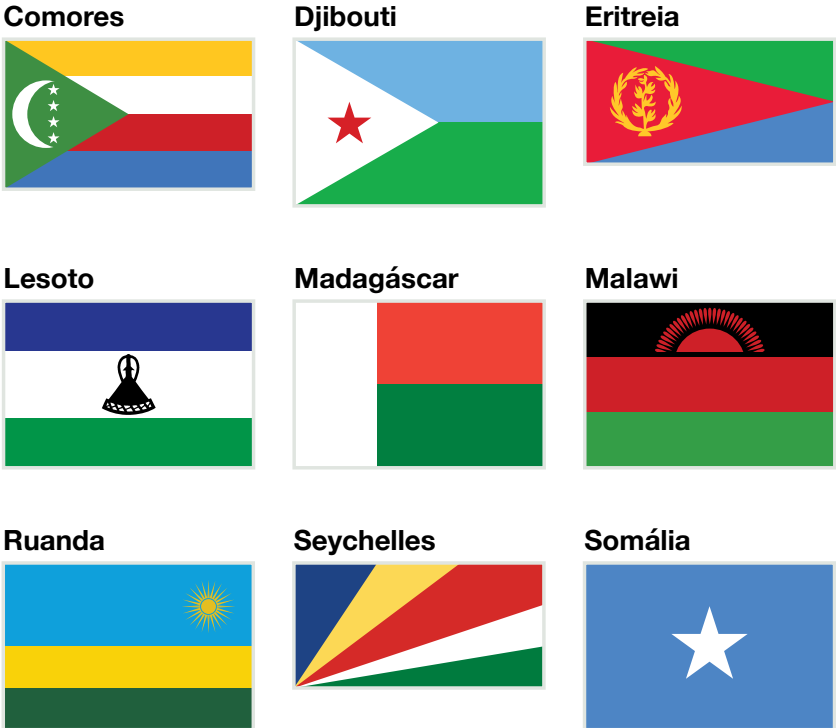

Eswatini
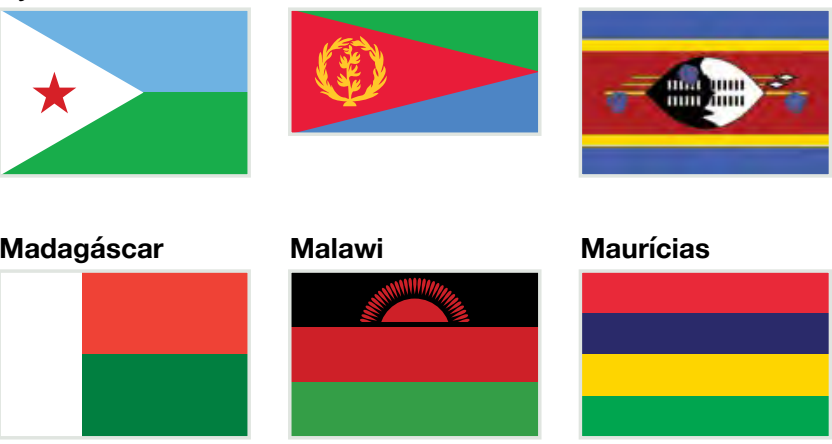

Maurícias

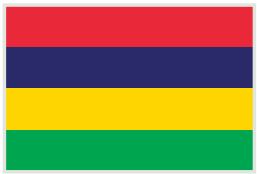

Somália
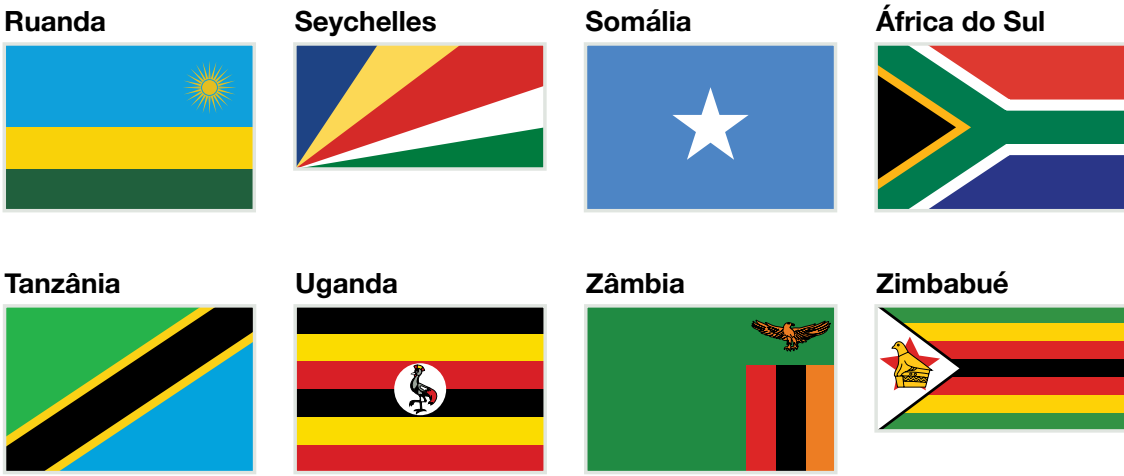

Zimbabué

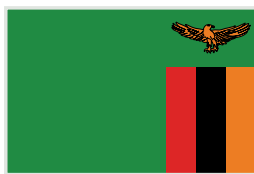

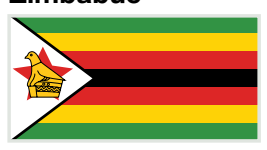




\section{Índice}

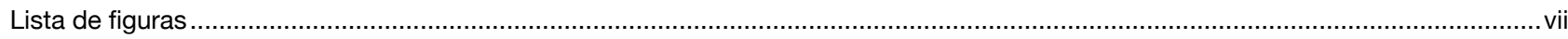

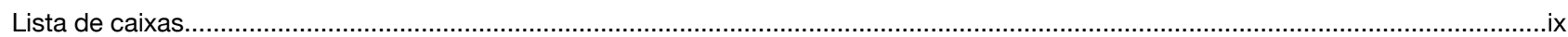

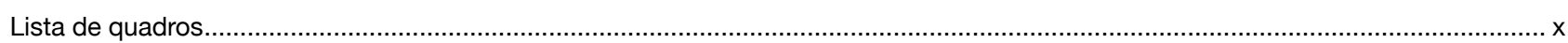

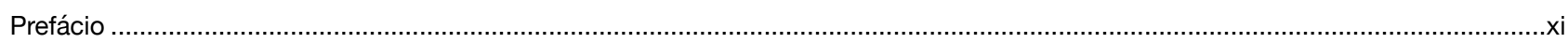

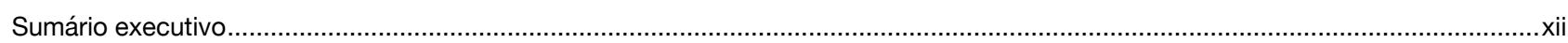

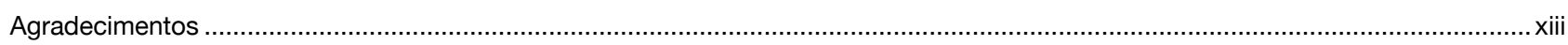

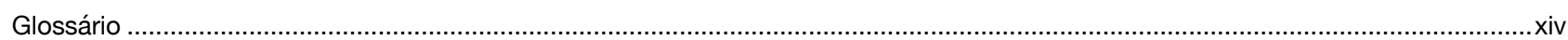

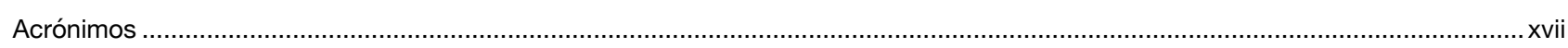

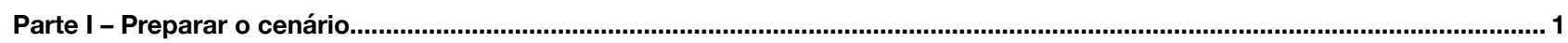

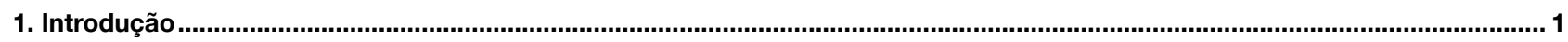

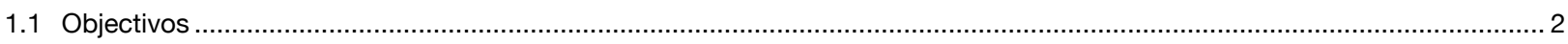

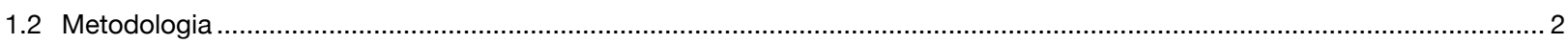

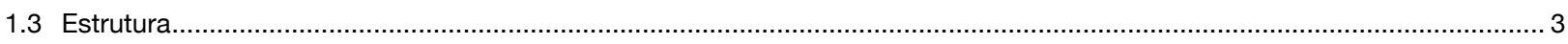

2. Quadro conceptual e internacional .....................................................................................................................................

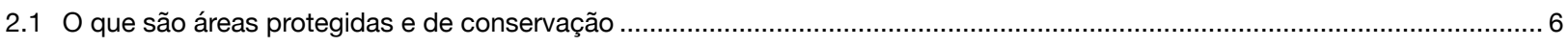

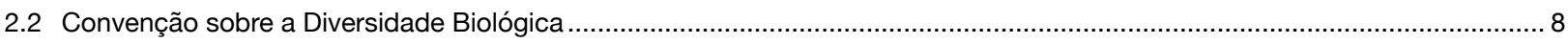

2.3 Outras medidas de conservação eficazes baseadas na área (OECMs) ....................................................................... 8

2.4 A Lista Verde de Áreas Protegidas e de Conservação da UICN....................................................................................... 8

2.5 Designações internacionais para as áreas protegidas e de conservação...................................................................... 11

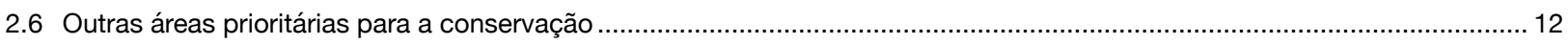

2.7 Monitorização das áreas protegidas e de conservação - Uma visão geral ................................................................ 12

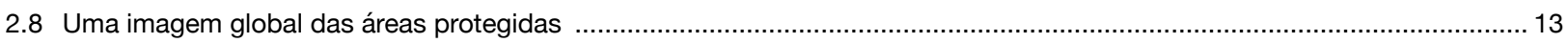

Parte II - Contexto regional, dados e perfis dos países ............................................................................................................ 17

3. Visão geral da região................................................................................................................................................................................ 17

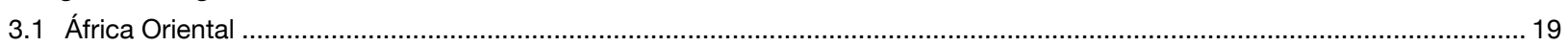

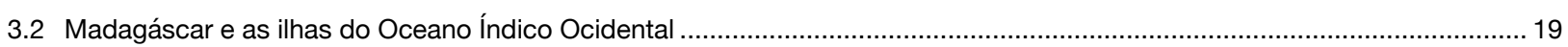

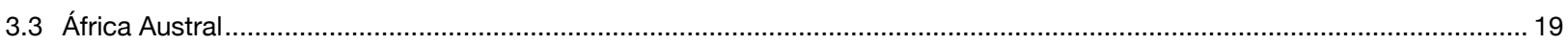

4. Áreas protegidas e de conservação na África Oriental e Austral.................................................................................................. 21

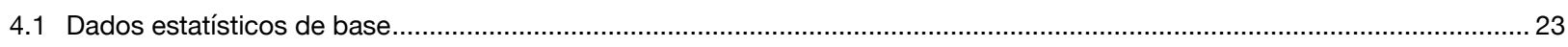

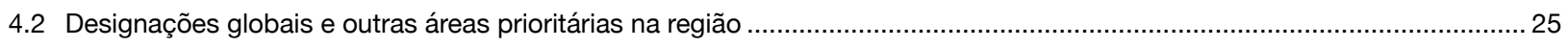

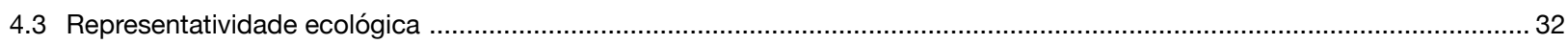

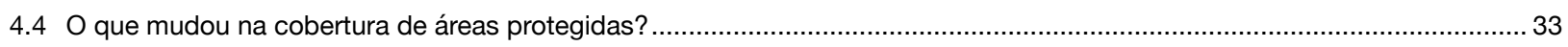

4.5 Áreas transfronteiriças protegidas e de conservação........................................................................................... 35

5. Serviços de ecossistema das áreas protegidas na África Oriental e Austral................................................................................ 43

6. Políticas regionais e quadros relevantes relacionados com a conservação da biodiversidade e gestão das áreas protegidas . 47

7. Comunidades Económicas Regionais.................................................................................................................................... 51

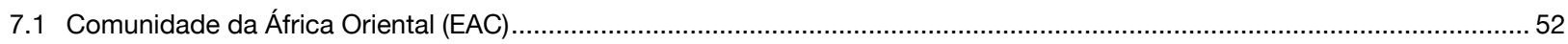

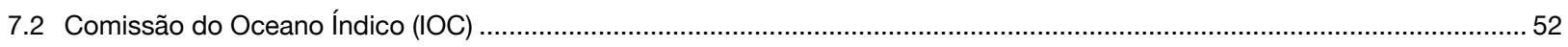

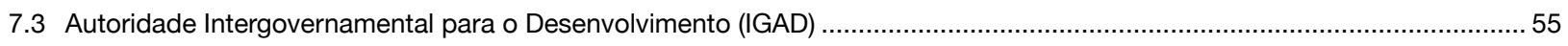

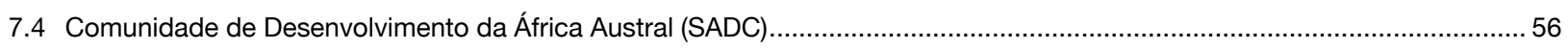

8. Perfis dos países ................................................................................................................................................................

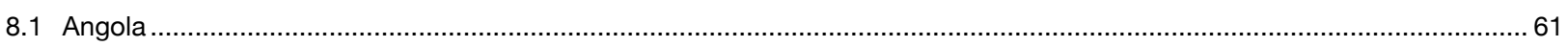

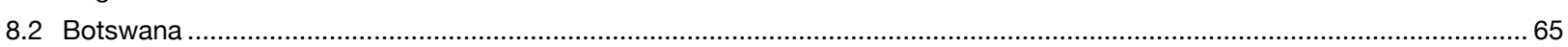

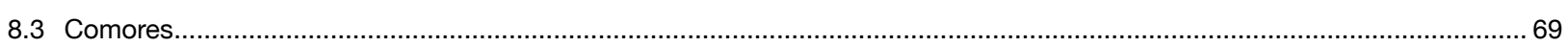

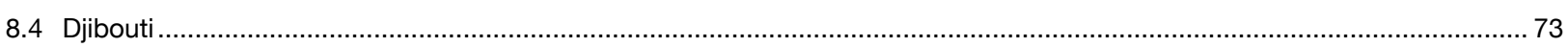

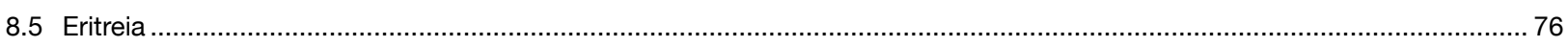

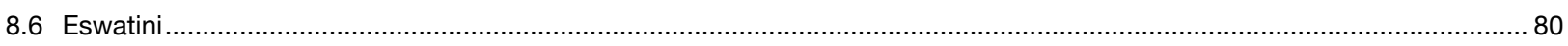

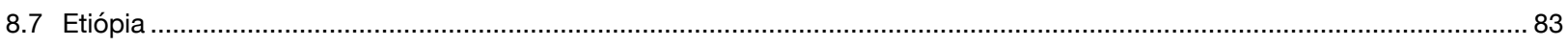

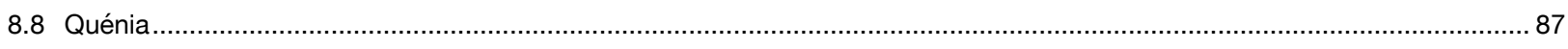

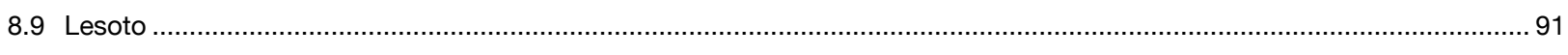

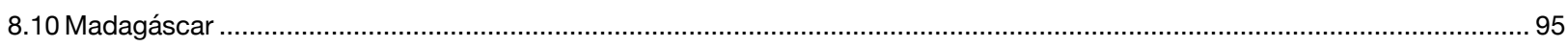




\section{Índice (continuação)}

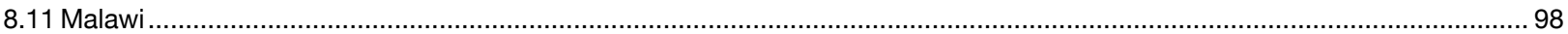

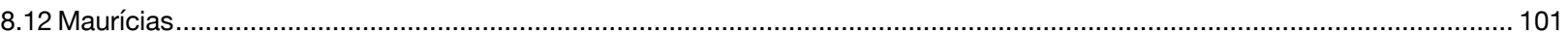

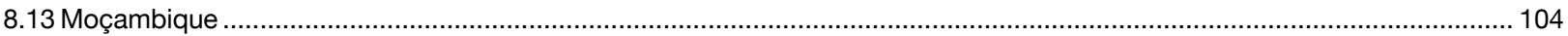

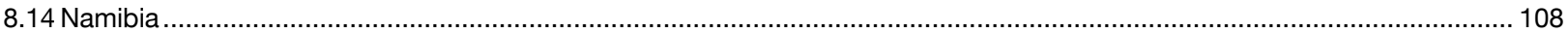

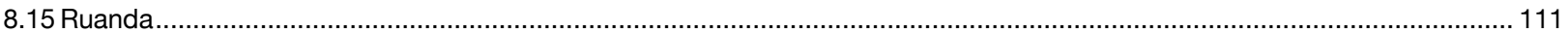

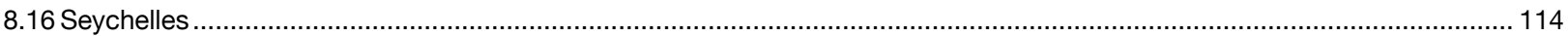

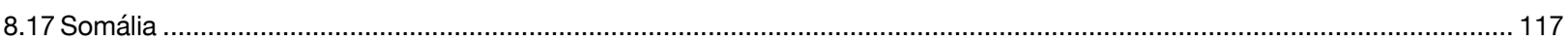

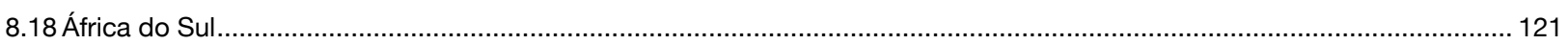

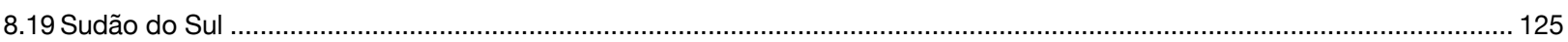

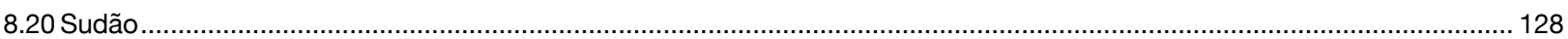

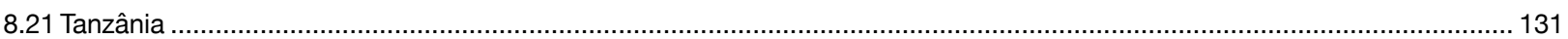

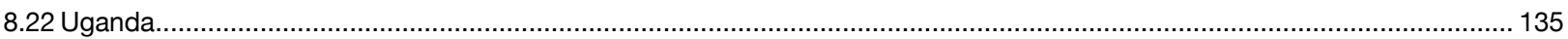

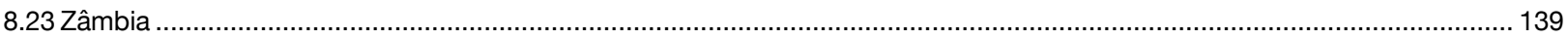

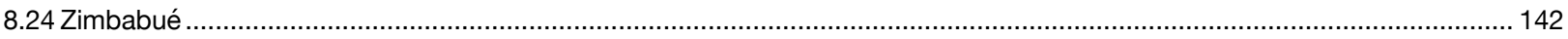

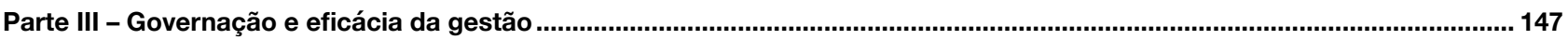

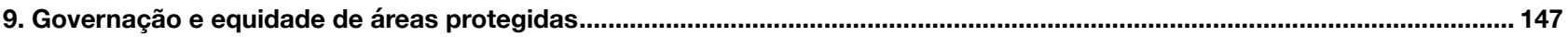

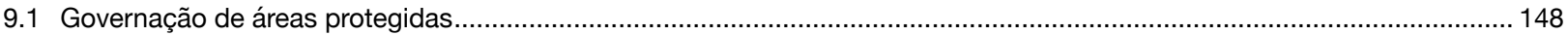

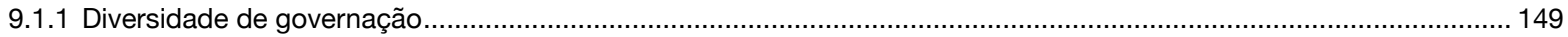

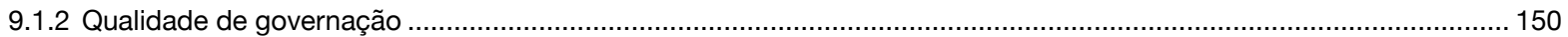

9.2 Boa governação e a Lista Verde das Áreas Protegidas e de Conservação da UICN..................................................... 152

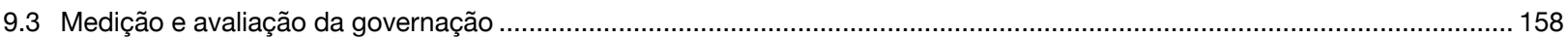

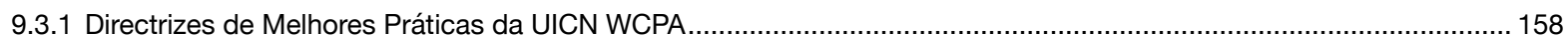

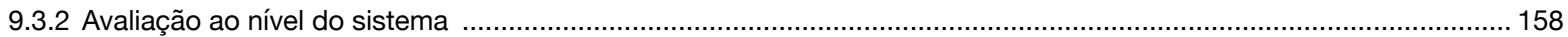

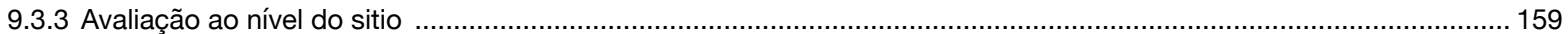

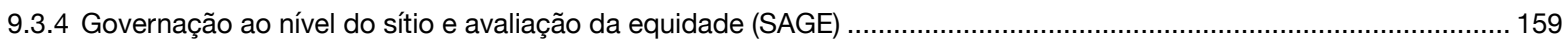

9.3.5 Avaliação da Governação das Áreas Protegidas e de Conservação (GAPA)............................................................... 159

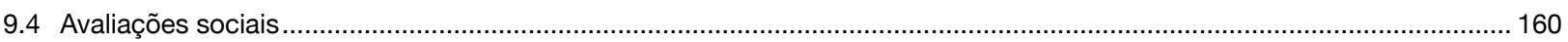

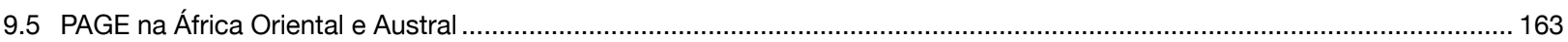

9.5.1 Avaliações da governação na África Oriental e Austral...................................................................................... 163

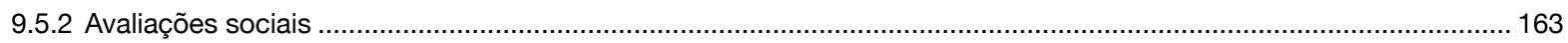

9.6 Resultados das avaliações sociais e de governação na África Oriental e Austral ............................................................. 163

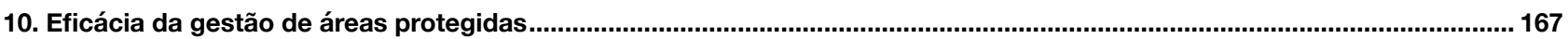

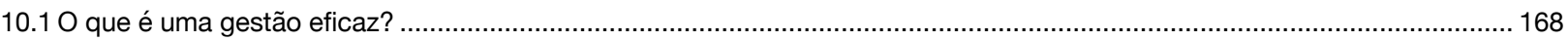

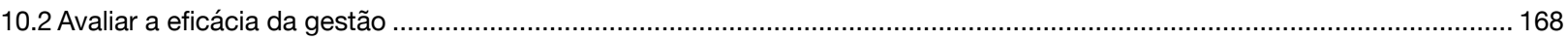

10.3 Compromissos internacionais para a avaliação da eficácia da gestão

10.4 Base de dados global sobre a eficácia da gestão de áreas protegidas (GD-PAME) ......................................................169

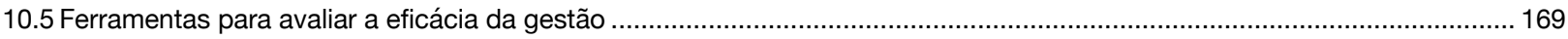

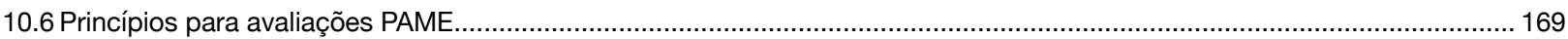

10.7 Integrar a eficácia da gestão com a governação e as avaliações sociais ................................................................... 170

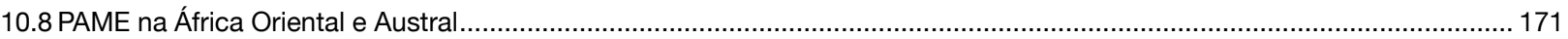

10.8.1 Inventário das avaliações PAME na África Oriental e Austral ............................................................................ 171

10.8.2 Inventário das avaliações combinadas na África Oriental e Austral ............................................................................ 174

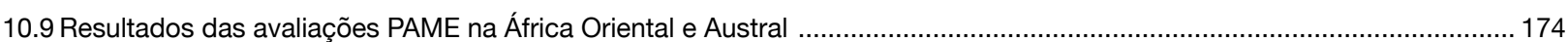

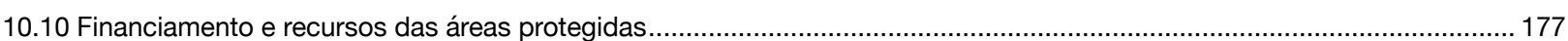

10.10.1 A lacuna de financiamento na África Oriental e Austral .................................................................................... 178

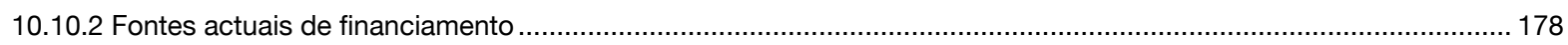

10.10.3 Fontes de financiamento novas e emergentes para as áreas protegidas ......................................................... 183

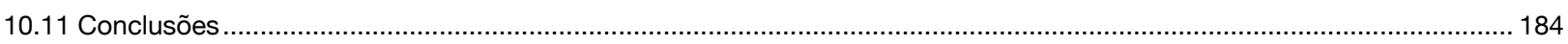

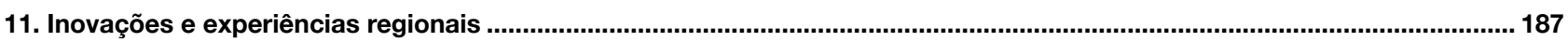

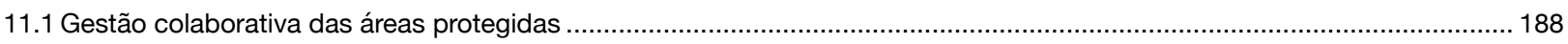

11.2 Construção de capacidade para as áreas protegidas e de conservação ..................................................................... 190 


\section{Índice (continuação)}

11.30 papel da tecnologia na gestão de áreas protegidas .............................................................................................. 190

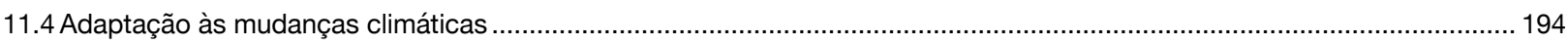

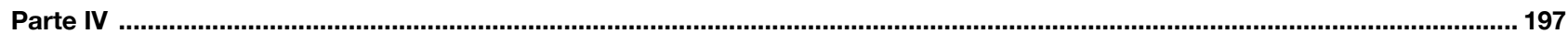

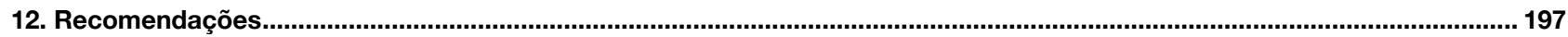

12.1 Aumentar o financiamento sustentável e o apoio político das áreas protegidas e de conservação........................................ 198

12.2 Aumentar as capacidades de gestão das áreas protegidas e de conservação ...................................................................198

12.3 Diversificar a governação das áreas protegidas e reconhecer iniciativas eficazes de governação local,

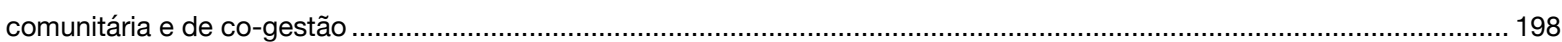

12.4 Abordar as lacunas na cobertura de ecossistemas marinhos e terrestres em áreas protegidas e de conservação ............... 198

12.5 Melhorar a colaboração além fronteiras e sectores para responder às ameaças existentes e emergentes........................... 199

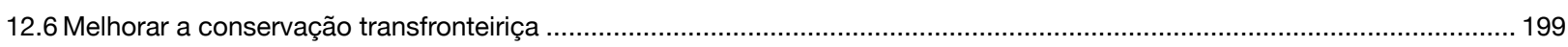

12.7 Melhorar a cobertura das avaliações da eficácia da gestão, governação e equidade ........................................................ 199

12.8 Aumentar a frequência e a abrangência dos relatórios à Base de Dados Mundial de Áreas Protegidas .............................. 199

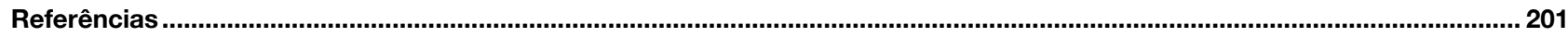

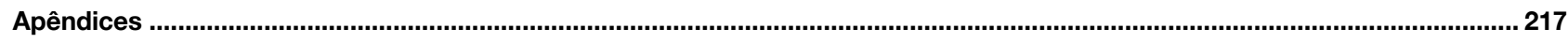

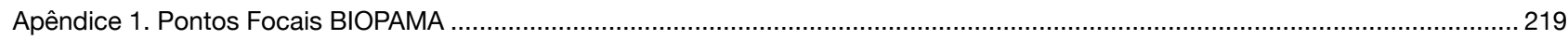

Apêndice 2. Estatísticas regionais sobre áreas protegidas e de conservação na África Oriental e Austral ........................................ 220

A2-Quadro 1. Áreas terrestres protegidas e de conservação na África Oriental e Austral ......................................................220

A2-Quadro 2. Áreas costeiras e marinhas protegidas e de conservação na África Oriental e Austral ....................................... 221

A2-Quadro 3. Categorias de gestão da UICN de áreas protegidas e de conservação na África Oriental e Austral ...................... 221

A2-Quadro 4. Tipos de governação da UICN de áreas protegidas e de conservação na África Oriental e Austral...................... 222

Apêndice 3. Sítios globais de importância na África Oriental e Austral .............................................................................................. 222

A3-Quadro 1. Sítios de Ramsar na África Oriental e Austral.............................................................................................. 222

A3-Quadro 2. Reservas Humanas e da Biosfera na África Oriental e Austral e da Biosfera na África Oriental e Austral ............... 226

Apêndice 4. Representatividade ecológica na África Oriental e Austral .....................................................................................227

A4-Quadro 1. Representatividade ecológica nas áreas protegidas da África Oriental e Austral...................................................227

A4-Quadro 2. Níveis de protecção das ecorregiões marinhas e das províncias pelágicas representadas na região ..................... 2227

Apêndice 5. Instrumentos legais de apoio à equidade e governação não estatal de áreas protegidas..................................................228

Apêndice 6. Áreas protegidas e de conservação nas Categorias de Gestão da UICN por país........................................................2230

Apêndice 7. Áreas protegidas e de conservação nos Tipos de governação da UICN por país ......................................................... 236

\section{Lista de figuras}

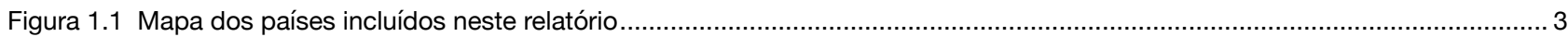

Figura 2.1 Sistemas de gestão de dados globais e regionais para áreas protegidas ..................................................................... 13

Figura 4.1 Áreas protegidas e de conservação na África Oriental e Austral ..................................................................................... 22

Figura 4.2 Cobertura de áreas protegidas terrestres na África Oriental e Austral ................................................................................2 23

Figura 4.3 Áreas costeiras e marinhas protegidas e de conservação na África Oriental e Austral....................................................... 24

Figura 4.4 Categorias de gestão das áreas protegidas e de conservação da UICN na África Oriental e Austral ..................................24

Figura 4.5 Tipos de governação da UICN de áreas protegidas e de conservação na África Oriental e Austral ..................................24

Figura 4.6 Níveis de protecção para as ecorregiões terrestres representadas na região ........................................................... 33

Figura 4.7 Níveis de protecção das ecorregiões marinhas e das províncias pelágicas representadas na região................................... 33

Figura 4.9 Número de registos de áreas protegidas na WDPA de 1998 a 2019 ...................................................................... 34

Figura 4.10 Áreas de Conservação Transfronteiriças da Comunidade de Desenvolvimento da África Austral (SADC TFCAS)...............36

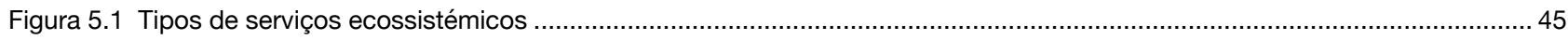

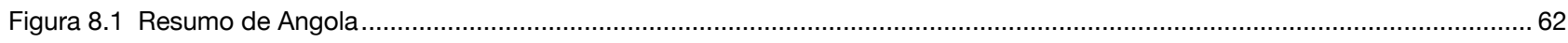

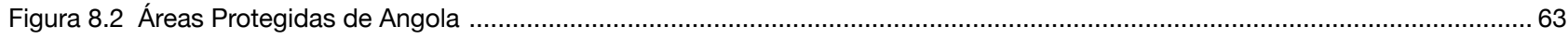

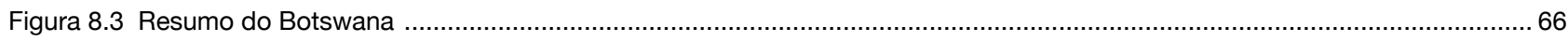

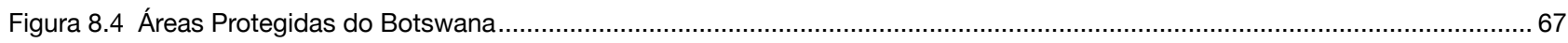




\section{Lista de figuras (continuação)}

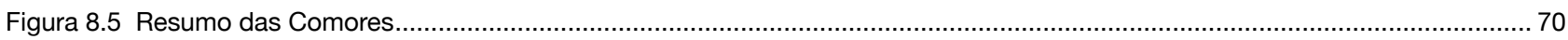

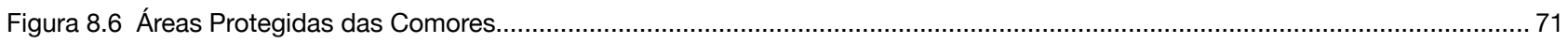

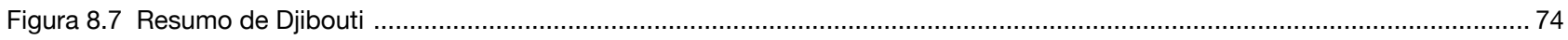

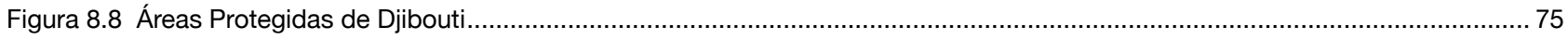

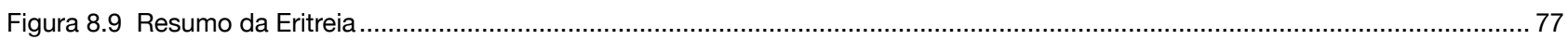

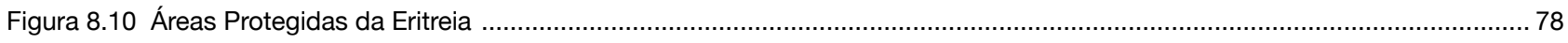

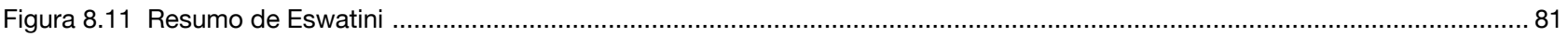

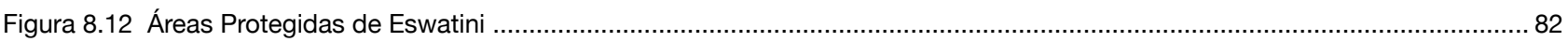

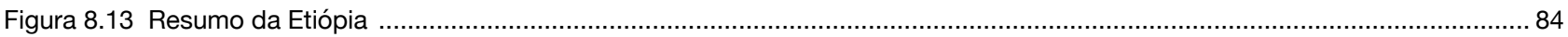

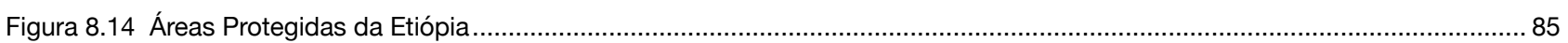

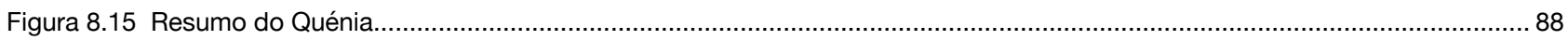

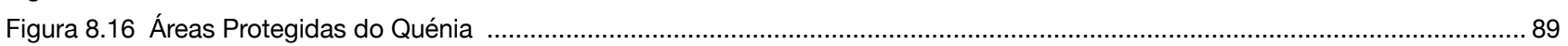

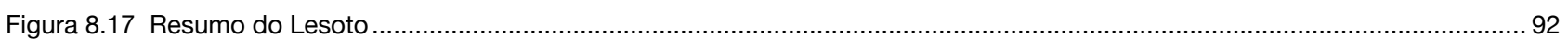

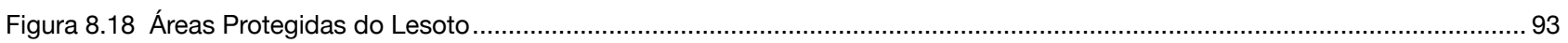

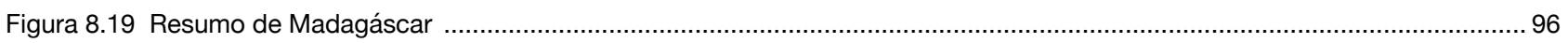

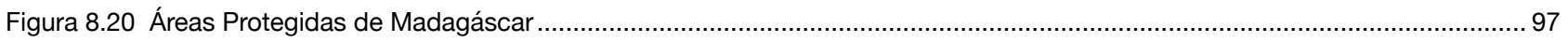

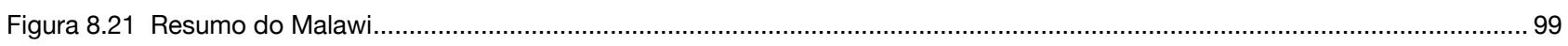

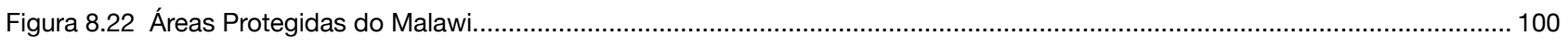

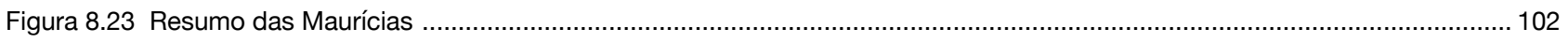

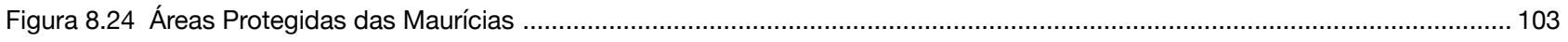

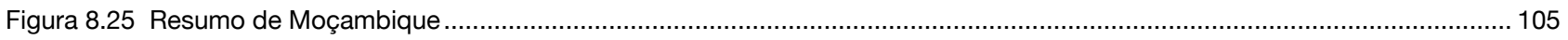

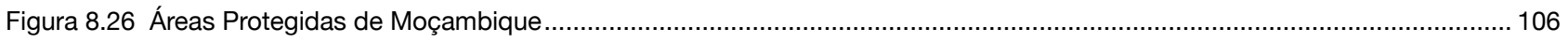

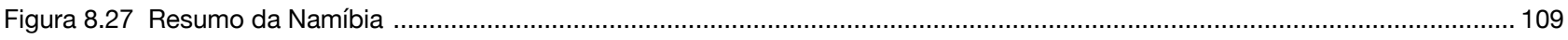

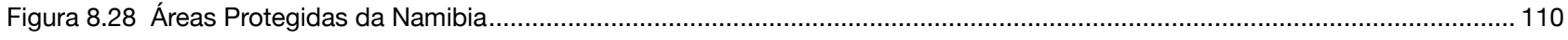

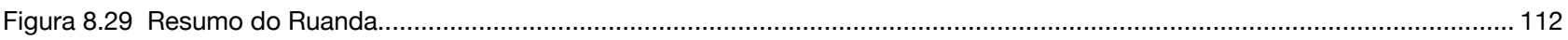

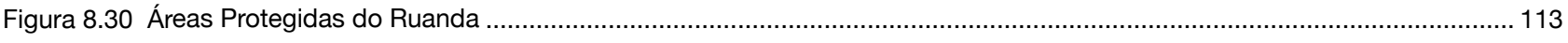

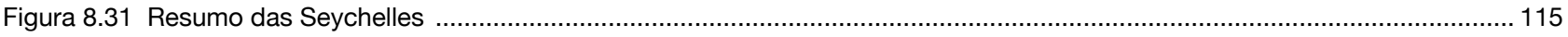

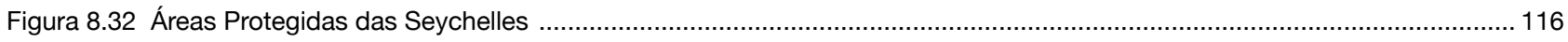

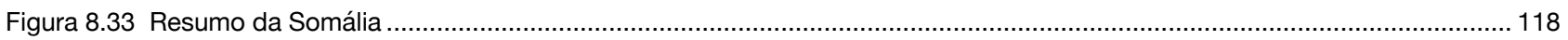

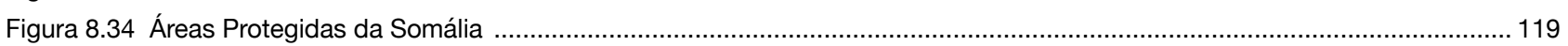

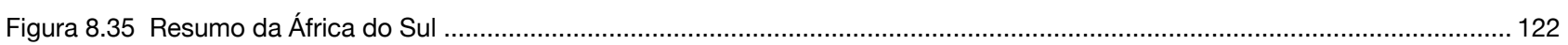

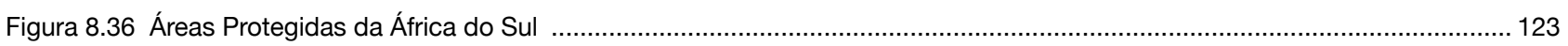

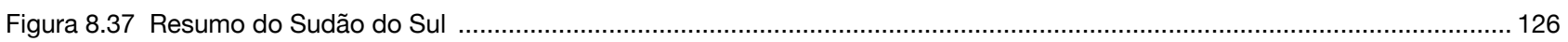

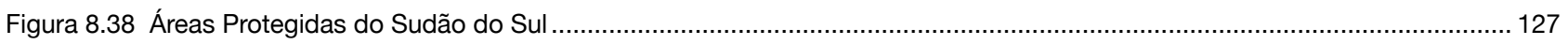

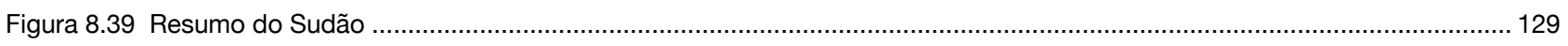

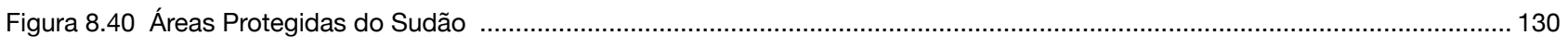

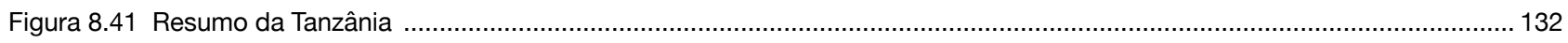

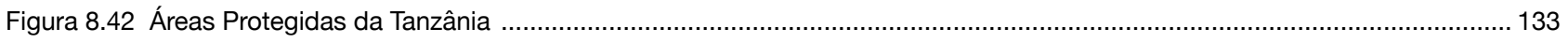

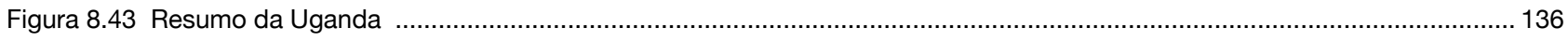

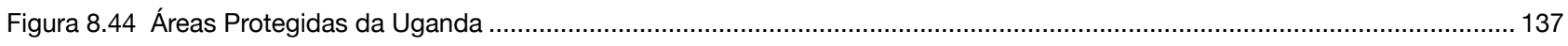

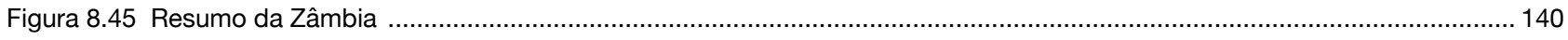

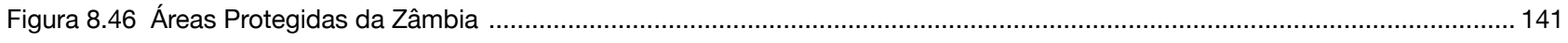

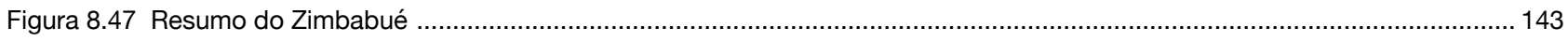

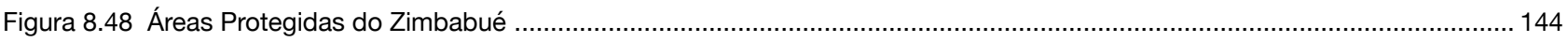

Figura 9.1 Avaliações de governação inventariadas por metodologia ….......................................................................... 163

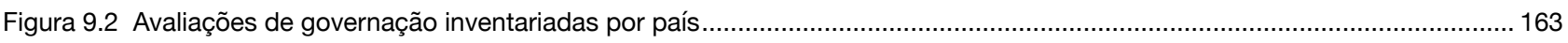

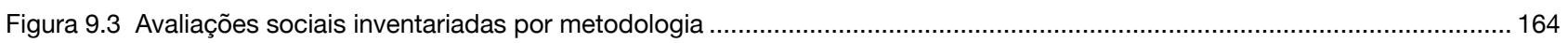

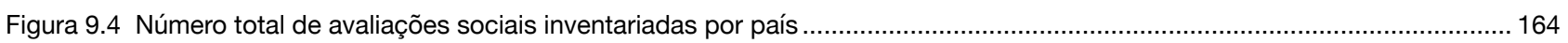

Figura 10.1 O ciclo de gestão e avaliação da gestão das áreas protegidas .................................................................................. 168

Figura 10.2 Percentagem de cobertura das avaliações da eficácia da gestão por região ............................................................... 172

Figura 10.3 Número de áreas protegidas com avaliações PAME no GD-PAME para a África Oriental e Austral.................................173 


\section{Lista de figuras (continuação)}

Figura 10.4 Percentagem de área protegida com avaliações PAME no GD-PAME.................................................................... 173

Figura 10.5 Avaliações PAME inventariadas na África Oriental e Austral por metodologia/ferramenta .......................................... 173

Figura 10.6 Distribuição das avaliações PAME inventariadas por país .................................................................................... 173

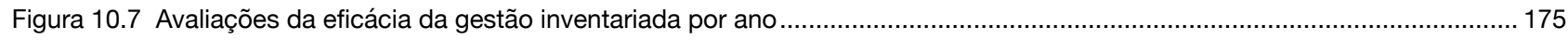

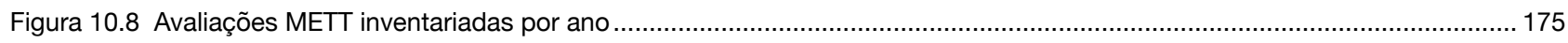

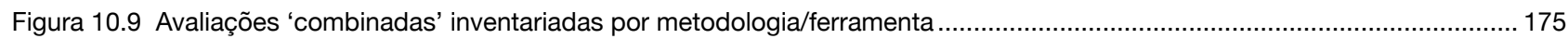

Figura 10.10 Resultados da eficácia da gestão de áreas protegidas avaliadas na África Oriental .............................................. 175

Figura 10.11 Mapa mostrando resultados de eficácia de gestão para áreas protegidas avaliadas na África Oriental ......................... 176

Figura 10.12 Pontuações médias dos indicadores principais das avaliações mais recentes ......................................................... 177

Figura 10.13 Lacuna de financiamento e recursos financeiros disponíveis em 15 países da África Oriental e Austral ........................ 179

Figura 10.14 Divisão das receitas geradas internamente em sete países: Eswatini, Etiópia, Quénia, Namíbia, África do Sul,

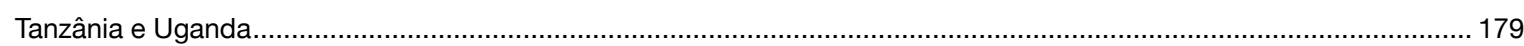

Figura 11.1 O quadrante mágico para aplicação de tecnologia em áreas protegidas em África ...................................................... 191

\section{Lista de caixas}

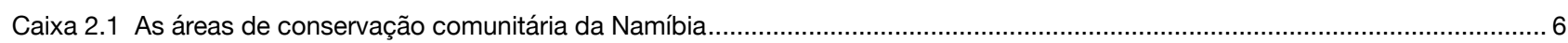

Caixa 2.2 Outras medidas de conservação eficazes baseadas na área (OECM) em África...............................................................

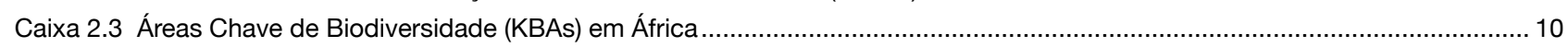

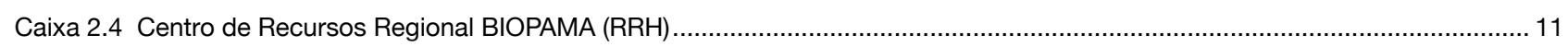

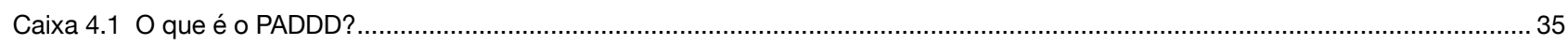

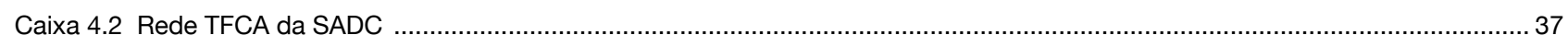

Caixa 7.3 Conservação marinha transfronteiriça entre Quénia e a Tanzânia ........................................................................... 54

Caixa 9.1 Titulares de direitos versus partes interessadas: Qual é a diferença? ....................................................................... 148

Caixa 9.2 Arrancar com a conservação marinha através da gestão local das pescas.............................................................. 151

Caixa 9.3 Diversidade de governação em acção: iniciar áreas marinhas geridas localmente para combater o declínio dos

peixes no Kuruwitu, na costa norte do Quénia ........................................................................................... 152

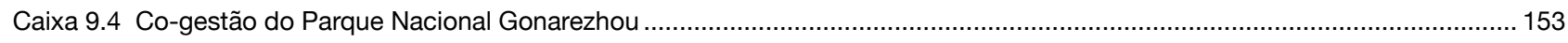

Caixa 9.5 Trabalhar com comunidades para a conservação .............................................................................................. 154

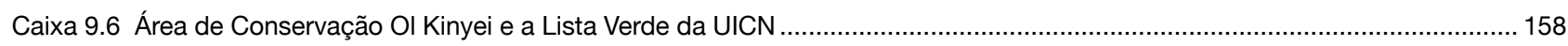

Caixa 9.7 Avaliação da governação ao nível do sistema na Tanzânia ..................................................................................... 160

Caixa 9.8 Avaliação da governação ao nível do sítio na GMA de Mumbwa na Zâmbia.............................................................. 161

Caixa 9.9 Estado das Áreas Indígenas e de conservação comunitária na Tanzânia ......................................................................... 162

Caixa 9.10 Avaliação social no Ol Pejeta Conservancy no Quénia .................................................................................... 164

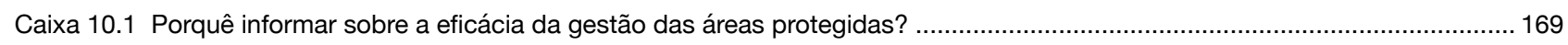

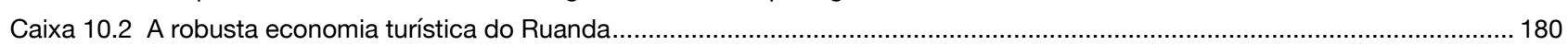

Caixa 10.3 O primeiro incentivo fiscal eficaz da África do Sul em matéria de biodiversidade .............................................................. 185

Caixa 10.4 Impacto da pandemia da COVID-19 nas áreas protegidas na África Oriental e Austral .................................................... 185

Caixa 11.1 Construir capacidade para combater à caça furtiva: o caso do Colégio da Vida Selvagem da África Austral .................. 190

Caixa 11.2 EarthRanger: consciência situacional para garantir áreas protegidas e reduzir os conflitos entre o

homem e a vida selvagem ..................................................................................................................... 192

Caixa 11.3 Programa de monitorização de rinocerontes após a sua reintrodução .................................................................. 193

Caixa 11.4 Armadilhas fotográficas para monitorização ecológica e segurança ....................................................................... 194

Caixa 11.5 SPARC: Redução do risco climático para as redes de conservação ....................................................................... 195 


\section{Lista de quadros}

Quadro 2.1 Categorias de gestão de áreas protegidas da UICN ......................................................................................... 7

Quadro 2.2 Norma da Lista Verde da UICN - Componentes e critérios ....................................................................................... 9

Quadro 2.3 Três ameaças mais frequentemente relatadas no bioma Afrotropical ........................................................................... 14

Quadro 4.1 Sítios globais de importância na África Oriental e Austral .......................................................................................2 25

Quadro 4.2 Lista anotada de Sítios do Património Mundial naturais e "mistos" (naturais/culturais) da África Oriental e Austral

(a partir de 2019), incluindo resultados da Avaliação das Perspectivas de Conservação da UICN e datas das missões de monitorização do Centro do Património Mundial/UICN .

Quadro 4.3 Áreas de conservação transfronteiriças na África Oriental e Austral .......................................................................... 38

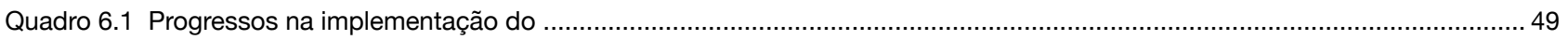

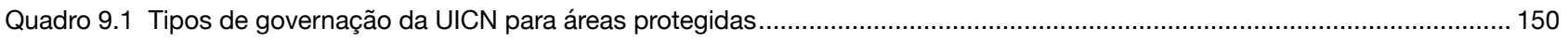

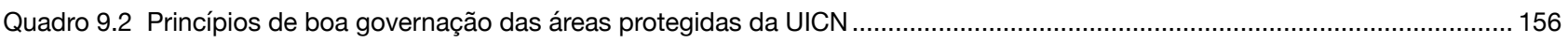

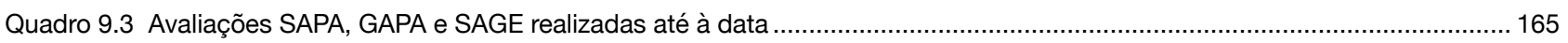

Quadro 10.1 Metodologias PAME utilizadas mais frequentemente na África Oriental e Austral .................................................... 170

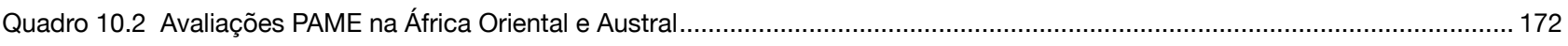

Quadro 11.1 Modelo de estrutura para parcerias de gestão colaborativa .............................................................................. 189

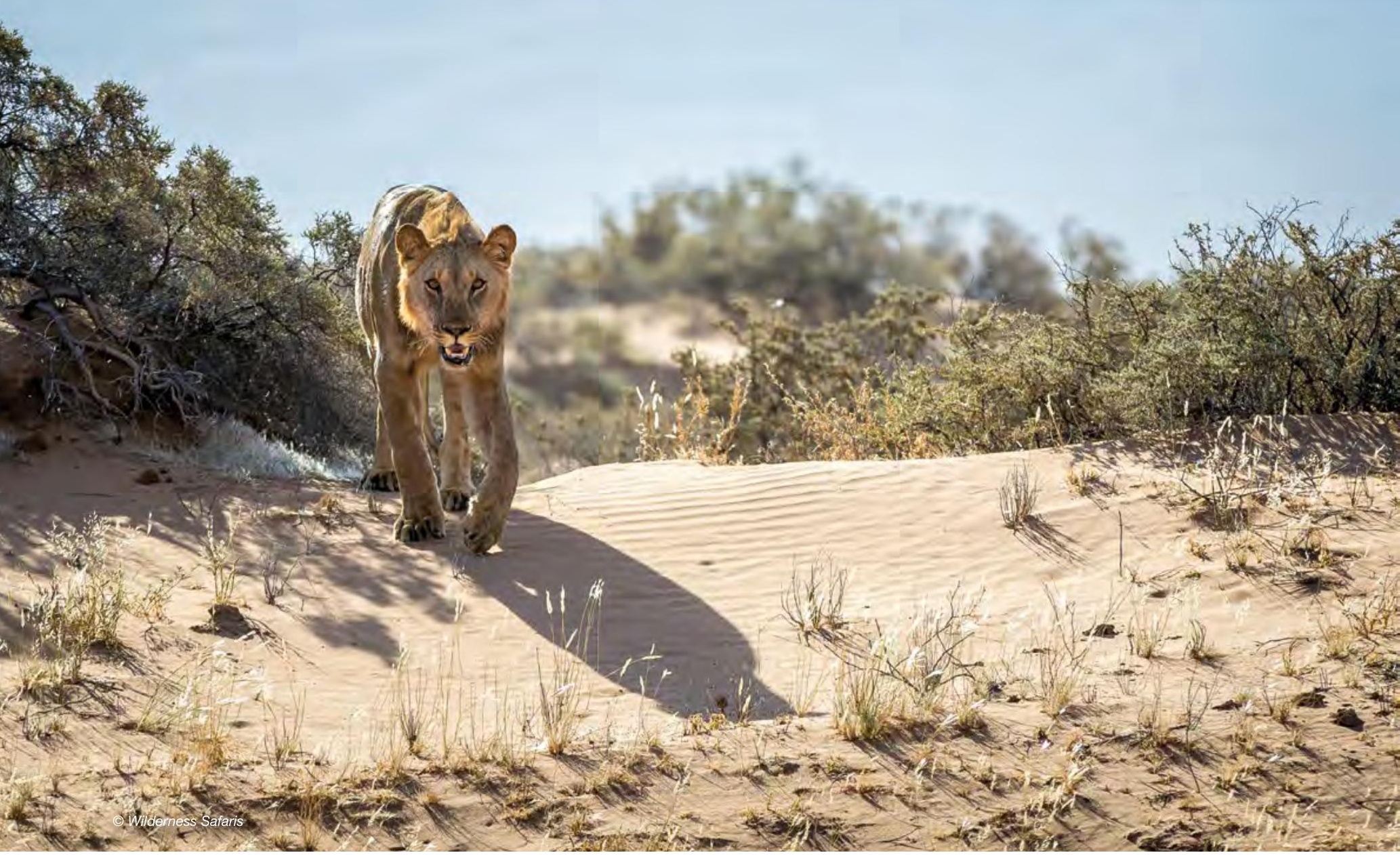




\section{Prefácio}

O ano 2020 marca um momento crucial na conservação da natureza, uma vez que o mundo faz o balanço dos progressos do Plano Estratégico para a Biodiversidade 2011-2020 e negoceia o novo Quadro Global para a Biodiversidade pós-2020. A publicação deste valioso relatório é um marco importante numa viagem que começou na região da África Oriental e Austral no V Congresso Mundial de Parques da UICN, realizado em Durban em 2003. Nessa reunião, o audacioso Plano de Acção de Durban foi elaborado, constituindo a base do primeiro acordo multilateral abrangente do mundo sobre áreas protegidas. O Programa de Trabalho sobre Áreas Protegidas foi subsequentemente adoptado na $7^{\text {a }}$ Conferência das Partes da Convenção sobre Diversidade Biológica em Kuala Lumpur, em 2004. Muitos dos objectivos, princípios, métodos e acções adoptados nessa decisão são a base para este relatório. Por exemplo, foi em Durban que foi documentado o pleno entendimento da governação, equidade e direitos para as áreas protegidas e de conservação, e que é destacado nesta publicação.

No decurso do Plano Estratégico para a Biodiversidade 2011-2020, os governos nacionais e outras partes interessadas alcançaram grandes progressos nos muitos elementos essenciais do Objectivo 11 de Aichi sobre áreas protegidas. Um retrato destas realizações foi apresentado nos bienais Relatórios Planeta Protegido, com base na recolha de informação na Base de Dados Mundial de Áreas Protegidas. Este relatório documenta este progresso, e ilustra-o com numerosos estudos de casos da África Oriental e Austral. Demonstra também como os sistemas de áreas protegidas e de conservação são uma estratégia de conservação essencial para a região, sem a qual a perda de biodiversidade teria sido muito mais significativa. Também destaca as muitas lacunas na compreensão e implementação, e mostra-nos como é desafiante alcançar resultados eficazes para a conservação da natureza.

O relatório enfatiza a lógica subjacente à implementação de sistemas eficazes de áreas protegidas e de conservação. Como Nelson Mandela declarou no Congresso Mundial de Parques da UICN em Durban "Sabemos que a chave para um futuro sustentável para as áreas protegidas reside no desenvolvimento de parcerias. Só através de alianças e parcerias é que as áreas protegidas podem ser tornadas relevantes para as necessidades da sociedade". A compreensão e documentação da relevância das áreas protegidas e de conservação para as necessidades da sociedade é uma das principais contribuições deste relatório. A crise contemporânea da pandemia da COVID-19 lança esta questão num alívio agudo. As pandemias que são causadas pela transferência de agentes patogénicos da fauna selvagem para hospedeiros humanos são frequentemente o resultado da degradação, fragmentação ou perturbação da integridade dos ecossistemas naturais, e do aumento do movimento e contacto dos seres humanos com a fauna selvagem. A manutenção da integridade dos ecossistemas, tanto dentro como fora das áreas protegidas, é portanto fundamental, e os esforços para gerir eficazmente os ecossistemas, ou para para restaurar os investimentos valiosos para reduzir o risco de ocorrência de zoonoses e para manter a subsistência das comunidades.
As áreas protegidas e de conservação são uma componente essencial da maioria dos programas de conservação da natureza, onde tanto a governação como a gestão são necessárias para manter programas eficazes que possam identificar e abordar ameaças que levam à interrupção do ecossistema. Com a crescente pressão populacional e o consumo dos recursos naturais, há poucos lugares no mundo onde não é necessário investir numa governação e gestão eficazes para enfrentar as ameaças e manter a integridade do ecossistema. Para além de proteger a sociedade contra pandemias, os ecossistemas naturais proporcionam uma enorme gama de benefícios à sociedade através do fornecimento de água potável limpa e segura, recursos alimentares, armazenamento de carbono, saúde e bem-estar em geral, e todos estes têm um valor humano e económico. Muitas vezes os governos não investem na manutenção dos ecossistemas essenciais que geram este valor. Pensam apenas nos custos relativamente menores da gestão de áreas protegidas, mas colocam em risco as enormes contribuições que os ecossistemas intactos e as áreas protegidas fazem para a economia, inclusive através de meios de subsistência dependentes. Sem financiamento público, não só a governação e gestão destas áreas são enfraquecidas, como as suas funções e serviços essenciais para a sociedade são comprometidos.

Este relatório sobre o Estado das Áreas Protegidas e de Conservação contribui significativamente para a avaliação do estado actual dos muitos factores que contribuem para o sucesso dos sistemas de áreas protegidas e de conservação. Examina os progressos alcançados no sentido do cumprimento dos objectivos nacionais e globais, e mede-os contra padrões credíveis de eficácia, tais como a Lista Verde de Áreas Protegidas e de Conservação da UICN, que estabelece a fasquia para o que se entende por sistemas eficazes e equitativos de áreas protegidas e de conservação. Fornece também um diagnóstico do que falta, onde se encontram as lacunas, e como resolvê-las através do desenvolvimento de capacidades específicas.

O balanço desta situação foi possível graças ao Programa BIOPAMA, um investimento da União Europeia e da Organização dos Estados de África, Caraíbas e Pacífico. O relatório estabelece, portanto, uma base de referência valiosa em relação à qual é possível medir mais progressos. Contribui para os Sistemas de Informação de Referência Regionais e Globais, e para as parcerias que irão apoiar uma tomada de decisão mais bem informada à escala nacional e global. Ajudará a visar onde a intervenção e o investimento são necessários para melhorar tanto a governação como a gestão, e apoiar a eficácia destes sistemas como base, não só para a vida na terra e a vida debaixo de água, mas também para os objectivos essenciais de desenvolvimento humano fundamentais para o futuro do nosso planeta.

\section{Trevor Sandwith}

Director

Programa Global de Áreas Protegidas da UICN 


\section{Sumário executivo}

A região da África Oriental e Austral abrange 24 países desde a África do Sul no sul até ao Sudão no norte e quatro das seis nações das ilhas do Oceano Índico Ocidental. A região é culturalmente diversa e extremamente rica em biodiversidade, com uma abundância de vida selvagem espectacular, e muitas espécies endémicas de flora e fauna. Estão a ser feitos esforços consideráveis para conservar a biodiversidade da região, mas o crescimento das populações humanas, os conflitos pelo uso da terra, a exploração excessiva dos recursos, as actividades recreativas insustentáveis, a desflorestação e o comércio ilegal estão a ameaçar as áreas protegidas, as espécies e os ecossistemas. Para além destes desafios, a actual pandemia da COVID-19 resultou no encerramento da indústria do turismo e, por conseguinte, numa diminuição significativa do financiamento relacionado com a conservação das áreas protegidas, cujas principais receitas são baseadas no turismo. A pandemia está a exacerbar a lacuna no financiamento de áreas protegidas e constitui um duro aviso da necessidade de diversificação das receitas.

O Estado das Áreas Protegidas e de Conservação na África Oriental e Austral é o primeiro relatório que reúne informação sobre áreas ${ }^{1}$ protegidas e de conservação para toda a região da África Oriental e Austral. É um relatório de base, que apresenta os dados e informações actualmente disponíveis. Sempre que possível, foram realizadas análises inovadoras e incluídos estudos de casos e caixas de texto para acrescentar à informação de base. $O$ relatório é complementado por uma série de outras análises realizadas através do programa BIOPAMA, que também estão disponíveis como publicações separadas. O relatório consiste em doze capítulos, sendo o tema geral do relatório centrado na governação de áreas protegidas e de conservação, equidade e eficácia de gestão.

O relatório inclui uma visão global da conservação e das políticas e programas relacionados, bem como uma análise regional. Como região, a África Oriental e Austral tem $16.54 \%$ da área terrestre protegida em 4,821 áreas protegidas cobrindo 2,120,112 km². Pelo menos sete países da região excederam o Objectivo 11 de Aichi (17\%) para a cobertura terrestre. A região está a meio caminho de cumprir o objectivo de cobertura costeira e marinha (10\%) com $5.60 \%$ da área marinha e costeira protegida em 411 áreas protegidas cobrindo 473,815 km². Três países da região ultrapassaram o Objectivo 11 de Aichi para a cobertura de áreas marinhas e costeiras protegidas.

A maioria das áreas protegidas na região são governadas pela agência governamental nacional relevante, embora muitos países da região estejam cada vez mais a incluir áreas governadas por comunidades e pelo sector privado, incluindo as geridas sob parcerias públicas privadas. Os tipos de governação de muitas áreas protegidas ainda não foram comunicados à Base de Dados Mundial de Áreas Protegidas. A África Oriental e Austral alberga 39 Reservas do Homem e da Biosfera, 27 Sítios do Património Mundial e 109 Sítios de Ramsar (Zonas Húmidas de Importância Internacional). A região é também o lar de 30 áreas de conservação transfronteiriças, desde desenhos conceptuais a áreas de conservação transfronteiriças sustentadas por tratados completos. A África Austral tem um forte programa de Áreas de Conservação Transfronteiriças, onde a primeira Área de Conservação Transfronteiriça foi declarada em 1990 e da qual se poderiam extrair lições para outras partes de África.

O objectivo das Comunidades Económicas Regionais na região é facilitar a integração económica regional entre os estados membros de cada região e através da Comunidade Económica Africana em geral. Desempenham também um papel importante em termos de promoção da conservação transfronteiriça na região.

Um resumo dos dados disponíveis para cada um dos 24 países abrangidos no relatório reúne informações da Base de Dados Mundial sobre Áreas Protegidas, bem como relatórios dos países à Convenção sobre Diversidade Biológica. Esta informação serve como uma base de informação disponível. Pretende-se em relatórios futuros fornecer mais detalhes e análises em nível de país à medida que estas se tornem disponíveis.

O relatório inclui uma introdução à governação de áreas protegidas, revendo o trabalho da UICN e outros para fornecer ferramentas para ajudar os países a cumprirem os requisitos do Objectivo 11 de Aichi de que as áreas protegidas sejam governadas equitativamente. São descritas as ferramentas disponíveis para avaliar a diversidade e qualidade de governação em nível do sistema e do local e são apresentados estudos de caso da região. Estas ferramentas incluem a Lista Verde de Áreas Protegidas e de Conservação da UICN, que se concentra em quatro componentes: boa governação, concepção e planeamento sólidos; gestão eficaz e resultados de conservação bem sucedidos. Um relatório preparado através do programa BIOPAMA analisou 380 avaliações de governação e 50 avaliações sociais realizadas na África Oriental e Austral. Verificou-se que embora haja um aumento na governação e avaliações sociais, este número é ainda limitado em toda a região e muito poucas avaliações repetidas estão a ser conduzidas.

A avaliação da eficácia da gestão das áreas protegidas (PAME) também apoia a elaboração de relatórios sobre os progressos no sentido do Objectivo 11 de Aichi, reflectindo a exigência de uma gestão eficaz. Aproximadamente $13 \%$ das áreas protegidas na região têm pelo menos uma avaliação PAME comunicada. A análise inventariou 2,686 avaliações da eficácia da gestão, a maioria das quais foram avaliações da Ferramenta de Rastreamento da Eficácia da Gestão (METT). A nova base de dados global UNEP-WCMC sobre Eficácia da Gestão de Áreas Protegidas (GD-PAME) foi utilizada na avaliação, mas ainda existem grandes lacunas nos dados, que precisam de ser preenchidas para permitir um verdadeiro reflexo do número, localização e calendário das avaliações PAME. Muitos países, tais como Madagáscar e África do Sul, têm vindo a realizar avaliações da eficácia da gestão há vários anos, incluindo avaliações repetidas em muitas áreas protegidas. Os resultados destas avaliações estão a ser utilizados para melhorar a gestão nestes locais.

\footnotetext{
"Áreas de Conservação" não tem actualmente uma definição amplamente aceite. É utilizada neste relatório, seguindo a quinta opção delineada por Jonas e Sandwith (2019), como "áreas que sustentam a integridade ecológica e/ou de conservação eficaz in situ da biodiversidade".
} 
Existem muitos desafios na região, e as ameaças à conservação estão a crescer, mas os compromissos dos países em relação a acordos internacionais, metas e compromissos para assegurar uma governação equitativa e uma gestão eficaz das áreas protegidas e de conservação podem promover e assegurar a conservação de espécies e ecossistemas na região. Estes compromissos precisam de ser apoiados com a vontade política necessária e a atribuição de recursos para assegurar a plena implementação em benefício das áreas protegidas e de conservação. Dados exactos, actuais e comparáveis para medir o progresso em relação a metas e compromissos é essencial para apoiar o planeamento e a afectação de recursos. Este relatório espera fornecer a base para estes dados e encorajar melhorias na recolha de dados e na elaboração de relatórios para assegurar uma conservação equitativa e eficaz na África Oriental e Austral.

\section{Agradecimentos}

São devidos agradecimentos sinceros à União Europeia e à Organização dos Estados de África, Caraíbas e Pacífico pelo seu apoio financeiro à publicação. O Conselho Editorial e o Comité das Publicações da UICN agradecem o seu apoio e orientação na preparação do documento.

Todos os pontos focais BIOPAMA e Estado das Áreas Protegidas e de Conservação na África Oriental e Austral (SoPACA) dos 24 países apresentados neste relatório forneceram um contributo inestimável, assim como os pontos focais das Comunidades Económicas Regionais.

A equipa central envolvida na elaboração do presente relatório incluiu: Sue Snyman, Beryl Nyamgeroh, Christine Mentzel e Leo Niskanen (UICN ESARO); Jessica Stewart (UNEP-WCMC); Bastian Bertzky e Lucy Bastin (JRC), Patrick Kabatha e Ngugi Kimani (RCMRD); e Diane Skinner e Eleanor Shadwell.

Os contributos importantes para capítulos específicos foram muito bem-vindos: Programa Global de Áreas Protegidas da UICN Jennifer Kelleher; Phil Franks (International Institute of Environment and Development); Daniel Marnewick (BirdLife South Africa); Rachel Golden Kroner (Conservation International); Lily Arison Réné De Roland (The Peregrine Fund); Ashwell Glasson (Southern African Wildlife College); Drew Bantlin (African Parks); Candice Stevens
(Wilderness Foundation South Africa); Claudia Capitani; Jan Philipp Schägner e Andrew Cottam (JRC); François Barnard e Kathleen Fitzgerald (Conservation Capital); Caitlin Kelly (Projecto de Planeamento Espacial para a Conservação Baseada na Área em Resposta às Alterações Climáticas); Ted Schmitt (Vulcan); Lisa Blanken (Deutsche Gesellschaft für Internationale Zusammenarbeit); Elsabé van der Westhuizen (Sociedade Zoológica de Frankfurt); Stephen Nindi (Tanzânia National Land Use Planning Commission); Arthur Tuda (Quénia Wildlife Service); Jessica Campese, Emmanuel Sulle e Yemeserach Tessema; Beatrice Chataigner (UICN); Des Bowden (Kuruwitu Conservation and Welfare Association); e Rupert Quinan (Blue ventures).

A UICN, RCMRD, UNEP-WCMC, JRC, Peace Parks Foundation e Birdlife International agradecem o fornecimento dos dados que sustentam o relatório.

Três revisores - Peter Lindsey, Evans Mwangi e Andrew Parker dedicaram tempo e esforço significativo à revisão do relatório, o que tornou o relatório muito mais forte. Finalmente, os editores Marc Hockings e Fiona Leverington, o editor de cópias Diwata Hunziker, e a designer Mary-Anne van der Byl são agradecidos pelo seu trabalho abrangente e detalhado para assegurar que o relatório seja ao mesmo tempo preciso e visualmente apelativo.

Agradecemos também a todos os indivíduos e organizações que gentilmente forneceram fotografias para o relatório. 


\section{Glossário}

\begin{tabular}{|c|c|}
\hline Termo & Significado \\
\hline Gestão adaptativa & $\begin{array}{l}\text { O processo cíclico de testar sistematicamente os pressupostos, gerando aprendizagem através da } \\
\text { avaliação dos resultados de tais testes, e de rever e melhorar ainda mais as práticas de gestão. O } \\
\text { objectivo da gestão adaptativa num contexto de área protegida é uma maior eficácia e um maior } \\
\text { progresso no sentido da realização de metas e objectivos. }\end{array}$ \\
\hline Avaliação & A medição ou estimativa de um aspecto da gestão. \\
\hline Linha de base & $\begin{array}{l}\text { Informação recolhida sobre um alvo específico (por exemplo, condição de um recurso, conhecimento, } \\
\text { população de uma determinada espécie, etc.) nas fases iniciais de um projecto, fornecendo assim } \\
\text { uma base para medir o progresso ou mudança ao longo do tempo. }\end{array}$ \\
\hline Biodiversidade & $\begin{array}{l}\text { A variabilidade entre organismos vivos de todas as fontes, incluindo, inter alia, os ecossistemas } \\
\text { terrestres, marinhos e outros ecossistemas aquáticos e os complexos ecológicos dos quais fazem } \\
\text { parte; isto inclui a diversidade dentro das espécies, entre espécies e dos ecossistemas. }\end{array}$ \\
\hline Bioma & $\begin{array}{l}\text { Uma parte importante do ambiente de vida de uma determinada região caracterizada pela sua } \\
\text { vegetação característica e mantida em grande parte pelas condições climáticas locais. }\end{array}$ \\
\hline Reserva da biosfera & $\begin{array}{l}\text { Área que forma uma rede internacional de ecossistemas reconhecida pela UNESCO, e que promove } \\
\text { a biodiversidade, conservação e utilização sustentável, juntamente com abordagens interdisciplinares } \\
\text { para a compreensão e gestão das mudanças e interacções entre os sistemas sociais e ecológicos. }\end{array}$ \\
\hline Comunidade & $\begin{array}{l}\text { Um grupo social de qualquer dimensão cujos membros residem numa localidade específica, partilham } \\
\text { o governo e podem ter um património cultural e histórico comum/s. Pode também referir-se a um } \\
\text { grupo de indivíduos que interagem no seu ambiente imediato, exibe coesão e continuidade através } \\
\text { do tempo, e exibe características tais como interacção social, intimidade, compromissos morais, } \\
\text { relações multifacetadas, e reciprocidade. }\end{array}$ \\
\hline $\begin{array}{l}\text { Área Conservada pela } \\
\text { Comunidade }\end{array}$ & $\begin{array}{l}\text { Ecossistemas naturais e modificados, incluindo uma biodiversidade significativa, serviços ecológicos e } \\
\text { valores culturais voluntariamente conservados pelos povos indígenas e comunidades locais e móveis } \\
\text { através de leis consuetudinárias ou outros meios eficazes. }\end{array}$ \\
\hline Conectividade (biológica) & $\begin{array}{l}\text { O grau em que a produção local resulta no recrutamento para outras populações. Para qualquer } \\
\text { população local, a conectividade pode ser caracterizada por: (1) a proporção do recrutamento na } \\
\text { população local que é auto-sustentável; (2) as contribuições proporcionais de outras populações para } \\
\text { o recrutamento na população local, de forma espacialmente explícita; e (3) a distribuição espacial } \\
\text { e representação proporcional das contribuições da produção local para o recrutamento externo de } \\
\text { outras populações. }\end{array}$ \\
\hline Conservação & $\begin{array}{l}\text { A manutenção ou utilização sustentável dos recursos da Terra, a fim de manter o ecossistema, as } \\
\text { espécies e a diversidade genética e os processos evolutivos e outros que os moldam. }\end{array}$ \\
\hline Áreas de conservação & $\begin{array}{l}\text { As áreas de conservação são definidas como áreas que sustentam a integridade ecológica e/ou a } \\
\text { conservação eficaz in situ da biodiversidade. }\end{array}$ \\
\hline Corredor & $\begin{array}{l}\text { Forma de manter a conectividade ecológica ou ambiental vital, mantendo as ligações físicas entre } \\
\text { as áreas nucleares. }\end{array}$ \\
\hline Gestão de dados & $\begin{array}{l}\text { O acto, processo, ou meio pelo qual os dados são geridos. Isto pode incluir a compilação, } \\
\text { armazenamento, salvaguarda, listagem, organização, extracção, recuperação, manipulação e } \\
\text { disseminação de dados. }\end{array}$ \\
\hline Ecossistema & $\begin{array}{l}\text { Um complexo dinâmico de comunidades vegetais, animais e microrganismos e o seu ambiente não } \\
\text { vivo, interagindo como uma unidade funcional. }\end{array}$ \\
\hline
\end{tabular}




\begin{tabular}{|c|c|}
\hline Termo & Significado \\
\hline Serviços de ecossistema & $\begin{array}{l}\text { Os benefícios que as pessoas obtêm dos ecossistemas. Estes incluem serviços de abastecimento } \\
\text { como a alimentação e a água; serviços de regulação como a regulação de cheias, seca, degradação } \\
\text { da terra e doenças; serviços de apoio como a formação do solo e o ciclismo de nutrientes; e serviços } \\
\text { culturais como os recreativos, espirituais, religiosos e outros benefícios não materiais. }\end{array}$ \\
\hline Ecoturismo & $\begin{array}{l}\text { Viagens responsáveis a áreas naturais que preservam o ambiente, sustentam o bem-estar da população } \\
\text { local e envolvem interpretação e educação. }\end{array}$ \\
\hline Equidade & $\begin{array}{l}\text { Procura o acesso das pessoas à igualdade de oportunidades e o desenvolvimento de capacidades } \\
\text { básicas; isto significa que as barreiras que impedem as oportunidades económicas e políticas, bem } \\
\text { como o acesso à educação e serviços básicos, devem ser eliminadas, para que as pessoas (mulheres } \\
\text { e homens de todas as idades, condições e cargos) possam usufruir de tais oportunidades e beneficiar } \\
\text { das mesmas. Significa justiça; ou seja, dar a cada pessoa ou grupo aquilo que é seu por direito, } \\
\text { reconhecendo as condições ou características específicas de cada pessoa ou grupo humano (sexo, } \\
\text { sexo, classe, religião, idade). É o reconhecimento da diversidade, sem dar razões para discriminação. }\end{array}$ \\
\hline Avaliação & $\begin{array}{l}\text { O julgamento do estatuto/condição ou desempenho de algum aspecto da gestão contra critérios } \\
\text { pré-determinados (geralmente um conjunto de normas ou objectivos); neste caso incluindo os } \\
\text { objectivos para os quais as áreas protegidas foram estabelecidas. }\end{array}$ \\
\hline Governação & $\begin{array}{l}\text { No contexto das áreas protegidas, a governação foi definida como as interacções entre estruturas, } \\
\text { processos e tradições que determinam a forma como o poder é exercido, como as decisões são } \\
\text { tomadas sobre questões de interesse público, e como os cidadãos ou outros interessados têm uma } \\
\text { palavra a dizer. As disposições de governação são expressas através de quadros jurídicos e políticos, } \\
\text { estratégias e planos de gestão; incluem as disposições organizacionais para o acompanhamento de } \\
\text { políticas e planos e a monitorização do desempenho. A governação abrange as regras da tomada de } \\
\text { decisões, incluindo quem tem acesso à informação e participa no processo de tomada de decisões, } \\
\text { bem como as próprias decisões. }\end{array}$ \\
\hline Autoridade de governação & $\begin{array}{l}\text { A instituição, indivíduo, povos indígenas ou grupo comunal ou outro organismo reconhecido como } \\
\text { tendo autoridade e responsabilidade pela tomada de decisões e gestão de uma área. }\end{array}$ \\
\hline Qualidade de governação & $\begin{array}{l}\text { Até que ponto uma área protegida está a ser governada - até que ponto está a responder aos princípios } \\
\text { e critérios de "boa governação" identificados e escolhidos pelos povos, comunidades e governos } \\
\text { relevantes (parte do seu sentido de moralidade, identidade cultural e orgulho) e geralmente ligados } \\
\text { aos princípios defendidos pelas agências e convenções internacionais. }\end{array}$ \\
\hline Tipos de governação & $\begin{array}{l}\text { Os quatro principais tipos de governação das áreas protegidas são (i) governação governamental, (ii) } \\
\text { governação partilhada, (iii) governação privada (incluindo gestão por ONG), e (iv) áreas e territórios } \\
\text { governados por Povos Indígenas e comunidades locais. Em cada tipo, é possível que a responsabilidade } \\
\text { pelo turismo ou algum outro aspecto da gestão seja delegada a outra autoridade governante, ou } \\
\text { contratada a operadores privados. }\end{array}$ \\
\hline Habitat & O local ou tipo de local onde ocorre naturalmente um organismo ou população. (Artigo 2 da CDB). \\
\hline $\begin{array}{l}\text { Povos indígenas e } \\
\text { comunidades locais }\end{array}$ & $\begin{array}{l}\text { Este Relatório segue a Convenção sobre a Diversidade Biológica, que utiliza os termos "Povos } \\
\text { Indígenas" e "comunidades locais".? }\end{array}$ \\
\hline $\begin{array}{l}\text { Territórios e áreas } \\
\text { conservados pelos povos } \\
\text { indígenas e comunidades } \\
\text { (ICCAs) }\end{array}$ & $\begin{array}{l}\text { Os territórios e áreas de conservação pelos povos indígenas e comunidades são ecossistemas } \\
\text { naturais e/ou modificados contendo valores de biodiversidade significativos, serviços ecológicos e } \\
\text { valores culturais, conservados voluntariamente pelos povos indígenas e comunidades locais, tanto } \\
\text { sedentários como móveis, através de leis consuetudinárias ou outros meios eficazes. }\end{array}$ \\
\hline Espécies invasoras & $\begin{array}{l}\text { As áreas de conservação pelos povos indígenas e comunidades locais podem ser potencialmente } \\
\text { reconhecidas como áreas protegidas ou de conservação, sujeitas ao seu "consentimento prévio } \\
\text { informado" ou "livre e prévio informado". }\end{array}$ \\
\hline
\end{tabular}

2 https://www.cbd.int/doc/meetings/tk/aheg-lcr-01/official/aheg-lcr-01-02-en.pdf 


\begin{tabular}{|c|c|}
\hline Termo & Significado \\
\hline $\begin{array}{l}\text { Áreas Marítimas Geridas } \\
\text { Localmente }\end{array}$ & $\begin{array}{l}\text { Uma área de águas próximas da costa e dos seus recursos costeiros e marinhos associados que é em } \\
\text { grande parte ou totalmente gerida a nível local pelas comunidades costeiras, grupos de proprietários } \\
\text { de terras, organizações parceiras e/ou representantes governamentais colaborativos que residem } \\
\text { ou estão sediados na área imediata. }\end{array}$ \\
\hline Eficácia da gestão & $\begin{array}{l}\text { Até que ponto uma área protegida está a ser gerida - principalmente até que ponto está a proteger } \\
\text { valores e a alcançar metas e objectivos. }\end{array}$ \\
\hline Monitorização & $\begin{array}{l}\text { Recolher informação sobre indicadores repetidamente ao longo do tempo para descobrir tendências } \\
\text { no estatuto da área protegida ou dos seus componentes, atributos da comunidade e actividades e } \\
\text { processos de gestão. }\end{array}$ \\
\hline $\begin{array}{l}\text { Estratégias Nacionais de } \\
\text { Biodiversidade e Planos de } \\
\text { Acção }\end{array}$ & $\begin{array}{l}\text { Os principais instrumentos para implementar a CDB a nível nacional, os NBSAPs expõem o } \\
\text { compromisso de cada Parte Contratante com a conservação e utilização sustentável da diversidade } \\
\text { biológica e com a inclusão desse compromisso em todos os sectores da economia nacional e do } \\
\text { quadro de elaboração de políticas. }\end{array}$ \\
\hline Conservação da natureza & $\begin{array}{l}\text { Neste contexto, a natureza refere-se sempre à biodiversidade, a nível genético, de espécies e de } \\
\text { ecossistemas, e muitas vezes também se refere à geodiversidade, ao relevo e a valores naturais } \\
\text { mais amplos. No contexto de áreas protegidas, conservação refere-se à manutenção in situ de } \\
\text { ecossistemas e habitats naturais e semi-naturais e de populações viáveis de espécies no seu meio } \\
\text { natural e, no caso de espécies domesticadas ou cultivadas, no meio em que desenvolveram as suas } \\
\text { propriedades distintivas. }\end{array}$ \\
\hline Turismo baseado na natureza & $\begin{array}{l}\text { Formas de turismo que utilizam recursos naturais de uma forma selvagem ou não desenvolvida. } \\
\text { O turismo baseado na natureza é uma viagem com o objectivo de desfrutar de áreas naturais não } \\
\text { desenvolvidas ou da vida selvagem. }\end{array}$ \\
\hline Área Protegida & $\begin{array}{l}\text { A CDB define uma área protegida como: "Uma zona geograficamente definida que é designada } \\
\text { ou regulamentada e gerida para atingir objectivos específicos de conservação" (artigo } 2^{\circ} \text { da CDB). } \\
\text { A UICN tem uma definição mais detalhada: "Um espaço geográfico claramente definido, reconhecido, } \\
\text { dedicado e gerido, através de meios legais ou outros meios eficazes, para alcançar a conservação } \\
\text { a longo prazo da natureza com serviços ecossistémicos e valores culturais associados" (Dudley, } \\
\text { 2008). A CDB e a UICN reconhecem as duas como sendo equivalentes na prática, já que em ambos } \\
\text { os casos estas áreas se destinam a alcançar a conservação in situ. }\end{array}$ \\
\hline $\begin{array}{l}\text { Categorias de áreas } \\
\text { protegidas }\end{array}$ & $\begin{array}{l}\text { Um conjunto de seis classes, concebidas pela UICN, nas quais uma área protegida pode ser agrupada } \\
\text { de acordo com os seus objectivos primários de gestão global. Algumas áreas protegidas, contudo, } \\
\text { estão divididas em zonas, cada uma das quais pode ter um objectivo de gestão diferente que serve } \\
\text { o objectivo global primário. }\end{array}$ \\
\hline Gestor da área protegida & $\begin{array}{l}\text { Um profissional ou outro interveniente que trabalhe em áreas protegidas. O termo inclui administradores, } \\
\text { gestores e planificadores que podem trabalhar para e com agências governamentais, organizações } \\
\text { não governamentais, grupos comunitários locais, proprietários de terras privadas, ou outras entidades. }\end{array}$ \\
\hline Sítios Ramsar & $\begin{array}{l}\text { Um sistema internacional de zonas húmidas protegidas reconhecidas como globalmente importantes } \\
\text { ao abrigo da Convenção de Ramsar. (Ramsar é o nome de uma cidade no Irão onde a convenção } \\
\text { foi adoptada). }\end{array}$ \\
\hline Titulares de direitos & $\begin{array}{l}\text { Pessoas socialmente dotadas de direitos legais ou consuetudinários em relação à terra, água e } \\
\text { recursos naturais. }\end{array}$ \\
\hline Espécie & $\begin{array}{l}\text { Um grupo de organismos diferentes de outros grupos de organismos e que podem procriar e produzir } \\
\text { descendência fértil. }\end{array}$ \\
\hline Riqueza das espécies & O número de espécies diferentes que existem dentro de uma determinada área ou comunidade. \\
\hline Intervenientes & $\begin{array}{l}\text { Pessoas ou organizações que possuem interesses e preocupações directos ou indirectos no que diz } \\
\text { respeito à terra, água e recursos naturais, mas que não gozam necessariamente de um direito legal } \\
\text { ou socialmente reconhecido a estes. }\end{array}$ \\
\hline
\end{tabular}




\begin{tabular}{l|l}
\hline Termo & Significado \\
\hline Sustentabilidade & $\begin{array}{l}\text { Para as áreas protegidas, a condição da sua persistência durante muito tempo com valores naturais } \\
\text { e culturais fundamentais intactos, embora não necessariamente inalterados. }\end{array}$ \\
\hline Desenvolvimento sustentável & $\begin{array}{l}\text { Um desenvolvimento que satisfaça as necessidades do presente sem comprometer a capacidade } \\
\text { das gerações futuras de satisfazerem as suas próprias necessidades. }\end{array}$ \\
\hline Utilização sustentável & $\begin{array}{l}\text { A utilização de componentes da diversidade biológica de uma forma e a um ritmo que não leve ao } \\
\text { declínio a longo prazo da diversidade biológica, mantendo assim o seu potencial para satisfazer as } \\
\text { necessidades e aspirações das gerações presentes e futuras. }\end{array}$ \\
\hline Turismo & $\begin{array}{l}\text { As actividades das pessoas que viajam e permanecem em lugares fora do seu ambiente habitual } \\
\text { durante não mais do que um ano consecutivo para fins de lazer, negócios e outros. }\end{array}$ \\
\hline Sítios do Património Mundial & $\begin{array}{l}\text { Um sistema internacional de áreas protegidas, criado ao abrigo da Convenção do Património Mundial, } \\
\text { que pretende incluir os exemplos mais notáveis do património natural e cultural do mundo. }\end{array}$ \\
\hline
\end{tabular}

\section{Acrónimos}

\begin{tabular}{|c|c|}
\hline AZE & Aliança para Extinção Zero \\
\hline BIOFIN & $\begin{array}{l}\text { Iniciativa de Financiamento da Biodiversidade } \\
\text { do UNDP }\end{array}$ \\
\hline BIOPAMA & $\begin{array}{l}\text { Programa de Gestão da Biodiversidade e das } \\
\text { Áreas Protegidas }\end{array}$ \\
\hline CBD & Convenção sobre a Diversidade Biológica \\
\hline DOPA & Observatório Digital de Áreas Protegidas \\
\hline EAC & Comunidade da África Oriental \\
\hline EC & Comissão Europeia \\
\hline ESARO & Escritório Regional da África Oriental e Austral \\
\hline GAPA & $\begin{array}{l}\text { Avaliação da Governação de Áreas Protegidas } \\
\text { e de Conservação }\end{array}$ \\
\hline GD-PAME & $\begin{array}{l}\text { Base de Dados Global sobre a Eficácia da } \\
\text { Gestão de Áreas Protegidas }\end{array}$ \\
\hline GDP & Produto Interno Bruto \\
\hline GMA & Área de Gestão de Caça \\
\hline IBA & Área Importante de Aves \& Biodiversidade \\
\hline ICCA & $\begin{array}{l}\text { Áreas Indígenas e de conservação pela } \\
\text { Comunidade }\end{array}$ \\
\hline IGAD & $\begin{array}{l}\text { Autoridade Intergovernamental para o } \\
\text { Desenvolvimento }\end{array}$ \\
\hline IIED & $\begin{array}{l}\text { Instituto Internacional para o Ambiente e } \\
\text { Desenvolvimento }\end{array}$ \\
\hline IMET & Ferramenta de Eficácia de Gestão Integrada \\
\hline IOC & Comissão do Oceano Índico \\
\hline JRC & $\begin{array}{l}\text { Centro Comum de Investigação da Comissão } \\
\text { Europeia }\end{array}$ \\
\hline KBA & Área Chave de Biodiversidade \\
\hline METT & $\begin{array}{l}\text { Ferramenta de Rastreamento da Eficácia da } \\
\text { Gestão }\end{array}$ \\
\hline MPA & Área Marítima Protegida \\
\hline NBSAP & $\begin{array}{l}\text { Estratégia Nacional de Biodiversidade e Plano } \\
\text { de Acção }\end{array}$ \\
\hline OECD & $\begin{array}{l}\text { Organização para a Cooperação e } \\
\text { Desenvolvimento Económico }\end{array}$ \\
\hline OECM & $\begin{array}{l}\text { Outras Medidas de Conservação Eficazes na } \\
\text { Área }\end{array}$ \\
\hline
\end{tabular}

PADDD

PAGE

PAME

POWPA

RAPPAM

RCMRD

REC

$\mathrm{RRH}$

RRIS

SADC

SAGE

SAPA

SDG

SMART

SoPACA

TFCA

TWIX

UICN

UNDP Programa das Nações Unidas de Desenvolvimento

UNEP-WCMC Programa das Nações Unidas do Ambiente Centro Mundial de Monitorização da Conservação

UNESCO Organização das Nações Unidas para a Educação, Ciência e Cultural

WD-OECM Base de Dados Mundial sobre Outras Medidas de Conservação Eficazes em Áreas

WCMC Centro Mundial de Monitorização da Conservação WCPA Comissão Mundial sobre Áreas Protegidas da UICN

WDPA Base de Dados Mundial sobre Áreas Protegidas 


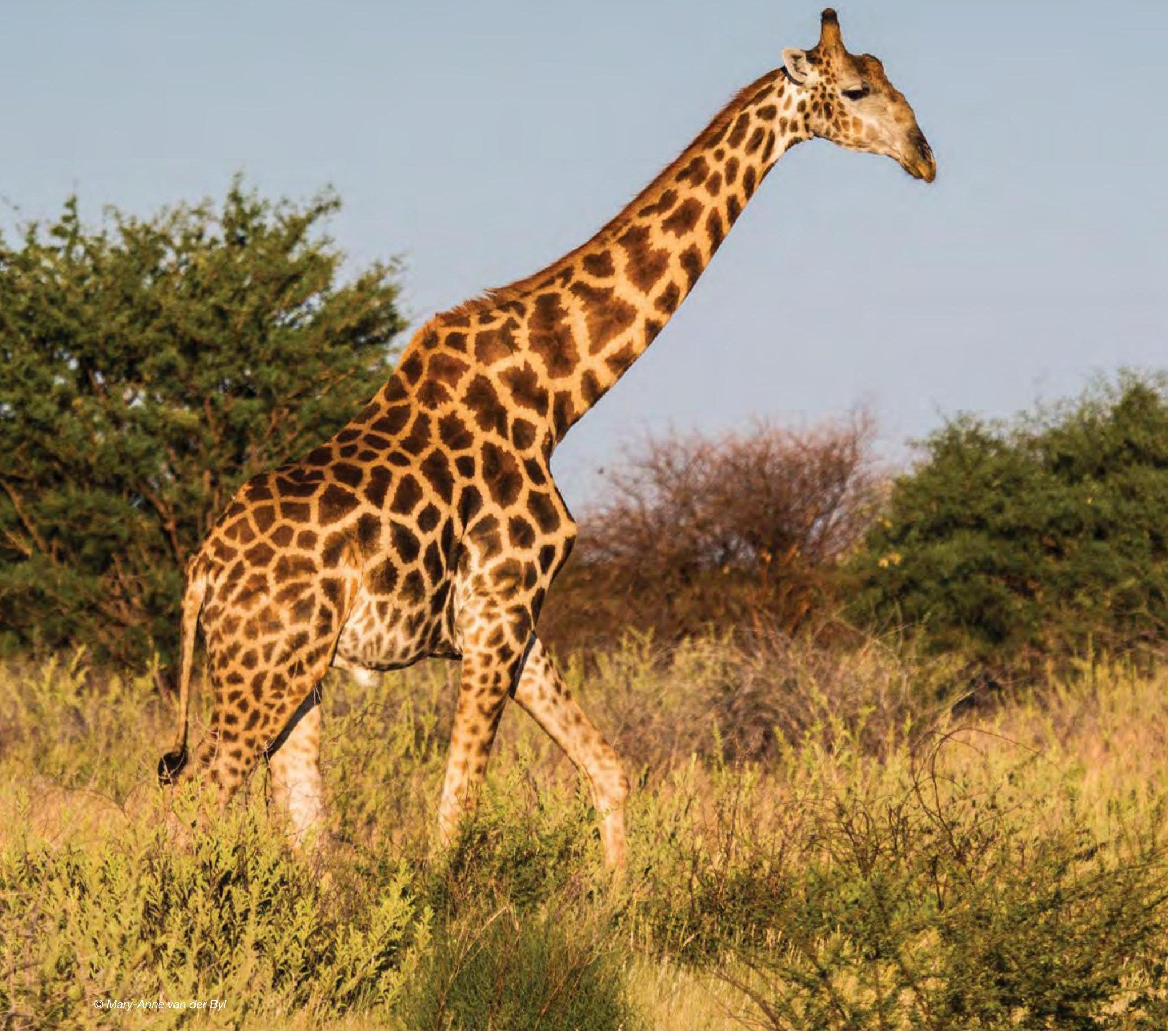


Parte I - Preparar o cenário

\section{Introdução}


A região da África Oriental e Austral é uma das áreas mais ricas em biodiversidade do mundo, consistindo numa série de diversas áreas protegidas e de conservação geridas por um vasto leque de intervenientes-governos, organizações não governamentais (ONG), comunidades locais, o sector privado e parcerias entre estas entidades. A região apresenta elevados níveis de pobreza e desemprego e, por esta razão, os governos tendem a concentrar-se no desenvolvimento socioeconómico, no aumento do emprego e na redução da pobreza. Em particular, a concentração no sector agrícola e mineiro, bem como nos grandes desenvolvimentos infra-estruturais, pode resultar em conflitos de uso da terra e num baixo investimento e financiamento de áreas protegidas e de conservação.

Contudo, ecossistemas saudáveis podem reduzir a vulnerabilidade sócio-económica ao apoiar o bem-estar, e os conhecimentos ambientais detidos pelos povos indígenas podem levar à descoberta de novas espécies e populações e podem melhorar a nossa compreensão do estatuto e tendências das espécies e ecossistemas, particularmente aqueles que contribuem para a subsistência $e$ bem-estar humano. A eficácia das áreas protegidas é fraca em muitas áreas da região devido a uma combinação de factores, tais como as alterações climáticas, sobre-exploração (caça furtiva, abate de árvores, pecuária), conflitos civis, e invasão das populações locais para sustentar a sua subsistência, e concepção, financiamento e administração inadequada dos parques (CE, 2015).

A biodiversidade de água doce em África está sob forte pressão com a maioria das espécies ameaçadas encontradas em áreas com elevados níveis de desenvolvimento e procura de recursos hídricos, tais como a África do Sul austral e oriental e nos grandes lagos da África Oriental. Grande parte da biodiversidade marinha e costeira de África está também ameaçada. A ampla plataforma continental ao longo da costa noroeste de África, as florestas de mangais da África Ocidental e Oriental e as ilhas adjacentes, proporcionam habitats diversos que suportam elevados níveis de biodiversidade de peixes e espécies invertebradas. A biodiversidade terrestre está também ameaçada, entre outras coisas, pela exploração mineira, caça furtiva, comércio ilegal de vida selvagem, perda de habitat, vegetação exótica e aumento das populações humanas e os conflitos de uso do solo daí resultantes (CE, 2015). Nesta perspectiva, a compreensão do estado das áreas protegidas e de conservação na região é importante para fornecer uma base de referência contra a qual se possa medir o progresso das metas de conservação com as quais os governos se comprometeram.

O relatório abrange os seguintes países da África Oriental e Austral: Angola, Botswana, Comores, Djibouti, Eritreia, Eswatini, Etiópia, Quénia, Lesoto, Madagáscar, Malawi, Maurícias, Moçambique, Namíbia, Ruanda, Seychelles, Somália, África do Sul, Sudão do Sul, Sudão, Tanzânia, Uganda, Zâmbia e Zimbabué (ver Figura 1.1).

\subsection{Objectivos}

Como primeira avaliação regional abrangente de áreas protegidas e de conservação para a África Oriental e Austral, o relatório sobre o Estado das Áreas Protegidas e de Conservação na África Oriental e Austral (SoPACA) tem como objectivo:

- Fornecer uma visão geral do estado das áreas protegidas e de conservação na região da África Oriental e Austral, com especial referência à Governação e Equidade das Áreas Protegidas (PAGE) e à Eficácia da Gestão das Áreas Protegidas (PAME), e os respectivos instrumentos de avaliação;

- Utilizar os dados disponíveis para fornecer uma visão geral dos progressos da região em direcção ao Objectivo 11 da Convenção sobre Diversidade Biológica (CDB), bem como a outros objectivos globais e regionais relevantes;

- Analisar e destacar questões de área protegida e conservada de particular relevância para a região, através da utilização de estudos de caso;

- Articular e aprofundar a compreensão dos sucessos e desafios-chave das áreas protegidas e de conservação que a região está a enfrentar;

- Fornecer factos e números exigidos pelos governos para tomar decisões informadas, acompanhar o progresso e fornecer orientações para a implementação do Objectivo 11 de Aichi e outros objectivos globais e regionais;

- Aumentar o perfil do valor dos sistemas regionais de gestão de dados, incluindo o Centro Regional de Recursos apoiado pelo BIOPAMA;

- Promover a aprendizagem de lições entre os países e regiões da África Oriental e Austral;

- Explorar questões relacionadas com o financiamento de áreas protegidas e de conservação e como isto afecta o PAGE e o PAME; e

- Fornecer recomendações chave para políticas e práticas.

Muitas instituições e indivíduos poderiam fazer uso do relatório. Estas incluem governos de toda a África Oriental e Austral, bem como governos parceiros e doadores, organizações e associações de base comunitária, Comunidades Económicas Regionais, empresas do sector privado, organizações de apoio, e instituições académicas e investigadores.

O relatório tem uma série de potenciais utilizações:

- Fornecer uma base de referência contra a qual o progresso possa ser acompanhado para objectivos nacionais, regionais e internacionais;

- Fornecer dados para decisões mais bem informadas;

- Para destacar inovações e potenciais vias para uma gestão sustentável das áreas protegidas na região;

- Demonstrar lacunas no conhecimento e na informação, bem como potenciais necessidades e oportunidades de investigação;

- Identificar prioridades para novas acções e acções futuras;

- Influenciar as políticas através de uma abordagem baseada no conhecimento; e

- Fornecer informação detalhada para melhores decisões dos doadores através do fornecimento de um resumo das principais prioridades regionais.

\subsection{Metodologia}

O relatório foi desenvolvido em parceria com os governos dos países atravésdos seus pontos focais BIOPAMA nomeados (ver Apêndice 1). Foram realizados workshops de planeamento para o relatório com os pontos focais nacionais BIOPAMA e outras organizações relevantes em Nairobi (13-14 de Fevereiro de 2019) e Joanesburgo (26-27 de Fevereiro de 2019). 
Figura 1.1 Mapa dos países incluídos neste relatório

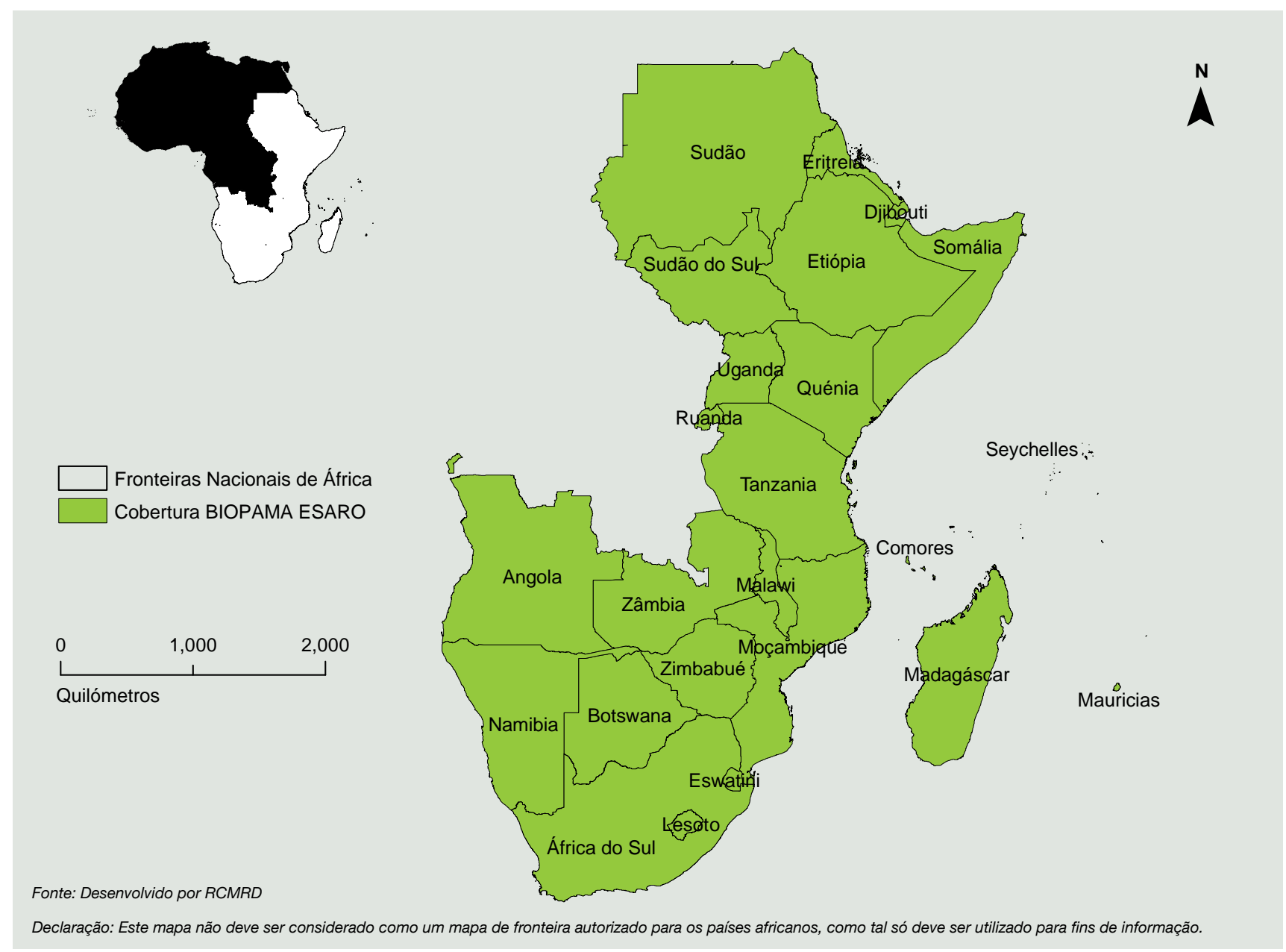

Ao longo do desenvolvimento do relatório, a equipa fez todos os esforços para considerar os relatórios nacionais e regionais existentes incluindo as Estratégias e Planos de Acção Nacionais de Biodiversidade (NBSAP) e os Relatórios Nacionais para a CDB. Os pontos focais nacionais BIOPAMA e outros peritos nacionais, regionais e globais relevantes foram contactados durante todo o processo de desenvolvimento para rever dados, informações e narrativas a fim de assegurar que as informações mais recentes e mais precisas fossem incluídas no relatório.

\subsection{Estrutura}

O relatório e os estudos de caso centrar-se-ão nos principais temas que afectam a gestão e a governação das áreas protegidas e de conservação na região da África Oriental e Austral.

A Parte I estabelece o cenário e esboça o quadro conceptual e internacional.

A Parte II fornece o contexto regional, dados e perfis dos países com o Capítulo 3 a fornecer um contexto regional, detalhando políticas e estatísticas regionais, enquanto que o Capítulo 4 se concentra numa visão regional do património da área protegida e o Capítulo 5 sobre serviços ecossistémicos. O Capítulo 6 (políticas regionais) e o Capítulo 7 (comunidades económicas regionais) fornecem um contexto regional para as estatísticas e informações nacionais para todos os 24 países abrangidos pelo presente relatório, que é delineado no Capítulo 8.

A Parte III analisa a governação, a eficácia da gestão e a inovação. O Capítulo 9 examina especificamente a governação e equidade, e inclui informação sobre governação a nível do sistema e do local, envolvimento das partes interessadas e ferramentas de avaliação relacionadas, enquanto que o Capítulo 10 se concentra na eficácia da gestão e nas ferramentas de avaliação relacionadas, e o Capítulo 11 fornece informações sobre inovações e experiências regionais, financiamento de áreas protegidas, utilização de tecnologia na gestão da conservação e conservação transfronteiriça.

A Parte IV inclui recomendações de políticas e práticas com base nos resultados do relatório. 


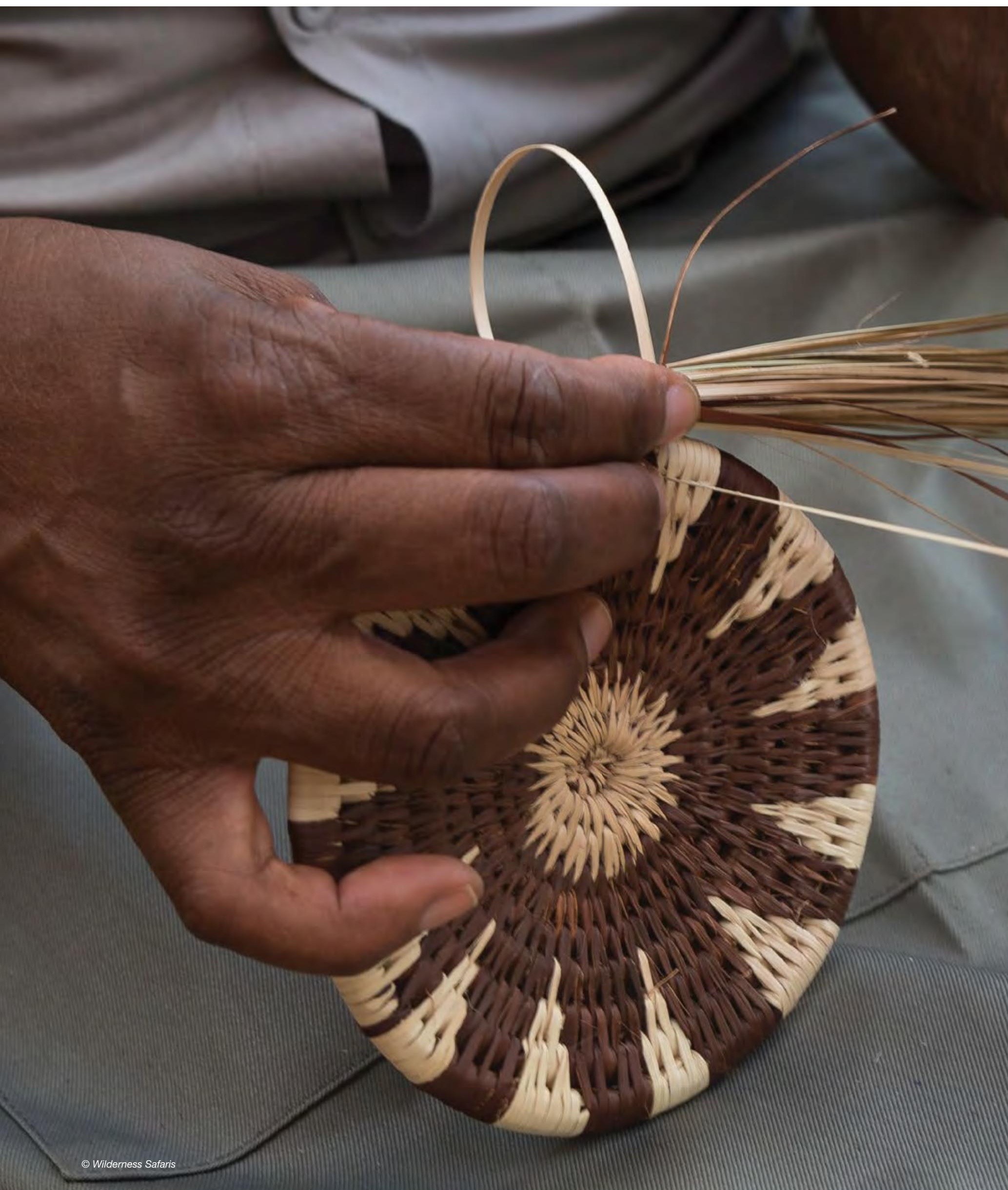




\section{Quadro conceptual e internacional}




\subsection{O que são áreas protegidas e de conservação}

As áreas protegidas são essenciais para a conservação da biodiversidade, sustentando a maioria das estratégias de conservação nacionais e regionais. Além do seu papel na manutenção dos ecossistemas naturais e na conservação das espécies, muitas contêm características importantes da história e processos da Terra, enquanto outras conservam a interacção entre a actividade humana e a natureza em paisagens de uso sustentável. Áreas protegidas maiores e mais naturais proporcionam também espaço para a evolução e futura adaptação e restauração ecológica: ambas cada vez mais importantes em condições de rápidas alterações climáticas (UNEP-WCMC et al., 2018).

As áreas protegidas são vitais para as culturas e meios de subsistência dos povos indígenas e comunidades locais, conservando lugares de valor cultural e sagrado. Proporcionam recreação e renovação, fornecem ar e água limpos, e trazem benefícios a milhões de pessoas através do turismo (UNEP-WCMC \& UICN, 2016).

A definição comumente aceite de área protegida, que será utilizada neste relatório, é "um espaço geográfico claramente definido, reconhecido, dedicado e gerido, através de meios legais ou outros meios eficazes, para alcançar a conservação a longo prazo da natureza com serviços ecossistémicos e valores culturais associados" (Dudley, 2008, p. 8).

A UICN desenvolveu um conjunto de categorias de gestão generalizada de áreas protegidas para ajudar no desenvolvimento e compreensão dos sistemas de áreas protegidas em diferentes contextos nacionais e sistemas jurídicos (Dudley, 2008). Cada país da região tem o seu próprio conjunto de tipos de áreas protegidas definidas na legislação e política, tais como parques nacionais, reservas nacionais e reservas florestais.

Estas definições variam normalmente de país para país. No entanto, podem, normalmente, corresponder às categorias da UICN, embora nem sempre haja uma correspondência "exacta" e muitas vezes nem todas as categorias estão representadas num país ou região em particular. A gama completa das categorias I - VI (ver Quadro 2.1) permite que os sistemas de áreas protegidas incluam aqueles em que as actividades humanas são estritamente limitadas, bem como aqueles em que são permitidas actividades sustentáveis.

As diferentes categorias e exemplos de gestão de áreas protegidas da UICN na região são descritas no Quadro 2.1. Na África Oriental e Austral, tem havido uma mudança ao longo do tempo, de um enfoque na Categoria II (parques nacionais) para a utilização de um leque mais amplo de categorias, embora ainda haja um número limitado de áreas protegidas das Categorias la e lb. Por conseguinte, é importante notar que duas ou mais categorias podem sobrepor-se.

As categorias de gestão de áreas protegidas são frequentemente utilizadas para fins muito para além das suas intenções originais, tais como o planeamento de áreas protegidas e sistemas de áreas protegidas, a melhoria da gestão de informação sobre áreas protegidas, a regulamentação de actividades em áreas protegidas, fornecendo a base para legislação e como instrumento de advocacia. As principais utilizações desenvolveram-se de tal forma que a UICN apoia e encoraja alguns, ao mesmo tempo que se opõem a outros (Dudley, 2008, pp. 5-6)

Qualquer categoria de áreas protegidas pode ser governada e gerida por comunidades, governos, organismos ou parcerias destes actores. Tradicionalmente, as áreas protegidas na região foram criadas pelos governos, mas nos últimos 40-50 anos muitas áreas protegidas e de

\section{Caixa 2.1 As áreas de conservação comunitária da Namíbia}

Na Namíbia, a gestão de recursos naturais baseada na comunidade (CBNRM) permite às comunidades integrar novas opções de utilização da terra com estratégias de subsistência existentes (por exemplo, criação de gado) a fim de ajudar a conservar a vida selvagem e melhorar o bem-estar dos agregados familiares rurais (Long, 2002). Existem actualmente 86 conservas comunitárias, cobrindo uma área total de 166,045 $\mathrm{km}^{2}$ (aproximadamente $20.2 \%$ do país), incorporando cerca de 227,941 pessoas (NACSO, n.d.). O relativo sucesso do CBNRM na Namíbia deve-se em grande parte a um ambiente político e legislativo favorável, que devolve a autoridade directamente em nível comunitário. Isto contrasta com o Programa de Gestão de Áreas Comunais para os Recursos Indígenas do Zimbabué (CAMPFIRE), que devolve autoridade aos conselhos distritais já estabelecidos e não directamente ao nível da comunidade. Esta abordagem foi bem sucedida nos anos 90 no Zimbabué principalmente devido ao apoio substancial dos doadores, mas desapareceu subsequentemente devido à situação política e económica do país (Snyman, 2012)

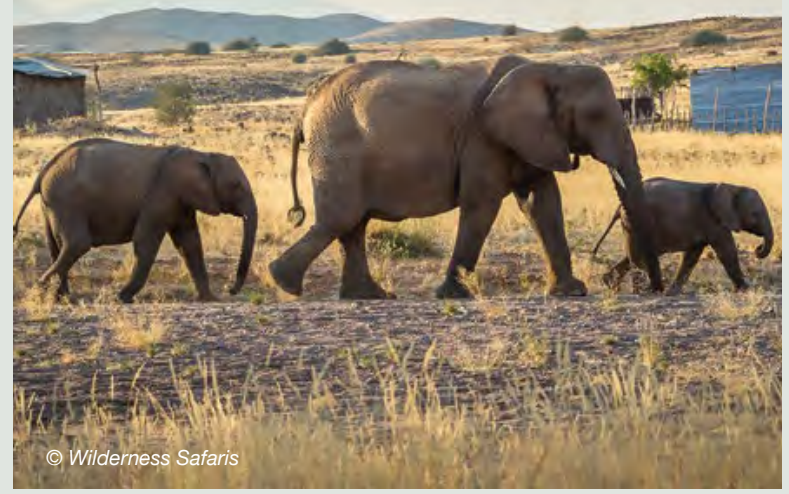


Quadro 2.1 Categorias de gestão de áreas protegidas da UICN

\begin{tabular}{|c|c|c|}
\hline Categoria & Descrição & Exemplos \\
\hline $\begin{array}{l}\text { la - Reserva } \\
\text { Natural Rígida }\end{array}$ & $\begin{array}{l}\text { Áreas estritamente protegidas que são reservadas para proteger } \\
\text { a biodiversidade e também possivelmente características } \\
\text { geológicas/geomorfológicas, onde a visitação, utilização e } \\
\text { impactos humanos são estritamente controlados e limitados } \\
\text { para assegurar a protecção dos valores de conservação. } \\
\text { Existem poucos exemplos desta categoria na região, embora } \\
\text { alguns parques nacionais tenham áreas restritas dentro deles, } \\
\text { em vez de serem totalmente categorizados como Categoria la. }\end{array}$ & $\begin{array}{l}\text { Tsingy de Bermaraha, Tsaratanana e Betampona } \\
\text { (Madagáscar) } \\
\text { Aldabra Atoll, Primo, La Digue e Aride (Seychelles) }\end{array}$ \\
\hline lb - Área silvestre & $\begin{array}{l}\text { Áreas protegidas que são geralmente grandes áreas não } \\
\text { modificadas ou ligeiramente modificadas, mantendo o } \\
\text { seu carácter natural e influência sem habitações humanas } \\
\text { permanentes ou significativas, que são protegidas e geridas } \\
\text { para preservar a sua condição natural. }\end{array}$ & $\begin{array}{l}\text { Moremi, Khutse e Reservas de caça do Kalahari } \\
\text { Central (Botswana) } \\
\text { Colina de Koko, Mamboya e Reservas Florestais de } \\
\text { lkwamba (Tanzânia) }\end{array}$ \\
\hline $\begin{array}{l}\text { II - Parque } \\
\text { Nacional }\end{array}$ & $\begin{array}{l}\text { Grandes áreas naturais ou próximas de áreas naturais } \\
\text { reservadas para proteger processos ecológicos em grande } \\
\text { escala, juntamente com o complemento de espécies e } \\
\text { ecossistemas característicos da área, que também fornecem } \\
\text { uma base para oportunidades ambientais e culturais } \\
\text { compatíveis, espirituais, científicas, educacionais, recreativas, } \\
\text { e de visitantes. Esta é a categoria de gestão mais comum } \\
\text { na região. }\end{array}$ & $\begin{array}{l}\text { Parc Marin de Mohéli (Comores) } \\
\text { Amboseli e Masai Mara (Reserva Nacional) (Quénia) } \\
\text { Niassa (Reserva Nacional) (Moçambique) } \\
\text { Volcans (Ruanda) } \\
\text { Kruger (África do Sul) } \\
\text { Serengeti (Tanzânia) } \\
\text { Bwindi Impenetrable (Uganda) } \\
\text { Kafue (Zâmbia) }\end{array}$ \\
\hline $\begin{array}{l}\text { III - Monumento } \\
\text { ou Característica } \\
\text { Natural }\end{array}$ & $\begin{array}{l}\text { As áreas protegidas reservadas para proteger um monumento } \\
\text { natural específico, que pode ser um relevo, um monte marinho, } \\
\text { uma caverna submarina, ou uma característica geológica, } \\
\text { como uma caverna ou mesmo uma característica viva, como } \\
\text { um bosque antigo. }\end{array}$ & $\begin{array}{l}\text { Parque Nacional Cataratas Vitória (Zimbabué) } \\
\text { Popa Game Park e Gross Barmen Hot Springs } \\
\text { (Namíbia) } \\
\text { Toro-Semliki, Karuma, Bugungu e uma série de outras } \\
\text { reservas de vida selvagem (Uganda) }\end{array}$ \\
\hline $\begin{array}{l}\text { IV - Área de } \\
\text { Gestão de Habitat/ } \\
\text { Espécies }\end{array}$ & $\begin{array}{l}\text { O objectivo é proteger determinadas espécies ou habitats e } \\
\text { a gestão reflecte esta prioridade. }\end{array}$ & $\begin{array}{l}\text { Reserva Parcial Namibe (Angola) } \\
\text { Santuário de Caça Maun (Botswana) } \\
\text { Gash-Setit Reserva Natural da Vida Selvagem (Eritreia) } \\
\text { Reservas de vida selvagem de Alledeghi e Bale (Etiópia) } \\
\text { Parque Nacional do Sehlabathebe (Lesoto) } \\
\text { Reservas de vida selvagem de Majete e Nkhotakota } \\
\text { (Malawi) } \\
\text { Reservas de Pesca de Poudre d'Or e Trou d'Eau Douce } \\
\text { (Maurícias) } \\
\text { Reserva de caça de Sabaloka (Sudão) }\end{array}$ \\
\hline $\begin{array}{l}\text { V - Paisagem } \\
\text { Protegida/ } \\
\text { Paisagem } \\
\text { Marítima }\end{array}$ & $\begin{array}{l}\text { Áreas protegidas onde a interacção das pessoas e da natureza } \\
\text { ao longo do tempo produziu uma área de carácter distinto com } \\
\text { valor significativo, ecológico, biológico, cultural e paisagístico, } \\
\text { e onde a salvaguarda da integridade desta interacção é vital } \\
\text { para proteger e sustentar a área e os seus valores associados } \\
\text { de conservação da natureza e outros valores. }\end{array}$ & $\begin{array}{l}\text { Iles Musha e Maskhali (Djibouti) } \\
\text { Libhetse Nature Reserve (Eswatini) } \\
\text { numerosas áreas no Madagáscar } \\
\text { Imatong (Sudão do Sul) }\end{array}$ \\
\hline $\begin{array}{l}\text { VI - Área protegida } \\
\text { com utilização } \\
\text { sustentável dos } \\
\text { recursos naturais }\end{array}$ & $\begin{array}{l}\text { Estas são áreas protegidas que conservam ecossistemas } \\
\text { e habitats juntamente com os valores culturais e sistemas } \\
\text { tradicionais de gestão de recursos naturais associados. São } \\
\text { geralmente grandes, com a maior parte da área em condições } \\
\text { naturais, onde uma proporção está sob gestão sustentável dos } \\
\text { recursos naturais e onde a utilização não industrial de baixo } \\
\text { nível dos recursos naturais compatíveis com a conservação } \\
\text { da natureza é vista como um dos principais objectivos da área. }\end{array}$ & $\begin{array}{l}\text { Vale de Dabus, Jikao, Tedo, Omo West e numerosas } \\
\text { outras áreas de caça controlada (Etiópia) } \\
\text { Reservas naturais Beacon, Booby Island, Etoile e } \\
\text { Mamelles (Seychelles) } \\
\text { Áreas Safari Matetsi, Sapi e Hurungwe (Zimbabué) }\end{array}$ \\
\hline
\end{tabular}


conservação foram estabelecidas por comunidades locais, povos indígenas, instituições de caridade ambiental, indivíduos privados, empresas e outros. A conservação baseada na comunidade tornou-se mais prevalecente e, em alguns países como a Namíbia e o Quénia, a legislação concede às comunidades o direito de gerir e beneficiar directamente destas conservas (ver Caixa 2.1). Dotadas de numerosos parques e reservas nacionais emblemáticos (tais como o Masai, Mara, Serengeti, Kruger e Vulcões), a região tem importantes atrativos para o turismo de vida selvagem, obtendo grandes receitas para os governos nacionais e subnacionais. Enquanto na África do Sul e na Namíbia, as áreas privadas de conservação compreendem uma proporção significativa da rede de áreas protegidas, noutros países da região, a propriedade privada de terras de conservação não está legislada, e toda a vida selvagem pertence ao Estado. Algumas questões, tais como o financiamento de actividades de gestão de áreas protegidas, levaram a algumas abordagens inovadoras com os governos a devolver a gestão às ONG. As parcerias público-privadas, particularmente na área do turismo da vida selvagem, tornaram-se mais prevalecentes em muitos países.

\subsection{Convenção sobre a Diversidade Biológica}

O Plano Estratégico para a Biodiversidade 2011-2020 foi adoptado pela Conferência das Partes da CBD na sua $10^{\mathrm{a}}$ reunião em Nagoya, Japão (CBD, 2010a). O plano traça uma abordagem estratégica global para a implementação da CDB, e inclui uma visão e missão, bem como objectivos e metas estratégicas, conhecidos como os Alvos de Biodiversidade de Aichi. Os cinco objectivos estratégicos (A a E) são sustentados por 20 metas. Todos os países da região são signatários da CDB e, portanto, obrigados a informar a CDB sobre os progressos das metas.

BIOPAMA concentra-se no Objectivo 11 de Aichi, no âmbito do Objectivo Estratégico C, que exorta as Partes a atingir:

- Até 2020 , pelo menos $17 \%$ das áreas de águas terrestres e interiores e $10 \%$ das áreas costeiras e marinhas, especialmente as áreas de particular importância para a biodiversidade e os serviços ecossistémicos, são conservadas através de sistemas de áreas protegidas eficaz e equitativamente geridos, ecologicamente representativos e bem conectados e de outras medidas de conservação eficazes baseadas em áreas, e integradas na paisagem e paisagens marinhas mais vastas (CBD, 2010a, p. 9).

\subsection{Outras medidas de conservação eficazes baseadas na área (OECMs)}

Embora as OECMs tenham feito parte do Objectivo 11 de Aichi desde 2011, o termo foi devidamente clarificado em 2018 quando a CDB definiu as OECMs como sendo OECMs:

[...] uma área geograficamente definida que não é uma Área Protegida, que é governada e gerida de forma a alcançar resultados positivos e sustentáveis a longo prazo para a conservação in situ da biodiversidade ${ }^{3}$, com funções e serviços ecossistémicos associados e, quando aplicável, valores culturais, espirituais, sócio-económicos e outros valores localmente relevantes (CDB, 2018, p. 1).

Para ser considerada OECM, uma área deve ter resultados positivos em termos de biodiversidade, independentemente dos seus objectivos primários de gestão, e deve demonstrar acções de gestão ligadas à garantia da conservação da biodiversidade (Task Force UICN-WCPA sobre OECMs 2019). Isto contrasta com uma área protegida, onde o objectivo primário deve ser a conservação. No âmbito da Iniciativa Planeta Protegido, a UNEP-WCMC mantém agora a Base de Dados Mundial sobre Outras Medidas de Conservação Efectivas em Áreas (WD-OECM) (UNEP-WCMC, 2019a). A WD-OECM pode ser combinada com a Base de Dados Mundial sobre Áreas Protegidas (WDPA) para fornecer uma imagem mais abrangente da rede mundial de conservação.

É provável que as OECM possam reforçar significativamente o património de conservação reconhecido de muitos países (Donald et al., 2019), incluindo em África, onde existem várias áreas de conservação que não se enquadram nas definições tradicionais da categoria, tais como bases militares ou áreas de conservação pela comunidade, utilizadas principalmente para a pecuária. Muito poucos países iniciaram o processo de avaliação de potenciais OECMs. Em resposta, a Task Force da UICN-WCPA (Comissão Mundial sobre Áreas Protegidas) sobre OECMs elaborou um Relatório Técnico para o Reconhecimento e Comunicação de OECMs (Task Force da UICN-WCPA sobre OECMs, 2019). O quadro para uma avaliação das OECMs em África, por exemplo, foi conduzido por Candice Stevens e Daniel Marnewick na África do Sul (ver Caixa 2.2).

\subsection{A Lista Verde de Áreas Protegidas e de Conservação da UICN}

A Lista Verde da UICN de Áreas Protegidas e de Conservação (UICN Green List Standard) é uma nova norma internacional de sustentabilidade para aferir as áreas protegidas e de conservação que são simultaneamente eficazes e equitativas. Formalmente aprovada pelo Conselho da UICN no final de 2017, foi mandatada para uma maior implementação pelos membros da UICN em todo o mundo (Hockings et al., 2019; UICN \& WCPA, 2017).

A Norma da Lista Verde da UICN descreve um conjunto de 17 critérios globalmente aplicáveis, categorizados em quatro componentes, acompanhados de 50 indicadores, para uma conservação bem sucedida a nível do local, em áreas protegidas e de conservação. Os sítios aderem voluntariamente à Lista Verde da UICN comprometendo-se a alcançar esta norma, e são certificados uma vez demonstrado o cumprimento da norma. A Norma da Lista Verde da UICN aborda quatro componentes: boa governação, boa concepção e planeamento, gestão eficaz, e resultados de conservação bem sucedidos (ver Quadro 2.2) (UICN \& WCPA, 2017). 


\section{Caixa 2.2 Outras medidas de conservação eficazes baseadas na área (OECM) em África}

Embora a identificação de OECMs só tenha começado a ganhar impulso no final da estratégia da CDB 2011-2020, foi sugerido que as OECMs contribuirão significativamente para o actual Objectivo 11, seu herdeiro e para o SDG 15, e que serão um quadro importante para a conservação de áreas fora das áreas protegidas formais. Isto ajudará os países africanos a salvaguardar e beneficiar da biodiversidade destas áreas.

As OECMs fornecerão um foco para o envolvimento e fortalecimento de uma vasta gama de partes interessadas na conservação basWeada em áreas, incluindo sectores agrícolas, empresas e comunidades locais e povos indígenas, que estão a contribuir para a conservação baseada em áreas fora do património da área protegida formal. Isto é especialmente verdade para África, onde a maioria das áreas naturais são propriedade de proprietários de terras comunitárias ou detentores de direitos. Além disso, as OECMs proporcionam uma plataforma ideal para incluir e desenvolver actividades económicas mais diversificadas e financiamento da biodiversidade, particularmente em torno da economia da vida selvagem.

A Equipa de Trabalho da UICN-WCPA (Comissão Mundial sobre Áreas Protegidas) sobre OECMs publicou um Relatório Técnico para o Reconhecimento e Comunicação de OECMs (Equipa de Trabalho da UICN-WCPA sobre OECMs, 2019). Um projecto de ferramenta de avaliação OECM, e um projecto de metodologia para identificar e avaliar OECMs a nível nacional, estão a serdesenvolvidos em conjunto com o Relatório Técnico para ajudar na identificação de OECMs.
Em parceria com a Equipa de Trabalho OECM da UICN, e várias partes interessadas governamentais e ONG, Daniel Marnewick e Candice Stevens desenvolveram e testaram a metodologia de avaliação nacional sul-africana. Os resultados da Área de Estudo de Caso OECM na Região da Biosfera de Kruger a Canyons na África do Sul indicam uma série de oportunidades para fundir OECMs com o quadro de gestão da biodiversidade existente, para identificar oportunidades para reforçar outros quadros nacionais, e para criar sinergias com a economia da vida selvagem para reforçar os quadros de gestão e governação associados, e os resultados da conservação da biodiversidade (Jonas \& Sandwith, 2019). Utilizando a metodologia de avaliação OECM da África do Sul, Daniel e Candice apoiaram a Equipa de Trabalho OECM da UICN para desenvolver um projecto de metodologia global de avaliação OECM.

As OECMs fornecerão o quadro para continuar a desenvolver e apoiar oportunidades económicas legítimas, diversas e sustentáveis e financiamento da biodiversidade que se fundem com as economias rurais, produzindo simultaneamente resultados de conservação da biodiversidade in situ, particularmente em torno da economia da vida selvagem.

Contribuição de Daniel Marnewick, Presidente da Comunidade $K B A$ e representante da Comunidade KBA em África, e do Ponto Focal Regional KBA África.

\section{Quadro 2.2 Norma da Lista Verde da UICN - Componentes e critérios}

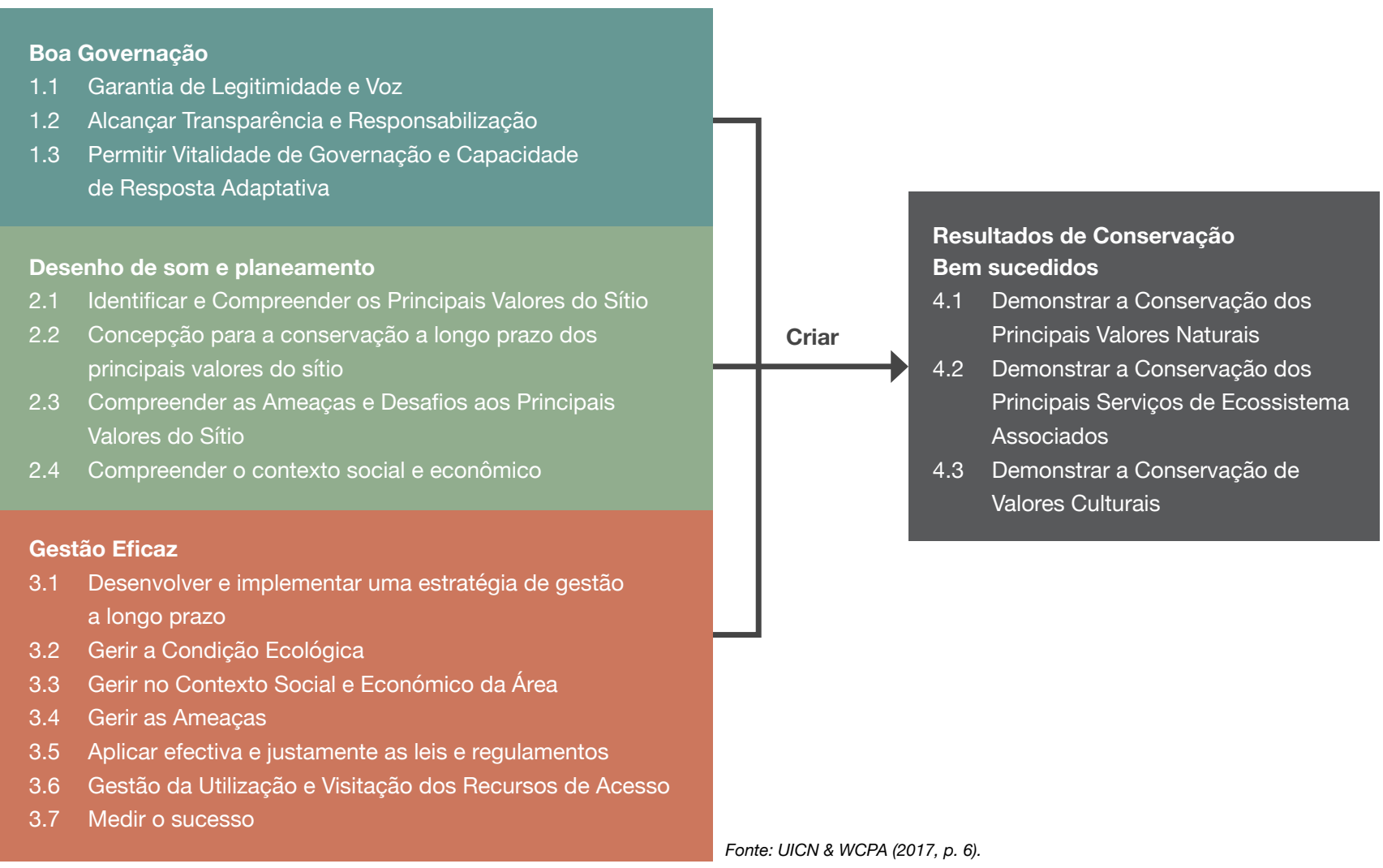


A Norma da Lista Verde da UICN foi concebida para ser globalmente consistente e localmente relevante, requisitos que descrevem colectivamente os esforços necessários para alcançar plenamente a Norma. Um sítio da "Lista Verde" é aquele que é actualmente avaliado como alcançando todos os critérios, em todos os quatro componentes. A Norma é adaptada a cada país ou região onde é adoptada. Para cada critério da Norma, um conjunto de Indicadores Genéricos e Meios de Verificação associados são mantidos pela UICN. Estes indicadores genéricos podem ser adaptados ao contexto de cada jurisdição participante para reflectir as características e circunstâncias regionais e locais em que as áreas protegidas e de conservação operam.

\section{Caixa 2.3 Áreas Chave de Biodiversidade (KBAs) em África}

Até à data, seis países em África criaram Grupos de Coordenação Nacional KBA, cinco dos quais completaram ou estão em processo de identificação de KBAs. Outros 11 países estão interessados em iniciar o processo. Em muitos países africanos, os KBAs serão o único mapeamento espacial a informar a priorização da biodiversidade, pelo que é imperativo continuar a identificar os KBAs em África.

A identificação dos KBAs e o seu reconhecimento na política nacional é importante para a conservação nacional e o planeamento do desenvolvimento. Em primeiro lugar, os países podem orientar melhor os seus investimentos em conservação, tais como na expansão de áreas protegidas e de conservação. Em segundo lugar, o planeamento do desenvolvimento pode evitar impactos negativos nos sítios globalmente importantes da região. E, em terceiro lugar, tal mapa ajudaria as empresas a evitar o elevado custo de planeamento de desenvolvimentos em áreas biologicamente sensíveis e o subsequente conflito com interesses de conservação que se segue.

É fornecida uma extensa orientação global para que os países identifiquem os KBAs. Estas incluem o Padrão Global para a Identificação de Áreas Chave de Biodiversidade (UICN, 2016a), as Directrizes para a utilização de Um Padrão Global para a Identificação de Áreas Chave de Biodiversidade (KBA Standards and Appeals Committee, 2019) e o Processo de Proposta de Áreas Chave de Biodiversidade: Orientações sobre Proposta, Revisão, Nomeação e Confirmação de Sítios (Secretariado KBA, 2019).

Contribuição de Daniel Marnewick (Presidente da Comunidade $K B A$ e representante da Comunidade KBA em África, e Ponto Focal Regional KBA África).

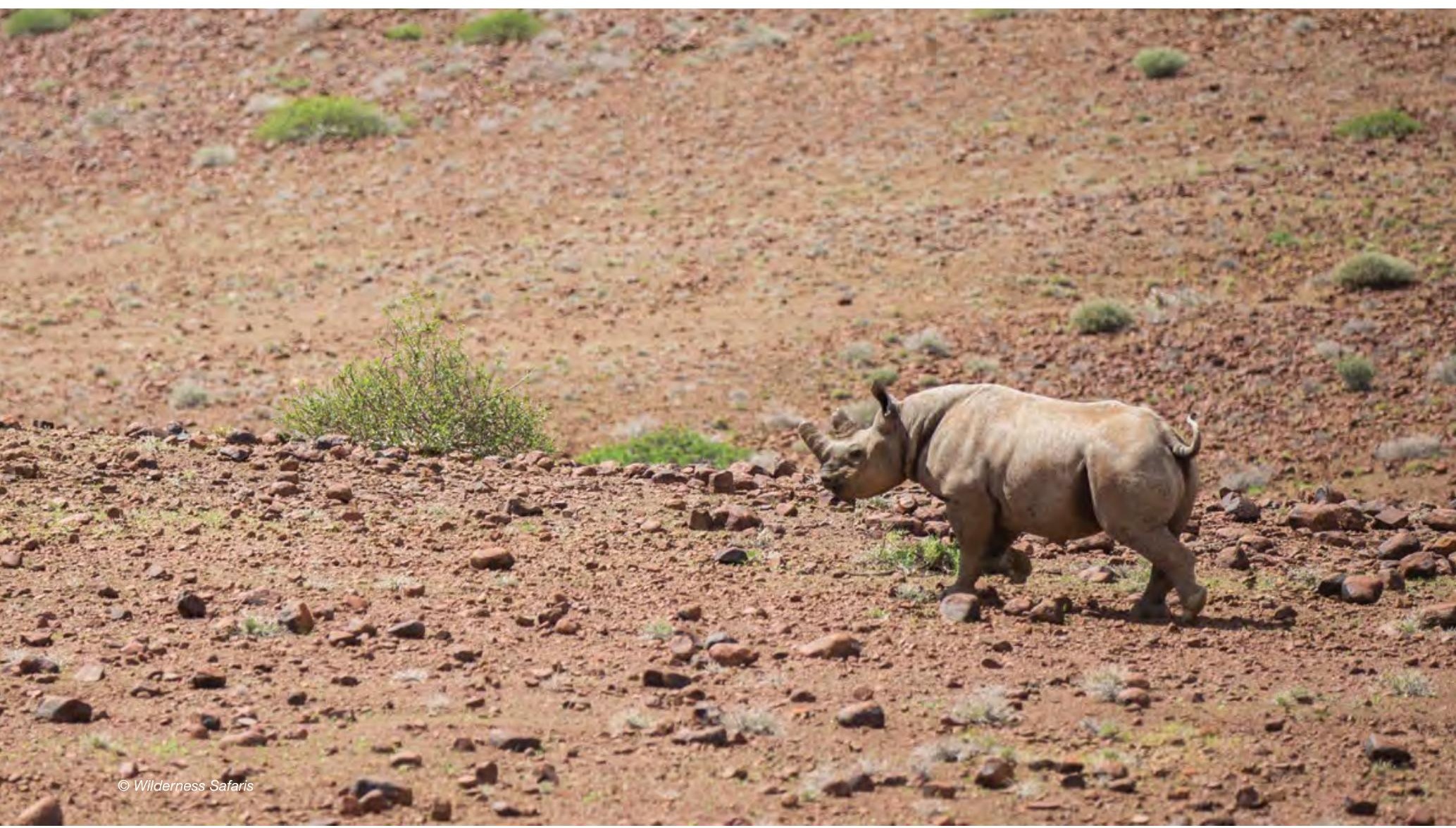




\subsection{Designações internacionais para as áreas protegidas e de conservação}

Políticas nacionais e regionais e convenções internacionais foram implementadas para promover a expansão da rede mundial de áreas protegidas, levando a uma diversificação das estratégias, tipos e designações de áreas protegidas. Como resultado, muitas áreas são protegidas por mais do que uma convenção, instrumento legal, ou outro meio eficaz. Esta sobreposição pode ser benéfica se a estrutura legal significar que é conferida protecção adicional através de cada designação, mas pode resultar numa falta de clareza em torno dos regimes de governação e gestão de determinados locais (Deguignet et al., 2017). As designações globais não só confirmam o significado global destas áreas - também apoiam a protecção, gestão, promoção e utilização sustentável destes locais, por exemplo, atraindo turismo adicional, recursos financeiros e técnicos, e apoio político e público. Algumas destas áreas globalmente designadas são também sítios transfronteiriços, partilhados por dois ou mais países (ver secção 4.5). As três designações globais para tais sítios são Reservas do Homem e da Biosfera da UNESCO, Sítios Património Mundial da UNESCO e Sítios de Ramsar (Zonas Húmidas de Importância Internacional) (UNESCO, 1971; 1972; 2019a; 2019b). Cada um tem critérios claros para a listagem de sítios.

\section{Caixa 2.4 Centro de Recursos Regional BIOPAMA (RRH)}

O RRH é o observatório regional da África Oriental e Austral no programa BIOPAMA. É uma plataforma única para facilitar o intercâmbio de dados/informações entre decisores e gestores de áreas protegidas e de conservação na região.

A visão do RRH é ser um centro de recursos líder que apoie (local, nacional e regional) a tomada de decisões e governação eficazes sobre áreas protegidas e biodiversidade e a sua ligação aos objectivos de desenvolvimento sustentável.

O RRH é central no trabalho do BIOPAMA e apoiará a recolha de dados, análise, monitorização e relatórios, desenvolvendo as capacidades do pessoal e das organizações para gerir os dados e fornecer orientação política para uma melhor tomada de decisões sobre a conservação da biodiversidade. Alguns dos produtos que serão preparados através do RRH incluem mapas de histórias, infografias, perfis nacionais e regionais, relatórios, directrizes, ferramentas, notícias e eventos, histórias de sucesso e dados resumidos de conjuntos de dados globais.

Um componente importante do Centro Regional de Recursos é o Sistema de Informação de Referência Regional (RRIS), ${ }^{*}$ que reúne ciência e conhecimento, tornando-o facilmente acessível a nível regional, nacional e local. O RRIS apoia a elaboração de políticas sobre os temas interligados da biodiversidade, conservação e desenvolvimento, através das seguintes ferramentas:

1. Ferramenta de acompanhamento - indicadores de acompanhamento para políticas e objectivos de conservação;

2. Ferramentas analíticas - inclui uma ferramenta web MARXAN ${ }^{4}$ e dados de Observação da Terra;

3. Módulo de Governação de Áreas Protegidas e Equidade ligações a várias ferramentas de governação, social e de avaliação da equidade;
4. Módulo Eficácia da Gestão de Áreas Protegidas - inclui as ferramentas e tipos de avaliações e ligações para a Ferramenta Eficácia da Gestão Integrada, GD-PAME; e

5. Painel de bordo de áreas protegidas - cobre informação básica sobre áreas protegidas e biodiversidade.

O objectivo do RRIS é criar um sistema de gestão de conteúdos baseado na comunidade de utilizadores que seja relevante para a política e apoie a tomada de decisões. Centrado em áreas protegidas e de conservação, o RRIS irá integrar informação de fornecedores de dados, ao mesmo tempo que fornece ligações não só com conjuntos de dados globais (tais como WDPA, DOPA e GD-PAME), mas também com conjuntos de dados regionais e nacionais. A Figura 2.1 mostra o fluxo de dados através destes vários canais. O RRIS e o Centro Regional de Recursos permitirá aos interessados na região o acesso a dados de conservação relevantes a nível nacional e regional

Em resumo, $\mathrm{RRH}$ :

- Funciona como uma plataforma para facilitar o intercâmbio de dados/informações entre decisores e gestores de áreas protegidas e apoia as prioridades regionais para produtos de apoio à decisão;

- É um repositório/hub para dados e análises para apoiar a elaboração de relatórios, monitorização e tomada de decisões, personalizado para a região;

- Fornece ferramentas analíticas, produtos e outros serviços à região;

- Promove a criação de redes de peritos, ligações a parceiros-chave que trabalham em questões relevantes; e

- Fornece informação sobre oportunidades de formação e financiamento e identifica prioridades de acção para o financiamento.

* Para mais informações, ver http://biopama-rris.rcmrd.org/ https://esahub.rcmrd.org/

4 Marxan é um software de planeamento de conservação de acesso aberto. Fornece apoio à decisão para uma série de problemas de planeamento de conservação, incluindo a concepção de novos sistemas de reserva, relatórios sobre o desempenho dos sistemas de reserva existentes, e o desenvolvimento de planos de zoneamento de uso múltiplo para a gestão dos recursos naturais. 


\subsection{Outras áreas prioritárias para a conservação}

Para além das áreas globalmente designadas, foram identificadas várias outras classificações de áreas prioritárias para a conservação sob a égide das Áreas Chave de Biodiversidade (KBAs) (ver também Caixa 2.3). Estes são sítios que contribuem significativamente para a persistência global da biodiversidade e são identificados utilizando um conjunto padrão de critérios aplicáveis a plantas, animais e ecossistemas em ambientes terrestres, de águas interiores e marinhos (UICN, 2016a). As classificações abaixo são todos os subconjuntos de KBAs (Stattersfield et al., 1998).

- Sítios da Aliança para a Extinção Zero (AZE): um programa lançado globalmente em 2005, a AZE foi criada para identificar, conservar e salvaguardar eficazmente os sítios mais importantes para prevenir a extinção de espécies globais (Secretariado da AZE, 2019) .

- Áreas de Aves Endémicas (EBA): áreas que englobam as sobreposições de áreas de reprodução de espécies de alcance restrito, de modo a que as áreas completas de duas ou mais espécies de alcance restrito sejam inteiramente incluídas dentro dos limites da EBA (BirdLife International, 2019a) .

- Áreas Importantes de Aves e Biodiversidade (IBAs): KBAs identificadas para aves utilizando critérios acordados internacionalmente aplicados localmente pelos parceiros e peritos da BirdLife (UICN, 2016a).

\subsection{Monitorização das áreas protegidas e de conservação - Uma visão geral}

A Base de Dados Mundial sobre Áreas Protegidas (WDPA) é um produto conjunto do Programa das Nações Unidas para o Ambiente e da UICN, e é gerida pelo UNEP-WCMC ao abrigo da Iniciativa Planeta Protegido. Os dados no âmbito desta iniciativa são compilados e geridos em colaboração com governos, organizações não-governamentais, actores comunitários e privados, academias e outros intervenientes da indústria. O WDPA e o WD-OECM são actualizados mensalmente e disponibilizados em linha através do website Planeta Protegido, onde os dados podem ser visualizados e descarregados. É também publicado um relatório bianual sobre o Planeta Protegido, que se apresenta agora sob a forma de um relatório digital ao vivo sobre o Planeta Protegido. ${ }^{5}$

Os dados da Iniciativa Planeta Protegido são utilizados para relatar à CDB os progressos no sentido dos Objectivos de Biodiversidade de Aichi (particularmente o Objectivo 11) e às Nações Unidas (ONU) para acompanhar os progressos no sentido dos Objectivos de Desenvolvimento Sustentável de 2030, alguns indicadoresda Plataforma Intergovernamental Ciência-Política sobre Biodiversidade e Serviços de Ecossistema (IPBES), e outras avaliações e relatórios internacionais.

A Iniciativa Planeta Protegido baseia-se em actualizações regulares de informação dos fornecedores de dados. Os sítios nomeados como áreas protegidas devem obedecer à definição da UICN (ver secção 2.1). Cada área protegida deve ser comunicada à base de dados em formato SIG, por exemplo, shapefile (ponto ou polígono).

O WD-OECM ${ }^{6}$ tem uma estrutura semelhante à da WDPA e as bases de dados são totalmente interoperáveis. Para mais orientações sobre como submeter dados ao WD-OECM, ver secção 2 do manual do utilizador (UNEP-WCMC \& UICN, 2019a).

A Base de Dados Global sobre a Eficácia da Gestão de Áreas Protegidas (GD-PAME) também é abrangida pela Iniciativa Planeta Protegido. É a base de dados global mais abrangente de avaliações da eficácia da gestão de áreas protegidas e está ligada à WDPA. A GD-PAME é uma base de dados pesquisável que inclui dados sobre avaliações PAME submetidos por uma vasta gama de organizações governamentais e não governamentais ao UNEP-WCMC e é actualizada mensalmente. Até 2019 , mais de 28.000 avaliações de 169 países, utilizando 69 metodologias diferentes, foram registadas na base de dados. Existem, contudo, muito poucas ligações a avaliações reais ou aos relatórios relacionados. Alguns dos benefícios para os países ao submeterem as suas informações de avaliação PAME à base de dados incluem:

1. Trazer dados nacionais para um único local;

2. Informar as práticas de gestão adaptativa;

3. Dar prioridade à atribuição de recursos; e

4. Relatórios contra objectivos de conservação.

O Observatório Digital de Áreas Protegidas (DOPA) é mantido pelo Centro Comum de Investigação da Comissão Europeia (JRC). É um conjunto de serviços e aplicações web que pode ser utilizado principalmente para avaliar, monitorizar, reportar e possivelmente para prever o estado e as pressões sobre as áreas protegidas a múltiplas escalas. Os dados, indicadores, mapas e ferramentas fornecidos por DOPA são relevantes para os utilizadores finais, incluindo decisores políticos, agências de financiamento, agências e gestores de áreas protegidas, investigadores e a CDB. A informação pode ser utilizada, por exemplo, para apoiar o planeamento espacial, a atribuição de recursos, o desenvolvimento e gestão de áreas protegidas, e a elaboração de relatórios nacionais e internacionais. Utilizando conjuntos de dados de referência globais, DOPA apoia avaliações globais e fornece uma vasta gama de indicadores consistentes e comparáveis a nível de país, ecorregião e área protegida (Bastin et al., 2017; Dubois et al., 2016; EC JRC/DOPA, 2019a).

Os Observatórios Regionais de Áreas Protegidas e Biodiversidade foram estabelecidos no âmbito do programa BIOPAMA. Apoiam a recolha de dados, análise, monitorização e relatórios, bem como o desenvolvimento das capacidades do pessoal e das organizações para gerir os dados, e fornecem orientações políticas para uma melhor tomada de decisões sobre a conservação da biodiversidade. Um dos principais sistemas fornecidos no âmbito do sistema do observatório regional é o Sistema Regional de Informação de Referência (RRIS) ou o Centro Regional de Recursos (RRH), que para a África Oriental e Austral é acolhido pelo Centro Regional de Cartografia de Recursos para o Desenvolvimento (RCMRD) no Quénia (ver Caixa 2.4 e Figura 2.1). 


\section{Figura 2.1 Sistemas de gestão de dados globais e regionais para áreas protegidas}

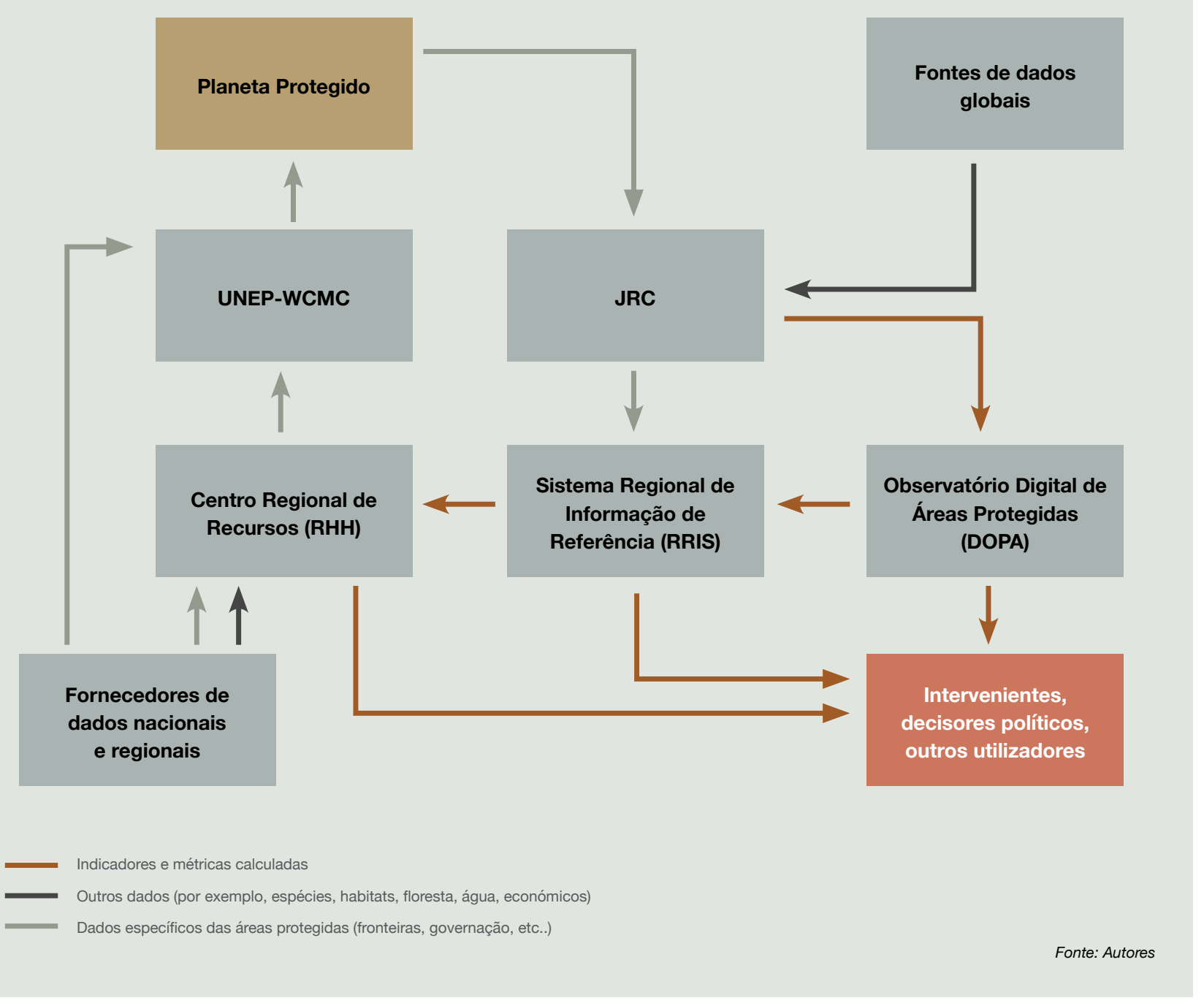

\subsection{Uma imagem global das áreas protegidas}

Há indicações de todo o mundo de stress crescente sobre o ambiente com as principais causas, incluindo o aumento da população e da industrialização, ambas contribuindo para as alterações climáticas. Um dos principais objectivos das áreas protegidas é a conservação da natureza, eliminando, minimizando, ou reduzindo as pressões e ameaças humanas que operam dentro dos seus limites.

Uma série de iniciativas ou mecanismos medem e avaliam as pressões e ameaças a nível global e regional. A teledetecção pode ser utilizada para medir algumas ameaças, enquanto outras requerem estudos in situ a fim de se obter uma compreensão abrangente do que está a afectar as áreas protegidas e de conservação. A UICN e a Parceria de Medidas de Conservação (CMP) produziram um conjunto de classificações padrão de ameaças directas queos conservacionistas encontram em todo o mundo e das acções de conservação que podem empreender para combater estas ameaças (TNC, n.d.)
A Lista Vermelha de Espécies Ameaçadas da IUCN ${ }^{\top M}$ utiliza este esquema de classificação para assegurar a comparabilidade entre espécies e habitats. A Lista Vermelha da UICN fornece informação sobre o alcance, tamanho da população, habitat e ecologia, uso e/ou comércio, ameaças, e acções de conservação que ajudarão a informar as decisões de conservação necessárias.

Além disso, muitas avaliações PAME (ver Capítulo 5) incluem também uma avaliação sistemática e comparável das ameaças aos valores das áreas protegidas e/ou taxas-chave, em muitos casos utilizando o esquema de classificação padrão. Isto proporciona uma base para esforços mais coordenados e investimentos direccionados para reduzir as ameaças e melhorar os resultados de conservação em áreas protegidas. A Ferramenta de Gestão Integrada Eficaz (IMET) desenvolvida através de BIOPAMA também analisa o contexto da área protegida e conservada a fim de determinar potenciais ameaças futuras (BIOPAMA \& UICN, 2016. 
Um estudo para ter uma visão global das ameaças enfrentadas pelas áreas protegidas terrestres a nível global e por bioma analisou dados recolhidos como parte das avaliações PAME em 1,961 áreas protegidas de 149 países, utilizando três metodologias diferentes: o Management Effectiveness Tracking Tool (METT); a avaliação do World Heritage Outlook; e o protocolo de monitorização da BirdLife International IBA (Schulze et al., 2018). O estudo descobriu que a caça insustentável era a ameaça mais comummente reportada e ocorreu em $61 \%$ de todas as áreas protegidas, seguida de perturbações de actividades recreativas que ocorreram em $55 \%$, e de modificações naturais do sistema devido a incêndios ou à sua supressão em $49 \%$. O número de ameaças comunicadas foi menor nas áreas protegidas com maior afastamento, maior controlo da corrupção e menor desenvolvimento humano (Schulze et al., 2018). Nos países em desenvolvimento, as principais ameaças relatadas estavam ligadas à sobre-exploração da extracção de recursos, enquanto os impactos negativos de actividades recreativas insustentáveis dominavam nos países desenvolvidos (Schulze et al., 2018). Os resultados mostraram que muitas das ameaças mais graves às áreas protegidas são difíceis de monitorizar com teledetecção, e salientam a importância de dados in situ sobre ameaças para informar a implementação de uma conservação mais eficaz da biodiversidade na área global protegida (Schulze et al., 2018). É de notar que esta análise incluiu dados até 2014, após o que a caça furtiva em grande escala para o comércio ilegal da vida selvagem global surgiu como uma grande ameaça à biodiversidade em toda a África. O Quadro 2.3 resume os resultados para o bioma Afrotropical que compreende a maior parte da África Subsaariana.

Num outro estudo, uma análise do desempenho das áreas protegidas africanas, com enfoque nos leões e nas suas presas, mostrou que a caça furtiva de animais selvagens era a ameaça mais grave para os leões e a vida selvagem em geral (Lindsey et al., 2017).

Para além da caça furtiva de carne de animais selvagens, considera-se também que as principais ameaças directas à conservação em África foram: perda e fragmentação de habitat; sobrepesca; tráfico ilegal de vida selvagem; e espécies invasoras alienígenas. Uma análise da Comissão Europeia (CE, 2015) concluiu que os principais motores destas ameaças na região eram:

- o crescimento populacional e a pobreza;

- má governação;

- propriedade inadequada da terra e direitos de recursos locais;

- conflitos nacionais e regionais;

- indiferença política e falta de consciência;

- alterações climáticas;

- doenças endémicas e emergentes; e

- conflito entre homem e vida selvagem.

Quadro 2.3 Três ameaças mais frequentemente relatadas no bioma Afrotropical

\begin{tabular}{l|l|r|l|l|l}
\hline Reino & Grupo de Biomas & Sítios (N) & $\begin{array}{l}\text { Ameaça mais } \\
\text { frequentemente } \\
\text { documentada }\end{array}$ & $\begin{array}{l}\text { Segunda ameaça } \\
\text { mais frequentemente } \\
\text { documentada }\end{array}$ & $\begin{array}{l}\text { Terceira ameaça mais } \\
\text { frequentemente } \\
\text { documentada }\end{array}$ \\
\hline Afrotropical & Florestas tropicais & 150 & $\begin{array}{l}\text { Caça e recolha de } \\
\text { animais terrestres }\end{array}$ & $\begin{array}{l}\text { Recolha de plantas } \\
\text { terrestres }\end{array}$ & $\begin{array}{l}\text { Exploração madeireira e } \\
\text { colheita de madeira }\end{array}$ \\
\hline Afrotropical & $\begin{array}{l}\text { Savanas, arbustos e } \\
\text { prados }\end{array}$ & 22 & $\begin{array}{l}\text { Espécies/doenças } \\
\text { invasivas não nativas/ } \\
\text { exóticas }\end{array}$ & $\begin{array}{l}\text { Fogo e supressão de } \\
\text { fogo }\end{array}$ & Actividades recreativas \\
\hline Afrotropical & Manguezais & 7 & Pesca e colheita & Caça e recolha & $\begin{array}{l}\text { Recolha de plantas } \\
\text { terrestres }\end{array}$ \\
\hline
\end{tabular}

Fonte: (Schulze et al., 2018, Quadro 1, p. 7/10). 


$$
\text { मींतs }
$$



(1)

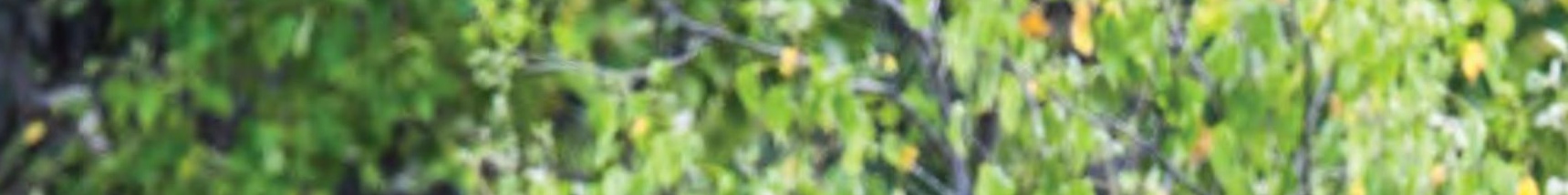

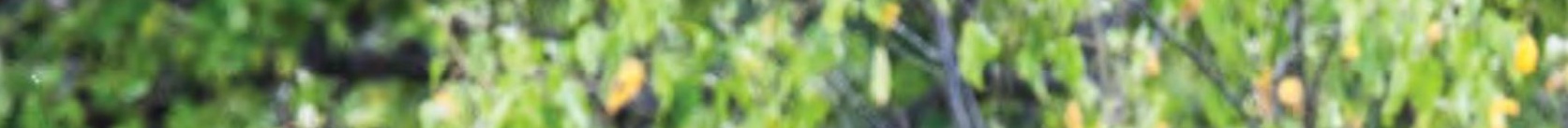

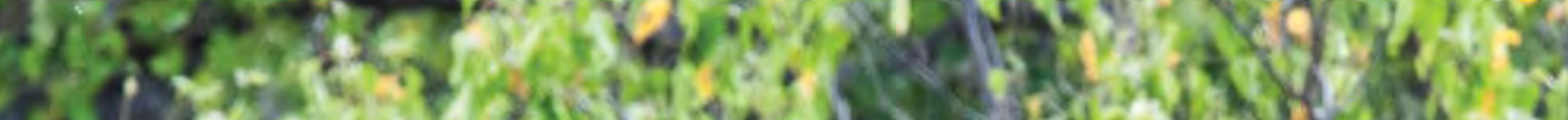
S.m. (4)

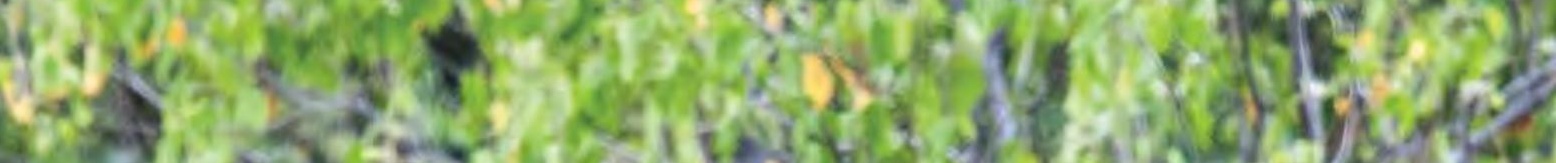

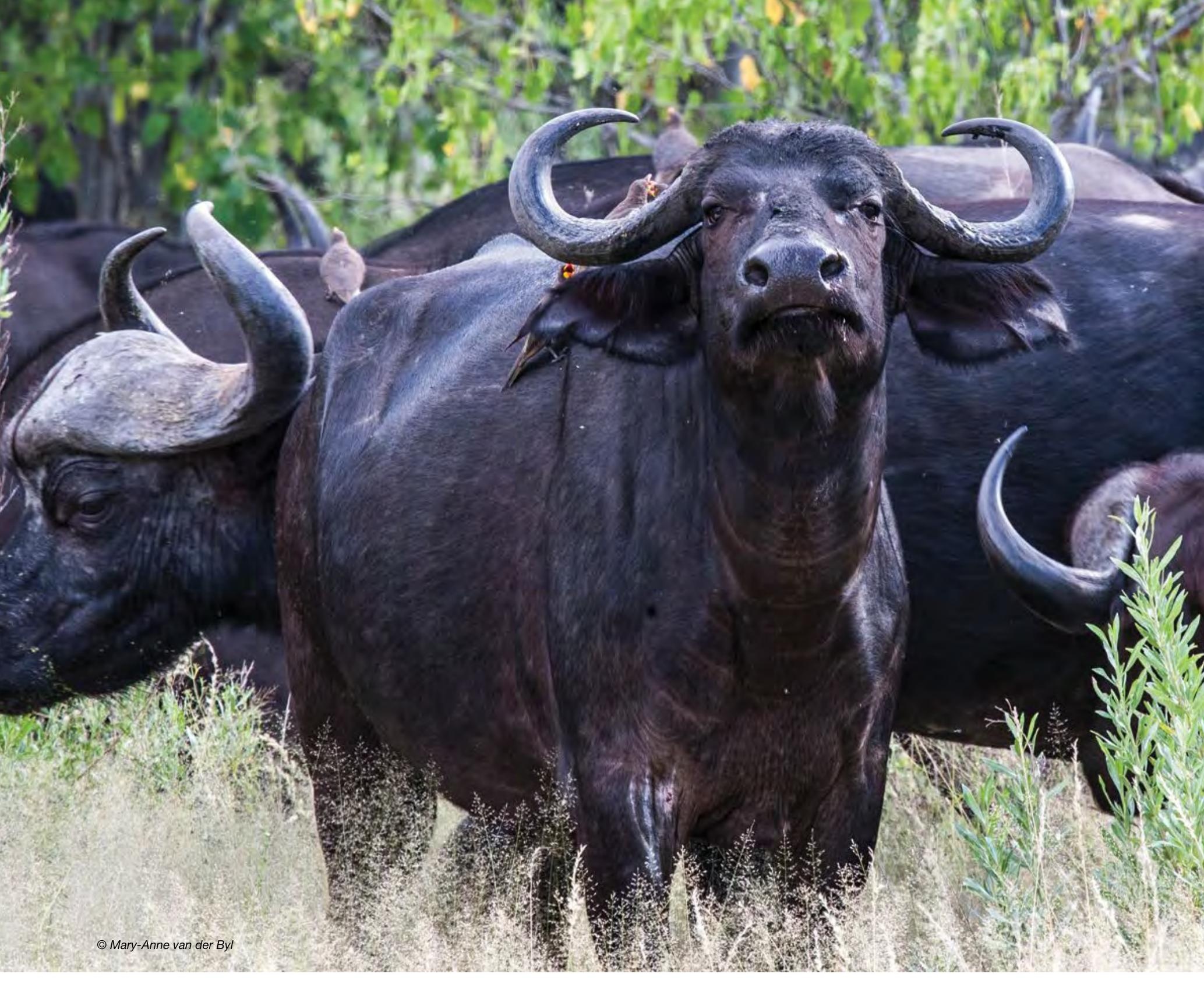

() Mary-Anne van der By 
Parte II - Contexto regional, dados e perfis dos países

\section{Visão geral da região ${ }^{7}$}

\footnotetext{
Esta secção é adaptada do relatório da UE Larger Than Elephants (CE, 2015) e do relatório de avaliação regional do IPBES sobre biodiversidade e serviços ecossistémicos para Africa (IPBES, 2018).
} 


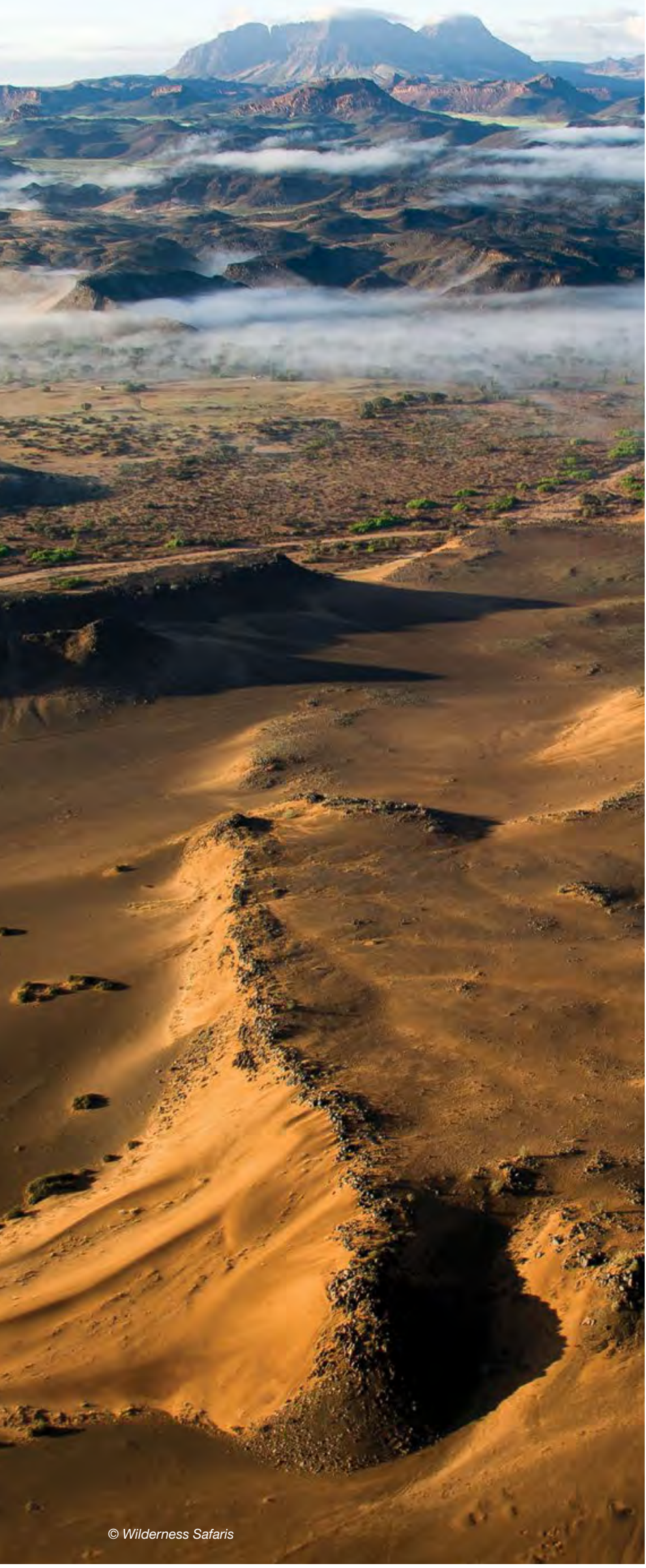

Esta secção fornece o contexto deste relatório e uma visão geral do estado das áreas protegidas e de conservação na região da África Oriental e Austral como um todo. Sempre que existem dados disponíveis, foram realizadas análises completas. Apresenta informação sobre as instituições formadas para responder às necessidades e prioridades específicas das sub-regiões, incluindo políticas regionais e instrumentos jurídicos. Abordagens inovadoras que informam e demonstram sucesso são destacadas e recomendadas.

A região da África Oriental e Austral abrange 24 países, incluindo as ilhas do Oceano Índico Ocidental. É sede de quatro Comunidades Económicas Regionais: a Comunidade da África Oriental (EAC); a Comissão do Oceano Índico (IOC), a Autoridade Intergovernamental para o Desenvolvimento (IGAD) e a Comunidade para o Desenvolvimento da África Austral (SADC). A região da África Oriental e Austral é vasta, cobrindo aproximadamente 16 milhões de $\mathrm{km}^{2}$, uma área equivalente a aproximadamente metade da massa terrestre africana. É uma região geograficamente diversificada que se estende desde o Mar Vermelho no norte até ao Cabo da Boa Esperança no sul, bem como as ilhas do Oceano Índico Ocidental. A região inclui numerosos biomas diferentes, incluindo savana, prados, terras secas e desérticas, floresta tropical e subtropical seca e húmida, zonas húmidas, e o único bioma fynbos da África do Sul.

As diferenças subregionais têm implicações na gestão e governação de áreas protegidas e de conservação. Entre os países, existe uma diversidade de necessidades e prioridades para o desenvolvimento, incluindo a conservação sustentável, tais como a revisão da legislação e políticas para permitir uma conservação mais inclusiva. Áreas ainda em conflito, como é o caso do Sul do Sudão e da Somália, podem exigir um maior enfoque na aplicação da lei, o que terá impacto nas prioridades e orçamentos de gestão. Os países encontram-se também em fases muito diferentes de conservação sustentável, com o Botswana, Quénia, Namíbia, Ruanda, África do Sul, Tanzânia e Uganda a terem políticas e processos mais avançados relacionados com a gestão e governação, enquanto a Eritreia, Somália, Sudão do Sul e Sudão ainda se encontram nas fases iniciais de desenvolvimento de políticas, estabelecimento de áreas de conservação e políticas de governação. As ilhas do Oceano Índico Ocidental têm oportunidades e desafios únicos.

Em 2019, a população de África atingiu 1,32 mil milhões (Worldometer, n.d.), representando $16,7 \%$ da população mundial total, com uma densidade populacional para o continente de 44 pessoas por $\mathrm{km}^{2}$. No mesmo ano, a população da África Oriental e Austral era de 512 milhões, representando $6,6 \%$ da população mundial, com uma densidade populacional de 32 pessoas por $\mathrm{km}^{2}$. Este número varia muito na região, tendo a Namíbia uma das densidades populacionais mais baixas (três pessoas por $\mathrm{km}^{2}$ ) e o Ruanda uma das mais altas (512 pessoas por $\mathrm{km}^{2}$ ). As estimativas populacionais sugerem que o crescimento permanecerá forte nas próximas décadas, de tal forma que, até 2050 , uma em cada quatro pessoas no mundo será africana. Um forte crescimento populacional apresenta desafios que precisam de ser eficazmente geridos (IPBES, 2018), juntamente com elevados níveis de pobreza e desemprego. Algumas das ameaças regionais à conservação estão directamente relacionadas com o crescimento populacional e a competição pela terra (CE, 2015; IPBES, 2018). 


\section{1 África Oriental}

A região da África Oriental marca os pontos mais altos e mais baixos do continente e inclui uma série de habitats, desde florestas tropicais e recifes costeiros até desertos. Algumas das características únicas são a fauna e flora montana das terras altas da Etiópia, incluindo o endémico e ameaçado Lobo Etíope (Canis simensis), as montanhas tropicais glaciares do Ruwenzori e Kilimanjaro, as escarpas florestadas do Vale do Rift Albertine, os grandes lagos de África, o único Corno de África, as maiores migrações de vida selvagem das savanas e importantes florestas de relíquias das costas da África Oriental. A região inclui também algumas das mais famosas áreas protegidas do continente, incluindo a Reserva Nacional Masai Mara e o Parque Nacional do Serengeti. É o lar de chimpanzés (Pan troglodytes) e da maior população mundial de leões (Panthera leo) (Tanzânia).

O lago Tanganica é o lago de água doce mais longo do mundo e acolhe 250 espécies diferentes de peixes ciclídeos, dos quais $98 \%$ são endémicos. O Lago Vitória mostra menos endemismo mas é uma pesca importante para as populações locais em três países. ${ }^{8}$

Semelhante a outras regiões tropicais, a extensão das florestas tropicais de planície e de montanha e das florestas secas na África Oriental tem vindo a diminuir. Nas florestas costeiras da África Oriental, a perda deve-se principalmente à conversão em terras agrícolas, principalmente através da mudança do cultivo. Na Tanzânia, por exemplo, a cobertura florestal costeira diminuiu mais de um terço, de 420,765 hectares em 1990 para 358,333 hectares em 2000, e para 273,709 hectares em 2007. No entanto, a taxa de desflorestação tem sido mais baixa dentro das reservas tanzanianas: $0.2 \%$ e $0.4 \%$ por ano durante $1990-2000$ e 2000-2007, respectivamente, em comparação com $1.3 \%$ e $0.6 \%$ por ano fora das reservas durante os mesmos períodos (Burgess et al., 2017; Godoy et al., 2012).

\subsection{Madagáscar e as ilhas do Oceano Índico Ocidental}

A ilha de Madagáscar tem uma grande riqueza de espécies e níveis extraordinários de endemismo, particularmente vistos em lémures, tenrecs e camaleões. Há mais espécies vegetais em Madagáscar do que em toda a bacia do Congo. As florestas do norte e leste são húmidas, com as do oeste e sul a serem cada vez mais áridas. A ilha constitui uma região de importância de conservação desproporcionada, com elevados níveis de endemismo e uma elevada proporção de espécies ameaçadas de extinção. As ilhas mais pequenas das Comores, Maurícias e Seychelles são também de excepcional importância de conservação como parte do hotspot da biodiversidade de Madagáscar e das Ilhas do Oceano Índico, com muitas espécies e ecossistemas endémicos e ameaçados, tais como as Seychelles white-eye (Zosterops modestus).
As florestas tropicais orientais malgaxes diminuíram $1.69 \%$ anualmente de $1990-2000$ e $1.08 \%$ de 2000-2010 (Mayaux et al., 2013), e estima-se que $97 \%$ das florestas ocidentais secas malgaxes tenham sido destruídas desde a colonização humana (WWF, 2017), com uma taxa anual de desflorestação de $0.75 \%$ de $1990-2000$ (Gorenflo et al., 2011).

\section{3 África Austral}

Os 10 países da África Austral compreendem a sub-região mais rica e mais desenvolvida da África Subsaariana, embora desigual. Exibem também uma grande diversidade de espécies e habitats.

As maravilhas naturais na África Austral incluem as grandes salinas Etosha, as Cataratas Vitória e o Rio Zambeze, e o único Delta interior do Okavango. Os desertos do Kalahari e do Namibe são ambos grandes desertos, sendo o Namibe considerado como o deserto mais antigo do mundo. O Deserto de Karoo na África do Sul tem a flora mais rica do mundo de plantas suculentas e o Fynbos shrubland forma um elemento importante da Região Florística do Cabo na África do Sul, que é um dos seis reinos florais reconhecidos do mundo, com mais de 9.000 espécies de plantas vasculares, das quais $69 \%$ são endémicas. A costa oriental da África Austral, abaixo da Grande Escarpa, é outro importante centro de endemismo vegetal.

O lago Malawi/Niassa/Nyasa tem 570-km de comprimento e é o lago mais meridional do Vale do Rift, contendo mais espécies de peixes do que qualquer outro lago na terra, incluindo mais de 1,000 espécies endémicas de peixes ciclídeos e muitos moluscos endémicos.

A África Austral contém mais elefantes e rinocerontes do que o resto do continente, bem como algumas das mais antigas e maiores reservas e parques em África. Os países da África Austral têm uma longa história de conservação da vida selvagem e de gestão da caça e têm sido pioneiros na utilização de recursos naturais baseados na comunidade, conservação transfronteiriça e outras abordagens inovadoras de conservação. O primeiro Parque da Paz surgiu na África Austral em 1990 e a Área de Conservação Transfronteiriça do Lubombo, estabelecida em 2000, foi a primeira ACTF marinha em África (ver secção 4.5 para mais informações sobre ACTFs).

8 Para mais informações sobre esta importante área, por favor ver: https://www.iucn.org/sites/dev/files/content/documents/2018/policy_brief_english_final.pdf. 


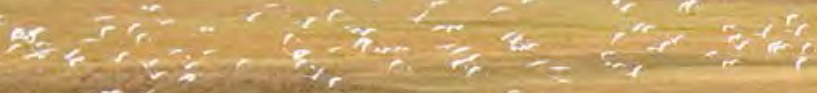

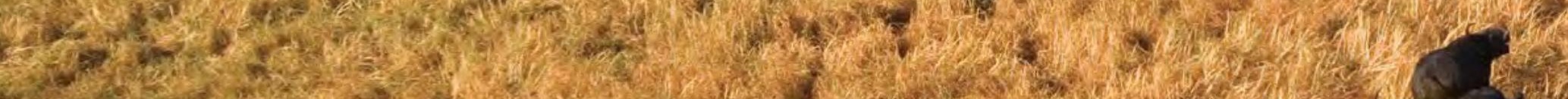

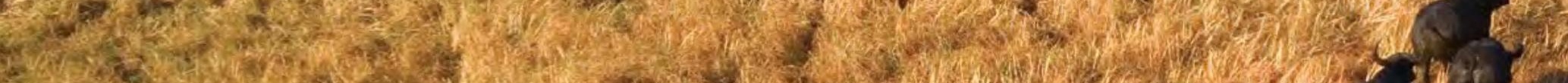

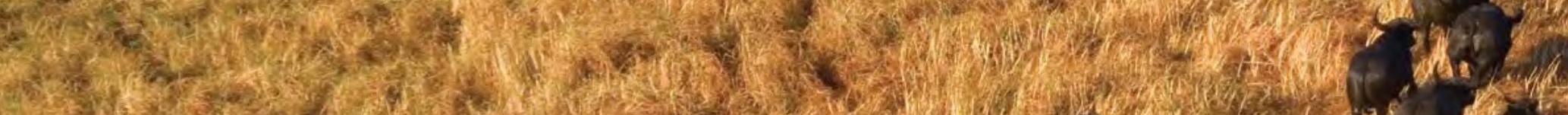
2.7.- - a C.

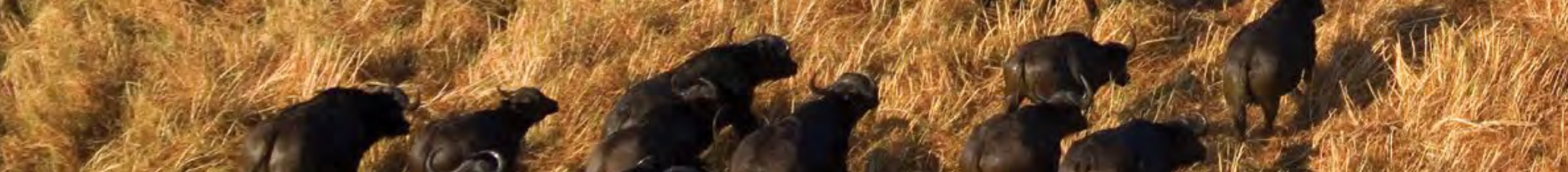

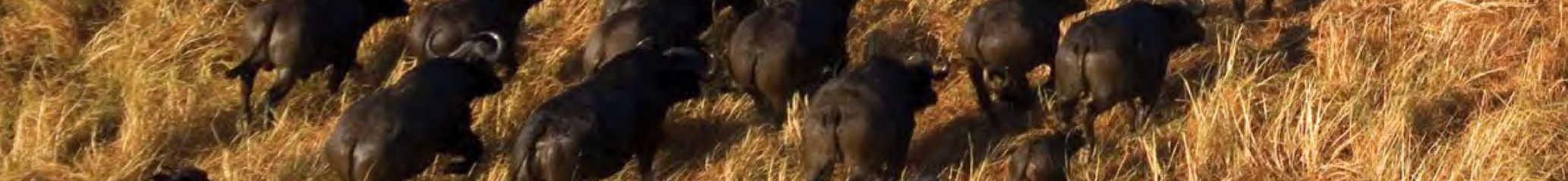

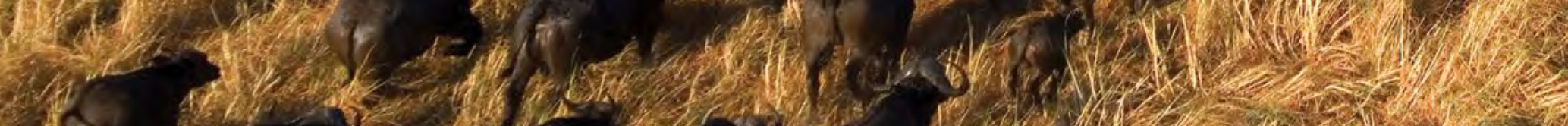
H.

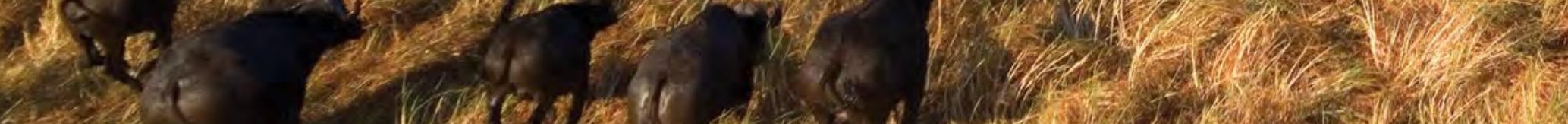

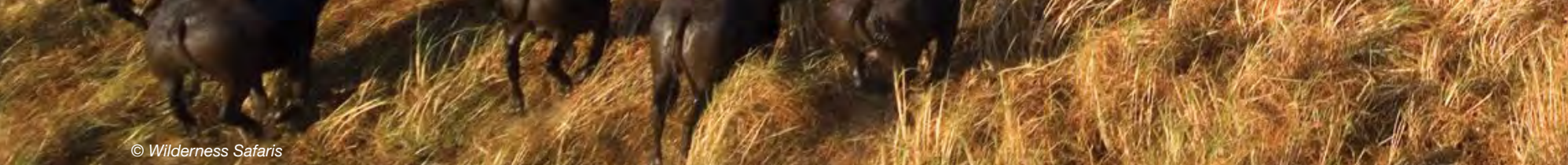




\section{4 Áreas protegidas e de conservação na África Oriental e Austral}


Figura 4.1 Áreas protegidas e de conservação na África Oriental e Austral

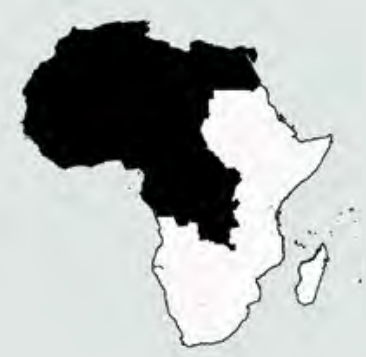

ÁREAS PROTEGIDAS DA ÁFRICA ORIENTAL \& AUSTRAL BIOPAMA

\section{Áreas protegidas \\ Fronteiras Nacionais da África}

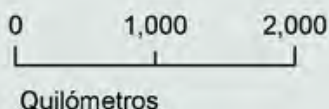

\section{Espécies endémicas do país}

522 Anfíbios dos quais

247 estão ameaçados (47.3\%)

365 Mamíferos dos quais 178 estão ameaçados (48.8\%)

306 Aves das quais

104 estão ameaçadas (34.0\%)

24 Tubarões e raias dos quais

6 estão ameaçados (25\%)

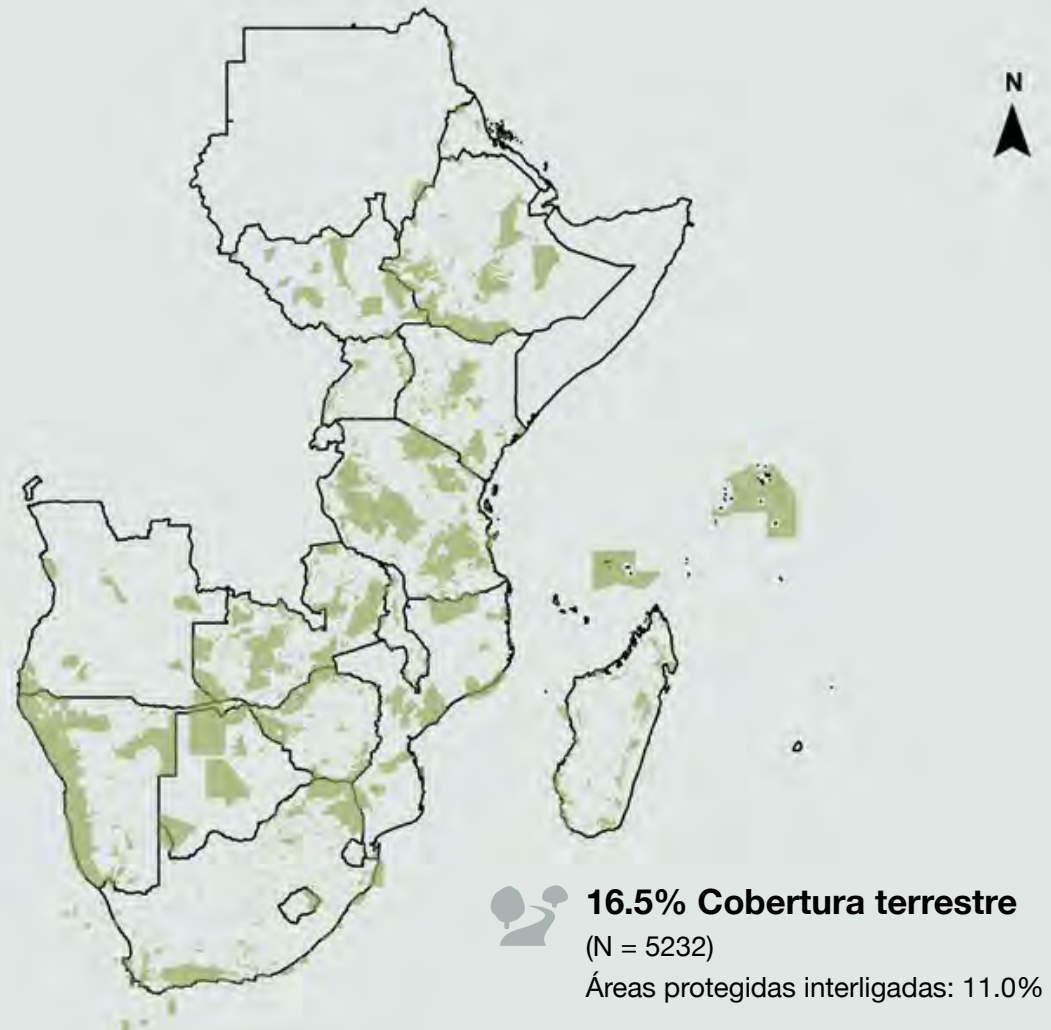

5.6\% Cobertura Marinha $(\mathrm{N}=411)$
Estatísticas regionais de ocupação do solo

88.1\% Terra natural ${ }^{\star}$ da qual $22.1 \%$ está protegida

$32.0 \%$ Cobertura florestal da qual $27.6 \%$ está protegida

$1.8 \%$ Águas interiores das quais $11.3 \%$ está protegida

53.1 Pg Estoque total de carbono do qual $21.9 \%$ está protegido

$5.3 \%$ Cobertura urbana e de terras de cultivo da superfície total da área protegida

Dados introduzidos:

- Global Administrative Unit Layers (GAUL). Revision 2015. Available at: http://www.fao.org/geonetwork/srv/en/metadata.show?id=12691

- Exclusive Economic Zones (EEZ) v9 (2016-10-21). Available at: http://www.marineregions.org/downloads.php

- UNEP-WCMC \& IUCN (2019). Protected Planet: The World Database on Protected Areas (WDPA). [On-line]. Data for May 2019 used for PA connectivity and regional land cover

statistics; and data for September 2019 used for PA coverage and the map. Cambridge, UK: UNEP-WCMC and IUCN. Available at: www.protectedplanet.net

- JRC-VITO-IIASA (2019). Copernicus Global 100m Land Cover map for the year 2015. Available at: https://land.copernicus.eu/global/products/lc

- IUCN (2019). IUCN Red List of Threatened Species. Derived from Quadro 8a. Version 2019.1. Available at: https://www.iucnredlist.org/resources/summary-statistics Available, V., Garcia Bendito, E., Delli, G., Mandrici, A., Battistella, L., Dubois, G. (2019). Global map of total carbon stock. [On-line]. Available at: https://dopa.jrc.ec.europa.eu/sites/ default/files/dopa_explorer_4-total_carbon.zip [10/2019]. Ispra, Italy.

* Categoria de terra natural inclui todas as classes excepto terra de cultivo (classe 40) e urbana (classe 50))

Fonte: EC JRC/DOPA, 2019a. 


\subsection{Dados estatísticos de base}

Para este relatório, foram retirados dados da WDPA, bem como informações que estão disponíveis nos relatórios de cada país para a CDB, com destaque para o Quinto e Sexto Relatórios Nacionais elaborados entre 2014 e 2019. Alguns relatórios de países incluem informação sobre áreas de conservação e protegidas.

A África Oriental e Austral tem 5,232 áreas protegidas cobrindo $2,120,112 \mathrm{~km}^{2}$ da terra e $473,815 \mathrm{~km}^{2}$ do oceano (UNEP-WCMC \& UICN, 2019b). A figura 4.1 apresenta o mapa destas áreas, bem como uma visão geral das espécies ameaçadas e da representação da cobertura terrestre nessas áreas protegidas. Os dados foram calculados utilizando a informação espacial disponível no WDPA, em combinação com uma série de outros conjuntos de dados autorizados. Contudo, em alguns casos, os limites das áreas protegidas na WDPA não estão actualizados ou completos, o que pode afectar a exactidão das estatísticas a nível nacional. Por exemplo, no caso da Somália, 21 áreas protegidas foram comunicadas à WDPA, mas nenhuma definiu limites poligonais, impedindo a geração de um mapa ou aplicando técnicas de análise espacial.

Como região, a África Oriental e Austral está perto de atingir o objectivo de cobertura do Objectivo 11 de Aichi com 16,54\% da área terrestre protegida em 5,232 áreas protegidas, cobrindo mais de 2,1 milhões km² (UNEP-WCMC \& UICN, 2019b). Como pode ser visto na Figura 4.2, pelo menos nove países da região excederam os objectivos de cobertura de Aichi para protecção terrestre, de acordo com os seus relatórios nacionais. No entanto, existe uma grande variabilidade na região, com $42 \%$ dos países a permanecerem abaixo dos $10 \%$ de cobertura terrestre com base no WDPA, enquanto que este valor pode chegar aos $33 \%$ com base em estatísticas nacionais.
O valor da conectividade apresentado na Figura 4.2 (barras azuis) considera a disposição espacial, dimensão e cobertura das áreas protegidas e representa a área de terra que pode ser alcançada dentro da rede de áreas protegidas por organismos com uma distância média de dispersão de 10 km (representativa de muitos vertebrados terrestres). ${ }^{9}$ Da mesma forma, a conectividade varia muito na região, com menos de $1 \%$ no Lesoto e mais de $36 \%$ nas Seychelles.

A África Oriental e Austral está a meio caminho de satisfazer o elemento de cobertura da área marinha protegida do Objectivo 11 de Aichi, com 5,60\% da área marinha protegida em 411 áreas costeiras e marinhas protegidas cobrindo $473,815 \mathrm{~km}^{2}$ (UNEP-WCMC \& UICN, 2019b). Como mostra a Figura 4.2, Seychelles, África do Sul e Sudão excederam a cobertura do Objectivo de Aichi para protecção marinha e costeira, de acordo com o WDPA.

As categorias de gestão da UICN para a maioria das áreas protegidas na África Oriental e Austral não foram comunicadas ao WDPA (Figura 4.4), embora com base nos dados disponíveis, as Categorias II, IV e VI são mais comummente utilizadas. A discrepância deve-se em parte à falta de relatórios, bem como à forma como as outras categorias são entendidas em África, onde o conceito histórico de "conservação de fortalezas", centrado na protecção formal dos recursos naturais através da formação de parques nacionais, tem sido um paradigma dominante. É provável que haja um aumento nas outras categorias à medida que a política e a legislação para gerir estas abordagens à conservação sejam desenvolvidas e implementadas em toda a região. Alguns países, tais como a África do Sul, com mais de 1,500 áreas protegidas, não as classificaram especificamente de acordo com as categorias de gestão da UICN.

\section{Figura 4.2 Cobertura de áreas protegidas terrestres na África Oriental e Austral}

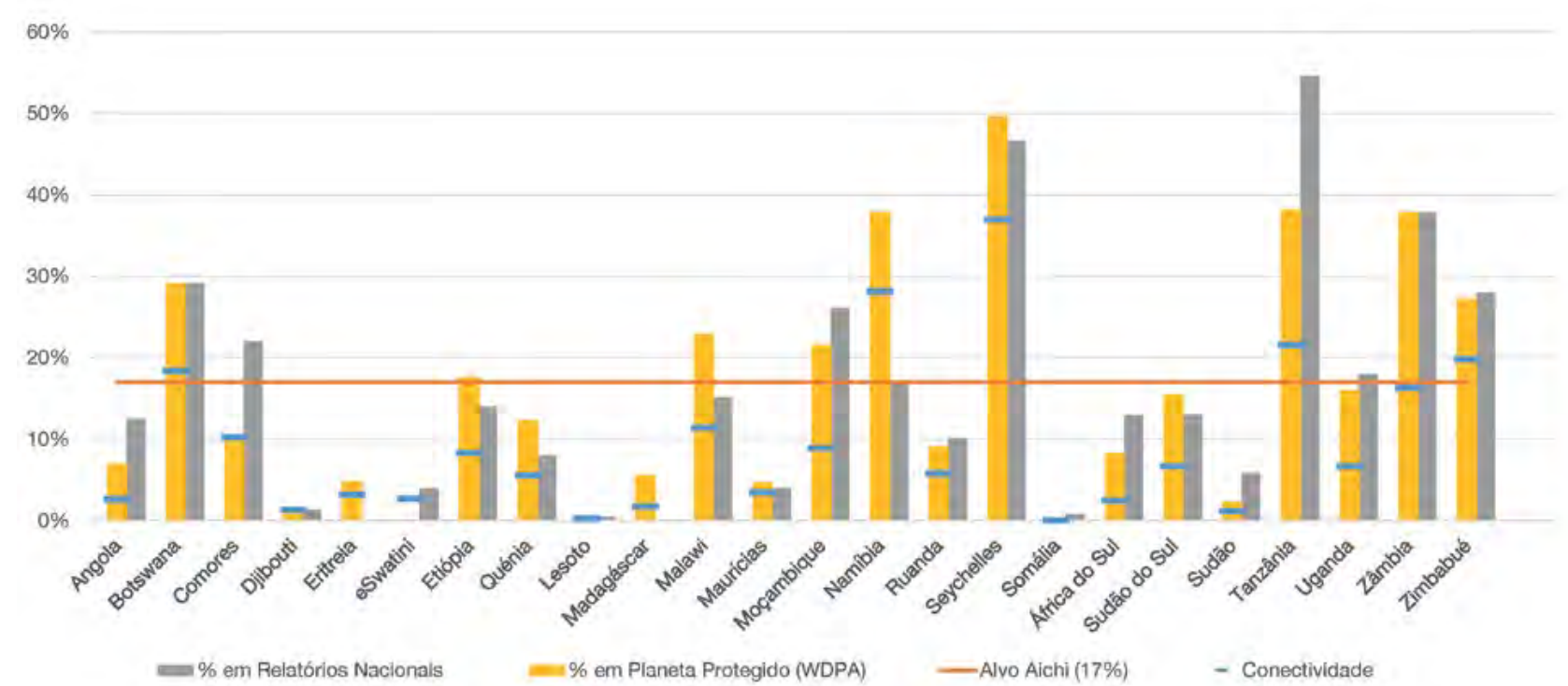

Nota: Ver Apêndice 2 para a fonte de dados desta figura, e Capítulo 8 para informações detalhadas sobre os relatórios dos países.

Fontes: Base de Dados Mundial sobre Áreas Protegidas (UNEP-WCMC \& UICN, 2019b), EC JRC/DOPA (2019a) e Relatórios Nacionais à Convenção sobre a Diversidade Biológica

9 O indicador é calculado através da análise da rede (EC JRC/DOPA, 2019b; Saura et al., 2017, 2018 \& 2019). 
Figura 4.3 Áreas costeiras e marinhas protegidas e de conservação na África Oriental e Austral

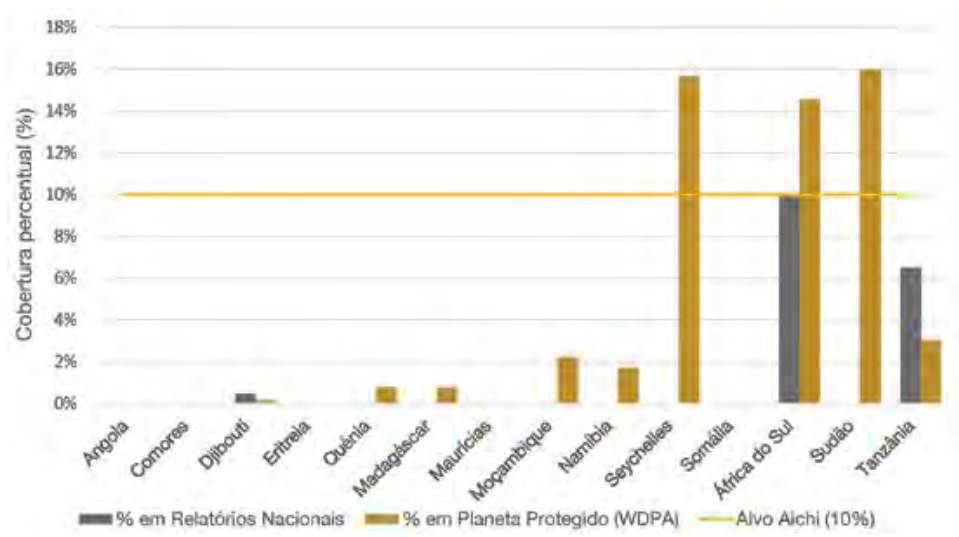

Nota: Ver Apêndice 2 para os dados subjacentes a esta figura, e Capítulo 3 para informações detalhadas

Fontes: Base de Dados Mundial sobre Áreas Protegidas (UNEP-WCMC \& UICN, 2019b) e Relatórios Nacionais à Convenção sobre a Diversidade Biológica.

Figura 4.4 Categorias de gestão das áreas protegidas e de conservação da UICN na África Oriental e Austral

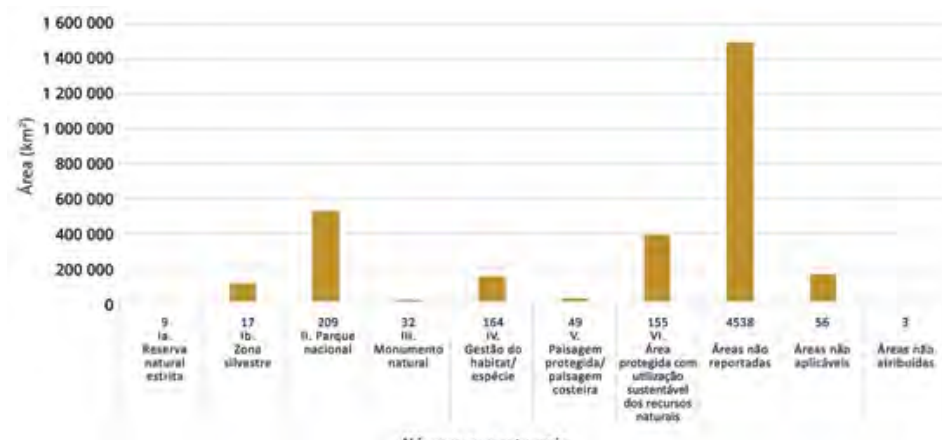

Nota: Ver Apêndice 2 para os dados sobre esta figura.

Fonte: Base de dados mundial sobre Áreas Protegidas (UNEP-WCMC \& UICN, 2019a).

Figura 4.5 Tipos de governação da UICN de áreas protegidas e de conservação na África Oriental e Austral

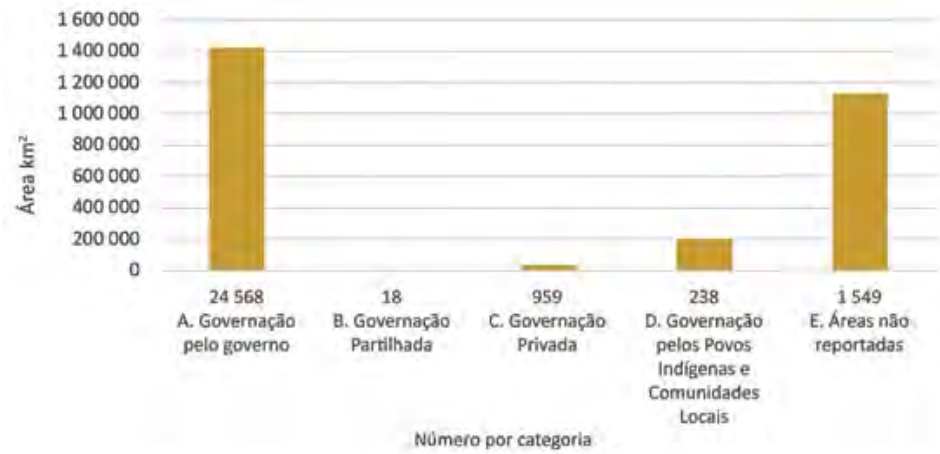

Ver Apêndice 2 para os dados subjacentes a esta figura.

Fonte: Base de dados mundial sobre Áreas Protegidas (UNEP-WCMC \& UICN, 2019a). 
Embora o tipo de governação de muitas áreas protegidas na região não tenha sido relatado no WDPA a maioria é governada pelo Estado ou agências governamentais (Governação Tipo A; ver Figura 4.5). O domínio da governação do Estado resulta, em grande parte, de processos históricos relacionados com o estabelecimento de áreas protegidas, de acordo com o conceito de "conservação da fortaleza". Isto tem vindo a mudar ao longo do tempo, com uma maior inclusão das comunidades na governação da conservação e das áreas protegidas. Por exemplo, das 238 áreas protegidas sob governação pelos povos indígenas e comunidades locais, $47 \%$ encontram-se na Namíbia sob governação pelas comunidades locais e as restantes encontram-se no Quénia, Madagáscar e Tanzânia, com um local no Botswana. Em termos de governação privada, ainda se encontra em grande parte restrita à África Austral, em países como a Namíbia e África do Sul (98\% dos 959 sítios sob governação privada encontram-se na África do Sul), e está em grande parte relacionada com o turismo de vida selvagem, criação de caça e indústrias de caça de troféus.

\subsection{Designações globais e outras áreas prioritárias na região}

Na África Oriental e Austral, 175 locais foram designados como de importância internacional (Quadro 4.1). No topo da lista estão sítios de Ramsar que salientam a importância da conservação das zonas húmidas na região.

O Quadro 4.2 fornece uma lista anotada de sítios naturais africanos e "mistos" (naturais/culturais) do Património Mundial (a partir de 2019), que inclui os resultados das Avaliações de Perspectivas de Conservação da IUCN ${ }^{10}$ e as datas das missões de monitorização do Centro do Património Mundial/UICN realizadas (Howard \& Bertzky, 2019).
Muitas "áreas de particular importância para a biodiversidade" (como referido no Objectivo 11 de Aichi) foram reconhecidas como KBAs. Subgrupos específicos de KBAs incluem a Aliança para Sítios de Extinção Zero (AZE), que são os últimos refúgios remanescentes de uma ou mais espécies em perigo ou criticamente ameaçadas, e IBAs que são importantes para a conservação das aves do mundo (ver secção 2.6). Actualmente, foram identificados $735 \mathrm{KBAs}$ na região, dos quais 107 são AZEs e 692 IBAs (Secretariado AZE, 2019; BirdLife International, 2019b \& 2019c). Uma vez que as AZE, IBAs e KBAs são sítios prioritários reconhecidos para a conservação da biodiversidade, muitos já estão cobertos por áreas protegidas e de conservação, incluindo as diferentes designações globais que acabam de ser mencionadas. As AZEs, IBAs e KBAs não protegidas devem ser consideradas como prioridades para a expansão de áreas protegidas.

\section{Quadro 4.1 Sítios globais de importância na África Oriental e Austral}

\begin{tabular}{l|r}
\hline Designação global & Número de sítios \\
\hline $\begin{array}{l}\text { Sítios de Ramsar (Zonas húmidas de } \\
\text { importância internacional) }\end{array}$ & 109 \\
\hline $\begin{array}{l}\text { Reservas do Homem e da Biosfera da } \\
\text { UNESCO }\end{array}$ & 39 \\
\hline $\begin{array}{l}\text { Sítios de Património Mundial da UNESCO } \\
\text { (Natural ou Misto) }\end{array}$ & 27 \\
\hline
\end{tabular}

Fonte: Convenção de Ramsar sobre Zonas Húmidas (2019); UNESCO (2019a; 2019b). Informação detalhada sobre os sítios de Ramsar e Reservas da Biosfera está disponivel no Apêndice 3.

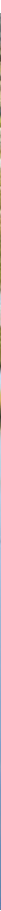

10 Para mais informações, por favor ver: https://www.iucn.org/resources/conservation-tools/iucn-world-heritage-outlook 
Quadro 4.2 Lista anotada de Sítios do Património Mundial naturais e "mistos" (naturais/culturais) da África Oriental e Austral (a partir de 2019), incluindo resultados da Avaliação das Perspectivas de Conservação da UICN e datas das missões de monitorização do Centro do Património Mundial/UICN

\begin{tabular}{|c|c|c|c|c|c|c|c|c|c|c|c|c|}
\hline $\begin{array}{l}\stackrel{\varrho}{E} \\
\text { Z }\end{array}$ & $\frac{\mathscr{n}}{\tilde{N}}$ & 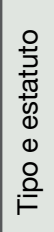 & 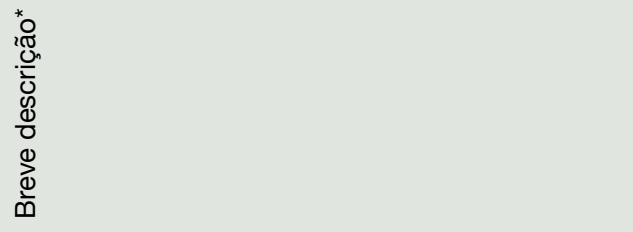 & 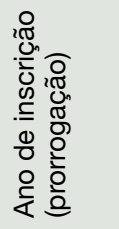 & 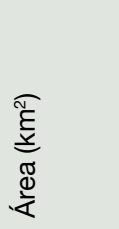 & 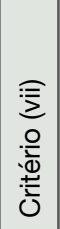 & 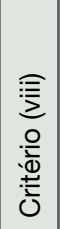 & 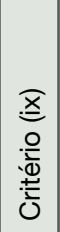 & 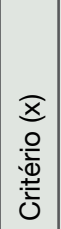 & 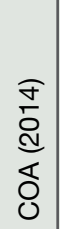 & 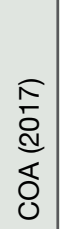 & 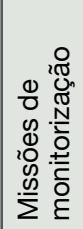 \\
\hline $\begin{array}{l}\overline{\overline{0}} \\
\frac{1}{\pi} \\
\frac{\pi}{0} \\
\frac{0}{0} \\
\frac{\pi}{2}\end{array}$ & 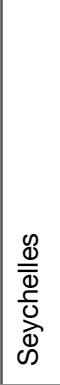 & 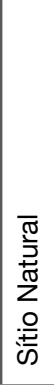 & $\begin{array}{l}\text { O atol é composto por quatro grandes ilhas de coral } \\
\text { que encerram uma lagoa pouco profunda; o grupo } \\
\text { de ilhas está ele próprio rodeado por um recife } \\
\text { de coral. Devido a dificuldades de acesso e ao } \\
\text { isolamento do atol, Aldabra tem sido protegido da } \\
\text { influência humana e retém assim cerca de } 152.000 \\
\text { tartarugas gigantes, a maior população mundial } \\
\text { deste réptil. Para mais detalhes ver: } \\
\text { http://whc.unesco.org/en/list/185 }\end{array}$ & 1982 & 350 & & & & & & & - \\
\hline 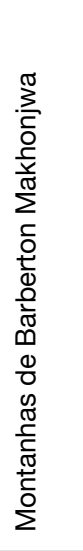 & 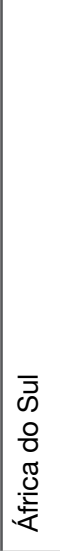 & 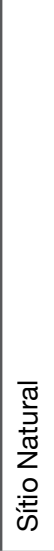 & $\begin{array}{l}\text { Situadas no nordeste da África do Sul, as montanhas } \\
\text { de Barberton Makhonjwa compreendem } 40 \% \\
\text { do Cinturão de Barberton Greenstone, uma das } \\
\text { estruturas geológicas mais antigas do mundo. } \\
\text { A propriedade representa a sucessão mais bem } \\
\text { preservada de rochas vulcânicas e sedimentares, } \\
\text { datada de } 3,6 \text { a } 3,25 \text { mil milhões de anos e } \\
\text { forma um repositório diversificado de informação } \\
\text { sobre as condições de superfície, impactos dos } \\
\text { meteoritos, vulcanismo, processos de construção } \\
\text { de continentes e o ambiente dos primórdios da } \\
\text { vida. Para mais detalhes ver: } \\
\text { http://whc.unesco.org/en/list/1575 }\end{array}$ & 2018 & 1131 & & & & & & & - \\
\hline 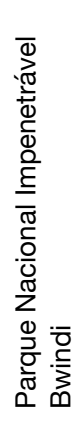 & $\begin{array}{l}\frac{\pi}{0} \\
\stackrel{5}{\sigma} \\
\frac{\pi}{J} \\
د\end{array}$ & 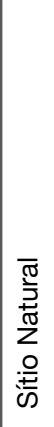 & $\begin{array}{l}\text { Localizada no sudoeste do Uganda, Bwindi cobre } \\
32.000 \text { ha de floresta montana e é conhecida pela } \\
\text { sua excepcional biodiversidade, com mais de } \\
160 \text { espécies de árvores e mais de } 100 \text { espécies } \\
\text { de samambaias. Também aí se podem encontrar } \\
\text { muitos tipos de aves e borboletas, bem como } \\
\text { numerosas espécies globalmente ameaçadas, } \\
\text { incluindo o gorila de montanha ameaçado de } \\
\text { extinção. Para mais detalhes ver: } \\
\text { http://whc.unesco.org/en/list/682 }\end{array}$ & 1994 & 321 & & & & & & & - \\
\hline 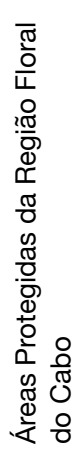 & 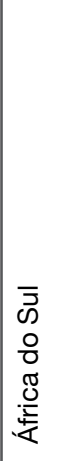 & 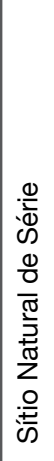 & $\begin{array}{l}\text { A área é um dos grandes centros de biodiversidade } \\
\text { terrestre do mundo. A área alargada inclui parques } \\
\text { nacionais, reservas naturais, áreas selvagens, } \\
\text { florestas estatais e bacias hidrográficas de } \\
\text { montanha. Suporta um número significativo de } \\
\text { espécies endémicas associadas à vegetação de } \\
\text { Fynbos, um arbusto esclerófilo de folhas finas } \\
\text { adaptado tanto a um clima mediterrânico como a } \\
\text { incêndios periódicos, que é único na Região Floral } \\
\text { do Cabo. Para mais detalhes ver: } \\
\text { http://whc.unesco.org/en/list/1007 }\end{array}$ & $\begin{array}{r}2004 \\
(2015)\end{array}$ & 10947 & & & & & & & - \\
\hline
\end{tabular}

\section{Classificação das Perspectivas de Conservação 2017}

$\square$ Bom $\square$ Bom com algumas preocupações

Preocupação significativa

Crítica

Deficiência de dados 


\begin{tabular}{|c|c|c|c|c|c|c|c|c|c|c|c|c|}
\hline $\begin{array}{l}\stackrel{0}{E} \\
\text { ¿ } \\
z\end{array}$ & $\frac{\frac{0}{\pi}}{0}$ & 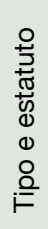 & 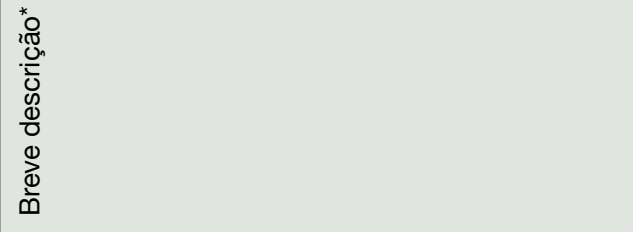 & 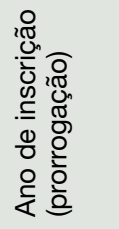 & 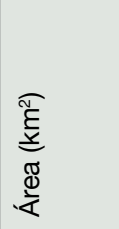 & 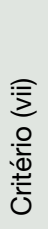 & 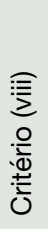 & 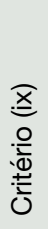 & 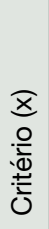 & 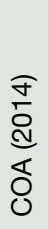 & 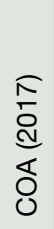 & 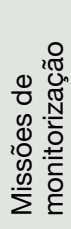 \\
\hline 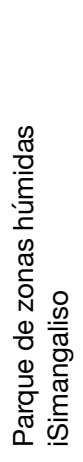 & 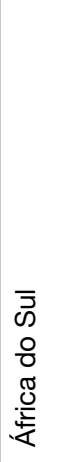 & 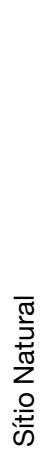 & $\begin{array}{l}\text { Os processos fluviais, marinhos e eólicos em curso } \\
\text { no local produziram uma variedade de formas de } \\
\text { aterro, incluindo recifes de coral, longas praias } \\
\text { de areia, dunas costeiras, sistemas lacustres, } \\
\text { pântanos, e extensas zonas húmidas de caniço e } \\
\text { papiro. O mosaico de formas e tipos de habitat cria } \\
\text { paisagens de cortar a respiração. O local contém } \\
\text { habitats críticos para uma variedadede espécies } \\
\text { de ambientes marinhos, zonas húmidas e savanas } \\
\text { de África. Para mais detalhes ver: } \\
\text { http://whc.unesco.org/en/list/914 }\end{array}$ & 1999 & 2396 & & & & & & & - \\
\hline 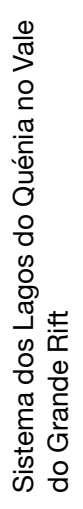 & 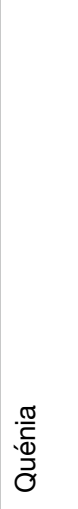 & 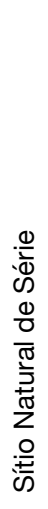 & $\begin{array}{l}\text { O sítio compreende três lagos pouco profundos } \\
\text { interligados: Lago Bogoria, Lago Nakuru e Lago } \\
\text { Elementaita, no Vale do Rift. A propriedade é o lar } \\
\text { de } 13 \text { espécies de aves globalmente ameaçadas } \\
\text { e algumas das mais altas diversidades de } \\
\text { aves do mundo. É o mais importante local de } \\
\text { procura de alimentos para o Flamingo Menor. } \\
\text { A área apresenta populações consideráveis } \\
\text { de mamíferos, incluindo o rinoceronte negro, } \\
\text { a Girafa do Rothschild, o Grande Kudu, o leão, } \\
\text { a chita e os cães selvagens. Para mais detalhes } \\
\text { ver: http://whc.unesco.org/en/list/1060 }\end{array}$ & 2011 & 320 & & & & & & & - \\
\hline 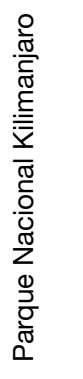 & 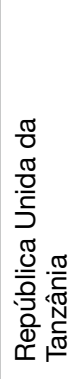 & 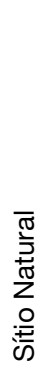 & $\begin{array}{l}\text { Com 5,895 m, o Kilimanjaro é o ponto mais alto } \\
\text { de África. Este maciço vulcânico encontra-se } \\
\text { em esplêndido isolamento acima das planícies } \\
\text { circundantes, com o seu pico nevado a pairar sobre } \\
\text { a savana. A montanha é cercada por floresta de } \\
\text { montanha. Numerosos mamíferos, muitos deles } \\
\text { espécies ameaçadas de extinção, vivem no parque. } \\
\text { Para mais detalhes ver: } \\
\text { http://whc.unesco.org/en/list/403 }\end{array}$ & 1987 & 756 & & & & & & & - \\
\hline 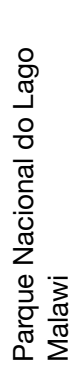 & 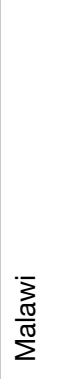 & 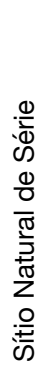 & $\begin{array}{l}\text { Localizado no extremo sul da grande extensão do } \\
\text { lago Malawi/Nyasa/Niassa, com as suas águas } \\
\text { profundas e límpidas e o seu pano de fundo de } \\
\text { montanha, o parque nacional alberga muitas } \\
\text { centenas de espécies de peixes, quase todos } \\
\text { endémicos. A sua importância para o estudo da } \\
\text { evolução é comparável à das llhas Galápagos. Para } \\
\text { mais detalhes ver: } \\
\text { http://whc.unesco.org/en/list/289 }\end{array}$ & 1984 & 94 & & & & & & & $\begin{array}{l}1995 \\
2014\end{array}$ \\
\hline
\end{tabular}




\begin{tabular}{|c|c|c|c|c|c|c|c|c|c|c|c|c|}
\hline 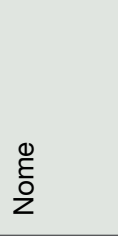 & $\begin{array}{l}\frac{0}{\tilde{N}} \\
0\end{array}$ & 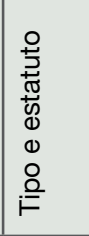 & 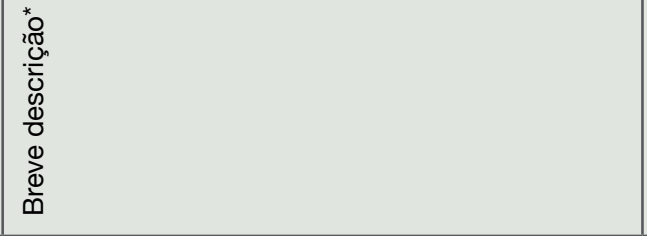 & 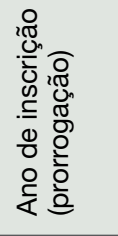 & 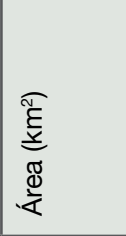 & 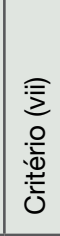 & 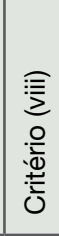 & 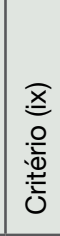 & 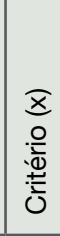 & 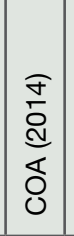 & 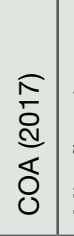 & 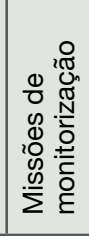 \\
\hline 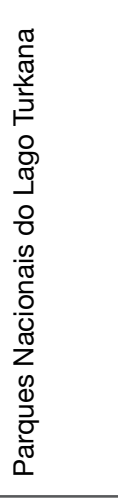 & 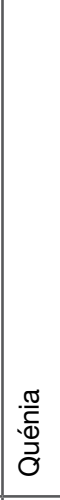 & 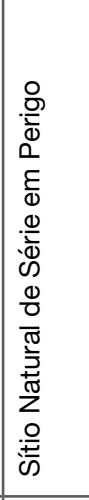 & $\begin{array}{l}\text { O mais salgado dos grandes lagos de África, } \\
\text { Turkana é um excelente laboratório para o estudo } \\
\text { das comunidades vegetais e animais. Os três } \\
\text { parques nacionais servem de escala para as aves } \\
\text { aquáticas migrantes e são importantes locais de } \\
\text { reprodução para o Crocodilo do Nilo, e outras } \\
\text { espécies. Os depósitos de Koobi Fora, ricos em } \\
\text { restos de mamíferos, moluscos e outros fósseis, } \\
\text { têm contribuído mais para a compreensão dos } \\
\text { paleoambientes do que qualquer outro local do } \\
\text { continente. Para mais detalhes ver: } \\
\text { http://whc.unesco.org/en/list/800 }\end{array}$ & 2001 & 1615 & & & & & & & $\begin{array}{l}2012 \\
2015\end{array}$ \\
\hline 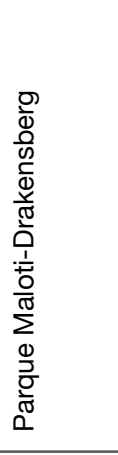 & 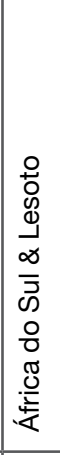 & 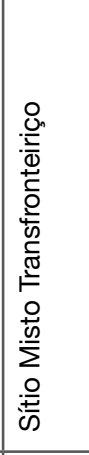 & $\begin{array}{l}\text { O local tem uma beleza natural excepcional } \\
\text { nos seus basaltos basálticos, cortes dramáticos } \\
\text { incisivos, e muralhas de arenito dourado, enquanto } \\
\text { a diversidade de habitats protege um elevado nível } \\
\text { de plantas endémicas e globalmente importantes, } \\
\text { e várias espécies animais ameaçadas de extinção. } \\
\text { Este espectacular sítio natural contém muitas } \\
\text { grutas e abrigos de rochas com o maior e mais } \\
\text { concentrado grupo de pinturas em África a sul do } \\
\text { Sara. Para mais detalhes ver: } \\
\text { http://whc.unesco.org/en/list/985 }\end{array}$ & $\begin{array}{r}2000 \\
(2013)\end{array}$ & 2493 & & & & & & & - \\
\hline 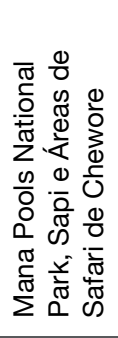 & 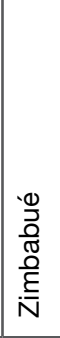 & 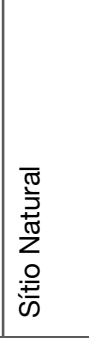 & $\begin{array}{l}\text { Nas margens do rio Zambeze, grandes penhascos } \\
\text { sobrevoam o rio e as planícies aluviais. A área é } \\
\text { o lar de uma notável concentração de animais } \\
\text { selvagens, incluindo elefantes, búfalos, leopardos e } \\
\text { chitas. Uma importante concentração de crocodilos } \\
\text { do Nilo também se encontra na área. Para mais } \\
\text { detalhes ver: } \\
\text { http://whc.unesco.org/en/list/302 }\end{array}$ & 1984 & 6766 & & & & & & & 2011 \\
\hline 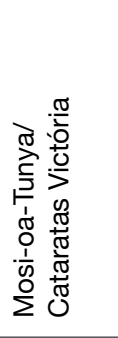 & 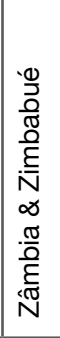 & 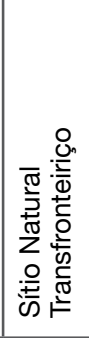 & $\begin{array}{l}\text { Estas estão entre as quedas de água mais } \\
\text { espectaculares do mundo. O rio Zambeze, que } \\
\text { tem mais de } 2 \mathrm{~km} \text { de largura neste ponto, mergulha } \\
\text { ruidosamente por uma série de desfiladeiros de } \\
\text { basalto e levanta uma névoa iridescente que pode } \\
\text { ser vista a mais de } 20 \mathrm{~km} \text { de distância. Para mais } \\
\text { detalhes, ver: } \\
\text { http://whc.unesco.org/en/list/509 }\end{array}$ & 1989 & 69 & & & & & & & $\begin{array}{l}2000 \\
2006\end{array}$ \\
\hline
\end{tabular}




\begin{tabular}{|c|c|c|c|c|c|c|c|c|c|c|c|c|}
\hline $\begin{array}{l}\stackrel{0}{E} \\
\dot{0} \\
z\end{array}$ & $\frac{0}{\pi}$ & 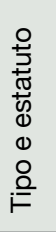 & 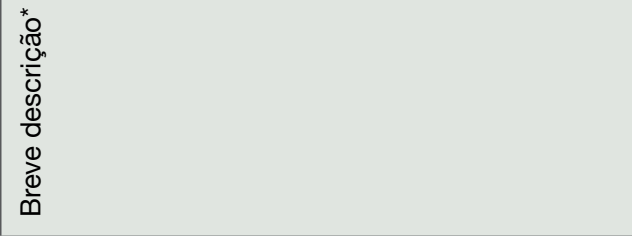 & 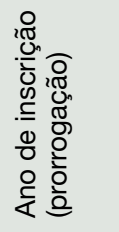 & 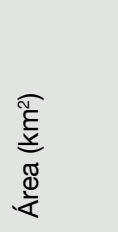 & 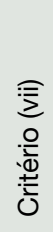 & 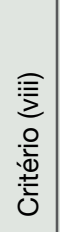 & 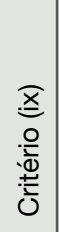 & 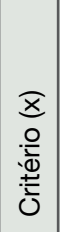 & \begin{tabular}{l}
\multirow{\sigma}{\sigma}{} \\
$\stackrel{d}{d}$ \\
$\delta$ \\
$\delta$ \\
$\mathcal{\sigma}$
\end{tabular} & $\begin{array}{l}\text { E } \\
\vdots \\
\stackrel{d}{\sigma} \\
\delta \\
0\end{array}$ & 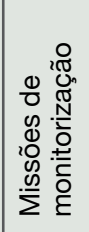 \\
\hline 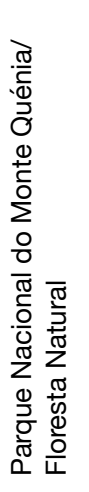 & 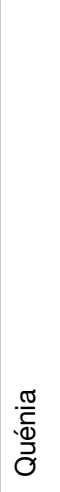 & 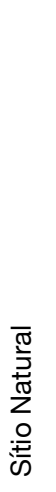 & $\begin{array}{l}\text { O Monte Quénia é o segundo pico mais alto } \\
\text { de África, um antigo vulcão extinto. Existem } 12 \\
\text { glaciares remanescentes na montanha, todos a } \\
\text { recuar rapidamente, e quatro picos secundários } \\
\text { que se situam na cabeça dos vales glaciares em } \\
\text { forma de U. Com os seus cimos escarpados de } \\
\text { glaciares e encostas médias florestadas, o Monte } \\
\text { Quénia é uma das paisagens mais impressionantes } \\
\text { da África Oriental. A evolução e ecologia da sua } \\
\text { flora afro-alpina fornecem um exemplo notável } \\
\text { de processos ecológicos e biológicos. Para mais } \\
\text { detalhes ver: http://whc.unesco.org/en/list/800 }\end{array}$ & $\begin{array}{r}1997 \\
(2013)\end{array}$ & 2023 & & & & & & & 2008 \\
\hline 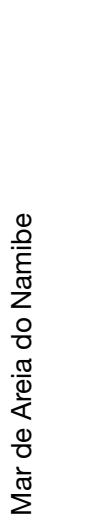 & $\begin{array}{l}\frac{\pi}{0} \\
\frac{0}{\bar{\epsilon}} \\
\frac{\pi}{2}\end{array}$ & 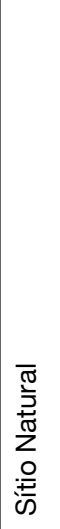 & $\begin{array}{l}\text { O Mar de Areia do Namibe é o único deserto } \\
\text { costeiro do mundo que inclui extensos campos de } \\
\text { dunas influenciados pelo nevoeiro. O site apresenta } \\
\text { planícies de cascalho, planícies costeiras, colinas } \\
\text { rochosas, inselbergs dentro do mar de areia, uma } \\
\text { lagoa costeira e rios efémeros, resultando numa } \\
\text { paisagem de beleza excepcional. O nevoeiro é a } \\
\text { principal fonte de água no local, sendo responsável } \\
\text { por um ambiente único no qual invertebrados, } \\
\text { répteis e mamíferos endémicos se adaptam a uma } \\
\text { variedade sempre em mudança de microhabitats e } \\
\text { nichos ecológicos. Para mais detalhes, ver: } \\
\text { http://whc.unesco.org/en/list/1430 }\end{array}$ & 2013 & 30777 & & & & & & & - \\
\hline 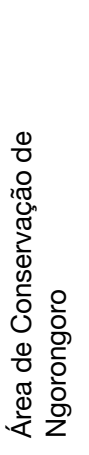 & 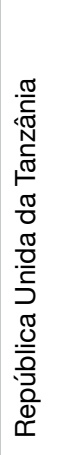 & 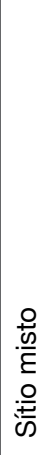 & $\begin{array}{l}\text { Esta área de uso múltiplo da terra, com a vida } \\
\text { selvagem a coexistir com os pastores Maasai } \\
\text { semi-nómadas que praticam o pastoreio tradicional, } \\
\text { inclui a espectacular cratera de Ngorongoro, a maior } \\
\text { caldeira do mundo. A propriedade confina com o } \\
\text { Parque Nacional do Serengeti e acolhe a migração } \\
\text { anual de gnu, zebra e gazela nas suas planícies do } \\
\text { norte durante parte do ano. O sítio fornece provas } \\
\text { da evolução humana, incluindo pegadas hominídeas } \\
\text { antigas datadas de } 3,6 \text { milhões de anos. Para mais } \\
\text { detalhes ver: http://whc.unesco.org/en/list/39 }\end{array}$ & $\begin{array}{r}1979 \\
(2010)\end{array}$ & 8094 & & & & & & & $\begin{array}{l}1986 \\
2007 \\
2012 \\
2017 \\
2019\end{array}$ \\
\hline 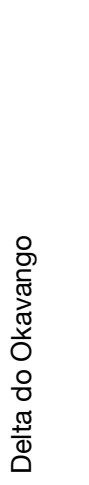 & 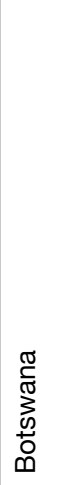 & 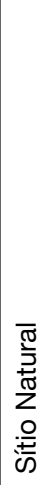 & $\begin{array}{l}\text { Este delta compreende pântanos permanentes } \\
\text { e planícies sazonalmente inundadas. É um dos } \\
\text { poucos grandes sistemas de deltas interiores } \\
\text { que não fluem para um mar ou oceano com um } \\
\text { sistema de zonas húmidas que está quase intacto. } \\
\text { É um exemplo excepcional da interacção entre os } \\
\text { processos climáticos, hidrológicos e biológicos. O } \\
\text { Delta do Okavango é o lar de algumas das espécies } \\
\text { de grandes mamíferos mais ameaçadas do mundo, } \\
\text { tais como a chita, o rinoceronte branco, o rinoceronte } \\
\text { preto, o cão selvagem africano e o leão. Para mais } \\
\text { detalhes, ver: http://whc.unesco.org/en/list/1432 }\end{array}$ & 2014 & 20236 & & & & & & & - \\
\hline
\end{tabular}




\begin{tabular}{|c|c|c|c|c|c|c|c|c|c|c|c|}
\hline $\begin{array}{l}\stackrel{0}{\varepsilon} \\
\text { हे } \\
z\end{array}$ & $\frac{.0}{\tilde{\sigma}}$ & 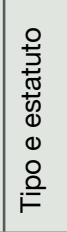 & 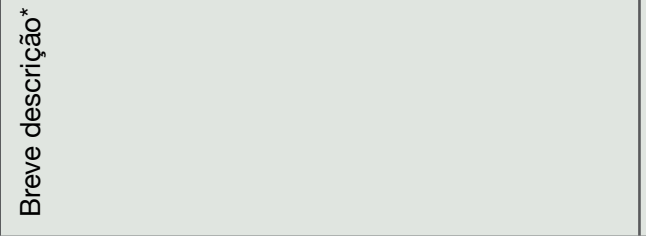 & 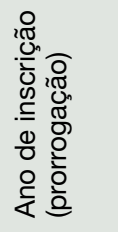 & 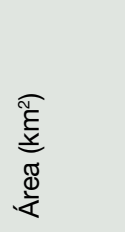 & 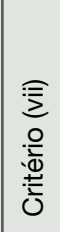 & 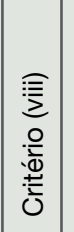 & 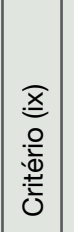 & 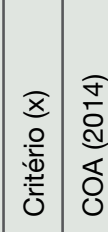 & 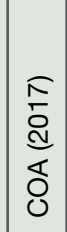 & 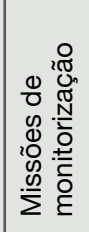 \\
\hline 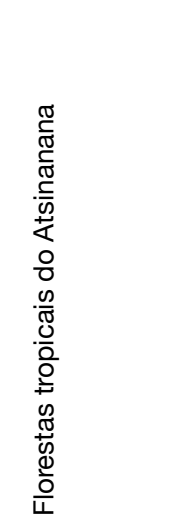 & 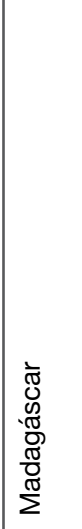 & 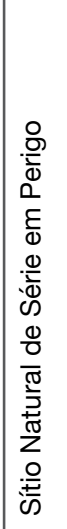 & $\begin{array}{l}\text { O sítio compreende seis parques nacionais que } \\
\text { protegem florestas de relicção que são criticamente } \\
\text { importantes para manter os processos ecológicos } \\
\text { em curso necessários para a sobrevivência da } \\
\text { biodiversidade única de Madagáscar. A vida vegetal } \\
\text { e animal de Madagáscar evoluiu em isolamento } \\
\text { e muitas espécies são raras e globalmente } \\
\text { ameaçadas, especialmente os lémures icónicos. } \\
\text { As florestas tropicais são importantes tanto para } \\
\text { os processos ecológicos e biológicos como para a } \\
\text { sua biodiversidade e para as espécies ameaçadas } \\
\text { que apoiam. Para mais detalhes, ver: } \\
\text { http://whc.unesco.org/en/list/1257 }\end{array}$ & 2007 & 4797 & & & & & & $\begin{array}{l}2011 \\
2015\end{array}$ \\
\hline 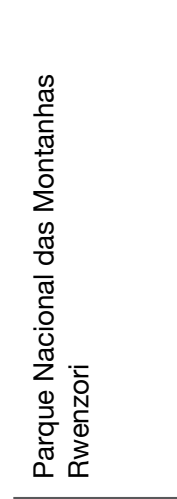 & 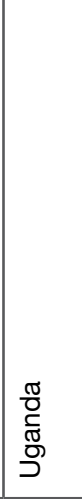 & 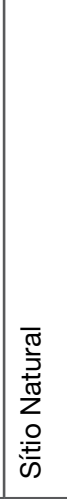 & $\begin{array}{l}\text { O Parque Nacional das Montanhas Rwenzori cobre } \\
\text { quase } 100.000 \text { ha na parte ocidental do Uganda } \\
\text { e compreende a parte principal da cadeia de } \\
\text { montanhas Rwenzori, que inclui o terceiro pico } \\
\text { mais alto de África (Monte Margherita: } 5.109 \mathrm{~m} \text { ). } \\
\text { Os glaciares, cascatas e lagos da região fazem } \\
\text { dele uma das mais belas zonas alpinas de África. } \\
\text { O parque tem muitos habitats naturais de espécies } \\
\text { ameaçadas de extinção e uma flora rica e invulgar } \\
\text { que inclui, entre outras espécies, a urze gigante. } \\
\text { Para mais detalhes ver: } \\
\text { http://whc.unesco.org/en/list/684 }\end{array}$ & 1994 & 996 & & & & & & - \\
\hline 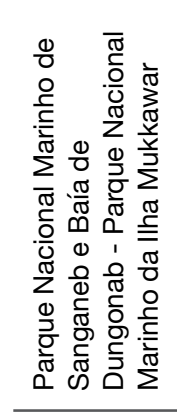 & $\begin{array}{l}\frac{i}{0} \\
\frac{2 \pi}{0} \\
0 \\
0\end{array}$ & 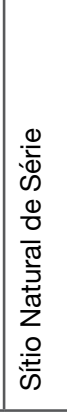 & $\begin{array}{l}\text { O site consiste em duas áreas distintas: Sanganeb } \\
\text { é um atol de coral isolado no Mar Vermelho central, } \\
\text { e a componente da Baía de Dungonab e da llha } \\
\text { de Mukkawar inclui um sistema diversificado de } \\
\text { recifes de coral, mangues, leitos de ervas marinhas, } \\
\text { praias e ilhotas. O local fornece um habitat para } \\
\text { uma importante população de dugongos, bem } \\
\text { como aves marinhas, mamíferos marinhos, peixes, } \\
\text { tubarões, tartarugas e arraias manta. Para mais } \\
\text { detalhes, ver: } \underline{\text { http://whc.unesco.org/en/list/262 }}\end{array}$ & 2016 & 2607 & & & & & & - \\
\hline 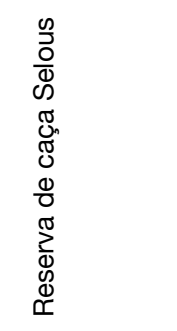 & 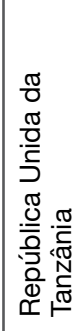 & 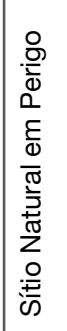 & $\begin{array}{l}\text { Grandes números de elefantes, rinocerontes } \\
\text { negros, chitas, girafas, hipopótamos e crocodilos } \\
\text { vivem neste imenso santuário, que mede } 50.000 \\
\mathrm{~km}^{2} \text { e não é perturbado pelo impacto humano. } \\
\text { parque tem uma variedade de zonas de vegetação, } \\
\text { desde densos matos a prados arborizados abertos. } \\
\text { Para mais detalhes, ver: } \\
\text { http://whc.unesco.org/en/list/199 }\end{array}$ & 1982 & 51200 & & & & & & $\begin{array}{l}2007 \\
2008 \\
2013 \\
2017\end{array}$ \\
\hline
\end{tabular}




\begin{tabular}{|c|c|c|c|c|c|c|c|c|c|c|c|c|}
\hline $\begin{array}{l}\stackrel{0}{E} \\
\text { ¿ํ }\end{array}$ & $\frac{\frac{\omega}{\sigma}}{\Omega}$ & 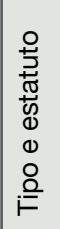 & 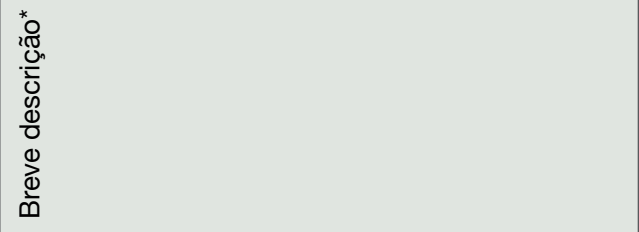 & 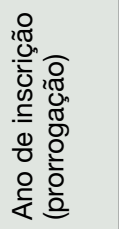 & 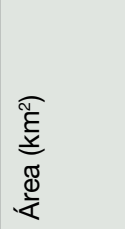 & 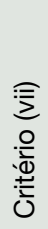 & 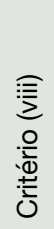 & 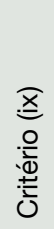 & $\begin{array}{l}x \\
\stackrel{x}{\circ} \\
: \frac{1}{0} \\
\stackrel{ \pm}{0} \\
0\end{array}$ & 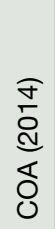 & 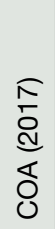 & 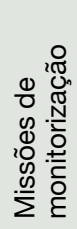 \\
\hline 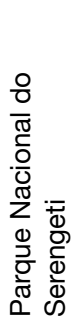 & 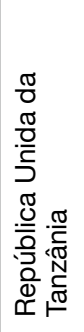 & 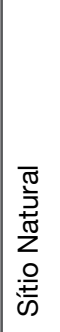 & $\begin{array}{l}\text { As vastas planícies do Serengeti compreendem } \\
1,5 \text { milhões de hectares de savana. A migração } \\
\text { anual para os buracos de água permanentes de } \\
\text { vastos rebanhos de herbívoros (gnu, gazela e } \\
\text { zebra), seguida pelos seus predadores, é um dos } \\
\text { acontecimentos naturais mais impressionantes do } \\
\text { mundo. Para mais detalhes ver: } \\
\text { http://whc.unesco.org/en/list/156 }\end{array}$ & 1981 & 14763 & & & & & & & - \\
\hline 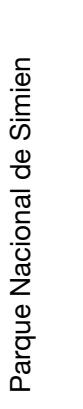 & 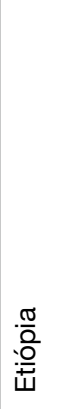 & 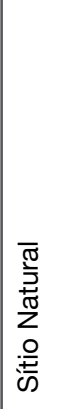 & $\begin{array}{l}\text { A erosão maciça ao longo de milhões de anos } \\
\text { no planalto etíope criou uma das paisagens mais } \\
\text { espectaculares do mundo, com picos de montanha } \\
\text { irregulares, vales profundos e precipícios abruptos } \\
\text { que descem cerca de } 1.500 \text { m. O parque é o lar } \\
\text { de alguns animais extremamente raros como o } \\
\text { Babuíno Gelada, o Lobo Etíope e o lbex Walia, um } \\
\text { bode que não se encontra em mais lado nenhum } \\
\text { do mundo. Para mais detalhes ver: } \\
\text { http://whc.unesco.org/en/list/9 }\end{array}$ & 1978 & 136 & & & & & & & $\begin{array}{l}1981 \\
1996 \\
1997 \\
2017\end{array}$ \\
\hline 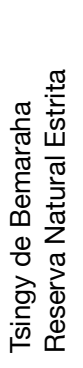 & 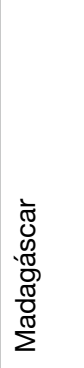 & 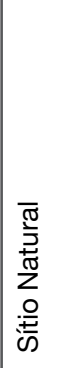 & $\begin{array}{l}\text { Este sítio inclui paisagens cársicas e planaltos } \\
\text { calcários cortados em impressionantes picos } \\
\text { 'tsingy' e uma 'floresta' de agulhas calcárias, o } \\
\text { espectacular desfiladeiro do rio Manambolo, } \\
\text { colinas onduladas e picos altos. As florestas não } \\
\text { perturbadas, lagos e mangues são o habitat de } \\
\text { lémures e aves raros e em perigo de extinção. Para } \\
\text { mais detalhes, ver: } \\
\text { http://whc.unesco.org/en/list/494 }\end{array}$ & 1990 & 1520 & & & & & & & - \\
\hline 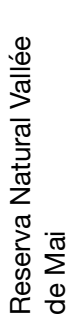 & $\begin{array}{l}\mathscr{0} \\
\frac{0}{\overline{0}} \\
\frac{0}{0} \\
\text { बे } \\
\infty\end{array}$ & 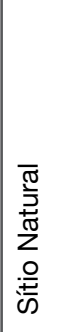 & $\begin{array}{l}\text { No coração da pequena ilha de Praslin, a reserva } \\
\text { tem os vestígios de uma floresta de palmeiras } \\
\text { natural única preservada quase no seu estado } \\
\text { original. O famoso coco de mer, de uma palmeira } \\
\text { que outrora se acreditava crescer nas profundezas } \\
\text { do mar, é a maior semente do reino vegetal. Para } \\
\text { mais detalhes ver: } \\
\text { http://whc.unesco.org/en/list/261 }\end{array}$ & 1982 & 0.2 & & & & & & & - \\
\hline 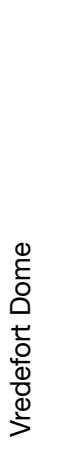 & 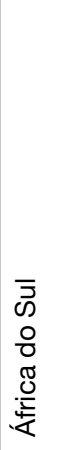 & 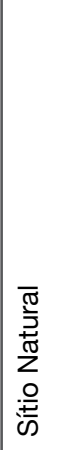 & $\begin{array}{l}\text { O Vredefort Dome é uma parte representativa } \\
\text { de uma estrutura de impacto de meteorito, ou } \\
\text { astrobleme. Fornece provas do maior evento } \\
\text { mundial conhecido de libertação única de energia, } \\
\text { que teve efeitos globais devastadores, incluindo, } \\
\text { segundo alguns cientistas, grandes mudanças } \\
\text { evolutivas na Terra. Datada de há } 2,023 \text { milhões de } \\
\text { anos, é a astroblema mais antiga ainda encontrada } \\
\text { e, com um raio de } 190 \mathrm{~km} \text {, é também a maior e a } \\
\text { mais profundamente erodida. Para mais detalhes, } \\
\text { ver: http://whc.unesco.org/en/list/1162 }\end{array}$ & 2005 & 300 & & & & & & & - \\
\hline
\end{tabular}

Fonte: Howard \& Bertzky (2019). 


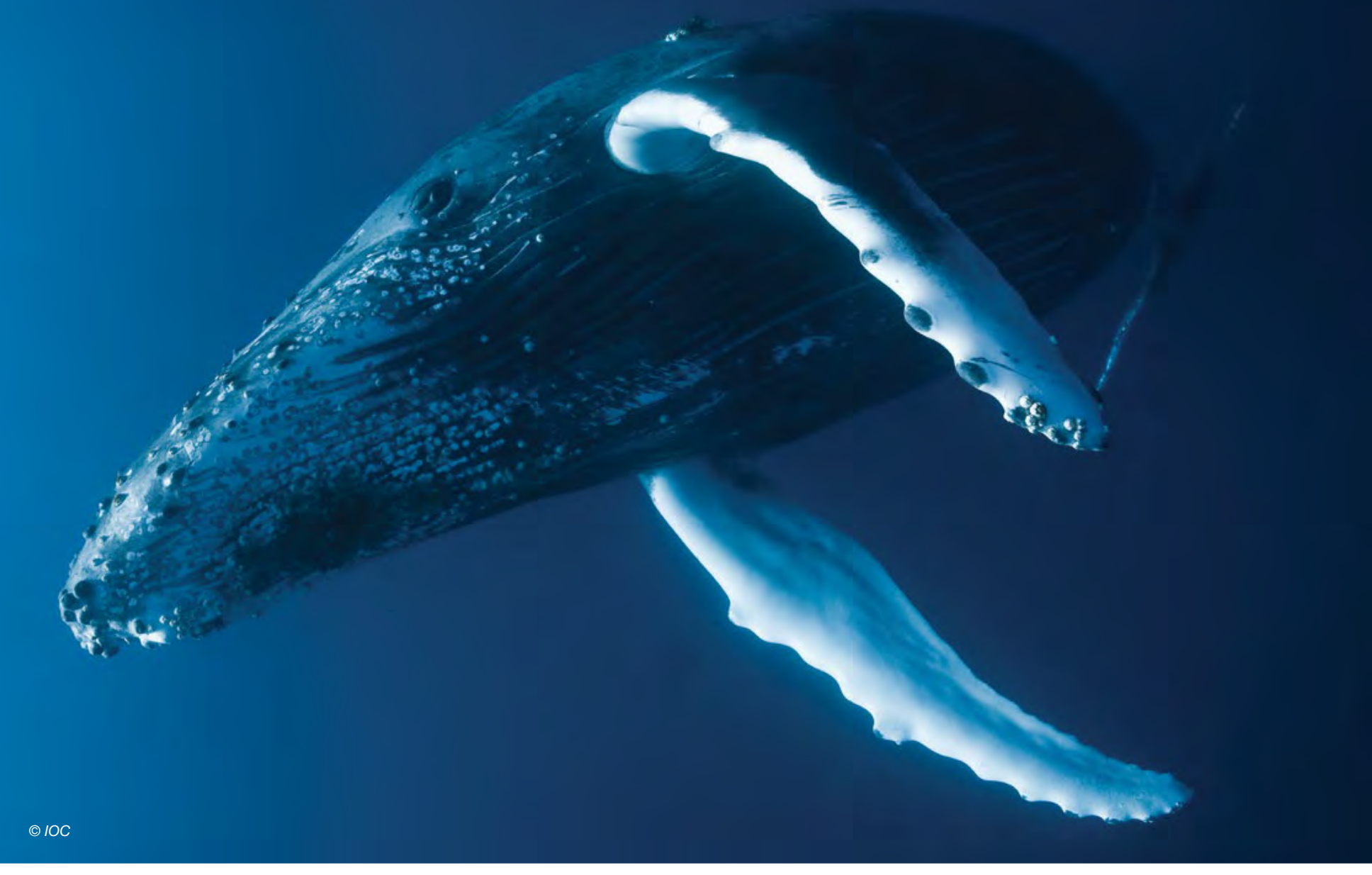

\subsection{Representatividade ecológica}

Um dos principais compromissos na CDB é o princípio da conservação de amostras representativas de todas as espécies e ecossistemas dentro da rede de áreas protegidas a uma escala suficiente para assegurar a sua persistência a longo prazo. As lacunas de representação referem-se a espécies, ecossistemas e processos ecológicos que não estão incluídos, ou não estão suficientemente incluídos, dentro do sistema de áreas protegidas. Esta secção fornece uma análise inicial das lacunas ecológicas, avaliando até que ponto as ecorregiões estão representadas em áreas protegidas na região da África Oriental e Austral.

É igualmente importante assegurar que as áreas protegidas sejam geridas de forma equitativa e eficaz (ver Capítulo 9 e Capítulo 10). Só se as áreas protegidas forem bem geridas é que as espécies e ecossistemas da rede de áreas protegidas serão conservados.

O resumo regional completo da representatividade das ecorregiões marinhas e terrestres e das províncias pelágicas está disponível no Apêndice 4. Estas estatísticas foram compiladas através da sobreposição dos rede de áreas protegidas numa camada combinada representando as ecorregiões marinhas e terrestres e as províncias pelágicas do mundo, que foi preparada pelo JRC/DOPA da CE com base em dados definidos por Olson et al. (2001) e Spalding et al. (2007 e 2012). As ecorregiões marinhas foram recortadas na costa das ecorregiões terrestres e um limite exterior correspondente aos 200 metros de isóbata (Spalding et al., 2007), tal como descrito no sítio web do DOPA. ${ }^{11}$

Oitenta e seis das ecorregiões terrestres do mundo enquadram-se na região da África Oriental e Austral definida para este relatório. Sessenta e três destas ecorregiões terrestres têm mais de $97 \%$ da sua área na região, e destas, 32 (cerca de 50\%) atingem áreas de protecção superiores a 17\% (Spalding et al., 2007; 2012).

Algumas ecorregiões endémicas, tais como o mosaico da floresta montana angolana, o deserto costeiro da Eritreia, os prados e pastagens de Hobyo e as florestas xéricas montanas da Somália, têm menos de $1 \%$ das áreas protegidas e de conservação formalmente delineadas no WDPA. 
Figura 4.6 Níveis de protecção para as ecorregiões terrestres representadas na região
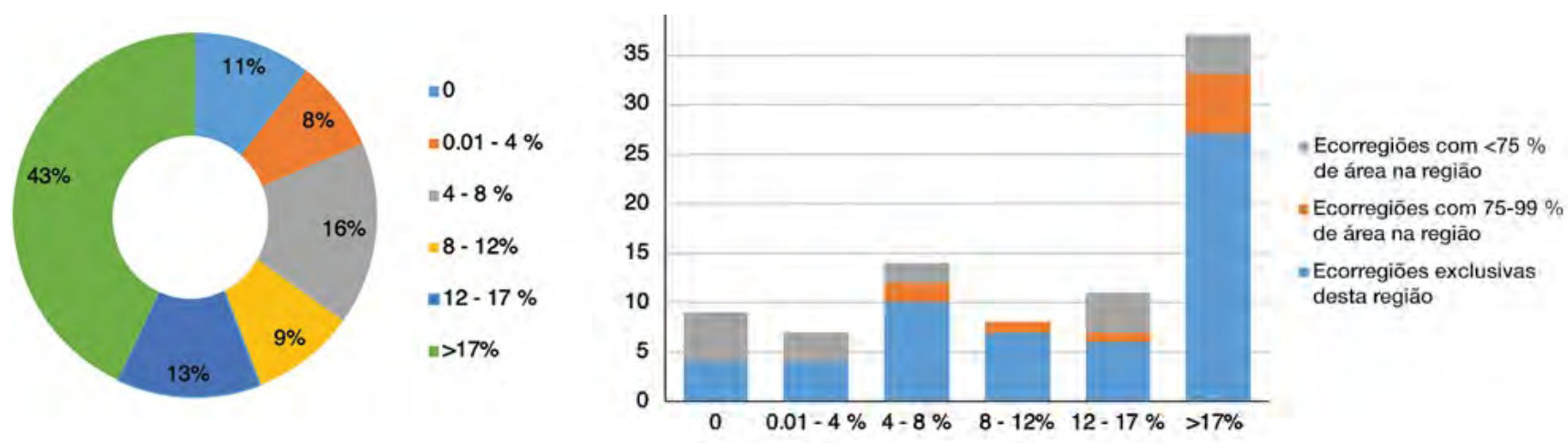

Fonte: EC JRC/DOPA (2019a).

Figura 4.7 Níveis de protecção das ecorregiões marinhas e das províncias pelágicas representadas na região
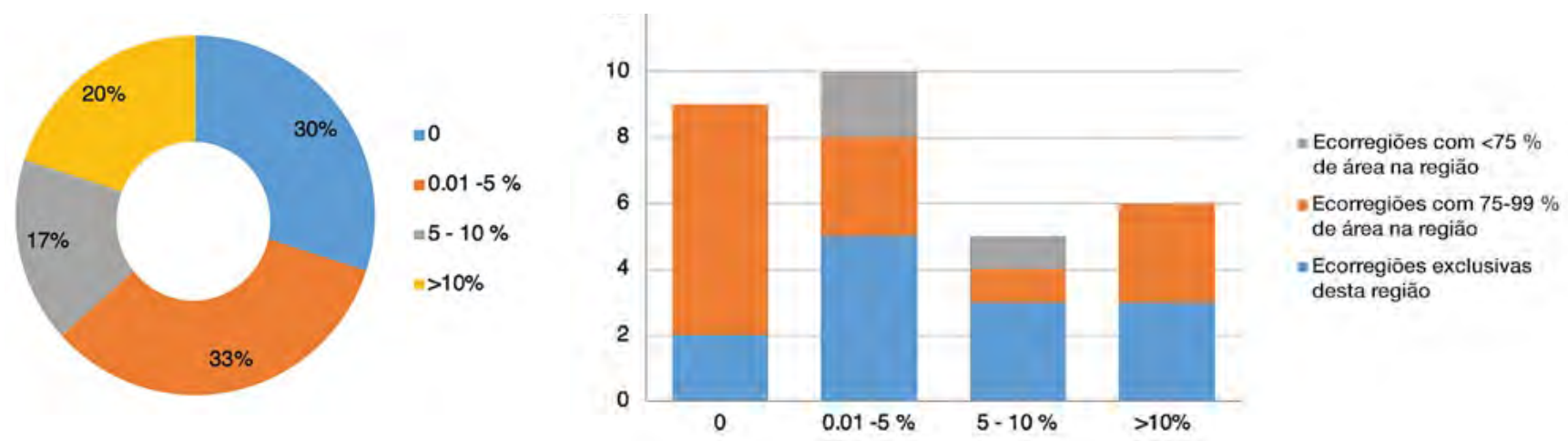

Fonte: EC JRC/DOPA (2019a)

Das ecorregiões marinhas ou províncias pelágicas do mundo, 30 encontram-se na região (Figura 4.7), 13 situam-se na região, representando mais de $95 \%$ dessa área. Três têm áreas de protecção que excedem $10 \%$ da quota regional: a Baía de Sofala em Moçambique, a Costa de Coral da África Oriental e as Ilhas Príncipe Eduardo. A ecorregião das Ilhas Príncipe Eduardo (pertencentes à África do Sul) é $100 \%$ endémica e $100 \%$ protegida, mas apenas uma parte da sua área é de não captura (o nível de protecção mais elevado, que proíbe a remoção de qualquer peixe ou outros organismos) como para muitas outras áreas marinhas protegidas. O resumo regional completo da representatividade das ecorregiões terrestres, tal como definidas pela WWF, está disponível no Apêndice 4.

Os sistemas de classificação biogeográfica podem ajudar os planeadores a incluir toda a gama de ecossistemas nas estratégias globais e regionais de conservação e desenvolvimento. O melhor mapeamento disponível para a representatividade ecológica é o mapeamento da 'ecorregião terrestre' (ver os resultados na Figura 4.8). Contudo, seguindo a prática actual, as Reservas de Homem e Biosfera da UNESCO não são incluídas nos cálculos, uma vez que muitas das suas áreas tampão não correspondem à definição de áreas protegidas da UICN (UNEP-WCMC \& UICN, 2016).
As ecorregiões são um substituto amplo para a representatividade ecológica, e seleccionadas porque os dados são consistentes para análises em grande escala. A um nível mais fino, os países realizam análises muito mais detalhadas para assegurar a protecção dos ecossistemas, paisagens e espécies vegetais e animais.

\subsection{O que mudou na cobertura de áreas protegidas?}

O Objectivo 11 da Aichi encorajou os países a proteger $10 \%$ da sua área marinha e $17 \%$ da sua área terrestre, e estão a ser feitos progressos na consecução deste objectivo. No entanto, é por vezes difícil compreender a natureza dinâmica do património da área protegida. Há muitas mudanças, incluindo a criação de novos sítios através de gazettal, a remoção de sítios por degattement e a expansão ou redução de sítios existentes (Golden Kroner et al., 2019; Lewis et al., 2017). As restrições e regulamentos de áreas protegidas podem também ser alterados, através da actualização ou redução das protecções (Golden Kroner et al., 2019). Por vezes, uma alteração na designação ou nome de um sítio, ou a combinação de duas áreas protegidas para formar uma maior, pode aparecer como uma degazettement e ao mesmo tempo como um novo gazettal, talvez 
Figura 4.8 Cobertura da ecorregião na África Oriental e Austral por percentagem de protecção

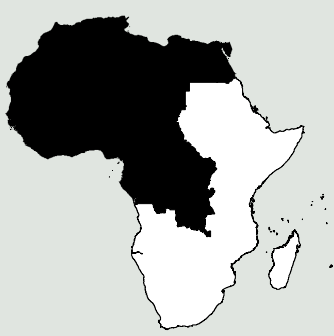

Porcentagem de Proteção

$0.0-1.3 \%$

$1.3-4.7 \%$

$4.7-7.5 \%$

$7.5-10.4 \%$

$10.4-15.6 \%$

15.6- $25.6 \%$

$25.6-38.0 \%$

$38.0-50.0 \%$

$\mathbf{5 0 . 0}-\mathbf{7 2 . 0 \%}$

$72.0-100 \%$
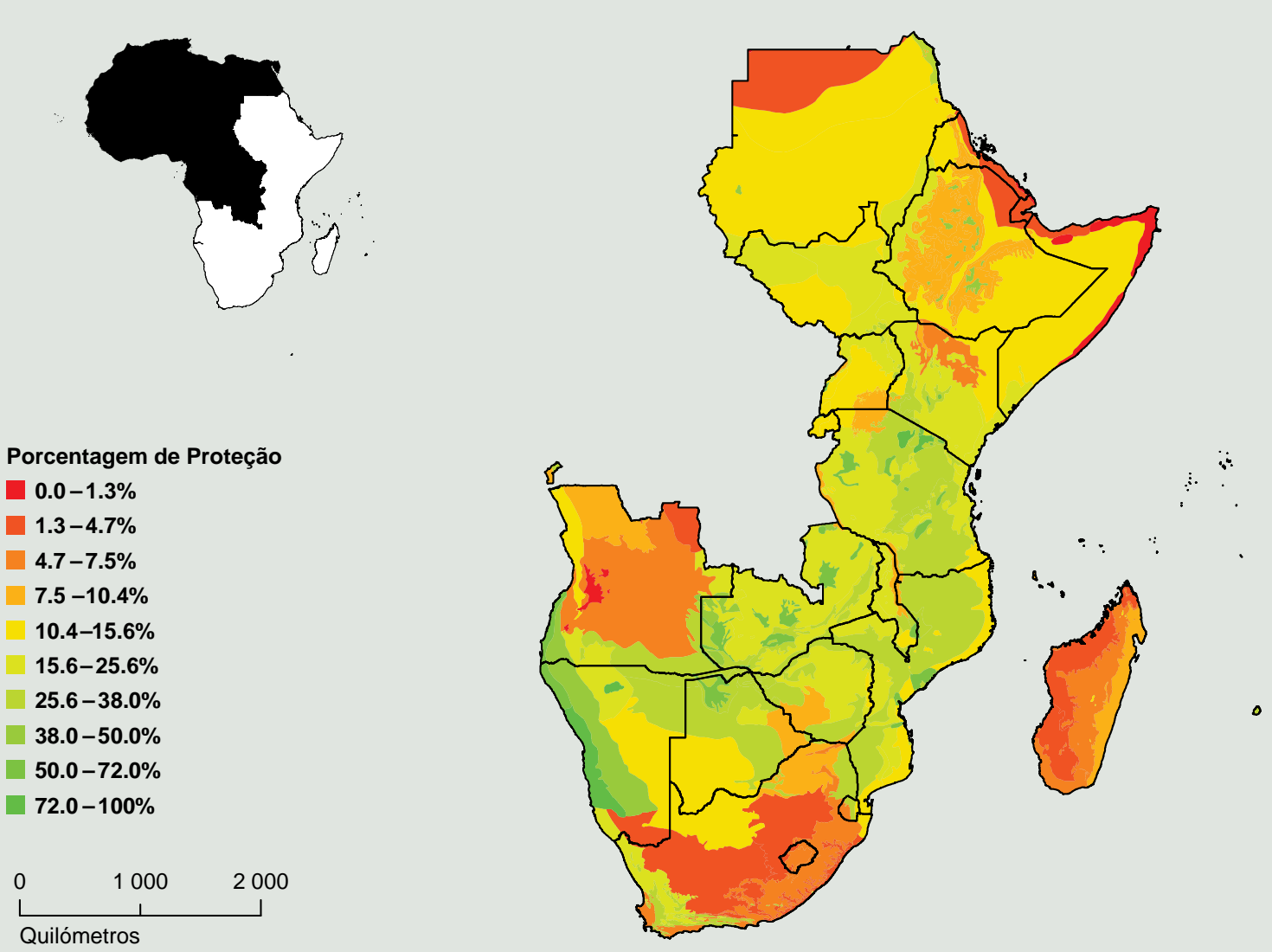

Fonte: Desenvolvido por EC JRC e RCMRD baseado nos dados DOPA

12 Os limites da ecorregião terrestre são fornecidos pela WWF, The Nature Conservancy e parceiros (Olson et al., 2001). Para as águas da plataforma costeira e continental, foram utilizadas as 232 fronteiras fornecidas pelas Ecorregiões Marinhas do Mundo (MEoW) (Spalding et al., 2007). Estas ecorregiões estendem-se desde a costa (zona intertidais) até ao contorno de $200 \mathrm{~m}$ de profundidade (estendido para além das águas por um tampão de $5 \mathrm{~km}$ ). Foram também utilizadas as 37 províncias pelágicas do mundo (PPOW) que ultrapassam os $200 \mathrm{~m}$ de profundidade (Spalding et al., 2012). As áreas protegidas propostas (mas ainda não totalmente designadas ou estabelecidas) e as áreas protegidas registadas como pontos sem uma área notificada estão excluídas das análises. Além disso, todas as sobreposições entre registos diferentes são removidas dos cálculos para evitar a dupla contagem. É utilizada uma análise SIG para calcular a protecção. Para tal, é criada uma camada de área protegida global através da protecção dos pontos registados na WDPA com base nas suas áreas notificadas e combinando-os com os polígonos registados na WDPA. Esta camada é sobreposta aos limites dos países e às ecorregiões para obter a cobertura absoluta e relativa das áreas protegidas.

\section{Figura 4.9 Número de registos de áreas protegidas na WDPA de 1998 a 2019}

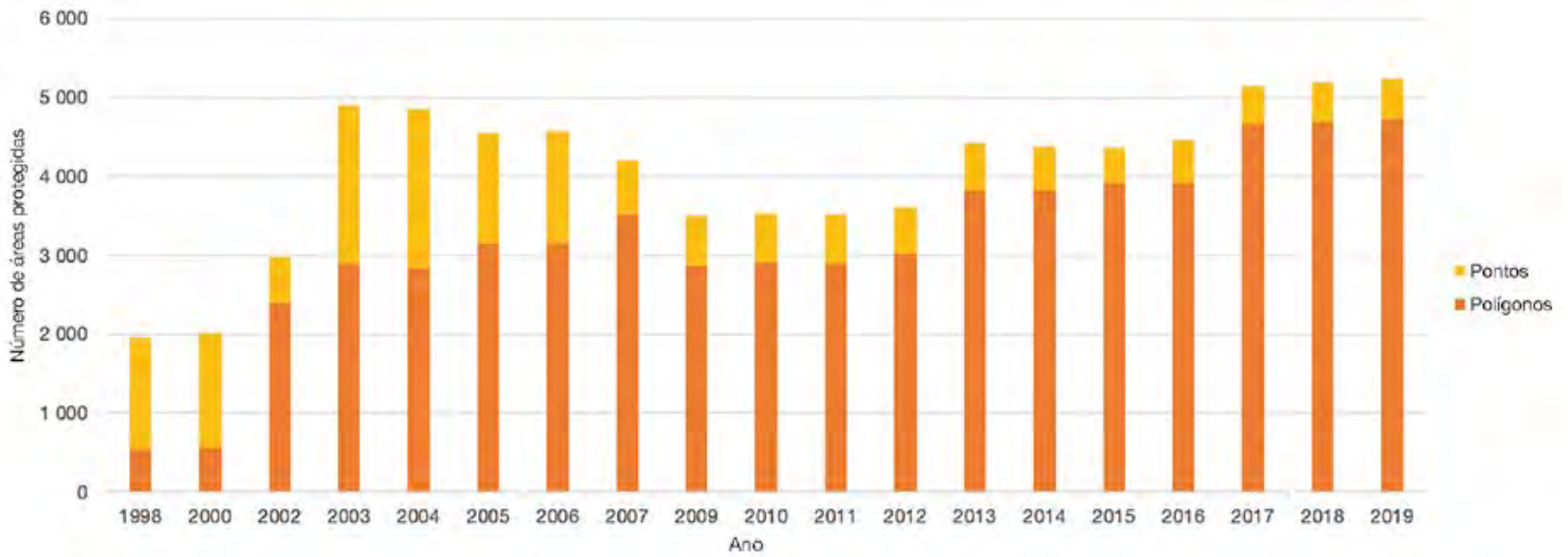

Fonte: UNEP-WCMC \& UICN (2019a). 
com um nome diferente, tornando as alterações reais na extensão e protecção dos sítios difíceis de interpretar. Um caso em questão é o Parque Nacional Julius Nyerere, da Tanzânia, que foi anteriormente incorporado na Reserva de Caça Selous e é agora o maior parque nacional em África.

O acompanhamento preciso da cobertura de áreas protegidas ao longo do tempo é um desafio, uma vez que existem limitações a qualquer abordagem (Lewis et al., 2017). É particularmente difícil na África Oriental e Austral devido à qualidade variável dos dados em lançamentos anteriores da WDPA, sobretudo o grande número de dados pontuais. Quando apenas estão disponíveis dados pontuais, é necessário confiar na dimensão das áreas protegidas comunicadas, que muitas vezes podem estar em falta ou ser inexactas, por oposição às áreas reais de polígonos. Isto resulta em inexactidões na métrica das áreas protegidas (Visconti et al., 2013), e ainda assim omitir pontos por completo subdeclararia drasticamente a cobertura das áreas protegidas. Por este motivo, em vez da área, foi utilizada a alteração do número de áreas protegidas na região, apesar das suas limitações. Neste contexto e região, foi considerada a abordagem mais precisa e resultou nos dados apresentados na Figura 4.9.

A política e a prática de conservação assumem geralmente que as áreas protegidas são instalações permanentes na paisagem e esta é a intenção de acordo com a definição, mas as provas apontam para uma degradação generalizada - mas largamente negligencia - da área protegida, redução de tamanho e degazettement (PADDD) (Mascia \& Pailler, 2011), ver Caixa 4.1. De acordo com a análise global mais recente, pelo menos 3.700 eventos PADDD foram decretados em 73 países entre 1892 e 2018, afectando uma área de cerca de 2 milhões de km² (Golden Kroner et al., 2019), e mais de 800 eventos propostos foram registados nos 24 países da África Oriental e Austral durante o mesmo período.

Globalmente, embora não existam requisitos existentes para seguir ou relatar o PADDD (Qin et al., 2019), as análises mostraram que o PADDD é um fenómeno episódico e fragmentado, em grande parte associado às seguintes actividades: extracção e desenvolvimento de

\section{Caixa 4.10 que é o PADDD?}

PADDD significa degradação de áreas protegidas, redução e degazettement

- Degradação é a autorização legal de um aumento do número, magnitude ou extensão das actividades humanas dentro de uma área protegida.

- Redução é a diminuição da dimensão de uma área protegida como resultado da excisão de uma área terrestre ou marítima através de uma alteração dos limites legais.

- Degazettement é a perda de protecção legal para toda uma área protegida

Os eventos PADDD são compilados pela Conservation International e pelo World Wildlife Fund. Os dados estão disponiveis em: https://www.padddtracker.org/.

Fonte: $\mathrm{Cl} \& W W F$ (n.d.). recursos naturais à escala industrial (62\%); pressões locais sobre a terra e reivindicações de terra (28\%); e planeamento da conservação $(1,7 \%)$ (Mascia et al., 2014). As maiores áreas protegidas que estão mais próximas dos centros populacionais têm mais probabilidades de serem reduzidas ou degazettement (Symes et al., 2016).

A nível regional em África, o acompanhamento de eventos PADDD tem sido conduzido numa base ad hoc, e nenhum dos países da África Oriental e Austral foi ainda objecto de uma análise detalhada. Até 2019, os eventos disponíveis na base de dados do PADDD mostram 296 eventos decretados e oito eventos propostos na África Oriental e Austral em 13 países (Cl \& WWF, n.d.). A base de dados inclui as causas imediatas dos eventos de degraduação, redução e degazettement, que no contexto da região incluem: planeamento da conservação $(21)^{13}$; pesca (1); silvicultura (9); agricultura industrial (16); industrialização (5); infra-estruturas (5); reclamações de terras (20); exploração mineira (24); petróleo e gás (3); alojamento para refugiados (2); assentamentos rurais (18); e subsistência (4).

\section{5 Áreas transfronteiriças protegidas e de conservação}

Há um reconhecimento crescente da importância da cooperação transfronteiriça na conservação em toda a África Oriental e Austral, onde os ecossistemas e as populações de fauna bravia não reconhecem fronteiras nacionais. As áreas de conservação transfronteiriças variam desde parques transfronteiriços, que incluem duas ou mais áreas protegidas adjacentes, a áreas de conservação que incluem uma complexidade de usos do solo, tais como terras comunitárias, terras privadas e áreas formalmente protegidas. Estas áreas de conservação transfronteiriças desempenham um papel crítico na salvaguarda de recursos regionalmente importantes que atravessam fronteiras, tais como florestas e outros ecossistemas chave, bacias hidrográficas, habitats e refúgios contínuos de fauna bravia, e corredores de conectividade para o movimento da fauna bravia. As áreas de conservação transfronteiriças são importantes para o desenvolvimento nacional e regional, fornecendo um foco para o desenvolvimento do turismo baseado na natureza. É provável que as abordagens transfronteiriças desempenhem um papel ainda mais importante na adaptação às alterações climáticas, uma vez que permitirão mudanças no habitat, bem como o movimento de espécies, devido à sua vasta dimensão e à abordagem paisagística da gestão do uso da terra. Em termos de financiamento, tende a ser maior nas áreas protegidas que fazem parte de áreas de conservação transfronteiriças (Lindsey et al., 2018).

Na África Austral, a SADC adoptou um programa sobre Áreas de Conservação Transfronteiriças (ZFCAs), cuja missão é: Desenvolver a SADC numa rede funcional e integrada de Áreas de Conservação Transfronteiriças onde os recursos naturais partilhados são co-geridos e conservados de forma sustentável para fomentar o desenvolvimento socioeconómico, e a integração regional em benefício das pessoas que vivem dentro e em redor das áreas de conservação transfronteiriças, da região da SADC, e do mundo (Secretariado da SADC, 2013, p. 4).

13 Normalmente refere-se a alterações legais concebidas para aumentar a eficiência e eficácia de conservação de uma classe, grupo ou conjunto geograficamente distinto de áreas protegidas. 


\section{Figura 4.10 Áreas de Conservação Transfronteiriças da Comunidade de Desenvolvimento da África Austral (SADC TFCAS)}

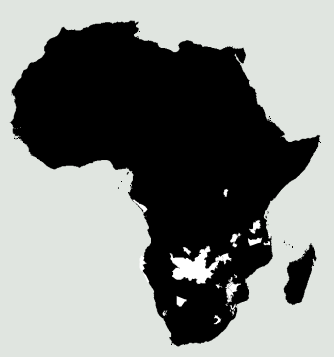

Cobertura BIOPAMA ESARO

SADC TFCAS

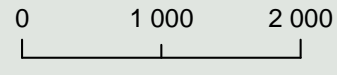

Quilometros

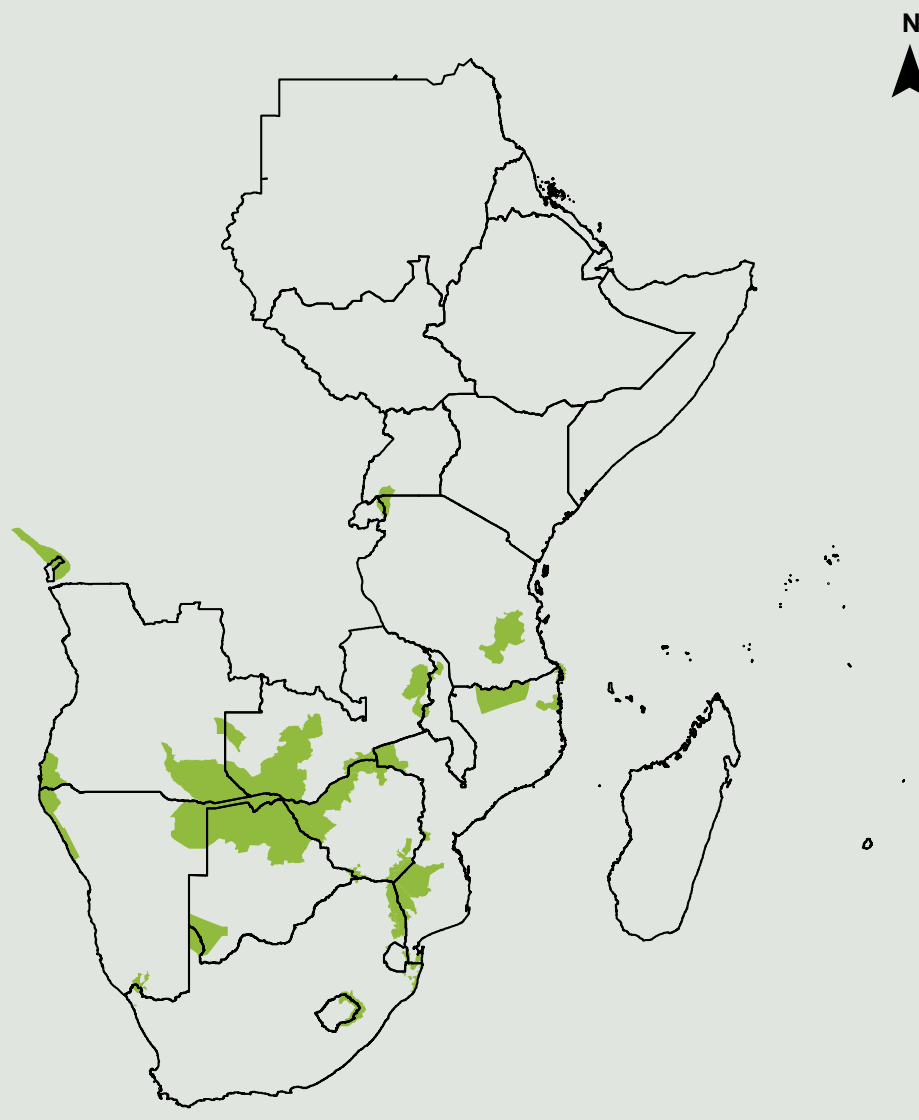

Fonte: Developed by RCMRD based on data from Peace parks and SADC

Em apoio à implementação do programa, foi criada uma Rede TFCA da SADC para reunir profissionais de toda a região (ver Caixa 4.2)

A rede desenvolveu uma série de documentos úteis para apoiar a conservação transfronteiriça. Estes incluem:

- Directrizes para o envolvimento comunitário nas TFCAs da SADC (Secretariado da SADC, 2018);

- Directrizes da SADC para produtos turísticos transfronteiriços (Spenceley, 2018); e

- Directrizes sobre o estabelecimento e desenvolvimento de iniciativas da TFCA entre os estados membros da SADC (Zunckel, 2014)

As duas primeiras directrizes aguardam aprovação ministerial, enquanto que as directrizes sobre o estabelecimento já foram aprovadas.

$\mathrm{Na}$ África Oriental, existem várias iniciativas para melhorar a gestão transfronteiriça de ecossistemas chave, mas estas parecem ser mais impulsionadas por sítios e organizações individuais, do que por uma abordagem coesa apoiada pelas agências nacionais (BIOPAMA, inédito). Em 2010, a EAC apresentou um projecto de lei para a gestão de ecossistemas transfronteiriços que fornece um quadro potencial e uma ferramenta para ajudar a facilitar uma abordagem mais coordenada da conservação transfronteiriça na região (EAC, 2010). Até à data, porém, o projecto de lei ainda não foi ratificado pelos Estados Parceiros da EAC.

Enquanto muitas das áreas de conservação transfronteiriças na região foram formalmente adoptadas pelos governos participantes através de um tratado assinado pelos Chefes de Estado, outras são geridas ao abrigo de um Memorando de Acordo (MOU) entre vários departamentos ou agências governamentais, ou permanecem conceptuais (ver Quadro 4.3). A Figura 4.10 mostra as TFCAs estabelecidas na região. 


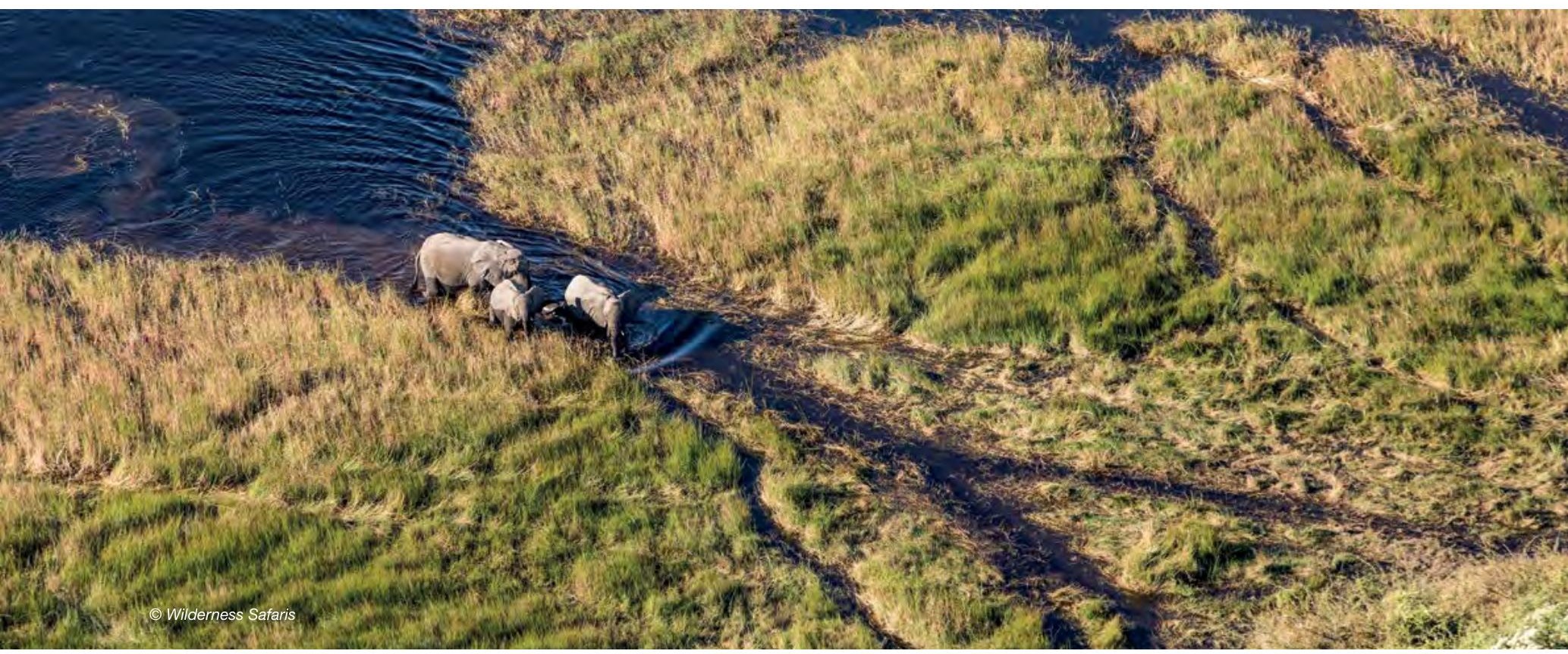

\section{Caixa 4.2 Rede TFCA da SADC}

Desde a criação em 1990 do Parque Transfronteiriço de Kgalagadi, o primeiro Parque Transfronteiriço na África Austral entre Botswana e a África do Sul, a SADC tem estado na linha da frente da conservação transfronteiriça. A fim de promover o estabelecimento e desenvolvimento de TFCAs como um modelo de conservação e desenvolvimento em toda a região, foi aprovado em Outubro de 2013 um Programa TFCA da SADC. Actualmente, existem 18 TFCAs terrestres e marinhas existentes e potenciais em toda a região da SADC, cobrindo mais de um milhão de quilómetros quadrados, o que corresponde a mais de metade da área protegida na África Austral.

A Rede TFCA da SADC foi estabelecida no mesmo ano que o Programa TFCA para acelerar a implementação do programa e melhorar a aprendizagem e cooperação regional entre governos, implementadores, a comunidade internacional de doadores, representantes comunitários, sector privado e especialistas em conservação transfronteiriça. Especificamente, concordaram em: partilhar informação entre os profissionais e o público; aprender uns com os outros e criar e expandir conhecimentos sobre as ACTF; fomentar a inovação no terreno bem como a nível político; mobilizar recursos; e contribuir para a capacitação dos administradores finais dos recursos naturais, as comunidades.

Até à data, a rede é composta por mais de 350 membros de todos os grupos de interessados relevantes que comunicam e partilham informações através de um portal Web da SADC TFCA www.tfcaportal.org. A rede está integrada nas estruturas de governação da SADC e é orientada por um Comité Director composto pelo Secretariado e pelos pontos focais da TFCA dos Estados Membros. Desta forma, a Direcção da Rede de TFCA da SADC O Comité e a Rede facilitaram e aceleraram os processos de tomada de decisão da SADC, por exemplo, no desenvolvimento e promoção de produtos turísticos transfronteiriços e nas directrizes acima enumeradas, bem como a adopção em 2019 do Programa de Turismo TFCA da SADC, ambos impulsionados pela rede.

Algumas das suas realizações incluem:

1. Adesão de mais de 350 aderentes activos, a nível regional e global, demonstrando o sucesso das TFCAs da SADC;

2. Convocação de reuniões anuais da rede TFCA da SADC e participação em eventos globais, tais como o Congresso Mundial de Parques da UICN de 2014, a COP17 da CITES de 2016 e a COP14 da CDB de 2018.

3. Permitiu reuniões comunitárias transfronteiriças, tais como o Fórum de Intercâmbio Intercomunitário Transfronteiriço;

4. Apoiou a criação de uma Facilidade de Financiamento regional da SADC TFCA;

5. Documentação das lições aprendidas através do apoio ao desenvolvimento de directrizes regionais de TFCA da SADC sobre Desenvolvimento de TFCA, Concessões Turísticas, Produções Turísticas Transfronteiriças e Envolvimento da Comunidade; e

6. Estabelecimento de cinco Comunidades de Prática para ajudar a informar as estruturas estatutárias da SADC com peritos nos domínios de:

- Gestão, monitorização e avaliação dos dados;

- Desenvolvimento de capacidades e formação;

- Turismo;

- Envolvimento da comunidade; e

- Aplicação da lei e luta contra a caça furtiva.

Contribuição de Lisa Blanken, Deutsche Gesellschaft für Internationale Zusammenarbeit 
Quadro 4.3 Áreas de conservação transfronteiriças na África Oriental e Austral

\begin{tabular}{|c|c|c|c|c|c|c|}
\hline Nome & $\begin{array}{l}\text { Países } \\
\text { incluídos }\end{array}$ & $\begin{array}{l}\text { Área } \\
\left(\mathrm{km}^{2}\right)\end{array}$ & Estado & $\begin{array}{l}\text { Ecótipo/ } \\
\text { bioma }\end{array}$ & Áreas Protegidas & $\begin{array}{l}\text { Características/ } \\
\text { Significados } \\
\text { especiais }\end{array}$ \\
\hline $\begin{array}{l}\text { /Ai-/Ais- } \\
\text { Richtersveld TFCA }\end{array}$ & $\begin{array}{l}\text { Namíbia, } \\
\text { África do Sul }\end{array}$ & 5920 & $\begin{array}{l}\text { Tratado } \\
\text { assinado }\end{array}$ & $\begin{array}{l}\text { Deserto; } \\
\text { Riverine }\end{array}$ & $\begin{array}{l}\text { Namíbia: } \\
\text { Ais-Ais Hot Spring Game Park } \\
\text { África do Sul: } \\
\text { Parque Nacional Richtersveld }\end{array}$ & $\begin{array}{l}\text { Desfiladeiro do Rio } \\
\text { Peixe }\end{array}$ \\
\hline $\begin{array}{l}\text { Amboseli } \\
\text {-Kilimanjaro- } \\
\text { Longido }\end{array}$ & $\begin{array}{l}\text { Quénia, } \\
\text { Tanzânia }\end{array}$ & N/A & Conceitual & $\begin{array}{l}\text { Montana; } \\
\text { Floresta; } \\
\text { Savana }\end{array}$ & $\mathrm{N} / \mathrm{A}$ & $\begin{array}{l}\text { Montanas endémicas; } \\
\text { carnívoros; } \\
\text { área de elefantes } \\
\text { muito importante }\end{array}$ \\
\hline $\begin{array}{l}\text { Paisagem de } \\
\text { Boma-Gambella }\end{array}$ & $\begin{array}{l}\text { Sudão do Sul, } \\
\text { Etiópia }\end{array}$ & $\mathrm{N} / \mathrm{A}$ & Conceitual & $\begin{array}{l}\text { Savana; } \\
\text { Pântano }\end{array}$ & $\mathrm{N} / \mathrm{A}$ & $\begin{array}{l}\text { Principal migração de } \\
\text { caça para as planícies }\end{array}$ \\
\hline $\begin{array}{l}\text { Parque Nacional } \\
\text { Chimanimani }\end{array}$ & $\begin{array}{l}\text { Moçambique, } \\
\text { Zimbabué }\end{array}$ & 4091 & $\begin{array}{l}\text { Tratado } \\
\text { assinado }\end{array}$ & $\begin{array}{l}\text { Montanhas e } \\
\text { bosques de } \\
\text { miombo }\end{array}$ & $\begin{array}{l}\text { Zimbabué: } \\
\text { Parque Nacional Chimanimani } \\
\text { Moçambique: } \\
\text { Reserva Natural Chimanimani }\end{array}$ & $\begin{array}{l}\text { Floresta, paisagem, } \\
\text { vida selvagem e } \\
\text { cultura }\end{array}$ \\
\hline $\begin{array}{l}\text { Parque } \\
\text { Transfronteiriço } \\
\text { do Grande } \\
\text { Limpopo \& Área } \\
\text { de Conservação }\end{array}$ & $\begin{array}{l}\text { Moçambique, } \\
\text { África do Sul, } \\
\text { Zimbabué }\end{array}$ & 37572 & $\begin{array}{l}\text { Tratado } \\
\text { assinado }\end{array}$ & $\begin{array}{l}\text { Florestas de } \\
\text { Miombos }\end{array}$ & $\begin{array}{l}\text { Moçambique: } \\
\text { Parque Nacional do Limpopo } 0 \\
\text { África do Sul: } \\
\text { Parque Nacional do Kruger } 0 \\
\text { Zimbabué: } \\
\text { Parque Nacional de Gonarezhou } 0\end{array}$ & $\begin{array}{l}\text { Florestas fluviais; } \\
\text { endemismo regional; } \\
\text { importantes áreas de } \\
\text { dispersão de elefantes }\end{array}$ \\
\hline $\begin{array}{l}\text { Greater } \\
\text { Mapungubwe } \\
\text { TFCA }\end{array}$ & $\begin{array}{l}\text { Botswana, } \\
\text { África do Sul, } \\
\text { Zimbabué }\end{array}$ & 5909 & $\begin{array}{l}\text { MOU } \\
\text { assinado }\end{array}$ & Savana & $\begin{array}{l}\text { Botswana: } \\
\text { Tuli do Norte GR } 0 \\
\text { Zimbabué: } \\
\text { Tuli Circle Safari Área 0 } \\
\text { África do Sul: } \\
\text { Parque Nacional Mapungubwe e a } \\
\text { Paisagem Cultural Mapungubwe, } \\
\text { WHS 0 }\end{array}$ & $\begin{array}{l}\text { Artefactos culturais; } \\
\text { geologia única; } \\
\text { fauna e flora distintas }\end{array}$ \\
\hline $\begin{array}{l}\text { Paisagem da } \\
\text { Grande Virunga }\end{array}$ & $\begin{array}{l}\text { Ruanda, } \\
\text { Uganda, } \\
\text { RDC }\end{array}$ & 15000 & $\begin{array}{l}\text { Tratado } \\
\text { assinado } \\
\text { (ratificação } \\
\text { pendente) }\end{array}$ & $\begin{array}{l}\text { Rift Albertine } \\
\text { em média } \\
\text { altitude } \\
\text { e floresta } \\
\text { montana; } \\
\text { savana } \\
\text { sudanesa } \\
\text { oriental; Zonas } \\
\text { húmidas }\end{array}$ & $\begin{array}{l}\text { RDC: } \\
\text { Sítio Património Mundial Virunga / } \\
\text { Parque Nacional } \\
\text { Ruanda: } \\
\text { Parque Nacional Volcans } \\
\text { Uganda: } \\
\text { Parque Nacional de Mgahinga } \\
\text { Parque Nacional Queen Elizabeth } \\
\text { Sítio Património Mundial Bwindi / } \\
\text { Parque Nacional } \\
\text { Parque Nacional de Semuliki } \\
\text { Sítio Património Mundial } \\
\text { Ruwenzori / Parque Nacional } \\
\text { Parque Nacional de Kibale } \\
\text { Reserva Florestal Kasyoha-Kitomi } \\
\text { Reserva Florestal } \\
\text { Kalinzu-Maramgambo } \\
\text { Reserva de Kayumbura Wetland }\end{array}$ & $\begin{array}{l}\text { Albertine Rift } \\
\text { Ecoregion; } 3 \text { Sítios } \\
\text { Património Mundial; } \\
\text { população inteira de } \\
\text { Gorilas de Montanha e } \\
\text { importante população } \\
\text { de chimpanzés; a } \\
\text { maioria das endemias } \\
\text { Albertinas; potencial } \\
\text { turístico excepcional; } \\
\text { protecção das } \\
\text { populações vitais de } \\
\text { peixes de água doce; } \\
\text { protecção das bacias } \\
\text { hidrográficas }\end{array}$ \\
\hline $\begin{array}{l}\text { Iona Skeleton } \\
\text { Coast TFCA }\end{array}$ & $\begin{array}{l}\text { Angola, } \\
\text { Namíbia }\end{array}$ & 47698 & $\begin{array}{l}\text { MOU } \\
\text { assinado }\end{array}$ & Deserto & $\begin{array}{l}\text { Angola: } \\
\text { Parque Nacional de lona, } \\
\text { Namíbia: } \\
\text { Parque Nacional da Costa de } \\
\text { Skeleton }\end{array}$ & $\begin{array}{l}\text { Rio Kunene e } \\
\text { ecossistemas } \\
\text { nascentes naturais }\end{array}$ \\
\hline
\end{tabular}




\begin{tabular}{|c|c|c|c|c|c|c|}
\hline Nome & $\begin{array}{l}\text { Países } \\
\text { incluídos }\end{array}$ & $\begin{array}{l}\text { Área } \\
\left(\mathrm{km}^{2}\right)\end{array}$ & Estado & $\begin{array}{l}\text { Ecótipo/ } \\
\text { bioma }\end{array}$ & Áreas Protegidas & $\begin{array}{l}\text { Características/ } \\
\text { Significados } \\
\text { especiais }\end{array}$ \\
\hline Kagera TFCA & $\begin{array}{l}\text { Ainda por ser } \\
\text { finalizado, } \\
\text { mas inclui } \\
\text { Ruanda, } \\
\text { Tanzânia, } \\
\text { Uganda }\end{array}$ & 2500 & $\begin{array}{l}\text { MOU } \\
\text { assinado }\end{array}$ & $\begin{array}{l}\text { Savana; } \\
\text { Pradarias; } \\
\text { Floresta } \\
\text { húmida; } \\
\text { Zonas húmidas; } \\
\text { Floresta } \\
\text { afro-montana; } \\
\text { Floresta tropical }\end{array}$ & $\begin{array}{l}\text { Ruanda: } \\
\text { Parque Nacional de Akagera } \\
\text { Tanzânia: } \\
\text { Parques Nacionais Ibanda e } \\
\text { Rumanyika }\end{array}$ & $\begin{array}{l}\text { Rio Kagera; a maior } \\
\text { zona húmida protegida } \\
\text { em África Oriental; } \\
\text { quedas de água de } \\
\text { florestas sagradas, } \\
\text { sistemas de cavernas } \\
\text { e pinturas rupestres } \\
\text { antigas; biodiversidade } \\
\text { excepcional }\end{array}$ \\
\hline $\begin{array}{l}\text { Kavango- } \\
\text { Zambeze TFCA }\end{array}$ & $\begin{array}{l}\text { Angola, } \\
\text { Botswana, } \\
\text { Namíbia, } \\
\text { Zâmbia, } \\
\text { Zimbabué }\end{array}$ & 520000 & $\begin{array}{l}\text { Tratado } \\
\text { assinado }\end{array}$ & $\begin{array}{l}\text { Mata de } \\
\text { Miombo; } \\
\text { Pastagens } \\
\text { inundadas da } \\
\text { Zambézia; } \\
\text { Savana }\end{array}$ & $\begin{array}{l}\text { Angola: } \\
\text { Parque Nacional Luengue-Luiana } \\
\text { Parque Nacional de Mavinga } \\
\text { Botswana: } \\
\text { Parque Nacional de Chobe } \\
\text { Parque Nacional de Makgadikgadi } \\
\text { Parque Nacional Pan Nxai } \\
\text { Reserva de Caça Moremi } \\
\text { Namíbia: } \\
\text { Parque Nacional de Mamili } \\
\text { Parque Nacional de Mudumu } \\
\text { Parque Nacional de Bwabwata } \\
\text { Zâmbia: } \\
\text { Parque Nacional de Kafue } \\
\text { Parque Nacional Mosi-oa-Tunya } \\
\text { Parque Nacional Sioma Ngwezi } \\
\text { Zimbabué: } \\
\text { Parque Nacional de Hwange } \\
\text { Parque Nacional Kazuma Pan } \\
\text { Parque Nacional de Matusadona } \\
\text { Parque Nacional do Zambeze } \\
\text { Parque Nacional Cataratas Vitória }\end{array}$ & $\begin{array}{l}\text { Zonas húmidas } \\
\text { do Delta único do } \\
\text { Okavango; migrações } \\
\text { de vida selvagem; } \\
\text { grande população } \\
\text { de elefantes; outros } \\
\text { grandes mamíferos; } \\
\text { Parque da Paz; } \\
\text { potencial turístico } \\
\text { excepcional }\end{array}$ \\
\hline $\begin{array}{l}\text { Kidepo } \\
\text { Paisagem }\end{array}$ & $\begin{array}{l}\text { Uganda, } \\
\text { Sudão do Sul }\end{array}$ & N/A & $\begin{array}{l}\text { Parcial } \\
\text { MOU (para } \\
\text { cerca de } \\
\text { floresta } \\
\text { reservas) }\end{array}$ & Savannah & N/A & $\begin{array}{l}\text { Chita, Cão Selvagem } \\
\text { Africano, Kudu Menor, } \\
\text { Karamoja Apalis }\end{array}$ \\
\hline $\begin{array}{l}\text { Parque } \\
\text { Transfronteiriço } \\
\text { Kgalagadi }\end{array}$ & $\begin{array}{l}\text { Botswana, } \\
\text { África do Sul }\end{array}$ & 35551 & $\begin{array}{l}\text { Tratado } \\
\text { assinado }\end{array}$ & Desert & $\begin{array}{l}\text { Botswana: } \\
\text { Parque Nacional Gemsbok } \\
\text { África do Sul: } \\
\text { Parque Nacional Gemsbok Kalahari }\end{array}$ & $\begin{array}{l}\text { Ecossistema único } \\
\text { do Kalahari; leões } \\
\text { de homem negro; } \\
\text { Gemsbok, etc. }\end{array}$ \\
\hline $\begin{array}{l}\text { Planícies Liuwa- } \\
\text { Mussuma TFCA }\end{array}$ & $\begin{array}{l}\text { Angola, } \\
\text { Zâmbia }\end{array}$ & 14464 & $\begin{array}{l}\text { TFCA } \\
\text { Conceitual }\end{array}$ & $\begin{array}{l}\text { Ecorregião } \\
\text { das pastagens } \\
\text { inundadas da } \\
\text { Zambézia, a } \\
\text { ecorregião } \\
\text { das florestas } \\
\text { de miombo e } \\
\text { a ecorregião } \\
\text { das florestas } \\
\text { secas de } \\
\text { crip-tosepalum } \\
\text { da Zambézia }\end{array}$ & $\begin{array}{l}\text { Zâmbia: } \\
\text { Parque Nacional Liuwa Plains } \\
\text { Angola: } \\
\text { Parque Nacional Massuma }\end{array}$ & $\begin{array}{l}\text { Segunda maior } \\
\text { migração de gnus } \\
\text { em África; porção } \\
\text { significativa da bacia } \\
\text { hidrográfica do rio } \\
\text { Zambeze; o quarto } \\
\text { maior sistema fluvial } \\
\text { de África }\end{array}$ \\
\hline $\begin{array}{l}\text { Baixo } \\
\text { Awash-Lago } \\
\text { Abbé Paisagem }\end{array}$ & $\begin{array}{l}\text { Djibouti, } \\
\text { Etiópia }\end{array}$ & $\mathrm{N} / \mathrm{A}$ & Conceitual & Terra Seca & N/A & N/A \\
\hline $\begin{array}{l}\text { Baixa Zambeze } \\
\text { - Mana Pools } \\
\text { TFCA }\end{array}$ & $\begin{array}{l}\text { Zâmbia, } \\
\text { Zimbabué }\end{array}$ & 17745 & $\begin{array}{l}\text { TFCA } \\
\text { conceitual }\end{array}$ & $\begin{array}{l}\text { Florestas de } \\
\text { Miombo }\end{array}$ & $\begin{array}{l}\text { Zimbabué: } \\
\text { Parque Nacional Mana Pools / } \\
\text { WHS Sapi e Chewore Safari Áreas } \\
\text { do Parque Nacional do Baixo } \\
\text { Zambeze }+6 \text { reservas adicionais }\end{array}$ & $\begin{array}{l}\text { Rio Zambeze; planície } \\
\text { de inundação; } \\
\text { escarpa; grandes } \\
\text { populações de } \\
\text { mamíferos }\end{array}$ \\
\hline
\end{tabular}




\begin{tabular}{|c|c|c|c|c|c|c|}
\hline Nome & $\begin{array}{l}\text { Países } \\
\text { incluídos }\end{array}$ & $\begin{array}{l}\text { Área } \\
\left(\mathrm{km}^{2}\right)\end{array}$ & Estado & $\begin{array}{l}\text { Ecótipo/ } \\
\text { bioma }\end{array}$ & Áreas Protegidas & $\begin{array}{l}\text { Características/ } \\
\text { Significados } \\
\text { especiais }\end{array}$ \\
\hline Lubombo TFCA & $\begin{array}{l}\text { Eswatini, } \\
\text { Moçambique, } \\
\text { África do Sul }\end{array}$ & 10029 & $\begin{array}{l}\text { Tratado } \\
\text { assinado }\end{array}$ & $\begin{array}{l}\text { Planície } \\
\text { costeira }\end{array}$ & $\begin{array}{l}\text { Ligações } 5 \text { projectos TFCA } \\
\text { Eswatini: } \\
\text { Parque Nacional Hlana Royal } \\
\text { África do Sul: } \\
\text { Parque de Elefantes Tembe } \\
\text { Moçambique: } \\
\text { Reserva Especial de Maputo } \\
+12 \text { áreas protegidas do estado } \\
\text { e outras reservas, bem como } \\
\text { terrenos privados }\end{array}$ & $\begin{array}{l}\text { Alta biodiversidade; } \\
5 \text { sítios Ramsar; zonas } \\
\text { húmidas; bosques }\end{array}$ \\
\hline $\begin{array}{l}\text { Malawi - Zâmbia } \\
\text { TFCA }\end{array}$ & $\begin{array}{l}\text { Malawi, } \\
\text { Zâmbia }\end{array}$ & 32278 & $\begin{array}{l}\text { Tratado } \\
\text { assinado }\end{array}$ & $\begin{array}{l}\text { Montana; } \\
\text { Prados; } \\
\text { Pântanos; }\end{array}$ & $\begin{array}{l}3 \text { areas protegidas incluindo: } \\
\text { Parque Nacional Nyika, Vwaza } \\
\text { Marsh Wildlife Reserve }\end{array}$ & $\begin{array}{l}\text { Pastagens e flora } \\
\text { montana; zonas } \\
\text { húmidas; Programa de } \\
\text { repovoamento }\end{array}$ \\
\hline $\begin{array}{l}\text { Maloti } \\
\text { Drakensberg } \\
\text { TFCA (também } \\
\text { um sítio } \\
\text { transfronteiriço } \\
\text { do Património } \\
\text { Mundial) }\end{array}$ & $\begin{array}{l}\text { Lesoto, } \\
\text { África do Sul }\end{array}$ & 14740 & $\begin{array}{l}\text { MOU } \\
\text { assinado }\end{array}$ & Montane & $\begin{array}{l}\text { Lesoto: } \\
\text { Maloti Drakensberg } \\
\text { Património Mundial } \\
\text { Transfronteiriço, inclui o Parque } \\
\text { Nacional do Sehlabathebe } \\
\text { África do Sul: } \\
\text { Parque Ukhahlamba Drakensberg }\end{array}$ & $\begin{array}{l}\text { Montanhas do Sul; } \\
\text { escarpas; rica flora } \\
\text { endémica; zonas } \\
\text { húmidas; cultura San }\end{array}$ \\
\hline $\begin{array}{l}\text { Área Protegida } \\
\text { Transfronteiriça } \\
\text { da Floresta }\end{array}$ & $\begin{array}{l}\text { Angola, } \\
\text { República } \\
\text { Democrática } \\
\text { do Congo, } \\
\text { Gabão, } \\
\text { República do } \\
\text { Congo }\end{array}$ & 36000 & $\begin{array}{l}\text { MOU } \\
\text { assinado }\end{array}$ & Floresta tropical & $\begin{array}{l}\text { Angola: } \\
\text { Parque Nacional Mayombe } \\
\text { RDC: } \\
\text { Parque Nacional de Luki } \\
\text { República do Congo: } \\
\text { Reserva da Biosfera } \\
\text { Dimonika, Parque Nacional } \\
\text { de Conkouati-Douli e Reserva } \\
\text { Nacional de Tchimpounga }\end{array}$ & $\begin{array}{l}\text { Floresta tropical da } \\
\text { bacia; Chimpanzés e } \\
\text { gorilas das planícies }\end{array}$ \\
\hline $\begin{array}{l}\text { Baía Mnazi } \\
\text { - Quirimbas TFCA }\end{array}$ & $\begin{array}{l}\text { Moçambique, } \\
\text { Tanzânia }\end{array}$ & 8150 & $\begin{array}{l}\text { TFCA } \\
\text { conceitual }\end{array}$ & $\begin{array}{l}\text { Bioma das } \\
\text { florestas e } \\
\text { arbustos do } \\
\text { litoral da África } \\
\text { Oriental }\end{array}$ & $\begin{array}{l}\text { Moçambique: } \\
\text { Parque Nacional das Quirimbas } \\
\text { Tanzânia: } \\
\text { Parque Marinho do Estuário da } \\
\text { Baía de Mnazi-Ruvuma }\end{array}$ & $\begin{array}{l}\text { Um refúgio importante } \\
\text { para a diversidade dos } \\
\text { recifes nas zonas a } \\
\text { jusante no norte e sul } \\
\text { das zonas costeiras } \\
\text { continentais }\end{array}$ \\
\hline $\begin{array}{l}\text { Mosi-oa-Tunya } \\
\text { / Cataratas } \\
\text { Vitória \Sítio } \\
\text { do Património } \\
\text { Mundial } \\
\text { Transfronteiriço }\end{array}$ & $\begin{array}{l}\text { Zambia, } \\
\text { Zimbabwe }\end{array}$ & 69 & $\begin{array}{l}\text { Tratado } \\
\text { assinado }\end{array}$ & Riverine & $\begin{array}{l}\text { Zâmbia: } \\
\text { Parque Nacional Mosi-oa-Tunya } \\
\text { Zimbabué: } \\
\text { Parque Nacional Cataratas Vitória }\end{array}$ & $\begin{array}{l}\text { Cataratas Vitória; } \\
\text { Património Mundial; } \\
\text { características } \\
\text { geológicas e } \\
\text { geomorfológicas } \\
\text { excepcionais }\end{array}$ \\
\hline Mt Elgon & $\begin{array}{l}\text { Uganda, } \\
\text { Kenya }\end{array}$ & N/A & $\begin{array}{l}\text { MOU } \\
\text { redigido }\end{array}$ & Montane & $\begin{array}{l}\text { Uganda: } \\
\text { Parque Nacional do Monte Elgon } \\
\text { Quénia: } \\
\text { Parque Nacional do Monte Elgon } \\
\text { e Reservas Florestais do Monte } \\
\text { Elgon e Trans-Nzoia } \\
\text { Reserva Nacional Chepkitale }\end{array}$ & Vulcão-escudo extinto \\
\hline $\begin{array}{l}\text { Niassa-Selous } \\
\text { TFCA }\end{array}$ & $\begin{array}{l}\text { Moçambique, } \\
\text { Tanzânia }\end{array}$ & 154000 & $\begin{array}{l}\text { MOU } \\
\text { assinado }\end{array}$ & $\begin{array}{l}\text { Mata de } \\
\text { Miombo; } \\
\text { Pântanos; } \\
\text { Savana }\end{array}$ & $\begin{array}{l}\text { Moçambique: } \\
\text { Niassa NR } \\
\text { Tanzânia: } \\
\text { Sítio Património Mundial Selous/ } \\
\text { GR Parque Nacional Mikumi } \\
\text { Parque Nacional Udzungwa } \\
\text { Kilombero GCA } \\
+ \text { WMAs, conservas, e blocos de } \\
\text { caça }\end{array}$ & $\begin{array}{l}\text { Corredor de migração; } \\
\text { área de elefantes } \\
\text { muito importante; } \\
\text { búfalos, hipopótamos }\end{array}$ \\
\hline
\end{tabular}




\begin{tabular}{|c|c|c|c|c|c|c|}
\hline Nome & $\begin{array}{l}\text { Países } \\
\text { incluídos }\end{array}$ & $\begin{array}{l}\text { Área } \\
\left(\mathbf{k m}^{2}\right)\end{array}$ & Estado & $\begin{array}{l}\text { Ecótipo/ } \\
\text { bioma }\end{array}$ & Áreas Protegidas & $\begin{array}{l}\text { Características/ } \\
\text { Significados } \\
\text { especiais }\end{array}$ \\
\hline Nyungwe-Kibira & $\begin{array}{l}\text { Burundi, } \\
\text { Ruanda }\end{array}$ & 1171 & $\begin{array}{l}\text { MOU } \\
\text { assinado }\end{array}$ & $\begin{array}{l}\text { Floresta } \\
\text { montana de } \\
\text { altitude média }\end{array}$ & $\begin{array}{l}\text { Ruanda: } \\
\text { Nyungwe NP } \\
\text { Burundi: } \\
\text { Kibira }\end{array}$ & Floresta e endemismos \\
\hline $\begin{array}{l}\text { Sango Bay - } \\
\text { Minziro }\end{array}$ & $\begin{array}{l}\text { Tanzânia, } \\
\text { Uganda }\end{array}$ & 861 & Conceitual & $\begin{array}{l}\text { Zonas húmidas } \\
\text { e florestas } \\
\text { pantanosas }\end{array}$ & $\begin{array}{l}\text { Tanzânia: } \\
\text { Reserva Natural da Floresta } \\
\text { Minziro } \\
\text { Uganda: } \\
\text { Sistema de zonas húmidas da } \\
\text { Baía de Sango-Musambwa e } \\
\text { Kagera }\end{array}$ & $\begin{array}{l}\text { Florestas de } \\
\text { Baikiaea-Podocarpus, } \\
\text { papiros endémicos }\end{array}$ \\
\hline Serengeti-Mara & $\begin{array}{l}\text { Tanzânia, } \\
\text { Quénia }\end{array}$ & 25000 & Conceitual & Savanna & $\begin{array}{l}\text { Parque Nacional do Serengeti } \\
\text { Reserva Nacional Masai Mara }\end{array}$ & $\begin{array}{l}\text { Migração anual de } \\
\text { cerca de } 2 \text { milhões de } \\
\text { herbívoros }\end{array}$ \\
\hline $\begin{array}{l}\text { Tana-Kipini-Laga } \\
\text { Badana Bushbush } \\
\text { Land and } \\
\text { Seascape }\end{array}$ & $\begin{array}{l}\text { Quénia, } \\
\text { Somália }\end{array}$ & $\mathrm{N} / \mathrm{A}$ & Conceitual & $\mathrm{n} / \mathrm{a}$ & N/A & $\mathrm{N} / \mathrm{A}$ \\
\hline $\begin{array}{l}\text { Sistema de } \\
\text { Reservas } \\
\text { Marinhas de } \\
\text { Tanga e Parque } \\
\text { Marinho do } \\
\text { Celacanto de } \\
\text { Tanga (TZ) e (KE) } \\
\text { Diani Chale MPA } \\
\text { e Kisite- Mpunguti } \\
\text { MPA }\end{array}$ & $\begin{array}{l}\text { Tanzânia, } \\
\text { Quénia }\end{array}$ & $\mathrm{N} / \mathrm{A}$ & Conceitual & & N/A & $\mathrm{N} / \mathrm{A}$ \\
\hline $\begin{array}{l}\text { Parque Marinho } \\
\text { Transfronteiriço } \\
\text { do Oceano Índico } \\
\text { Ocidental }\end{array}$ & $\begin{array}{l}\text { Ainda a ser } \\
\text { finalizado, } \\
\text { mas inclui } \\
\text { Madagáscar, } \\
\text { Maurícias, } \\
\text { Moçambi-que, } \\
\text { Sey-chelles, } \\
\text { Tanzânia }\end{array}$ & $\mathrm{N} / \mathrm{A}$ & Conceitual & Marinha & N/A & $\begin{array}{l}\text { Terceiro maior recife } \\
\text { de coral do planeta; } \\
\text { lar de cinco das sete } \\
\text { espécies de tartarugas } \\
\text { marinhas; dugongos }\end{array}$ \\
\hline ZIMOZA TFCA & $\begin{array}{l}\text { Moçambique, } \\
\text { Zâmbia, } \\
\text { Zimbabué }\end{array}$ & 29859 & Conceitual & $\begin{array}{l}\text { Prados, } \\
\text { bosques } \\
\text { ribeirinhos e } \\
\text { florestas secas }\end{array}$ & $\begin{array}{l}\text { Nenhuma área formalmente } \\
\text { protegida em Moçambique } \\
\text { Zâmbia: } \\
\text { Parque Nacional do Baixo } \\
\text { Zambeze e toda a Área de Gestão } \\
\text { de Caça de Rufunsa Zimbabué: } \\
\text { Área de Chewore e o Dande } \\
\text { Safari }\end{array}$ & $\begin{array}{l}\text { Muitos corredores } \\
\text { de vida selvagem; } \\
\text { variedade de espécies } \\
\text { incluindo elefantes, } \\
\text { hipopótamos, búfalos, } \\
\text { leões, leopardos, } \\
\text { zibelinas e galos }\end{array}$ \\
\hline
\end{tabular}

Nota: Existem alguns TFCAs cuja dimensão de área não pode ser determinada como sendo 100\% exacta, uma vez que são na sua maioria conceptuais, tais como Kagera, Planícies de Liuwa, Piscinas do baixo Zambeze-Mana, Baía de Mnazi-Quirimbas e ZIMOZA. Daí que as fronteiras não estejam definidas em nenhum documento oficial. No caso do Parque Marinho Transfronteiriço do Oceano Indico Ocidental, é completamente impossível de determinar antes de qualquer acordo ter tido lugar, sendo assim declarado como N/A.

Fontes: BIOPAMA (2017); EC (2015); SADC TFCA Portal (n.d.). 


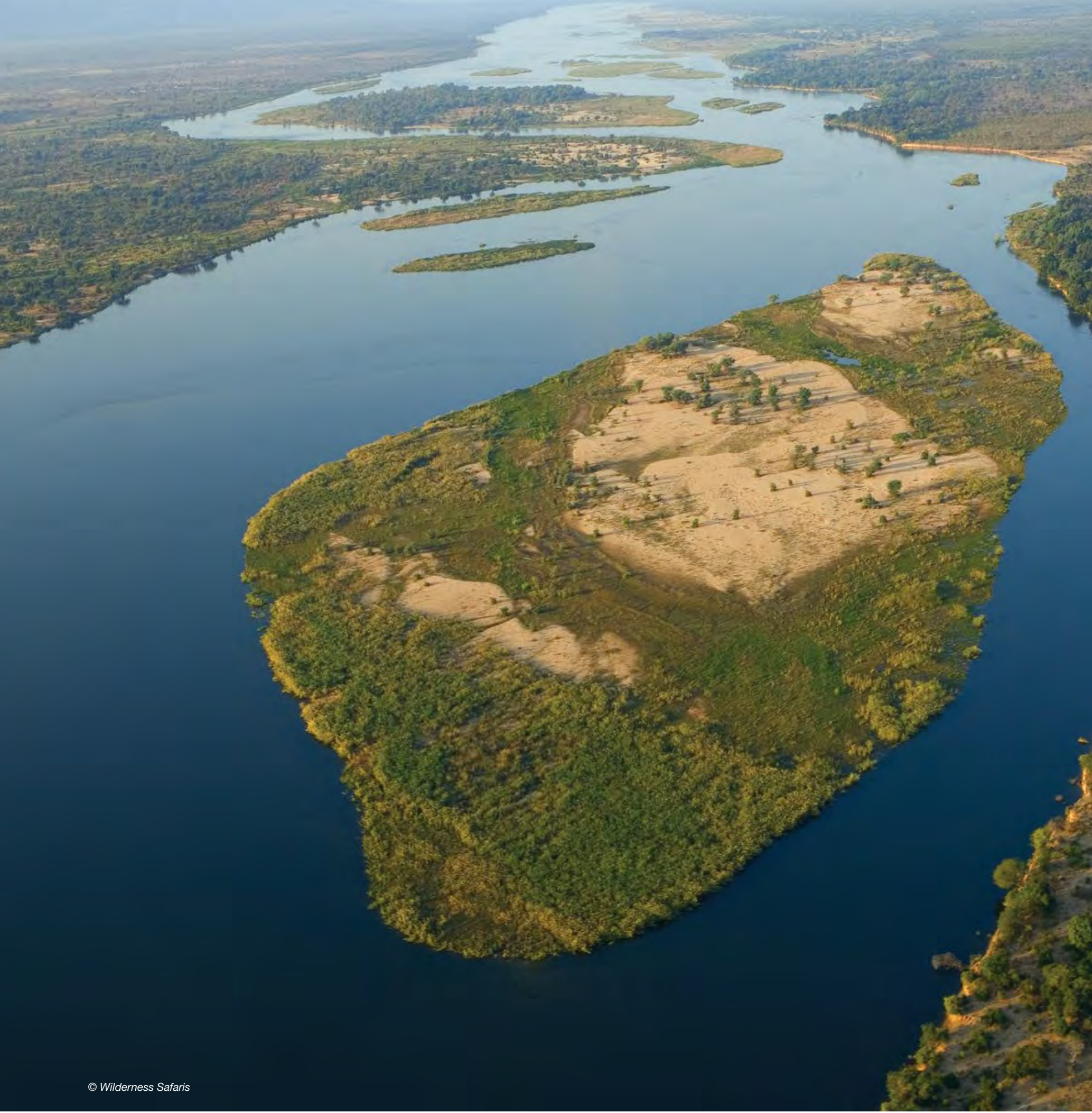




\section{Serviços de}

ecossistema das áreas protegidas na África Oriental e Austral 


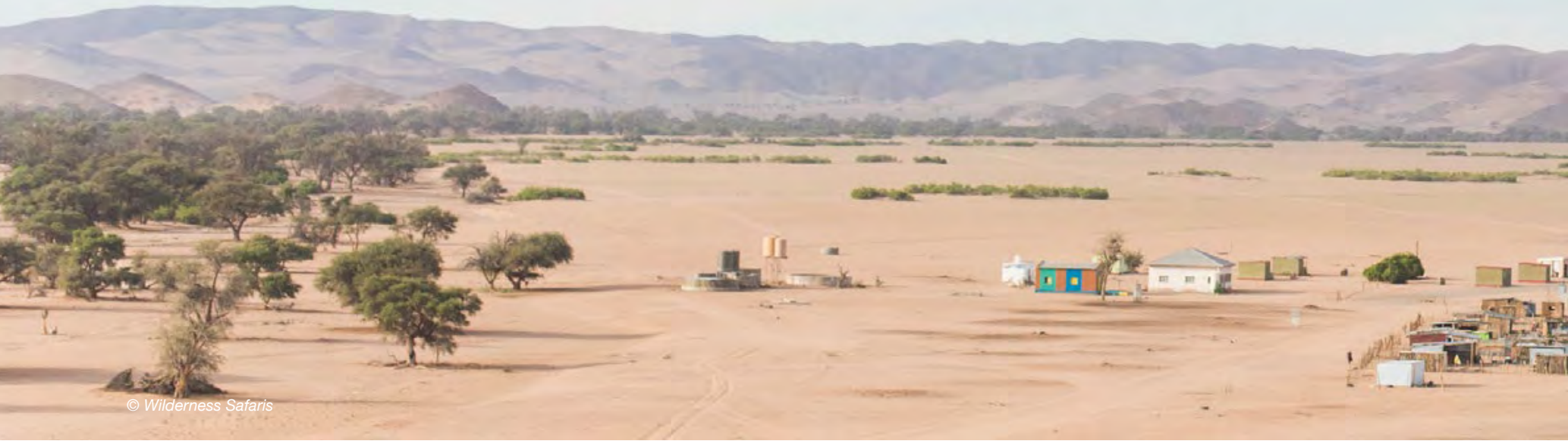

Os serviços de ecossistema (ES) descrevem os benefícios ou contribuições da natureza para as pessoas. A natureza fornece aos humanos não só oxigénio, água, alimentos e matérias-primas para satisfazer necessidades básicas, mas também inúmeros outros serviços que contribuem para o bem-estar humano, tais como oportunidades recreativas, regulação climática, regulação de inundações e valores espirituais (ver Figura 5.1).

ES surgiu pela primeira vez nos anos 80 para avaliar e comunicar os benefícios e contribuições da natureza às pessoas dentro de um quadro abrangente e consistente. O seu objectivo é reconhecer os múltiplos serviços prestados pela natureza a fim de melhorar a gestão dos ecossistemas e recursos naturais dentro de vários domínios políticos, tais como políticas de uso do solo, práticas agrícolas, conservação da natureza ou gestão de áreas protegidas. A Avaliação dos Ecossistemas do Milénio (MEA) é amplamente conhecida por examinar as ligações entre os ecossistemas e o bem-estar humano (MEA, 2005).

O conceito tem vindo a ser cada vez mais aplicado no desenvolvimento de políticas de conservação da natureza numa vasta gama de actividades. Por exemplo, no campo da defesa da conservação da natureza, o conceito facilita a comunicação dos benefícios das áreas protegidas observáveis e compreensíveis o suficiente para reforçar os compromissos políticos e financeiros. Destacar os benefícios e valores das áreas protegidas pode aumentar a aceitação das políticas de conservação da natureza entre os políticos e o público em geral, e estimular o financiamento.

No domínio das áreas protegidas, o conceito de serviços ecossistémicos foi introduzido nas estratégias de gestão e planeamento da conservação espacial (Hummel et al., 2019). É também amplamente aderido noutros sectores, tais como o turismo de áreas protegidas, a agricultura sustentável e a produção hidroeléctrica. Embora a sua aplicação aumente a complexidade e a informação necessária, o conceito oferece grandes oportunidades para melhorar o zoneamento, planeamento e gestão de áreas protegidas, ao mesmo tempo que melhora os conhecimentos para responder aos interesses e necessidades dos diferentes grupos de interessados dentro e em redor das áreas protegidas. O conceito pode ajudar a facilitar negociações e processos de decisão relacionados com as áreas protegidas.

Dependendo da categoria da área protegida, esta mudança também se reflecte em objectivos políticos recentes em estratégias de gestão de áreas protegidas, por exemplo no Parque Nacional Kruger na África do Sul, onde os membros da comunidade local são autorizados a recolher minhocas mopane numa base anual para ganharem rendimentos e como fonte de alimentação.

Na África Oriental e Austral, um serviço ecossistémico importante é a recreação sob a forma de turismo da vida selvagem, que traz uma grande quantidade de receitas para muitos países da região. Os serviços de fornecimento de alimentos e medicamentos tradicionais são também fundamentais e a dependência de muitas comunidades dos recursos naturais para a sobrevivência é elevada. Numa pesquisa realizada numa área adjacente ao Parque Nacional Mosi-oa-Tunya em Zâmbia, em 2017, verificou-se que 79\% dos 136 agregados familiares comunitários entrevistados recolhem os recursos naturais em redor da aldeia, com $5 \%$ a dizer que recolhem dentro da reserva florestal e 2\% recolhem dentro do Parque Nacional (Snyman, 2012); é ilegal recolher em qualquer um destes locais. A fim de determinar o valor aproximado dos recursos naturais para os agregados familiares rurais, foi pedido aos inquiridos que dessem um valor aproximado aos recursos recolhidos, ou seja, se tivessem de comprar os recursos, qual seria o valor aproximado? Os resultados revelam que o valor médio era de aproximadamente US\$340 por agregado familiar por mês. Em relação aos rendimentos médios totais do agregado familiar, esta é uma contribuição substancial para o bem-estar geral do agregado familiar, fornecendo quase $30 \%$ adicionais aos rendimentos mensais do agregado familiar e salientando a dependência da comunidade dos recursos naturais para o bem-estar geral do agregado familiar e serviços de fornecimento de alimentos.

Os serviços de ecossistemas críticos prestados por áreas protegidas e de conservação na região incluem o sequestro de carbono e o fornecimento de água. Os serviços de apoio (habitat, produção primária, biomassa, polinização, formação de solos, tratamento de resíduos, ciclagem de nutrientes e controlo da erosão) são também todos de importância na região. 


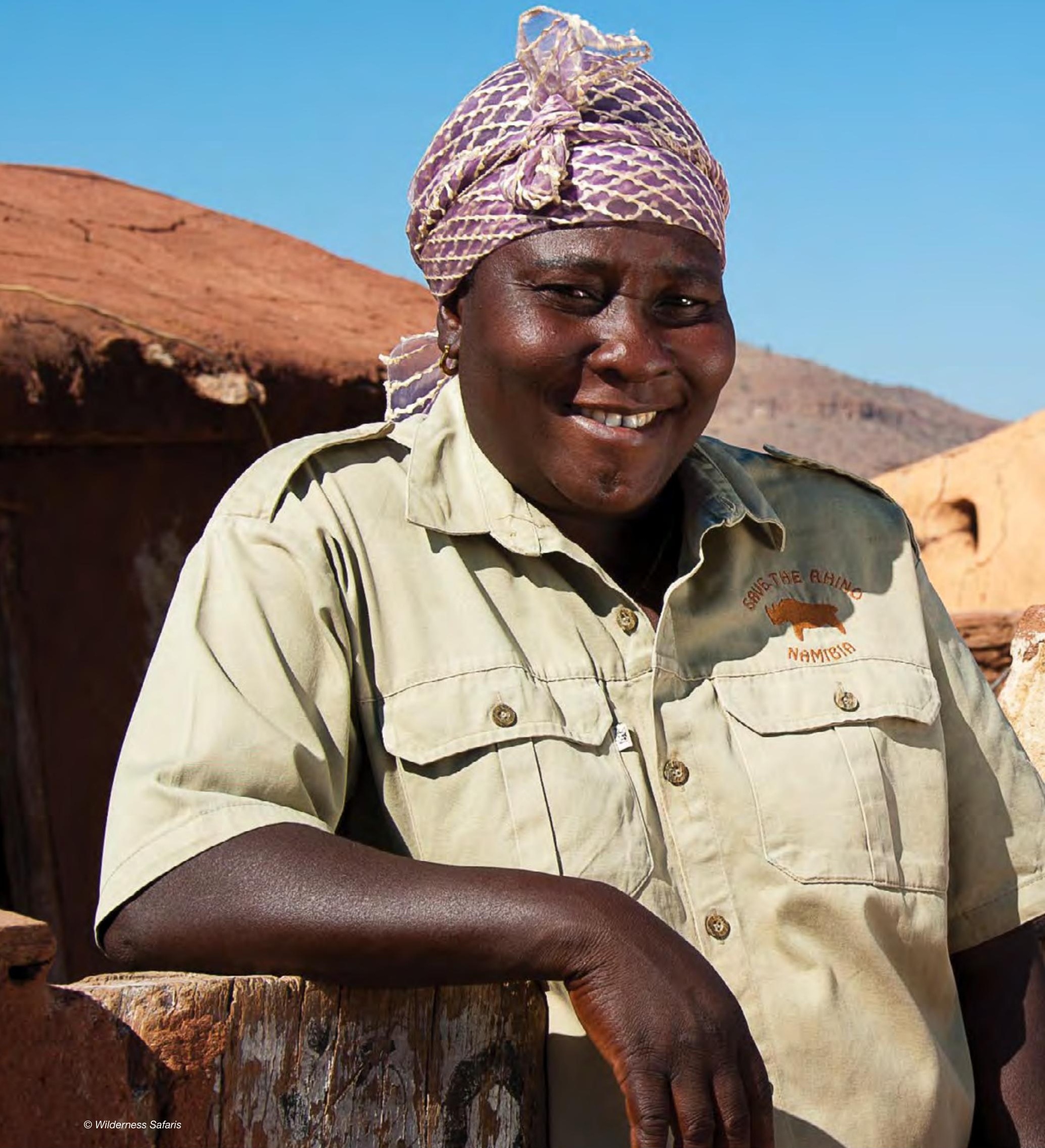


6 Políticas regionais e quadros relevantes relacionados com a conservação da biodiversidade e gestão das áreas protegidas 
Agenda $2063^{14}$ é o projecto estratégico da África que visa cumprir o seu objectivo de promover o desenvolvimento inclusivo e sustentável, complementado por NBSAPs como instrumentos nacionais para incorporar a estratégia de biodiversidade no planeamento do desenvolvimento. Alguns países, tais como Botswana e Tanzânia, foram mais longe ao incluir a biodiversidade e os serviços ecossistémicos nas suas estratégias de redução da pobreza, enquanto países como o Malawi e as Seychelles incorporaram a conservação da biodiversidade nos planos de desenvolvimento relativos à agricultura e silvicultura (IPBES, 2018). Vários países, incluindo Etiópia, Quénia e Maurícias, também incorporaram Avaliações Ambientais Estratégicas nos seus quadros legais (UNEP-WCMC \& UICN, 2016), embora em vários outros seja menos explícita (IPBES, 2018). Idealmente, a conservação e as áreas protegidas deveriam ser integradas nas políticas nacionais e regionais para assegurar a sua inclusão na tomada de decisões, especialmente em relação ao planeamento do uso do solo.

No âmbito do Programa BIOPAMA (Tessema, 2019) foi realizada uma revisão da política e legislação relacionada com a gestão de áreas protegidas, governação e equidade na região da África Oriental e Austral. A revisão conclui que embora vários países tenham feito grandes progressos no desenvolvimento de quadros legais robustos que estão orientados para o reforço da gestão, governação e equidade das áreas protegidas e de conservação, subsistem diferenças substanciais nas carteiras legislativas entre países, e entre os países da EAC, IGAD e SADC. No entanto, a revisão conclui que mesmo enquanto a governação estatal continua a ser o modelo dominante, existe uma tendência encorajadora de políticas e legislação que faz avançar uma variedade de tipos de governação não estatal envolvendo comunidades, indivíduos privados e acordos de colaboração.

Estas mudanças também apoiam a expansão de áreas protegidas e áreas de conservação, e procuram uma maior equidade na gestão de áreas protegidas e na partilha de benefícios. Outra descoberta importante refere-se à gestão conjunta de áreas de conservação transfronteiriças, e como as políticas e legislação são em grande parte inexistentes em todas as áreas excepto na região da SADC (Tessema, 2019) (ver secção 4.5).

As principais constatações da revisão BIOPAMA da política e legislação da África Oriental e Austral incluem:

- Os países mais recentes, como Sudão do Sul e Sudão, precisam de apoio no desenvolvimento do seu quadro legal para áreas protegidas e de conservação;

- Algumas das leis que regem as áreas protegidas no Botswana, Eswatini, Djibouti, Eritreia, Comores, Lesoto, Seychelles, Somália, Sudão e Zimbabué foram desenvolvidas desde há algum tempo, e poderiam ser revistas para incorporar o pensamento e a prática actuais na gestão de áreas protegidas;

- Vários países, tais como Namíbia, África do Sul e Ruanda, têm quadros legais robustos para a gestão de áreas protegidas, pelo que a troca de experiências e conhecimentos especializados entre países deve ser encorajada;
- Existem semelhanças entre países das organizações regionais da EAC, IGAD e SADC, que podem ser exploradas como plataformas para o desenvolvimento de capacidades regionais específicas;

- Os quadros jurídicos que reconhecem e apoiam a tendência crescente de tipos de governação diversificados e colaborativos precisam de ser reforçados;

- Falta de sinergia e leis conflituosas são relatadas em muitos países da EAC, particularmente entre as leis que regem os recursos naturais e as da indústria extractiva; e

- Os princípios da cooperação transfronteiriça estão bem avançados na SADC e podem informar os da EAC e IGAD.

Globalmente, os países da região da África Oriental e Austral têm feito progressos no desenvolvimento de políticas e legislação relacionadas com a área protegida e conservada durante a última década. Tessema (2019) descobriu que 14 dos 24 países da África Oriental e Austral submeteram Planos de Acção ao Programa de Trabalho sobre Áreas Protegidas (PoWPA) da CDB (CDB, 2004) durante o período 2010-2014. Ao abrigo do Elemento 3 do Programa (Actividades de Habilitação) e do Objectivo 3.1 "Providenciar um ambiente político, institucional e socioeconómico favorável às áreas protegidas" da PoWPA (CBD, 2004, p. 15), os países auto-avaliaram o progresso da sua implementação de 1 a 4, com 1 para o apenas iniciado, progresso limitado a 4 para a actividade concluída. A classificação geral para o progresso da implementação na região é 2 (actividade totalmente em curso), e 11 dos 14 países relataram estar no intervalo ou acima do intervalo geral de progresso de implementação para alcançar o Objectivo 3.1 (ver Quadro 4.4).

É de notar que vários países desenvolveram instrumentos legais especificamente para apoiar tipos de equidade e governação não estatal, nomeadamente Quénia, Moçambique, Namíbia, África do Sul, Uganda e Zimbabué. No entanto, o número de quadros jurídicos pode não sugerir necessariamente um progresso na implementação. Da mesma forma, o número de leis por país, tal como mostrado no Quadro 4.4, não é um indicador da eficácia da legislação, uma vez que como uma única lei bem implementada pode ser mais eficaz do que 20 leis sub-standard ou fragmentadas. A este respeito, uma investigação mais aprofundada sobre a implementação da legislação e a sua eficácia seria útil para fornecer uma análise mais detalhada da política e da legislação na região. 
Quadro 6.1 Progressos na implementação do Objectivo 3.1 da PoWPA

\begin{tabular}{|c|c|c|}
\hline País & $\begin{array}{r}\text { Objectivo } 3.1 \\
\text { Implementação } \\
\text { Progresso }^{15} \\
\text { (escala 1 a 4) }\end{array}$ & $\begin{array}{r}\mathrm{N}^{\circ} \text { de instrumentos } \\
\text { jurídicos } \\
\text { desenvolvidos } \\
\text { desde } 2010^{16}\end{array}$ \\
\hline Angola & 3 & 28 \\
\hline Botswana & - & 8 \\
\hline Comores & - & 5 \\
\hline Djibouti & - & 2 \\
\hline Eritreia & - & 3 \\
\hline Eswatini & 1 & 1 \\
\hline Etiópia & 3 & 10 \\
\hline Quénia & 3 & 24 \\
\hline Lesoto & - & 3 \\
\hline Madagáscar & 1 & 23 \\
\hline Malawi & - & 6 \\
\hline Maurícias & - & 10 \\
\hline Moçambique & 4 & 30 \\
\hline Namíbia & - & 11 \\
\hline Ruanda & 2 & 36 \\
\hline Seychelles & - & 4 \\
\hline Somália & - & 4 \\
\hline África do Sul & 4 & 58 \\
\hline Sudão do Sul & - & 2 \\
\hline Sudão & 2 & 3 \\
\hline Tanzânia & - & 11 \\
\hline Uganda & 4 & 16 \\
\hline Zâmbia & 2 & 16 \\
\hline Zimbabué & - & 8 \\
\hline
\end{tabular}

Fonte: Tessema (2019). 


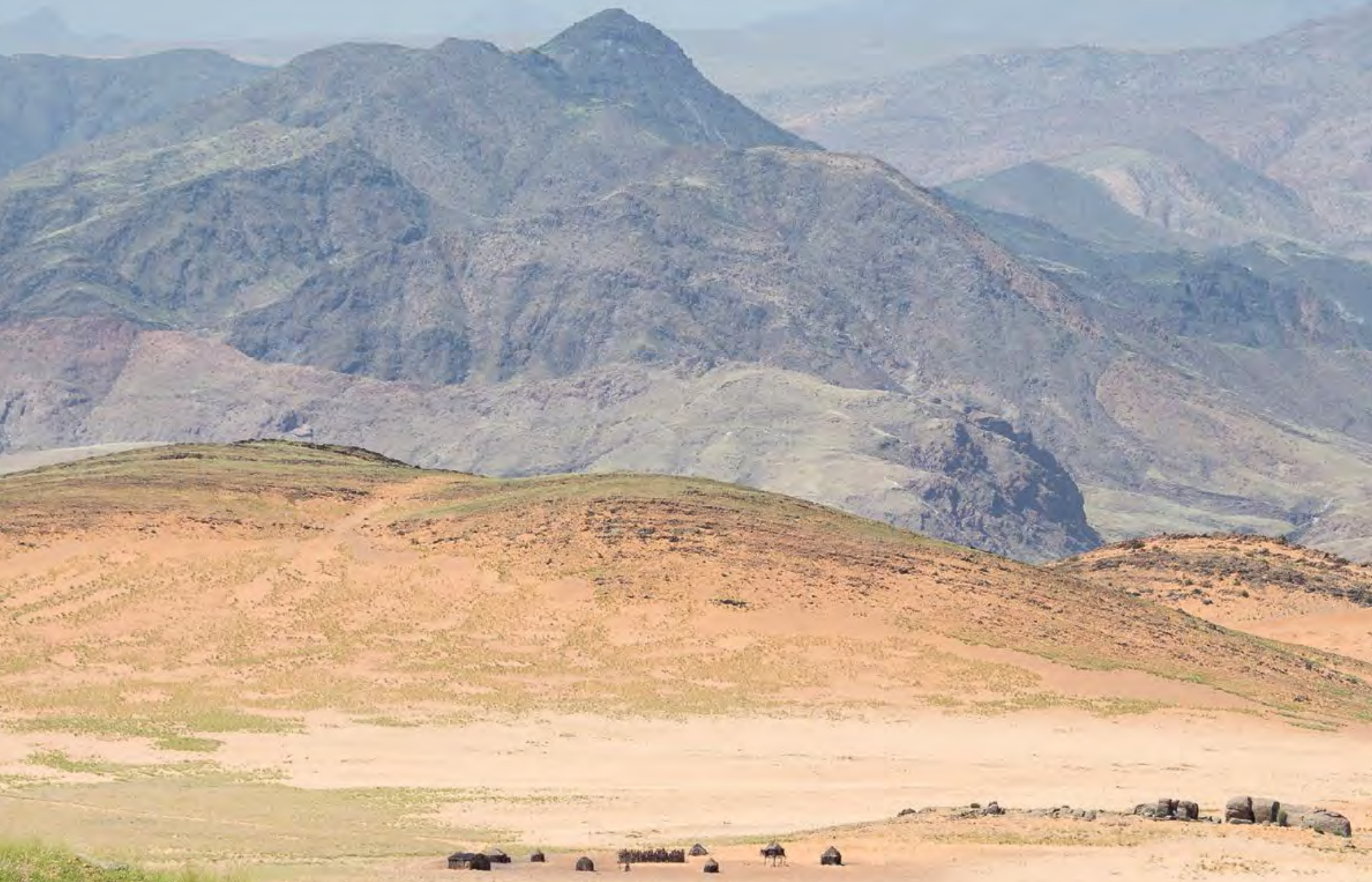

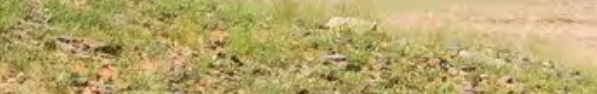

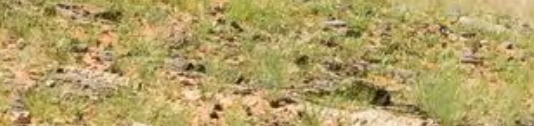

P.

P.

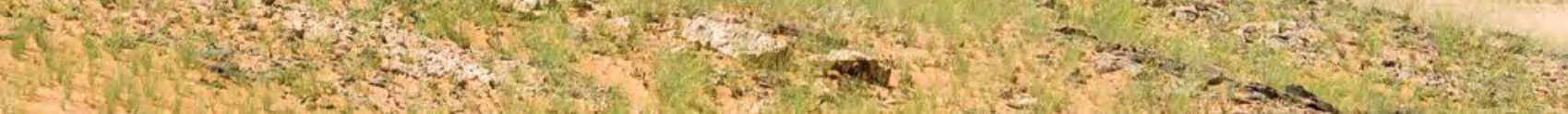

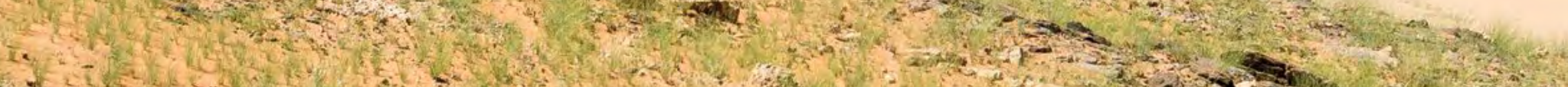

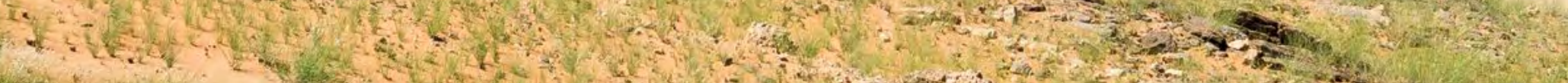

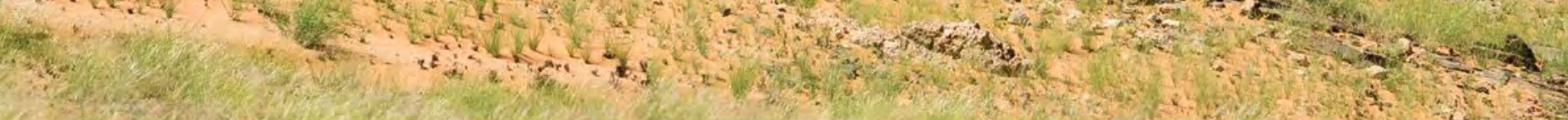

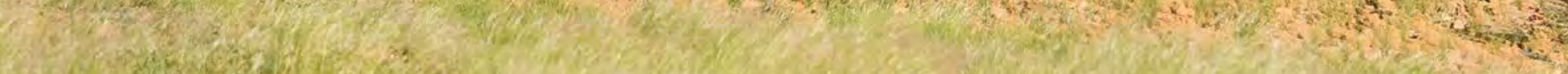

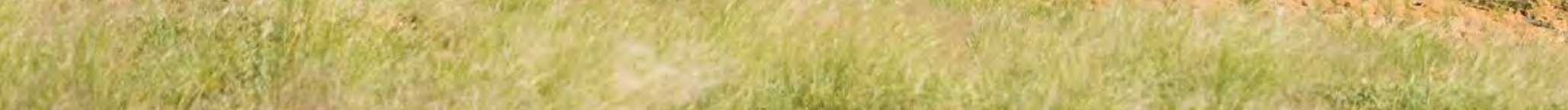

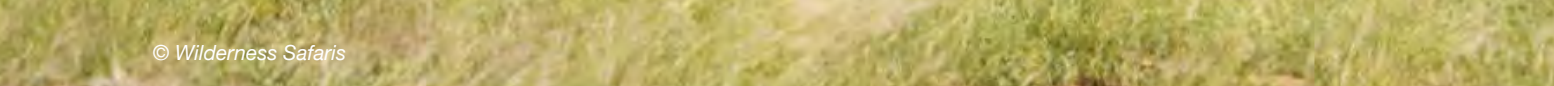




\section{Comunidades Económicas Regionais}


As Comunidades Económicas Regionais (CERs) são agrupamentos regionais de Estados africanos cujo objectivo é facilitar a integração económica regional entre os membros de cada região e através da Comunidade Económica Africana mais alargada. Desempenham também um papel importante em termos de promoção daconservação transfronteiriça na região. Na África Oriental e Austral, o programa BIOPAMA colabora com a EAC, IGAD, SADC e COI. São parceiros importantes no programa BIOPAMA e na região como um todo, uma vez que coordenam actividades regionais com os estados membros, incluindo a abordagem das prioridades e necessidades regionais específicas.

As CERs ajudam no desenvolvimento de prioridades para necessidades regionais específicas. Além disso, colaboram para determinar instrumentos e produtos úteis de análise e de tomada de decisão para a sua região, juntamente com a preparação de sínteses políticas e outros documentos. Os CER também ajudam na comunicação das questões das áreas protegidas aos decisores de nível mais elevado, assegurando assim que a investigação e informação produzida pelo programa a partir do programa desempenhe um papel importante na elaboração de políticas.

Os países sob as organizações regionais17 da EAC, IGAD e SADC fornecem grupos prontos para comparações actuais e futuras de quadros legais relacionados com áreas protegidas que podem potencialmente proporcionar e promover uma plataforma para o intercâmbio de conhecimentos entre as regiões.

\subsection{Comunidade da África Oriental (EAC)}

A EAC é uma organização intergovernamental regional de seis Estados Parceiros, incluindo Burundi, Quénia, Ruanda, Sudão do Sul, Tanzânia18 e Uganda, com a sua sede em Arusha, Tanzânia. Considerando que os recursos naturais são os motores do desenvolvimento económico nacional e regional, o objectivo do sector do Ambiente e Gestão dos Recursos Naturais no âmbito da EAC é promover a utilização e gestão sustentável dos recursos naturais e promover a adaptação às alterações climáticas.

O Tratado EAC, estabelecido em Julho de 2000, prevê a cooperação no domínio do ambiente e dos recursos naturais, e os Estados Parceiros EAC concordaram em fazer um esforço conjunto para cooperar na gestão eficiente destes recursos. A CEA está centrada no reforço da resiliência e gestão sustentável dos ecossistemas de água doce transfronteiriços de importância biológica (CEA, 2010) e no apoio às capacidades de adaptação, e resiliência aos impactos negativos das alterações climáticas.

A Assembleia Legislativa da África Oriental (EALA), que é um ramo da EAC, aprovou a Lei do Ecossistema Transfronteiriço da África Oriental em Janeiro de 2012. O projecto de lei ainda não foi ratificado pelos Estados Parceiros da EAC e, consequentemente, a respectiva Comissão ainda não foi estabelecida e as EIAs estão a ser realizadas em virtude das leis dos Estados Parceiros da EAC. Para esse efeito, a Comissão da Bacia do Lago Vitória e a Iniciativa da Bacia do Nilo têm proporcionado uma plataforma de colaboração para a gestão de recursos hídricos e terrestres partilhados durante vários anos. No entanto, está ainda em desenvolvimento um vasto plano da EAC para harmonizar políticas e leis para melhor gerir os recursos naturais transfronteiriços (Tessema, 2019).

Outros instrumentos desenvolvidos pela EAC para melhorar a conservação na região incluem uma estratégia 2017-2022 para combater a caça furtiva, o comércio ilegal e o tráfico de fauna e produtos da fauna e da flora selvagens (EAC, 2018). Esta é uma cooperação transfronteiriça significativa relacionada com a conservação de recursos partilhados. Apoiará a implementação de actividades, incluindo o desenvolvimento de uma política regional de conservação da vida selvagem, a valorização económica e não económica da vida selvagem, o reforço da participação comunitária na gestão dos recursos transfronteiriços da vida selvagem e o estabelecimento de um Sistema de Troca de Informações sobre o Comércio de Vida Selvagem (TWIX).

O Protocolo da EAC sobre o Ambiente e Gestão dos Recursos Naturais 2006 (ainda não ratificado pela Tanzânia) rege os Estados Parceiros na sua cooperação na gestão do ambiente e dos recursos naturais em áreas da sua jurisdição, incluindo o ambiente eos recursos naturais transfronteiriços.

\subsection{Comissão do Oceano Índico (IOC)}

A COI é uma organização intergovernamental criada em 1984 através de um acordo geral de cooperação conhecido como Acordo Vitória.19 Os membros da COI são as Comores, Madagáscar, Maurícias, Seychelles e a ilha de La Réunion (um departamento ultramarino da França).

As ilhas partilham pontos comuns em termos de recursos naturais ricos em biodiversidade, bem como características ambientais que têm uma influência significativa no seu desenvolvimento nacional. A economia é altamente dependente dos seus recursos naturais costeiros e marinhos, e o turismo baseado na dotação de recursos naturais. A boa qualidade ambiental é essencial para o turismo ecológico de alto valor acrescentado prosseguido pelos países. O ambiente e a gestão dos recursos naturais tem sido uma das principais áreas de cooperação entre os Estados membros com mais de 205 milhões de euros investidos no sector, representando quase 20 projectos implementados pela COI desde 1999.

Com o desenvolvimento das actividades de pesca industrial do atum no Oceano Índico, a COI implementou o seu primeiro projecto regional de pesca do atum, onde foi dada ênfase à gestão dos stocks de atum e à assistência aos países no desenvolvimento da sua capacidade de gestão da pesca. No início de 2000, a COI, em colaboração com a Comissão do Atum do Oceano Índico, 
implementou o primeiro projecto regional de marcação do atum e apoiou as autoridades pesqueiras nacionais no desenvolvimento de capacidades de monitorização, controlo e vigilância da pesca.

As actividades da $\mathrm{COI}$ no ambiente marinho e costeiro continuam a aumentar, com enfoque na gestão das áreas marinhas protegidas, monitorização e vigilância do recife de coral e ecossistemas associados, poluição marinha resultante de derrames de petróleo, gestão integrada da zona costeira e espécies marinhas invasoras. Foram criadas capacidades a nível institucional e comunitário e desenvolvidos instrumentos para apoiar a gestão dos habitats costeiros e a conservação dos recursos marinhos e costeiros, nomeadamente:

- Participação em instrumentos regionais do ambiente marinho A Comissão do Oceano Índico contribuiu directa e indirectamente para o estabelecimento de instrumentos regionais e para o desenvolvimento de instrumentos no meio marinho. Foram criados e apoiados importantes quadros de acção estratégica regional, plataformas e redes, tais como a Rede de Recifes de Coral e a Rede de Áreas Marinhas Protegidas, para mencionar apenas alguns. Dada a importância do ambiente costeiro e marinho para os estados membros da COI, está a ser desenvolvida uma Estratégia de Economia Azul que foi adoptada pelo Conselho de Ministros na reunião da COI em Março de 2020.

- Desenvolvimento de uma Estratégia Regional e de um Plano de Acção para Conservação de Ecossistemas Marinhos e Pesca para a Ecorregião Marinha da Ilha do Oceano Índico Ocidental

$\mathrm{O}$ quadro estratégico da $\mathrm{COI}$ compreende as seguintes áreas de intervenção:

1. Organizar a aquisição de dados sobre ecossistemas marinhos, recursos marinhos e suas utilizações, partilhando-os e valorizando-os de forma sustentável através de um observatório regional;

2. Partilhar conhecimentos com todas as comunidade interessadas, fornecer e promover ferramentas de apoio à tomada de decisões;

3. Formar todas as partes interessadas, capitalizar e trocar boas práticas sobre o desenvolvimento sustentável marinho;

4. Apoio à implementação da estratégia de gestão das pescas para promover a pesca e a aquicultura coordenadas, responsáveis e sustentáveis;

5. Reforçar a gestão sustentável das áreas marinhas protegidas e a sua ligação em rede;

6. Implementar acções de conservação das espécies migratórias e/ou com amplo alcance, de acordo com as suas convenções pertinentes;

7. Apoiar a implementação da Estratégia Regional de adaptação às alterações climáticas para contribuir para uma melhor resiliência e redução da vulnerabilidade dos ecossistemas marinhos; e

8. Desenvolver uma abordagem responsável e concertada da exploração de recursos não renováveis (gás, petróleo, energias renováveis, minerais, biomoléculas, etc.)
- Estabelecimento de uma Gestão Integrada da Zona Costeira (ICZM) Protocolo

A abordagem à gestão integrada da zona costeira nos estados membros da COI foi desenvolvida através do seu programa ambiental regional implementado no final dos anos 90 . A principal linha de acção foi a sensibilização para uma abordagem integrada e concertada para a gestão da zona costeira. Com base nos resultados do programa ambiental regional 'PRE-COI', de 1996 a 2011, a COI implementou o Programa Regional de Gestão Sustentável da Zona Costeira. Isto permitiu que os países criassem e/ou reforçassem o seu Comité Nacional de Gestão Integrada da Zona Costeira. A COI, em colaboração com os seus parceiros regionais, apoiou o desenvolvimento do Protocolo GIZC a ser estabelecido no âmbito da Convenção de Nairobi (ver secção seguinte). O projecto de protocolo foi agora acordado e espera-se que seja apresentado para aprovação na próxima COP da Convenção de Nairóbi.

- Adopção da Convenção de Nairóbi para a Protecção, Gestão e Desenvolvimento do Ambiente Costeiro e Marinho do Oceano Índico Ocidental (1985) ${ }^{20}$

Os Estados Membros da COI são todos Partes da Convenção de Nairobi e os programas ambientais da COI consideram as disposições da Convenção. A COI e o Secretariado da Convenção de Nairobi colaboram nos vários programas regionais. Em 2012, o PNUA, em nome do Secretariado da Convenção de Nairobi e da COI formalizou a sua colaboração e assinou um Memorando de Entendimento para reforçar a colaboração em áreas de interesse comum para incluir áreas marinhas protegidas. A COI tem o estatuto de observador na COP da Convenção de Nairobi e participa em vários grupos de trabalho e programas da Convenção. Para este efeito, a COI alinhou todos os seus programas e actividades em relação aos ecossistemas costeiros e marinhos com as disposições da Convenção e dos seus protocolos relevantes. Muito tem sido alcançado através desta colaboração, nomeadamente: o desenvolvimento do Protocolo GIZC; o reforço do Fórum Ciência para a Política; o estabelecimento da Área de Conservação Transfronteiriça entre Quénia e Tanzânia (Caixa 7.3); o reforço da monitorização dos recifes de coral; o reforço da capacidade de gestão das Áreas Marinhas Protegidas; o reforço da capacidade de prevenção e gestão da poluição marinha derivada de derrames de petróleo, entre outros.

- Criação do Consórcio de Cetáceos do Oceano Índico

As acções da $\mathrm{COI}$ em relação à conservação de espécies migratórias e de grandes mamíferos tiveram início em 2005. A COI foi incumbido pelos seus estados membros de sensibilizar para a necessidade de protecção das espécies migratórias marinhas. Em 2008, a COI embarcou numa iniciativa regional para a conservação de cetáceos e espécies de dugongos. O objectivo era melhorar o conhecimento científico sobre os cetáceos, estudar o movimento da população, criar uma rede de intervenientes envolvidos na protecção dos cetáceos e reduzir o impacto das actividades humanas sobre os cetáceos, tais como a pesca, a observação de baleias e o som/acústica. 


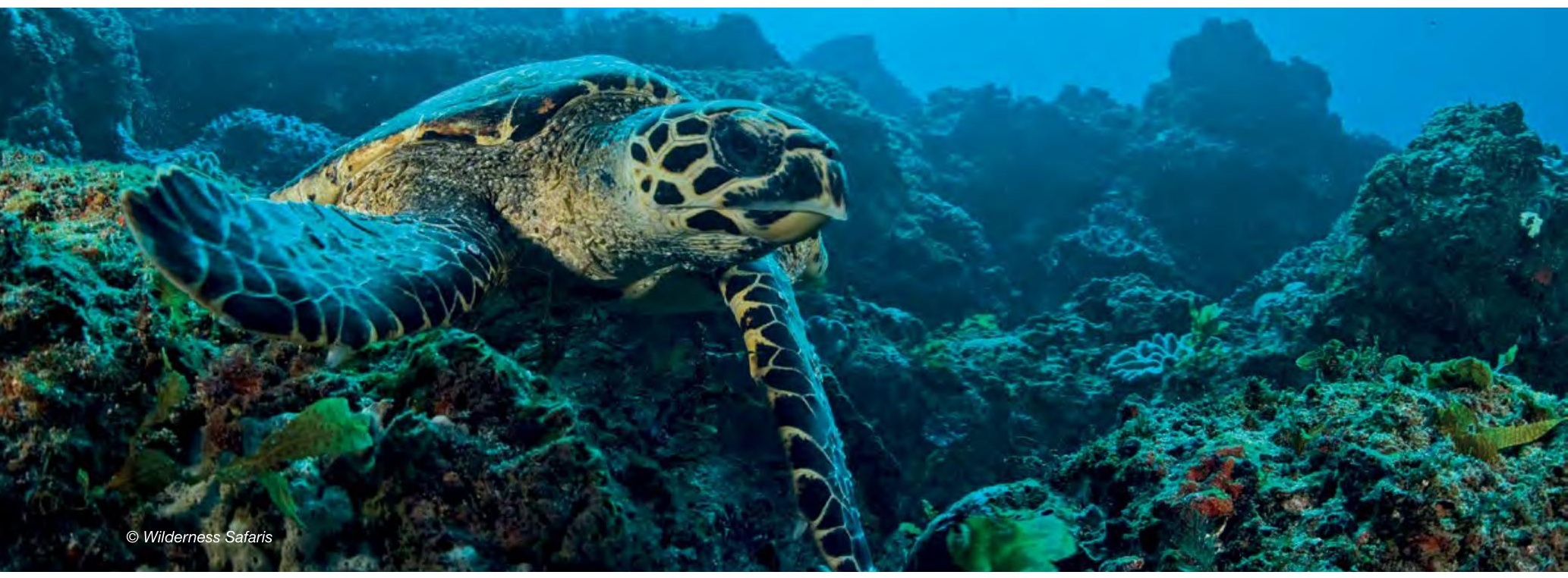

\section{Caixa 7.3 Conservação marinha transfronteiriça entre Quénia e a Tanzânia}

A costa da África Oriental, que Quénia e Tanzânia, é rica em recursos marinhos naturais, com praias intocadas de corais, estuários, mangais, lagoas e várias belas ilhas ricas em biodiversidade. Estes ambientes sustentam uma vida marinha diversificada e são críticos para a subsistência das comunidades costeiras. Contudo, o ambiente costeiro está ameaçado pelas alterações climáticas, pela poluição, pela destruição do habitat e pela pressão do crescimento das populações costeiras, pelo turismo e pela urbanização. Os recifes de coral de Quénia e Tanzânia foram amplamente branqueados durante o El Niño 1997-1998, tendo a cobertura de coral diminuído em mais de $80 \%$ na maioria das áreas. A recuperação do branqueamento tem sido muito lenta em muitos sistemas de recifes de coral devido à crescente pressão das actividades relacionadas com o homem. A crescente população costeira, tanto em Quénia como na Tanzânia, está também a exercer pressão sobre os recursos marinhos e costeiros com uma procura crescente de alimentos e materiais. Devido às linhas costeiras contíguas dos dois países, existe um potencial para a perda e degradação dos habitats costeiros num ter impacto no outro, em resultado da perturbação e fragmentação.

Para inverter a perda da biodiversidade marinha, tanto Quénia como a Tanzânia fizeram esforços para melhorar a gestão dos recursos marinhos através de quadros políticos e legais. Foram estabelecidas várias áreas marinhas protegidas (ZMP) em ambos os países para proteger habitats e espécies críticas. Recentemente, Quénia e Tanzânia começaram a explorar a possibilidade de cooperação transfronteiriça na conservação marinha, através do estabelecimento de uma área marinha transfronteiriça de conservação (TBCA). O PNUA, através do Secretariado da Convenção de Nairobi, iniciou uma série de discussões entre as agências de gestão de áreas protegidas dos dois países para levar este processo por diante.
O objectivo do TBCA marinho em Quénia e Tanzânia é integrar os objectivos e prioridades da gestão dos ecossistemas nas práticas e políticas do sector produtivo. O conceito procura reforçar a capacidade para restaurar a saúde dos ecossistemas e conservar a biodiversidade a nível local, nacional e transfronteiriço nos dois países. A iniciativa procura pilotar abordagens orientadas para os ecossistemas em matéria de planeamento espacial, gestão dos recursos hídricos, agricultura, florestas, pescas e gestão de áreas protegidas. O local proposto estende-se do limite norte da Reserva Nacional Marinha de Diani-Chale em Quénia até ao limite sul do Distrito de Mkinga na Tanzânia, a norte do Parque Marinho do Coelacanto de Tanga. A área de interesse alberga uma biodiversidade marinha e costeira altamente significativa. Devido à sua rica biodiversidade e contribuição para a vida socioeconómica das comunidades costeiras, a área tem sido reconhecida por várias agências internacionais como uma área de importância merecedora de atenção especial de conservação.

O TBCA proposto é complementar aos esforços dos dois países para gerir e conservar de forma sustentável os recursos costeiros e marinhos, contribuir para a redução da pobreza das comunidades costeiras, e promover a implementação de instrumentos regionais e internacionais chave para a conservação dos recursos marinhos e costeiros e da biodiversidade. Além disso, a protecção da TBCA complementa os esforços da Tanzânia para proteger todas as reservas marinhas de pequenas ilhas a sul da sua fronteira, nomeadamente Ulenge, Kwale, Kirui e Reservas Marinhas de Mwewe. Também aumentará a área que Quénia e Tanzânia reservaram para a conservação marinha que vai no sentido de cumprir o Objectivo 11 e o SDG 14 da CDB Aichi.

Contribuido por Arthur Tuda (Quénia Wildlife Service). 
A COI colaborou com a Agência Francesa para as Áreas Marinhas Protegidas na realização da Campanha do Oceano Índico para estudar a migração dos cetáceos. Também apoiou a criação da Rede de Investigação e Conservação de Cetáceos do Oceano Índico (IndoCet) de ONG na região do Oceano Índico Ocidental que trabalham para a protecção dos cetáceos, principalmente baleias e golfinhos. A rede criou um website e desenvolveu uma ferramenta para ajudar na identificação dos cetáceos. ${ }^{21}$

- Colaboração internacional ao abrigo do Acordo de Cotonou (2000)

Em conformidade com o Acordo de Cotonou, ${ }^{22}$ a COI beneficiou de vários programas de desenvolvimento regional na agricultura, pescas, ambiente e segurança marítima num montante superior a 156 milhões de euros. Os programas contribuíram para reforçar a colaboração e cooperação entre os países da região do Leste, Sul e Oceano Índico para uma pesca sustentável, gestão dos recursos naturais, protecção, gestão integrada das zonas costeiras, educação ambiental, conservação e utilização da biodiversidade, alterações climáticas e para melhorar a segurança marítima na região. Em particular, abriu também oportunidades para a cooperação inter regional entre a COI, as Caraíbas e o Pacífico em assuntos que afectam os Pequenos Estados Insulares, tais como as alterações climáticas e as catástrofes naturais e o oceano. Através da abrangente ajuda europeia ao desenvolvimento das regiões de África, das Caraíbas e do Pacífico, a COI, juntamente com a União Africana e outras comunidades regionais africanas, conseguiu melhorar o acesso aos dados de Observação da Terra da Agência Espacial Europeia para a gestão dos recursos naturais e monitorização da degradação costeira.

Ao abrigo do Acordo de Cotonou, a COI está a colaborar com o secretariado ACP em programas de sensibilização nos Pequenos Estados Insulares de África no que diz respeito às alterações climáticas e à biodiversidade costeira e marinha.

\subsection{Autoridade Intergovernamental para o Desenvolvimento (IGAD)}

Composto por oito países da África Oriental e Austral - Djibouti, Eritreia, Etiópia, Quénia, Somália, Sudão do Sul, Sudão e Uganda - o principal objectivo da IGAD é alcançar a paz e o desenvolvimento sustentável na região. Ricos em biodiversidade, os principais factores de crescimento dos membros do IGAD são os seus recursos naturais, mais especificamente água doce e ecossistemas marinhos e costeiros, florestas e vida selvagem, zonas húmidas, serras, terras aráveis e montanhas, e recursos minerais e energéticos.

Duas das prioridades da IGAD para o ambiente costeiro e marinho incluem o apoio e implementação das Convenções de Abidjan e Nairobi e o Processo Africano de gestão dos recursos costeiros e marinhos de África. Em termos concretos, estas envolvem: controlo da poluição e erosão costeira; e promoção da utilização sustentável dos recursos vivos, gestão sustentável de habitats e ecossistemas chave e desenvolvimento económico sustentável.
Os instrumentos desenvolvidos pela IGAD para a conservação ambiental incluem:

- 2007 Estratégia de Recursos Naturais e Ambiente: visa apoiar a harmonização dos recursos naturais e políticas ambientais, bem como promover a gestão de recursos transfronteiriços.

- IGAD Estratégia de Protecção de Recursos Naturais e Ambiente 2016-2020 uma parte da estratégia regional quinquenal do IGAD: desenvolvida através da realização de extensos estudos de base para identificar questões e desafios-chave em cada país, incluindo a degradação da terra, das zonas húmidas e das florestas, as alterações climáticas, o crescimento demográfico, a governação dos recursos, a falta de investimentos nos mercados de desenvolvimento e a mudança de valor, e a questão contínua da marginalização dos ecossistemas áridos e semi-áridos.

- Política Regional de Biodiversidade: visa ajudar a conservar e gerir de forma sustentável os recursos da biodiversidade, e fomentar o desenvolvimento sócio-económico para meios de subsistência sustentáveis, sustento ambiental, coexistência pacífica e segura, e integração regional através da gestão sustentável dos recursos da biodiversidade na região.

- Protocolo Regional de Biodiversidade: desenvolvido e aprovado a nível ministerial em Julho de 2017 para implementar a Política Regional de Biodiversidade. Fornece um guia sobre como fomentar a cooperação na implementação da política regional e a questão do desenvolvimento sustentável dos ecossistemas na região.

- Estratégia de Partilha dos Benefícios da Biodiversidade: desenvolvida e aprovada a nível ministerial; promove a partilha equitativa dos benefícios da biodiversidade entre os Estados membros da IGAD, respeitando a situação dos países menos dotados, de modo a ajudar a desenvolver a unidade e a paz na região.

- Estratégia de Controlo e Gestão das Espécies Invasoras: desenvolvida e aprovada a nível Ministerial; aborda a introdução de espécies invasoras alienígenas através da expansão, gestão, utilização ou, sempre que possível, erradicação controladas, em particular nos sectores agrícola e florestal da região.

- IGAD Wildlife Management Strategy: desenvolvido e aprovado a nível ministerial; fornece uma estratégia conjunta sobre como gerir os recursos da vida selvagem na região.

- Rede Especializada IGAD: estabelecida como parte da estrutura IGAD para acompanhar e coordenar as actividades de aplicação da lei sobre a fauna bravia na região.

- Djibouti Seascape Management Plan: desenvolvido no âmbito do Programa de Gestão da Biodiversidade, onde foram identificadas e estabelecidas áreas de conservação marinha baseadas na comunidade local. ${ }^{23}$

- Plano de Implementação da Estratégia Regional IGAD (2016-2020): procura promover activamente a cooperação e integração económica na região IGAD através do reforço da capacidade regional, incluindo mas não se limitando à gestão dos recursos naturais e à protecção ambiental, promovendo a gestão sustentável do ambiente e dos recursos naturais. 


\subsection{Comunidade de Desenvolvimento da África Austral (SADC)}

A SADC é uma organização intergovernamental regional com sede em Gaborone, Botswana e compreende 16 Estados Parceiros - Angola, Botswana, Comores, República Democrática do Congo, Eswatini, Lesoto, Madagáscar, Malawi, Maurícias, Moçambique, Namíbia, Seychelles, África do Sul, República Unida da Tanzânia, Zâmbia e Zimbabué. ${ }^{24}$

Os recursos naturais são de importância vital para a economia da região e para o seu crescimento. A SADC e os seus Estados Membros reconhecem a importância de uma melhor utilização e gestão dos recursos naturais para assegurar o desenvolvimento sustentável e o crescimento no futuro. Os recursos naturais importantes incluem florestas, água, vida selvagem (espécies aquáticas, terrestres e marinhas) e minerais. Para ajudar a proteger estes recursos e fomentar a cooperação regional, protocolos e iniciativas, tais como o desenvolvimento de TFCAs, têm sido liderados pela SADC.

Ao abrigo do Protocolo de Conservação da Vida Selvagem e Aplicação da Lei, o Programa da SADC de 2013 para Áreas de Conservação Transfronteiriças define a sua missão como sendo o desenvolvimento da SADC numa rede funcional e integrada de áreas de conservação transfronteiriças, onde os recursos naturais partilhados são co-geridos e conservados de forma sustentável para fomentar o desenvolvimento sócio-económico e a integração regional em benefício daqueles que vivem dentro e à volta das TFCAs.

A harmonização de políticas e legislação para a gestão eficaz destas áreas de conservação transfronteiriças é uma parte reconhecida do Programa TFCA da SADC. Algumas das políticas regionais e instrumentos legais da SADC incluem:

\section{- Protocolo sobre o Desenvolvimento do Turismo (1998) ${ }^{25}$} O protocolo estabelece o objectivo da SADC de construir sobre o potencial da região como destino turístico. A SADC pretende assegurar uma distribuição uniforme do desenvolvimento turístico em toda a região e criar um ambiente favorável ao turismo, utilizando assim o turismo como veículo para o desenvolvimento sócio-económico.

- Protocolo sobre Conservação da Vida Selvagem e Aplicação da Lei (1999). ${ }^{26}$

Entrou em vigor em 2003 e é juridicamente vinculativo para os países que o assinaram e ratificaram. Os objectivos do Protocolo incluem a harmonização de instrumentos legais sobre a vida selvagem, o intercâmbio de informação relevante para a conservação da vida selvagem, o desenvolvimento de capacidades nacionais e regionais para a conservação, o estabelecimento de áreas de conservação transfronteiriças e a promoção da gestão de recursos baseada na comunidade. Fornece os mecanismos para a conservação e gestão de recursos partilhados, ao mesmo tempo que reconhece os direitos dos Estados individuais a gerir os seus respectivos recursos da fauna bravia.

- Protocolo Revisto sobre Cursos de Água Partilhados (2000) ${ }^{27}$ Muitos cursos de água na região são partilhados entre vários Estados Membros, uma situação que exige o seu desenvolvimento de uma forma ambientalmente sã. O Protocolo visa promover uma cooperação mais estreita entre os Estados Membros para a protecção, gestão e utilização de cursos de água partilhados na região. Os Estados Membros concordam em cooperar em projectos e trocar informações sobre cursos de água partilhados, consultando-se mutuamente e colaborando em iniciativas que equilibrem o desenvolvimento dos cursos de água com a conservação do ambiente.

\section{- Protocolo sobre silvicultura (2002) ${ }^{28}$}

O Protocolo visa promover o desenvolvimento, conservação, gestão sustentável e utilização de todos os tipos de florestas e árvores, comércio de produtos florestais e alcançar uma protecção eficaz do ambiente. Fornece orientações sobre a realização de avaliações florestais nacionais e políticas, programas e leis florestais nacionais. As políticas e mecanismos adoptados nos Estados Membros devem permitir às populações locais e às mulheres participar efectivamente nas actividades de gestão florestal, bem como respeitar os conhecimentos tradicionais relacionados com as florestas.

\section{- Política Regional da Água (2005) ${ }^{29}$}

A região da SADC tem 15 grandes bacias hidrográficas transfronteiriças que são. A política fornece o contexto e a intenção para a gestão dos recursos hídricos a nível regional da SADC, representando as aspirações e interesses dos Estados Membros. O Protocolo sobre os Cursos de Água Partilhados é o instrumento jurídico para a implementação desta política, ao abrigo do qual podem ser desenvolvidos acordos bilaterais e multilaterais entre os Estados dos Cursos de Água

\section{- Estratégia Regional da Água da SADC (2006). ${ }^{30}$}

A estratégia tem como objectivo fornecer um quadro estratégico para o desenvolvimento sustentável, integrado e coordenado, utilização, protecção e controlo dos recursos hídricos nacionais e transfronteiriços. Descreve os planos de implementação da estratégia, incluindo os objectivos associados no Plano de Acção Estratégico Indicativo Regional e no Programa de Implementação Estratégica conduzido pelos Planos de Acção Estratégicos Regionais para o Sector da Água da SADC (RSAP). O documento conclui com uma discussão sobre os indicadores de monitorização e avaliação que serão utilizados para proporcionar uma supervisão sobre o quadro de implementação.

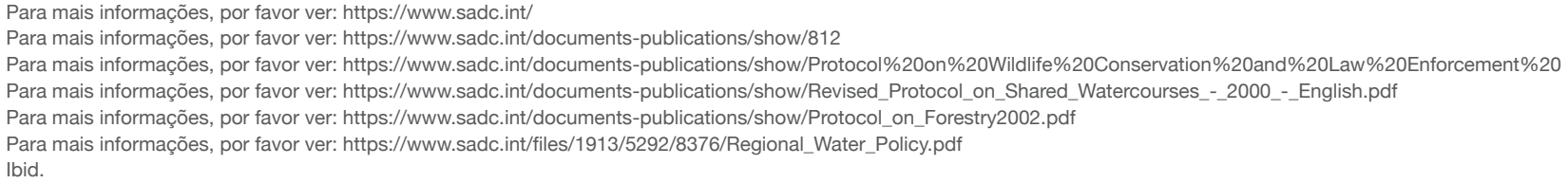




\section{- Protocolo da SADC sobre Pescas (2006)}

O Protocolo visa fazer avançar a utilização responsável e sustentável dos recursos aquáticos vivos e dos ecossistemas aquáticos de interesse para os Estados Partes, a fim de: (i) promover e reforçar a segurança alimentar e a saúde humana, (ii) salvaguardar a subsistência das comunidades pesqueiras, (iii) gerar oportunidades económicas dos nacionais da região, (iv) assegurar que as gerações futuras beneficiem destes recursos renováveis; e (v) aliviar a pobreza com o objectivo final da sua erradicação.

- Directrizes de Concessão Turística para as TFCAs na SADC (2015) ${ }^{32}$

O objectivo das directrizes é fornecer orientações para a gestão das concessões turísticas nas TFCAs no âmbito da SADC, assegurando ao mesmo tempo que tanto a conservação como os objectivos de desenvolvimento das TFCAs regionais são cumpridas, incluindo o desenvolvimento rural e a participação comunitária. O principal benefício da orientação é a aquisição de informação básica sobre como encorajar, desenvolver e operar concessões turísticas nas TFCAs dentro da SADC. Há espaço para a partilha regional de conhecimentos, especialmente em termos de conservação transfronteiriça e a experiência de 20 anos da SADC neste campo. Os esforços anti-população e de aplicação da lei também beneficiariam da partilha regional cruzada de informação relacionada com políticas, legislação e a partilha de informação através das redes TWIX.

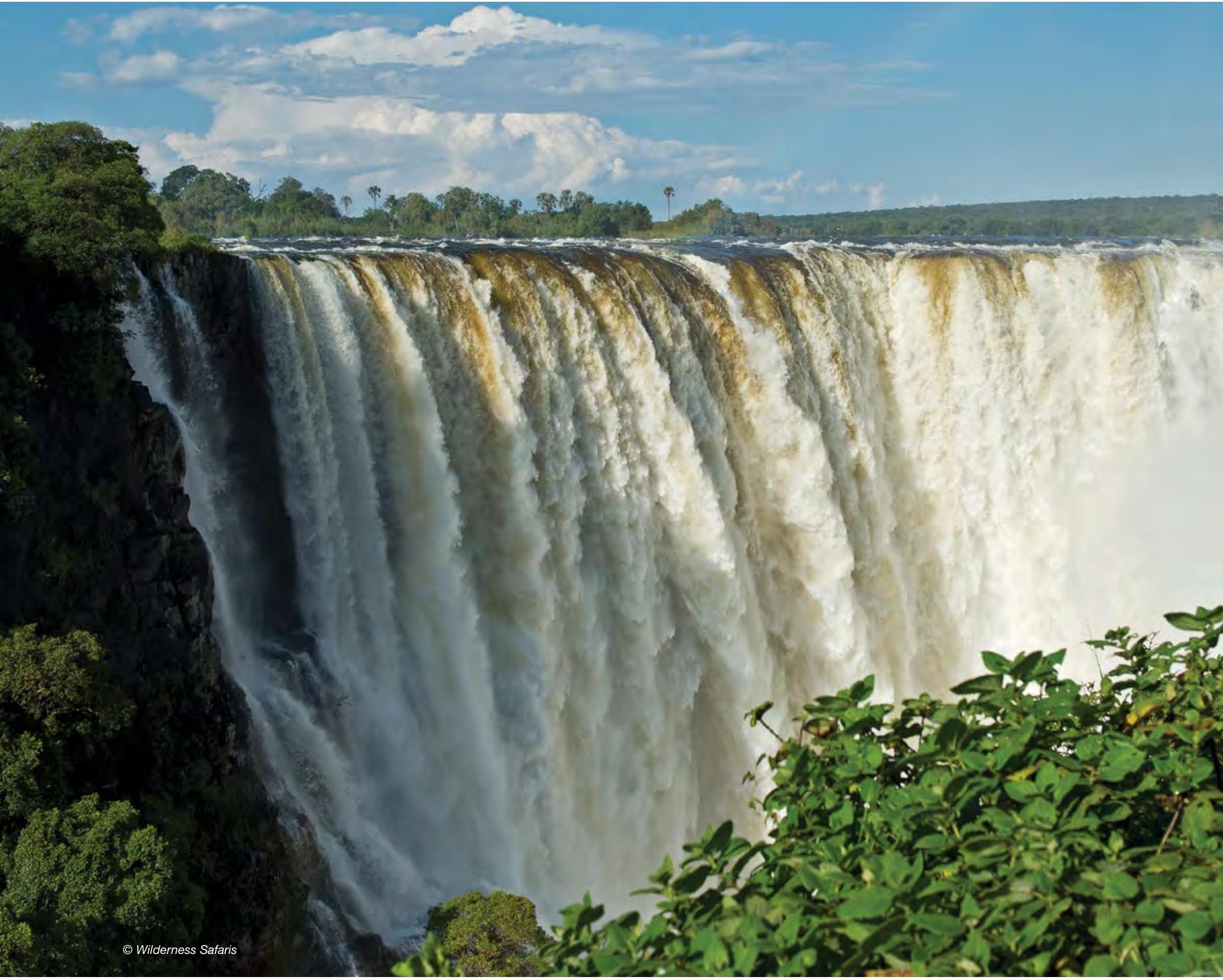

31 Para mais informações, por favor ver: https://www.sadc.int/files/8214/7306/3295/SADC Protocol on Fisheries.pdf

32 Para mais informações, por favor ver: https://www.sadc.int/files/3215/6578/5119/Tourism_Concession_Guidelines_SADC_TFCAs_English.pdf. 

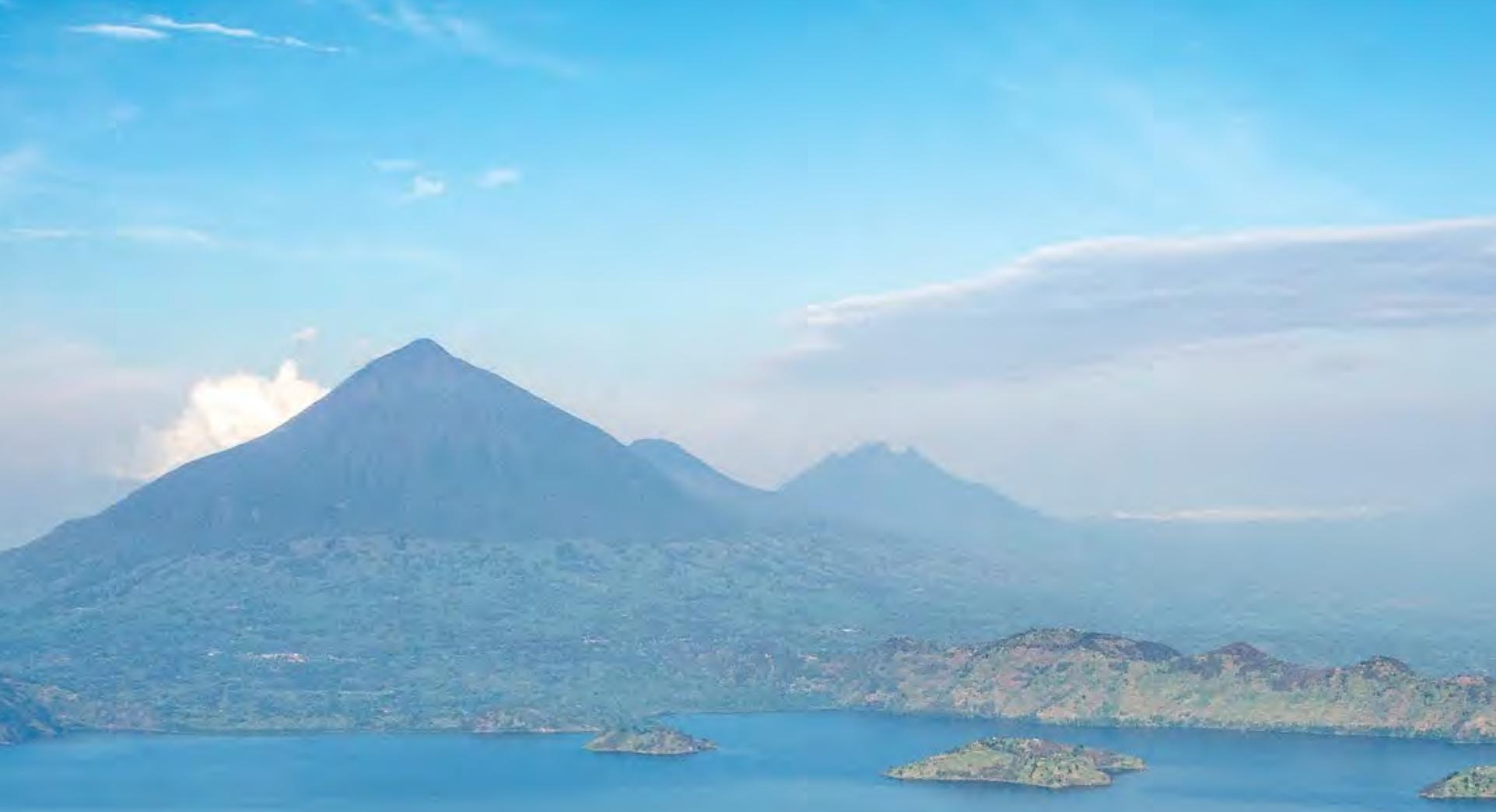

-4 setres

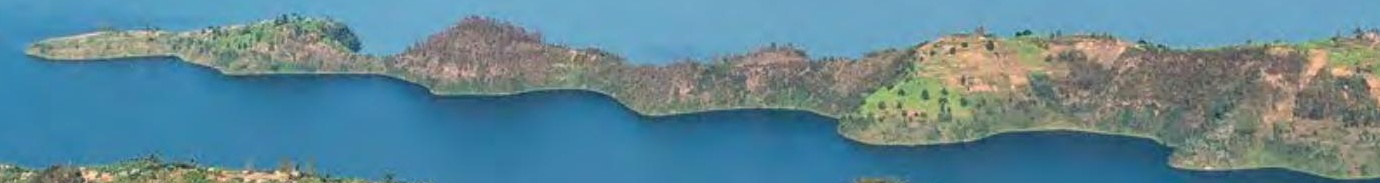

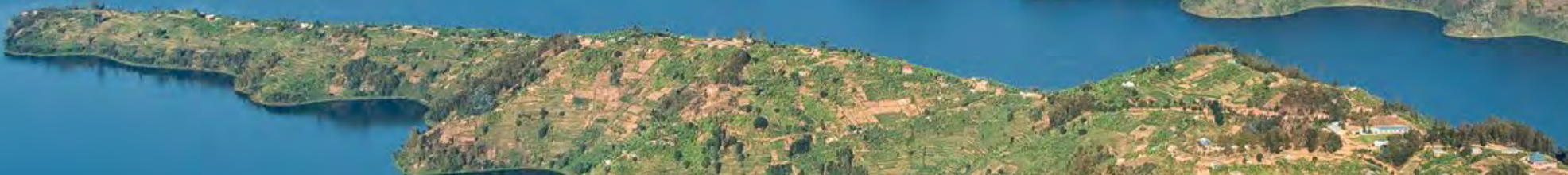

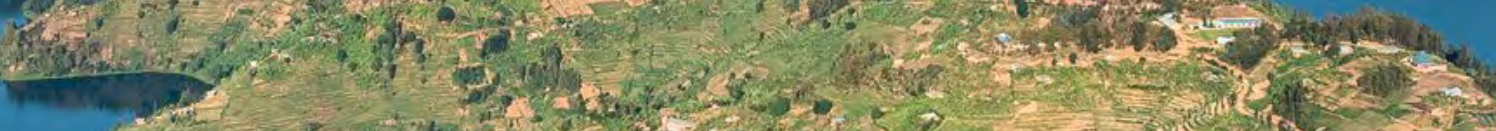

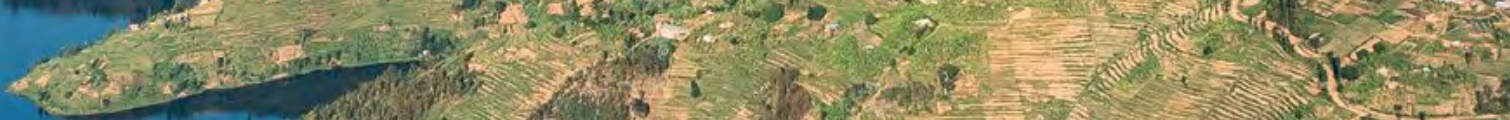

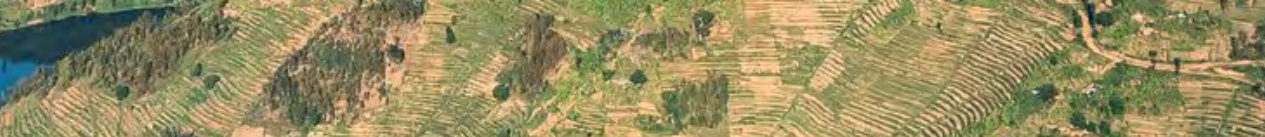

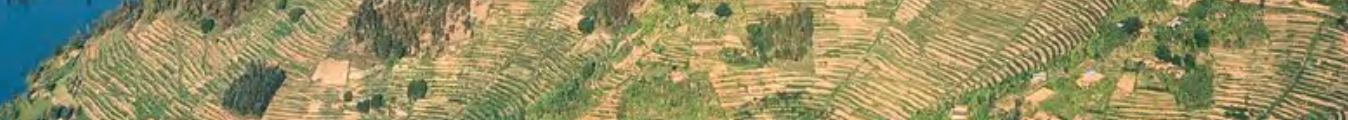
(2) 14.

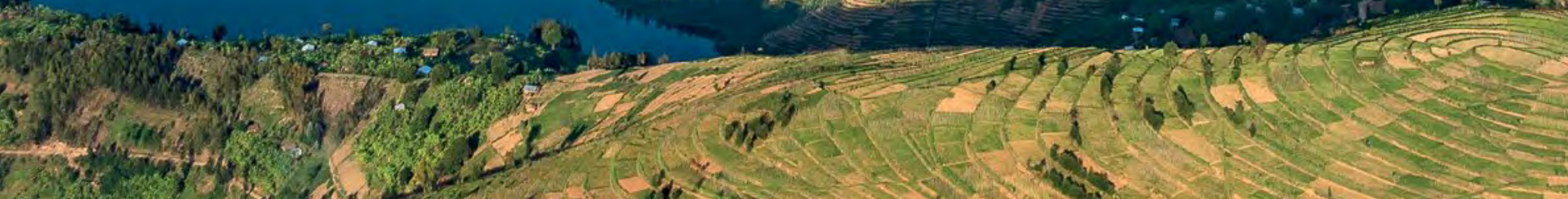

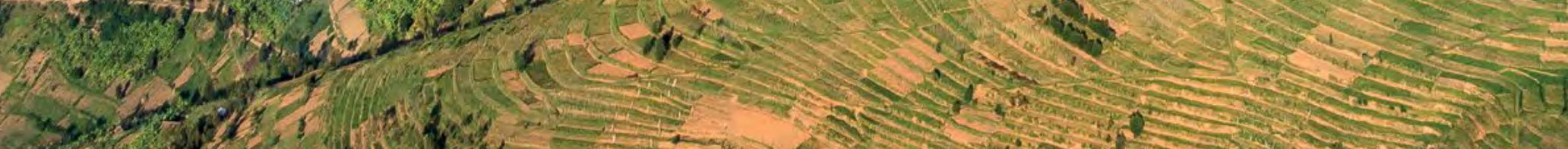
woth

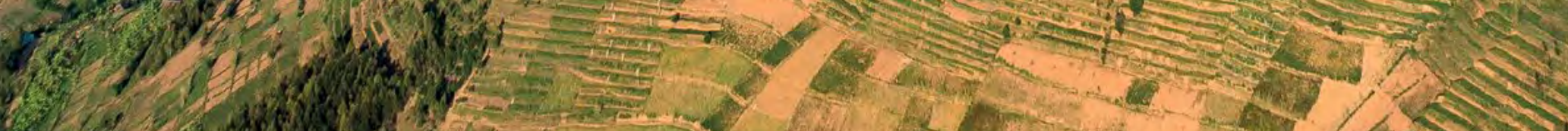

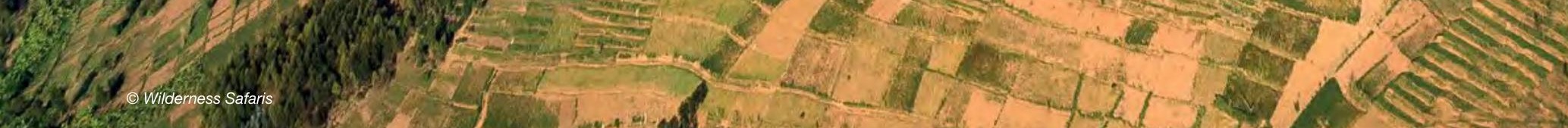




\section{Perfis dos países}

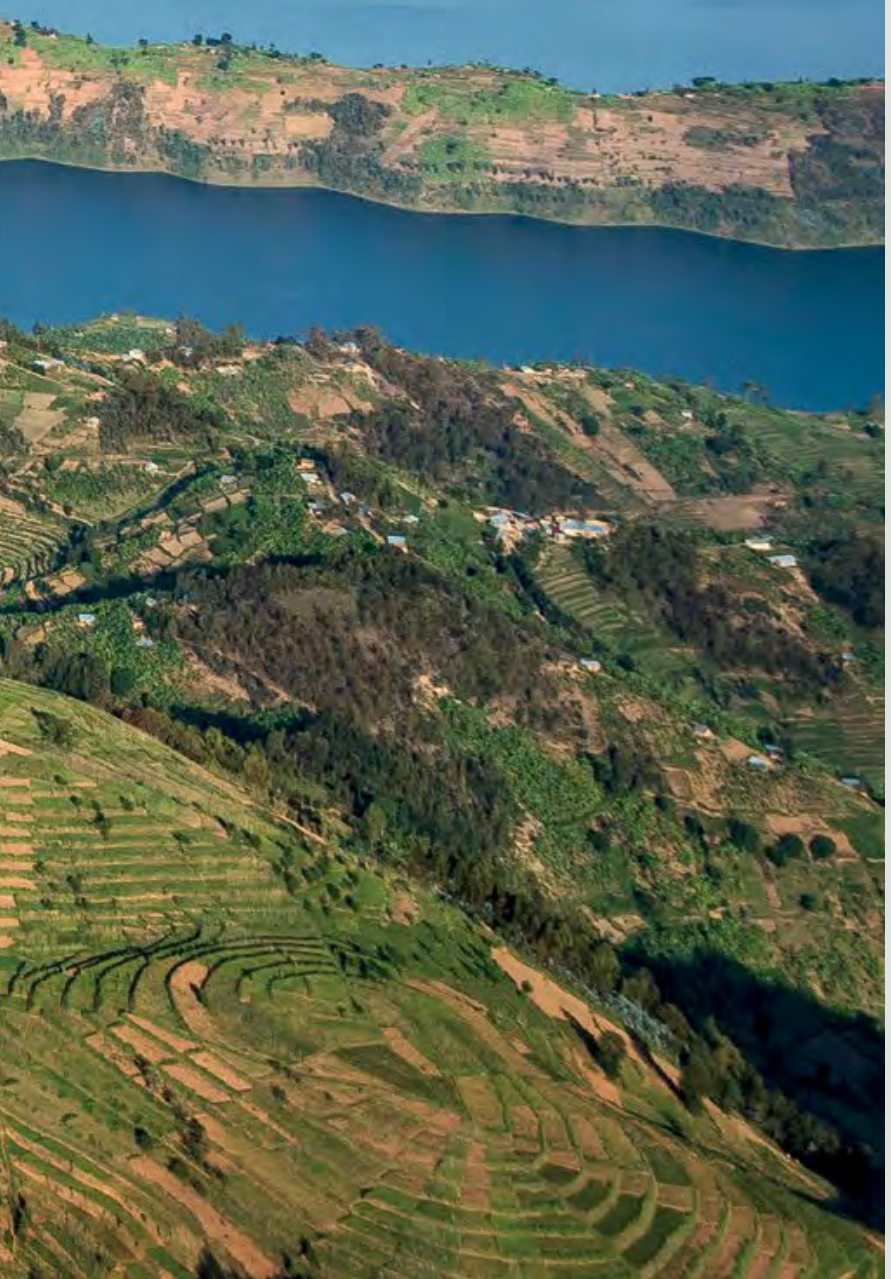




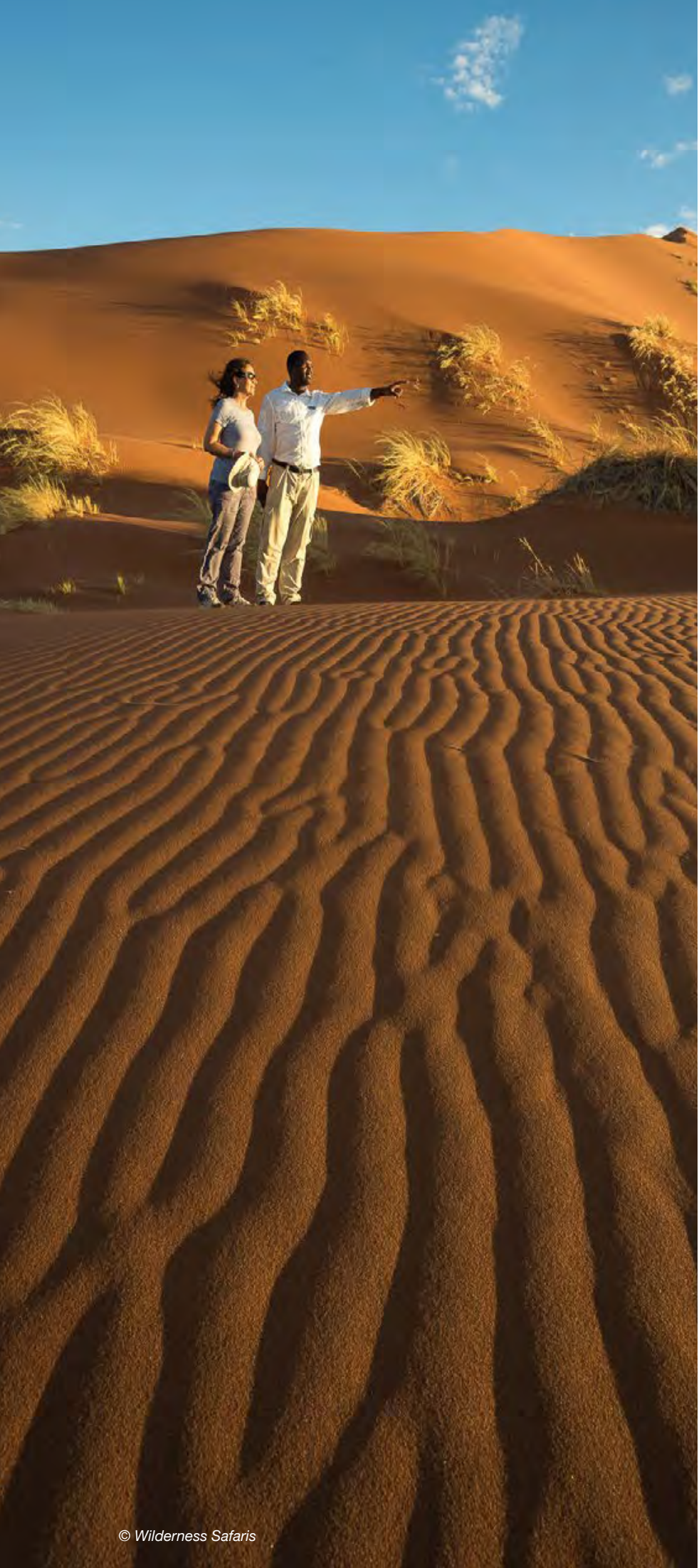

Esta secção apresenta um perfil das áreas protegidas e de conservação de cada um dos 24 países da região da África Oriental e Austral. Cada perfil inclui os seguintes dados:

- Uma breve descrição das áreas protegidas e de conservação, e a sua cobertura;

- Dados sobre o número de áreas protegidas e de conservação ao abrigo dos tipos de governação e categorias de gestão da UICN;

- Data sobre o número e área das designações nacionais de áreas protegidas e de conservação;

- Áreas prioritárias de acordo com três designações: Alliance for Zero Extinction, BirdLife International's Important Bird \& Biodiversity Areas (IBAs) e Key Biodiversity Areas (KBAs) da UICN; e

- Outros dados: zonas de conservação transfronteiriças, contexto político, espécies-chave, e pressões e ameaças.

Apêndice 6 e 7 fornece informações detalhadas (estatísticas) de acordo com as Categorias de Gestão da UICN e Tipos de Governação respectivamente por país. Cada perfil de país nesta secção tem um hyperlink para a página relevante na Apêndice para facilitar o leitor.

Para permitir a comparabilidade na região, foram utilizadas as mesmas análises e conjuntos de dados para todos os 24 países. Para estatísticas sobre áreas protegidas, foi utilizada a WDPA, a fonte global autorizada de dados sobre áreas protegidas, especificamente a actualização de Setembro de 2019. Alguns países, contudo, ainda não estão actualizados na WDPA. As estatísticas de países diferentes da WDPA são indicadas em conformidade.

As estatísticas por país foram extraídas de relatórios nacionais à $C D B$ e às Estratégias e Planos de Acção Nacionais para a Biodiversidade (NBSAPs). Na maioria dos casos, a data foi retirada do quinto relatório nacional do país e em alguns casos do sexto relatório nacional quando este estava disponível no momento em que foi redigido (Setembro de 2019)

\section{Metodologia utilizada para criar as estatísticas da WDPA}

Todas as estatísticas de contagem, tais como o número de áreas protegidas num país, ou o número de áreas protegidas sob uma determinada Categoria de Gestão da UICN, derivam da versão não modificada de Setembro de 2019 da WDPA para os 24 países. As estatísticas de cobertura, tais como a área coberta em áreas protegidas para um país, ou a área coberta por uma determinada Categoria de Gestão da UICN, derivam também de um subconjunto da versão de Setembro de 2019 da WDPA. Neste subconjunto, certos sítios foram removidos em conformidade com o método padrão de cálculo da cobertura utilizando a WDPA.$^{33}$ Os sítios com as seguintes características foram removidos do subconjunto WDPA:

- Aqueles com o estatuto de 'Proposto' ou 'Não Reportado'.

- Pontos que não têm uma área reportada

- Reservas do Homem e da Biosfera da UNESCO. Estes sítios são excluídos com base no facto de terem sido notificados como tendo uma área que inclui as zonas tampão e de transição, embora estas zonas não correspondam frequentemente à definição de uma área protegida

\section{Disclaimer}

A cobertura $\left(\mathrm{km}^{2}\right)$ pode sobrepor-se entre as categorias, mas não dentro delas. Isto é insignificante. No entanto, onde ocorrer sobreposição, os totais combinados somarão mais de $100 \%$ da área protegida do país. A WDPA é uma agregação de dados nacionais e, portanto, a qualidade dos limites depende da qualidade dos dados no país. O UNEP-WCMC não altera os limites ou a localização dos sítios, mas trabalhamos com os fornecedores de dados para tentar garantir a exactidão.

33 Para mais informações, por favor ver: https://www.protectedplanet.net/c/calculatingprotected-area-coverage 
Figura 8.1 Resumo de Angola

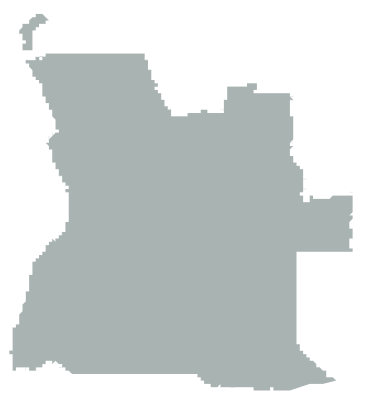

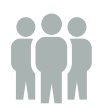

População Total (milhões) 30.81

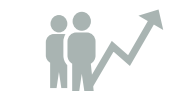

Crescimento da população (\% anual) 3.30

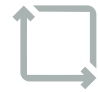

Superfície $\left(\mathrm{km}^{2}\right)$ (milhares)

1246.70

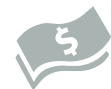

GDP (actuais US\$) (bilhões)

105.75

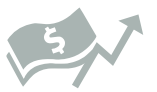

Crescimento do GDP (\% anual) $-2.10$

Fonte: The World Bank Group, 2018.

Área Protegida:

14

Áreas protegidas

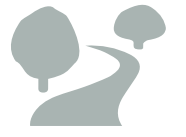

cobrindo 87531 km $^{2}$ de terra

Fonte: UNEP-WCMC \& UICN, 2019c.

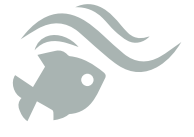

cobrindo $24 \mathbf{k m}^{2}$ de oceano
Áreas protegidas e de conservação em Angola em Categorias de Gestão da UICN

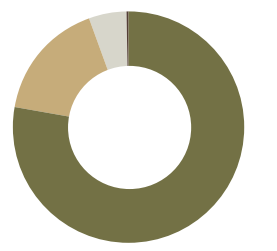

II. Parque Nacional (No. 8)

IV. Habitat / Gestão de Espécies (No. 4)

V. Paisagem Protegida / Paisagem Marítima (No. 1)

Não reportado (No. 1)

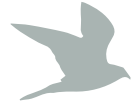

25 espécies de aves endémicas

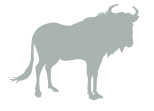

291 espécies de animais nativos alta biodiversidade marinha de água doce
Cobertura de áreas protegidas em Angola

\begin{tabular}{l|r|r}
\hline Tipo de zona protegida & $\begin{array}{r}\text { Área } \\
\text { protegida ou } \\
\text { conservada* }\end{array}$ & $\begin{array}{r}\text { Área } \\
\text { protegida ou } \\
\text { conservada** }\end{array}$ \\
\hline Águas terrestres e interiores & $6.97 \%$ & $12.50 \%$ \\
\hline Litoral e marinho & $0.00 \%$ & $\begin{array}{r}\text { Não } \\
\text { encontrado }\end{array}$ \\
\hline
\end{tabular}

*WDPA dataset $\quad$ ** Do Relatório Nacional sobre Biodiversidade

Fonte: República de Angola (2014); UNEP-WCMC \& UICN (2019c).

Áreas protegidas e de conservação em Angola nos tipos de governação da UICN

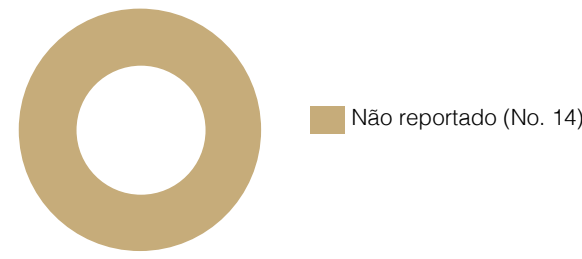

Fonte: UNEP-WCMC \& UICN (2019C).

\section{Áreas prioritárias para a conservação}

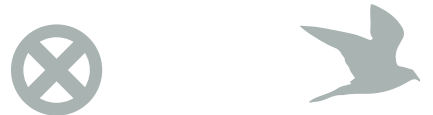

1 sítio

23 sítios

2 sítios

Aliança para os sítios Áreas importantes de Áreas-chave da de Extinção Zero 
Figura 8.2 Áreas Protegidas de Angola

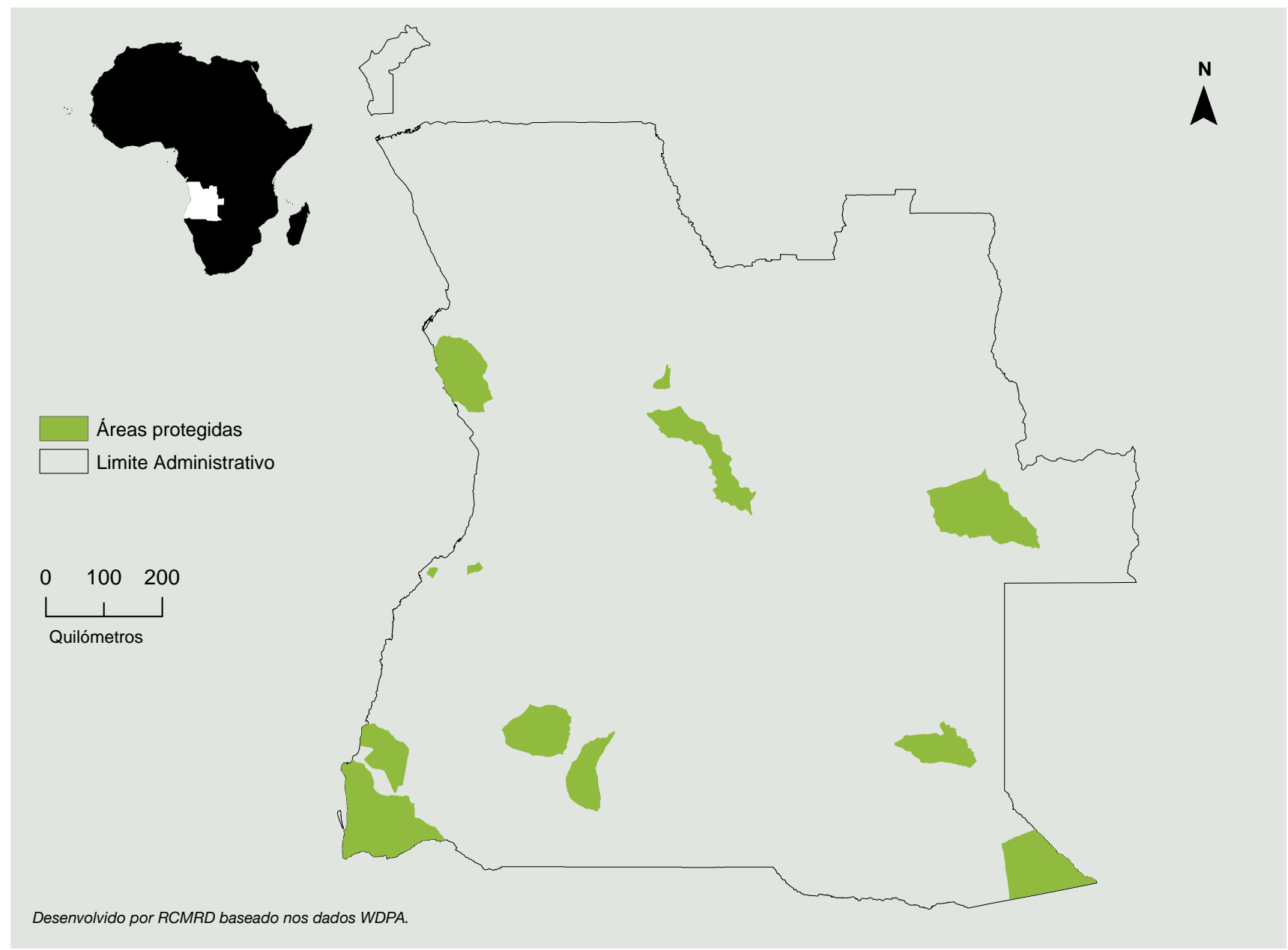

\section{Espécies-chave ${ }^{35}$}

Angola é lar de uma incrivel diversidade de habitats, e portanto também de uma enorme variedade de espécies, com até 291 espécies nativas, a maioria das quais são da Rodentia (85), Chiroptera (73), Carnivora (39) e Cetartiodactyla (33) encomendas. Há um grande número de espécies endémicas e quase endémicas, a maioria das quais são roedores ou morcegos.

De acordo com o Quinto Relatório Nacional de Angola para a CDB (2014), os mamíferos de particular interesse incluem a zibelina gigante endémica (Hippotragus niger variani), o gorila da planície ocidental (Gorilla gorilla ssp. gorilla), o peixe-boi africano (Trichechus senegalensis), e a zebra da montanha (Equus zebra). O estado de conservação de muitas destas espécies é mal compreendido. As populações de elefante africano (Loxodonta africana), hippopotamus (Hippopotamus amphibius) e foca de pêlo castanho (Arctocephalus pusillus) são consideradas estáveis.

Angola é o lar de 25 espécies de aves endémicas. Pouco se sabe sobre a diversidade da microfauna e flora de Angola, mas sabe-se que muitas espécies sofrem de elevados níveis de exploração de madeira, carvão vegetal, alimentos, bem como de comércio vivo local e internacional.
O país tem também uma elevada biodiversidade marinha e de água doce, incluindo cinco espécies de tartarugas marinhas, e muitas espécies de cetáceos. A pesca em pequena escala de peixe e crustáceos é uma parte crítica da subsistência das comunidades costeiras rurais. A cavala tem sido objecto de uma sobrepesca crítica, resultando na imposição de uma proibição anual de quatro meses. A introdução de espécies exóticas de tilápia é provável devido à prevalência de projectos de piscicultura.

\section{Pressões e ameaças ${ }^{36}$}

A biodiversidade de Angola está sujeita a muitas ameaças e pressões. As principais pressões provêm do habitat devido à agricultura de subsistência, à exploração mineira, às infra-estruturas, à desflorestação para carvão e madeira, e a uma incidênciamuito elevada de incêndios. A caça furtiva, inclusive para o comércio de carne de animais selvagens, é também uma grande ameaça. A sobrepesca, particularmente da cavala, tem resultado numa proibição anual de quatro meses. Angola está em vias de actualizar a sua legislação, mas a sua implementação e aplicação são necessárias.

35 Esta secção baseia-se na informação contida no Quinto Relatório Nacional de Angola à CDB (República de Angola, 2014).

36 Dados sobre a informação contida no Quinto Relatório Nacional de Angola para a CDB (República de Angola, 2014 


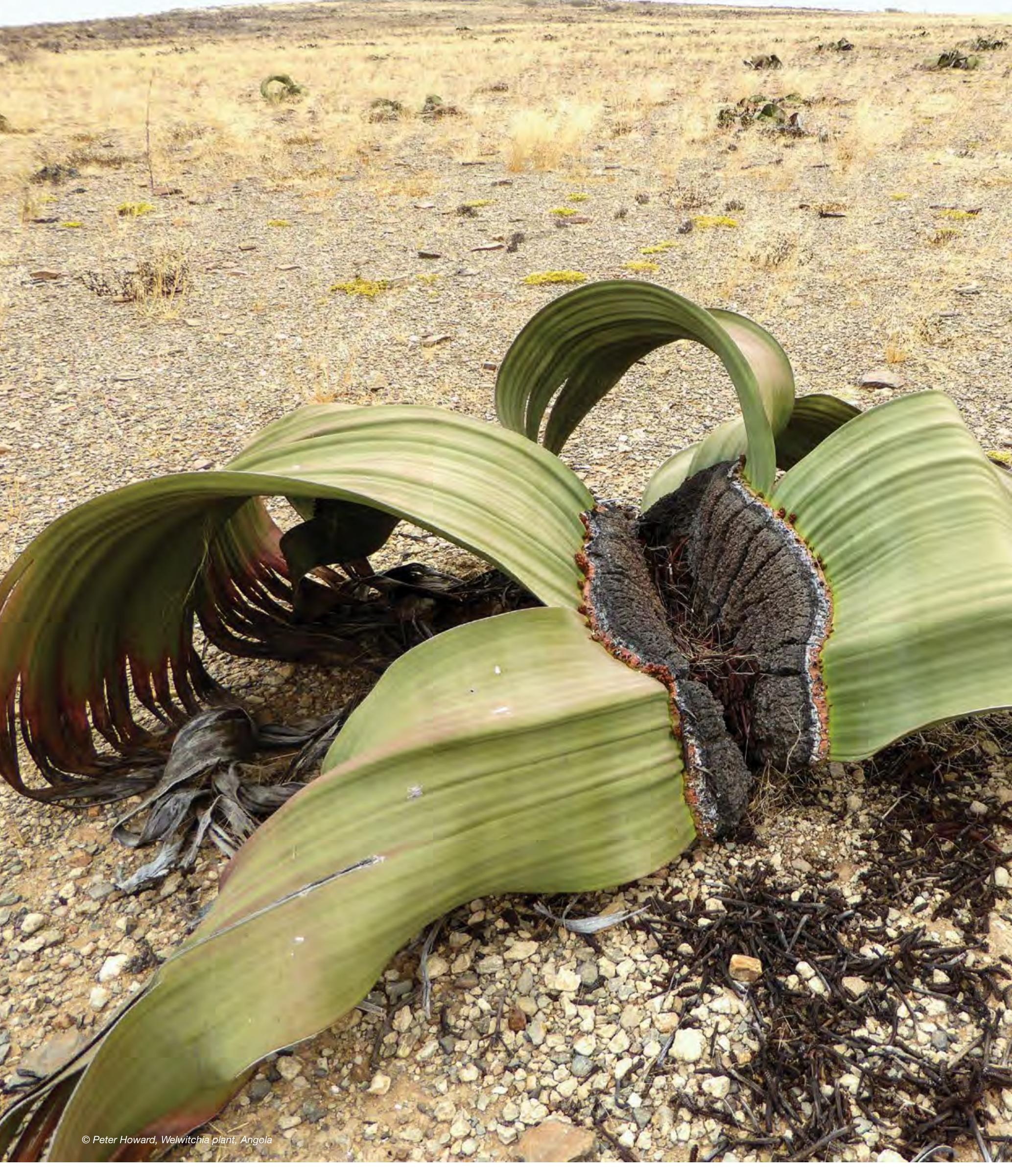




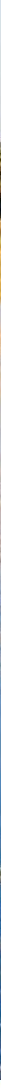

\subsection{Botswana}

\section{Áreas protegidas e de conservação em Botswana ${ }^{37}$}

Botswana tem 22 áreas protegidas cobrindo 169,370 km² de terra (UNEP-WCMC \& UICN, 2019d).

Dentro do Botswana, o uso da terra está dividido em áreas protegidas, áreas de gestão da vida selvagem (WMAs), áreas residenciais pastoris, quintas e áreas de concessão mineira. Como Botswana é um grande país com uma baixa população, tem sido possível estabelecer extensas áreas protegidas com mais de $45 \%$ do país sob alguma forma de gestão ambiental. A maioria dos ecossistemas do país está moderada ou bem representada, o que significa que estão dentro de $50 \%$ ou mais de $100 \%$ dos $17 \%$ do objectivo de Aichi. Uma elevada proporção dos ecossistemas encontra-se completamente dentro de áreas protegidas.

Desde 2009 tem havido alguma mudança na cobertura de áreas formalmente protegidas. Embora tenha havido um aumento nas áreas protegidas, há áreas onde a probabilidade de o estatuto de protecção estar a ser diminuído. Estas incluem várias áreas que têm sido listadas como áreas de gestão da vida selvagem (WMAs) propostas há mais de 15 anos. Estas nunca foram oficialmente contempladas. Botswana faz parte de grandes áreas de conservação transfronteiriças (TFCA) e isto promove as ligações e os objectivos de conservação do país e da região.

\section{Áreas transfronteiriças protegidas e de conservação}

Botswana inclui parte de três áreas de conservação transfronteiriças, nomeadamente a Greater Mapungubwe TFCA, Kavango-Zambezi TFCA e Kgalagadi TFCA.

\section{Contexto político}

Um relatório abrangente sobre legislação e política relacionada com a gestão de áreas protegidas, governação e equidade foi levado a cabo pelo programa BIOPAMA. Identificou 49 leis e políticas relevantes no Botswana (Tessema, 2019).

\section{Espécies-chave ${ }^{38}$}

Botswana tem uma elevada biodiversidade, especialmente no Delta do Okavango e arredores, com um índice de riqueza de espécies entre 9.3 e 15 . As espécies vegetais estão estimadas entre 2.150 e 3.000 , das quais 15 são endémicas e 43 estão na Lista Vermelha da UICN.

Existe um número rico e diversificado de fauna com 157 espécies de mamíferos identificadas, das quais três são endémicas e 112 estão na Lista Vermelha. Botswana é o lar de uma das maiores populações restantes do cão selvagem africano (Lycaon pictus) e a maior população restante de elefante africano (Loxodonta africana). As planícies de inundação sazonais à volta do Okavango

A secção baseia-se na informação contida no Sexto Relatório Nacional do Botswana ao CBD e Terceiro NBSAP (República do Botswana, 2016 e 2019 ).

38 A secção baseia-se na informação contida no Quinto e Sexto Relatórios Nacionais do Botswana ao CBD e Terceiro NBSAP (República do Botswana, 2015; 2016; 2019). 
Figura 8.3 Resumo do Botswana
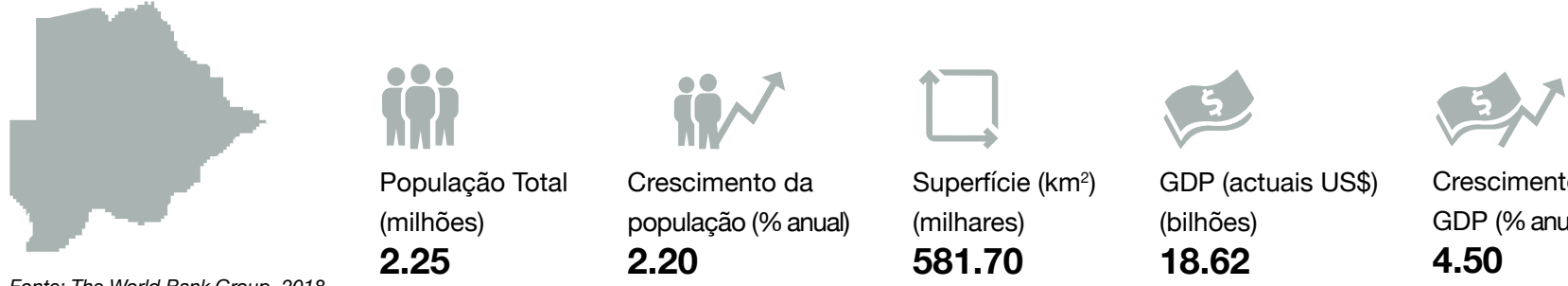

Crescimento do população (\% anual) (milhares)

Fonte: The World Bank Group, 2018

Área protegida:

\section{2 áreas protegidas}

Fonte: UNEP-WCMC \& UICN, 2019d

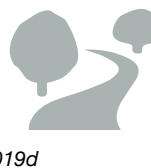

cobrindo 169370 km$^{2}$ de terra

\section{Áreas prioritárias para a conservação}

\section{2 sítios}

Fonte: Secretariado AZE (2019; BirdLife Internationa,( 2019b, 2019c).
Áreas protegidas e de conservação em Botswana em Categorias de Gestão da UICN

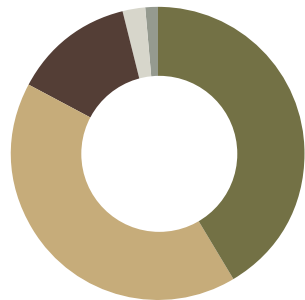

Ib. Área Selvagem (No. 7)

Não Reportado (No. 1)

Não Aplicável (No. 1)

II. Parque Nacional (No. 6)

IV. Habitat / Gestão de Espécies (No. 7)

Fonte: UNEP-WCMC \& UICN (2019c)

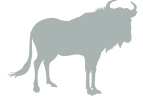

157 espécies de mamíferos

112 na lista vermelha

131 espécies

de répteis entre

$2150-3000$

espécies de plantas

15 endémicas

43 estão na lista vermelha

\section{Cobertura de áreas protegidas em Botswana}

\begin{tabular}{l|r|r}
\hline Tipo de zona protegida & $\begin{array}{r}\text { Área } \\
\text { protegida ou } \\
\text { conservada* }\end{array}$ & $\begin{array}{r}\text { Área } \\
\text { protegida ou } \\
\text { conservada** }\end{array}$ \\
\hline Águas terrestres e interiores & $29.14 \%$ & $29.10 \%$ \\
\hline${ }^{*}$ WDPA dataset \\
Fonte: República do Botswana (2019; UNEP-WCMC \& UICN (2019d).
\end{tabular}

Áreas protegidas e de conservação em Botswana nos tipos de governação da UICN

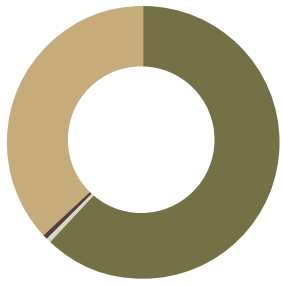

Não Reportado (No. 2)

D. Governação pelos povos indígenas

e comunidades locais (No. 1)

C. Governação Privada (No. 1)

A. Governação pelo Governo (No. 18)
Designações nacionais de áreas protegidas e de conservação em Botswana

\begin{tabular}{l|r|r}
\hline Designação Nacional & No. & Área $\mathbf{( k m}^{\mathbf{2}}$ \\
\hline Parque Nacional & 4 & 43926 \\
\hline Reserva de Caça & 6 & 60352 \\
\hline Santuário de Caça & 1 & 89 \\
\hline Reserva Florestal & 6 & 4057 \\
\hline Santuário de Pássaros & 3 & 974 \\
\hline
\end{tabular}

Fonte: UNEP-WCMC \& UICN (2019c).

Áreas protegidas e de conservação designadas como sítios globais de importância em Botswana

\begin{tabular}{l|r}
\hline Designação global & No. de sítios \\
\hline $\begin{array}{l}\text { Sítios Património Mundial da UNESCO } \\
\text { (Natural ou Misto) }\end{array}$ & 1 \\
\hline $\begin{array}{l}\text { Zonas húmidas de importância internacional } \\
\text { (sítios Ramsar) }\end{array}$ & 1 \\
\hline
\end{tabular}

Fonte: Ramsar (2019); UNESCO (2019a, 2019b). 
e do Zambeze e extensas áreas selvagens suportam algumas das principais rotas de migração da vida selvagem na África Austral, fazendo do Botswana um dos últimos refúgios para espécies que necessitam de campo aberto.

Botswana é o lar de 587 espécies de aves. Existem 25 espécies de aves globalmente ameaçadas no Botswana e mais oito consideradas como espécies nacionais ameaçadas e duas espécies quase endémicas.

Das 99 espécies de peixes de água doce registadas no Botswana, duas estão globalmente ameaçadas. Além disso, 131 espécies de répteis e 44 espécies de anfíbios estão registadas. Há pouca informação disponível sobre invertebrados, embora as borboletas e libélulas tenham sido inventariadas mais de perto do que outras.

Botswana é o lar de 13 espécies endémicas de plantas, com outras 10 potencialmente endémicas e sete quase endémicas.

\section{Pressões e ameaças ${ }^{39}$}

A principal ameaça à biodiversidade no Botswana é a perda e degradação do habitat. As causas indirectas destas ameaças incluem: sobrepastoreio através do pastoreio não regulamentado do gado; degradação do habitat; incêndios; mineração; erosão eólica; aumento da extracção de água para irrigação resultando no aumento da salinidade; falta de protecção dos locais de criação de aves; turismo descontrolado; e perturbação das rotas de migração através de vedações. A caça furtiva de produtos da vida selvagem e de carne de animais selvagens é outra séria ameaça à biodiversidade do país. O conflito entre o homem e a vida selvagem é uma questão crítica e contínua no país.

O Quinto Relatório Nacional do Botswana para a CDB apresentou as principais ameaças à biodiversidade do Botswana, ligando as ameaças directas às causas subjacentes, principais impactos e implicações fundamentais (República do Botswana, 2015). O relatório enumera as principais ameaças internas como destruição de habitat, barreiras ao movimento da vida selvagem, caça furtiva, regimes de incêndio perturbados e sobre-exploração, enquanto que as principais ameaças externas são as alterações climáticas e as alterações à hidrologia.

As ameaças secundárias incluem espécies invasoras tanto em ecossistemas terrestres como em ecossistemas de água doce. As alterações climáticas estão a emergir como uma grande ameaça para o ecossistema do Delta do Okavango e a Bacia do Kalahari.

\section{Figura 8.4 Áreas Protegidas do Botswana}

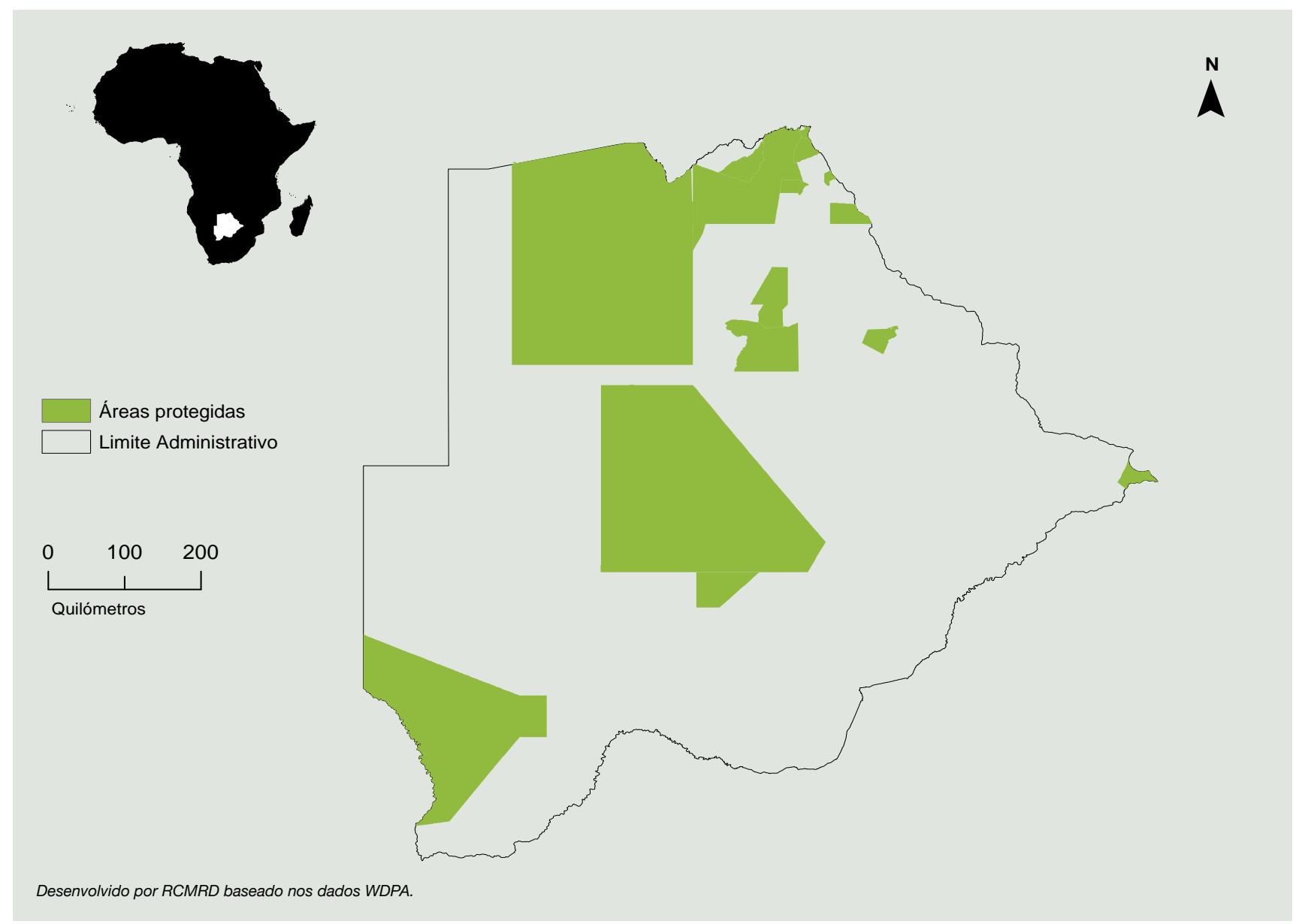

39 A secção baseia-se na informação contida no Sexto Relatório Nacional do Botswana ao CBD e Terceiro NBSAP (República do Botswana, 2016, 2019). 


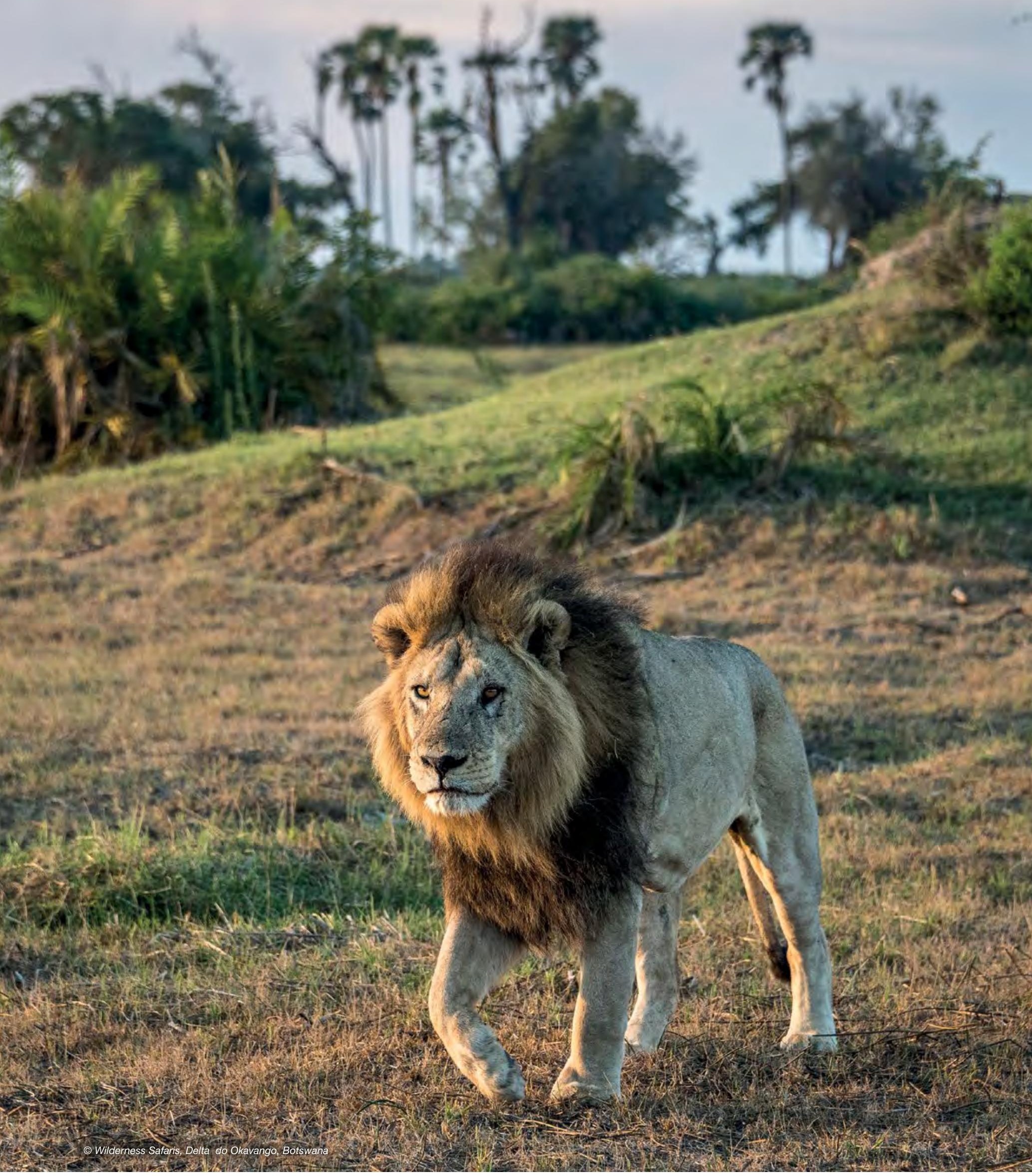




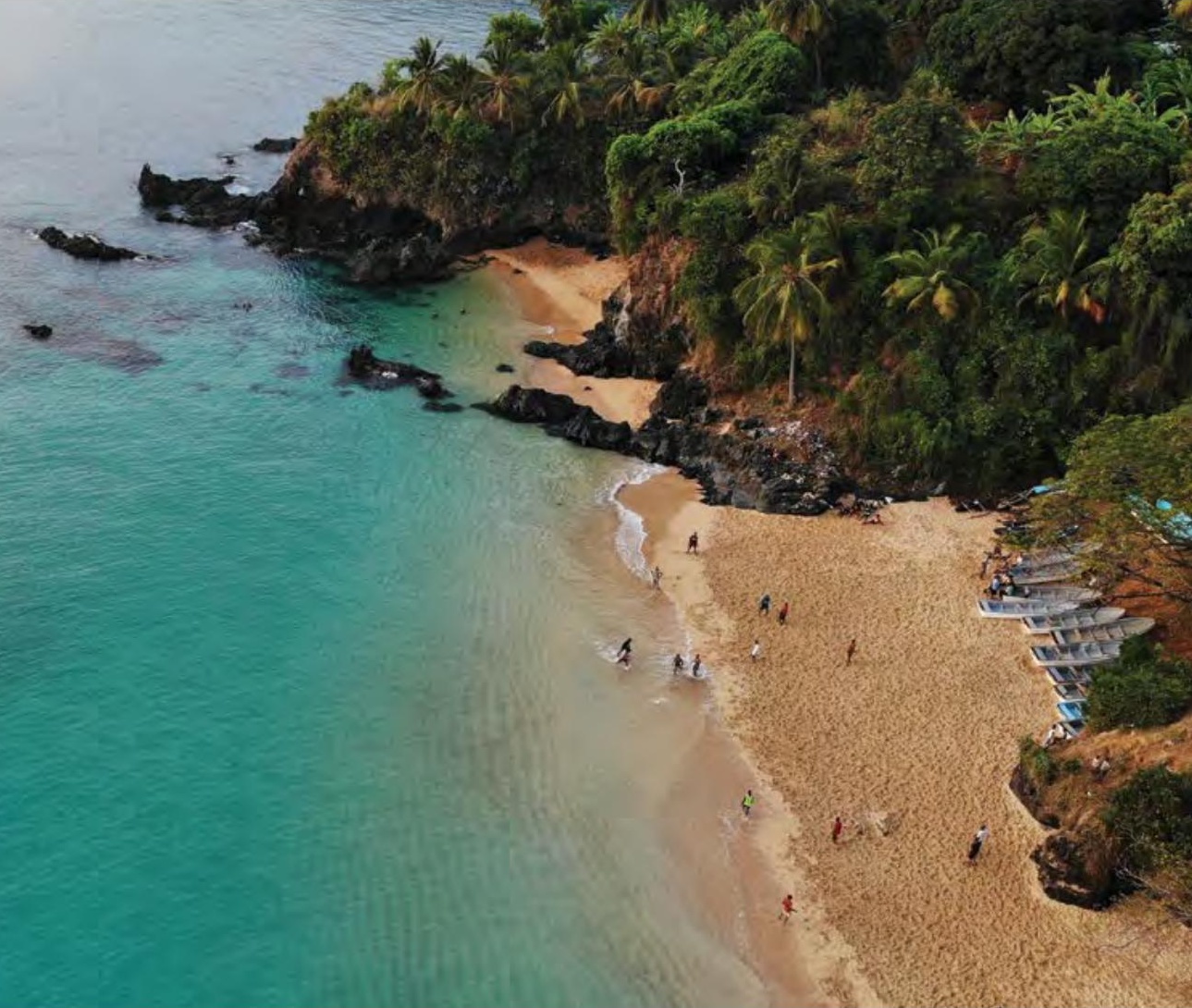

\subsection{Comores}

\section{Áreas protegidas e de conservação em Comores ${ }^{40}$}

Comores tem oito áreas protegidas cobrindo $173 \mathrm{~km}^{2}$ de terra e $37 \mathrm{~km}^{2}$ do oceano (UNEP-WCMC \& UICN, 2019d).

As áreas terrestres e interiores em áreas protegidas permanecem pequenas e não estão ligadas em redes de áreas protegidas ecologicamente representativas. Há necessidade de aumentar a cobertura para cumprir o Objectivo 11 de Aichi, que envolverá a criação de novas áreas protegidas em ecossistemas frágeis com elevada e sensível biodiversidade e o aumento das acções de conservação e gestão da biodiversidade de ONG e particulares. Contudo, é importante notar que desde 2014, a União das Comores aumentou o seu património de áreas protegidas de uma para cinco áreas protegidas. Este aumento na cobertura de áreas protegidas envolve as comunidades locais no processo de desenvolvimento e gestão das áreas protegidas. A criação de novas áreas protegidas, para além do Parque Nacional Mohéli existente, faz parte do compromisso do Governo de alcançar o Objectivo 11 de Aichi.

\section{Áreas transfronteiriças protegidas e de conservação}

Comores não faz parte de nenhuma zona de conservação transfronteiriça.

\section{Contexto político}

Um relatório abrangente sobre legislação e política relacionada com a gestão de áreas protegidas, governação, e equidade foi levado a cabo pelo programa BIOPAMA. Identificou 15 leis e políticas relevantes em Comores (Tessema, 2019).

\section{Espécies-chave ${ }^{41}$}

Noventa e seis espécies de aves foram registadas em Comores, das quais 33 estão ameaçadas. A União das Comores é o lar de vários mamíferos ameaçados, incluindo o endémico Comores rousette (Rousettus obliviosus), o lêmure mangusto (Eulemur mongoz), a raposa voadora endémica de Livingstone (Pteropus livingstonii), o dugongo (Dugong dugon), a baleia jubarte (Megaptera novaeangliae) e o tenrec (Tenrec ecaudatus).

Mais de 1.200 espécies de insectos foram registadas nas Comores e pelo menos 16 espécies de plantas estão ameaçadas de extinção.

Foram também registadas duas espécies de anfíbios e 29 répteis. As duas espécies de anfíbios e 14 das 29 espécies de répteis terrestres são endémicas. Alguns dos répteis estão ameaçados de extinção. Várias espécies de tartarugas marinhas também fazem ninho nas Comores, e o seu estado de conservação está a melhorar.

40 A secção baseia-se na informação contida no Sexto Relatório Nacional à CDB (Union des Comores, 2019).

41 A secção baseia-se na informação contida no Quinto Relatório Nacional das Comores à CDB e no seu Segundo Plano de Acção e Estratégia Nacional de Biodiversidade (NBSAP) (Union des Comores, 2014; 2016) e na sua Estratégia 2017-2021 para expandir o sistema nacional de áreas protegidas (Union des Comores, 2017). 
Figura 8.5 Resumo das Comores

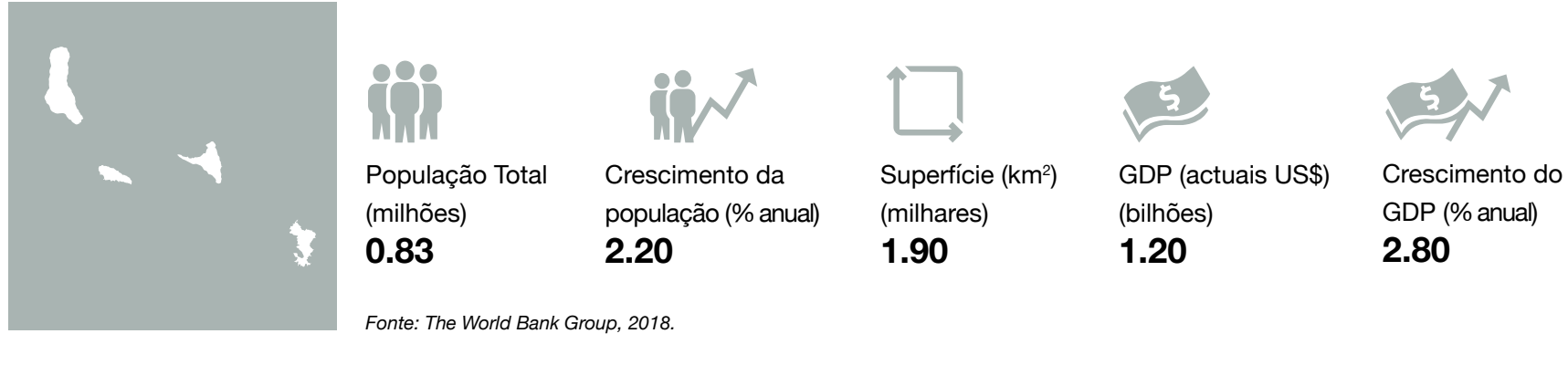

\section{Área Protegida:}

8 áreas protegidas

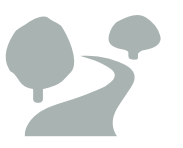

cobrindo $173 \mathrm{~km}^{2}$ de terra

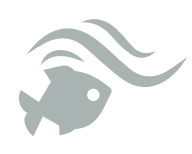

cobrindo

$37 \mathrm{~km}^{2}$ de oceano
Áreas protegidas e de conservação em Comores em Categorias de Gestão da UICN

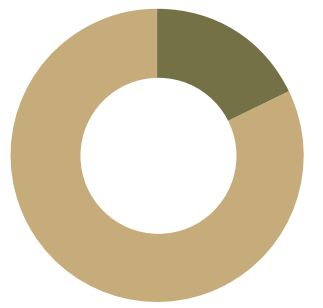

Fonte: UNEP-WCMC \& UICN (2019d)
Não Reportado (No. 7)

II. Parque Nacional (No. 1)

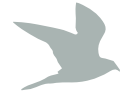

96 espécies de aves 33 estão ameaçadas
16 espécies de plantas ameaçadas

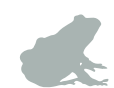

2 espécies de anfíbios endémicas
14 répteis endémico
Cobertura de áreas protegidas em Comores

\begin{tabular}{l|r|r}
\hline Tipo de área protegida & $\begin{array}{r}\text { Área } \\
\text { protegida ou } \\
\text { conservada* }\end{array}$ & $\begin{array}{r}\text { Área } \\
\text { protegida ou } \\
\text { conservada** }\end{array}$ \\
\hline Águas terrestres e interiores & $10.15 \%$ & $22.00 \%$ \\
\hline Litoral e marinho & $0.02 \%$ & $\begin{array}{r}\text { Não } \\
\text { encontrado }\end{array}$ \\
\hline
\end{tabular}

*WDPA dataset $\quad$ ** Do Relatório Nacional sobre Biodiversidade

Fonte: UNEP-WCMC \& UICN (2019d); Union des Comores (2014).

Áreas protegidas e de conservação em Comores nos tipos de governação da UICN

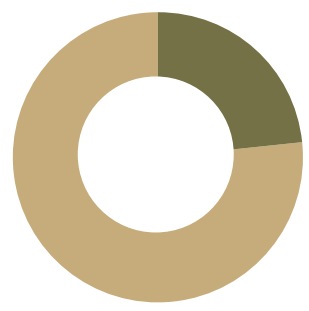

Não Reportado (No. 2)

B. Governação Partilhada (No. 6)
Designações nacionais de áreas protegidas e de conservação em Comores

\begin{tabular}{l|r|r}
\hline Designação Nacional & No. & Área $\left.\mathbf{( k m}^{2}\right)$ \\
\hline Parque Nacional & 1 & 37 \\
\hline Área protegida Nacional & 4 & 573 \\
\hline
\end{tabular}

Fonte: UNEP-WCMC \& UICN (2019d).

Áreas protegidas e conserdas designada como sítios globais de importância em Comores

\begin{tabular}{l|r}
\hline Designação global & No. de sítios \\
\hline $\begin{array}{l}\text { Zonas húmidas de importância internacional } \\
\text { (sítios Ramsar) }\end{array}$ & 3 \\
\hline
\end{tabular}

Fonte: Ramsar (2019; UNESCO (2019a, 2019b).

\section{Áreas prioritárias para a conservação}
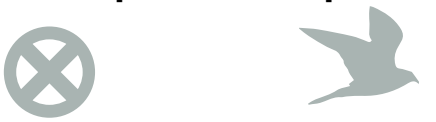

\section{3 sítios $\quad 4$ sítios}

Aliança para os sítios Áreas importantes de Áreas-chave da de Extinção Zero

Aves \& Biodiversidade

Biodiversidade 


\section{Figura 8.6 Áreas Protegidas das Comores}

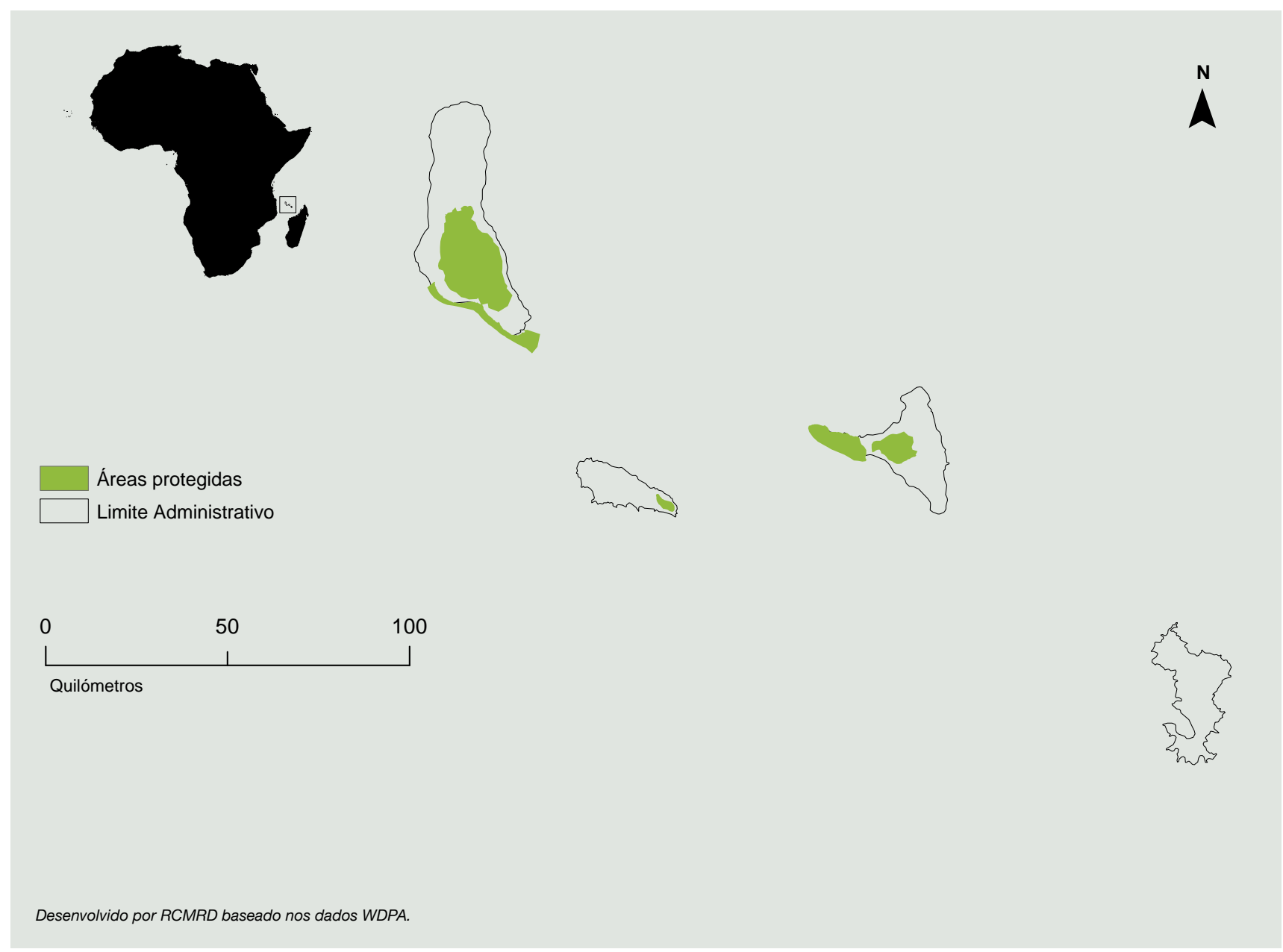

O país é também o lar do celacanto (Latimeria chalumnae) que é classificado como criticamente em perigo. Há várias espécies de cetáceos protegidas pela CITES, como a baleia jubarte (Megaptera novaeangliae), a baleia franca do Sul (Eubalaena australis), a baleia de Bryde (Balaenoptera edeni) e o cachalote (Physeter macrocephaleus), que frequenta as águas marinhas comorianas.

Algumas espécies de coral, como o coral negro (Antipathes dichotoma), estão listadas nos apêndices da CITES devido à elevada procura de jóias. Pelo menos 16 espécies de plantas estão ameaçadas de extinção.

\section{Pressões e ameaças ${ }^{42}$}

As principais pressões directas sobre a biodiversidade nas Comores são a perda e degradação do habitat devido à agricultura de queimadas, espécies exóticas invasoras, a necessidade crescente de lenha para destilação de ylang-ylang, a extracção excessiva de coral e areia para construção, e a poluição. A sobre-exploração de certas espécies, incluindo répteis e uma série de espécies marinhas diferentes, constitui uma grande ameaça. Algumas espécies de moluscos desapareceram devido à sobrecolheita.
As principais causas indirectas destas ameaças incluem a fragilidade natural do ecossistema, com uma população humana em crescimento que tem um nível de pobreza muito elevado. Existem fraquezas no quadro institucional, incluindo baixas capacidades humanas, estabilidade insegura, quadro regulador inadequado e não reforçado e políticas públicas ineficientes.

As alterações climáticas representam uma grande ameaça a curto e longo prazo para a biodiversidade das Comores. Em alguns locais, os recifes sofreram mais de $60 \%$ de branqueamento devido à subida da temperatura do mar, enquanto 30-40 metros de prados costeiros desapareceram devido à subida do nível do mar.

42 A secção baseia-se na informação contida no Quinto Relatório Nacional das Comores à CDB e no seu Segundo NBSAP (Union des Comores, 2014, 2016) e no seu Sistema Nacional de Explicação da Estratégia de Áreas Protegidas 2017-2021 (DGEF, 2017). 


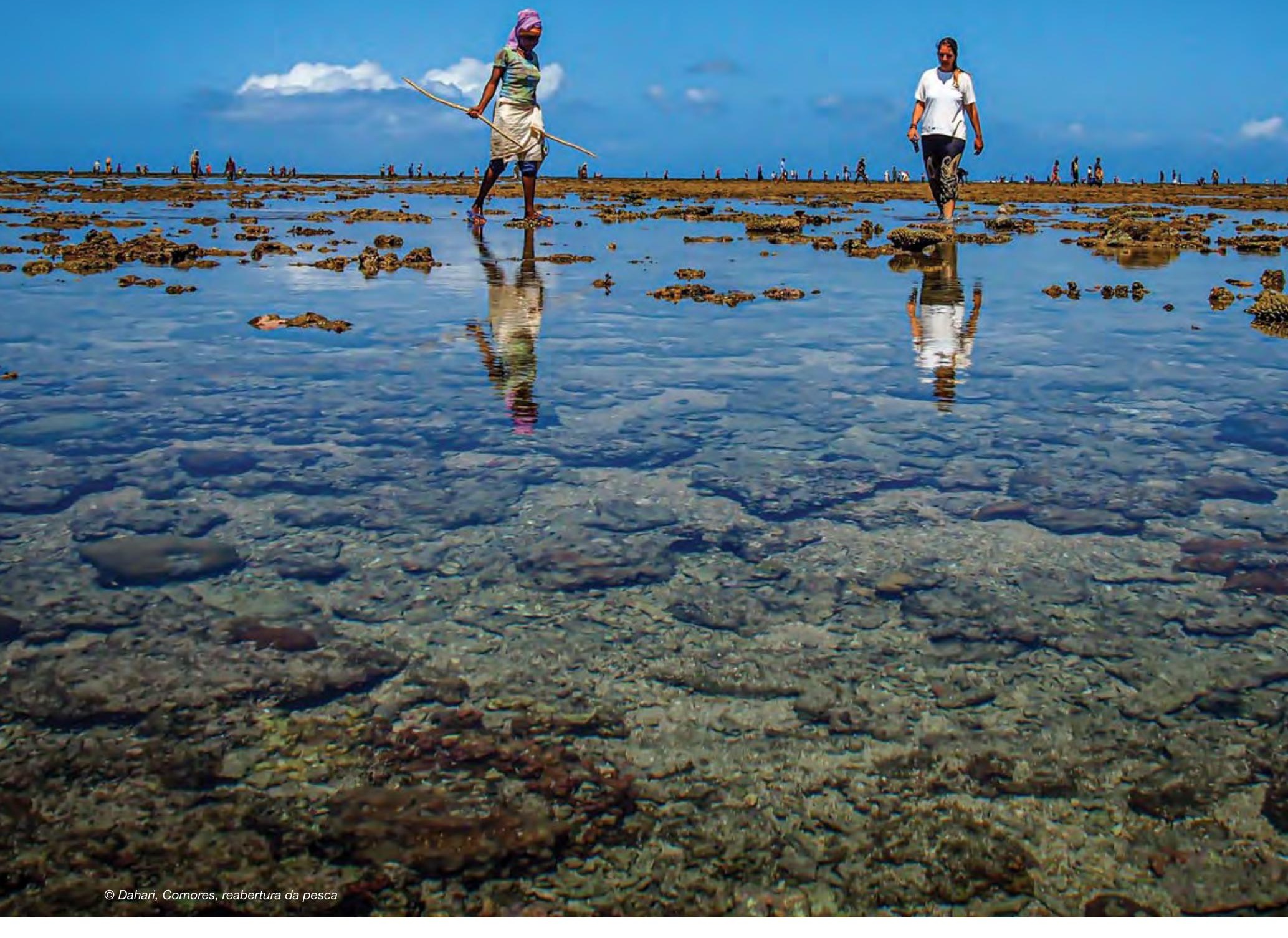




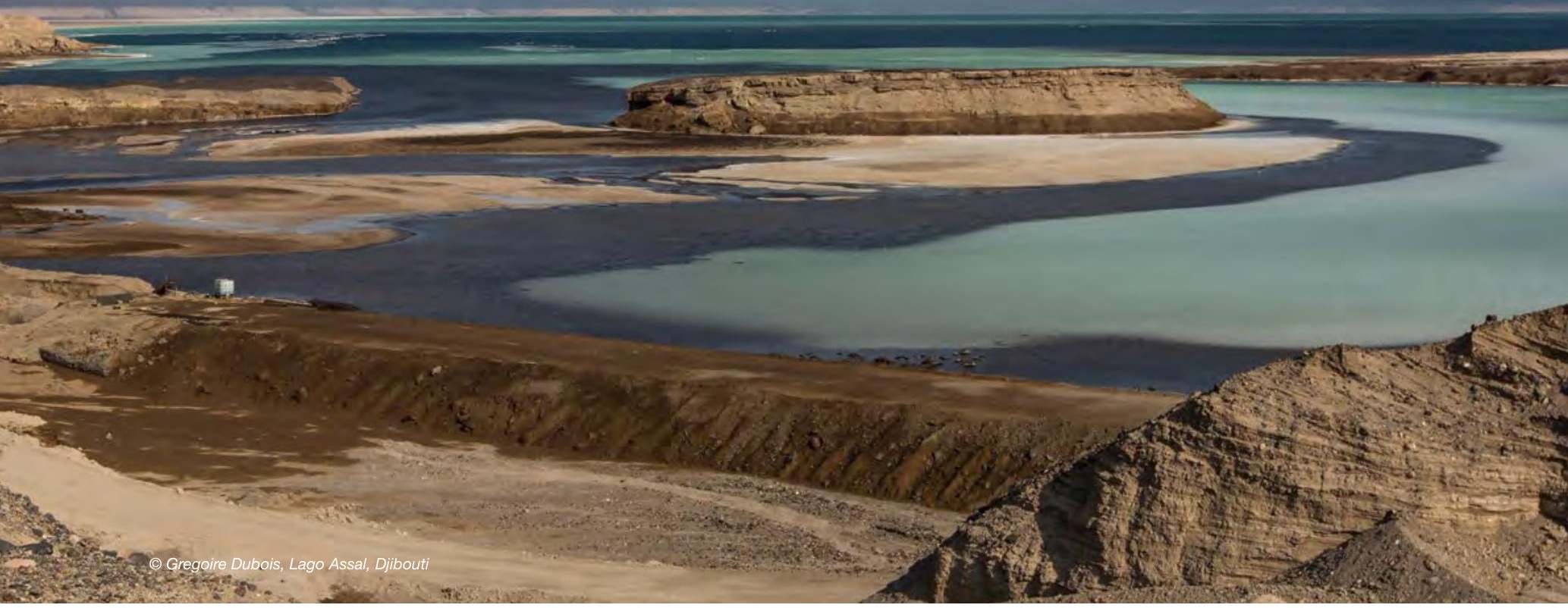

\subsection{Djibouti}

\section{Áreas protegidas e de conservação em Djibouti ${ }^{43}$}

Djibouti tem sete áreas protegidas cobrindo $344 \mathrm{~km}^{2}$ de terra e $12 \mathrm{~km}^{2}$ do oceano (UNEP-WCMC \& UICN (2019e).

Em 2015, foi proposta a extensão da rede de MPAs ao sector marítimo e costeiro. O objectivo é formar uma grande unidade de gestão que estenda a área dos AMP a uma cobertura total de 56.500 ha de paisagem marítima. Além disso, em 2019, vários sítios terrestres foram identificados como candidatos a protecção.

No Djibouti, as áreas protegidas terrestres e marinhas não são áreas fechadas. As actividades tradicionais de agricultura e pesca, assim como o ecoturismo, são autorizadas mas regulamentadas e controladas com vista a preservar a biodiversidade. No entanto, restrições como o abate ou a poda de árvores, a colheita ou arranque de plantas são reguladas e controladas em áreas protegidas terrestres.

\section{Áreas transfronteiriças protegidas e de conservação}

Djibouti inclui parte da área de conservação transfronteiriça da paisagem do Baixo Awash-Lake Abbé.

\section{Contexto político}

Um relatório abrangente sobre legislação e política relacionada com a gestão de áreas protegidas, governação, e equidade foi levado a cabo pelo programa BIOPAMA. Identificou 21 leis e políticas relevantes no Djibouti (Tessema, 2019).

\section{Espécies-chave ${ }^{44}$}

Estes relatórios não fornecem um resumo geral das espécies no país, mas tomam nota dos principais ecossistemas, incluindo florestas e mangais. É dada especial atenção à Day Forest e ao Maciço Goda, lar de uma variedade de plantas, animais e aves, incluindo o Djibouti francolin (Francolinus ochropectus), endémico e criticamente ameaçado.

\section{Pressões e ameaças ${ }^{45}$}

A biodiversidade do Djibouti enfrenta grandes ameaças. Os escassos recursos de água doce do país estão ameaçados pela salinização, deterioração das infra-estruturas, poluição e degradação das principais bacias hidrográficas, através da desflorestação para lenha e carvão vegetal. Djibouti também sofre de uma severa invasão do Prosopis, ou mesquite, que degrada as serras. Os ambientes marinhos são também afectados pela poluição, incluindo a partir do armazenamento de produtos petrolíferos. A pesca ilegal e não regulamentada resulta na sobre-exploração de certas espécies. As pressões indirectas incluem a seca, o crescimento urbano, o aumento da população, a pressão das populações refugiadas nos países vizinhos, e a persistente pobreza rural e insegurança alimentar.

43 A secção baseia-se na informação contida no Sexto Relatório Nacional do Djibouti ao CBD (République de Djibouti, 2019) e Segundo NBSAP (République de Djibouti, 2017).

44 A secção baseia-se na informação contida no Quinto Relatório Nacional do Djibouti ao CBD e Segundo NBSAP (République de Djibouti, 2014; 2017).

45 Ibid. 
Figura 8.7 Resumo de Djibouti

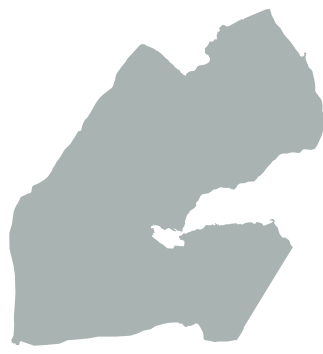

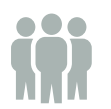

População Total (milhões) 0.96

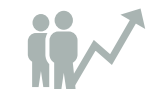

Crescimento da população (\% anual) 1.60

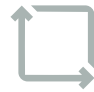

Superfície $\left(\mathrm{km}^{2}\right)$ (milhares)

23.2

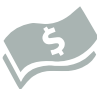

GDP (actuais US\$) (bilhões)

1.97
Crescimento do GDP (\% anual) 6.00

\section{Área Protegida:}

\section{7 áreas protegidas}

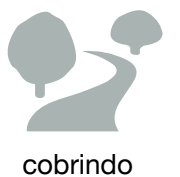

344 km $^{2}$ de terra

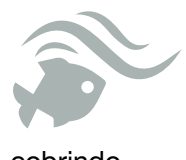

cobrindo

$12 \mathbf{k m}^{2}$ de oceano
Fonte: UNEP-WCMC \& UICN, 2019e

\section{ecossistemas-chave \\ incluem: florestas e mangues}

Áreas protegidas e de conservação em Djibouti em Categorias de Gestão da UICN

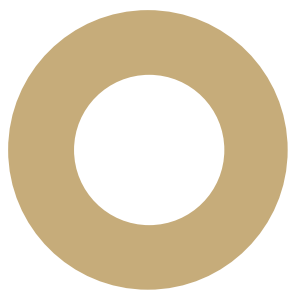

Não Reportado (No. 3)

VI. Área Protegida com Utilização Sustentável dos Recursos Naturais (No.1)

IV. Habitat / Gestão de Espécies (No. 1)

V. Paisagem Protegida / Paisagem Marítima (No. 2)

Fonte: UNEP-WCMC \& UICN (2019e).
Cobertura de áreas protegidas em Djibouti

\begin{tabular}{|c|c|c|}
\hline Tipo de área protegida & $\begin{array}{r}\text { Área } \\
\text { protegida ou } \\
\text { conservada* }\end{array}$ & $\begin{array}{r}\text { Área } \\
\text { protegida ou } \\
\text { conservada* }^{\star *}\end{array}$ \\
\hline Águas terrestres e interiores & $1.57 \%$ & $1.34 \%$ \\
\hline Litoral e marinho & $0.17 \%$ & $0.46 \%$ \\
\hline
\end{tabular}

Fonte: UNEP-WCMC \& UICN (2019d); Union des Comores (2014).

Áreas protegidas e de conservação em Djibouti nos tipos de governação da UICN

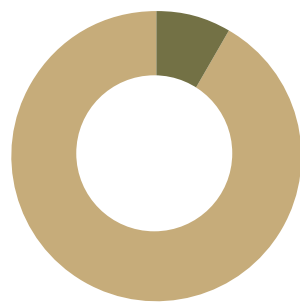

A. Governação pelo Governo (No. 3) Não Reportado (No. 1)
Designações nacionais de áreas protegidas e de conservação em Djibouti

\begin{tabular}{l|r|r}
\hline Designação Nacional & No. & Área $\left.\mathbf{( k m}^{2}\right)$ \\
\hline Área protegida Terrestre & 2 & 323 \\
\hline Paisagem marinha protegida & 3 & 514 \\
\hline $\begin{array}{l}\text { Área protegida para habitat e } \\
\text { espécies }\end{array}$ & 1 & 26 \\
\hline
\end{tabular}

Fonte: UNEP-WCMC \& UICN (2019e).

Áreas protegidas e de conservação designadas como sítios globais de importância em Djibouti

\begin{tabular}{l|r}
\hline Designação global & No. de sítios \\
\hline $\begin{array}{l}\text { Zonas húmidas de importância internacional } \\
\text { (sítios Ramsar) }\end{array}$ & 1 \\
\hline
\end{tabular}

Fonte: Ramsar (2019); UNESCO (2019a, 2019b).

\section{Áreas prioritárias para a conservação}

\section{7 sitios}

Áreas importantes de Aves \& Biodiversidade 


\section{Figura 8.8 Áreas Protegidas de Djibouti}
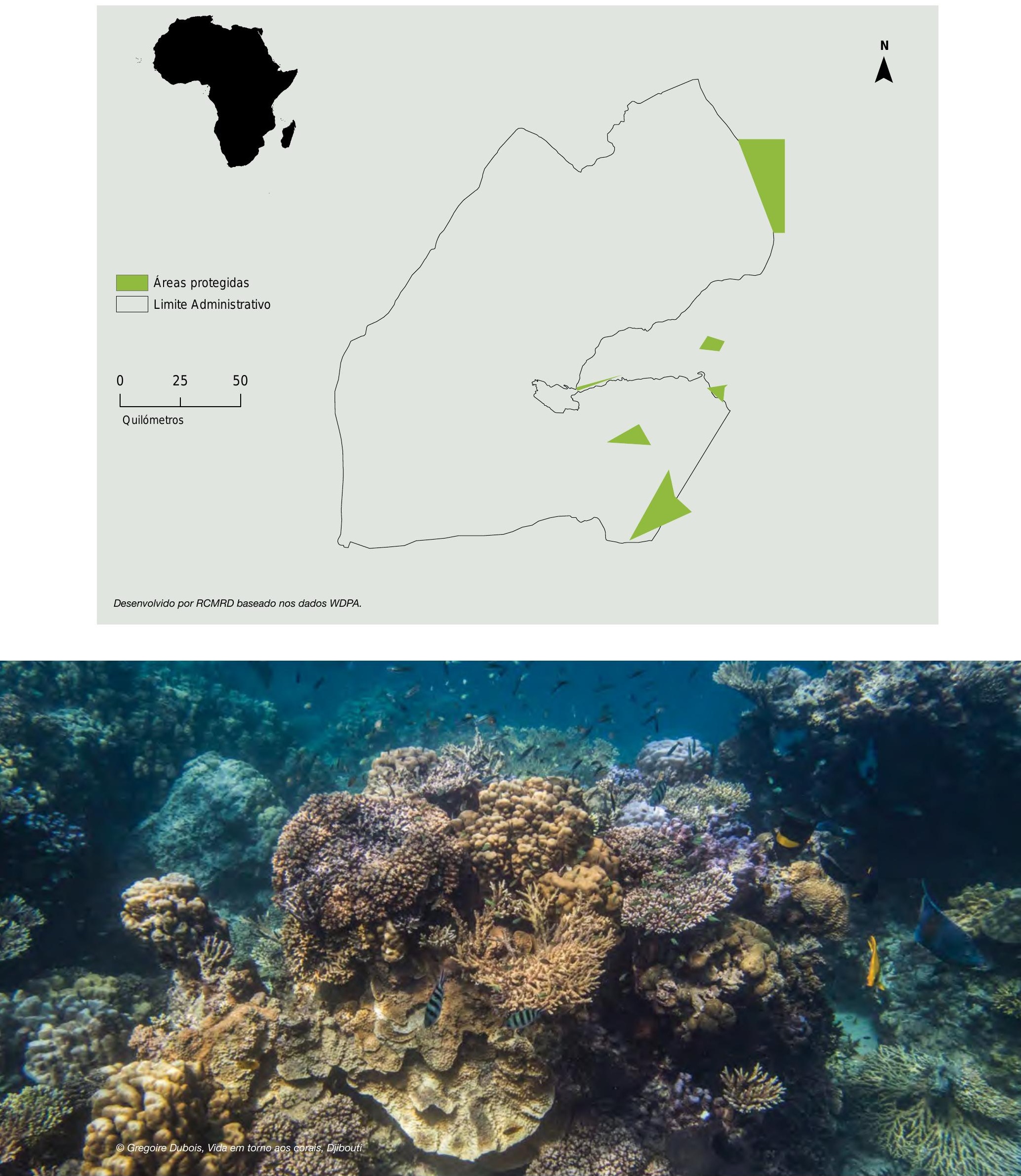


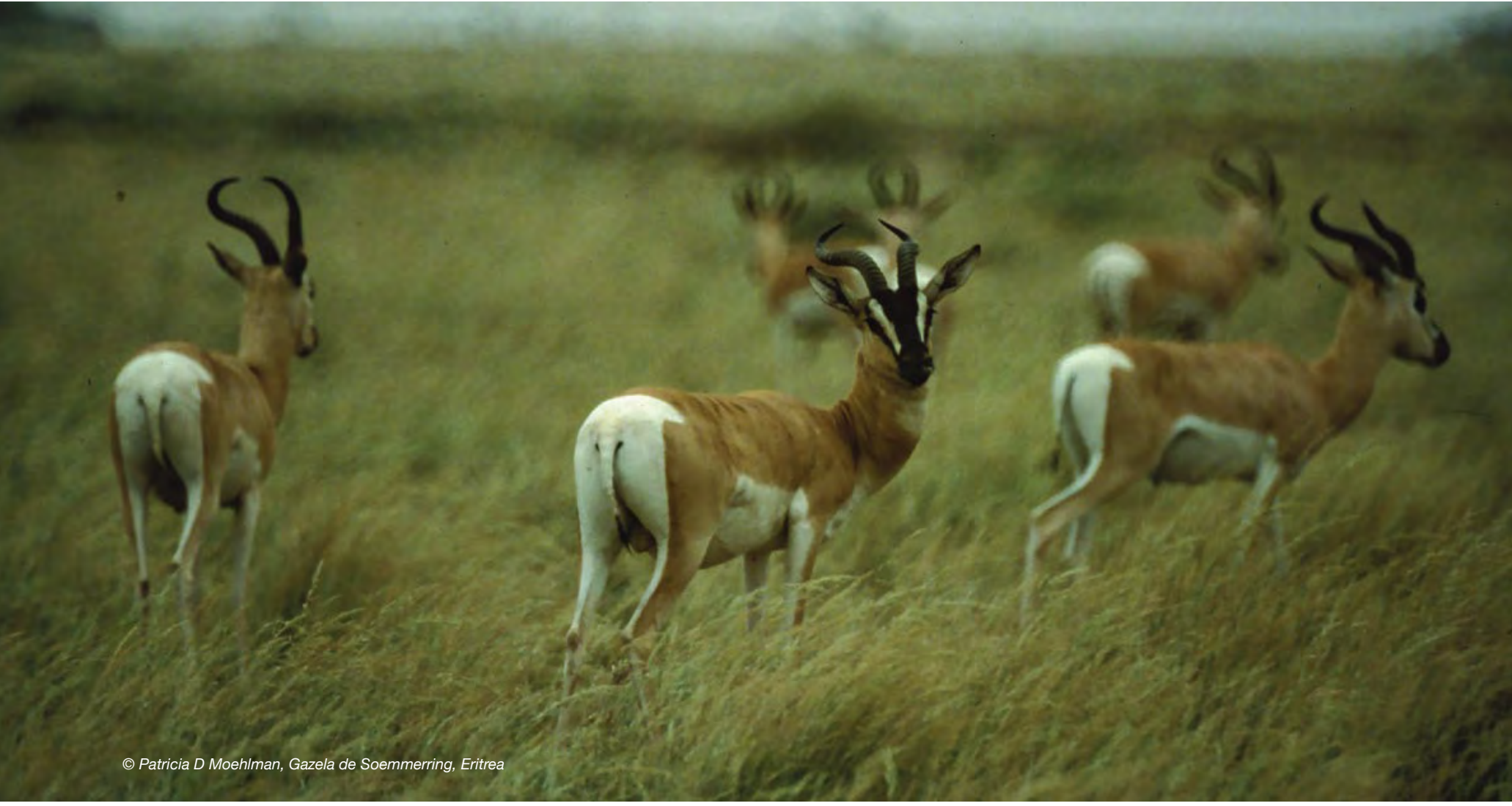

\subsection{Eritreia}

\section{Áreas protegidas e de conservação em Eritreia ${ }^{46}$}

A Eritreia tem quatro áreas protegidas cobrindo $5,936 \mathrm{~km}^{2}$ de terra e não tem nenhuma área marinha protegida (UNEP-WCMC \&UICN (2019f).

Embora não existam áreas oficialmente protegidas no país, existem algumas áreas reservadas para protecção através de directivas governamentais. As áreas protegidas de facto não têm planos de gestão ou de negócios. Foi preparado um projecto de Proclamação de Área Protegida e foram identificadas áreas protegidas propostas em 2018. A implementação do sistema de áreas protegidas proposto é dificultada devido à capacidade humana inadequada.

\section{Áreas transfronteiriças protegidas e de conservação}

A Eritreia não tem quaisquer áreas de conservação transfronteiriças.

\section{Contexto político}

Um relatório abrangente sobre legislação e política relacionada com a gestão de áreas protegidas, governação, e equidade foi levado a cabo pelo programa BIOPAMA. Identificou sete leis e políticas relevantes na Eritreia (Tessema (2019).

\section{Espécies-chave ${ }^{47}$}

A Eritreia registou a presença de aproximadamente 600 espécies de aves e é uma rota de migração e um local de paragem muito importante para muitas espécies. Um total de 90 répteis e 19 espécies de anfíbios foram registados na Eritreia, incluindo dois possivelmente répteis endémicos e um possivelmente anfíbio endémico. As áreas offshore são importantes para a procura de tartarugas e nidificação de tartarugas marinhas.

Não existe um inventário completo de plantas para o país, mas um local registou quase 700 espécies. A Eritreia é reconhecida como um centro de origem e diversidade para uma série de espécies de culturas, e tem grandes áreas de mangais e ervas marinhas. O país tem também uma diversidade notável em algas marinhas, halófitos e plâncton.

Existe uma grande diversidade de corais e peixes, com pelo menos 38 géneros de coral representando 220 espécies, algumas das quais endémicas da Eritreia. A Eritreia alberga também cinco das sete espécies de tartarugas marinhas do mundo e um grande número de cetáceos, bem como uma vasta gama de invertebrados.

Finalmente, a Eritreia é o lar de várias espécies de mamíferos globalmente raros, incluindo o asno selvagem africano (Equus africanus) e o ibex núbio (Capra nubiana). 
Figura 8.9 Resumo da Eritreia

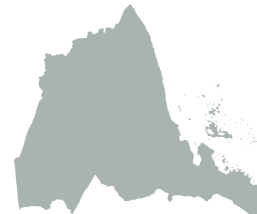

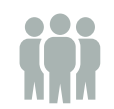

População Total (milhões) 3.17

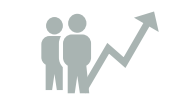

Crescimento da população (\% anual) 1.60

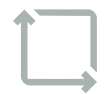

Superfície $\left(\mathrm{km}^{2}\right)$ (milhares) 117.6

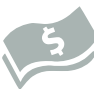

GDP (actuais US\$) (bilhões)

2.12
Crescimento do GDP (\% anual) 2.20
Área Protegida:

4 áreas protegidas cobrindo 5936 km² $^{2}$ de terra

Áreas protegidas e de conservação em Eritreia em Categorias de Gestão da UICN

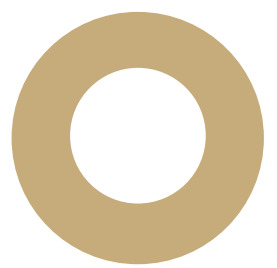

Não Reportado (No 1)

IV. Habitat / Gestão de Espécies (No. 3)

Fonte: UNEP-WCMC \& UICN, $2019 f$

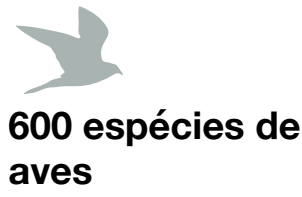

aves

\section{0 espécies de} répteis

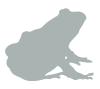

19 espécies de anfíbios
220 espécies de corais
Cobertura de áreas protegidas em Eritreia

\begin{tabular}{l|r|r}
\hline Tipo de área protegida & $\begin{array}{r}\text { Área } \\
\text { protegida ou } \\
\text { conservada* }\end{array}$ & $\begin{array}{r}\text { Área } \\
\text { protegida ou } \\
\text { conservada** }\end{array}$ \\
\hline Águas terrestres e interiores & $4.87 \%$ & $\begin{array}{r}\text { Não } \\
\text { Encontrado }\end{array}$ \\
\hline Litoral e marinho & $0.00 \%$ & $\begin{array}{r}\text { Não } \\
\text { Encontrado }\end{array}$ \\
\hline
\end{tabular}

* WDPA dataset $\quad$ ** Do Relatório Nacional sobre Biodiversidade

Fonte: UNEP-WCMC \& UICN (2019f).

Áreas protegidas e de conservação em Eritreia nos tipos de governação da UICN

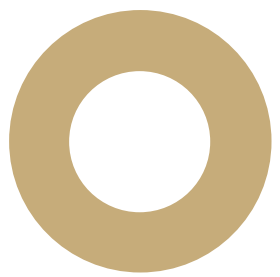

Não Reportado (No. 4)
Designações nacionais de áreas protegidas e de conservação em Eritreia

\begin{tabular}{l|r|r}
\hline Designação nacional & No. & Área (km²) \\
\hline Reserva de Vida Selvagem & 3 & 5903 \\
\hline Parque Nacional Marinho & 1 & 652 \\
\hline Fonte: UNEP-WCMC \& UICN (2019f). &
\end{tabular}

Áreas prioritárias para a conservação

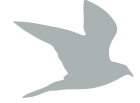

\section{4 sítios \\ 9 sítios \\ Áreas importantes de Áreas-chave da \\ Aves \& Biodiversidade Biodiversidade}

Fonte: BirdLife International (2019b, 2019c). 


\section{Pressões e ameaças ${ }^{48}$}

Uma das maiores ameaças directas à biodiversidade na Eritreia é a transformação do habitat, devido à expansão da agricultura e à poluição dos ecossistemas de água doce e marinha, bem como a transformação para o desenvolvimento urbano e industrial. As ervas marinhas e algas marinhas são afectadas pelo aumento da sedimentação. Espécies exóticas invasoras são grandes ameaças. A desflorestação e a polinização excessiva estão a ter impacto nos recursos florestais. A caça ilegal de animais selvagens para o comércio de carne de animais selvagens é um problema, particularmente nos ecossistemas de pastagem.

A sobre-exploração de corais, peixes e outras espécies marinhas representam sérias pressões sobre estas espécies. As espécies invasivas são uma ameaça para muitas espécies e ecossistemas, incluindo as espécies de mamíferos predadores que se aproveitam das aves reprodutoras das ilhas. As tartarugas marinhas estão ameaçadas pela perturbação dos locais de nidificação, caça furtiva de ovos e caça ilegal de animais maduros, bem como capturas acessórias em arrastões.

\section{Figura 8.10 Áreas Protegidas da Eritreia}

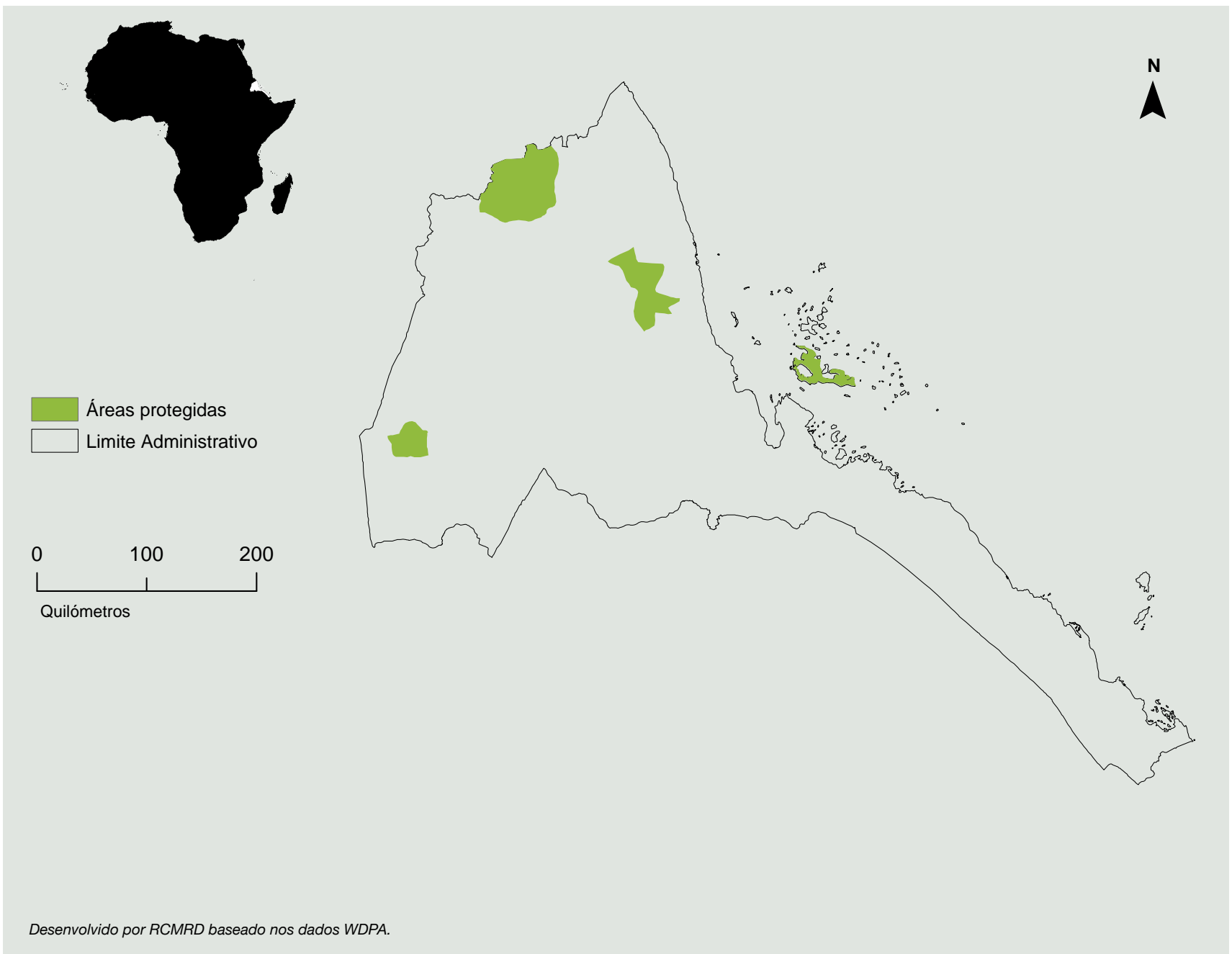




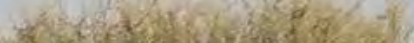

(2)

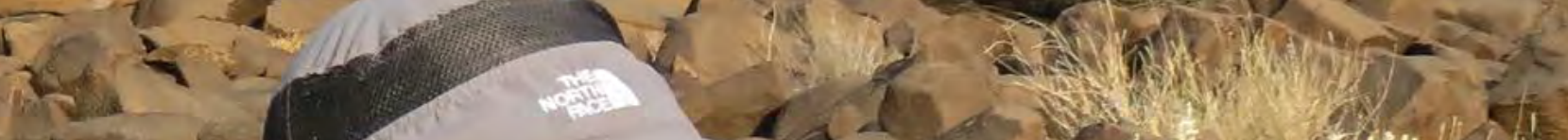
F.
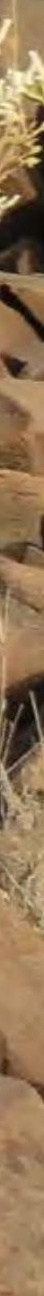


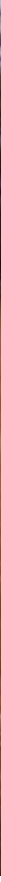

\subsection{Eswatini}

\section{Áreas protegidas e de conservação em Eswatini ${ }^{49}$}

Eswatini tem 14 áreas protegidas cobrindo $738 \mathrm{~km}^{2}$ de terra (UNEP-WCMC \& UICN (2019g).

A área protegida do país aumentou num período de um ano, de $3.9 \%$ em 2017 para $4.26 \%$ em 2018. A área protegida de Eswatini é composta por áreas protegidas muito pequenas e vulneráveis, mal distribuídas pelos ecossistemas. Existe, portanto, uma necessidade de expandir o património de áreas protegidas, reforçando ao mesmo tempo as competências de gestão das áreas protegidas. Isto, por sua vez, exigirá a participação de uma vasta gama de interessados, incluindo proprietários de terras privadas, comunidades locais e a indústria do turismo.

\section{Áreas transfronteiriças protegidas e de conservação}

Eswatini inclui parte da área de conservação transfronteiriça de Lubombo.

\section{Contexto político}

Um relatório abrangente sobre legislação e política relacionada com a gestão de áreas protegidas, governação, e equidade foi levado a cabo pelo programa BIOPAMA. Identificou 10 leis e políticas relevantes em Eswatini (Tessema, 2019).

\section{Espécies-chave ${ }^{50}$}

Para um país pequeno, Eswatini tem uma rica diversidade floral e faunística. Das mais de 3,500 espécies de plantas que foram registadas, 12 são endémicas. 89 espécies de vertebrados e 305 espécies de plantas estão listadas nas Listas Vermelhas Nacionais. 813 espécies de vertebrados foram registadas, com apenas uma endémica, a grande osga das rochas (Afroedura major).

\section{Pressões e ameaças ${ }^{51}$}

As principais pressões subjacentes à mudança da biodiversidade do país incluem a perda de habitat e a mudança de habitat para o aumento da agricultura e para a urbanização e assentamentos, bem como incêndios florestais e espécies invasoras. $80 \%$ de Eswatini está infestado com pelo menos uma espécie vegetal invasora. A colheita insustentável de espécies vegetais e animais para fins medicinais é uma grande ameaça para muitas espécies. Da mesma forma, a colheita insustentável de árvores para a produção de carvão vegetal tem tido um grande impacto no habitat de muitas espécies de aves e mamíferos.

As alterações climáticas são uma pressão emergente em Eswatini, susceptível de perturbar os ecossistemas naturais em todo o Eswatini. As ameaças indirectas incluem pressões económicas, demográficas, sócio-políticas, e culturais. Com mais de $40 \%$ da população com idade inferior a 25 anos, prevê-se que a população duplique num futuro próximo.

\footnotetext{
A secção baseia-se na informação contida no Sexto Relatório Nacional de Eswatini à CDB (Reino de Eswatini, 2019).

A secção baseia-se na informação contida no Quinto Relatório Nacional de Eswatini à CDB e no seu Segundo NBSAP (Eswatini Environment Authority, 2014; 2016).

A secção baseia-se na informação contida no Quinto Relatório Nacional de Eswatini à CDB (Eswatini Environment Authority, 2014; 2016).
} 
Figura 8.11 Resumo de Eswatini

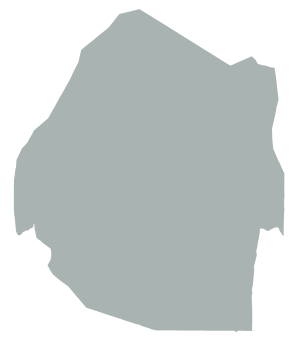

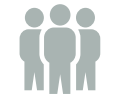

População Total (milhões) 1.14

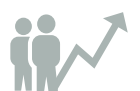

Crescimento da população (\% anual) 1.00

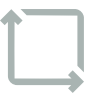

Superfície $\left(\mathrm{km}^{2}\right)$ (milhares) 17.40
Áreas protegidas e de conservação em Eswatini em Categorias de Gestão da UICN

Área Protegida:

14 áreas protegidas

cobrindo $738 \mathrm{~km}^{2}$ de terra

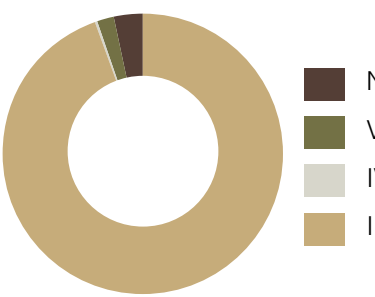

Não Reportado

V. Paisagem Protegida / Paisagem Marítima (No. 1)

V. Habitat / Gestão de Espécies (No. 2)

II. Parque Nacional (No. 6)

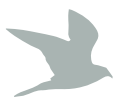

Rica diversidade floral e faunística
3500 espécies de plantas

12 são endémicas

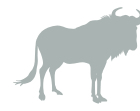

813 espécies de vertebrados

\section{Cobertura de áreas protegidas em Eswatini}

\begin{tabular}{|c|c|c|}
\hline Tipo de área protegida & $\begin{array}{r}\text { Área } \\
\text { protegida ou } \\
\text { conservada* }\end{array}$ & $\begin{array}{r}\text { Área } \\
\text { protegida ou } \\
\text { conservada** }\end{array}$ \\
\hline Águas terrestres e interiores & $4.26 \%$ & $3.90 \%$ \\
\hline
\end{tabular}

* WDPA dataset $\quad$ ** Do Relatório Nacional sobre Biodiversidade

Fonte: Autoridade Ambiental Eswatini (2014); UNEP-WCMC and UICN (2019g).

Áreas protegidas e de conservação em Eswatini nos tipos de governação da UICN

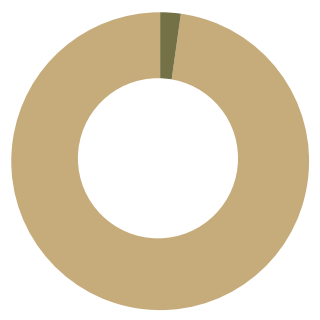

Não Reportado (No. 11)

B. Privado (No. 3)
Designações nacionais de áreas protegidas e de conservação em Eswatini

\begin{tabular}{l|r|r}
\hline Designação nacional & No. & Área $\left.\mathbf{( k m}^{\mathbf{2}}\right)$ \\
\hline Parque Nacional & 1 & 217 \\
\hline Reserva Natural & 10 & 520 \\
\hline
\end{tabular}

Fonte: UNEP-WCMC \& UICN (2019g).

Áreas protegidas e de conservação designadas como sítios globais de importância em Eswatini

\begin{tabular}{l|r}
\hline Designação global & No. de sítios \\
\hline $\begin{array}{l}\text { Zonas húmidas de importância internacional } \\
\text { (sítios Ramsar) }\end{array}$ \\
\hline Fonte: Ramsar (2019); UNESCO (2019a, 2019b)
\end{tabular}

Áreas prioritárias para a conservação

$\begin{array}{ll}\mathbf{3} \text { sítios } & \mathbf{3} \text { sítios } \\ \text { Áreas importantes de } & \text { Áreas-chave da } \\ \text { Aves \& Biodiversidade } & \text { Biodiversidade }\end{array}$

Fonte: BirdLife International (2019b, 2019c). 


\section{igura 8.12 Áreas Protegidas de Eswatini}

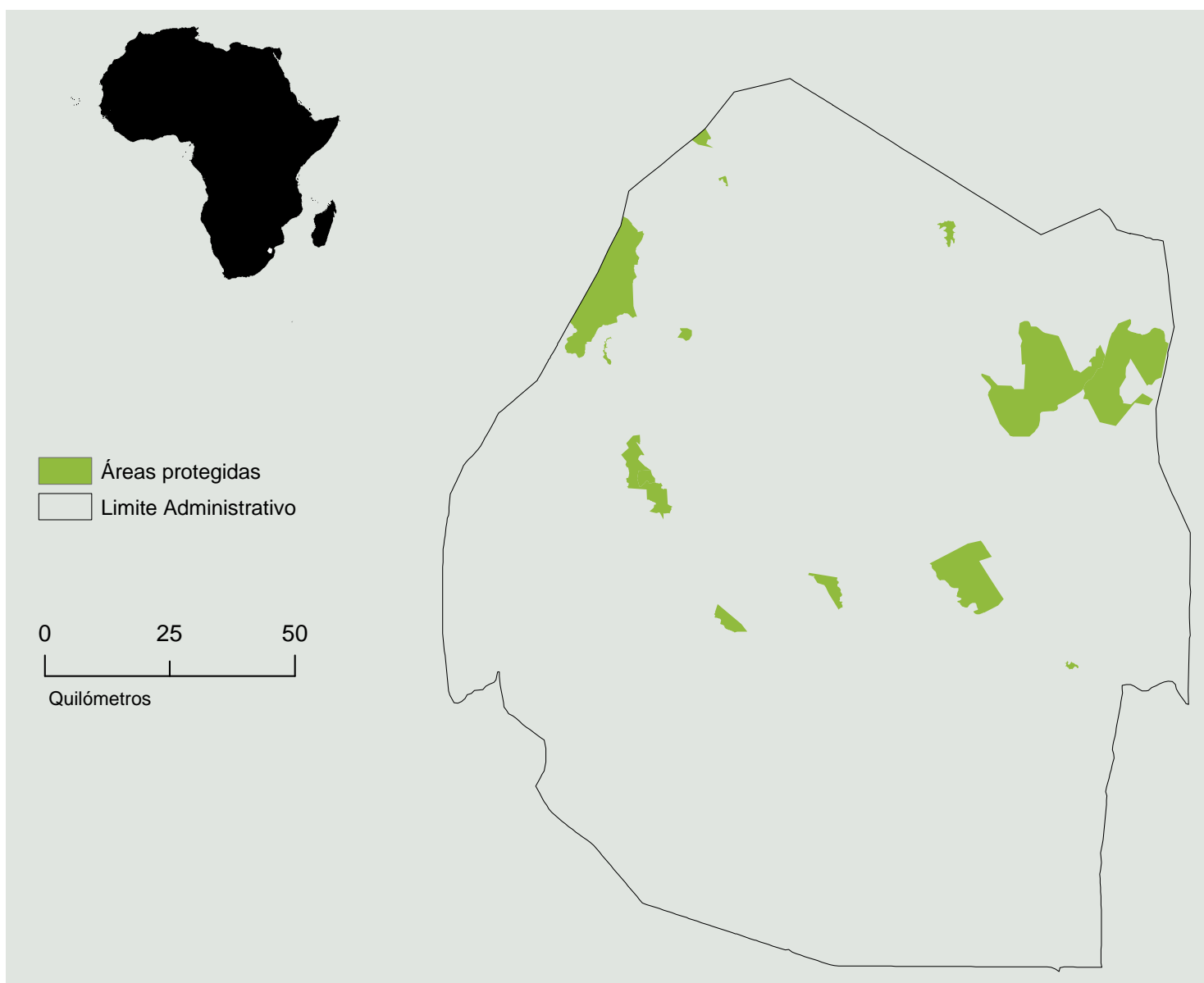

$\stackrel{N}{N}$

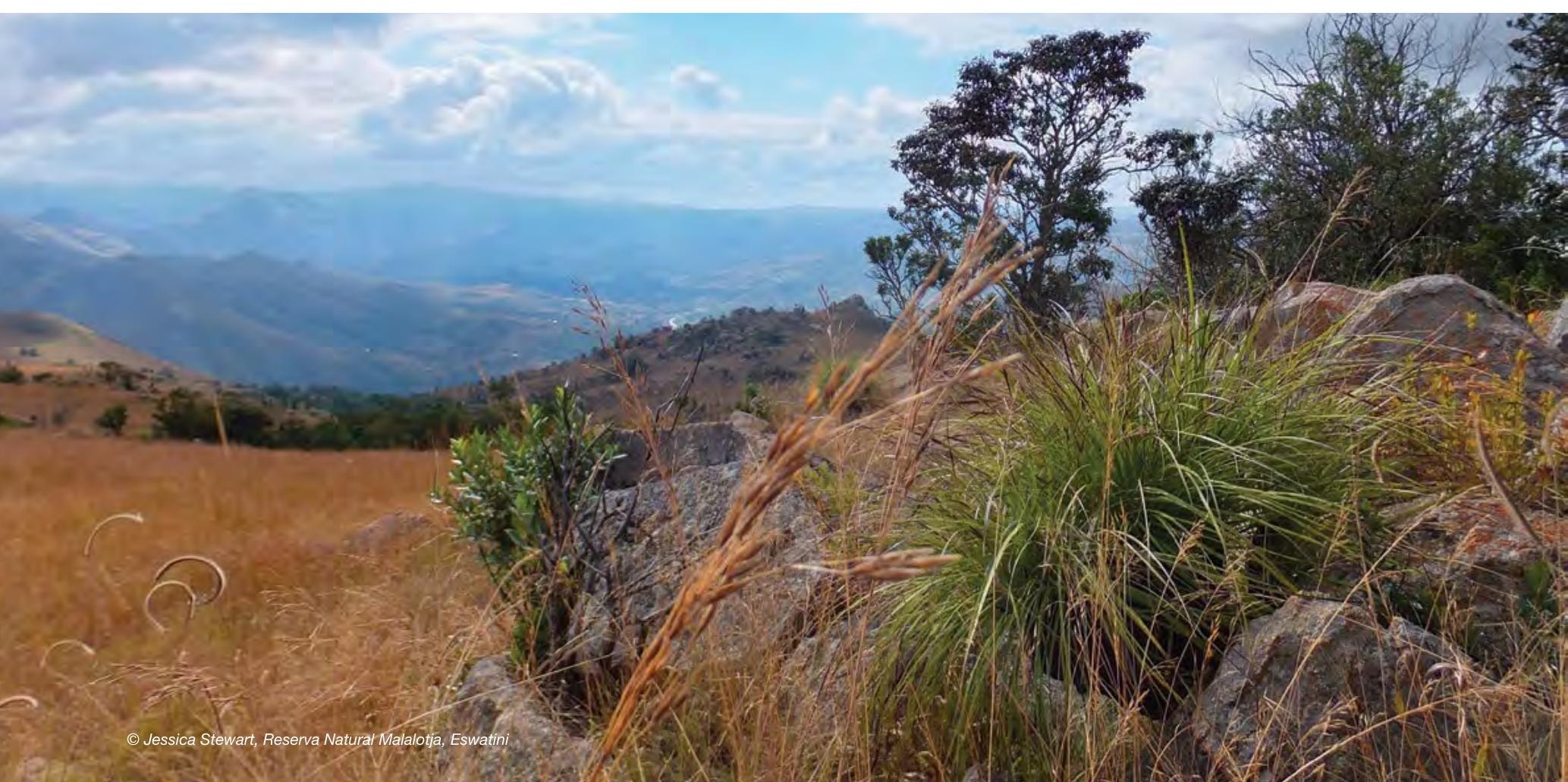




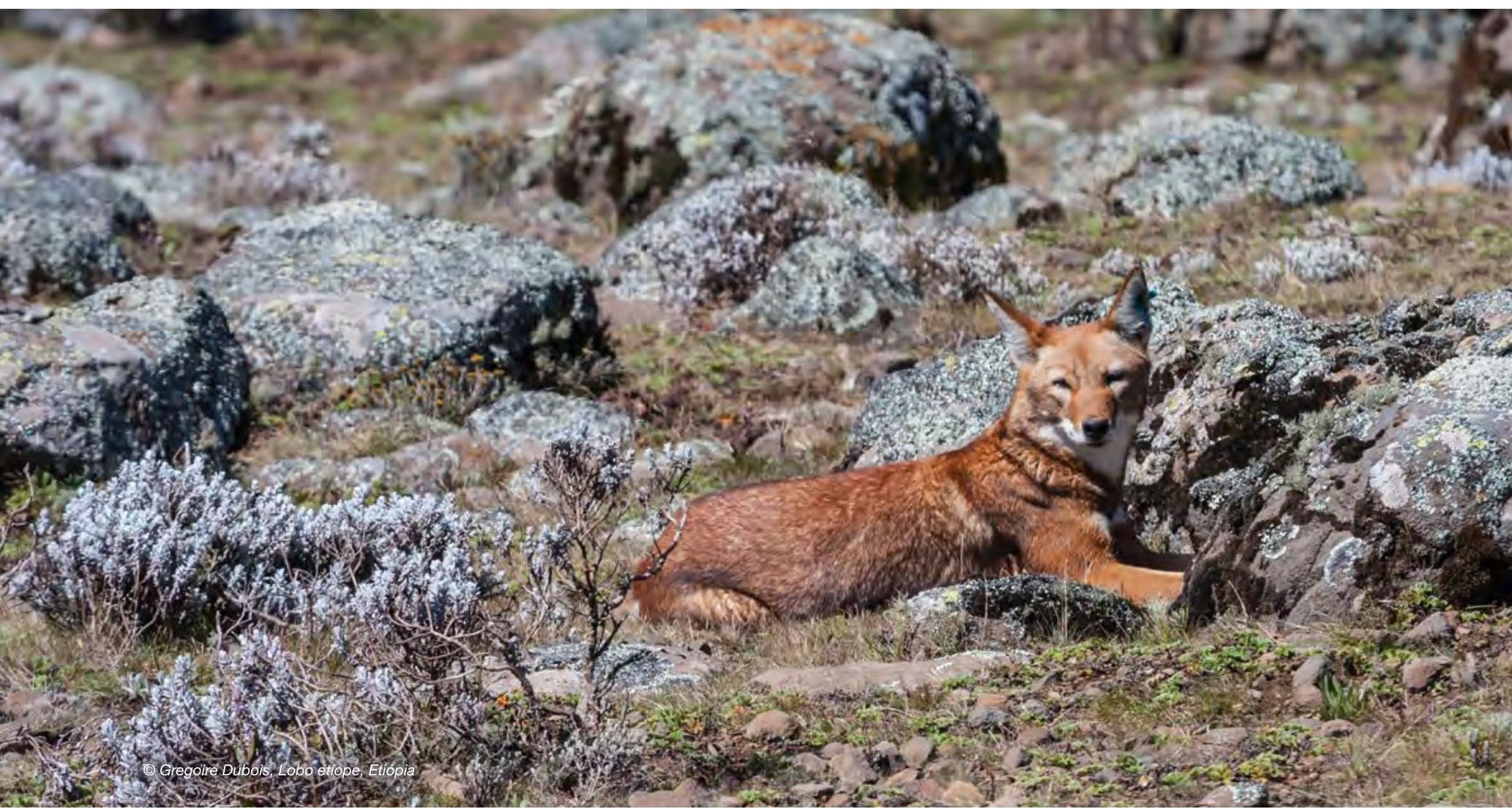

\subsection{Etiópia}

\section{Áreas protegidas e de conservação em Etiópia ${ }^{52}$}

Etiópia tem 104 áreas protegidas cobrindo $200,074 \mathrm{~km}^{2}$ de terra (UNEP-WCMC \& UICN, 2019h).

Localizada no Corno de África, Etiópia é um país relativamente grande encravado, com uma grande diversidade de topografia, de rochedos e climas parentais. Esta diversidade topográfica, numa extensão de 4.620 metros de altitude, resultou em grandes variações na precipitação, humidade, temperatura e solos, o que a qualifica para abrigar seis dos maiores biomas terrestres do mundo (florestas alpinas, coníferas, floresta decídua, floresta tropical húmida, savana e deserto) e nove tipos de ecossistemas distintos.

O financiamento internacional sob diferentes formas de mecanismos de comércio internacional para a mitigação das alterações climáticas, tais como o Mecanismo de Desenvolvimento Limpo (MDL) e REDD+, ajuda a financiar a protecção dos quatro parques nacionais da Etiópia, um dos santuários da vida selvagem e três das áreas de conservação da comunidade.

Um grande desafio em Etiópia é a ausência de estatuto legal da maioria das áreas protegidas. A Autoridade de Conservação da Vida Selvagem da Etiópia, criada em 2008, gere apenas 13 Parques Nacionais, reservas e santuários de vida selvagem.
O resto é gerido pelas autoridades regionais, comunidades rurais e pelo sector privado, e está inadequadamente protegido, particularmente os ecossistemas de zonas húmidas e de água doce. Há necessidade de aumentar a cobertura de áreas formalmente protegidas, com a devida atenção à sua representação dos ecossistemas, bem como à sua eficácia em termos de gestão.

\section{Áreas transfronteiriças protegidas e de conservação}

Etiópia inclui parte da Paisagem Boma-Gambella e das áreas de conservação transfronteiriça da Paisagem do Baixo Awash-Lake Abbé.

\section{Contexto político}

Um relatório abrangente sobre legislação e política relacionada com a gestão de áreas protegidas, governação, e equidade foi levado a cabo pelo programa BIOPAMA. Identificou 29 leis e políticas relevantes em Etiópia (Tessema, 2019).

\section{Espécies-chave ${ }^{53}$}

Etiópia é lar de cerca de 6.000 espécies de plantas superiores 10\% das quais são endémicas. O país tem 284 espécies de mamíferos selvagens e 861 espécies de aves.

\footnotetext{
52 A secção baseia-se na informação contida no Sexto Relatório Nacional da Etiópia ao CBD (República da Etiópia \& Instituto de Biodiversidade Etíope, 2014) e no seu Segundo NBSAP (República da Etiópia, 2019).

53 A secção baseia-se na informação contida no Quinto e Sexto Relatórios Nacionais da Etiópia à CBD e no seu Segundo NBSAP (Governo da República Federal Democrática da Etiópia \& Instituto de Biodiversidada Etiópia, 2014; 2015; República da Etiópia, 2019).
} 
Figura 8.13 Resumo da Etiópia

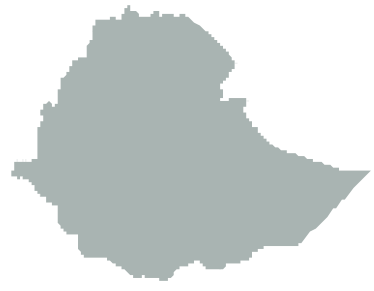

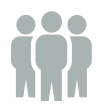

População Total (milhões) 109.22

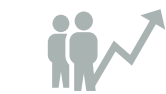

Crescimento da população (\% anual) 2.60

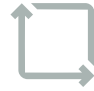

Superfície $\left(\mathrm{km}^{2}\right)$ (milhares) 1104.03

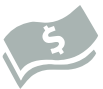

GDP (actuais US\$) (bilhões)

84.36
Crescimento do GDP (\% anual)

6.80

Fonte: The World Bank Group, 2018.

\section{Área Protegida:}

104 áreas protegidas

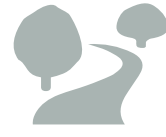

cobrindo 200074 km² de terra

Áreas protegidas e de conservação em Etiópia em Categorias de Gestão da UICN

Fonte: UNEP-WCMC \& UICN, (2019h)

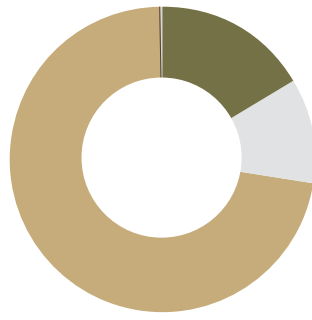

Não Aplicável (No. 3)

Não Reportado (No. 58)

VI. Área Protegida com Utilização

Sustentável dos Recursos Naturais (No.1

IV. Habitat / Gestão de Espécies (No. 8)

II. Parque Nacional (No.17)

Fonte: UNEP-WCMC \& UICN (2019h)

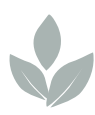

6000 espécies de plantas

$10 \%$ são endémicas

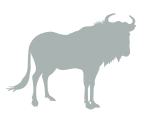
284 espécies de
mamíferos

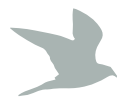
861 espécies de
aves

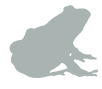

63 anfíbios
200 espécies de peixes

\section{9 são endémicas 18 são endémicas}

Cobertura de áreas protegidas em Etiópia

\begin{tabular}{l|r|r}
\hline Tipo de área protegida & $\begin{array}{r}\text { Área } \\
\text { protegida ou } \\
\text { conservada* }\end{array}$ & $\begin{array}{r}\text { Área } \\
\text { protegida ou } \\
\text { conservada** }^{*}\end{array}$ \\
\hline Águas terrestres e interiores & $17.62 \%$ & $14.00 \%$ \\
\hline *WDPA dataset ${ }^{* *}$ Do Relatório Nacional sobre Biodiversidade \\
Fonte: República da Etiópia (2019); UNEP-WCMC \& UICN (2019h).
\end{tabular}

Áreas protegidas e de conservação designadas como sítios globais de importância em Etiópia

\begin{tabular}{l|r}
\hline Designação global & No. de sítios \\
\hline Reservas do Homem e da Biosfera da UNESCO & 5 \\
\hline $\begin{array}{l}\text { Sítios Património Mundial da UNESCO } \\
\text { (Natural ou Misto) }\end{array}$ & 1 \\
\hline
\end{tabular}

Fonte: Ramsar (2019); UNESCO (2019a, 2019b).

Áreas protegidas e de conservação em Etiópia nos tipos de governação da UICN

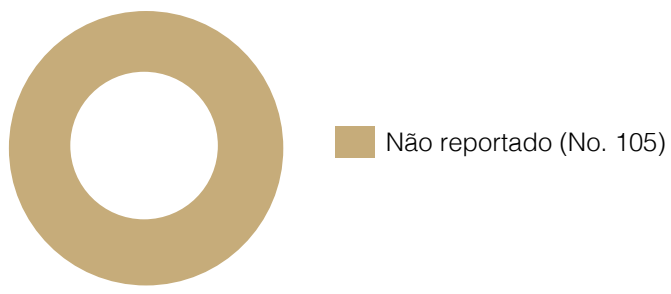

Designações nacionais de áreas protegidas e de conservação em Etiópia

\begin{tabular}{l|r|r}
\hline Designação nacional & No. & Área $\left.\mathbf{( k m}^{\mathbf{2}}\right)$ \\
\hline Santuário & 4 & 11037 \\
\hline Parque Nacional & 13 & 23672 \\
\hline Reserva de Vida Selvagem & 8 & 23392 \\
\hline $\begin{array}{l}\text { Área Florestal Nacional } \\
\text { Prioritária }\end{array}$ & 58 & 44132 \\
\hline Área de Caça Controlada & 18 & 151577 \\
\hline
\end{tabular}

Fonte: UNEP-WCMC \& UICN (2019h).

\section{Áreas prioritárias para a conservação}

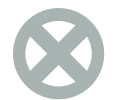

\section{3 sítios \\ Aliança para os sítios}

67 sítios

Áreas importantes de

79 sítios

de Extinção Zero

Aves \& Biodiversidade

Áreas-chave da

Biodiversidade 


\section{Figura 8.14 Áreas Protegidas da Etiópia}

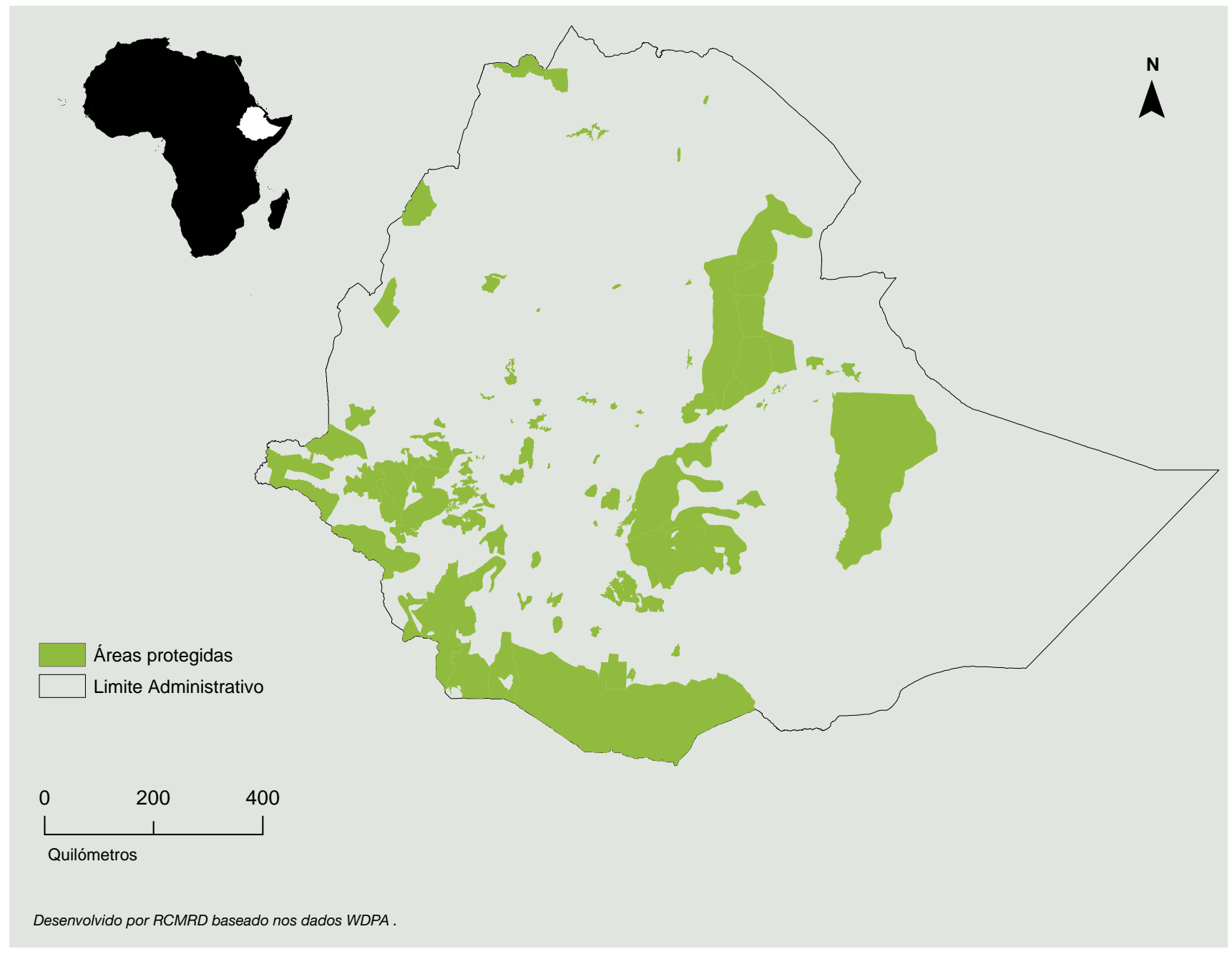

Faltam dados sobre outros animais selvagens, e até agora o número de espécies identificadas são: 201 répteis, 200 peixes, 63 anfíbios e 1,225 artrópodes. Destes recursos faunísticos, 29 mamíferos selvagens, 18 aves, 10 répteis, 40 peixes, 25 anfíbios e sete espécies de artrópodes são endémicos da Etiópia, tais como o lobo Etiópiano (Canis simensis). Etiópia tem também uma grande diversidade de biodiversidade microbiana, que é dificilmente explorada.

\section{Pressões e ameaças ${ }^{54}$}

As principais ameaças directas à biodiversidade da Etiópia incluem: perda e degradação do habitat devido à expansão da agricultura e assentamentos e invasão de espécies invasoras; utilização insustentável da biodiversidade devido ao sobrepastoreio, sobrecolheita, e caça não regulamentada; proliferação de espécies invasoras; e poluição. As causas indirectas da perda da biodiversidade no país são as alterações demográficas, a pobreza, e a falta de sensibilização e coordenação. A longo prazo, as alterações climáticas representam desafios, particularmente através da mudança das estações de crescimento.

54 A secção baseia-se na informação contida nos Quinto e Sexto Relatórios Nacionais da Etiópia ao CBD e ao seu Segundo NBSAP (Governo da República Federal Democrática da Etiópia \& Instituto de Biodiversidade Etíope, 2014 \& 2015; República da Etiópia, 2019). 


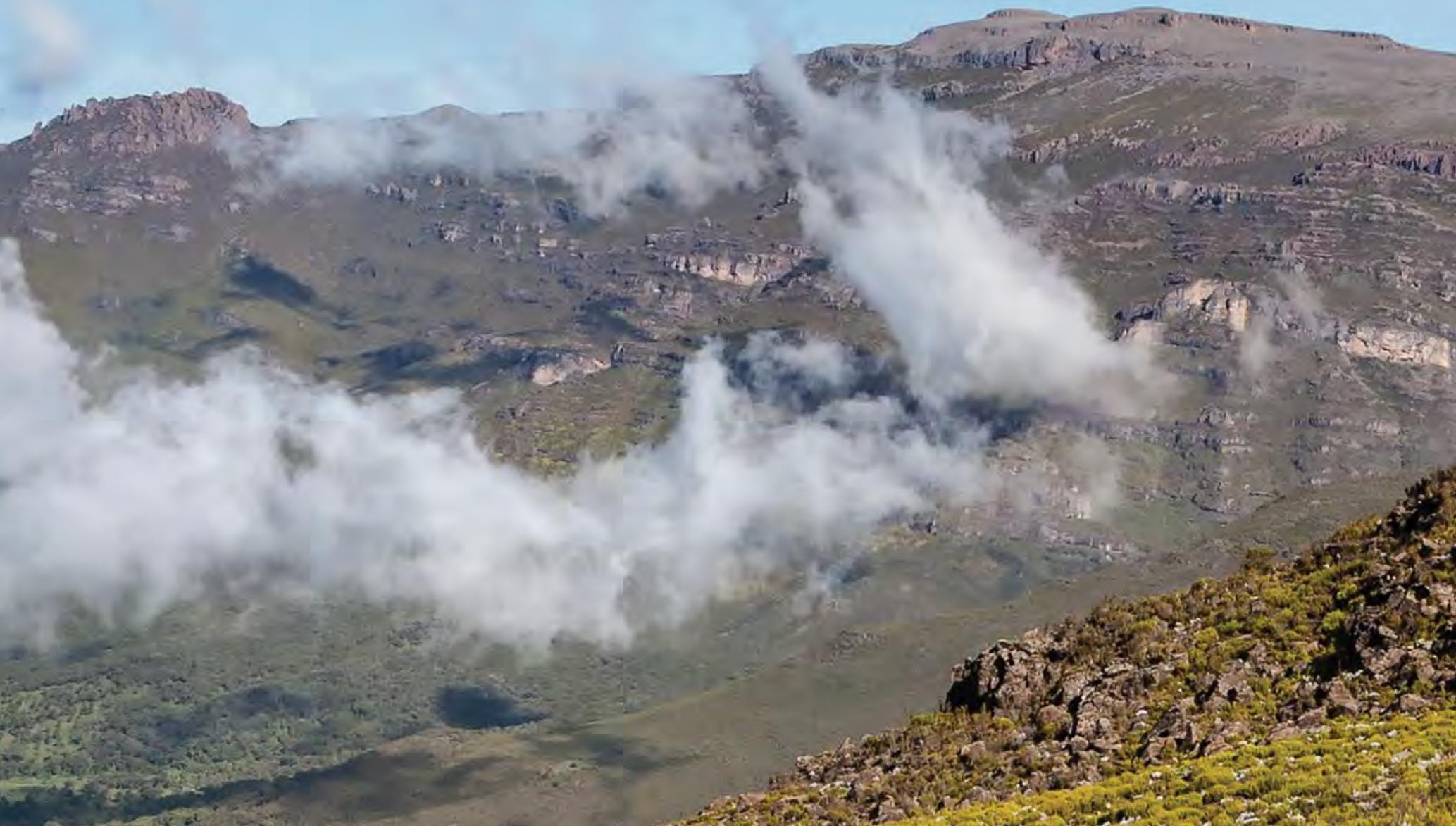

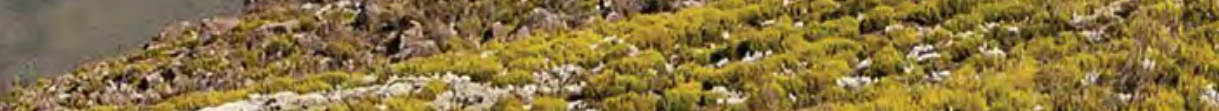
S1:

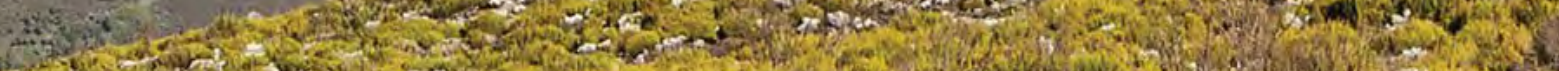

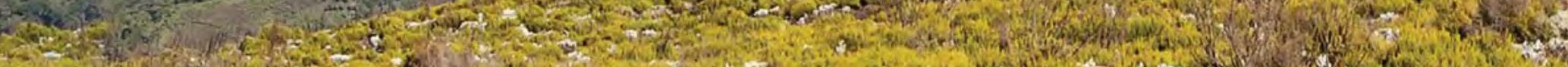

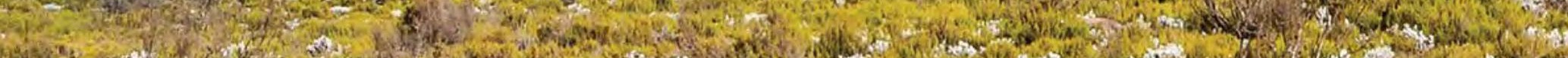
947 . 2. 25m

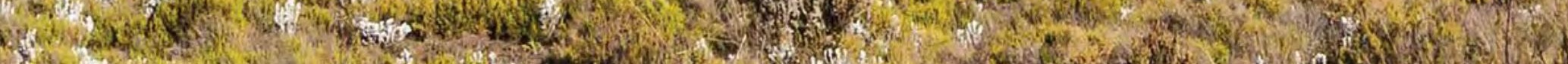

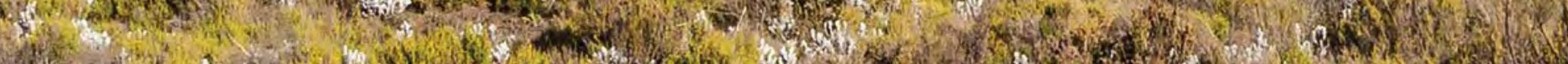

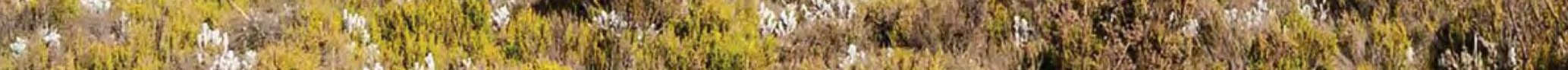

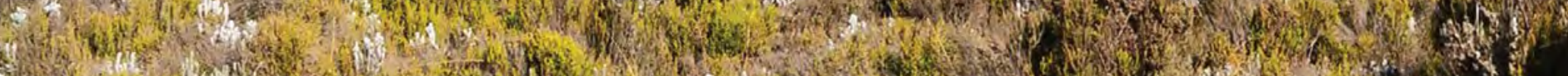

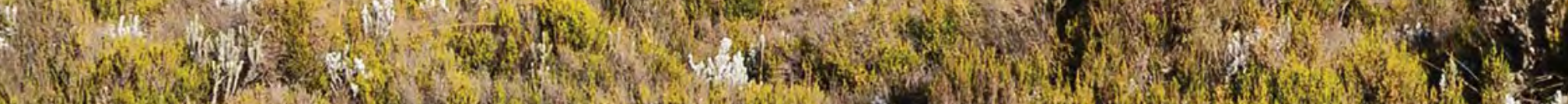

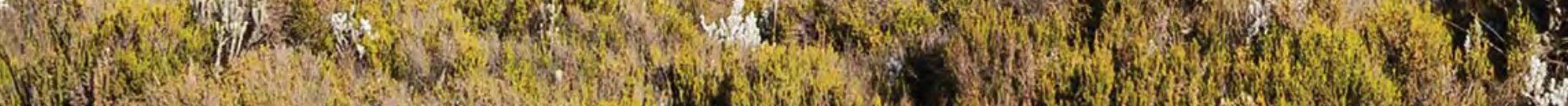
Non

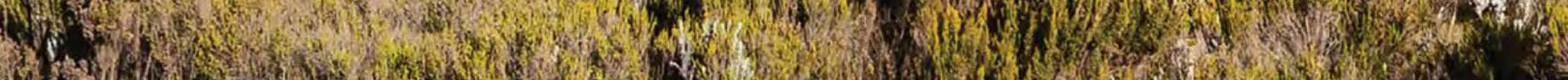

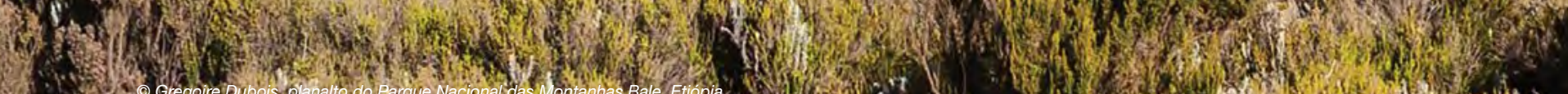

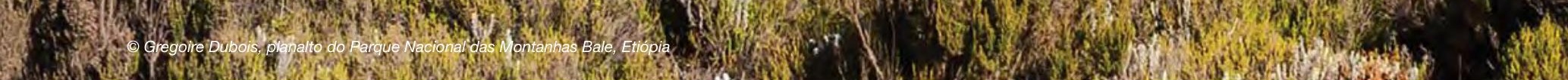




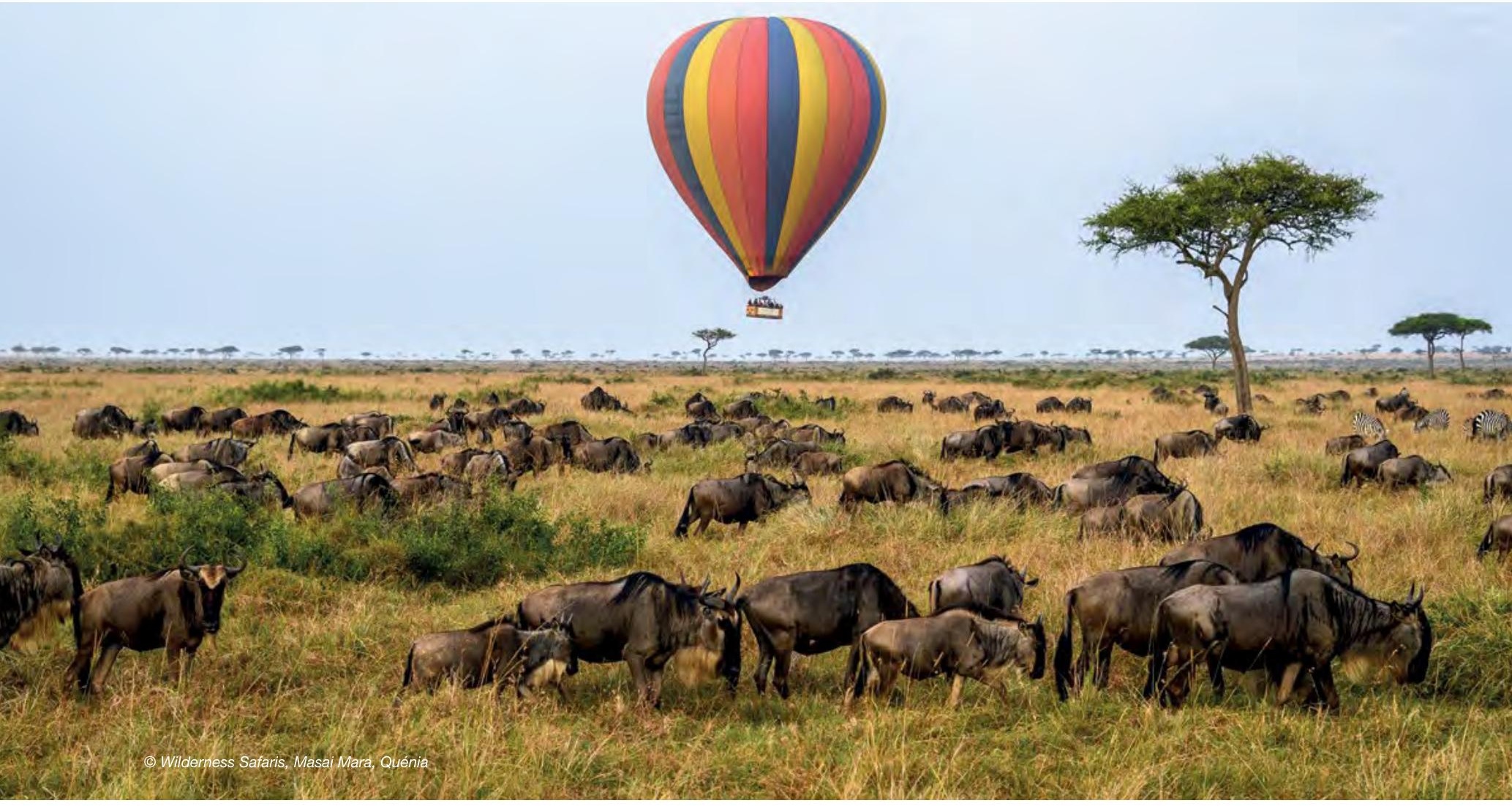

\subsection{Quénia}

\section{Áreas protegidas e de conservação em Quénia ${ }^{55}$}

Quénia tem 411 áreas protegidas cobrindo $72,545 \mathrm{~km}^{2}$ de terra e $904 \mathrm{~km}^{2}$ do oceano (UNEP-WCMC \& UICN (2019i).

O governo da pós-independência herdou quatro parques nacionais e seis reservas de caça, contemplados através de um processo parlamentar. Além disso, existe um grande número de reservas de caça que estão sob a gestão das autoridades locais. Há também uma série de conservas de vida selvagem privadas ou/e comunitárias. Subsequentemente, os números dos parques e reservas aumentaram consideravelmente.

Do $12 \%$ de terra designado como áreas protegidas, incluindo florestas, $50 \%$ encontram-se em terras áridas e semi-áridas. A tendência actual mostra um declínio acentuado na diversidade das espécies animais e na abundância populacional nestes ecossistemas. Percebendo que estas áreas protegidas eram incapazes de cumprir adequadamente os objectivos de conservação da biodiversidade e de fornecer apoio à subsistência, a ideia de estabelecer santuários privados e conservas comunitárias ganhou ímpeto ao longo das últimas décadas em Quénia. Estes formam o sangue vital do actual sistema de áreas protegidas, com mais de $70 \%$ de toda a grande fauna selvagem a viver permanentemente ou sazonalmente fora das áreas protegidas geridas por agências governamentais.

\section{Áreas transfronteiriças protegidas e de conservação}

Quénia inclui parte de cinco áreas de conservação transfronteiriças, nomeadamente: i) Amboseli-Kilimanjaro-Longido, ii) Monte Elgon, iii) Serengeti-Mara, iv) Tana-Kipini-Laga Badana Bushbush Land e Seascape, e v) Tanga Marine Reserves System e Tanga Coelacanth Marine Park e Diani Chale e Kisitee-Mpunguti.

\section{Contexto político}

Um relatório abrangente sobre legislação e política relacionada com a gestão de áreas protegidas, governação, e equidade foi levado a cabo pelo programa BIOPAMA. Identificou 41 leis e políticas relevantes em Quénia (Tessema, 2019).

\section{Espécies-chave ${ }^{56}$}

Quénia é dotada de diversos ecossistemas e habitats que albergam uma flora e fauna únicas e diversificadas. Mais de 7,000 espécies vegetais foram registadas em Quénia com mais de 1,000 dessas espécies endémicas ou quase endémicas. Cerca de 356 espécies de plantas foram avaliadas através do processo da Lista Vermelha da UICN como ameaçadas, um terço das quais são endémicas de Quénia. Estima-se que mais de 5,000 espécies de fungos ocorrem no país, embora apenas 2,000 tenham sido documentadas.

As 1,100 espécies de aves de Quénia incluem oito endémicas.

55 A secção baseia-se nas informações contidas no Quinto Relatório Nacional de Quénia à CDB (República de Quénia, 2015).

56 Ibid. 
Figura 8.15 Resumo do Quénia

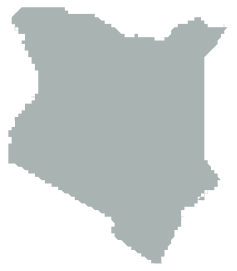

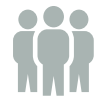

População Total

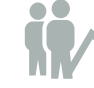

(milhões)

51.39
Crescimento da

população (\% anual)

2.30

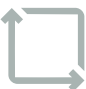

Superfície $\left(\mathrm{km}^{2}\right)$

(milhares)

580.40

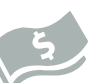

GDP (actuais US\$) (bilhões)

87.91
Crescimento do GDP (\% anual)

6.30

Fonte: The World Bank Group, 2018.

Área Protegida:

411 áreas protegidas

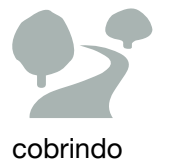

72545 km² de terra

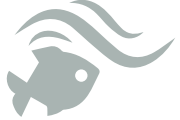

cobrindo 904 km² $^{2}$ de oceano

Fonte: UNEP-WCMC \& UICN, 2019

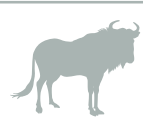

315 espécies de mamíferos

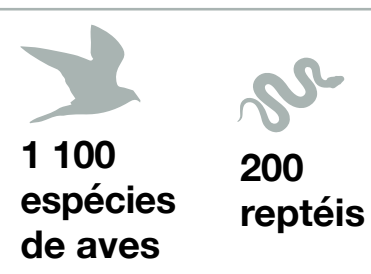

Cobertura de áreas protegidas no Quénia

\begin{tabular}{l|r|r}
\hline Tipo de área protegida & $\begin{array}{r}\text { Área } \\
\text { protegida ou } \\
\text { conservada* }\end{array}$ & $\begin{array}{r}\text { Área } \\
\text { protegida ou } \\
\text { conservada** }\end{array}$ \\
\hline Águas terrestres e interiores & $12.36 \%$ & $8.00 \%$ \\
\hline Litoral e marinho & $0.80 \%$ & $\begin{array}{r}\text { Não } \\
\text { Encontrado }\end{array}$ \\
\hline
\end{tabular}

*WDPA dataset

** Do Relatório Nacional sobre Biodiversidade

Fonte: República do Quénia (2015); UNEP-WCMC \& UICN (2019i).

\section{Áreas protegidas e de conservação no Quénia nos} tipos de governação da UICN

Fonte: UNEP-WCMC \& UICN (2019i).

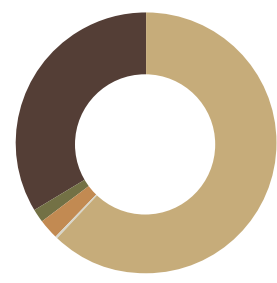

Não reportado (No. 267)

D. Governação pelos povos indígenas e comunidades locais (No. 51)

C. Governação Privada (No. 16)

B. Governação Partilhada (No. 1)

A. Governação pelo Governo (No. 76)

\section{Áreas prioritárias para a conservação}

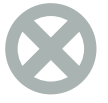

\section{6 sítios}

\section{8 sítios}

Aliança para os sítios de Extinção Zero

\section{Áreas importantes de} Aves \& Biodiversidade

\section{2 sítios}

Áreas-chave da Biodiversidade

\section{Áreas protegidas e de conservação em Quénia em} Categorias de Gestão da UICN

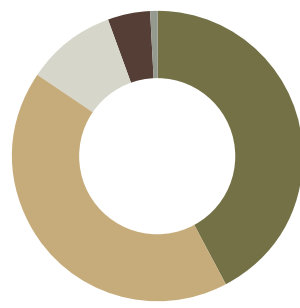

Não Aplicável (No. 9)

Não Reportado (No. 345)

VI. Área Protegida com Utilização

Sustentável dos Recursos Naturais (No.16)

IV. Habitat / Gestão de Espécies (No. 5)

II. Parque Nacional (No. 36)
Áreas protegidas e de conservação designadas como sítios globais de importância no Quénia

\begin{tabular}{l|r}
\hline Designação global & No. de sítios \\
\hline Reservas do Homem e da Biosfera da UNESCO & 6 \\
\hline $\begin{array}{l}\text { Sítios Património Mundial da UNESCO } \\
\text { (Natural ou Misto) }\end{array}$ & 3 \\
\hline $\begin{array}{l}\text { Zonas húmidas de importância internacional } \\
\text { (sítios Ramsar) }\end{array}$ & 6 \\
\hline
\end{tabular}

Fonte: Ramsar (2019); UNESCO (2019a (2019b).

Designação nacional de áreas protegidas e de conservação no Quénia

\begin{tabular}{l|r|r}
\hline Designação nacional & No. & Área $\mathbf{( k m}^{2} \mathbf{)}$ \\
\hline Santuário Comunitário de Vida Selvagem & 1 & 223 \\
\hline Parque Nacional & 23 & 28844 \\
\hline Reserva Nacional & 31 & 17941 \\
\hline Rancho de Grupo & 1 & 66 \\
\hline Reserva Natural Privada & 1 & 197 \\
\hline Santuário de Caça & 1 & 0 \\
\hline Área Privada Protegida & 2 & 522 \\
\hline Santuário Nacional & 6 & 36 \\
\hline Rancho Privado & 4 & 645 \\
\hline Reserva Nacional Marinha & 5 & 510 \\
\hline Parque Nacional Marinho & 4 & 61 \\
\hline Reserva Natural & 2 & 17941 \\
\hline Não Reportado & 5 & 8 \\
\hline Reserva Florestal & 234 & 18776 \\
\hline Parque Nacional (proposto) & 1 & 145 \\
\hline Conservância Comunitária & 21 & 2719 \\
\hline Reserva Natural da Comunidade & 28 & 30016 \\
\hline Reserva Privada & 16 & 8121 \\
\hline Santuário de Vida Selvagem & 1 & 109 \\
\hline Área Marítima Gerida Localmente & & 37 \\
\hline & & \\
\hline
\end{tabular}

Fonte: UNEP-WCMC \& UICN (2019i) 
Mais de 200 répteis (cinco tartarugas marinhas, cinco tartarugas, 100 cobras, 100 lagartos, um crocodilo e cinco espécies de cágados) e 110 espécies de anfíbios ocorrem em todo o país, excepto no topo de altas montanhas como o Monte Quénia. Quénia é também o lar de 315 espécies de mamíferos, incluindo várias espécies endémicas e quase endémicas, incluindo a zebra de Grevy (Equus grevyi) e a hirola (Beatragus hunteri). O declínio de muitas espécies de mamíferos, para além do elefante africano (Loxodonta africana), tem sido atribuído à mudança do uso da terra, seca, caça furtiva, doenças e competição por recursos.

Os ecossistemas marinhos e de água doce do Quénia contêm populações de peixes biologicamente diversos e comercialmente importantes. Mais de 60 destas espécies estão ameaçadas de acordo com a Lista Vermelha da UICN. Mais de 35,000 taxa de invertebrados foram registados e descritos, restando muitos milhares para serem descritos.

\section{Pressões e ameaças ${ }^{57}$}

A principal ameaça enfrentada pela biodiversidade em Quénia é a degradação, fragmentação e perda de habitats, tais como alterações no uso da terra, modificação física dos rios ou retirada excessiva dos rios, perda de recifes de coral e danos no fundo do mar devido ao arrasto. Os principais motores são: o crescimento da população humana, exercendo pressão sobre os habitats da biodiversidade e os recursos da terra; e a pobreza que conduz à utilização insustentável dos recursos da terra e da biodiversidade e recursos financeiros limitados para apoiar a conservação da biodiversidade.

Outras ameaças críticas incluem as alterações climáticas, espécies exóticas invasoras, sobre-exploração e poluição. Alguns taxa, tais como anfíbios e répteis, são particularmente afectados pela sobre-exploração para o comércio local e internacional. O comércio internacional ilegal de marfim e corno de rinoceronte também tem sido uma ameaça para as populações de elefantes e rinocerontes no país, enquanto o menos conhecido sândalo africano (Osyris lanceolata) também é seriamente ameaçado pela sobre-exploração ilegal. O comércio ilegal de carne de arbusto tem afectado seriamente muitas espécies de antílopes.

\section{Figura 8.16 Áreas Protegidas do Quénia}

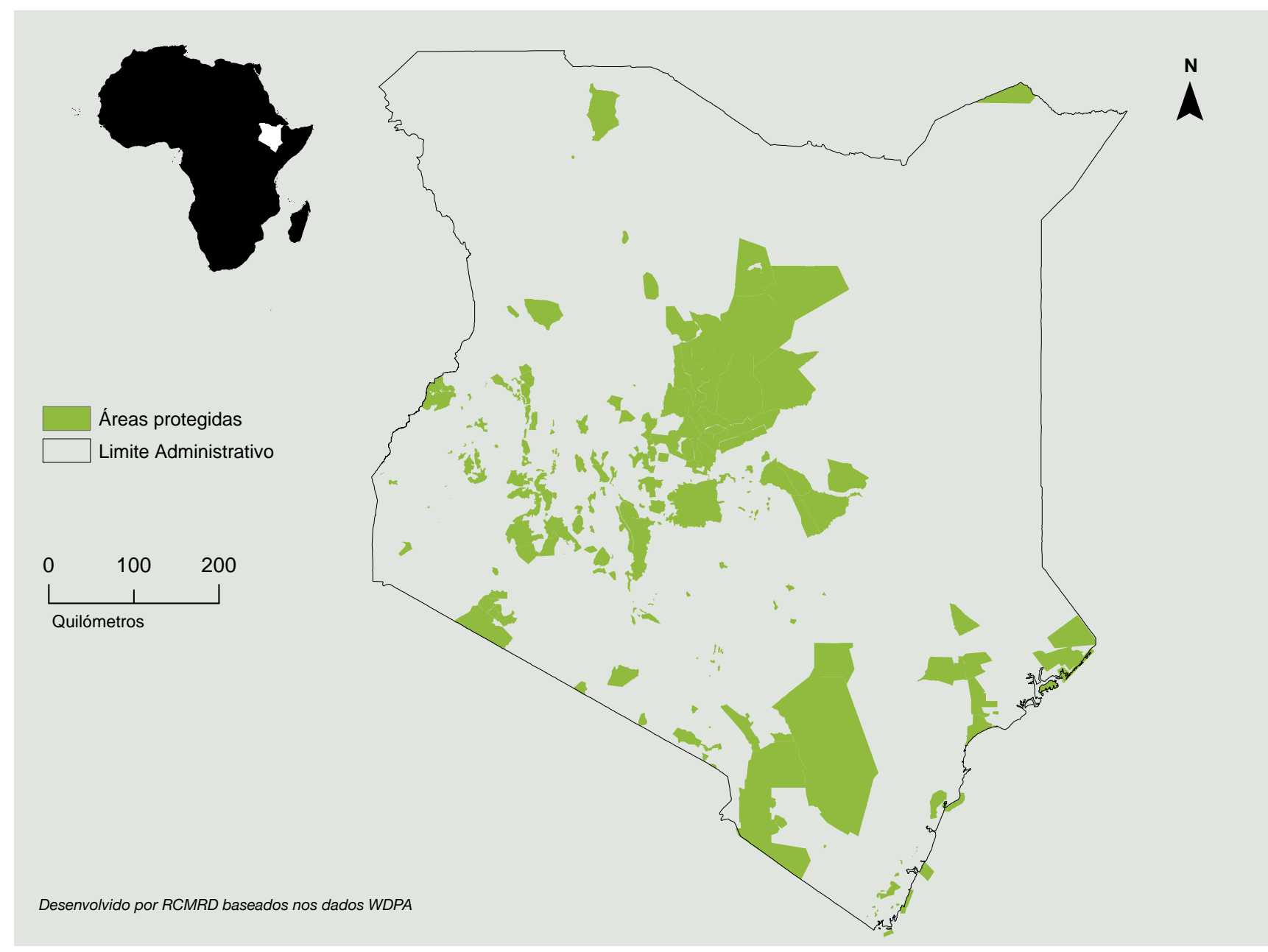



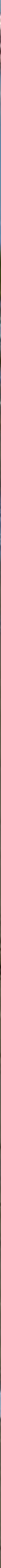

(๑) Gregoire Dubois, flamingos e búfalos, Parque Nacional do Lago Nakurü, Quênia 


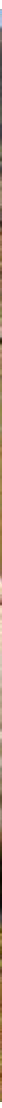

\subsection{Lesoto}

\section{Áreas protegidas e de conservação em Lesoto ${ }^{58}$}

Lesoto tem quatro áreas protegidas cobrindo $80 \mathrm{~km}^{2}$ de terra (UNEP-WCMC \& UICN, 2019j).

Um dos parques do Lesoto, o Parque Nacional Sehlabathebe é um sítio misto natural/cultural Património Mundial e, juntamente com o Khahlamba Drakensberg Parque Nacional na África do Sul, forma uma área protegida transfronteiriça, conhecida como Parque Maloti Drakensberg, um paraíso para muitas espécies ameaçadas e endémicas.

Para além das áreas protegidas formalmente designadas, existem várias áreas que são designadas informalmente ou propostas para protecção em várias partes do país. Existem planos para proclamar Letsa-La-Letsie Nature Reserve e Tsatsane como áreas protegidas. A fim de cumprir todas as metas de biodiversidade, $49 \%$ das terras altas do Lesoto deveriam estar sob alguma forma de gestão da conservação - possivelmente uma mistura de áreas de recursos geridos e áreas protegidas mais pequenas. Oito áreas-chave para uma acção prioritária foram identificadas pelo Projecto Transfronteiriço Maloti-Drakensberg.

\section{Áreas transfronteiriças protegidas e de conservação}

Lesoto inclui parte do Parque de Maloti Drakensberg, Património Mundial da Humanidade, que se encontra dentro da TFCA de Maloti Drakensberg.

\section{Contexto politico}

Um relatório abrangente sobre legislação e política relacionada com a gestão de áreas protegidas, governação, e equidade foi levado a cabo pelo programa BIOPAMA. Foram identificadas 17 leis e políticas relevantes em Lesoto (Tessema, 2019).

\section{Espécies-chave ${ }^{59}$}

Apesar da sua pequena dimensão, Lesoto tem níveis muito elevados de endemismo vegetal com pelo menos 54 espécies endémicas. Lesoto é também o lar de 340 espécies de aves e várias espécies de mamíferos, incluindo o rato endémico do gelo (Otomys sloggetti) e o rato de cauda branca (Mystromys albicaudatus). O chacma babuíno (Papio ursinus), outrora abundante, sofreu um declínio precipitado.

Lesoto também tem altos níveis de endemismo nos grupos de répteis e anfíbios. As 14 espécies de peixes registadas incluem uma espécie endémica.

\section{Pressões e ameaças ${ }^{60}$}

Uma das principais ameaças à biodiversidade em Lesoto é a perda e degradação do habitat, particularmente de zonas húmidas e de serranias. As más práticas de gestão da diversidade resultaram na perda da cobertura vegetal e da camada superficial do solo. Os incêndios incontrolados são também uma ameaça nos terrenos.

\footnotetext{
58 A secção baseia-se na informação contida no Sexto Relatório Nacional do Lesoto à CDB (Reino do Lesoto, 2019)

59 lbid

60 Ibid.
} 
Figura 8.17 Resumo do Lesoto

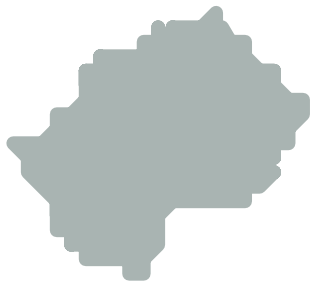

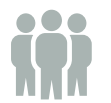

População Total (milhões)

2.11

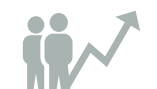

Crescimento da população (\% anual) 0.80

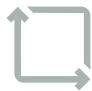

Superfície $\left(\mathrm{km}^{2}\right)$ (milhares)

30.40

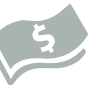

GDP (actuais US\$) (bilhões)

2.79
Crescimento do GDP (\% anual) 1.50

Fonte: The World Bank Group, 2018.

Área Protegida:

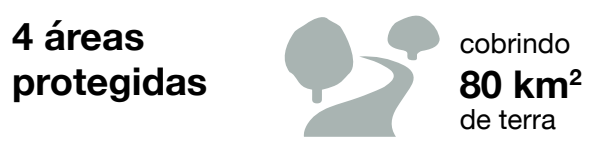

Fonte: UNEP-WCMC \& UICN, (2019j)

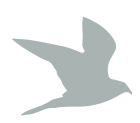

340 espécies de aves

\section{4 espécies} de peixes
Áreas protegidas e de conservação em Lesoto em Categorias de Gestão da UICN

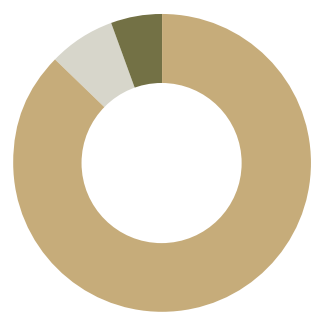

Não Aplicável (No. 1)

Não Reportado (No. 2)

IV. Habitat / Gestão de Espécies (No. 1)
Cobertura de áreas protegidas em Lesoto

\begin{tabular}{l|r|r}
\hline Tipo de área protegida & $\begin{array}{r}\text { Área } \\
\text { protegida ou } \\
\text { conservada }\end{array}$ & $\begin{array}{r}\text { Área } \\
\text { protegida ou } \\
\text { conservada }\end{array}$ \\
\hline Águas terrestres e interiores & $0.26 \%$ & $0.50 \%$ \\
\hline
\end{tabular}

*WDPA dataset $\quad$ ** Do Relatório Nacional sobre Biodiversidade

Fonte: Reino do Lesoto (2019); UNEP-WCMC \& UICN (2019j).

Designações nacionais de áreas protegidas e de conservação em Lesoto

\begin{tabular}{l|r|r}
\hline Designação nacional & No. & Área (km²) \\
\hline Parque Nacional & 2 & 6394 \\
\hline
\end{tabular}

Fonte: UNEP-WCMC \& UICN (2019j).

Áreas protegidas e de conservação em Lesoto nos tipos de governação da UICN

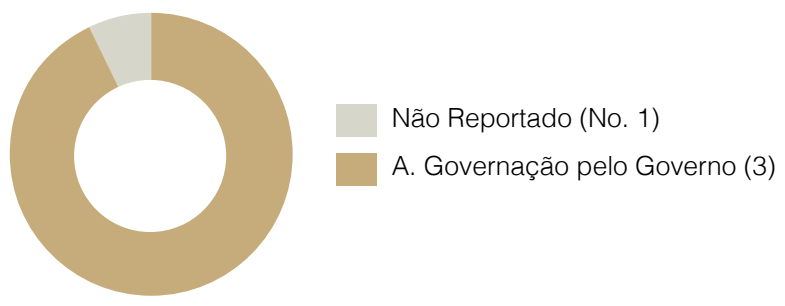

Áreas protegidas e de conservação designadas como sítios globais de importância em Lesoto

\begin{tabular}{l|r}
\hline Designação global & No. de sítios \\
\hline $\begin{array}{l}\text { Sítios Património Mundial da UNESCO } \\
\text { (Natural ou Misto) }\end{array}$ & 1 \\
\hline $\begin{array}{l}\text { Zonas húmidas de importância internacional } \\
\text { (sítios Ramsar) }\end{array}$ & 1 \\
\hline Fonte: Ramsar (2019); UNESCO (2019a, 2019b)
\end{tabular}

Áreas prioritárias para a conservação

\section{6 sítios}

Áreas importantes de Aves \& Biodiversidade

Fonte: UNEP-WCMC \& UICN (2019j) 
Iniciativas para o desenvolvimento económico, como a mineração, podem também representar ameaças aos habitats em Lesoto. Com a crescente incerteza climática, a agricultura de subsistência está cada vez mais a invadir os habitats remanescentes.
As espécies invasoras representam uma grande ameaça tanto nos ecossistemas terrestres como aquáticos. Além disso, as alterações climáticas estão a aumentar a incerteza climática.

\section{Figura 8.18 Áreas Protegidas do Lesoto}

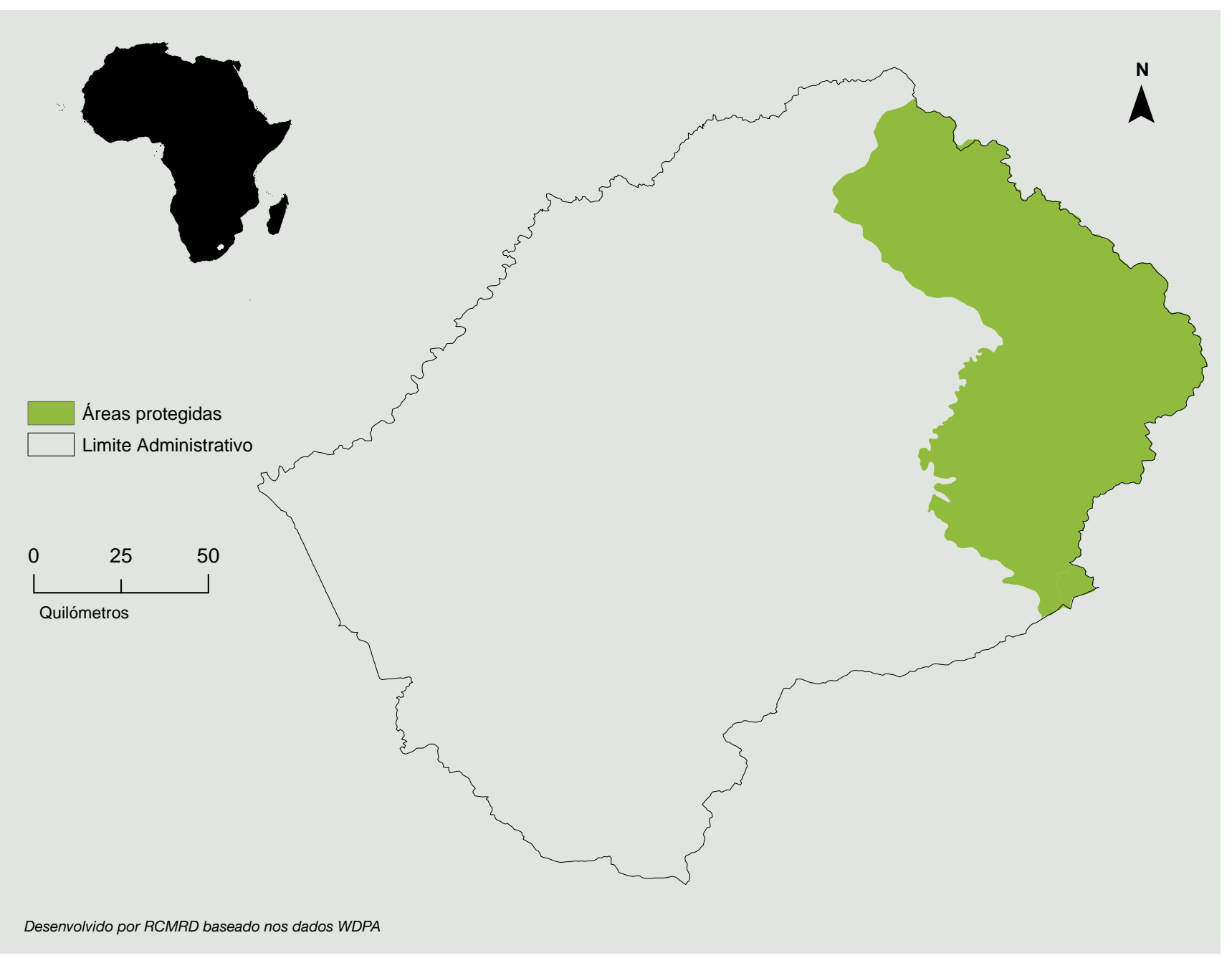



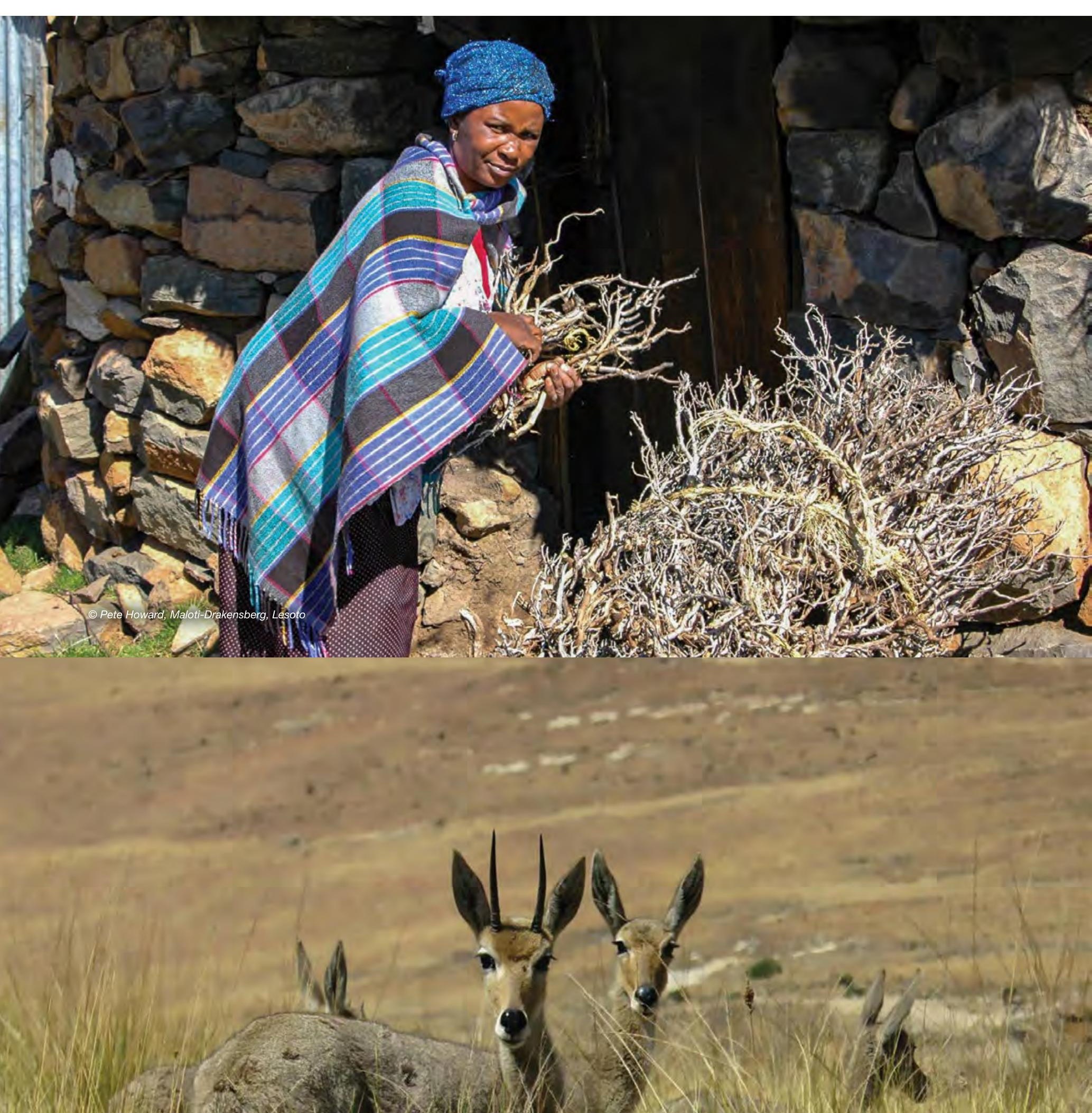


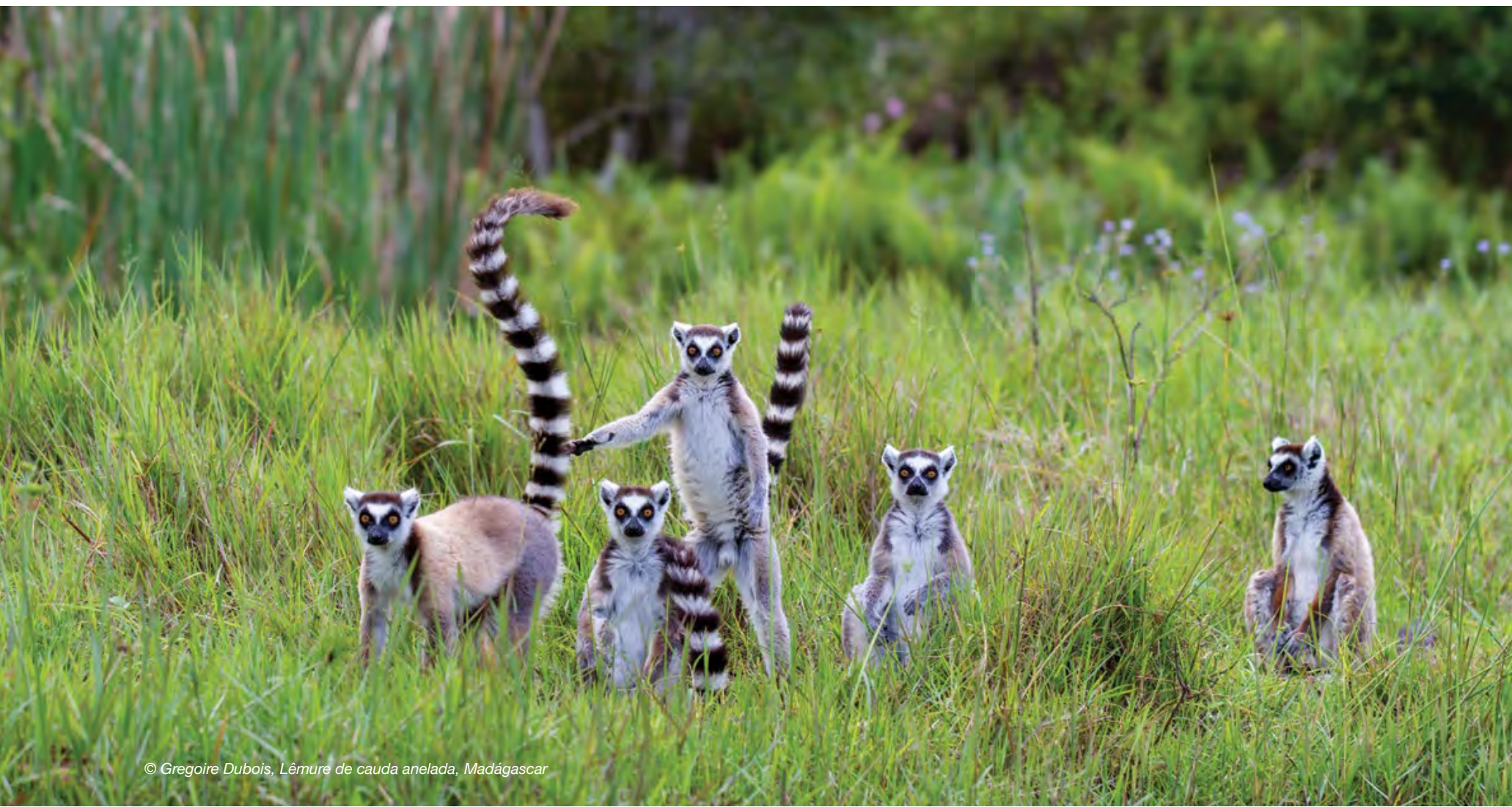

\subsection{Madagáscar}

\section{Áreas protegidas e de conservação em Madagáscar ${ }^{61}$}

Madagáscar tem 157 áreas protegidas cobrindo $33.242 \mathrm{~km}^{2}$ da terra e $8,998 \mathrm{~km}^{2}$ do oceano (UNEP-WCMC \& UICN, 2019k).

Madagáscar aceitou o desafio do Congresso Mundial de Parques de Sydney de triplicar a superfície das áreas marinhas protegidas, um objectivo que foi largamente alcançado. Alguns locais estão ainda em processo de criação e outros em processo de extensão. Um dos pontos centrais deste trabalho é assegurar a participação das comunidades locais. O maior desafio actual é a gestão eficaz e o financiamento sustentável destas áreas protegidas. Além disso, foram estabelecidos corredores de áreas protegidas numa extensão total de aproximadamente $1,200 \mathrm{~km}$, ligando seis áreas protegidas que fazem parte dos Sítios do Património Mundial.

\section{Áreas transfronteiriças protegidas e de conservação}

Madagáscar inclui parte do Parque Marítimo Transfronteiriço do Oceano Índico Ocidental.

\section{Contexto politico}

Um relatório abrangente sobre legislação e política relacionada com a gestão de áreas protegidas, governação e equidade foi levado a cabo pelo programa BIOPAMA. Identificou 75 leis e políticas relevantes em Madagáscar (Tessema, 2019).

\section{Espécies-chave ${ }^{62}$}

Estima-se que Madagáscar tenha entre 13,000 e 14,000 espécies vegetais, $80 \%$ das quais são endémicas. O endemismo é particularmente elevado entre os baobás, as palmeiras e as orquídeas, incluindo seis das oito espécies de baobás do mundo. Da mesma forma, os mamíferos também apresentam um elevado nível de endemismo, particularmente entre os lémures e outros primatas. Madagáscar é o lar de muitas espécies diferentes de aves. O conhecimento dos invertebrados de Madagáscar é incompleto, mas há altos níveis de endemismo entre formigas, camarões de água doce e caranguejos, e lagostins de água doce. Da mesma forma, peixes de água doce e marinha, anfíbios e répteis apresentam todos níveis elevados de endemismo, alguns perto dos $100 \% .23$ das 37 espécies de mamíferos marinhos da Região do Oceano Índico Ocidental foram observadas nas zonas costeiras de Madagáscar.

\section{Pressões e ameaças ${ }^{63}$}

As principais ameaças à biodiversidade de Madagáscar incluem: desflorestação e degradação florestal; exploração ilegal de recursos naturais, incluindo madeira, assim como muitas espécies terrestres e marinhas; o impacto de espécies invasoras alienígenas e doenças; e como impactos ambientais de indústrias extractivas como a mineração. As alterações climáticas continuam a ser uma ameaça a curto e longo prazo para os ecossistemas de Madagáscar, particularmente para os ecossistemas marinhos. 
Figura 8.19 Resumo de Madagáscar

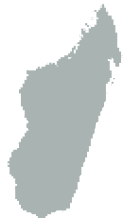

Fonte: The World Bank Group, 2018

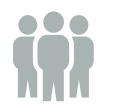

População Total (milhões)

26.26

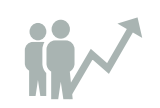

Crescimento da população (\% anual)

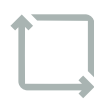

Superfície $\left(\mathrm{km}^{2}\right)$

(milhares)

587.30

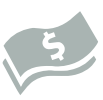

GDP (actuais US\$)

(bilhões)

12.10
Crescimento do GDP (\% anual)

\section{7 áreas protegidas}

Área Protegida:

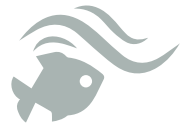

cobrindo 8998 km² $^{2}$ de oceano
Áreas protegidas e de conservação em Madagáscar em Categorias de Gestão da UICN

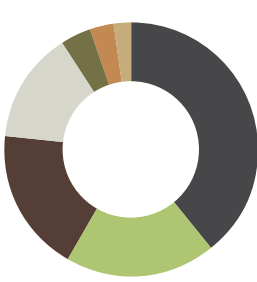

Fonte: UNEP-WCMC \& UICN, (2019k)

Fonte: UNEP-WCMC \& UICN (2019k)

Cobertura de áreas protegidas em Madagáscar

\begin{tabular}{l|r|r}
\hline Tipo de área protegida & $\begin{array}{r}\text { Área } \\
\text { protegida ou } \\
\text { conservada* }^{*}\end{array}$ & $\begin{array}{r}\text { Área } \\
\text { protegida ou } \\
\text { conservada* }^{\star *}\end{array}$ \\
\hline Águas terrestres e interiores & $5.59 \%$ & $\begin{array}{r}\text { Não } \\
\text { Encontrado }\end{array}$ \\
\hline Litoral e marinho & $0.75 \%$ & $\begin{array}{r}\text { Não } \\
\text { Encontrado }\end{array}$ \\
\hline
\end{tabular}

*WDPA dataset $\quad$ ** Do Relatório Nacional sobre Biodiversidade

Fonte: UNEP-WCMC \& UICN (2019k).

Áreas protegidas e de conservação designadas como sítios globais de importância em

Madagáscar

\begin{tabular}{l|r}
\hline Designação global & No. de sítios \\
\hline Reservas do Homem e da Biosfera da UNESCO & 3 \\
\hline $\begin{array}{l}\text { Sítios Património Mundial da UNESCO } \\
\text { (Natural ou Misto) }\end{array}$ & 2 \\
\hline $\begin{array}{l}\text { Zonas húmidas de importância internacional } \\
\text { (sítios Ramsar) }\end{array}$ & 20 \\
\hline Fonte: Ramsar (2019); UNESCO (2019a, 2019b).
\end{tabular}

Áreas protegidas e de conservação em Madagáscar nos tipos de governação da UICN

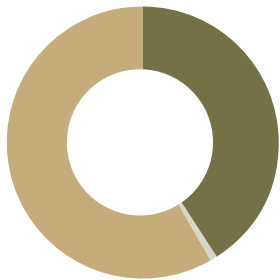

C. Governação Privada (No. 2)

B. Governação Partilhada (No. 2)

A.Governação pelo Governo (No. 8)

Fonte: UNEP-WCMC \& UICN (2019k).
Designações nacionais de áreas protegidas e de conservação em Madagáscar

\begin{tabular}{l|r|r}
\hline Designação nacional & No. & Área (km²) \\
\hline Reserva de Caça & 2 & 150 \\
\hline Paisagem Harmoniosa Protegida & 1 & 139 \\
\hline Parque Natural & 1 & 3649 \\
\hline Protegé Harmonieux Paga Harmonieux & 20 & 14015 \\
\hline Parque Nacional & 26 & 19136 \\
\hline Réserve de Ressources Naturelles & 1 & 443 \\
\hline Área Protegida Proposta & 14 & 5215 \\
\hline Parque Marinho & 4 & 119 \\
\hline Parque Nacional Marinho & 1 & $0 *$ \\
\hline Área de Gestão da Pesca Colaborativa & 1 & 2865 \\
\hline Reserva Natural Estrita & 3 & 1356 \\
\hline Parque Marinho proposto & 1 & 1564 \\
\hline Não Reportado & 1 & 469 \\
\hline Floresta Classificada & 1 & 400 \\
\hline Nova Área Protegida & 5 & 3701 \\
\hline Reserva Especial & 22 & 3550 \\
\hline Área Marítima Gerida Localmente & 26 & 2173 \\
\hline Área Marítima Protegida & 1 & 451 \\
\hline For unEPWMC\& & &
\end{tabular}

Fonte: UNEP-WCMC \& UICN (2019k)

* Nenhuma área reportada à WDPA

\section{Áreas prioritárias para a conservação}

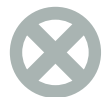

\section{0 sítios}

Aliança para os sítios de Extinção Zero

74 sítios

227 sítios

Aves \& Biodiversidade 
Figura 8.20 Áreas Protegidas de Madagáscar
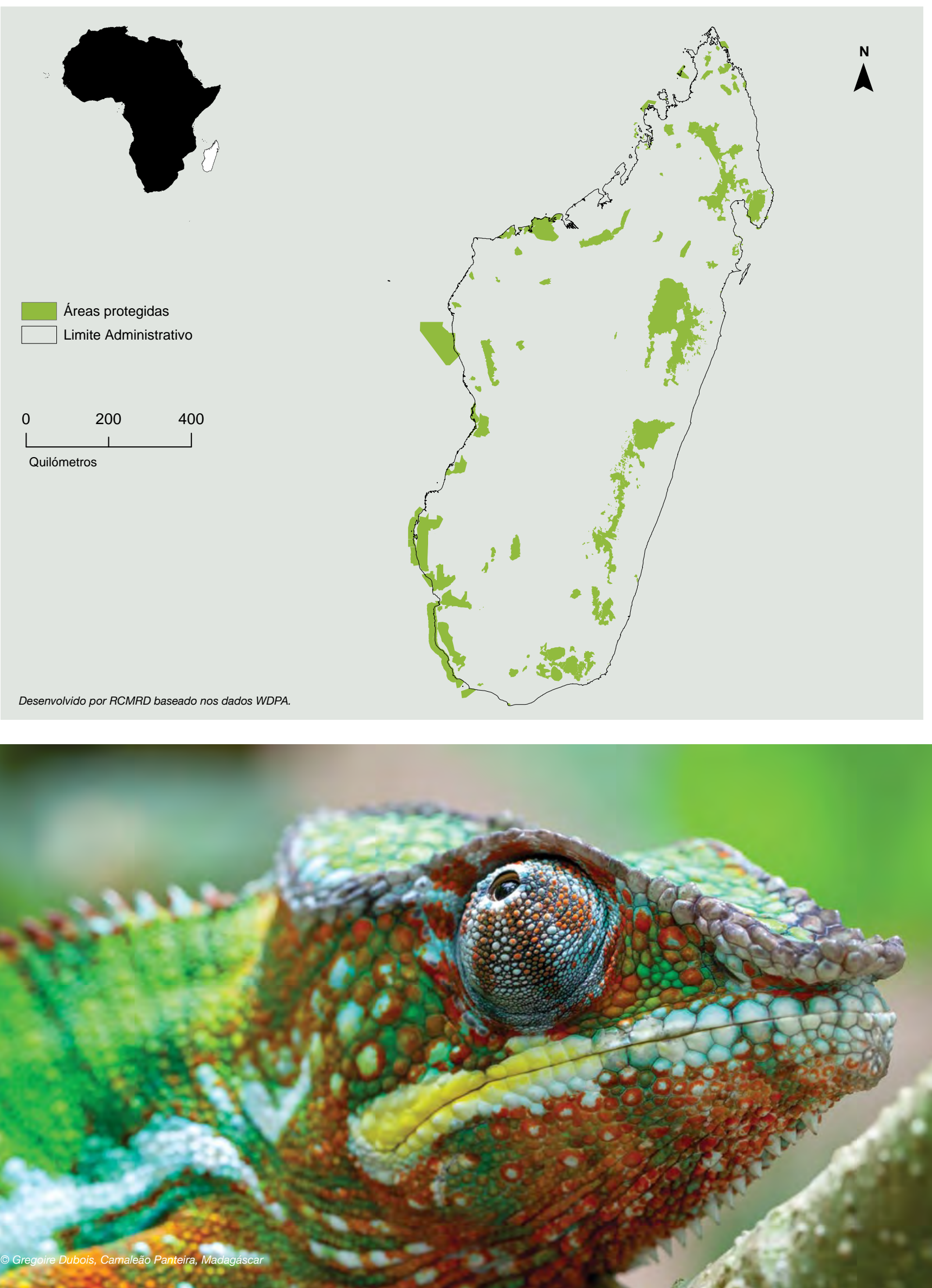


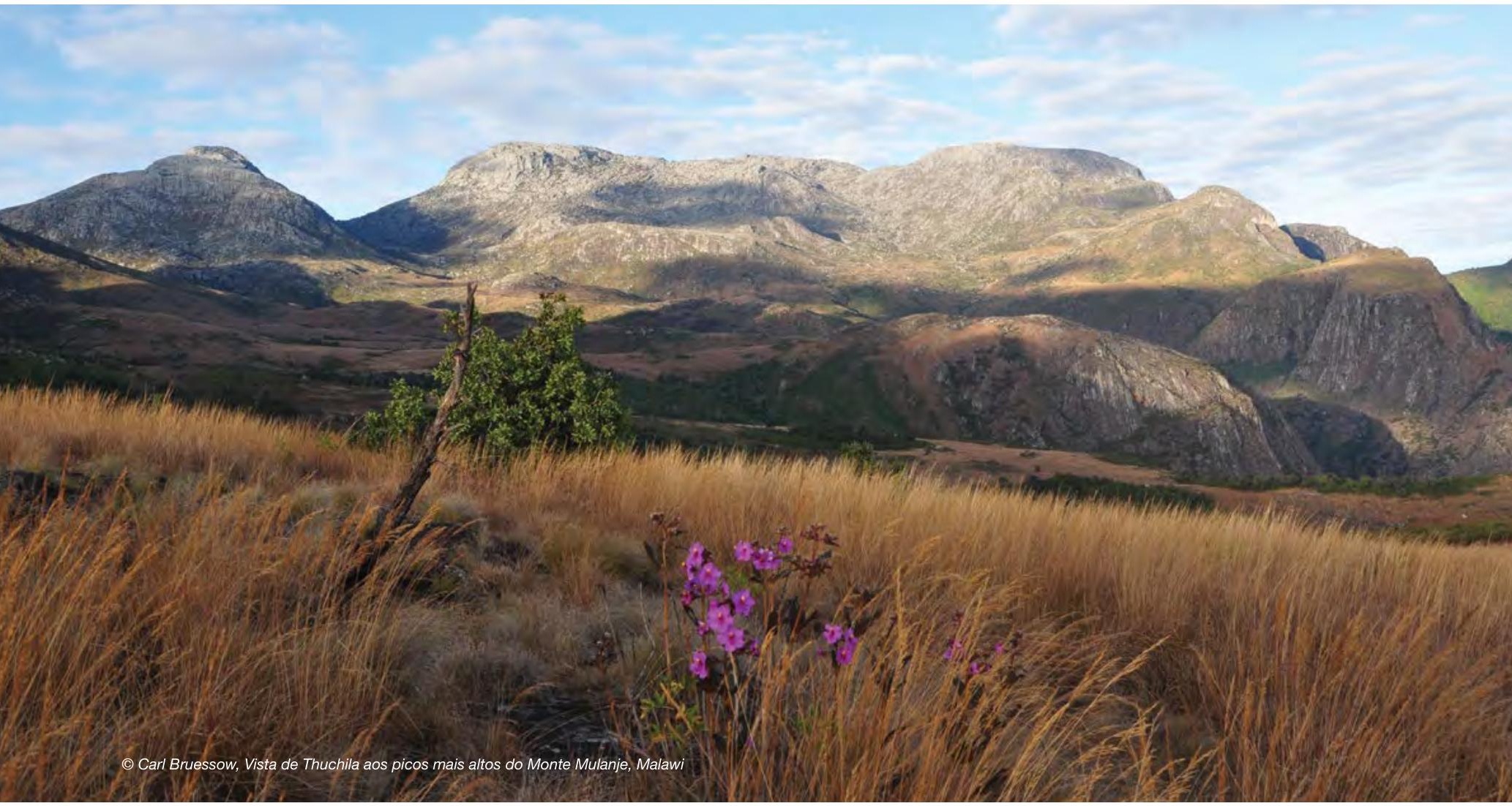

\subsection{Malawi}

\section{Áreas protegidas e de conservação em Malawi ${ }^{64}$}

O Malawi tem 133 áreas protegidas que cobrem $27.190 \mathrm{~km}^{2}$ da terra (UNEP-WCMC \& UICN, 2019l).

O Malawi tem uma alta densidade populacional com áreas protegidas com fronteiras difíceis, resultando em que a maioria dos ecossistemas em áreas protegidas são vulneráveis. O Governo do Malawi celebrou um acordo com o sector privado, com a African Parks Network aumentando a sua gestão de áreas protegidas de dois para cinco, para incluir a Nkhotakota Reserva de Caça, Liwonde Parque Nacional e Mangochi Reserva Florestal, a fim de as restaurar e proteger para a sustentabilidade.

\section{Áreas transfronteiriças protegidas e de conservação}

O Malawi tem uma zona protegida que faz parte da zona transfronteiriça de conservação da Malawi Zâmbia.

\section{Contexto politico}

Um relatório abrangente sobre legislação e política relacionada com a gestão de áreas protegidas, governação, e equidade foi levado a cabo pelo programa BIOPAMA. Identificou 25 leis e políticas relevantes no Malawi (Tessema, 2019).

\section{Espécies-chave $^{65}$}

O Malawi tem uma rica diversidade de plantas, com mais de 6.000 espécies de plantas com floração, das quais 122 são endémicas. Das 192 espécies de mamíferos do Malawi, oito estão listadas como ameaçadas na Lista Vermelha da UICN. 83 espécies de anfíbios foram registadas no Malawi, seis das quais são endémicas, enquanto oito das 145 espécies de répteis são endémicas. O Malawi tem mais de 630 espécies de aves registadas, com apenas uma endémica. Por outro lado, das mais de 850 espécies de peixes de água doce, 99\% são endémicas do pais. O Malawi é também o lar de uma grande variedade de invertebrados e microrganismos.

\section{Pressões e ameaças ${ }^{66}$}

As ameaças à biodiversidade no Malawi são principalmente induzidas pelo homem e incluem a perda e fragmentação do habitat, a sobre-exploração dos recursos biológicos, a introdução de espécies exóticas e as alterações climáticas. O aumento da população humana e o desenvolvimento económico levaram a grandes mudanças no uso da terra no Malawi, criando uma procura de terra para a agricultura e assentamentos. Os elevados níveis de pobreza aumentaram a dependência dos recursos naturais, e particularmente das florestas, que fornecem combustível para cozinhar para a grande maioria da população do Malawi. 
Figura 8.21 Resumo do Malawi

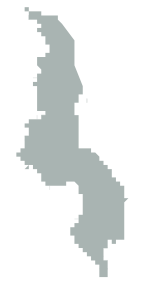

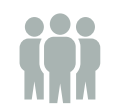

População Total (milhões)

18.14

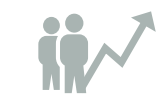

Crescimento da população (\% anual) 2.60

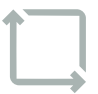

Superfície $\left(\mathrm{km}^{2}\right)$ (milhares) 118.50

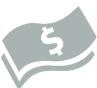

GDP (actuais US\$) (bilhões)

7.06
Crescimento do GDP (\% anual) 3.50

Fonte: The World Bank Group, 2018.

Área Protegida:

133 áreas
protegidas

cobrindo 27190 km² $^{2}$ de terra

Fonte: UNEP-WCMC \& UICN, 2019

Áreas protegidas e de conservação em Malawi em Categorias de Gestão da UICN

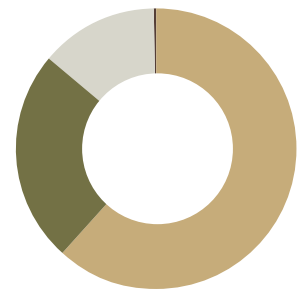

Não Aplicável (No. 3)

Não Reportado (No. 121)

IV. Habitat / Gestão de Espécies (No. 4)

II. Parque Nacional (No. 5)

Fonte: UNEP-WCMC \& UICN (2019I).

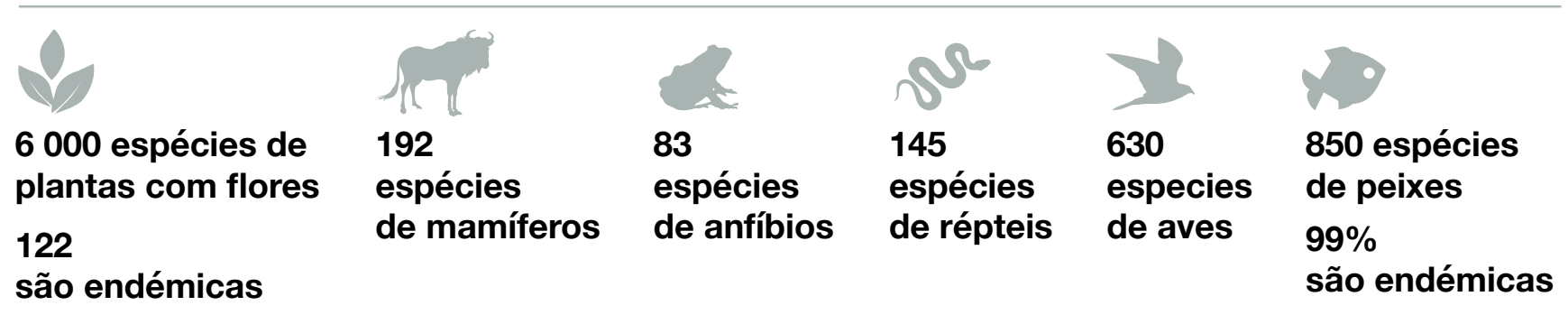

Cobertura de áreas protegidas em Malawi

\begin{tabular}{l|r|r}
\hline Tipo de área protegida & $\begin{array}{r}\text { Área } \\
\text { protegida ou } \\
\text { conservada* }\end{array}$ & $\begin{array}{r}\text { Área } \\
\text { protegida ou } \\
\text { conservada** }\end{array}$ \\
\hline Águas terrestres e interiores & $22.88 \%$ & $15.12 \%$ \\
\hline * WDPA dataset ${ }^{* *}$ Do Relatório Nacional sobre Biodiversidade \\
Fonte: Governo do Malawi (2015); UNEP-WCMC \& UICN (2019).
\end{tabular}

Designações nacionais de áreas protegidas e de conservação em Malawi

\begin{tabular}{l|r|r}
\hline Designação nacional & No. & Área (km²) \\
\hline Área de Conservação & 1 & 6493 \\
\hline Parque Nacional & 5 & 6961 \\
\hline Reserva de Vida Selvagem & 4 & 3816 \\
\hline Reserva Florestal & 118 & 1485 \\
\hline
\end{tabular}

Fonte: UNEP-WCMC \& UICN (2019I).

Áreas protegidas e de conservação em Malawi nos tipos de governação da UICN

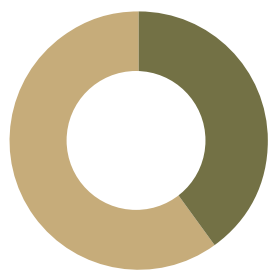

Não Aplicável (No. 123)

A. Governação pelo Governo (No. 10)
Áreas protegidas e de conservação designadas como sítios globais de importância em Malawi

\begin{tabular}{l|r}
\hline Designação global & No. de sítios \\
\hline $\begin{array}{l}\text { Reservas do Homem e da Biosfera da } \\
\text { UNESCO }\end{array}$ & 2 \\
\hline $\begin{array}{l}\text { Sítios Património Mundial da UNESCO } \\
\text { (Natural ou Misto) }\end{array}$ & 2 \\
\hline $\begin{array}{l}\text { Zonas húmidas de importância internacional } \\
\text { (sítios Ramsar) }\end{array}$ & 2 \\
\hline
\end{tabular}

Fonte: Ramsar (2019); UNESCO (2019a, 2019b).

Áreas prioritárias para a conservação

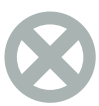

\section{3 sítios \\ Aliança para os Sítios \\ de Extinção Zero}

21 sítios

Áreas importantes de

Aves \& Biodiversidade

11 sítios

Áreas-chave da

Biodiversidade 


\section{Figura 8.22 Áreas Protegidas do Malawi}
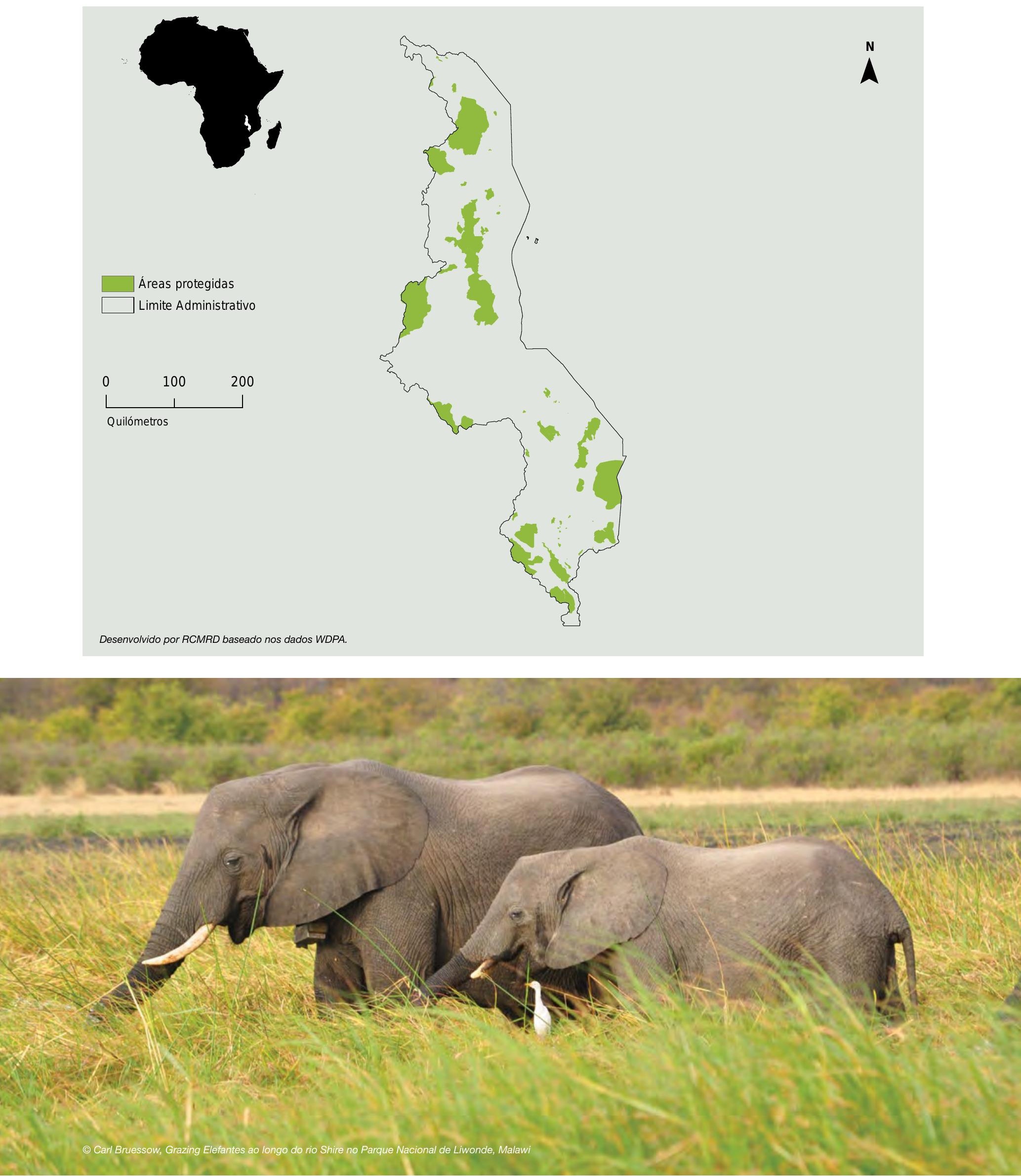


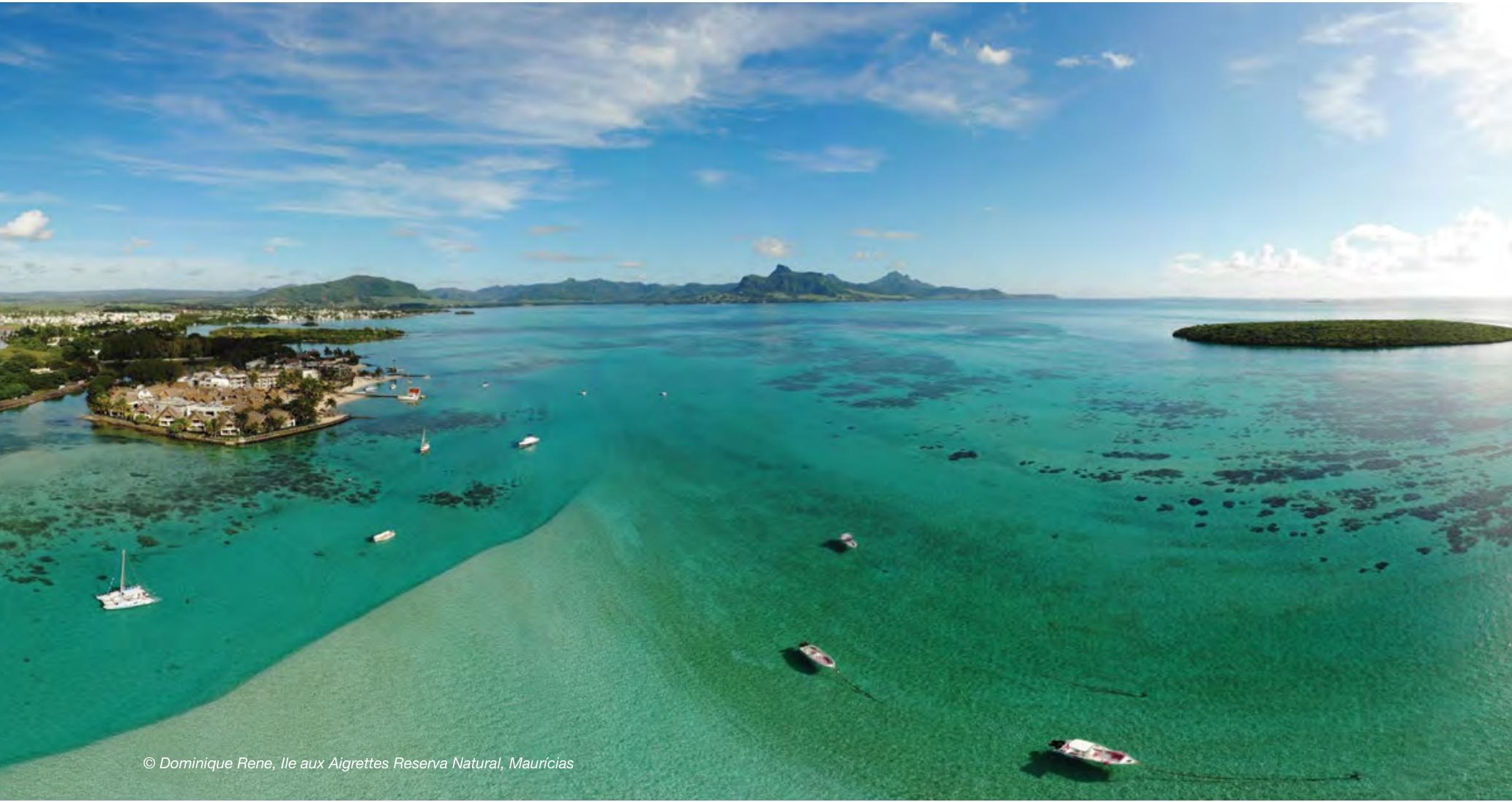

\subsection{Maurícias}

\section{Áreas protegidas e de conservação nas Maurícias ${ }^{67}$}

Maurícias tem 44 áreas protegidas cobrindo $97 \mathrm{~km}^{2}$ da terra e $50 \mathrm{~km}^{2}$ do oceano (UNEP-WCMC \& UICN, 2019m).

Embora a cobertura de áreas protegidas terrestres permaneça inalterada desde 2010, tem havido um enfoque na restauração de florestas nativas, e um grande sistema de áreas marinhas protegidas, incluindo reservas de pesca, parques marinhos e reservas marinhas, foi estabelecido nas águas em torno das Maurícias e Rodrigues. Maurícias estabeleceu também um novo paradigma para as áreas protegidas, promovendo o envolvimento do sector privado na propriedade e gestão de áreas protegidas.

\section{Áreas transfronteiriças protegidas e de conservação}

As Maurícias inclui parte do Parque Marítimo Transfronteiriço do Oceano Índico Ocidental.

\section{Contexto politico}

Um relatório abrangente sobre legislação e política relacionada com a gestão de áreas protegidas, governação, e equidade foi levado a cabo pelo programa BIOPAMA. Identificou 41 leis e políticas relevantes na Mauritânia (Tessema, 2019).

\section{Espécies-chave ${ }^{68}$}

Maurícias e Rodrigues são o lar de altos níveis de endemismo entre plantas, répteis, invertebrados e aves, embora tenha havido várias extinções devido a espécies invasoras. Existem 691 espécies de plantas nativas floridas, das quais 273 são endémicas (150 endémicas do Arquipélago de Mascarene) nas Maurícias e 150 espécies de plantas nativas floridas, das quais 47 são endémicas (72 endémicas do Arquipélago de Mascarene) em Rodrigues. Os únicos mamíferos nativos são morcegos (morcegos frugívoros e morcegos túmulos) e até à data existem nove espécies endémicas de aves de terra e onze espécies endémicas de répteis na ilha. Duas espécies de morcegos frugívoros ocorrem actualmente na República das Maurícias: Pteropus niger nas Maurícias e Pteropus rodricensis em Rodrigues. Das 17 espécies de répteis que costumavam ser encontradas nas Maurícias, apenas 12 permanecem, das quais 11 espécies são endémicas, e 7 destas estão restritas a ilhotas offshore onde escaparam à extinção de ratos. Além disso, cinco destas espécies estão restritas a llha Redonda.

\section{Pressões e ameaças ${ }^{69}$}

A limpeza do habitat e espécies exóticas invasoras têm sido a ameaça mais significativa para a biodiversidade de Maurícias até à data. As alterações climáticas e a poluição também têm causado pressão sobre os ecossistemas da ilha. Os factores indirectos da perda da biodiversidade incluem as alterações demográficas, e factores sociopolíticos, particularmente o financiamento e a capacidade para a conservação da biodiversidade.

67 A secção baseia-se na informação contida no Quinto Relatório Nacional de Maurícias ao CBD e no seu Segundo NBSAP (República de Maurícias, 2015; 2017).

68 Ibid.

69 lbid. 
Figura 8.23 Resumo das Maurícias

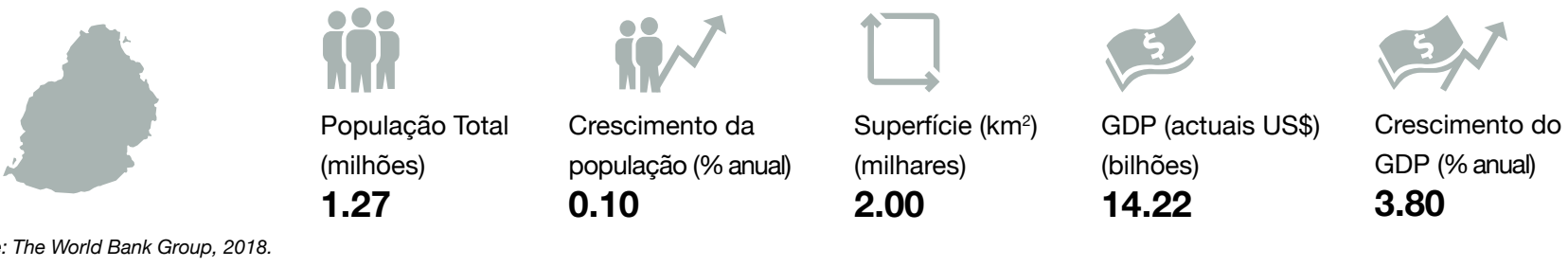

\section{Área Protegida:}

44 áreas protegidas

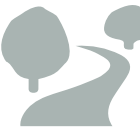

cobrindo

$97 \mathrm{~km}^{2}$ de terra

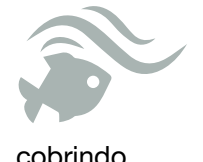

cobrindo

$50 \mathbf{k m}^{2}$ de oceano
Fonte: UNEP-WCMC \& UICN, 2019m
Áreas protegidas e de conservação nas Maurícias em Categorias de Gestão da UICN

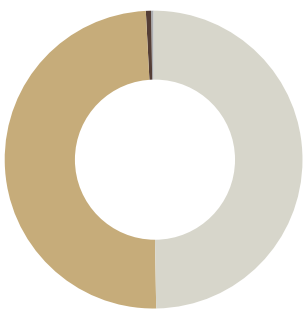

Não Atribuído (No. 1)

Não Reportado (No. 10)

IV. Habitat / Gestão de Espécies (No. 21)

II. Parque Nacional (No. 10)

la. Reserva Natural Estrita (No. 1)

\section{1 espécies de plantas com flores nativas}

só os mamíferos nativos são morcegos

\section{2 espécies de répteis}

\section{Cobertura de áreas protegidas nas Maurícias}

\begin{tabular}{l|r|r}
\hline Tipo de área protegida & $\begin{array}{r}\text { Área } \\
\text { protegida ou } \\
\text { conservada* }\end{array}$ & $\begin{array}{r}\text { Área } \\
\text { protegida ou } \\
\text { conservada** }\end{array}$ \\
\hline Águas terrestres e interiores & $4.73 \%$ & $4.00 \%$ \\
\hline Litoral e marinho & $0.00 \%$ & $0.01 \%$ \\
\hline
\end{tabular}

*WDPA dataset $\quad$ ** Do Relatório Nacional sobre Biodiversidade

Fonte: República das Maurícias (2017); UNEP-WCMC \& UICN (2019m).

Áreas protegidas e de conservação designadas como sítios globais de importância nas Maurícias

\begin{tabular}{l|r}
\hline Designação global & No. de sítios \\
\hline Reservas do Homem e da Biosfera da UNESCO & 1 \\
\hline $\begin{array}{l}\text { Zonas húmidas de importância internacional } \\
\text { (sítios Ramsar) }\end{array}$ & 3 \\
\hline
\end{tabular}

Fonte: Ramsar (2019; UNESCO (2019a, 2019b)

\section{Áreas protegidas e de conservação nas Maurícias} nos tipos de governação da UICN

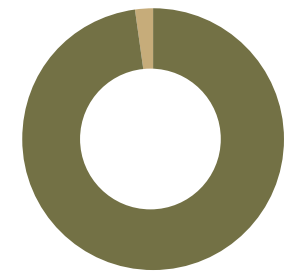

C. Governação Privada (No. 2)

A. Governação pelo Governo (No. 42)
Designações nacionais de áreas protegidas e de conservação nas Maurícias

\begin{tabular}{l|r|r}
\hline Designação nacional & No. & Área $\left.\mathbf{( k m}^{2}\right)$ \\
\hline Parque Nacional & 2 & 61 \\
\hline Parque Marinho & 2 & 6 \\
\hline Reserva Natural & 18 & 9 \\
\hline Reserva de Tartarugas & 2 & 0 \\
\hline Reserva de Pesca & 6 & 68 \\
\hline Islet Parque Nacional & 8 & 2 \\
\hline Jardim endémico & 1 & 3 \\
\hline Monumento Antigo & 1 & 0 \\
\hline
\end{tabular}

Fonte: UNEP-WCMC \& UICN (2019m)

\section{Áreas prioritárias para a conservação}

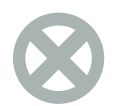

\section{2 sítios}

Aliança para os sítios de Extinção Zero

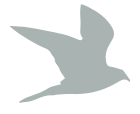

16 sítios

Áreas importantes de Aves \& Biodiversidade
18 sítios

Áreas-chave da

Biodiversidade 
Figura 8.24 Áreas Protegidas das Maurícias
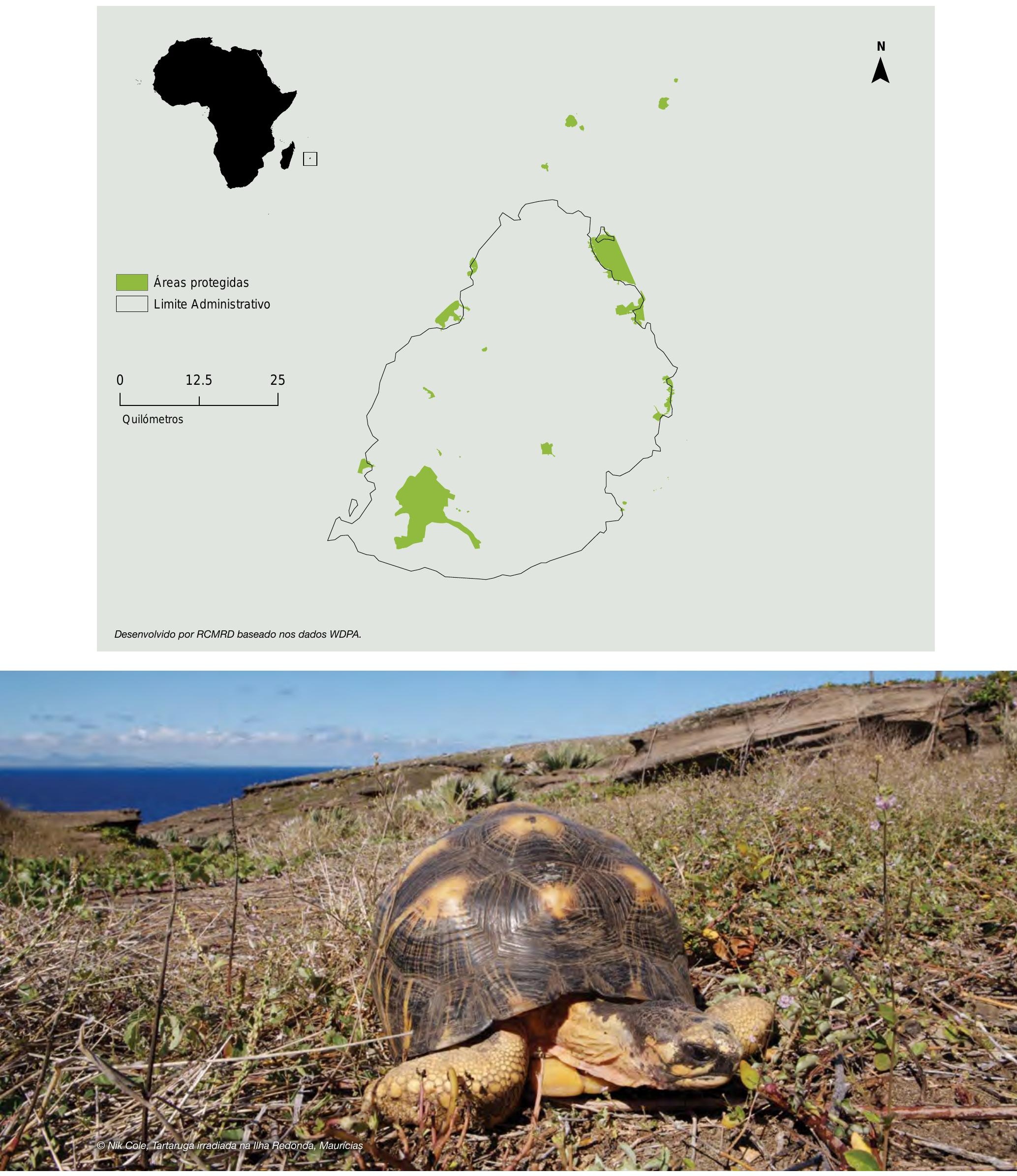


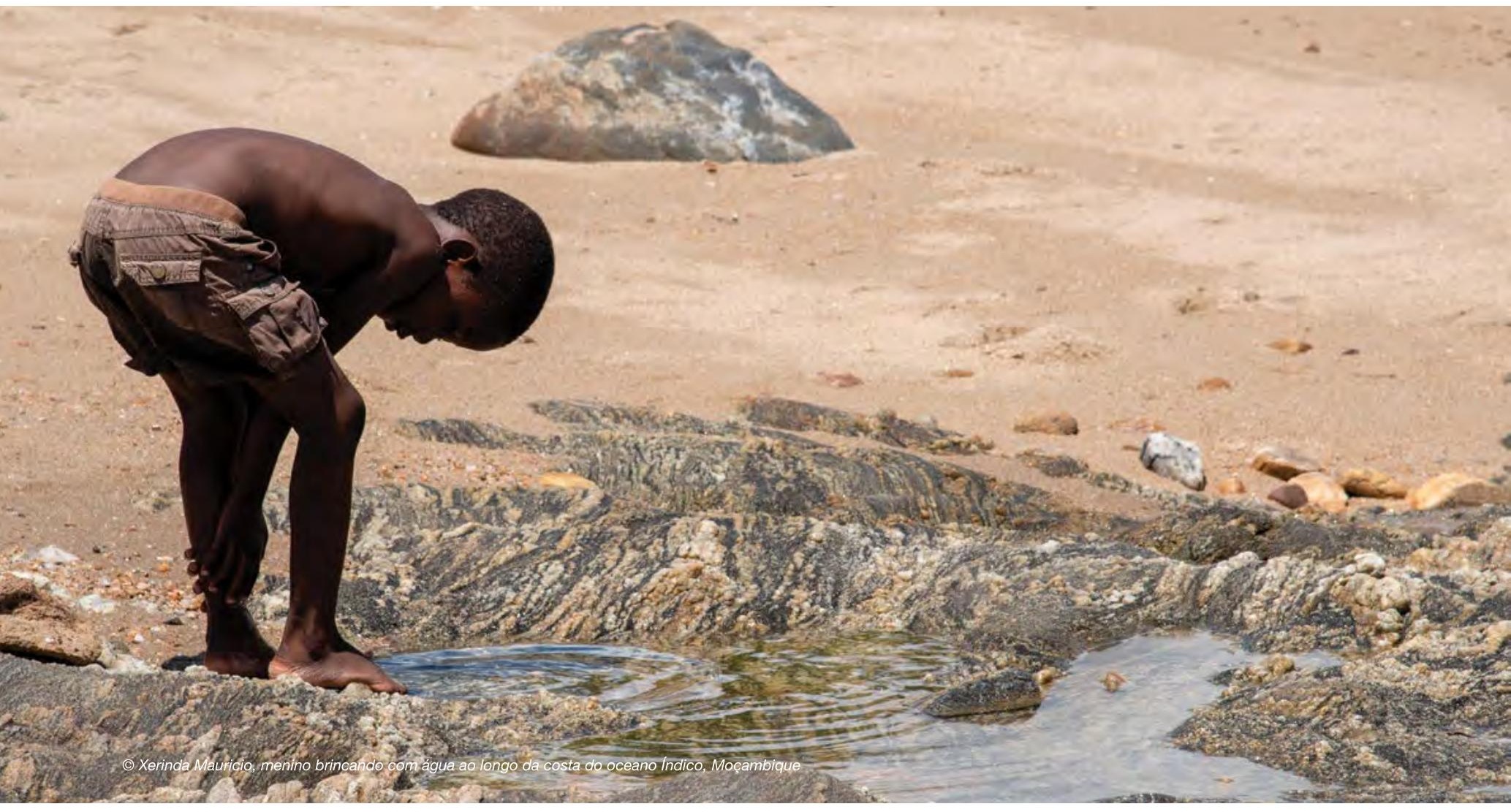

\subsection{Moçambique}

\section{Áreas protegidas e de conservação em Moçambique ${ }^{70}$}

Moçambique tem 44 áreas protegidas cobrindo $170.662 \mathrm{~km}^{2}$ da terra e 12,821 km² do oceano (UNEP-WCMC \& UICN, 2019n). A cobertura terrestre de áreas protegidas no país tem vindo a aumentar ao longo dos últimos 10 anos. Reconhecendo o valor nacional e global da biodiversidade, o Governo de Moçambique tem-se concentrado em assegurar a inclusão de ecossistemas que não estavam anteriormente representados, tais como o único ecossistema de água doce protegido do país, a Reserva Parcial do Lago Niassa.

As áreas marinhas protegidas foram também expandidas com a criação da Área de Protecção Ambiental das Ilhas Primeiras e Segundas e da Reserva Marinha Parcial Maputo-Ponta do Ouro. Alguns santuários marinhos foram também declarados.

O Governo de Moçambique empreendeu uma revisão dos vários modelos de co-gestão e abraçou parcerias público-privadas para melhorar a gestão do seu património de áreas protegidas. Isto inclui a Fundação Carr para o Parque Nacional Gorongosa e os Parques Africanos do Arquipélago do Parque Nacional Bazaruto, entre outros.

\section{Áreas transfronteiriças protegidas e de conservação}

Moçambique faz parte de sete áreas de conservação transfronteiriças, nomeadamente a TFCA de Chimanimani, a TFCA do Grande Parque
Transfronteiriço do Limpopo e Área de Conservação (GLTP), a TFCA do Lubombo, a TFCA da Área de Conservação Mnazi Bay-Quirimbas, a TFCA do Niassa-Selous, a TFCA da Reserva Marinha de Ponta de Ouro-Cosibay, a TFCA da REM-Tembe_Ndumo e a TFCA da ZIMOZA.

\section{Contexto politico}

Um relatório abrangente sobre legislação e política relacionada com a gestão de áreas protegidas, governação, e equidade foi levado a cabo pelo programa BIOPAMA. Identificou 80 leis e políticas relevantes em Moçambique (Tessema, 2019).

\section{Espécies-chave ${ }^{71}$}

O conhecimento da biodiversidade de Moçambique continua a ser baixo, mas está a melhorar. Foram registadas 4.271 espécies de animais terrestres, $72 \%$ das quais são representadas por insectos, $17 \%$ por aves, restando apenas $5 \%$ de mamíferos e anfíbios $2 \%$. A avaliação mais recente das plantas indica a ocorrência de cerca de 6,000 espécies. Os estudos de espécies endémicas são escassos, embora existam dois centros de endemismo vegetal - na área Maputalandia e Chimanimani.

Do número de espécies de plantas registadas em Moçambique, cerca de 800 espécies são endémicas e quase endémicas. As zonas montanhosas de Moçambique são relativamente ricas em espécies endémicas com pelo menos 45 espécies de plantas que só se encontram em Chimanimani.

70 A secção baseia-se na informação contida no Quinto Relatório Nacional de Moçambique à CDB e na Estratégia Nacional e Plano de Acção da Diversidade Biológica de Moçambique (2015-2035) (República de Moçambique, 2014; 2015).

71 A secção baseia-se na informação contida no Quinto Relatório Nacional de Moçambique à CDB (República de Moçambique, 2014) 
Figura 8.25 Resumo de Moçambique
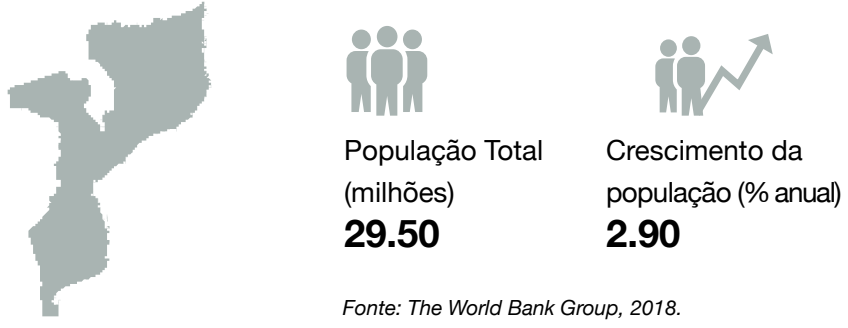

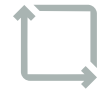

Superfície $\left(\mathrm{km}^{2}\right)$

(milhares)

$\mathbf{7 8 6 . 4 0}$
Áreas protegidas e de conservação em Moçambique em Categorias de Gestão da UICN

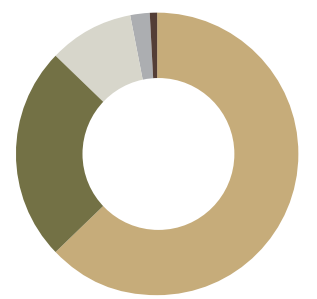

Não Atribuído (No. 2)

Não Reportado (No. 29)

VI. Área Protegida com Utilização

Sustentável dos Recursos Naturais (No. 3)

IV. Habitat / Gestão de Espécies (No. 4)

II. Parque Nacional (No. 6)

\section{1 espécies de animais terrestres}

Fonte: UNEP-WCMC \& UICN (2019n).

\section{Cobertura de áreas protegidas em Moçambique}

\begin{tabular}{l|r|r}
\hline Tipo de área protegida & $\begin{array}{r}\text { Área } \\
\text { protegida ou } \\
\text { conservada* }\end{array}$ & $\begin{array}{r}\text { Área } \\
\text { protegida ou } \\
\text { conservada** }\end{array}$ \\
\hline Águas terrestres e interiores & $21.57 \%$ & $26.00 \%$ \\
\hline Litoral e marinho & $2.23 \%$ & $\begin{array}{r}\text { Não } \\
\text { Encontrado }\end{array}$ \\
\hline
\end{tabular}

*WDPA dataset $\quad$ ** Do Relatório Nacional sobre Biodiversidade

Fonte: Ministério para a Coordenação dos Assuntos Ambientais, República de Moçambique (2014; UNEP-WCMC \& UICN (2019n)

Áreas protegidas e de conservação designadas como sítios globais de importância em Moçambique

\begin{tabular}{l|r}
\hline Designação global & No. de sítios \\
\hline $\begin{array}{l}\text { Zonas húmidas de importância internacional } \\
\text { (sítios Ramsar) }\end{array}$ & 2 \\
\hline
\end{tabular}

Fonte: Ramsar (2019); UNESCO (2019a, 2019b)

Áreas protegidas e de conservação em Moçambique nos tipos de governação da UICN

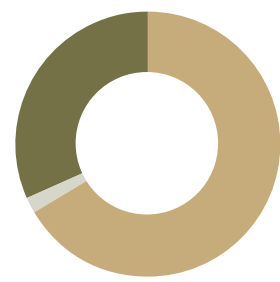

Não reportado (No. 14)

D. Governação pelos povos indígenas e comunidades locais (No. 1)

B. Governação Partilhada (No. 1)

A. Governação pelo Governo (No. 28)
Designações nacionais de áreas protegidas e de conservação em Moçambique

\begin{tabular}{l|r|r}
\hline Designação nacional & No. & Área $\left(\mathbf{k m}^{2} \mathbf{)}\right.$ \\
\hline Parque Nacional & 6 & 33569 \\
\hline Reserva de caça & 2 & 1683 \\
\hline Reserva Nacional & 2 & 44981 \\
\hline Reserva Especial & 1 & 1040 \\
\hline Reserva de caça & 14 & 38887 \\
\hline Reserva Natural & 1 & 1 \\
\hline Reserva Faunal & 1 & 20 \\
\hline Reserva Florestal & 13 & 5286 \\
\hline Área de Protecção Ambiental & 1 & 24589 \\
\hline Não Reportado & 1 & 1148 \\
\hline
\end{tabular}

Fonte: UNEP-WCMC \& UICN (2019n).

\section{Áreas prioritárias para a conservação}

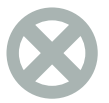

\section{4 sítios}

16 sítios

Aliança para os sítios

de Extinção Zero

Áreas importantes de

Aves \& Biodiversidade
11 sítios

Áreas-chave da

Biodiversidade 
Novas espécies foram descobertas em Moçambique como resultado de novos estudos científicos e expedições em locais anteriormente inacessíveis. Algumas das espécies foram identificadas por exemplo em Monte Inago e estas incluem: o camaleão pigmeu (Rhampholeon sp.), a borboleta (Cymothoe sp.), o carrangueijo de água doce (Potamonautes sp.) e possivelmente uma nova espécie (Encephalartos sp.).

O número de espécies ameaçadas mostra uma tendência para aumentar em Moçambique. Mais de 300 espécies de plantas estão na Lista Vermelha da UICN, 22\% das quais estão confirmadas como endémicas. Algumas espécies de Encefalartos que merecem atenção incluem a cycad (Encephalartos munchii) e a cycad (E. pterogonus). Por outro lado, a cicada-Jozini (E. senticosus) está criticamente ameaçada e a cicada-Libombo (E. lebomboensis), a cicada-Umbeluzi (E. umbeluziensis) e a cicada-Chimanimani (E. chimanimaniensis) estão ameaçadas.

Os mamíferos mais ameaçados em Moçambique incluem o rinoceronte branco (Ceratotherium simum), o tsessebe comum (Damaliscus lunatus), a sitatunga (Tragelaphus spekei), o rinoceronte preto (Diceros bicornis), a girafa (Giraffa camelopardalis), o reedbuck (Redunca fulvorufula) e a chita (Acinomyx jutabus). O rinoceronte branco, a girafa e o palapala cinzento foram reintroduzidos no Parque Nacional Limpopo e as girafas foram reintroduzidas na Reserva Nacional de Maputo.

Moçambique é também o lar de muitas espécies de aves ameaçadas, bem como de tartarugas marinhas e dugongos. A revista Nature Science está actualmente a realizar investigação em ecossistemas marinhos nas províncias de Inhambane, Zambézia e Nampula que ajudará a ANAC a estabelecer uma base de dados sobre a ocorrência de espécies marinhas em Moçambique.

\section{Pressões e ameaças ${ }^{72}$}

As principais ameaças imediatas à biodiversidade são: conversão de terras, perda e fragmentação de ecossistemas naturais, habitats e espécies por factores antropogénicos; exploração excessiva de certas espécies; invasão por espécies não nativas que danificam ecossistemas e espécies nativas; poluição ou contaminação por produtos químicos de habitats ou espécies de ecossistemas naturais; queimadas florestais descontroladas e alterações climáticas que danificam habitats ou espécies naturais, desenvolvimento e catástrofes naturais.

\section{Figura 8.26 Áreas Protegidas de Moçambique}

Áreas protegidas

Limite Administrativo

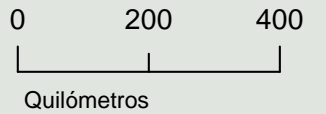

Desenvolvido por RCMRD baseados nos dados WDPA.

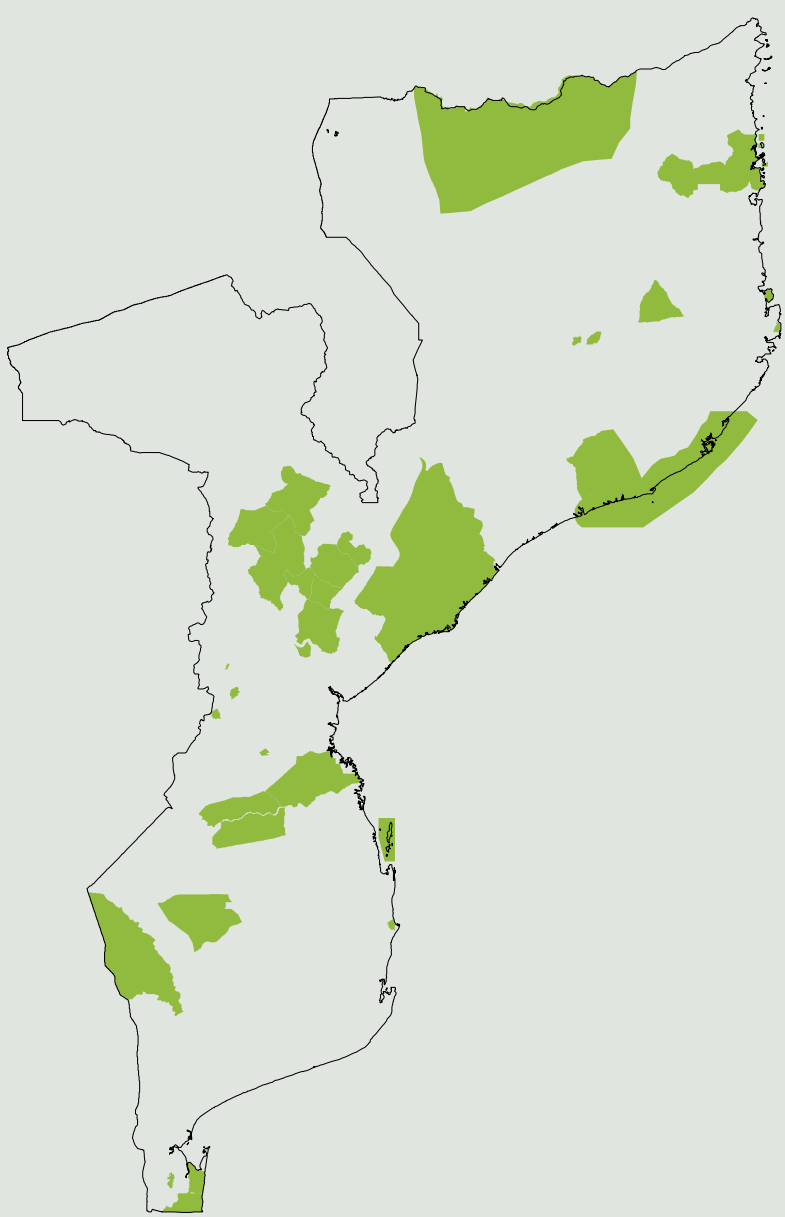

$\mathbf{N}$ 

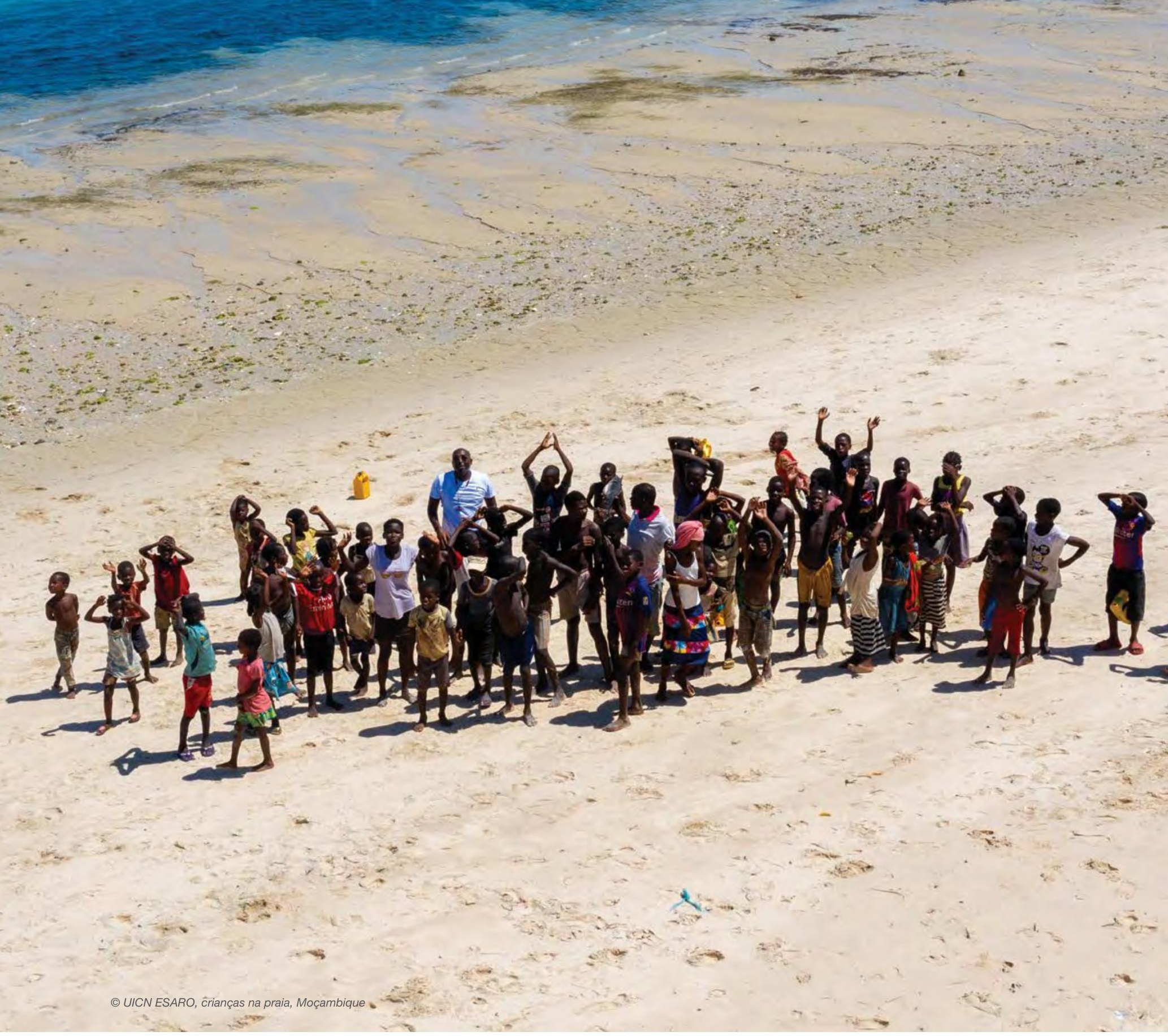


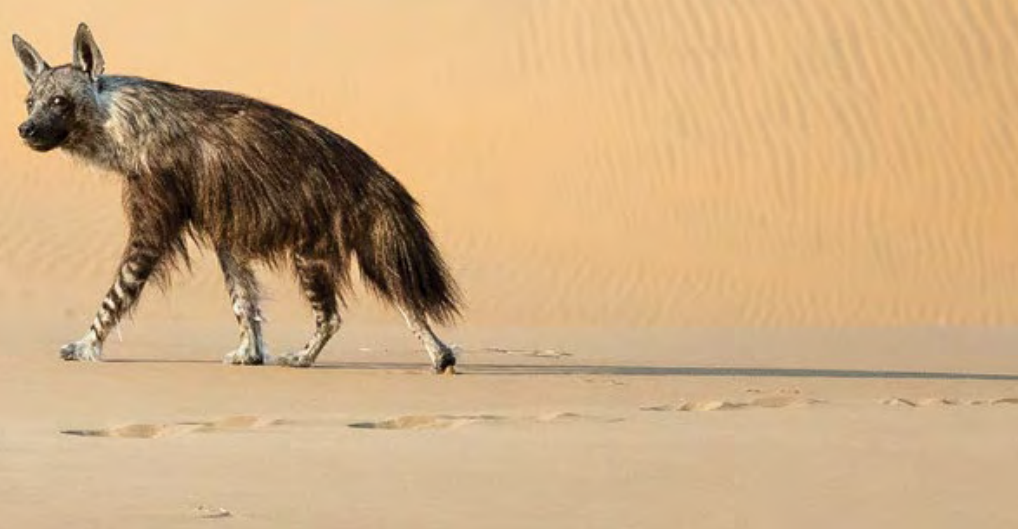

\subsection{Namibia}

\section{Áreas protegidas e de conservação na Namíbia ${ }^{73}$}

A Namíbia tem 148 áreas protegidas cobrindo $313.534 \mathrm{~km}^{2}$ da terra e $9.646 \mathrm{~km}^{2}$ do oceano (UNEP-WCMC \& UICN, 2019o).

Para proteger a sua rica biodiversidade, a Namíbia estabeleceu um sistema de 21 áreas protegidas geridas pelo Estado com o objectivo de proteger e conservar a diversidade biológica, e também de gerar receitas muito necessárias através do turismo. Estas áreas protegidas estão a ser complementadas por uma forte gestão dos recursos naturais baseada na comunidade através de conservas comunitárias. Notavelmente, toda a linha costeira da Namíbia está protegida. A Namíbia tem um rico ecossistema marinho, como resultado do sistema de afloramento de Benguela, que traz as águas ricas em nutrientes de cerca de 200-300 m de profundidade e alimenta altas taxas de crescimento do fitoplâncton, tornando-a num dos ecossistemas marinhos mais produtivos do mundo.

\section{Áreas transfronteiriças protegidas e de conservação}

A Namíbia inclui parte de três áreas de conservação transfronteiriças, nomeadamente /Ai/Ais-Richtersveld TFCA, Iona Costa dos Esqueletos TFCA e a Kavango Zambezi TFCA.

\section{Contexto politico}

Um relatório abrangente sobre legislação e política relacionada com a gestão de áreas protegidas, governação, e equidade foi levado a cabo pelo programa BIOPAMA. Foram identificadas 31 leis e políticas relevantes na Namíbia (Tessema, 2019).

\section{Espécies-chave ${ }^{74}$}

Embora a Namíbia tenha tido geralmente um número relativamente menor de espécies em comparação com os países com climas mais húmidos, tem um elevado nível de endemismo, particularmente entre plantas, invertebrados, répteis e sapos. A Namíbia alberga 50 espécies de anfíbios (12 endémicos), 618 espécies de aracnídeos (11 endémicos), 592 espécies de aves (2 endémicas), 114 espécies de peixes (8 endémicas), mais de 6.400 espécies de insectos (24 endémicas), 229 espécies de mamíferos (7 endémicas), mais de 4.000 espécies de plantas (14 endémicas), e 254 espécies de répteis (28 endémicas).

\section{Pressões e ameaças ${ }^{75}$}

As principais ameaças à biodiversidade na Namíbia são: uso insustentável da água (irrigação em larga escala, poluição, represas e captação excessiva de águas subterrâneas); impactos das alterações climáticas (aumento de secas e inundações, mudanças na distribuição das espécies, e impactos nos ecossistemas vulneráveis); indústrias extractivas (expansão da mineração e prospecção em áreas ecologicamente sensíveis); gestão insustentável da terra (erosão do solo, degradação da terra, desflorestação e invasão do mato); espécies exóticas invasoras; colheita e comércio ilegais de recursos faunísticos e vegetais; conflitos entre seres humanos e animais selvagens; e incêndios incontrolados de mato.

Muitas destas ameaças são impulsionadas pela expansão das áreas urbanas e pela crescente industrialização, levando a uma crescente procura de recursos e serviços e aumentando os tipos e volumes de resíduos e poluição. 
Figura 8.27 Resumo da Namíbia

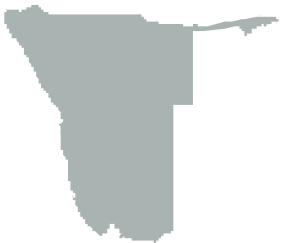

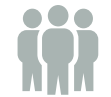

População Total (milhões)

2.45

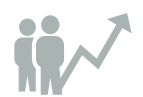

Crescimento da população (\% anual) 1.90

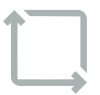

Superfície $\left(\mathrm{km}^{2}\right)$ (milhares)

824.30

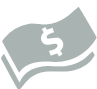

GDP (actuais US\$) (bilhões)

14.52

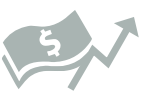

Crescimento do GDP (\% anual) $-0.10$

Fonte: The World Bank Group, 2018.

Área Protegida:

\section{8 áreas protegidas}

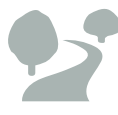

cobrindo 313534 km$^{2}$ de terra

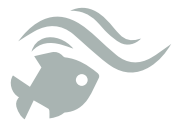

cobrindo

9646 km² $^{2}$ de oceano

Fonte: UNEP-WCMC \& UICN, 20190

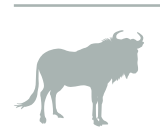

229 espécies de mamíferos

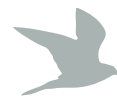

592

espécies de aves
254

espécies de répteis

Áreas protegidas e de conservação na Namíbia em Categorias de Gestão da UICN

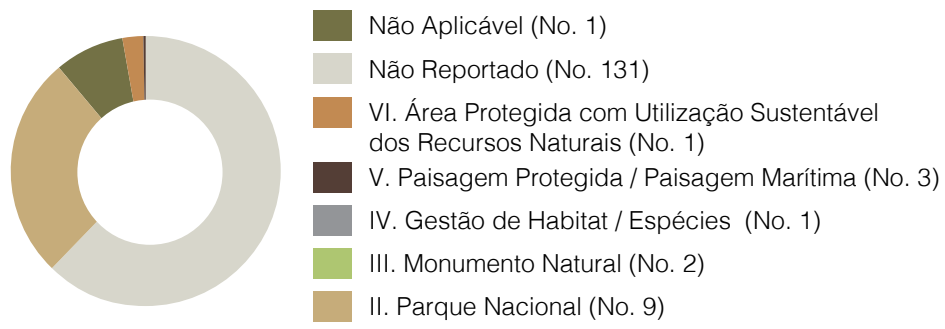

Fonte: UNEP-WCMC \& UICN (2019o).

\section{Cobertura de áreas protegidas na Namíbia}

\begin{tabular}{l|r|r}
\hline Tipo de área protegida & $\begin{array}{r}\text { Área } \\
\text { protegida ou } \\
\text { conservada* }\end{array}$ & $\begin{array}{r}\text { Área } \\
\text { protegida ou } \\
\text { conservada** }\end{array}$ \\
\hline Águas terrestres e interiores & $\mathbf{3 7 . 8 9 \%}$ & $\mathbf{1 7 . 0 0 \%}$ \\
\hline \multicolumn{2}{|c|}{$\mathbf{1 . 7 1 \%}$} & - \\
\hline "Witoral e marinho & "WDPA dataset Do Relatório Nacional sobre Biodiversidade de 2014 \\
Fonte: Ministério do Ambiente e Turismo, República da Namibia (2014); UNEP-WCMC \& \\
UICN (20190).
\end{tabular}

Áreas protegidas e de conservação designadas como sítios globais de importância na Namíbia

\begin{tabular}{l|r}
\hline Designação global & No. de sítios \\
\hline $\begin{array}{l}\text { Sítios Património Mundial da UNESCO } \\
\text { (Natural ou Misto) }\end{array}$ & 1 \\
\hline $\begin{array}{l}\text { Zonas húmidas de importância internacional } \\
\text { (sítios Ramsar) }\end{array}$ & 5 \\
\hline
\end{tabular}

Fonte: Ramsar (2019); UNESCO (2019a, 2019b).

Áreas protegidas e de conservação em Namíbia nos tipos de governação da UICN

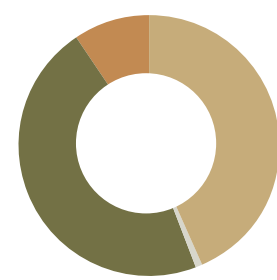

Não reportado (No. 3)

D. Governação pelos Povos Indígenas e

Comunidades Locais (No. 112)

C. Governação Privada (No. 2)

A. Governação pelo Governo (No. 31)
Designações nacionais de áreas protegidas e servidas na Namíbia

\begin{tabular}{l|r|r}
\hline Designação nacional & No. & Área $\left.\mathbf{( k m}^{2}\right)$ \\
\hline Reserva Privada & 2 & 2887 \\
\hline Floresta Comunitária & 33 & 31998 \\
\hline Parque Nacional & 19 & 137446 \\
\hline Área Marítima Protegida & 1 & 9492 \\
\hline Conservância Comunal & 79 & 160425 \\
\hline Concessão & 7 & 14535 \\
\hline Reserva Florestal & 1 & 1485 \\
\hline
\end{tabular}

Fonte: UNEP-WCMC \& UICN (2019o).

\section{Áreas prioritárias para a conservação}

\section{9 sítios}

Áreas importantes de Aves \& Biodiversidade

Fonte: BirdLife International (2019c). 


\section{Figura 8.28 Áreas Protegidas da Namibia}
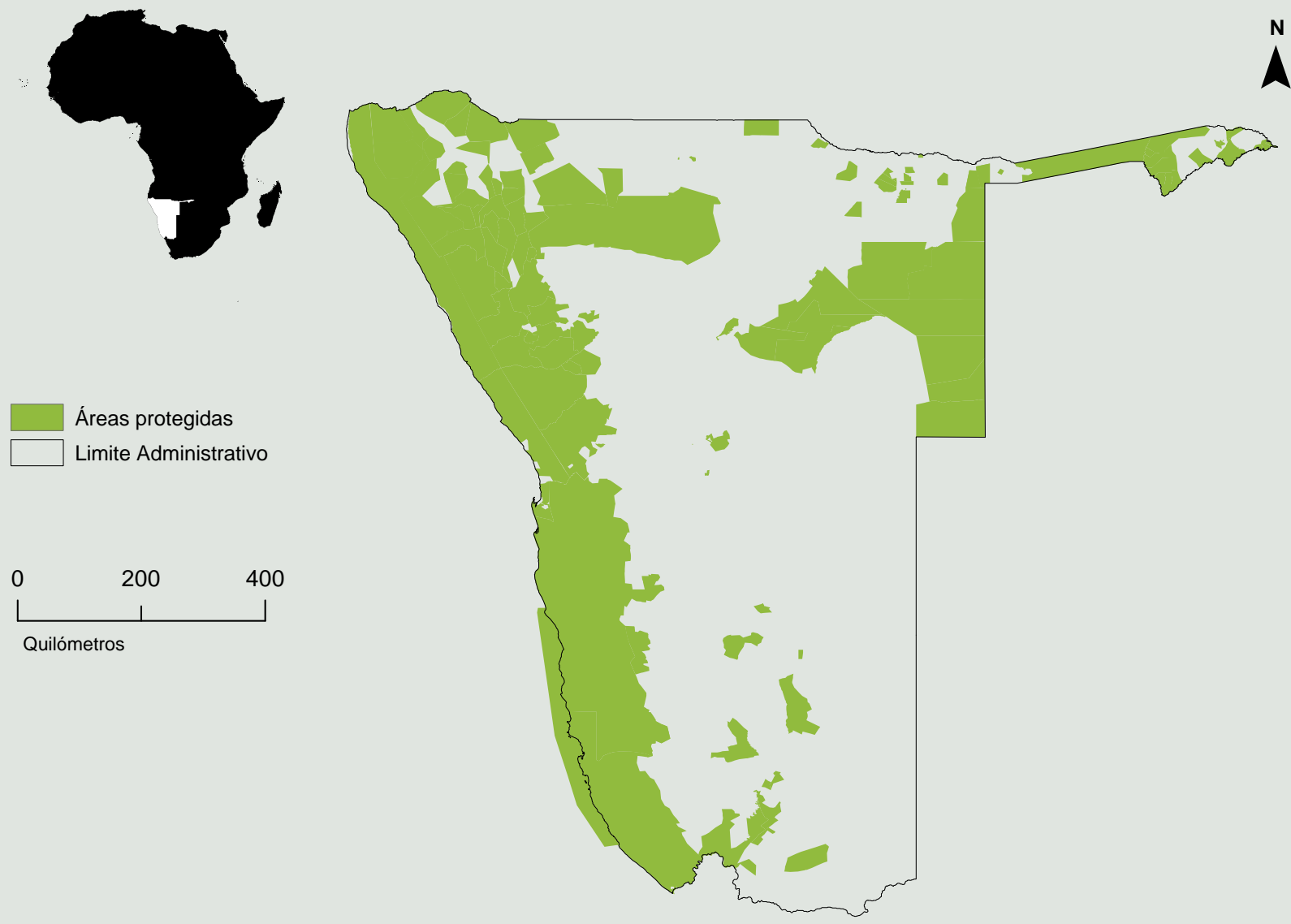

Desenvolvido por RCMRD baseado nos dados WDPA.

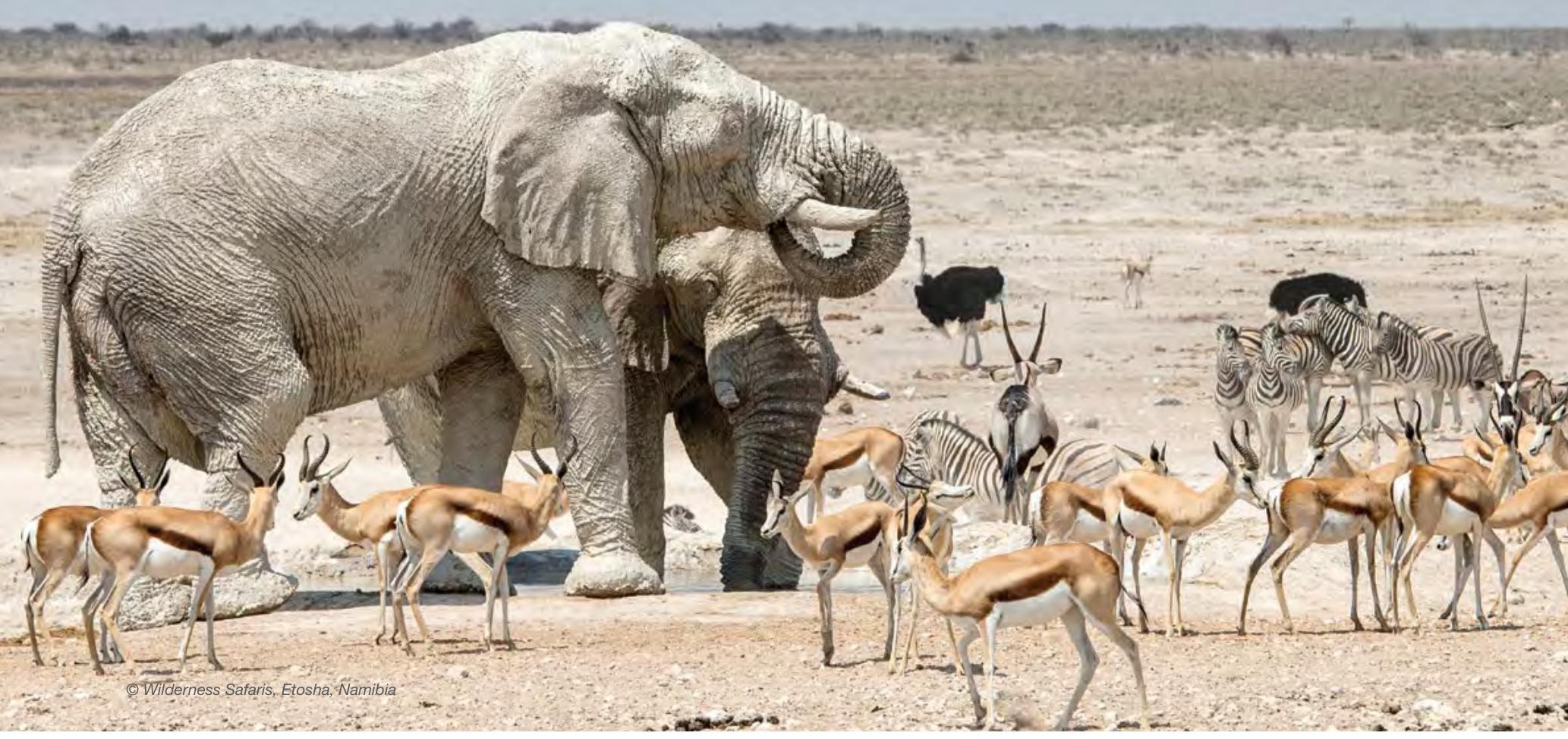




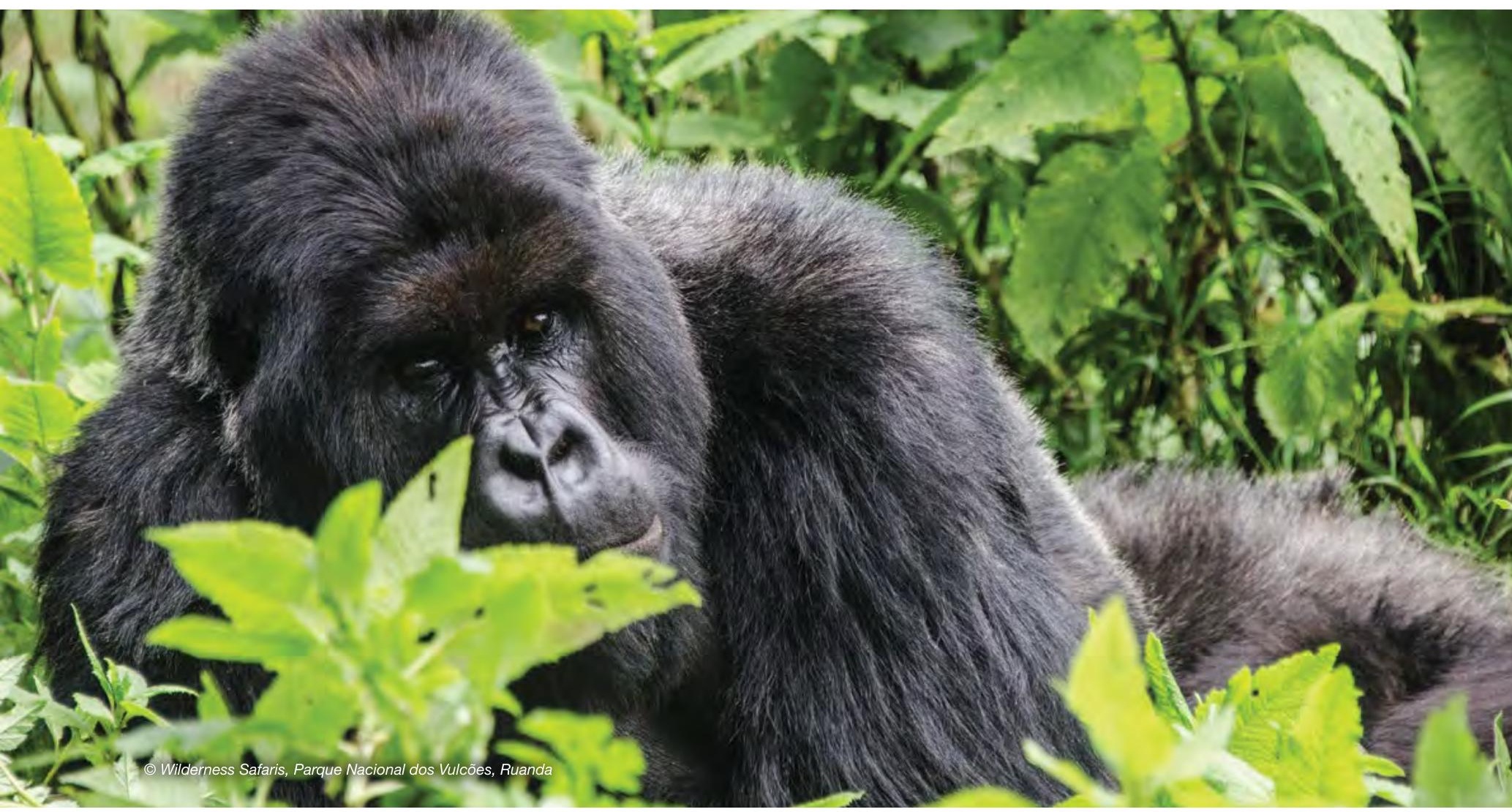

\subsection{Ruanda}

\section{Áreas protegidas e de conservação em Ruanda ${ }^{76}$}

Ruanda tem 10 áreas protegidas cobrindo $2320 \mathrm{~km}^{2}$ da terra (UNEP-WCMC \& UICN, 2019p).

A maioria das ecorregiões nacionais do país estão sob protecção, em particular as zonas húmidas que são reconhecidas como santuários da rica diversidade biológica. Uma análise do hiato ecológico do Ruanda tem vindo a identificar novos sítios a serem designados como áreas protegidas. O Akagera Parque Nacional é gerido através de uma parceria pública-privada com Parques Africanos.

\section{Áreas transfronteiriças protegidas e de conservação}

Ruanda inclui parte de três áreas de conservação transfronteiriças, nomeadamente Greater Virunga Landscape, Kagera TFCA, e Nyungwe-Kibira.

\section{Contexto politico}

Um relatório abrangente sobre legislação e política relacionada com a gestão de áreas protegidas, governação, e equidade foi levado a cabo pelo programa BIOPAMA. Identificou 47 leis e políticas relevantes no Ruanda (Tessema, 2019).

\section{Espécies-chave ${ }^{77}$}

A biodiversidade está altamente ameaçada devido às elevadas populações humanas e às pressões associadas sobre os recursos naturais. Dentro das áreas protegidas, incluindo parques nacionais e florestas, a biodiversidade está bem protegida, e representa um conjunto diversificado de ecossistemas. Ruanda é o lar do gorila de montanha (Gorilla beringei beringei), uma população partilhada com a República Democrática do Congo e Uganda que tem mostrado um aumento significativo da dimensão da população. O Akagera Parque Nacional foi submetido a um intenso esforço de restauração. A diversidade de aves do Ruanda é muito rica, particularmente porque existem muitos habitats diversos em todo o país. Os sistemas de água doce são também o lar de uma diversidade de espécies de peixes, incluindo algumas endémicas.

\section{Pressões e ameaças ${ }^{78}$}

As ameaças à biodiversidade no Ruanda incluem: a caça furtiva e outras actividades ilegais; incêndios; espécies invasoras alienígenas; desflorestação; mineração; pastagem ilegal; barragens; descida dos níveis de água; pesca insustentável; falta de conectividade; uso turístico insustentável e desenvolvimento de infra-estruturas; invasão de zonas húmidas; e poluição. O Ruanda tem uma densidade populacional humana muito elevada, o que coloca uma pressão crescente sobre os recursos naturais disponíveis. 
Figura 8.29 Resumo do Ruanda

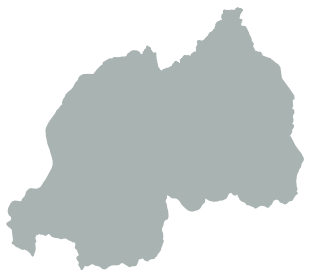

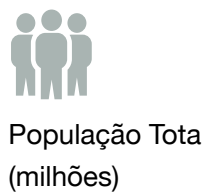

12.30

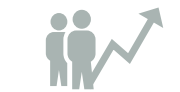

Crescimento da população (\% anual) 2.60

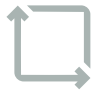

Superfície $\left(\mathrm{km}^{2}\right)$ (milhares)

26.30

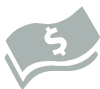

GDP (actuais US\$) (bilhões)

9.51
Crescimento do GDP (\% anual)

8.70

Source: The World Bank Group, 2018.

\section{Área Protegida:}

10 áreas protegidas
Áreas protegidas e de conservação em Ruanda em Categorias de Gestão da UICN

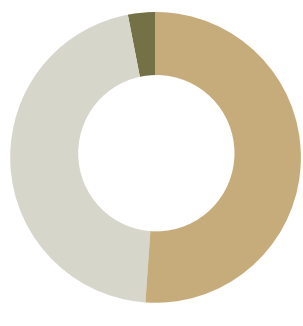

Fonte: UNEP-WCMC \& UICN (2019p).
Não reportado (No. 2)

IV. Habitat / Gestão de Espécies (No. 3)

II. Parque Nacional (No. 4)

Fonte: UNEP-WCMC \& UICN, (2019p)

2320 km $^{2}$

de terra

\section{Cobertura de áreas protegidas em Ruanda}

\begin{tabular}{l|r|r}
\hline Tipo de área protegida & $\begin{array}{r}\text { Área } \\
\text { protegida ou } \\
\text { conservada* }\end{array}$ & $\begin{array}{r}\text { Área } \\
\text { protegida ou } \\
\text { conservada** }\end{array}$ \\
\hline Águas terrestres e interiores & $9.11 \%$ & $10.10 \%$ \\
\hline
\end{tabular}

*WDPA dataset $\quad$ **Do Relatório Nacional sobre Biodiversidade

Fonte: República de Ruanda (2014); UNEP-WCMC \& UICN (2019p).

Designações nacionais de áreas protegidas e de conservação em Ruanda

\begin{tabular}{l|r|r}
\hline Designação nacional & No. & \multicolumn{2}{|l}{ Área (km²) } \\
\hline Outra Área & 3 & 308 \\
\hline Parque Nacional & 3 & 2201 \\
\hline Reserva Florestal & 2 & 34 \\
\hline
\end{tabular}

Fonte: UNEP-WCMC \& UICN (2019p).

Áreas protegidas e de conservação em Ruanda nos tipos de governação da UICN

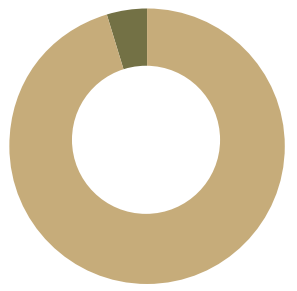

Não reportado (No. 7)

A.Governação pelo Governo (No. 3)
Áreas protegidas e de conservação designadas como sítios globais de importância em Ruanda

\begin{tabular}{l|r}
\hline Designação global & No. de sítios \\
\hline Reservas do Homem e da Biosfera da UNESCO & 1 \\
\hline $\begin{array}{l}\text { Zonas húmidas de importância internacional } \\
\text { (sítios Ramsar) }\end{array}$ & 1 \\
\hline
\end{tabular}

Fonte: Ramsar (2019; UNESCO (2019a, 2019b).

\section{Áreas prioritárias para a conservação}

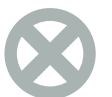

\section{2 sítios}

7 sítios

Aliança para os sítios Áreas importantes de de Extinção Zero

Aves \& Biodiversidade

14 sítios

Áreas-chave da

Biodiversidade

Fonte: Secretariado AZE (2019); BirdLife International (2019b, 2019c)

Fonte: UNEP-WCMC \& UICN (2019p). 


\section{Figura 8.30 Áreas Protegidas do Ruanda}

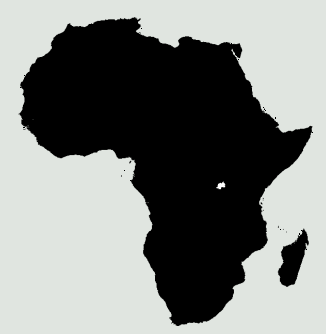

Áreas protegidas

Limite Administrativo

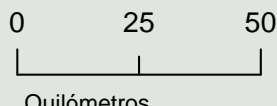

Quilómetros

\section{0}

Desenvolvido por RCMRD baseados nos dados WDPA. 


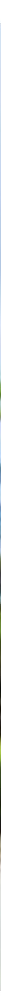

\subsection{Seychelles}

\section{Áreas protegidas e de conservação em Seychelles ${ }^{79}$}

As Seychelles têm 40 áreas protegidas cobrindo $242 \mathrm{~km}^{2}$ da terra e 209,930 $\mathrm{km}^{2}$ do oceano (UNEP-WCMC \& UICN, 2019q).

Uma grande parte da área terrestre das Seychelles está protegida. As Seychelles têm uma das mais antigas redes de áreas marinhas protegidas da África Oriental, mas até recentemente, esta cobria apenas cerca de $0,03 \%$ dos seus ecossistemas costeiros e marinhos. O défice foi reconhecido, e o Governo das Seychelles anunciou a sua intenção de proteger $30 \%$ das suas águas, metade das quais (ou 15\%) seria uma zona rigorosa de não captura. O Governo das Seychelles está empenhado num mecanismo de troca de dívidas para permitir esta designação.

\section{Áreas transfronteiriças protegidas e de conservação}

As Seychelles incluem parte do Parque Marítimo Transfronteiriço do Oceano Índico Ocidental.

\section{Contexto politico}

Um relatório abrangente sobre legislação e política relacionada com a gestão de áreas protegidas, governação, e equidade foi levado a cabo pelo programa BIOPAMA. Identificou 28 leis e políticas relevantes nas Seychelles (Tessema, 2019).

\section{Espécies-chave ${ }^{80}$}

As espécies marinhas e costeiras são economicamente importantes para as Seychelles, e a diversidade e abundância de espécies tem sido influenciada pelos padrões de colheita dos últimos dois séculos. O relatório nacional do país fornece dados em grande detalhe sobre as espécies marinhas e costeiras, incluindo as tendências actuais e os esforços de conservação. As Seychelles são o lar de vários cetáceos diferentes, assim como de cinco espécies de tartarugas marinhas.

Em termos de biodiversidade terrestre e de águas interiores, a diversidade fúngica é pouco conhecida, mas o país tem elevados níveis de diversidade em espécies invertebradas, assim como em plantas. Os níveis de endemismo são elevados entre a maioria dos grupos. De 11 espécies anfíbias registadas e duas serpentes, todas são endémicas. A tartaruga gigante Aldabra (Aldabrachelys gigantea) é endémica para o país. Nas Seychelles vivem pelo menos 65 espécies de aves, das quais 13 são endémicas. Todos os mamíferos nativos das Seychelles são morcegos, dos quais existem seis espécies (quatro endémicas).

\section{Pressões e ameaças ${ }^{81}$}

A principal ameaça aos ecossistemas terrestres são as contínuas incursões de espécies invasoras alienígenas. Com elevados níveis de endemismo, as ilhas são particularmente susceptíveis aos impactos das espécies invasoras. A ameaça secundária é a alteração do uso da terra e a perda de habitat, onde as pressões do desenvolvimento estão a ameaçar muitos habitats. A principal ameaça nos ecossistemas marinhos é a sobrepesca, que tem impactos para além das espécies visadas. As alterações climáticas representam uma grande ameaça tanto para os ecossistemas terrestres como marinhos.

7 A secção baseia-se nas informações contidas no Quinto Relatório Nacional das Seychelles ao CBD e ao NBSAP (Governo das Seychelles, 2014b; 2014a)

80 A secção baseia-se nas informações contidas no Quinto Relatório Nacional das Seychelles ao CBD (Governo das Seychelles, 2014a)

81 A secção baseia-se na informação contida no Segundo NBSAP das Seychelles (Governo das Seychelles, 2014b). 
Figura 8.31 Resumo das Seychelles

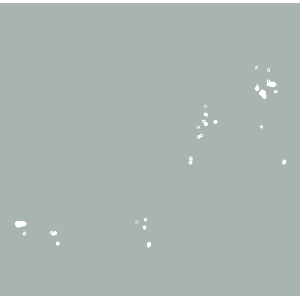

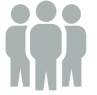

População Total (milhões)

0.10

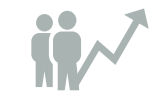

Crescimento da população (\% anual) 1.00

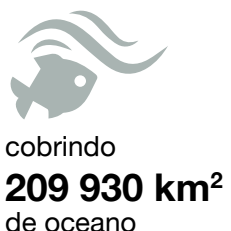

de oceano

\section{Área Protegida:}

40 áreas protegidas

cobrindo 242 km $^{2}$

de terra

Fonte: UNEP-WCMC \& UICN, 2019q

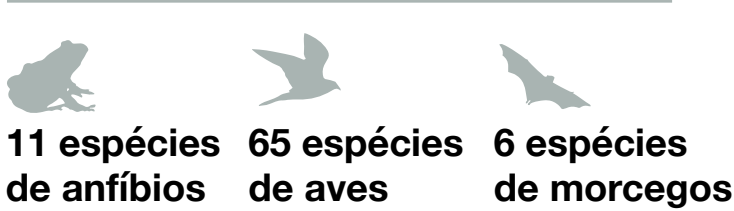

Áreas protegidas e de conservação nas Seychelles em Categorias de Gestão da UICN

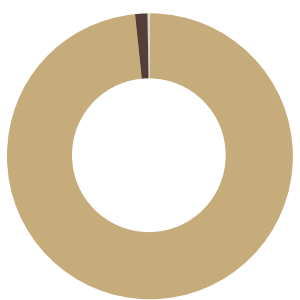

Não Aplicável (No. 2)

Não Reportado (No. 18)

VI. Área Protegida com Utilização Sustentável dos Recursos Naturais (No. 6)

II. Parque Nacional (No. 8)

lb. Área Selvagem (No. 1)

la. Reserva Natural Estrita (No. 5)
Crescimento do GDP (\% anual) 3.60

Fonte: UNEP-WCMC \& UICN (2019q).

Cobertura de áreas protegidas nas Seychelles

\begin{tabular}{l|r|r}
\hline Tipo de área protegida & $\begin{array}{r}\text { Área } \\
\text { protegida ou } \\
\text { conservada* }\end{array}$ & $\begin{array}{r}\text { Área } \\
\text { protegida ou } \\
\text { conservada** }\end{array}$ \\
\hline $\begin{array}{l}\text { Águas terrestres e } \\
\text { interiores }\end{array}$ & $49.64 \%$ & $46.60 \%$ \\
\hline Litoral e marinho & $15.66 \%$ & $0.03 \%$ \\
\hline
\end{tabular}

* WDPA dataset $\quad$ ** Do Relatório Nacional sobre Biodiversidade

Fonte: Governo de Seychelles (2014a); UNEP-WCMC \& UICN (2019q).

Áreas protegidas e de conservação designadas como sítios globais de importância nas Seychelles

\begin{tabular}{l|r}
\hline Designação global & No. de sítios \\
\hline $\begin{array}{l}\text { Sítios Património Mundial da UNESCO } \\
\text { (Natural ou Misto) }\end{array}$ & 2 \\
\hline $\begin{array}{l}\text { Zonas húmidas de importância } \\
\text { internacional (sítios Ramsar) }\end{array}$ & 4 \\
\hline
\end{tabular}

Source: Ramsar (2019); UNESCO (2019a, 2019b).

Áreas protegidas e de conservação das Seychelles nos tipos de governação da UICN

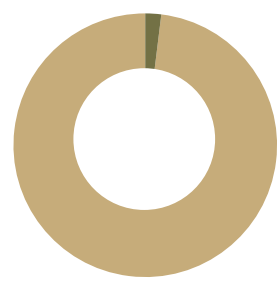

Não Reportado (No. 20)

A.Governação pelo Governo (No. 20)

Designações nacionais de áreas protegidas e de conservação nas Seychelles

\begin{tabular}{l|r|r}
\hline Designação nacional & No. & Área (km²) \\
\hline Parque Nacional & 4 & 55 \\
\hline Reserva Especial & 8 & 2436 \\
\hline Parque Nacional Marinho & 6 & 48 \\
\hline Reserva Natural & 9 & 0 \\
\hline MSP Zona 2 & 1 & 136717 \\
\hline MSP Zona 1 & 1 & 69524 \\
\hline Reserva de Conchas & 4 & 8 \\
\hline Área Protegida & 1 & 8 \\
\hline Fonte: UNEP-WCMC \& UICN (2019q). & &
\end{tabular}

\section{Áreas prioritárias para a conservação}

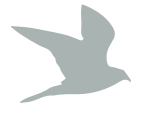

\section{2 sítios}

Aliança para os sítios de Extinção Zero

\section{0 sítios}

Áreas importantes de Aves \& Biodiversidade

\section{9 sítios}

Áreas-chave da

Biodiversidade 


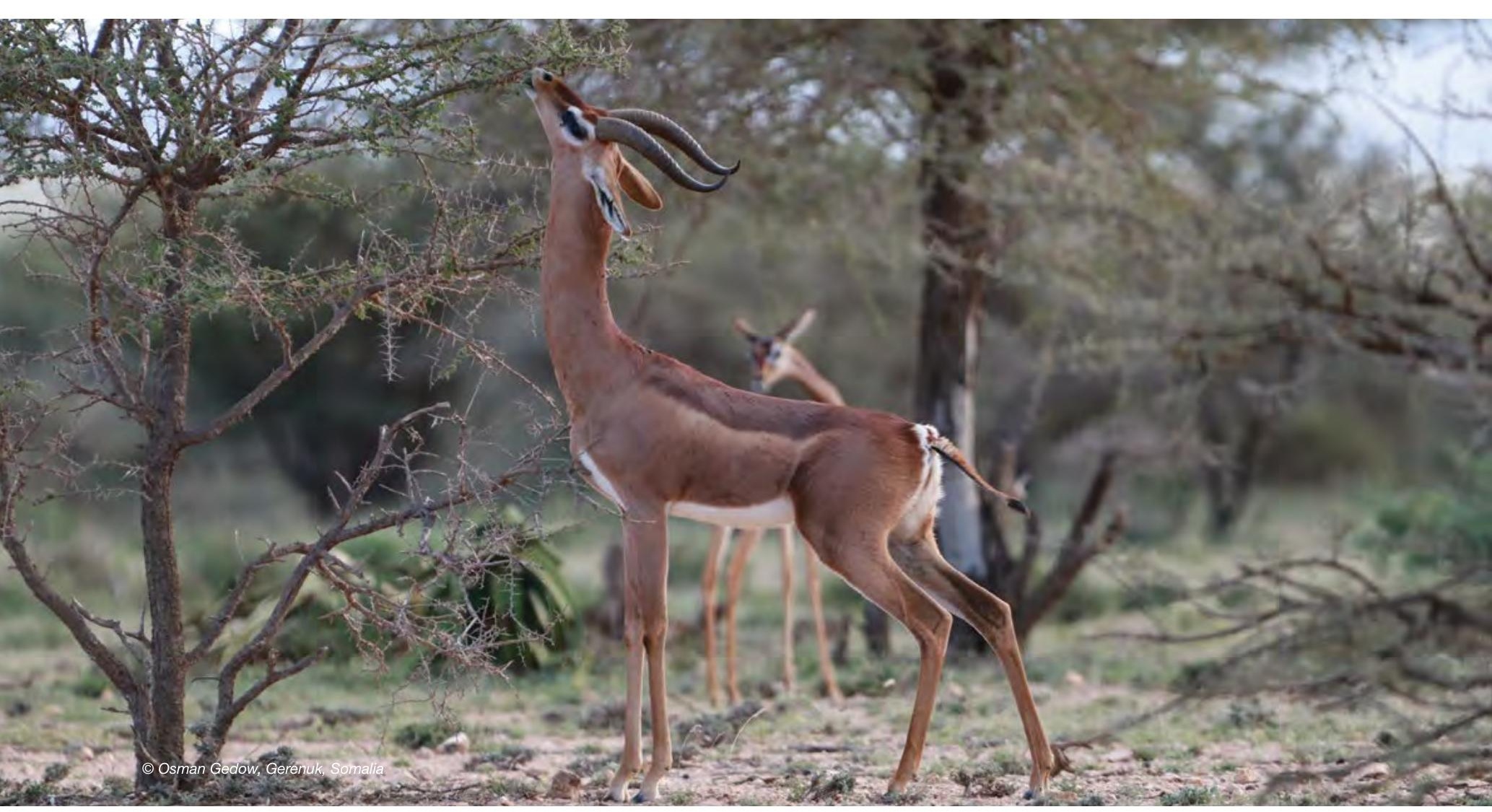

\subsection{Somália}

\section{Áreas protegidas e de conservação em Somália ${ }^{82}$}

A Somália tem 21 áreas protegidas. Estas são registos pontuais, sem área reportada, pelo que não é possível fornecer uma área para a cobertura destas áreas protegidas (UNEP-WCMC \& UICN, 2019r). Não tem havido uma gestão eficaz dos recursos da biodiversidade e uma protecção formal das áreas protegidas desde o colapso do governo central em 1991. A preocupação mais séria é a falta de legislação eficaz relativa à gestão das áreas protegidas e a ausência de uma infra-estrutura de conservação funcional. Onze áreas de vida selvagem foram declaradas desde os anos 70 , mas apenas duas foram consideradas como funcionais. Na prática, não tem sido oferecida qualquer protecção formal a nenhum destes sítios desde o início dos anos 90.

No ambiente marinho, foram propostas quatro áreas marinhas protegidas: a ilha Saad ad-Dim e Aibat na Somalilândia Ocidental perto de Zeila, uma cidade histórica; a ilha Maydh em Puntland com a vizinha floresta Daalo no continente; e Gara'ad na costa do Oceano Índico de Puntland. Esta última foi declarada como MPA em 2005 pela associação de pescadores local GARFISH. Saad-ad-din Island e Maydh Island são importantes zonas de reprodução de aves marinhas. Os recifes de coral da ilha Saad ad-Din representam os recifes mais diversos e bem formados da costa do Golfo de Aden.

\section{Áreas transfronteiriças protegidas e de conservação}

Somália inclui parte das áreas de conservação transfronteiriça Tana-Kipini-Laga Badana Bushbush Land e Seascape.

\section{Contexto político}

Um relatório abrangente sobre legislação e política relacionada com a gestão de áreas protegidas, governação, e equidade foi levado a cabo pelo programa BIOPAMA. Identificou 10 leis e políticas relevantes na Somália (Tessema, 2019).

\section{Espécies-chave ${ }^{83}$}

O endemismo no Corno de África, do qual a Somália faz parte, é elevado. Os estudos da diversidade de espécies na Somália têm sido pouco frequentes, mas acredita-se que seja o lar de mais de 175 espécies de mamíferos e 671 espécies de aves. Mais de 3.000 espécies de plantas foram registadas, 836 das quais se crê serem endémicas do país. A Somália tem 230 répteis únicos, $80 \%$ dos quais são endémicos da Somália, com 29 espécies de anfíbios. Há espécies adicionais da Somalilândia que não foram registadas.

O conhecimento das espécies marinhas e costeiras é baixo, embora estas estejam na base de muitas actividades económicas na costa.

2 A secção baseia-se na informação contida no Sexto Relatório Nacional da Somália à CDB (República da Somália, 2019).

83 A secção baseia-se na informação contida no Quinto Relatório Nacional da Somália à CBD (República Federal da Somália, 2014) 
Figura 8.33 Resumo da Somália

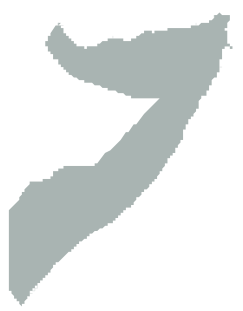

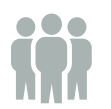

População Total (milhões)

15.01

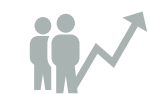

Crescimento da população (\% anual) 2.80

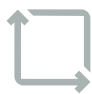

Superfície $\left(\mathrm{km}^{2}\right)$ (milhares) 637.70

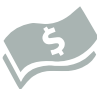

GDP (actuais US\$) (bilhões)

4.72
Crescimento do GDP (\% anual) $-1.50$

Fonte: The World Bank Group, 2018

Área Protegida:

Fonte: UNEP-WCMC \& UICN, 2019r
21 áreas protegidas
Áreas protegidas e de conservação em Somália em Categorias de Gestão da UICN

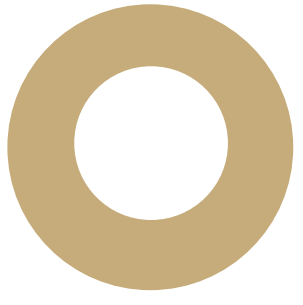

Fonte: UNEP-WCMC \& UICN (2019r)
Não Reportado (No. 21)

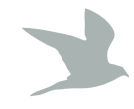

671 espécies de aves

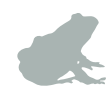

29 espécies de anfíbios
175 espécies de mamíferos
Área

\begin{tabular}{l|r|r}
\hline Tipo de área protegida & $\begin{array}{r}\text { Área } \\
\text { protegida ou } \\
\text { conservada* }\end{array}$ & $\begin{array}{r}\text { Área } \\
\text { protegida ou } \\
\text { conservada** }\end{array}$ \\
\hline Águas terrestres e interiores & $0.00 \%$ & $0.80 \%$ \\
\hline Litoral e marinho & $0.00 \%$ & $\begin{array}{r}\text { Não } \\
\text { Encontrado }\end{array}$ \\
\hline
\end{tabular}

*WDPA dataset $\quad$ ** Do Relatório Nacional sobre Biodiversidade

Fonte: República Federal da Somália (2014); UNEP-WCMC \& UICN (2019r

Áreas protegidas e de conservação na Somália nos tipos de governação da UIÇ

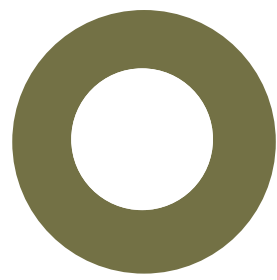

Governação pelo Governo (No. 21)

Fonte: UNEP-WCMC \& UICN (2019r).
Designações nacionais de áreas protegidas e de conservação na Somália

\begin{tabular}{l|r}
\hline Designação nacional & Número \\
\hline Parque Nacional & 12 \\
\hline Reserva de Vida Selvagem & 9 \\
\hline Fonte: UNEP-WCMC \& UICN (2019r).
\end{tabular}

Áreas prioritárias para a conservação

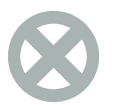

2 sítios

Aliança para os sítios de Extinção Zero

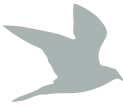

22 sítios

Áreas importantes de Aves \& Biodiversidade

\section{2 sítios}

Áreas-chave da

Biodiversidade 
Figura 8.34 Áreas Protegidas da Somália

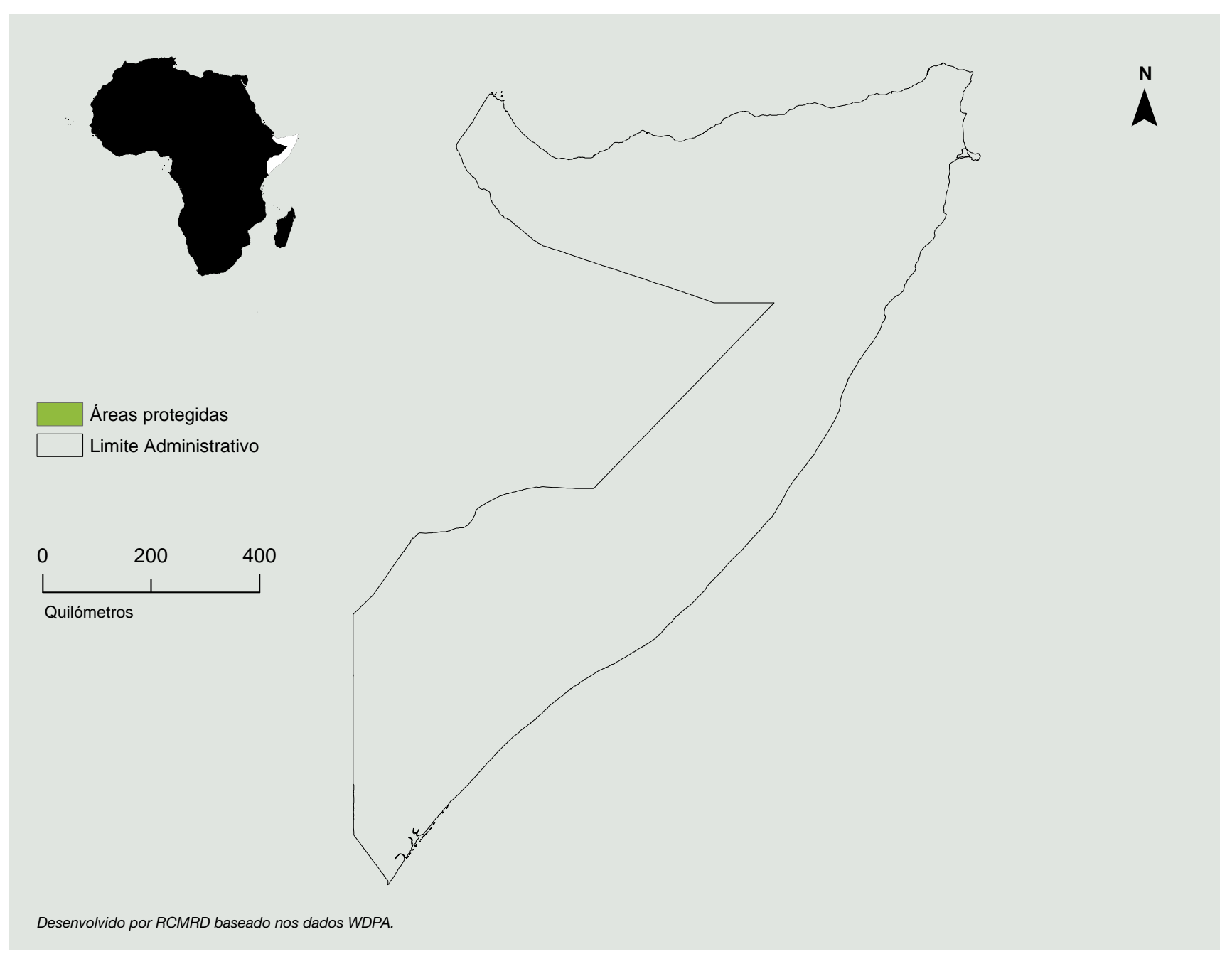

\section{Pressões e ameaças ${ }^{84}$}

As ameaças críticas à biodiversidade na Somália incluem: perda e degradação do habitat, desflorestação, pobreza, poluição, pressão política, alterações climáticas, conversão das florestas em agricultura e urbanização, colheita insustentável e espécies exóticas invasoras. Estas são sustentadas por factores indirectos, tais como pobreza, insegurança e conflito civil e falta de capacidade institucional para a conservação.

84 A secção baseia-se na informação contida no Quinto Relatório Nacional da Somália ao CBD (República Federal da Somália, 2014). 


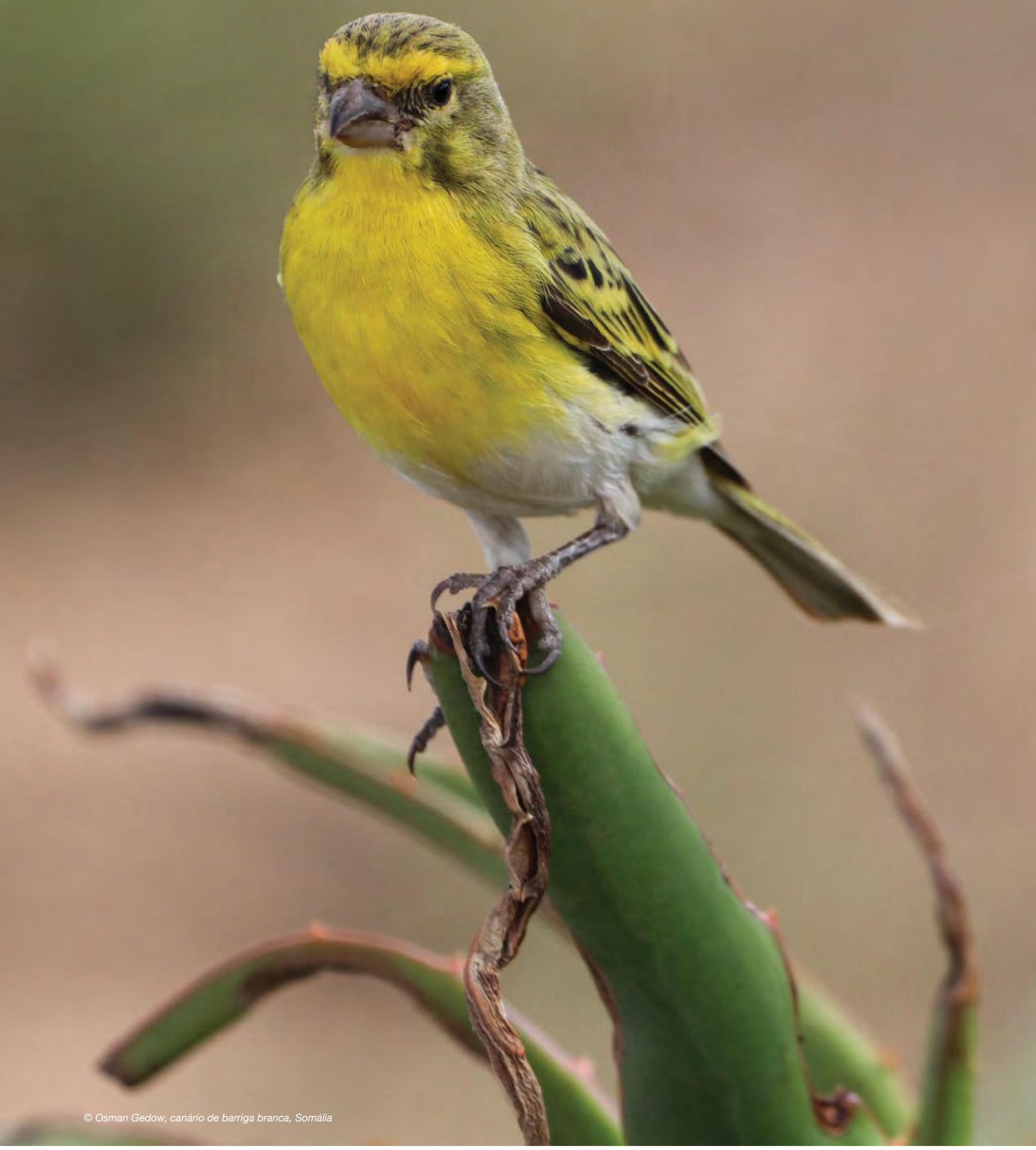




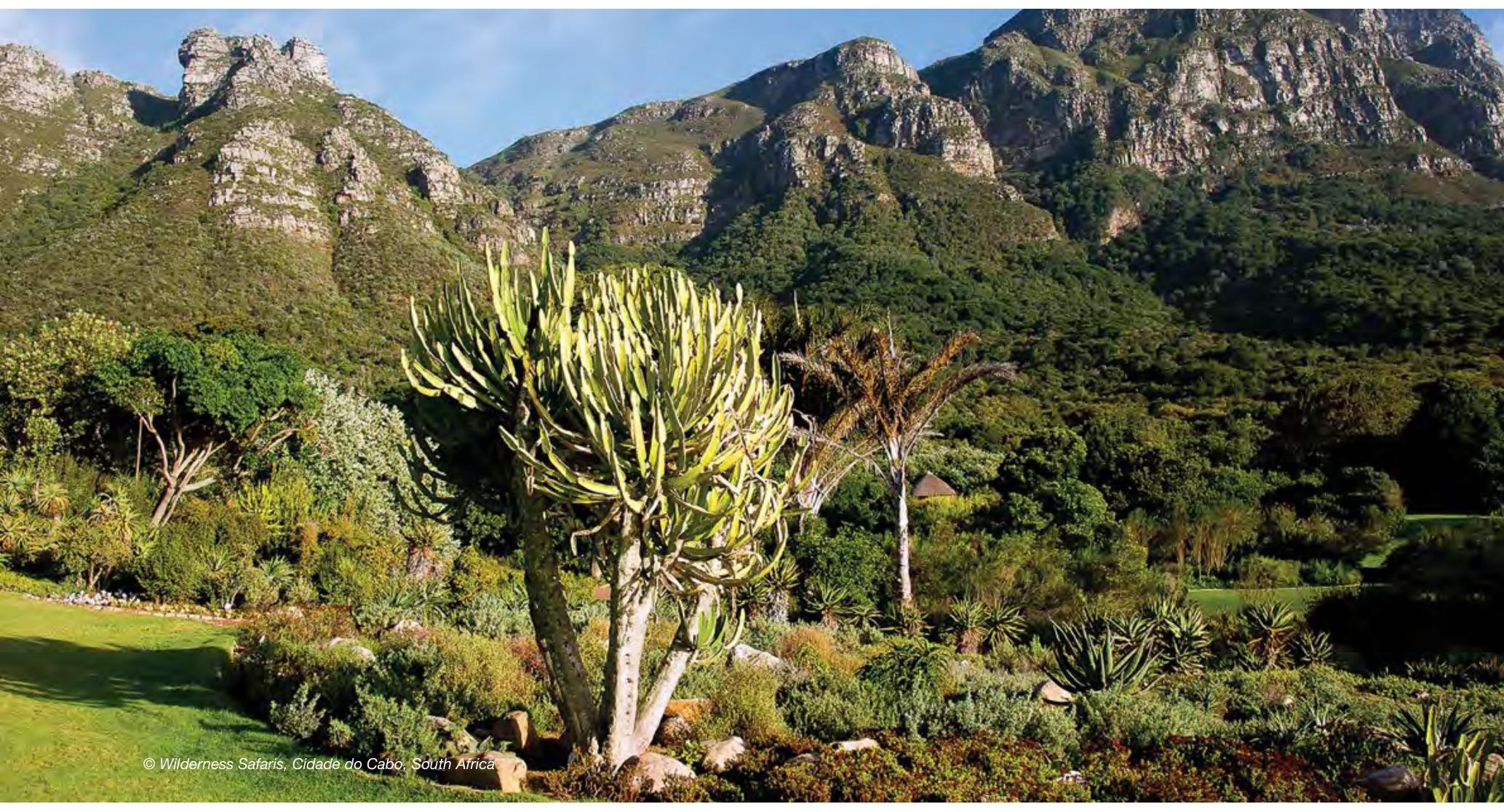

\subsection{8 África do Sul}

\section{Áreas protegidas e de conservação na África do $\mathrm{Sul}^{85}$}

África do Sul tem 1,580 áreas protegidas cobrindo $102.060 \mathrm{~km}^{2}$ da terra e 224,640 km² do oceano (UNEP-WCMC \& UICN, 2019s).

Em Outubro de 2018, o gabinete de África do Sul aprovou a declaração de 18 novas áreas protegidas, aumentando assim a rede de áreas protegidas. Existem nove autoridades provinciais de conservação e a Agência de Parques Nacionais da África do Sul que gerem as áreas protegidas e implementam a conservação da diversidade vegetal fora das reservas. O nível de protecção não está uniformemente distribuído pelos nove biomas da África do Sul, com alguns (deserto, floresta e fynbos) a terem mais de $17 \%$ da sua área protegida, enquanto os seis restantes têm todos muito menos de $17 \%$ da sua área protegida. Particularmente preocupantes são os biomas pastagem e Nama-Karoo, que têm menos de 5\% das suas áreas protegidas.

No que diz respeito ao ambiente marinho, os AMP em torno da África do Sul continental cobrem aproximadamente $0.4 \%$ da área marinha em torno da África do Sul. Existe também um grande AMP offshore em torno da Zona Económica Exclusiva das Ilhas Príncipe Eduardo. No conjunto, a área costeira e marinha protegida total é superior a $10 \%$.

\section{Áreas transfronteiriças protegidas e de conservação}

África do Sul inclui parte de seis áreas de conservação transfronteiriças, nomeadamente /Ai/Ais-Richtersveld TFCA, Parque Transfronteiriço e Área de Conservação do Grande Limpopo, TFCA do Grande Mapungubwe, Parque Transfronteiriço de Kgalagadi, TFCA do Lubombo, e TFCA de Maloti Drakensburg, que é também um Sítio Transfronteiriço Património Mundial.

\section{Contexto politico}

Um relatório abrangente sobre legislação e política relacionada com a gestão de áreas protegidas, governação e equidade foi levado a cabo pelo programa BIOPAMA. Foram identificadas 158 leis e políticas relevantes em África do Sul (Tessema, 2019).

\section{Espécies-chave ${ }^{86}$}

A África do Sul é considerado um dos países mais diversificados do mundo do ponto de vista biológico. Tem uma elevada taxa de endemismo e ecossistemas diversos. Enquanto ocupa apenas 2\% da superfície terrestre mundial, África do Sul é o lar de mais de 95,000 espécies, contribuindo uma proporção significativa para as espécies vegetais mundiais (6\%), répteis (5\%), aves (8\%) e mamíferos (6\%), com mais espécies regularmente descobertas e descritas. Além disso, alberga cerca de $15 \%$ das espécies marinhas do mundo. As taxas de endemismo atingem $56 \%$ para os anfíbios, $65 \%$ para as plantas, $49 \%$ para os peixes de água doce, $48 \%$ para os répteis, $36 \%$ para as douradas, e até $70 \%$ para os invertebrados.

85 A secção baseia-se na informação contida no Sexto Relatório Nacional de África do Sul à CDB (República de África do Sul, 2019).

86 A secção baseia-se na informação contida no Quinto e Sexto Relatórios Nacionais de África do Sul ao CBD (República de África do Sul, 2014; 2019). 
Figura 8.35 Resumo da África do Sul

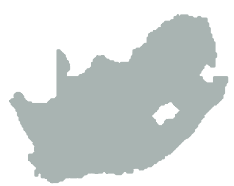

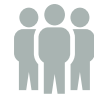

População Total (milhões)

57.78

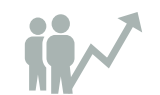

Crescimento da população (\% anual) 1.40

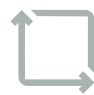

Superfície $\left(\mathrm{km}^{2}\right)$ (milhares)

1219.10

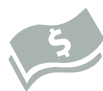

GDP (actuais US\$) (bilhões)

368.29

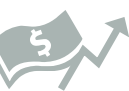

Crescimento do GDP (\% anual) 0.80

Fonte: The World Bank Group, 2018

\section{Área Protegida:}

\section{0 áreas protegidas}

de terra

Fonte: UNEP-WCMC \& UICN, 2019s cobrindo

102060 km$^{2}$

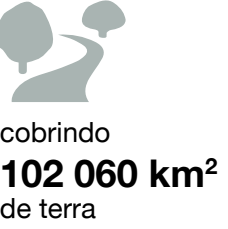

224640 km² $^{2}$ de oceano

Um dos países mais diversificados do mundo do ponto de vista biológico
Áreas protegidas e de conservação em África do Sul em Categorias de Gestão da UICN

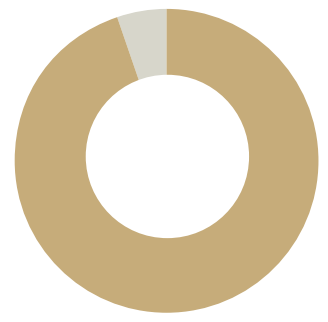

Não Aplicável (No. 13)

Não Reportado (No. 1567)

Fonte: UNEP-WCMC \& UICN (2019s).

Cobertura de áreas protegidas na África do Sul

\begin{tabular}{l|r|r}
\hline Tipo de área protegida & $\begin{array}{r}\text { Área } \\
\text { protegida ou } \\
\text { conservada* }\end{array}$ & $\begin{array}{r}\text { Área } \\
\text { protegida ou } \\
\text { conservada** }\end{array}$ \\
\hline Águas terrestres e interiores & $8.34 \%$ & $12.96 \%$ \\
\hline Litoral e marinho & $14.56 \%$ & $10.00 \%$ \\
\hline "WDPA dataset ${ }^{* *}$ Do Relatório Nacional sobre Biodiversidade \\
Fonte: Governo de Seychelles (2014a); UNEP-WCMC \& UICN (2019q)
\end{tabular}

Áreas protegidas e de conservação designadas como sítios globais de importância na África do Sul

\begin{tabular}{l|r}
\hline Designação global & No. de sítios \\
\hline $\begin{array}{l}\text { Reservas do Homem e da Biosfera da } \\
\text { UNESCO }\end{array}$ & 10 \\
\hline $\begin{array}{l}\text { Sítios Património Mundial da UNESCO } \\
\text { (Natural ou Misto) }\end{array}$ & 5 \\
\hline $\begin{array}{l}\text { Zonas húmidas de importância internacional } \\
\text { (sítios Ramsar) }\end{array}$ & 23 \\
\hline Fonte: Ramsar (2019); UNESCO(2019a (2019b).
\end{tabular}

\section{Áreas protegidas e de conservação na África do} Sul nos tipos de governação da UICN

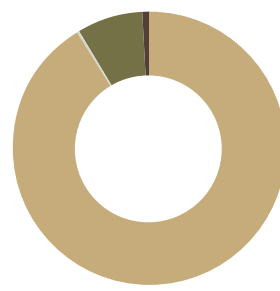

Não reportado (No. 2)

C. Governação Privada (No. 932)

B. Governação Partilhada (No. 1)

A.Governação pelo Governo (No. 645)
Designações nacionais de áreas protegidas e de conservação na África do Sul

\begin{tabular}{l|r|r}
\hline Designação nacional & No. & Área (km²) \\
\hline Parque Nacional & 21 & 39781 \\
\hline Área Florestal Silvestre & 12 & 2745 \\
\hline Reserva Natural da Floresta & 53 & 1732 \\
\hline Reserva Natural Especial & 2 & 336 \\
\hline Reserva Natural & 1371 & 38719 \\
\hline Ambiente Protegido & 30 & 7436 \\
\hline Área de Captação de Montanha & 16 & 6246 \\
\hline Área Marítima Protegida & 39 & 224682 \\
\hline Fonte: UNEP-WCMC \& UICN (2019s). & \multicolumn{3}{|l}{} \\
\hline
\end{tabular}

\section{Áreas prioritárias para a conservação}

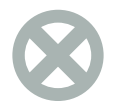

\section{0 sítios de Extinção Zero}

99 sítios

Aliança para os sítios Áreas importantes de Aves \& Biodiversidade

\section{6 sítios}

Áreas-chave da Biodiversidade 


\section{Figura 8.36 Áreas Protegidas da África do Sul}

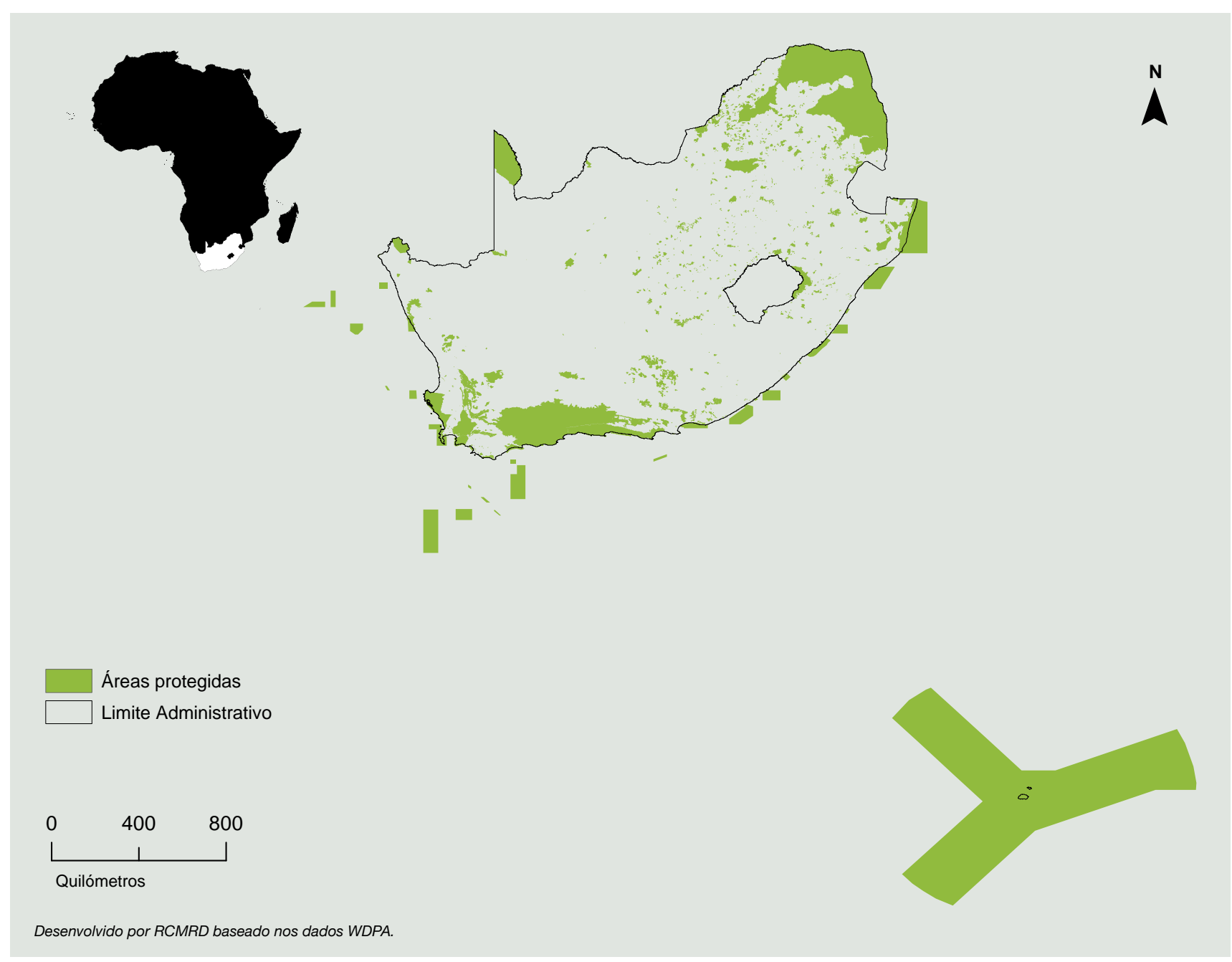

\section{Pressões e ameaças ${ }^{87}$}

As principais pressões sobre a biodiversidade da África do Sul incluem: perda e degradação do habitat natural nos ecossistemas terrestres, de água doce, estuarinos e marinhos devido a práticas insustentáveis de uso do solo, usos inadequados ou mal localizados da terra; espécies exóticas invasoras (tanto vegetais como animais); destruição e colheita excessiva de espécies, especialmente no ambiente marinho; tráfico ilegal de vida selvagem e outros usos ilegais dos recursos; captação excessiva de água e poluição dos ecossistemas aquáticos; perturbação dos motores naturais do funcionamento dos ecossistemas (tais como ciclos de incêndio); e impactos induzidos pelas alterações climáticas. 


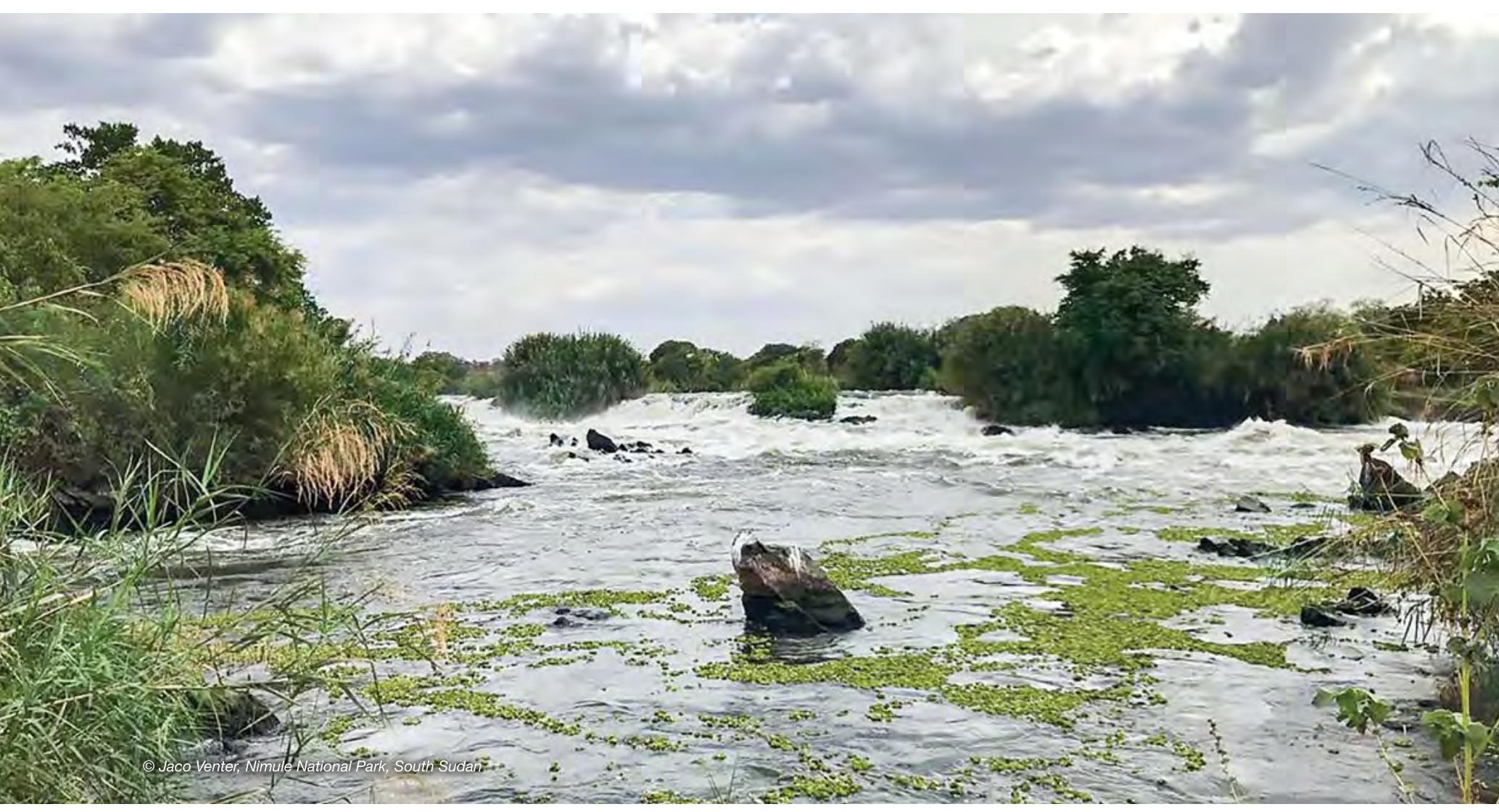

\subsection{Sudão do Sul}

\section{Áreas protegidas e de conservação em Sudão do Sul ${ }^{88}$}

Sudão do Sul tem 27 áreas protegidas cobrindo $98.214 \mathrm{~km}^{2}$ da terra (UNEP-WCMC \& UICN, 2019t).

Várias áreas foram propostas para gazettement como áreas protegidas, o que ajudaria a ultrapassar o Objectivo 11 de Aichi. Apesar de ter uma grande cobertura de áreas protegidas, há falta de gestão activa ou adequada na maioria das áreas protegidas. Um grande desafio diz respeito aos limites de várias áreas protegidas que não estão claramente delineadas, limitando um policiamento eficaz. Além disso, parece haver falta de clareza no sector florestal quanto a quem, nos diferentes níveis de gestão, possui qual o recurso florestal.

Devido a muitos anos de conflito, que inibiram acções no terreno, o património da área protegida precisa de ser reavaliado para garantir que ainda é representativo e ecologicamente relevante.

\section{Áreas transfronteiriças protegidas e de conservação}

Sudão do Sul inclui parte de quatro áreas de conservação transfronteiriças. Boma-Gambella Parque Nacional com Etiópia, Kidepo Reserva de Caça-Kidepo Valley com Uganda, LantotoGaramba com Congo e Nimule Parque Nacional-Otze Reserva de Vida Selvagem com Uganda.

\section{Contexto politico}

Um relatório abrangente sobre legislação e política relacionada com a gestão de áreas protegidas, governação e equidade foi levado a cabo pelo programa BIOPAMA. Identificou oito leis e políticas relevantes no Sudão do Sul (Tessema, 2019).

\section{Espécies-chave ${ }^{89}$}

Sudão do Sul tem uma vasta gama de habitats que suportam uma rica diversidade de animais e plantas. É o lar de uma das grandes migrações do mundo - o kobus kob leucotis (Kobus kob leucotis), o tiang (Damaliscus lunatus tiang), a gazela Mongalla (Eudorcas albonotata), e o bohor reedbuck (Redunca redunca). O país é um baluarte para o bico-de-tamanco (Balaeniceps rex), em vias de extinção, e para o guindaste de coroa negra (Balearica pavonina).

Sudão do Sul tem também muitas espécies de répteis, peixes de água doce e plantas, incluindo muitas espécies endémicas.

\section{Pressões e ameaças ${ }^{90}$}

As ameaças directas à biodiversidade no Sudão do Sul incluem: caça furtiva e tráfico de animais selvagens; desflorestação da produção de carvão vegetal e extracção ilegal de madeira dura; expansão da pecuária e agricultura; fragmentação do habitat, incluindo das indústrias extractivas; conflito entre homem e vida selvagem; e impactos das alterações climáticas, incluindo o aumento da desertificação e a alteração das estações de crescimento. 
Figura 8.37 Resumo do Sudão do Sul

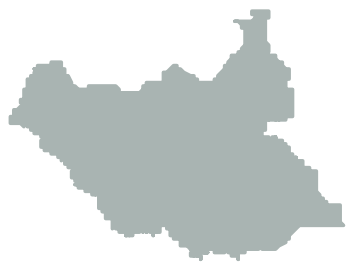

Fonte: The World Bank Group, 2018

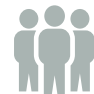

População Total (milhões)

10.98

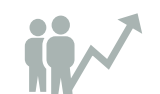

Crescimento da população (\% anual) 0.60

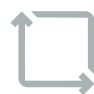

Superfície $\left(\mathrm{km}^{2}\right)$ (milhares) 1882.00

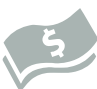

GDP (actuais US\$) (bilhões)

3.07
Crescimento do GDP (\% anual)

$-11.2$

\section{Área Protegida:}

\section{7 áreas protegidas}

cobrindo

98214 km² $^{2}$

de terra

Áreas protegidas e de conservação no Sudão do Sul em Categorias de Gestão da UICN

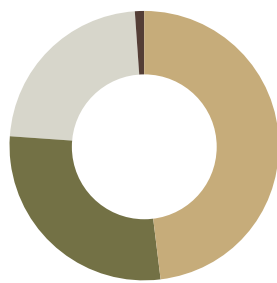

Não reportado (No. 1)

VI. Área Protegida com Utilização

Sustentável dos Recursos Naturais (No. 13)

V. Paisagem Protegida / Paisagem Marítima (No. 1)

IV. Gestão de Habitat / Espécies (No. 3)

II. Parque Nacional (No. 9)

\section{Coverage of protected areas in South Sudan}

\begin{tabular}{l|r|r}
\hline Tipo de área protegida & $\begin{array}{r}\text { Área } \\
\text { protegida ou } \\
\text { conservada* }\end{array}$ & $\begin{array}{r}\text { Área } \\
\text { protegida ou } \\
\text { conservada** }^{\star *}\end{array}$ \\
\hline Águas terrestres e interiores & $15.50 \%$ & $13.00 \%$ \\
\hline
\end{tabular}

*WDPA dataset $\quad$ ** Do Relatório Nacional sobre Biodiversidade

Fonte: República do Sudão do Sul (2015); UNEP-WCMC \& UICN (2019t).

Áreas protegidas e de conservação designadas como sítios globais de importância no Sudão do Sul

\begin{tabular}{l|r}
\hline Designação global & No. de sítios \\
\hline $\begin{array}{l}\text { Zonas húmidas de importância internacional } \\
\text { (sítios Ramsar) }\end{array}$ & 1 \\
\hline Fonte: Ramsar (2019): UNESCO (2019a, 2019b)
\end{tabular}

Áreas protegidas e de conservação no Sudão do Sul nos tipos de governação da UICN

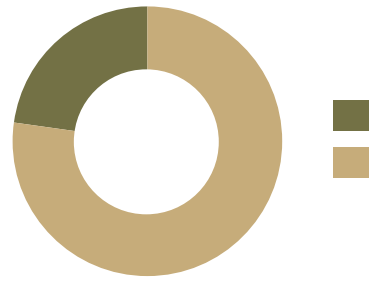

Não reportado (No. 1)

A.Governação pelo Governo (No. 26)
Designações nacionais de áreas protegidas e de conservação no Sudão do Sul

\begin{tabular}{l|r|r}
\hline Designação nacional & No. & Área $\mathbf{( k m}^{2} \mathbf{)}$ \\
\hline Parque Nacional & 10 & 74991 \\
\hline Reserva de Caça & 12 & 29792 \\
\hline Área de Conservação Natural & 2 & 2499 \\
\hline Reserva Florestal & 1 & 1160 \\
\hline Santuário de Pássaros & 1 & 4999 \\
\hline
\end{tabular}

Fonte: UNEP-WCMC \& UICN (2019t).

\section{Áreas prioritárias para a conservação}

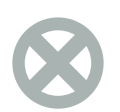

\section{1 sítio}

12 sítios

Aliança para os sítios de Extinção Zero

Áreas importantes de Aves \& Biodiversidade

\section{3 sítios}

Áreas-chave da Biodiversidade 
As ameaças indirectas incluem: conflitos armados passados e contínuos e a crise resultante de populações deslocadas internamente e proliferação de armas de fogo; capacidades legais, institucionais e administrativas inadequadas e ineficazes; impactos negativos de crescimento populacional e desenvolvimento económico; falta de planeamento do uso da terra; baixa sensibilização do público; e exploração e produção de petróleo emergente.

\section{Figura 8.38 Áreas Protegidas do Sudão do Sul}
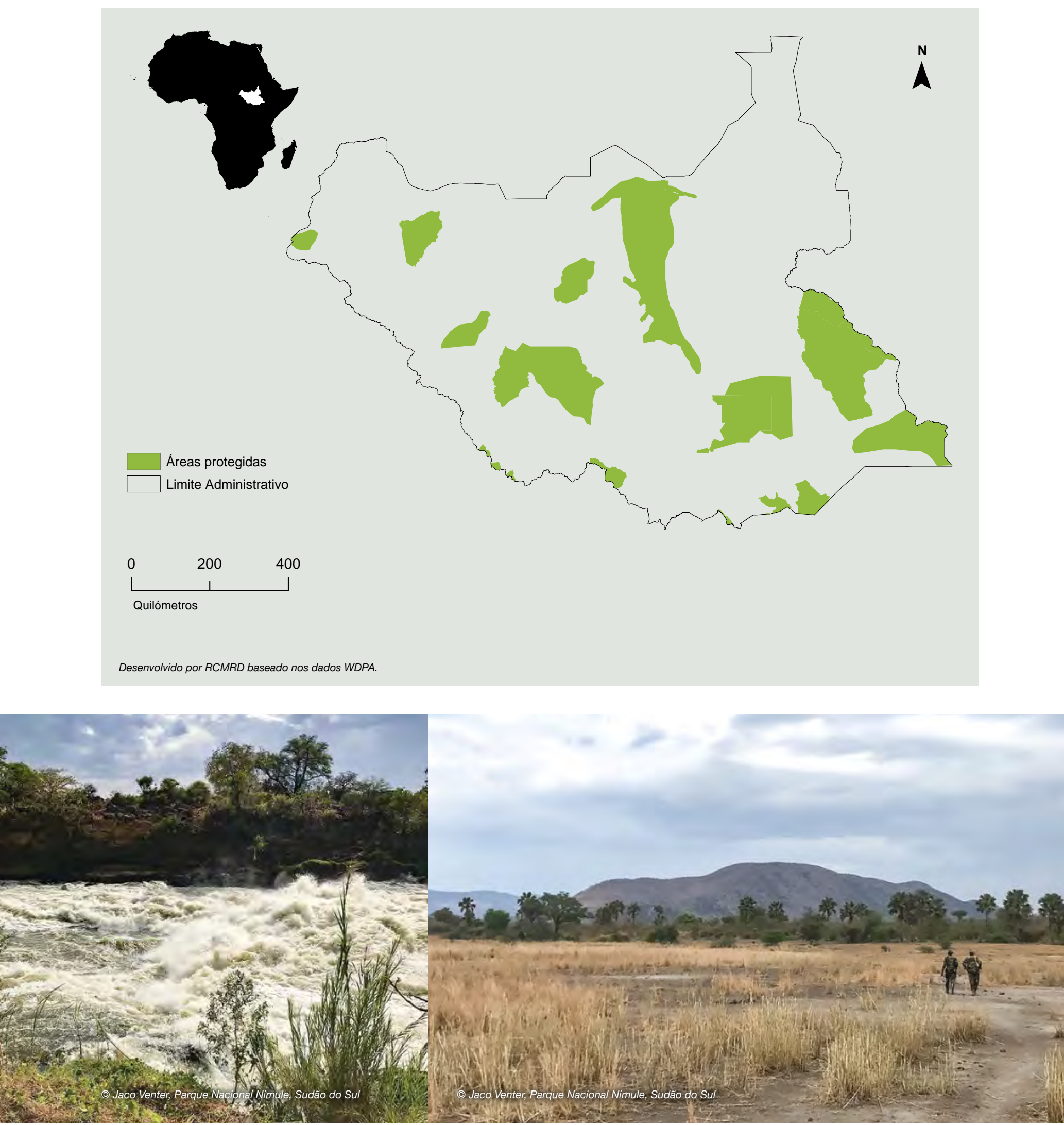


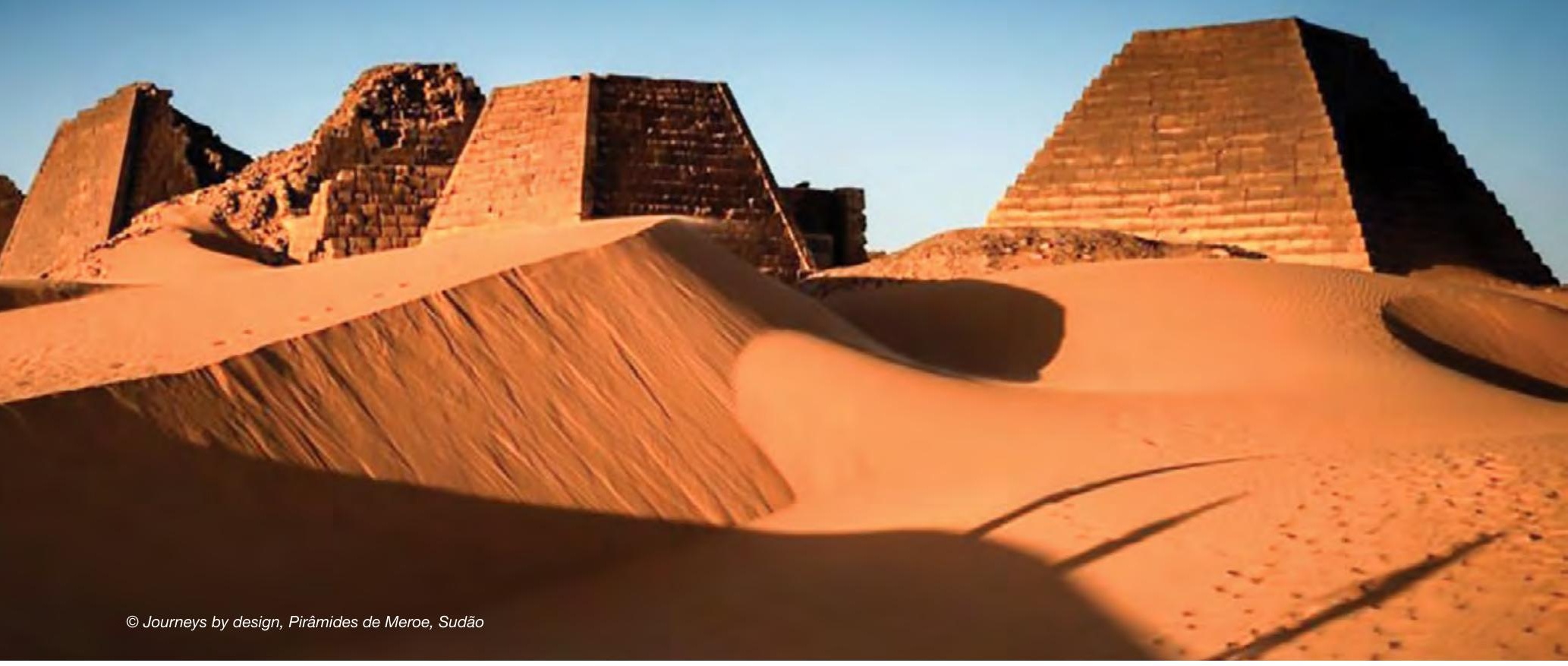

\subsection{Sudão}

\section{Áreas protegidas e de conservação no Sudão ${ }^{91}$}

Sudão tem 23 áreas protegidas cobrindo $42,698 \mathrm{~km}^{2}$ da terra e $10,662 \mathrm{~km}^{2}$ do oceano (UNEP-WCMC \& UICN, 2019u).

A vida selvagem ocorre em áreas protegidas e em habitats fragmentados fora das áreas protegidas no deserto, semi-deserto, floresta de savana de baixa pluviosidade, floresta de savana de alta pluviosidade e ecossistemas marinhos. O número de espécies diminuiu ou desapareceu de muitos dos seus antigos habitats.

Não há nenhuma área protegida designada que represente ecossistemas de água doce, excepto a área protegida proposta para as zonas húmidas Umgur.

\section{Áreas transfronteiriças protegidas e de conservação}

Sudão não tem nenhuma zona de conservação transfronteiriça.

\section{Contexto politico}

Um relatório abrangente sobre legislação e política relacionada com A gestão, governação e equidade das áreas protegidas foi levada a cabo pelo programa BIOPAMA. Identificou 18 leis e políticas relevantes no Sudão (Tessema, 2019).

\section{Espécies-chave $^{92}$}

A vasta gama de ecossistemas do Sudão alberga uma grande diversidade de espécies. A informação sobre a actual distribuição e abundância de recursos da vida selvagem no Sudão é muito limitada. Sudão é o lar de 937 espécies de aves, incluindo 17 espécies de preocupação global de conservação. Nos habitats costeiros, os mangais são uma espécie importante, mas são muito ameaçados. O Sudão tem uma biodiversidade marinha e de água doce diversa, incluindo recifes de coral, fundos de ervas marinhas, e uma vasta gama de espécies como tubarões, dugongos, tartarugas e aves marinhas. A informação sobre a composição das espécies não é bem conhecida, particularmente desde a separação do Sudão do Sul.

\section{Pressões e ameaças ${ }^{93}$}

Sudão enfrenta uma série de ameaças: degradação ambiental; expansão na construção civil e actividades económicas; alterações climáticas e seca; expansão do cultivo de terra; poluição e espécies invasoras alienígenas. 
Figura 8.39 Resumo do Sudão

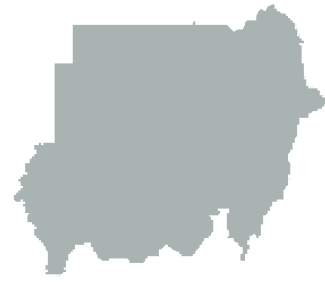

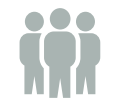

População Total (milhões) 41.80

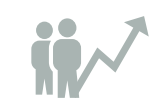

Crescimento da população (\% anual) 2.40

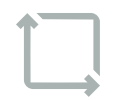

Superfície $\left(\mathrm{km}^{2}\right)$ (milhares) 658.84

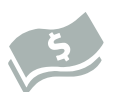

GDP (actuais US\$) (bilhões)

40.85
Crescimento do GDP (\% anual) $-2.30$

Fonte: The World Bank Group, 2018.

\section{Área Protegida:}

\section{3 áreas} protegidas

cobrindo 42698 km$^{2}$ de terra

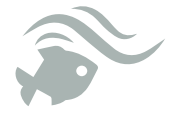

cobrindo 10662 km $^{2}$ de oceano

Fonte: UNEP-WCMC \& UICN, (2019u)

Áreas protegidas e de conservação em Sudão em Categorias de Gestão da UICN

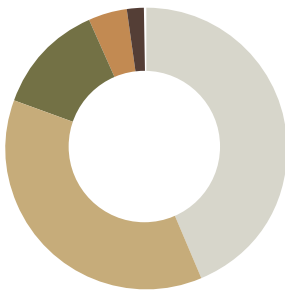

Não Aplicável (No. 3)

Não Reportado (No. 13)

VI. Área Protegida com Utilização

Sustentável dos Recursos Naturais (No. 3)

IV. Gestão de Habitat / Espécies (No. 1)

II. Parque Nacional (No. 3)
A informação sobre a composição das espécies não é bem conhecida
937 espécies de aves

17 de preocupação global de conservação
Cobertura de áreas protegidas no Sudão

\begin{tabular}{l|r|r}
\hline Tipo de área protegida & $\begin{array}{r}\text { Área } \\
\text { protegida ou } \\
\text { conservada* }\end{array}$ & $\begin{array}{r}\text { Área } \\
\text { protegida ou } \\
\text { conservada** }\end{array}$ \\
\hline Águas terrestres e interiores & $2.28 \%$ & $5.80 \%$ \\
\hline Litoral e marinho & $15.96 \%$ & $10.00 \%$ \\
\hline
\end{tabular}

* WDPA dataset $\quad$ ** Do Relatório Nacional sobre Biodiversidade

Fonte: República do Sudão (2019); UNEP-WCMC \& UICN (2019u).

Áreas protegidas e de conservação designadas como sítios globais de importância no Sudão

\begin{tabular}{l|r}
\hline Designação global & No. de sítios \\
\hline $\begin{array}{l}\text { Sítios Património Mundial da UNESCO } \\
\text { (Natural ou Misto) }\end{array}$ & 1 \\
\hline $\begin{array}{l}\text { Zonas húmidas de importância internacional } \\
\text { (sítios Ramsar) }\end{array}$ & 3 \\
\hline
\end{tabular}

Fonte: Ramsar (2019); UNESCO (2019a, 2019b).

Áreas protegidas e de conservação no Sudão nos tipos de governação da UICN

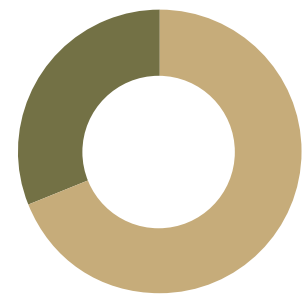

Não reportado (No. 14)

A.Governação pelo Governo (No. 9)
Designações nacionais de áreas protegidas e de conservação em Sudão

\begin{tabular}{l|r|r}
\hline Designação nacional & No. & Área $\left.\mathbf{( k m}^{2}\right)$ \\
\hline Reserva Natural Gerida & 1 & 300 \\
\hline Parque Nacional & 4 & 22398 \\
\hline Reserva de Caça & 2 & 7459 \\
\hline Área de Conservação Natural & 2 & 6299 \\
\hline Parque Nacional Marinho & 2 & 1012 \\
\hline Santuário de Pássaros & 4 & 1150 \\
\hline Santuário de Vida Selvagem & 2 & 940 \\
\hline
\end{tabular}

Fonte: UNEP-WCMC \& UICN (2019u).

\section{Áreas prioritárias para a conservação}

\section{1 sítios}

Áreas importantes de Aves \& Biodiversidade

Fonte: BirdLife International (2019c). 
Figura 8.40 Áreas Protegidas do Sudão
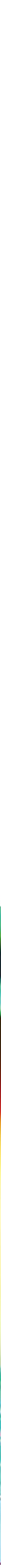


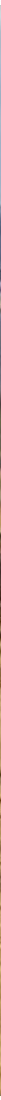

\subsection{Tanzânia}

\section{Áreas protegidas e de conservação na Tanzânia94}

A Tanzânia tem 840 áreas protegidas cobrindo $361,594 \mathrm{~km}^{2}$ da terra e 7,330 km² de oceano (UNEP-WCMC \& UICN, 2019v).

Os ecossistemas terrestres têm a maior protecção enquanto os ambientes costeiros e marinhos têm a menor protecção. Os extensos parques nacionais, as montanhas do Arco Leste, as zonas húmidas, as florestas costeiras, os sistemas marinhos e de água doce como reservatórios excepcionais de espécies vegetais e animais fazem da Tanzânia um dos maiores reservatórios de biodiversidade do mundo. A Tanzânia é também o lar de uma variedade de espécies endémicas de anfíbios, lagartos, cobras, pássaros, variedades de café selvagem e as famosas flores violetas africanas.

A Área de Conservação de Ngorongoro e o Parque Nacional Serengeti são Reservas da Biosfera e Sítios do Património Mundial conhecidos pela migração mais espectacular do mundo de grandes mamíferos todos os anos. No Serengeti Parque Nacional, atravessam as extensas pastagens e os bosques associados de Acacia-Commiphora, um dos maiores ecossistemas florestais do país, enquanto que na Área de Conservação de Ngorongoro, atravessam o corredor superior de Kitete/Selela ao longo do Vale do Grande Rift que o liga ao Parque Nacional do Lago Manyara, utilizado por elefantes e búfalos. Escusado será dizer que os corredores de vida selvagem estão seriamente ameaçados na Tanzânia, enfrentando uma intensa pressão devido à alteração do uso da terra. Recentemente, o Presidente assinou a lei de criação dos parques Julius Nyerere, Kigosi e Parques Nacionais do Rio Ugalla.

\section{Áreas transfronteiriças protegidas e de conservação}

A Tanzânia inclui partes de oito áreas de conservação transfronteiriças, nomeadamente Amboseli-Kilimanjaro-Longido, Kagera TFCA, Mnazi Bay-Quirimbas TFCA, Niassa-Selous TFCA, Sango Bay-Minziro, Serengeti-Mara, Tanga Marine Reserves System e Tanga Coelacanth Marine Park e Diani Chale e Kisitee-Mpunguti e o Parque Marinho Transfronteiriço do Oceano Índico Ocidental.

\section{Contexto politico}

Um relatório abrangente sobre legislação e política relacionada com a gestão de áreas protegidas, governação e equidade foi levado a cabo pelo programa BIOPAMA. Identificou 74 leis e políticas relevantes na Tanzânia (Tessema, 2019).

\section{Espécies-chave ${ }^{95}$}

A Tanzânia tem uma grande diversidade de espécies com pelo menos 14.500 espécies conhecidas e confirmadas, e está entre os 15 países com o maior número de espécies endémicas e ameaçadas a nível mundial. É responsável por mais de um terço do total de espécies vegetais em África e ocupa o décimo segundo lugar a nível mundial em termos de espécies de aves. O país é o lar de cerca de $20 \%$ da grande população de mamíferos em África.

Do número total de espécies existentes no país, mais de metade (54\%) constituem espécies vegetais. Notavelmente, mais de $25 \%$ de todas as espécies vegetais são utilizadas como plantas medicinais colhidas na natureza.

94 A secção baseia-se nas informações contidas no Quinto e Sexto Relatório Nacional sobre a Implementação da CDB da Tanzânia (República Unida da Tanzânia, 2014; 2019).

95 A secção baseia-se na informação contida no Quinto Relatório Nacional sobre a Implementação da CDB da Tanzânia (República Unida da Tanzânia, 2014; 2019). 
Figura 8.41 Resumo da Tanzânia

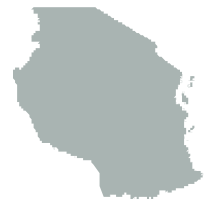

onte: The World Bank Group, 2018.

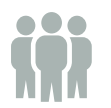

População Total (milhões) 56.32

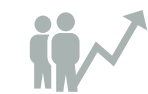

Crescimento da população (\% anual) 3.00

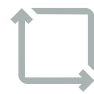

Superfície $\left(\mathrm{km}^{2}\right)$ (milhares) 947.30

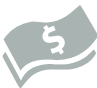

GDP (actuais US\$) (bilhões) 57.44
Crescimento do GDP (\% anual)
Área Protegida:

840 áreas protegidas

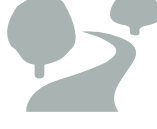

cobrindo 361594 km $^{2}$ de terra

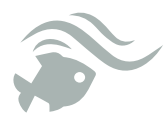

cobrindo $7330 \mathrm{~km}^{2}$ de terra
Fonte: UNEP-WCMC \& UICN (2019v).

\section{Áreas protegidas e de conservação em Tanzânia em Categorias de Gestão da UICN}

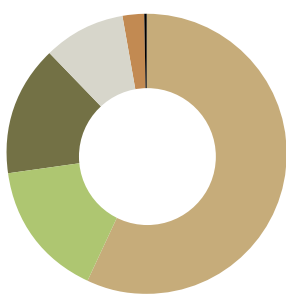

Não Aplicável (No. 7)

Não Reportado (No. 738)

VI. Área Protegida com Utilização

Sustentável dos Recursos Naturais (No. 19)

IV. Gestão de Habitat / Espécies (No. 53)

III. Monumento Natural (No. 1)

II. Parque Nacional (No. 14)

Ib. Área Selvagem (No. 8)

Fonte: UNEP-WCMC \& UICN (2019v).

\section{Cobertura de áreas protegidas na Tanzânia}

\begin{tabular}{l|r|r}
\hline Tipo de área protegida & $\begin{array}{r}\text { Área } \\
\text { protegida ou } \\
\text { conservada* }\end{array}$ & $\begin{array}{r}\text { Área } \\
\text { protegida ou } \\
\text { conservada** }\end{array}$ \\
\hline Águas terrestres e interiores & $38.17 \%$ & $54.60 \%$ \\
\hline Litoral e marinho & $3.02 \%$ & $6.50 \%$ \\
\hline
\end{tabular}

*WDPA dataset $\quad$ ** Do Relatório Nacional sobre Biodiversidade

Fonte: UNEP-WCMC \& UICN (2019v); República Unida da Tanzânia (2019).

Áreas protegidas e de conservação designadas como sítios globais de importância na Tanzânia

\begin{tabular}{l|r}
\hline Designação global & No de sítios \\
\hline $\begin{array}{l}\text { Reservas do Homem e da Biosfera da } \\
\text { UNESCO }\end{array}$ & 5 \\
\hline $\begin{array}{l}\text { Sítios Património Mundial da UNESCO } \\
\text { (Natural ou Misto) }\end{array}$ & 4 \\
\hline $\begin{array}{l}\text { Zonas húmidas de importância internacional } \\
\text { (sítios Ramsar) }\end{array}$ & 4 \\
\hline
\end{tabular}

Fonte: Ramsar (2019); UNESCO (2019a, 2019b).

\section{Áreas protegidas e de conservação na Tanzânia nos tipos de governação da UICN}

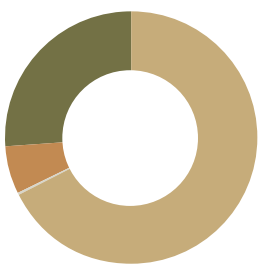

Não reportado (No. 19

D. Governação pelos povos indígenas e comunidades locais (No. 39)

C. Governação Privada (No. 1)

B. Governação Partilhada (No. 4)

A. Governação pelo Governo (No. 777)

Fonte: UNEP-WCMC \& UICN (2019v).

Designações nacionais de áreas protegidas e de conservação na Tanzânia

\begin{tabular}{l|r|r}
\hline Designação nacional & No. & Área (km²) \\
\hline Reserva Natural Florestal & 1 & 257 \\
\hline Área de Conservação & 4 & 9674 \\
\hline Reserva de Caça & 19 & 94050 \\
\hline Parque Nacional & 17 & 48430 \\
\hline Área controlada pela caça & 19 & 70901 \\
\hline Área de Gestão da Pesca Colaborativa & 1 & 1913 \\
\hline Reserva Marinha & 2 & 35 \\
\hline Área de Gestão da Vida Selvagem & 14 & 33162 \\
\hline Plantação florestal & 23 & 730 \\
\hline Área Marítima Gerida Localmente & 1 & 3 \\
\hline Parque Marinho & 2 & 1445 \\
\hline Reserva Natural & 6 & 1996 \\
\hline Área aberta & 24 & 53235 \\
\hline Área de gestão da vida selvagem & 13 & 3999 \\
\hline Reserva Florestal & 694 & 92195 \\
\hline Santuário e Reserva Florestal Fechada & 1 & 1 \\
\hline Reserva Florestal e Área de Caça & 1 & 1015 \\
Controlada & & \\
\hline For uvePWM \& &
\end{tabular}

Fonte: UNEP-WCMC \& UICN (2019v)

\section{Áreas prioritárias para a conservação}

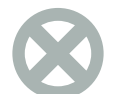

13 sítios

Aliança para os sítios de Extinção Zero

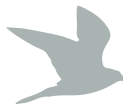

77 sítios

Áreas importantes de Aves \& Biodiversidade

\section{4 sítios}

Áreas-chave da

Biodiversidade 


\section{Figura 8.42 Áreas Protegidas da Tanzânia}

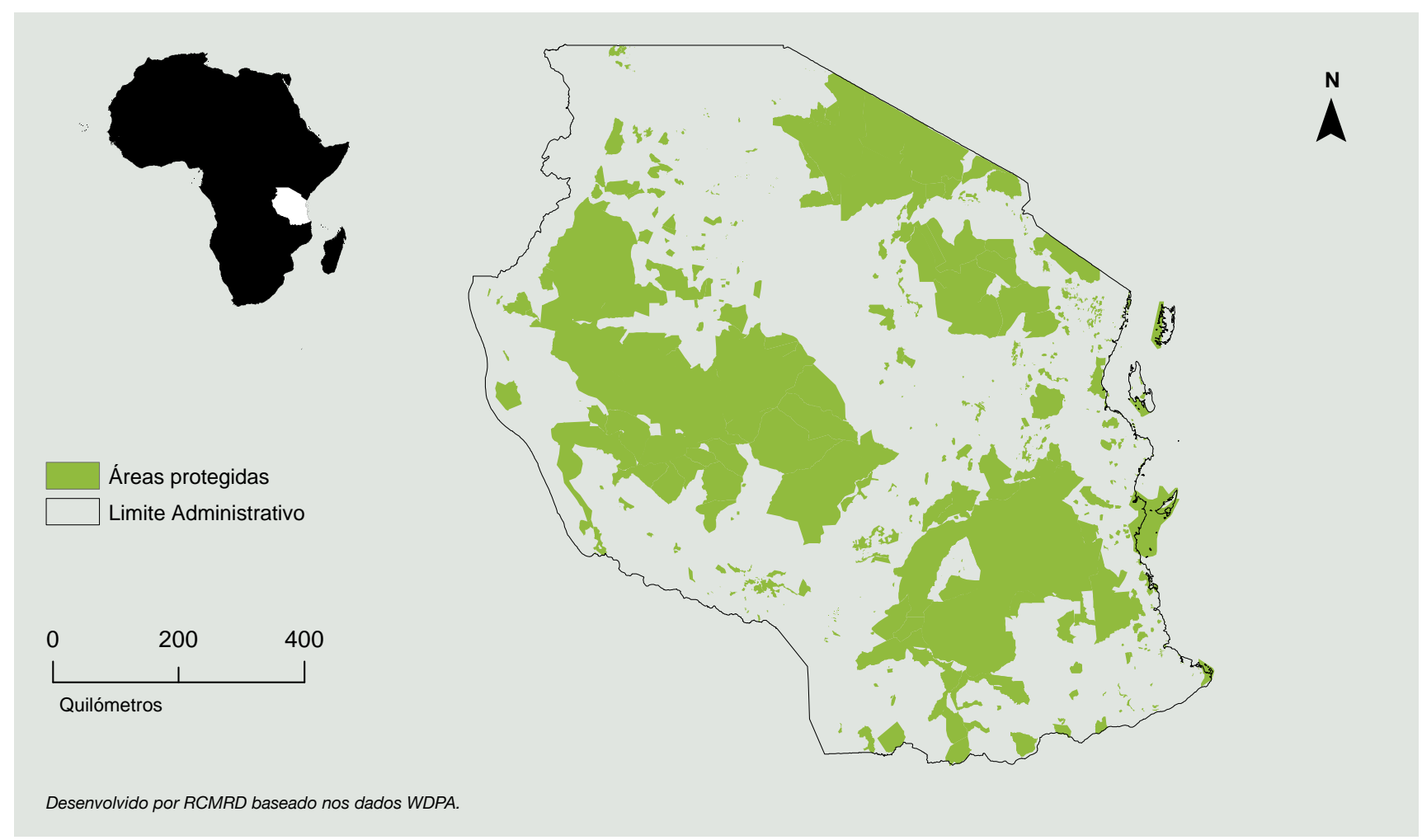

Não é conhecido o número exacto de espécies endémicas no país. No entanto, a informação disponível indica que as espécies endémicas variam entre 400 e 3,000 espécies.

Com base na análise das espécies ameaçadas no país, tendo em conta o significado ecológico, económico e social, as espécies que suscitam preocupação incluem, mas não se limitam a elas: Rinocerontes negros (Diceros bicornis) e elefantes (Loxodonta africana), que se encontram em perigo devido à caça furtiva. Outras espécies-chave de importância crítica incluem chimpanzés (Pan troglodytes), macacos colobus (p. ex. Procolobus gordonorum e Procolobus kirkii), macacos mangabey (p. ex. Rungwecebus kipunji, Cercocebus sanjei), o leopardo (Panthera pardus), o chita (Acinonyx jubatus) e o cão selvagem africano (Lycaon pictus). A Tanzânia é o lar da maior população mundial de leões (Panthera leo). Há também espécies de madeira de alto valor (p. ex. Afzelia spp, Pterocarpus spp, Diospyros mespiliformis). Além disso, existem espécies marinhas importantes, incluindo camarões (Metapenaeus monocerus, Penaeus indicus, $P$. monodon), atum, dugongo e tartarugas marinhas.

\section{Pressões e ameaças ${ }^{96}$}

A riqueza da Tanzânia em biodiversidade experimenta uma ameaça crescente, como noutros países, devido a uma série de factores naturais e humanos. A principal ameaça à biodiversidade na Tanzânia é a perda e destruição do habitat através da conversão para outras utilizações da terra, tais como assentamentos, agricultura e pastagem, sobre-exploração de espécies vegetais e animais, introdução de espécies não nativas, poluição e alterações climáticas.

Actividades humanas, tais como: a caça furtiva; a desflorestação, o arrasto de fundo nos oceanos e práticas de pesca insustentáveis; a barragem e dragagem de riachos, rios e lagos; e a drenagem e degradação de zonas húmidas, estuários e mangais são responsáveis pela perda de biodiversidade nos corpos de água. Estas actividades são agregadas pelo crescimento económico, crescimento populacional, pobreza, comércio global de espécies vegetais e animais e alterações climáticas.

Outras ameaças graves aos habitats incluem a desflorestação, a destruição de corais, a degradação do habitat devido a incêndios, o uso não planeado da terra, a extracção não gerida de recursos naturais, o aumento do comércio de carne de animais selvagens e a construção de estradas e outras infra-estruturas. Os corredores de vida selvagem são um desses tipos de habitat que enfrentam uma pressão intensa de serem convertidos em outras formas de terra.

Os habitats nos ecossistemas marinhos enfrentam sérias ameaças de destruição de mangais, destruição de corais, pesca com dinamite e redes de pesca ilegais, enquanto que os habitats de águas interiores têm uma grande ameaça relacionada com a diminuição dos níveis de água devido à redução das precipitações e ao aumento da evaporação, o declínio da diversidade de espécies de peixes devido à sobre-exploração dos recursos haliêuticos, a pesca ilegal, a introdução de peixes e espécies exóticas, especialmente a perca do Nilo e jacinto de água; a poluição e a eutrofização devido ao enriquecimento de nutrientes, especialmente fósforo e azoto.

Os habitats dos ecossistemas terrestres estão sob uma pressão tremenda devido à exploração insustentável das espécies animais. As espécies-chave que estão sob esta pressão incluem os maiores carnívoros como leões, leopardos, chitas, cães selvagens e o grupo dos herbívoros, incluindo a população de elefantes, a girafa (Giraffa camelopardalis), a zebra (Equus burchelli), o búfalo (Syncerus caffer), antílopes, o gnu (Connochaetus taurinus) e o rinoceronte preto (Diceros bicornis). 


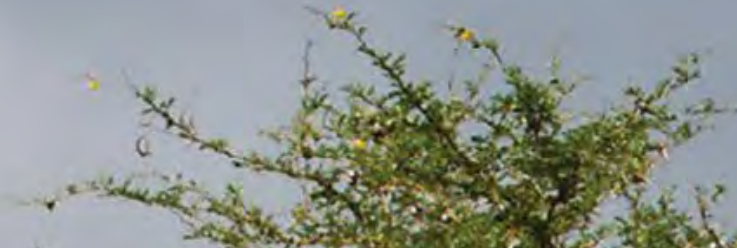

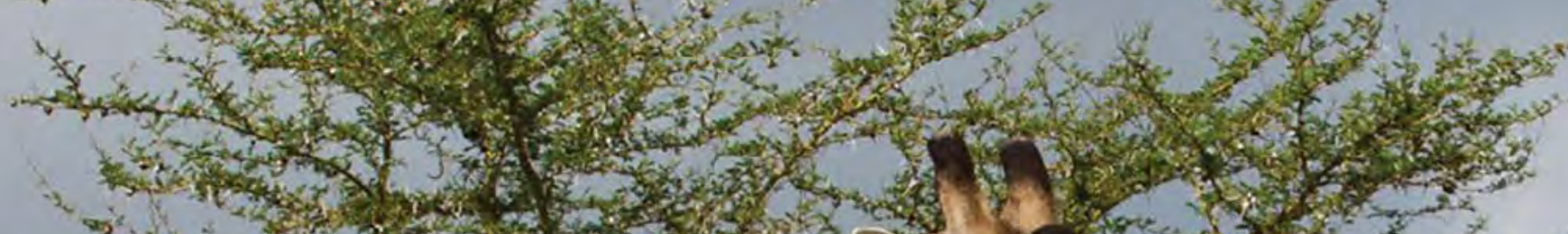
1)

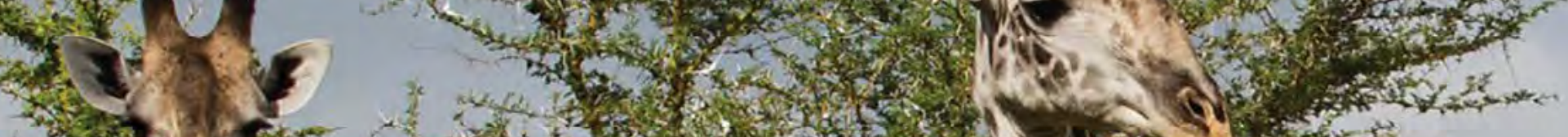

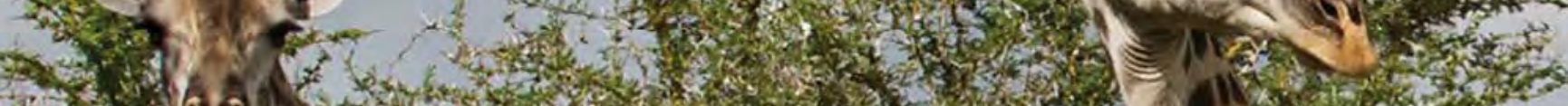

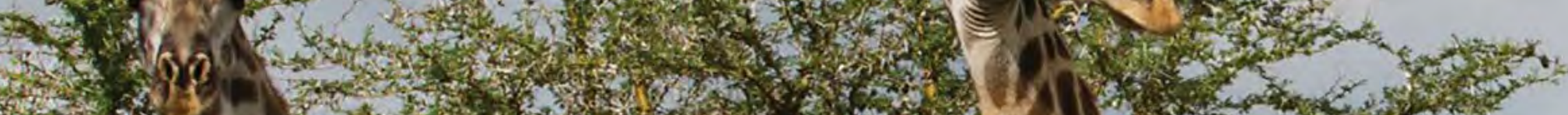

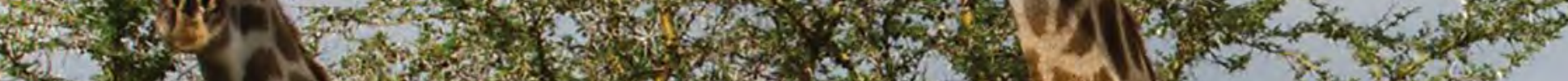

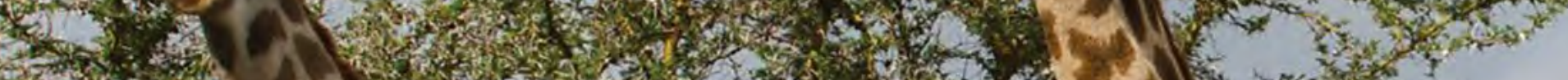

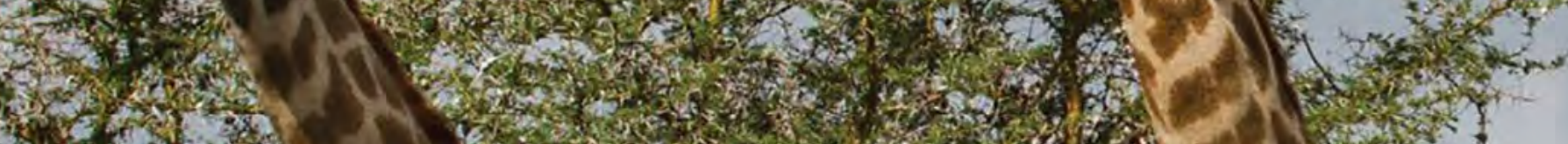

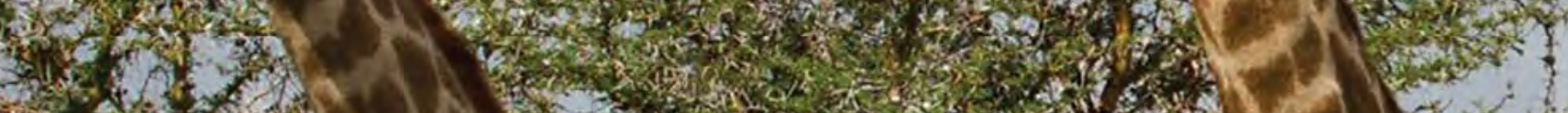

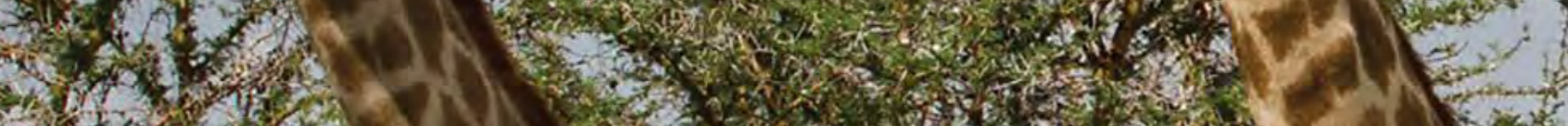

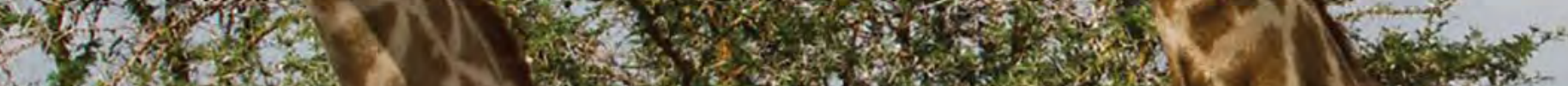

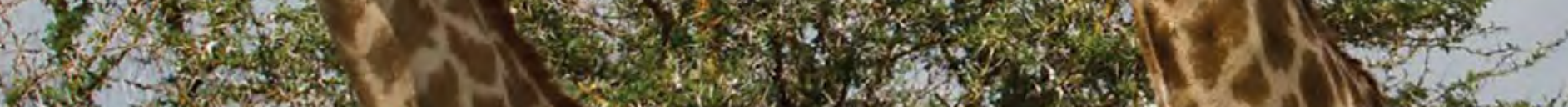

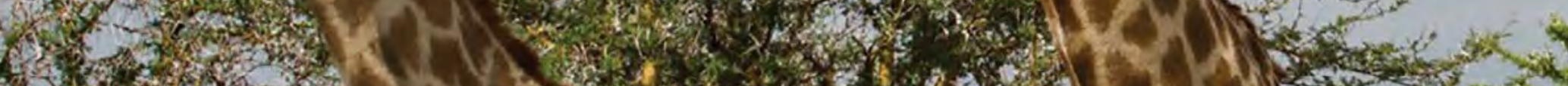
1.7. W.

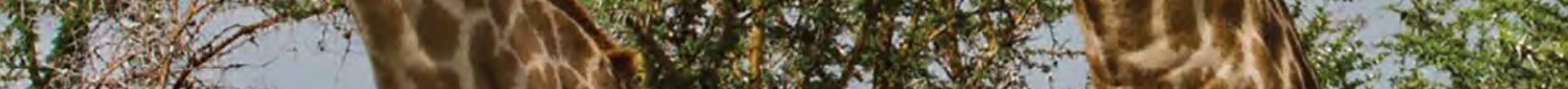

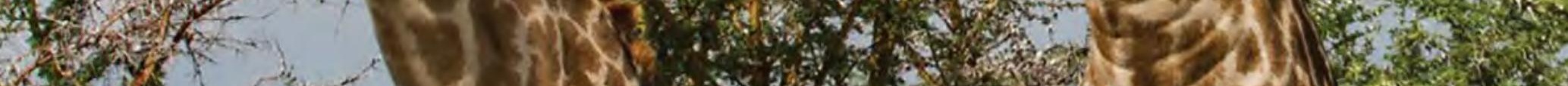

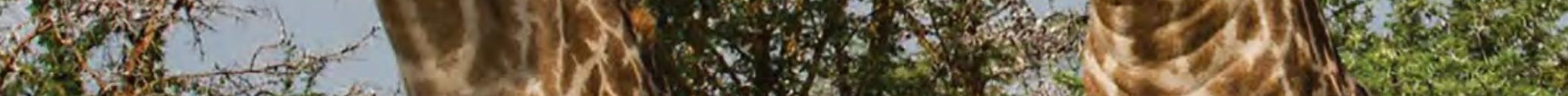

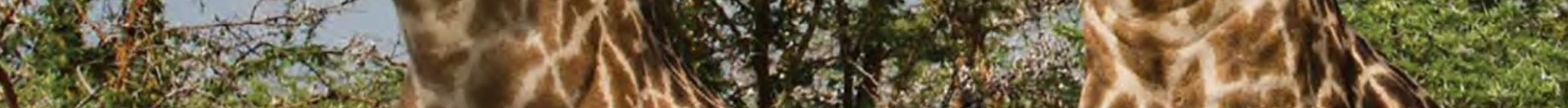
(1)

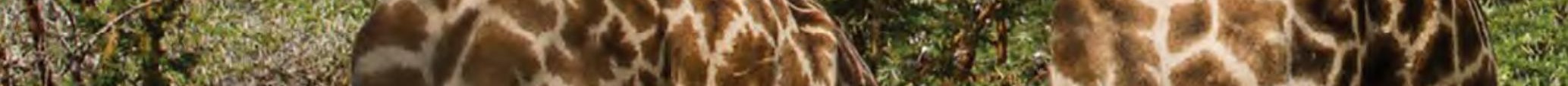
1. 26y

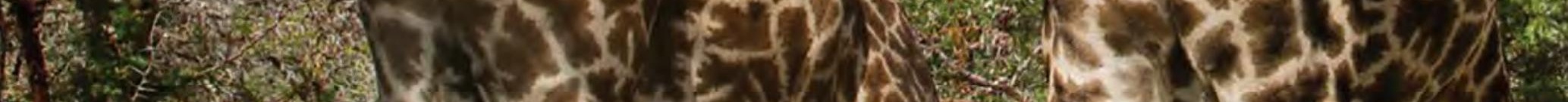

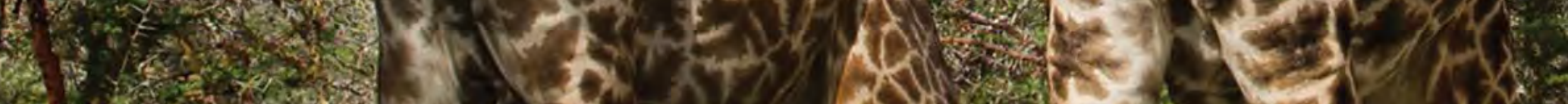
14. 


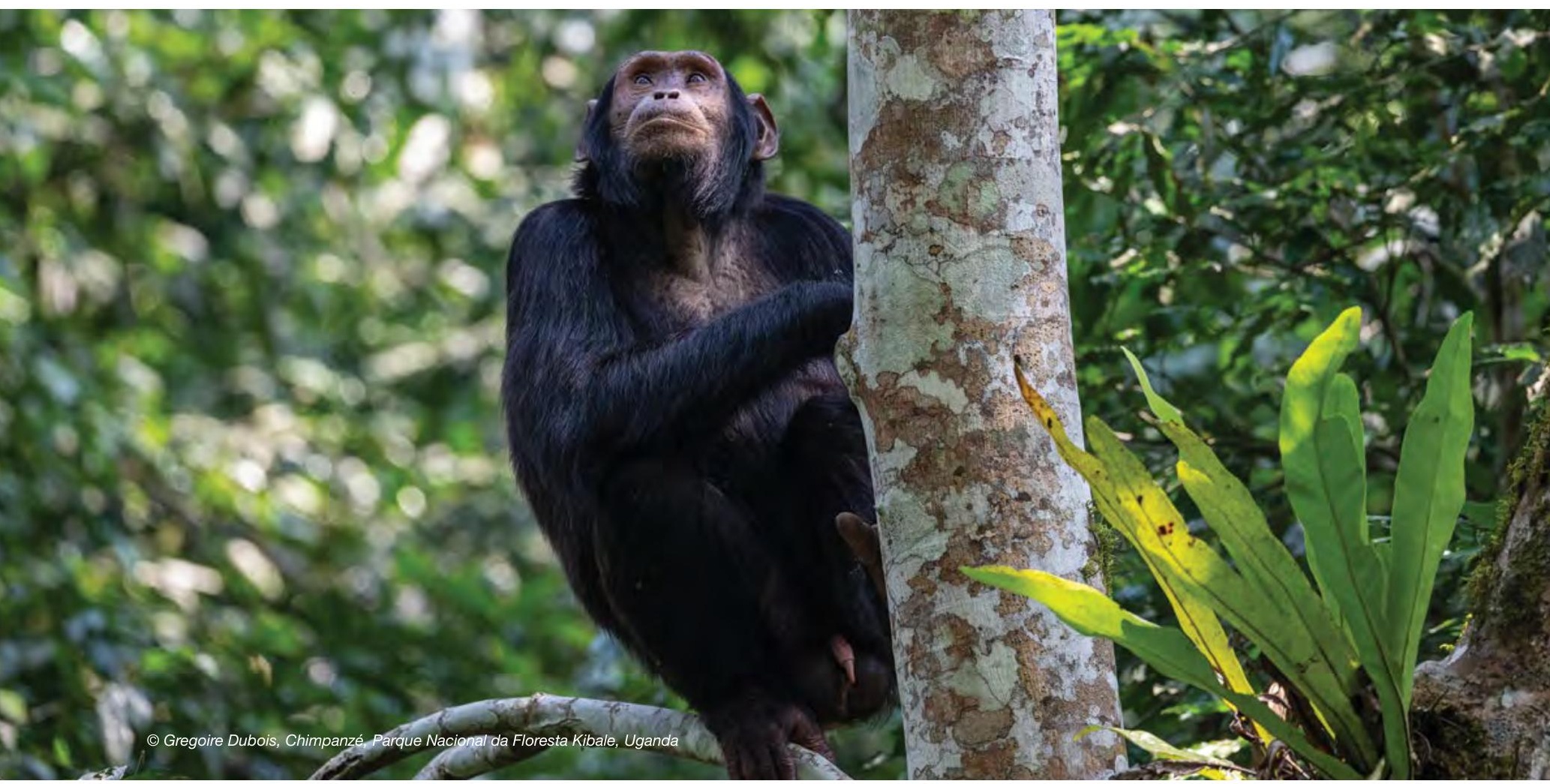

\subsection{Uganda}

\section{Áreas protegidas e de conservação em Uganda97}

O Uganda tem 712 áreas protegidas cobrindo $39.059 \mathrm{~km}^{2}$ da terra (UNEP-WCMC \& UICN, 2019w).

O Uganda é uma zona de convergência para cinco das zonas ecológicas importantes de África e alberga uma estimativa de metade da montanha do mundo. Nos últimos anos, o Uganda tem sido visto como um estudo de caso modelo para numerosas e variadas abordagens para lidar com desafios complexos e relacionados com a conservação e o desenvolvimento, tais como a conservação baseada na comunidade para pagamentos por serviços ecossistémicos. Um exemplo é o projecto financiado pelo Fundo Mundial do Ambiente (GEF) que fornece incentivos aos proprietários individuais de terras para conservar e restaurar habitats florestais importantes para os chimpanzés e outra flora e fauna. Forneceu incentivos a cerca de 400 agricultores (proprietários florestais privados) em 68 aldeias para a conservação da biodiversidade nas florestas em terras privadas e públicas não contempladas como reservas florestais.

Em 2018, o governo iniciou um processo de contemplação e declaração de parte da cobertura das zonas úmidas de Uganda como área protegida. As zonas húmidas do Uganda cobrem uma área de $11 \%$ da área de terra. Uma das principais tendências para as áreas protegidas no Uganda é a redução de áreas florestais nas áreas protegidas, em parques nacionais e reservas de vida selvagem e reservas florestais centrais. A cobertura florestal diminuiu de 1.59 milhões de ha em 1990 a 1.13 milhões de ha em 2015.

\section{Áreas transfronteiriças protegidas e de conservação}

O Uganda inclui zonas de cinco áreas de conservação transfronteiriças, nomeadamente a paisagem da Grande Virunga, a TFCA de Kagera, a paisagem de Kidepo, o Monte Elgon e a Baía de Sango-Minziro.

\section{Contexto politico}

Um relatório abrangente sobre legislação e política relacionada com a gestão de áreas protegidas, governação e equidade foi levado a cabo pelo programa BIOPAMA. Identificou 48 leis e políticas relevantes no Uganda (Tessema, 2019).

\section{Espécies-chave ${ }^{98}$}

O Uganda é rico em biodiversidade, com cerca de 19.000 espécies de flora e fauna. O conhecimento sobre estas espécies está inclinado para os mamíferos, aves, borboletas, algumas plantas, répteis, anfíbios e peixes. Uganda é o lar de cerca de 380 espécies de mamíferos e mais de 1.000 espécies de aves, representando quase a metade de todas as espécies registadas em África. A biodiversidade de peixe no Uganda é dominada pela família Cichlid, com um elevado nível de endemismo. Existem 98 espécies de anfíbios e 150 espécies de répteis encontrados na Uganda. Das aproximadamente 5.000 espécies de plantas superiores, 70 são endémicas. Os fungos, líquenes e insectos estão menos bem documentados.

7 A secção baseia-se nas informações contidas no Quinto Relatório Nacional do Uganda para a CBD (Agência Nacional de Gestão Ambiental do Uganda, 2014)

98 A secção baseia-se nas informações contidas no Quinto Relatório Nacional do Uganda ao CBD e no seu Segundo NBSAP (República do Uganda, 2016; Agência Nacional de Gestão Ambiental do Uganda, 2014) 
Figura 8.43 Resumo da Uganda
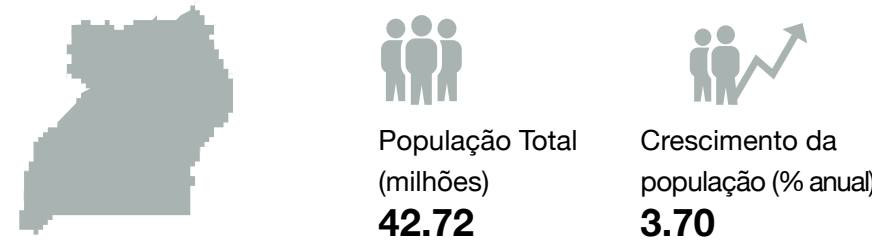

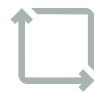

Superfície $\left(\mathrm{km}^{2}\right)$ (milhares)

241.60

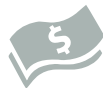

GDP (actuais US\$) (bilhões)

27.48
Crescimento do

GDP (\% anual)

6.10

Fonte: The World Bank Group, 2018.

\section{Área Protegida:}

712 protected areas

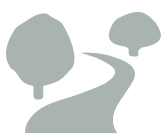

cobrindo 39059 km$^{2}$ de terra

Fonte: UNEP-WCMC \& UICN, (2019w)

\section{0 espécies de flora e fauna}

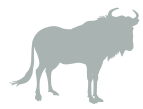
380 espécies
de mamíferos

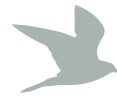

Áreas protegidas e de conservação em Uganda em Categorias de Gestão da UICN

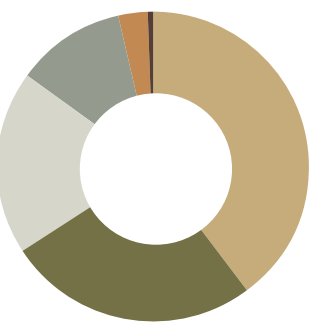

Fonte: UNEP-WCMC \& UICN (2019w)

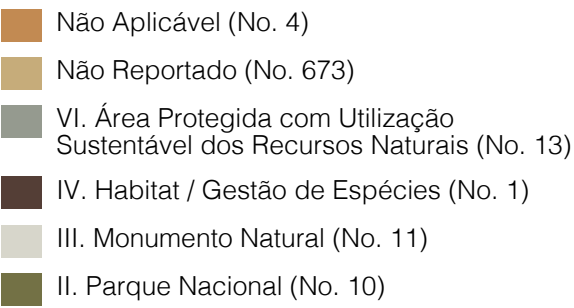

II. Parque Nacional (No. 10)

\section{Cobertura de áreas protegidas em Uganda}

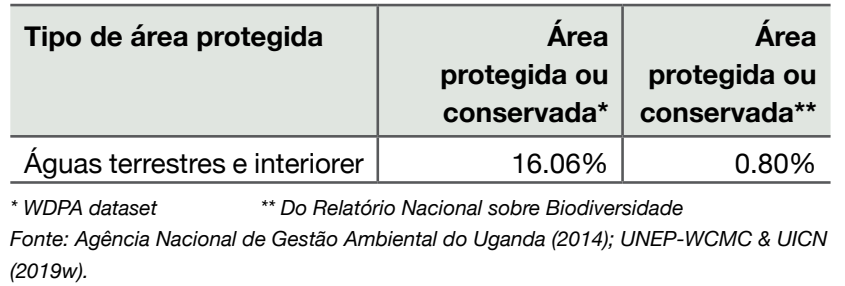

Áreas protegidas e de conservação designadas como sítios globais de importância em Uganda

\begin{tabular}{l|r}
\hline Designação global & No. de sítios \\
\hline Reservas do Homem e da Biosfera da UNESCO & 2 \\
\hline $\begin{array}{l}\text { Sítios Património Mundial da UNESCO } \\
\text { (Natural ou Misto) }\end{array}$ & 2 \\
\hline $\begin{array}{l}\text { Zonas húmidas de importância internacional } \\
\text { (sítios Ramsar) }\end{array}$ & 12 \\
\hline
\end{tabular}

Fonte: Ramsar (2019); UNESCO (2019a, 2019b).

Áreas protegidas e de conservação em Uganda nos tipos de governação da UICN

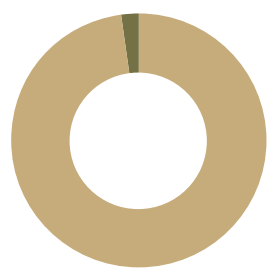

Não reportado (No. 13)

A. Governação pelo Governo (No. 699)
Designações nacionais de áreas protegidas e de conservação em Uganda

\begin{tabular}{l|r|r}
\hline Designação nacional & No. & Área (km²) \\
\hline Sanctuário & 1 & 187 \\
\hline Parque Nacional & 10 & 11251 \\
\hline Reserva de Vida Selvagem & 12 & 8461 \\
\hline Área de Comunidade de & 5 & 4239 \\
Gestão de Vida Selvagem & & \\
\hline Reserva Florestal & 661 & 12342 \\
\hline Sanctuário de Vida Selvagem & 7 & 554 \\
\hline
\end{tabular}

Fonte: UNEP-WCMC \& UICN (2019w).

Áreas prioritárias para a conservação

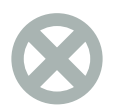

\section{4 sítios}

\section{4 sítios}

Aliança para os sítios Áreas importantes de de Extinção Zero Aves \& Biodiversidade

\section{3 sítios}

Áreas-chave da

Biodiversidade
5000 espécies de plantas 
Figura 8.44 Áreas Protegidas da Uganda

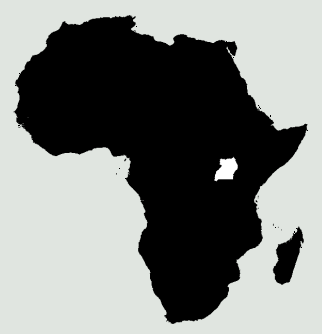

Áreas protegidas

Limite Administrativo
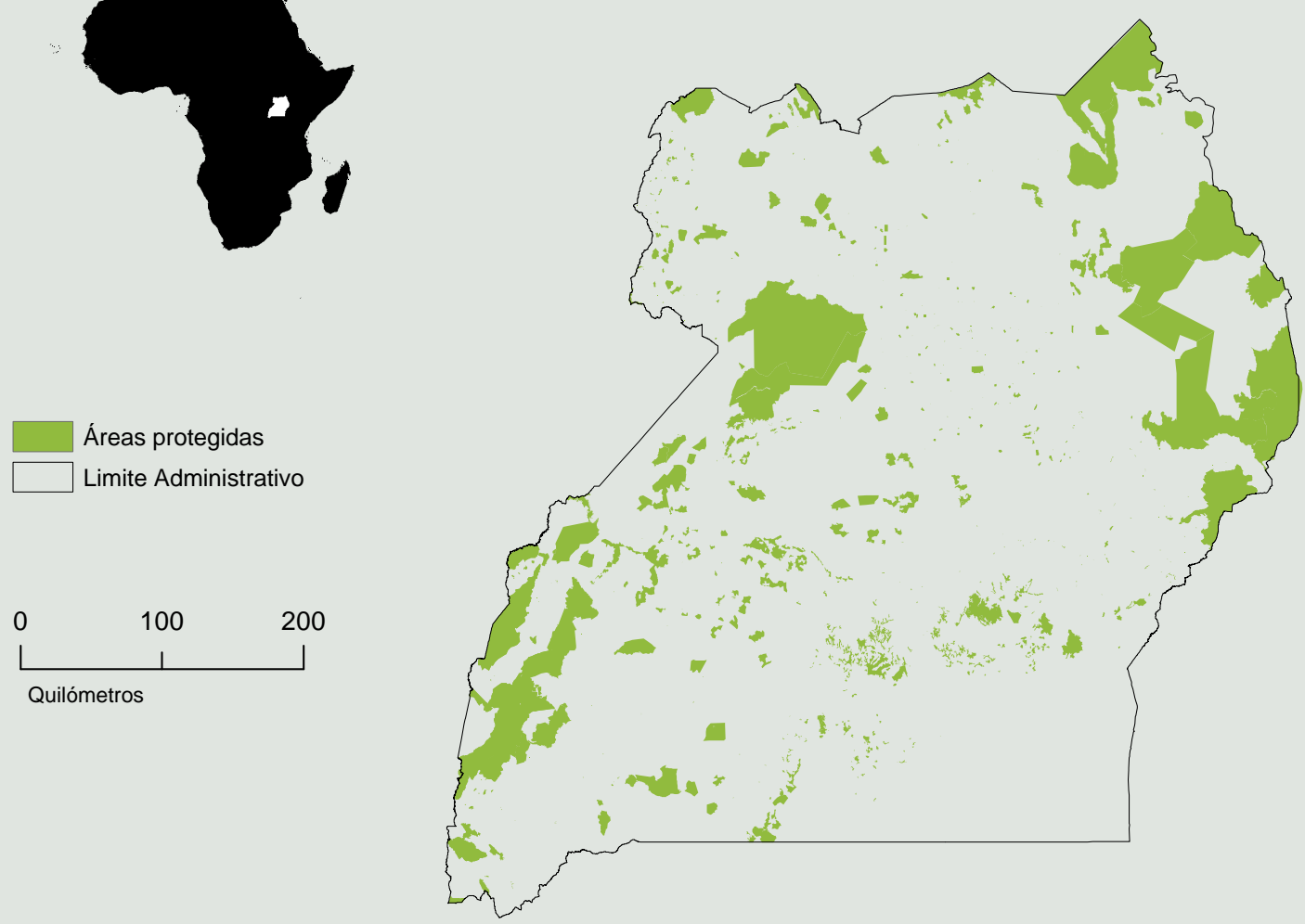

\section{Pressões e ameaças ${ }^{99}$}

O Uganda tem muitas ameaças à sua biodiversidade, a mais grave das quais é a perda e degradação do habitat. A invasão é prevalecente e o conflito entre homem e vida selvagem é um problema perene e crescente. A caça furtiva e o comércio ilícito de vida selvagem é também um problema grave, tal como as práticas de pesca destrutivas. As espécies invasoras alienígenas representam ameaças particulares a certos ecossistemas.

A elevada taxa de crescimento da população humana e o rápido desenvolvimento no Uganda estão a afectar os restantes habitats naturais do país. Os elevados níveis de pobreza significam que as pessoas continuam a depender dos recursos naturais para sobreviver.

99 A secção baseia-se nas informações contidas no Quinto Relatório Nacional do Uganda ao CBD e no seu Segundo NBSAP (República do Uganda, 2016; Agência Nacional de Gestão Ambiental do Uganda, 2014). 


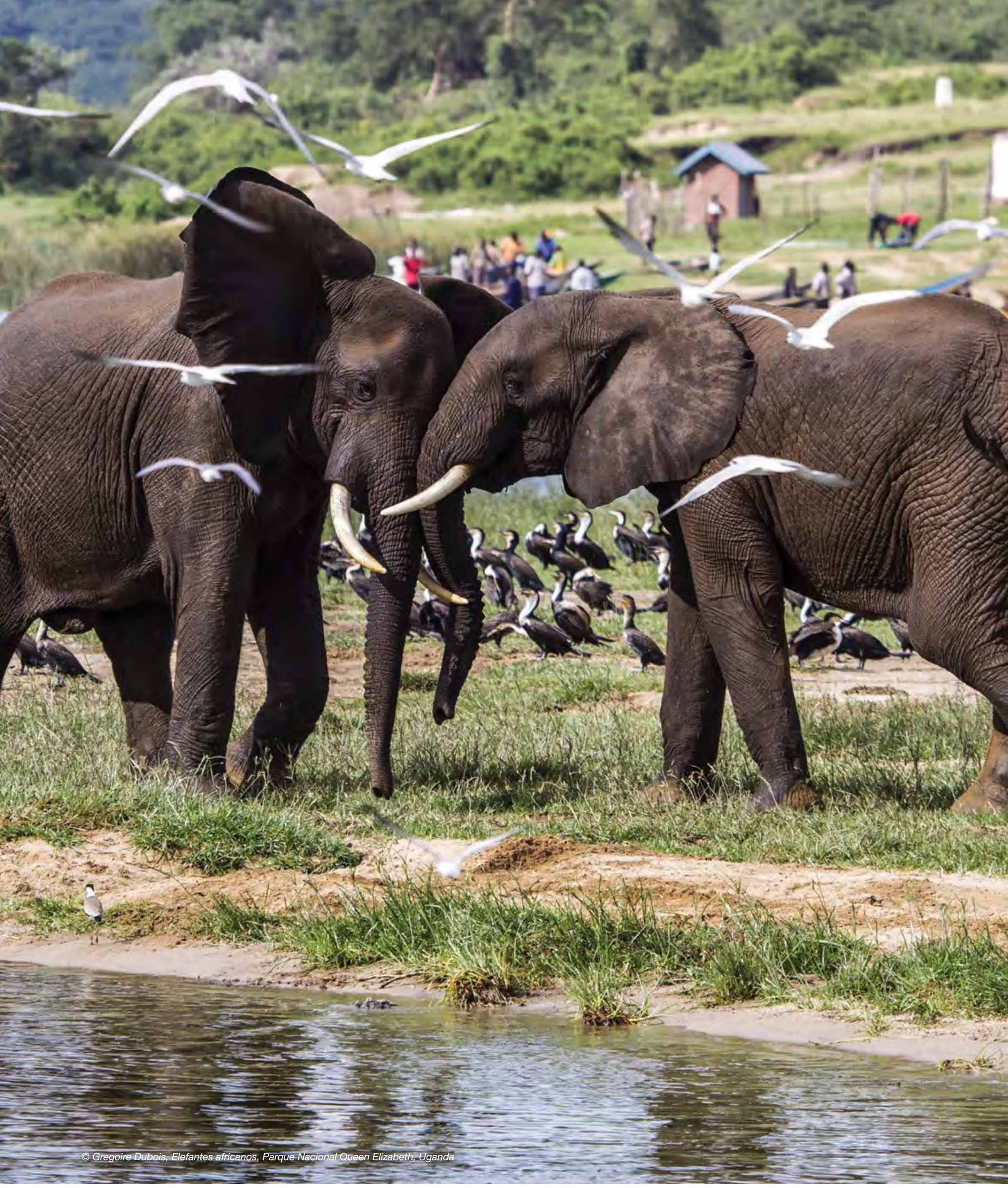




\subsection{Zâmbia}

\section{Áreas protegidas e de conservação na Zâmbia ${ }^{100}$}

Zâmbia tem 635 áreas protegidas cobrindo $286.161 \mathrm{~km}^{2}$ da terra (UNEP-WCMC \& UICN, 2019x).

Um país encravado na África Austral que inclui florestas, os agro-ecossistemas e as zonas húmidas da Zâmbia são os ecossistemas mais importantes para a economia nacional e para a subsistência rural. A conservação da biodiversidade até à data tem sido empreendida através da gestão do sistema de áreas protegidas existente, e a promoção da utilização sustentável dos recursos naturais em áreas abertas.

As principais alterações no estatuto dos parques nacionais, as reservas florestais e sistema de áreas protegidas de gestão de caça desde 2009 foram a criação de um novo Parque Nacional de Lusaka, a desgasificação de algumas reservas florestais e a identificação de lacunas de representação de espécies vegetais e animais dentro dos parques nacionais e áreas de gestão de caça existentes, tanto quanto possível, através do plano de conservação de reclassificação para orientar a acção de conservação.

\section{Áreas transfronteiriças protegidas e de conservação}

Zâmbia inclui partes de seis áreas de conservação transfronteiriças, nomeadamente a TFCA Kavango-Zambezi, a TFCA Liuwa Plain-Mussuma, a TFCA do Baixo Zambeze-Mana Piscinas, a TFCA da Malawi-Zâmbia, a TFCA da Mosi- oa-Tunya / Cataratas Vitória Transfronteiriço Património Mundial, e ZIMOZA TFCA.

\section{Contexto politico}

Um relatório abrangente sobre legislação e política relacionada com a gestão de áreas protegidas, governação e equidade foi levado a cabo pelo programa BIOPAMA. Identificou 79 leis e políticas relevantes na Zâmbia (Tessema, 2019).

\section{Espécies-chave ${ }^{101}$}

Zâmbia é o lar de mais de 12.500 espécies, das quais quase 200 foram avaliadas como ameaçadas de acordo com a Lista Vermelha da UICN. Foram registadas quase 4.000 espécies de plantas e 563 microrganismos. Há 224 espécies de mamíferos registadas, muitas das quais são economicamente importantes através da caça e do turismo, e 490 espécies de peixes. Zâmbia é também o lar de mais de 750 espécies de aves, comparativamente elevadas para um país sem litoral dominado por um único bioma.

\section{Pressões e ameaças ${ }^{102}$}

Os ecossistemas da Zâmbia enfrentam grandes ameaças: degradação das reservas florestais, principalmente para fins de mineração; desflorestação e degradação do habitat; invasão humana em áreas protegidas; incêndios tardios descontrolados; exploração excessiva de certas espécies arbóreas, bem como de mamíferos para o comércio ilegal de carne de animais selvagens, e sobrepesca de ecossistemas de água doce; poluição proveniente da agricultura, mineração e outras actividades industriais; e espécies invasoras alienígenas.

100 A secção baseia-se nas informações contidas nos Quinto e Sexto Relatórios Nacionais da Zâmbia à CDB (República da Zâmbia, 2015; 2019).

101 A secção baseia-se na informação contida no Quinto Relatório Nacional da Zâmbia ao CBD (República da Zâmbia, 2015; 2019).

102 lbid 
Figura 8.45 Resumo da Zâmbia

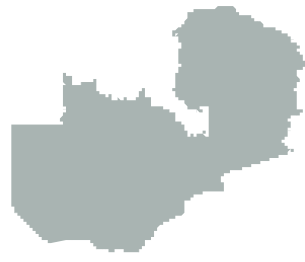

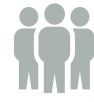

População Total (milhões)

17.35

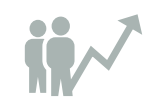

Crescimento da população (\% anual)

2.90

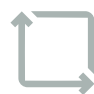

Superfície $\left(\mathrm{km}^{2}\right)$ (milhares)

752.60

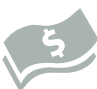

GDP (actuais US\$) (bilhões)

26.72
Crescimento do GDP (\% anual) 3.80

Fonte: The World Bank Group, 2018.

\section{Área Protegida:}

635

áreas protegidas

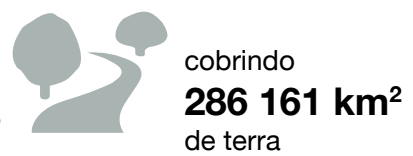

de terra

Fonte: UNEP-WCMC \& UICN, (2019x)

\section{Áreas protegidas e de conservação em Zâmbia em Categorias de Gestão da UICN}

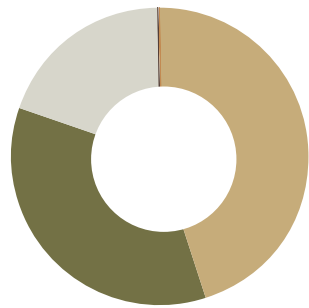

Não Aplicável (No. 1)

Não Reportado (No.562)

VI. Área Protegida com Utilização Sustentável dos Recursos Naturais (No. 36)

IV. Habitat / Gestão de Espécies (No. 1)

III. Monumento Natural (No. 16)

II. Parque Nacional (No. 19)

Mais de 12500 espécies

Fonte: UNEP-WCMC \& UICN (2019x)

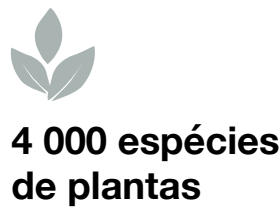

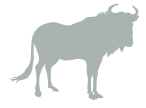

224 espécies de mamíferos
490 espécies de peixes
750 espécies de aves
Cobertura de áreas protegidas em Zâmbia

\begin{tabular}{l|r|r}
\hline Tipo de área protegida & $\begin{array}{r}\text { Área } \\
\text { protegida ou } \\
\text { conservada* }^{*}\end{array}$ & $\begin{array}{r}\text { Área } \\
\text { protegida ou } \\
\text { conservada }^{\star *}\end{array}$ \\
\hline Águas terrestres e interiores & $37.87 \%$ & $37.80 \%$ \\
\hline
\end{tabular}

* WDPA dataset $\quad{ }^{* *}$ Do Relatório Nacional sobre Biodiversidade

Fonte: República da Zâmbia (2019); UNEP-WCMC \& UICN (2019x).

Áreas protegidas e de conservação designadas como sítios globais de importância em Zâmbia

\begin{tabular}{l|r}
\hline Designação global & No. de sítios \\
\hline $\begin{array}{l}\text { Sítios Património Mundial da UNESCO } \\
\text { (Natural ou Misto) }\end{array}$ & 1 \\
\hline $\begin{array}{l}\text { Zonas húmidas de importância internacional } \\
\text { (sítios Ramsar) }\end{array}$ & 8 \\
\hline
\end{tabular}

Fonte Ramsar (2019); UNESCO (2019a, 2019b).

Áreas protegidas e de conservação na Zâmbia nos tipos de governação da UICN

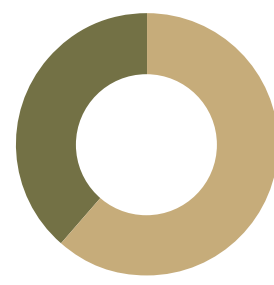

Não reportado (No. 586)

A. Governação pelo Governo (No. 49)
Designações nacionais de áreas protegidas e de conservação em Zâmbia

\begin{tabular}{l|r|r}
\hline Designação nacional & No. & Área $\mathbf{( k m}^{\mathbf{2}}$ \\
\hline Área de Conservação* & 1 & Desconhecido \\
\hline Parque Nacional & 19 & 60457 \\
\hline Monumento Natural & 16 & 74 \\
\hline Área de Gestão de Caça & 34 & 140447 \\
\hline Reserva Florestal & 555 & 79893 \\
\hline Santuário de Pássaros & 1 & 127 \\
\hline
\end{tabular}

Fonte: UNEP-WCMC \& UICN (2019x).

* Este site não tinha nenhuma área reportada na WDPA

\section{Áreas prioritárias para a conservação}

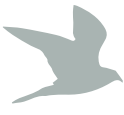

\section{2 sítios}

Áreas importantes de

\section{6 sítios}

Aves \& Biodiversidade

Áreas-chave da

Biodiversidade

Fonte: BirdLife International (2019b, 2019b). 
Figura 8.46 Áreas Protegidas da Zâmbia
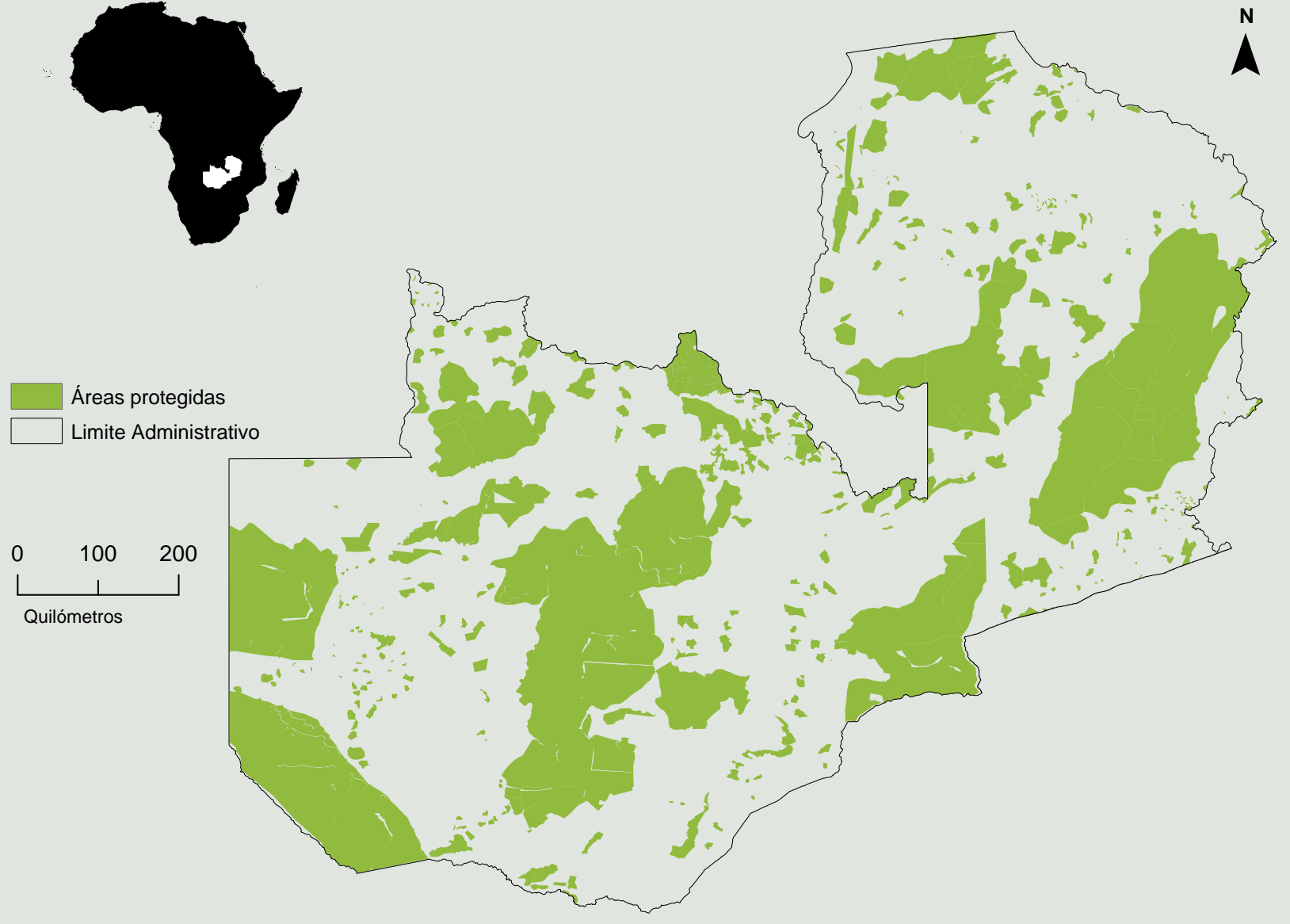

Desenvolvido por RCMRD baseado nos dados WDPA.

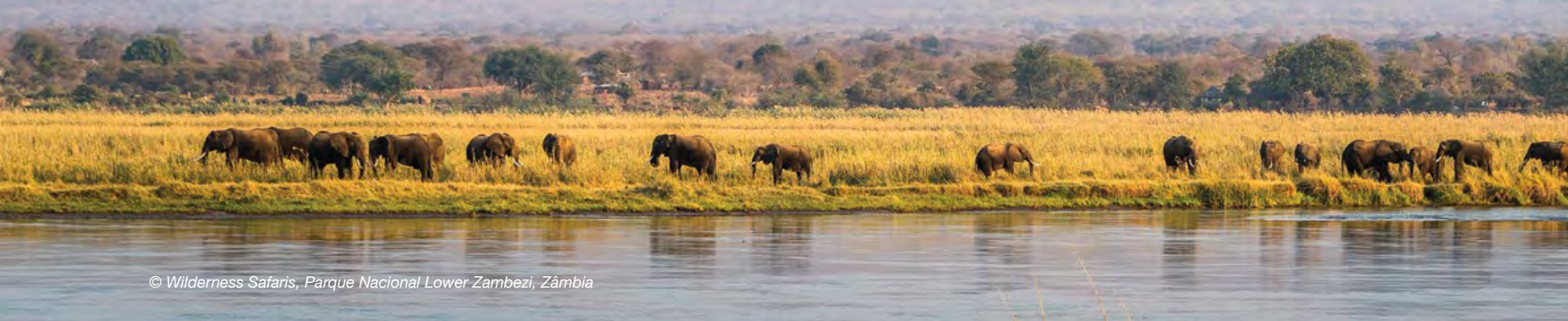




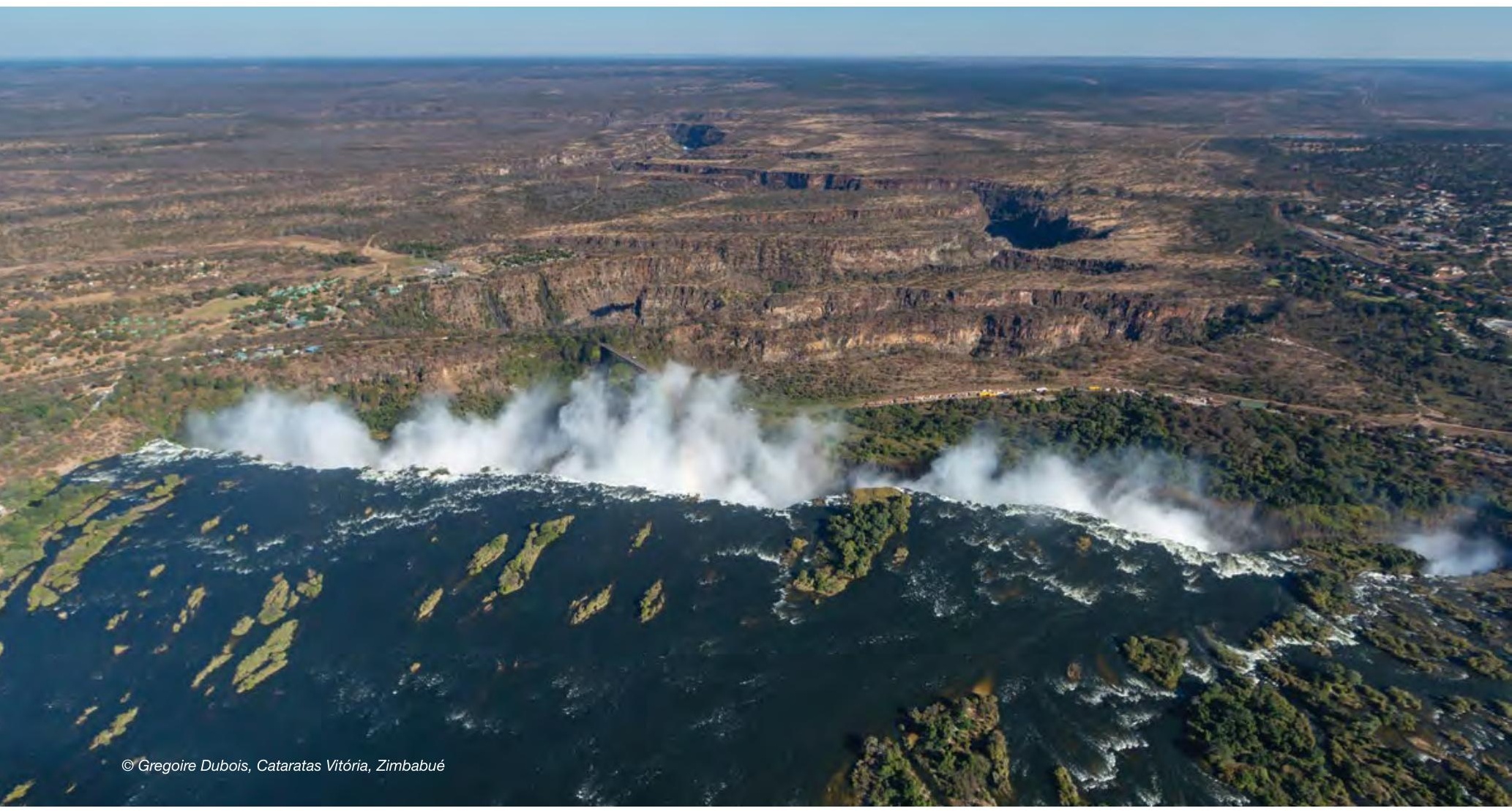

\subsection{Zimbabué}

\section{Áreas protegidas e de conservação no Zimbabué ${ }^{103}$}

Zimbabué tem 232 áreas protegidas cobrindo $106.838 \mathrm{~km}^{2}$ (UNEP-WCMC \& UICN, 2019y).

O Zimbabué tem uma rica história de conservação da biodiversidade. Estabeleceu uma extensa rede de áreas protegidas e promulgou uma legislação para a conservação e preservação rigorosa em algumas áreas e utilização sustentável noutras. A sua rede de áreas protegidas coloca o Zimbabué entre os 50 principais países a nível mundial no que diz respeito à cobertura de áreas protegidas. A biodiversidade é uma base importante para a economia do Zimbabué e apoia a subsistência da maioria da sua população. O quadro político e as estratégias desenvolvidas ao longo da última década reconhecem a importância da conservação da biodiversidade para o desenvolvimento sustentável e a biodiversidade tem sido racionalizada em todos os sectores.

O governo introduziu o programa CAMPFIRE para maximizar as opções de subsistência dos agricultores reinstalados, particularmente os que vivem em áreas onde a produção agrícola tem um potencial limitado, assegurando uma utilização rentável, equitativa e sustentável da vida selvagem e de outros recursos. Os projectos CAMPFIRE envolvem as comunidades na co-gestão da vida selvagem em áreas comunitárias

\section{Áreas transfronteiriças protegidas e de conservação}

Zimbabué inclui partes de sete áreas de conservação transfronteiriças, nomeadamente a TFCA Chimanimani, o Parque Transfronteiriço e Área de Conservação do Grande Limpopo, a TFCA do Grande Mapungubwe, a TFCA de Kavango-Zambezi, a TFCA do Baixo Zambeze-Mana Pools, o Sítio do Património Mundial Transfronteiriço da Mosi-oa-Tunya Cataratas Vitória e a TFCA da ZIMOZA.

\section{Contexto politico}

Um relatório abrangente sobre legislação e política relacionada com a gestão de áreas protegidas, governação e equidade foi levado a cabo pelo programa BIOPAMA. Foram identificadas 25 leis e políticas relevantes no Zimbabué (Tessema, 2019).

\section{Espécies-chave ${ }^{104}$}

Zimbabué é o lar de quase 6.000 espécies de plantas vasculares, das quais 214 são endémicas. Existem 211 espécies consideradas ameaçadas, mas esta não é uma contagem completa, uma vez que apenas $10 \%$ foram avaliadas para o estatuto de ameaça. O Zimbabué é também o lar de 670 espécies de aves, 270 mamíferos, 156 espécies de répteis, 120 anfíbios e 151 espécies de peixes. Há um conhecimento limitado de microrganismos.

103 A secção baseia-se na informação contida no Sexto Relatório Nacional do Zimbabué à CDB (República do Zimbabué, 2019).

104 A secção baseia-se na informação contida no Quinto Relatório Nacional do Zimbabué ao CBD e no seu Segundo NBSAP (República do Zimbabué, 2014, 2015) 
Figura 8.47 Resumo do Zimbabué

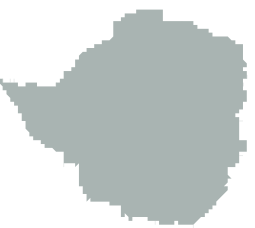

Fonte: The World Bank Group, 2018.

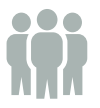

População Total (milhões)

14.44

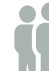

Crescimento da população (\% anual) 1.40

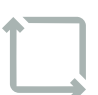

Superfície $\left(\mathrm{km}^{2}\right)$ (milhares) 390.80
GDP (actuais US\$) (bilhões)

31.00
Crescimento do GDP (\% anual)

6.20

\section{Área Protegida:}

\section{2} áreas protegidas

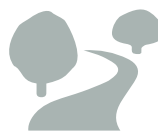

cobrindo 106838 km² $^{2}$ de terra
Áreas protegidas e de conservação no Zimbabué em Categorias de Gestão da UICN

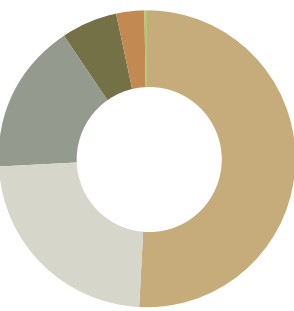

Não Aplicável (No. 3)

Não Reportado (No. 166)

VI. Área Protegida com Utilização

Sustentável dos Recursos Naturais (No. 19)

V. Paisagem Protegida / Paisagem Marítima (No. 12)

IV. Habitat / Gestão de Espécies (No. 19)

III. Monumento Natural (No. 2)

II. Parque Nacional (No. 10)

Fonte: UNEP-WCMC \& UICN (2019y).

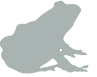

120 anfíbios
151 espécies de peixes

\section{$\int(1$, \\ 270 mamíferos}

156 espécies de répteis
670 espécies de aves

\section{Cobertura de áreas protegidas no Zimbabué}

\begin{tabular}{l|r|r}
\hline Tipo de área protegida & $\begin{array}{r}\text { Área } \\
\text { protegida ou } \\
\text { conservada }^{*}\end{array}$ & $\begin{array}{r}\text { Área } \\
\text { protegida ou } \\
\text { conservada** }\end{array}$ \\
\hline Águas terrestres e interiores & $27.21 \%$ & $28.00 \%$ \\
\hline
\end{tabular}

\section{*WDPA dataset $\quad$ ** Do Relatório Nacional sobre Biodiversidade}

Fonte: República do Zimbabué (2015); UNEP-WCMC \& UICN (2019y).

Áreas protegidas e de conservação designadas como sítios globais de importância no Zimbabué

\begin{tabular}{l|r}
\hline Designação global & No. de sítios \\
\hline Reservas do Homem e da Biosfera da UNESCO & 1 \\
\hline $\begin{array}{l}\text { Sítios Património Mundial da UNESCO } \\
\text { (Natural ou Misto) }\end{array}$ & 2 \\
\hline $\begin{array}{l}\text { Zonas húmidas de importância internacional } \\
\text { (sítios Ramsar) }\end{array}$ & 7 \\
\hline
\end{tabular}

Fonte: Ramsar (2019); UNESCO (2019a, 2019b).

Áreas protegidas e de conservação em Zimbabué nos tipos de governação da UICN

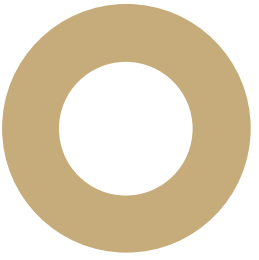

Não Reportado (No. 232)
Designações nacionais de áreas protegidas e de conservação no Zimbabué

\begin{tabular}{l|r|r}
\hline Designação nacional & No. & Área $\mathbf{( k m}^{2} \mathbf{~}$ \\
\hline Sanctuário & 11 & 6660 \\
\hline Parque Nacional & 11 & 26896 \\
\hline Parque de Recreacção & 9 & 3642 \\
\hline Monumento Nacional & 1 & 7 \\
\hline Área de Gestão de Vida Selvagem & 104 & 39376 \\
\hline Reserva Botânica & 14 & 16 \\
\hline Reserva Natural & 1 & 17 \\
\hline Parque de Recreacção & 3 & 129 \\
\hline Jardim Botânico & 3 & 6 \\
\hline Área de Safari & 16 & 18988 \\
\hline Floresta do Estado & 43 & 9341 \\
\hline Floresta Protegida & 6 & 608 \\
\hline Fonte: UNEP-WCMC\& UICN (2019y). & &
\end{tabular}

Fonte: UNEP-WCMC \& UICN (2019y).

\section{Áreas prioritárias para a conservação}
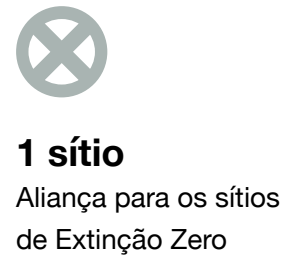

18 sítios

\section{6 sítios}

Áreas importantes de

Áreas-chave da Biodiversidade 
Figura 8.48 Áreas Protegidas do Zimbabué

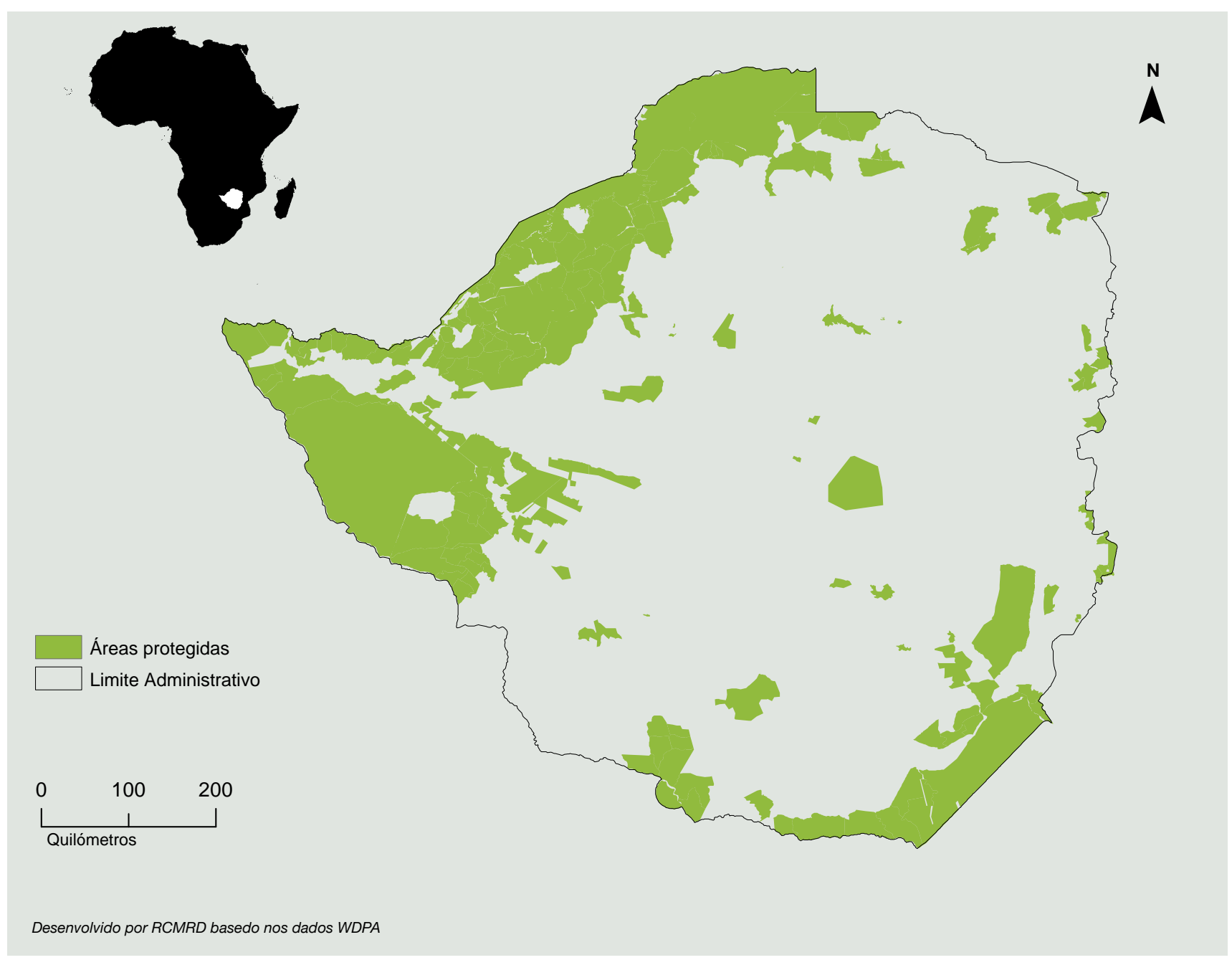

\section{Pressões e ameaças ${ }^{105}$}

As principais causas da perda de biodiversidade no Zimbabué são: a perda e degradação do habitat devido à expansão agrícola insustentável, o sobrepastoreio, a utilização de árvores como fonte de energia, os danos causados por incêndios, a exploração mineira e desenvolvimento de infra-estruturas; espécies exóticas invasoras; e alterações climáticas. Muitas aves, répteis, anfíbios e mamíferos são também directamente ameaçados pela colheita ilegal ou insustentável, para o comércio ilegal de carne de animais selvagens. Os elevados níveis de poluição nos sistemas aquáticos do Zimbabué tiveram também um grande impacto na biodiversidade do país.

Subjacentes a estas ameaças directas estão os desafios a longo prazo da pobreza, o desenvolvimento económico descontrolado e a falta de capacidade institucional para gerir de forma sustentável os recursos naturais. 

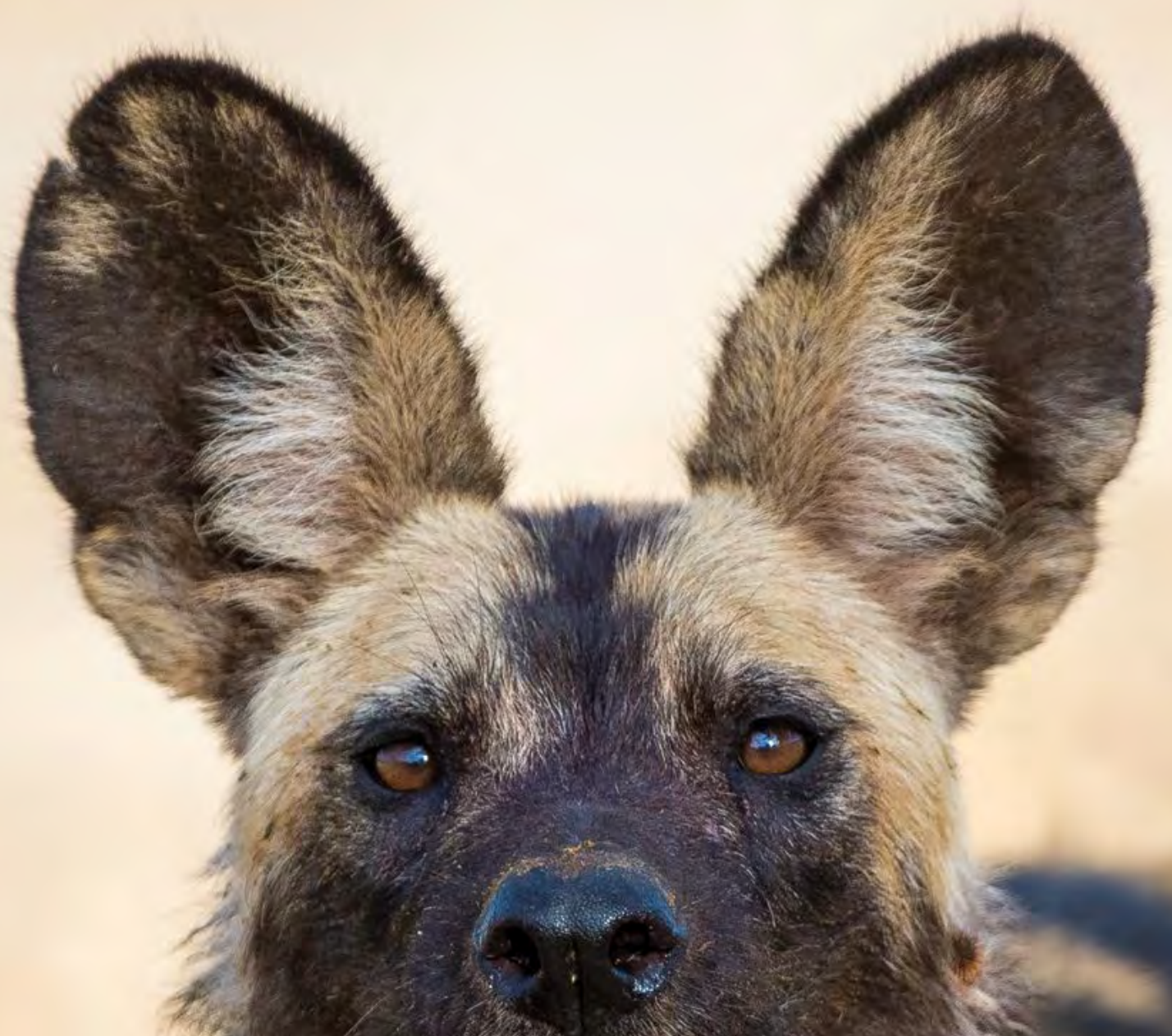

$\lim _{3 \rightarrow \infty}+x^{2}$

2.
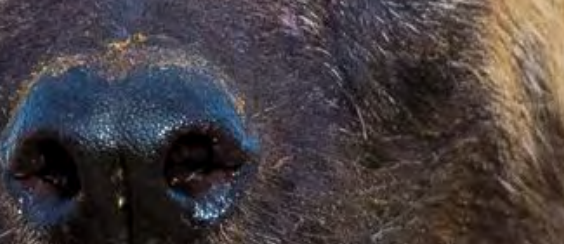

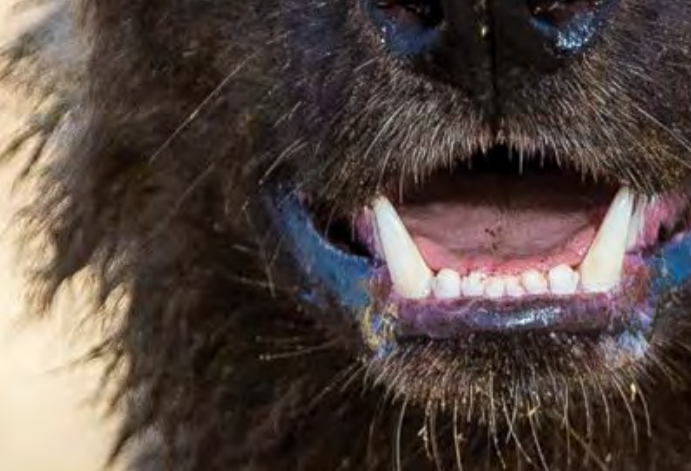

$(1)(x))^{\prime}$

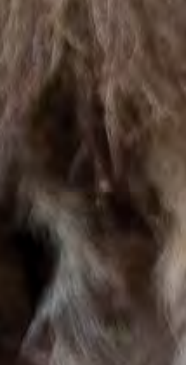

10.
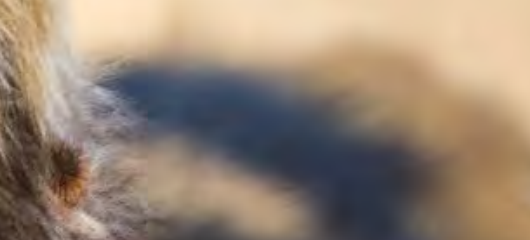

(n) 

Parte III - Governação e eficácia da gestão

\section{Governação e} equidade de áreas protegidas $^{106}$ 
As áreas protegidas são uma pedra angular dos esforços globais de conservação; protegem a biodiversidade, restauram paisagens degradadas, fornecem serviços ecológicos e oportunidades de subsistência e continuam a ser um lugar para as pessoas se reconectarem com a natureza. Contudo, as áreas protegidas têm sido também um foco de preocupações frequentes sobre resultados injustos para as pessoas, incluindo justiça social e questões de direitos humanos. Relatórios recentes dos Relatores Especiais das Nações Unidas destacaram a amplitude destas questões, particularmente no que diz respeito aos Povos Indígenas e comunidades locais (ONU, 2016).

Desde o início da década de 1980, estas questões têm sido consideradas na comunidade de conservação a nível internacional (McNeely \& Miller, 1984), e nomeadamente no V Congresso Mundial de Parques da UICN de 2003 (UICN, 2005a; 2005b). Em 2010, o Alvo 11 de Aichi, adoptado pelos 193 Estados Partes na CDB, declarou que as áreas protegidas devem ser geridas equitativamente até 2020 (CDB, 2010b). A palavra "equidade" capta a noção de equidade, e a fundamentação para a incutir na conservação baseada na área é articulada no texto de apoio ao Programa de Trabalho sobre Áreas Protegidas (PoWPA): "As áreas protegidas devem também ser estabelecidas e geridas em estreita colaboração com, e através de processos equitativos que reconheçam e respeitem os direitos das comunidades indígenas e locais, e das populações vulneráveis" (SBSTTA, 2010). Estes elementos do Alvo 11 de Aichi continuam a ser pouco relatados (Gannon et al., 2019). Isto está ligado tanto à complexidade do conceito de equidade, como à falta de sistemas de avaliação adequados.

Embora tenha havido tentativas limitadas de compreender e avaliar a equidade na conservação, tem havido um trabalho substancial sobre estas questões no contexto semelhante dos pagamentos por serviços ecossistémicos (McDermott et al., 2013). Este trabalho conclui que a equidade pode ser conceitualizada como tendo três dimensões centrais: reconhecimento, procedimento e distribuição.

No contexto da conservação de áreas protegidas, as três dimensões da equidade podem ser entendidas da seguinte forma:

- O reconhecimento refere-se ao reconhecimento e respeito pelos direitos e diversidade de identidades, valores, sistemas de conhecimento e instituições dos titulares de direitos e partes interessadas (ver também Caixa 9.1).

- O procedimento refere-se à transparência e responsabilização e à inclusão da regra e da tomada de decisões.

- A distribuição refere-se à mitigação dos custos que afectam as comunidades indígenas e locais e partilha equitativa dos benefícios resultantes da gestão de áreas protegidas (Schreckenberg et al., 2016).).

Com base neste quadro, as Partes na CDB adoptaram orientações voluntárias sobre equidade na COP14, em Novembro de 2018, que se pretendia aplicar em qualquer contexto para a conservação da natureza e o desenvolvimento sustentável (CDB, 2018).

O aumento da equidade aumenta a contribuição das áreas protegidas para o bem-estar humano tanto através do aumento e partilha mais justa dos benefícios e da redução dos custos (equidade na distribuição), como também através da contribuição directa para o bem-estar subjectivo de um maior reconhecimento e respeito pelas partes interessadas (equidade no reconhecimento) e processos mais justos (equidade nos procedimentos) (Franks et al., 2018). Há provas de que a melhoria da equidade pode contribuir para uma conservação mais bem-sucedida e eficaz da biodiversidade (Oldekop et al., 2016).

Neste capítulo, são considerados dois pontos de entrada distintos mas interrelacionados para abordar a equidade na conservação:

(1) Através da melhoria da governação, utilizando avaliações de governação para identificar os pontos fracos da governação a serem abordados e os pontos fortes a serem reforçados; e

(2) Aumentando os benefícios e reduzindo os custos utilizando avaliações sociais para compreender melhor os impactos positivos e negativos das áreas protegidas no bem-estar das pessoas.

Outra via para uma maior equidade na conservação baseada na área é o conceito emergente de "áreas de conservação". A secção 2.3 deste relatório aborda mais detalhadamente as áreas de conservação e o reconhecimento do conceito pela CDB através do termo "outras medidas de conservação eficazes baseadas na área” (OECMs).

\subsection{Governação de áreas protegidas}

A governação é um conceito poderoso para a equidade, direitos e meios de subsistência. De facto, a equidade na conservação é antes de tudo uma questão de governação (Franks et al., 2018)

A definição de governação pela UICN assume uma perspectiva dinâmica: abordar a governação não é apenas uma questãode compreender quem toma as decisões, mas vai além de considerar as interacções entre estruturas, processos e tradições que determinam como o poder e as responsabilidades são exercidos, como as decisões são tomadas, e como os cidadãos e outros interessados têm uma palavra a dizer (Borrini- Feyerabend et al., 2013). No contexto das áreas protegidas, a governação preocupa-se com quem toma as decisões, como estas decisões são tomadas e quão apropriadas, adaptáveis e justas são essas decisões para todos os

\section{Caixa 9.1 Titulares de direitos versus partes interessadas: Qual é a diferença?}

No contexto de áreas protegidas e de conservação, referimo-nos aos titulares de direitos como actores socialmente dotados de direitos legais ou consuetudinários no que diz respeito à terra, água e recursos naturais.

Os actores, por outro lado, possuem interesses directos ou indirectos no que respeita aos recursos naturais, mas não possuem necessariamente direitos legais ou sociais. (Borrini-Feyerabend et al., 2017).

interessados. Isto é fundamental, pois a governação deve considerar uma série de factores: desde diversos actores a diferentes processos e fenómenos que conduzem à tomada de decisões. Aborda também quem tem o mandato e os recursos para decidir, e quem deve ser responsabilizado e responsável por essas decisões. 


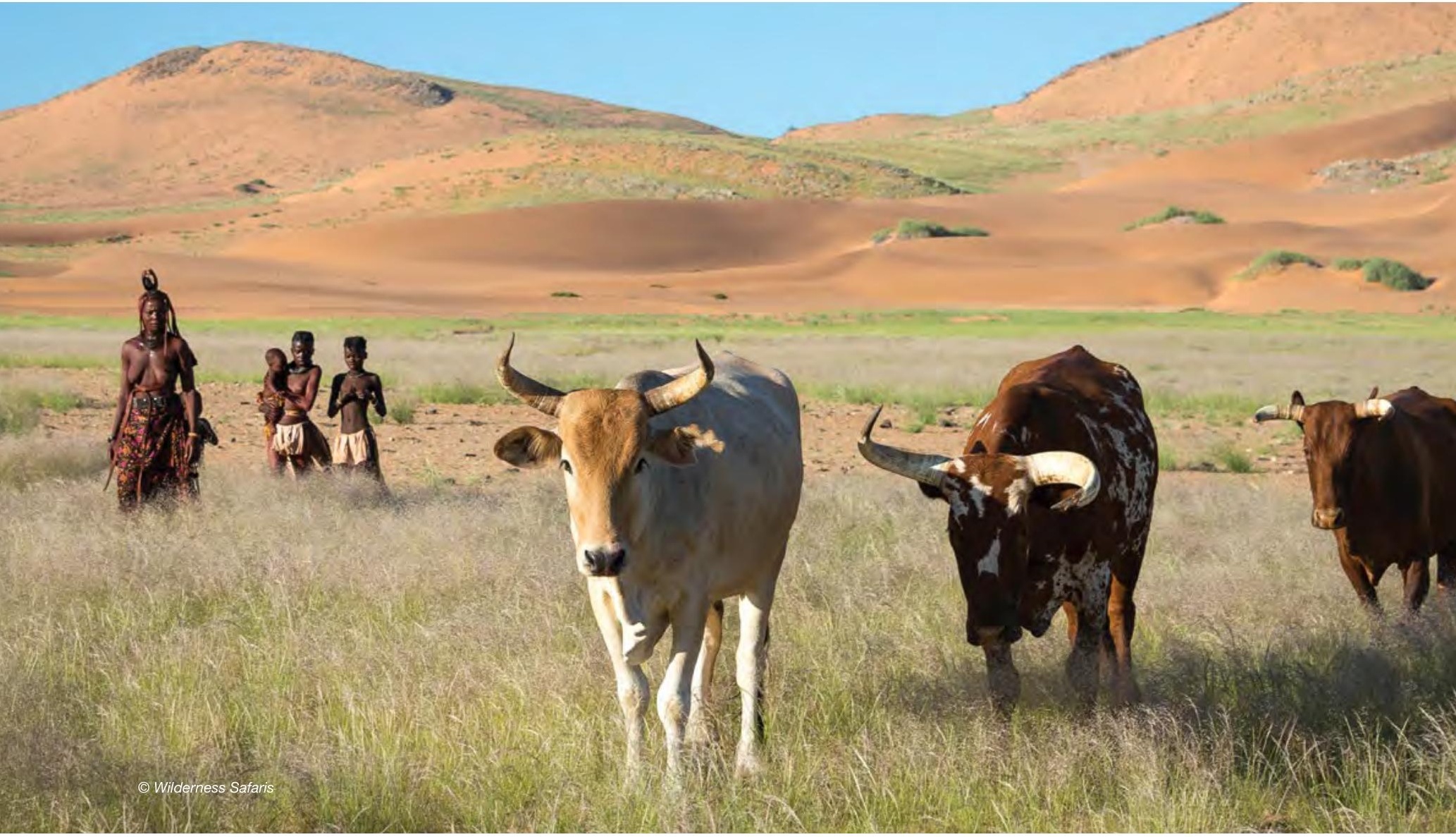

Um mandato de governação pode ser legitimado quer através do reconhecimento de jure (legal), como no caso de uma agência governamental de áreas protegidas, quer através do reconhecimento de facto, em que certos actores são considerados como tomando decisões legítimas (por exemplo, uma comunidade que adopta as suas próprias regras de proibição da pesca para restauração). Ver Caixa 9.2.

A governação deve ser distinguida da gestão, embora os dois termos estejam intimamente ligados. Enquanto a gestão diz respeito às actividades que são realizadas para alcançar determinados objectivos, tais como as actividades e os recursos delineados num plano de gestão, a governação preocupa-se com os actores que decidiram elaborar o plano de gestão e com as considerações que foram tomadas. A governação é geralmente discutida e cada vez mais avaliada em duas dimensões, diversidade de governação (ou tipo de governação) e qualidade de governação (ou boa governação).

\subsubsection{Diversidade de governação}

A diversidade de governação preocupa-se em reconhecer o amplo espectro de actores da governação, tanto de jure como de facto, que detêm responsabilidade e autoridade pelas áreas protegidas. Até à data, a maioria das áreas protegidas na região foram estabelecidas pelos governos estatais através de leis e políticas a nível nacional. Isto reflecte-se nos dados do WDPA (UNEP-WCMC \& UICN, 2019b). Contudo, muitas áreas protegidas existentes têm as suas raízes em alguma forma de acordos de governação local, por comunidades nas suas próprias áreas de conservação ou através de iniciativas privadas. Para além das áreas protegidas geridas pelo governo, existem áreas protegidas que são estabelecidas pelos povos indígenas, comunidades locais, indivíduos privados, operadores de ecoturismo e outros. Tal como com as seis categorias de gestão de áreas protegidas que vão desde reservas naturais rigorosas (Categoria la) a paisagens protegidas e paisagens marinhas com utilização sustentável dos recursos naturais (Categoria VI), a UICN e a CDB também encorajam o pleno reconhecimento da diversidade dos tipos de governação nos sistemas nacionais de áreas protegidas. A este respeito, são reconhecidos quatro grandes tipos de governação de áreas protegidas (ver Quadro 9.1), que entre eles representam um espectro completo de diversidade de governação no sistema de áreas protegidas (Belle et al., 2015; Borrini-Feyerabend et al., 2017; CBD, 2004 \& 2010a; Dudley, 2008).

Em todo o continente africano, a maioria das áreas protegidas são governadas pelo governo (tipo A) embora os tipos B e C também estejam representados, mas nem sempre são relatados ou bem compreendidos (UNEP-WCMC, 2019a; UNEP-WCMC \& UICN, 2019a). As áreas protegidas vão desde parques nacionais liderados pelo governo, a áreas protegidas partilhadas governadas conjuntamente por agências estatais e comunidades, a reservas privadas, bem como parcerias público-privadas entre governos e empresas privadas ou ONGs. A quarta categoria, ou Tipo D, talvez menos compreendida, mas cheia de potencial, são os povos indígenas e comunidades de conservação em territórios e áreas (ICCAs). 


\section{Quadro 9.1 Tipos de governação da UICN para áreas protegidas}

\begin{tabular}{|c|c|}
\hline Tipo de governação & Sub-tipos \\
\hline Tipo A: Governação pelo governo & $\begin{array}{l}\text { - Ministério Nacional ou uma agência de áreas protegidas } \\
\text { - Agência subnacional (a todos os níveis) }\end{array}$ \\
\hline Tipo B: Governação partilhada & $\begin{array}{l}\text { - Disposições transfronteiriças de governação } \\
\text { - Governação colaborativa (através de várias formas de trabalho conjunto de diversos } \\
\text { actores e instituições) } \\
\text { - Governação conjunta (conselho pluralista ou outro órgão de governação multipartidário }\end{array}$ \\
\hline Tipo C: Governação privada & $\begin{array}{l}\text { - Proprietários individuais de terras } \\
\text { - Entidades religiosas } \\
\text { - Organizações sem fins lucrativos ou com fins lucrativos }\end{array}$ \\
\hline $\begin{array}{l}\text { Tipo D: Governação por povos indígenas e/ } \\
\text { ou comunidades locais (muitas vezes } \\
\text { chamados ICCAs ou territórios de vida) }\end{array}$ & $\begin{array}{l}\text { - Territórios e áreas de conservação dos povos indígenas, estabelecidos e geridos } \\
\text { pelos povos indígenas } \\
\text { - Áreas comunitárias de conservação - estabelecidas e geridas por comunidades locais }\end{array}$ \\
\hline
\end{tabular}

Fonte: Borrini-Feyerabend et al. (2017).

As ICCAs são reconhecidas não só na CDB, mas também noutros acordos e políticas internacionais, e estão fortemente ligadas aos instrumentos da ONU sobre direitos humanos e povos indígenas. As ICCAs podem ser contadas como parte dos alvos nacionais no âmbito do Objectivo 11 de Aichi, ao abrigo das disposições para OECMs.

As áreas marinhas geridas localmente (LMMA) representam um modelo de governação que é estabelecido e gerido com forte envolvimento da comunidade e do governo local (ver Caixa 9.3) que pode igualmente ser reconhecido como uma área protegida ou OECM.

A nível político, a PoWPA (CBD, 2004) apelou às Partes na CBD para que o fizessem:

- apoiar tipos inovadores de governação para áreas protegidas (ver Caixa 9.3 para um exemplo do Zimbabué);

- reconhecê-los na legislação nacional ou através de outros meios eficazes;

- procurar equidade e eficácia na conservação enquanto se expande a cobertura;

- intensificar os esforços de restauração; e

- envolver conhecimentos, competências e instituições indígenas e tradicionais.

É fundamental notar que não existe um acordo de governação universal e "melhor" em qualquer dado contexto. É mais realista examinar quão apropriados, legítimos e úteis estes arranjos são em diferentes circunstâncias. Um acordo de governação para uma determinada área protegida só pode ser considerado apropriado quando adaptado ao seu contexto histórico e social, e eficaz na obtenção de resultados de conservação duradouros e benefícios de subsistência. Todos os princípios de qualidade de governação identificados na Secção 9.1.2 devem ser aplicáveis em qualquer sítio, independentemente do tipo de governação, embora o nível de envolvimento das partes interessadas e dos titulares de direitos varie.

\subsubsection{Qualidade de governação}

Incentivar todo o espectro de tipos de governação num contexto nacional é uma das condições essenciais para a equidade (Schreckenberg et al., 2016), embora não garanta que todas essas áreas protegidas estejam a ser governadas de forma equitativa ou eficaz.
A nível do local, também surgem outras preocupações, como por exemplo:

- Como estão a ser tomadas as decisões sobre a área protegida?

- Essas decisões são equitativas?

- Que valores orientam essas decisões?

- Até que ponto é transparente a tomada de decisões?

- Os titulares de direitos (aqueles com direito legal ou consuetudinário à terra e aos recursos) estiveram envolvidos?

- Foram incluídos os interessados (aqueles que têm um interesse directo ou indirecto)?

Com estas questões e com base nos princípios das Nações Unidas para a boa governação (Graham et al., 2003), começa a desenvolver-se um sentido de qualidade de governação, por vezes referido como boa governação (Quadro 9.2).

Os princípios da boa governação oferecem formas de operacionalizar abordagens baseadas nos direitos, e abordam a equidade e igualdade de género, e a inclusão de grupos marginalizados. Como tal, a boa governação confere poderes aos titulares de direitos e outros interessados, permitindo uma melhor integração das áreas protegidas na paisagem local e nas preocupações mais vastas da sociedade (ver Caixa 9.5).

No seu conjunto, a diversidade e a qualidade de governação são as pedras angulares tanto da equidade na conservação das áreas protegidas como da eficácia a longo prazo da conservação da biodiversidade (de Koning et al., 2016; Eklund \& Cabeza, 2017; Gutiérrez et al., 2011; Schultz et al., 2015; Stoll-Kleeman et al., 2006).

A elaboração de relatórios sobre diversidade e qualidade de governação utilizando a avaliação da governação é agora uma área chave de enfoque na comunidade de conservação (ver secção 9.4). 


\section{Caixa 9.2 Arrancar com a conservação marinha através da gestão local das pescas}

Em Andavadoaka, Madagáscar, os encerramentos voluntários e temporários dos pesqueiros de polvo são utilizados como ponto de entrada para a conservação baseada na comunidade. Os encerramentos cobrem normalmente $25 \%$ da área global de pesca do polvo de uma comunidade e estão em vigor durante 2-3 meses de cada vez. Há provas irrefutáveis de que isto melhora o rendimento da pesca e os rendimentos locais, criando assim apoio para proteger os recursos naturais através de áreas marinhas geridas localmente (LMMAs), áreas onde a gestão dos recursos marinhos está, pelo menos em parte, sob controlo comunitário. Os LMMAs empregam frequentemente estratégias de gestão marinha, tais como proibições, sobre práticas de pesca destrutivas e zonas de não captura permanente imposta pela comunidade.

Alguns dos desafios experimentados na região incluem as alterações climáticas, a sobrepesca, a crescente pobreza costeira e a insegurança alimentar e a falta de incentivos à conservação. Muitos esforços de conservação marinha falham. A declaração de cima para baixo de que grandes áreas estão permanentemente fora dos limites da pesca coloca com demasiada frequência a conservação à cabeça dos madeireiros com as necessidades das comunidades costeiras, privando as pessoas que dependem da pesca para a sua subsistência. Para muitas comunidades costeiras tropicais, a renúncia à pesca em áreas protegidas representa um sacrifício económico extremamente severo e um custo de oportunidade significativo.
A investigação sobre a eficácia dos encerramentos de polvos mostrou que estes podem melhorar as capturas e os rendimentos, com os desembarques dos locais de pesca encerrados a aumentarem mais de $700 \%$ no mês seguinte ao levantamento de um encerramento, aumentando as capturas por pescador por dia em quase $90 \%$ durante o mesmo período. Em Madagáscar, o sucesso dos encerramentos antecipados levou a que outras comunidades seguissem o exemplo, com mais de 270 encerramentos efectuados até à data. A adopção continua a crescer todos os anos, não só em Madagáscar, mas agora em outros países da região. A abordagem também foi introduzida à pesca artesanal de caranguejo de lama e lagosta espinhosa. Após o estabelecimento bem sucedido dos encerramentos, as comunidades pesqueiras de Madagáscar agruparam-se para estabelecer mais de 190 associações de gestão e 70 LMMAs que proíbem práticas de pesca destrutivas. MIHARI, a rede LMMA de Madagáscar, cobre actualmente mais de $17 \%$ do fundo marinho da ilha, e é defendida ao mais alto nível de governo. No final de 2017, o trabalho da Blue Ventures em Madagáscar está a melhorar a vida de mais de 200,000 pessoas. O imperativo agora é levar esta abordagem bem sucedida às comunidades costeiras de todo o Oceano Índico.

\section{Contribuído por Rupert Quinlan (Blue Ventures, Madagáscar)}

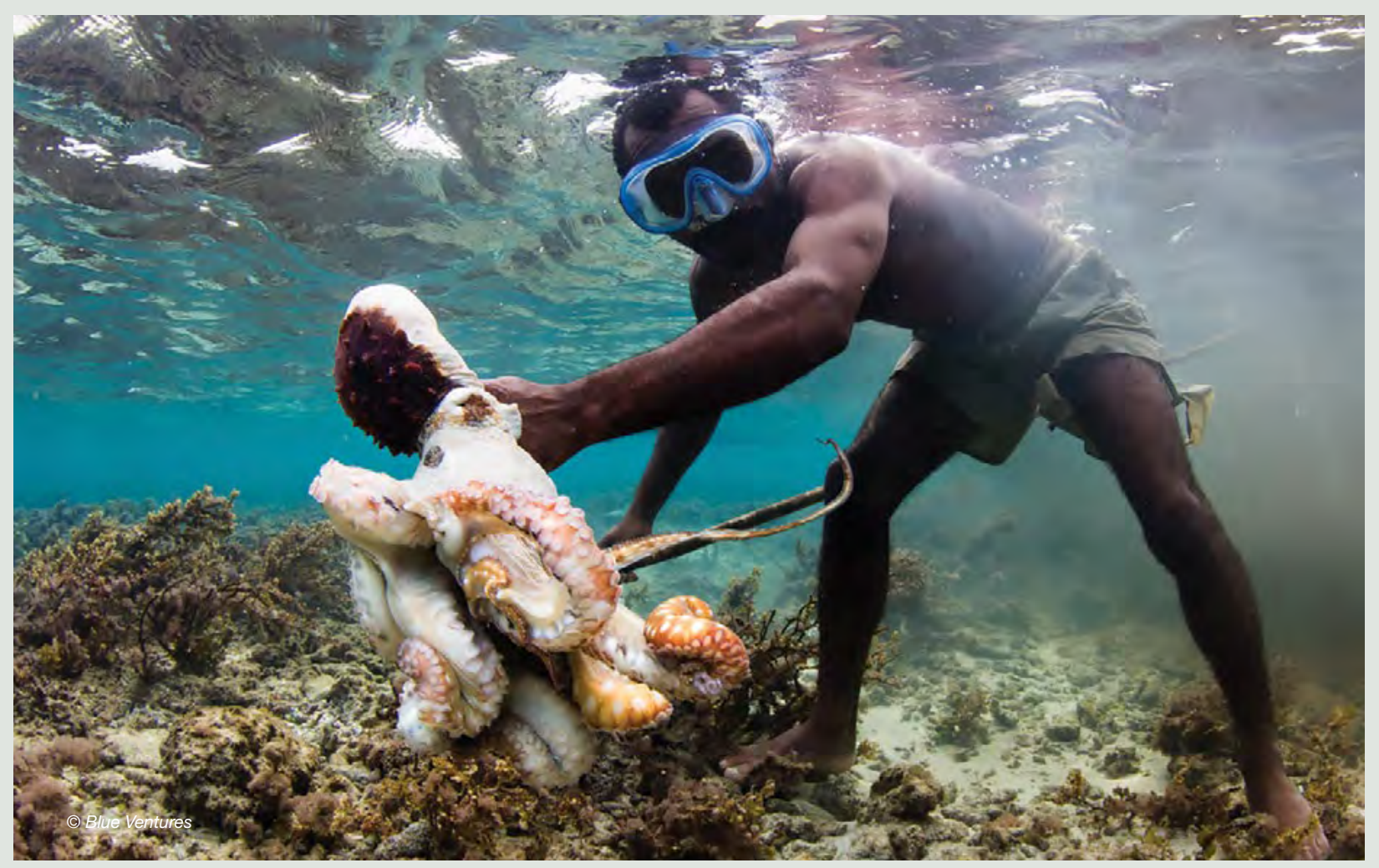




\subsection{Boa governação e a Lista Verde das Areas Protegidas e de Conservação da UICN}

Como descrito na Secção 2.4, a Lista Verde da UICN de Áreas Protegidas e de Conservação (UICN Green List Standard) é a nova norma internacional de sustentabilidade para aferir as áreas protegidas e de conservação que são simultaneamente eficazes e equitativas (Hockings et al., 2019).

A Norma da Lista Verde da UICN descreve um conjunto globalmente consistente de 17 critérios categorizados sob quatro componentes, acompanhados de 50 indicadores para áreas protegidas e de conservação, para uma conservação bem sucedida a nível do local. O primeiro componente da norma centra-se na boa governação ou qualidade de governação.

Os sítios que voluntariamente se comprometerem a aderir ao programa da Lista Verde da UICN como sítio candidato examinarão primeiro o critério da componente de Boa Governação da UICN que diz respeito à legitimidade e à voz. Isto procura assegurar a existência de uma autoridade de governação justa, funcional e legítima, e que considere as vozes e interesses de todos os titulares de direitos e partes interessadas locais de uma forma significativa. A avaliação começa com a própria autoridade de governação, e examina a legitimidade da autoridade e o seu funcionamento. Posteriormente, a norma procura assegurar que seja mantido um diálogo activo com todos os titulares de direitos e partes interessadas, em particular as mulheres. O objectivo é encontrar soluções que satisfaçam, pelo menos em parte, as preocupações e interesses de todos, promovendo ao mesmo tempo o respeito mútuo entre todos os actores.

O segundo critério da componente de Boa Governação da UICN procura assegurar que a autoridade governante seja responsabilizada perante o público como decisores, incluindo que as pessoas saibam quem é responsável e responda pelo cumprimento de diferentes responsabilidades a vários níveis. Isto pode incluir se a gestão considera mudanças históricas que ajudarão a informar projecções futuras das condições sociais, ecológicas e climáticas.

O terceiro e último critério diz respeito à vitalidade da governação. Examina até que ponto o planeamento e a gestão se baseiam nos melhores conhecimentos disponíveis sobre o contexto social e ecológico do local, e utiliza um quadro de gestão adaptável que antecipa, aprende e responde. Em particular, o critério centra-se na existência de procedimentos para assegurar que os resultados da monitorização informem as decisões de gestão. Isto pode incluir se a gestão considera mudanças históricas que ajudarão a informar projecções futuras de contexto social, ecológico e climático. Examina a capacidade de resposta das decisões às questões levantadas pelos titulares de direitos e partes interessadas. Um exemplo da utilização da Lista Verde da UICN é delineado na Caixa 9.6.

\section{Caixa 9.3 Diversidade de governação em acção: iniciar áreas marinhas geridas localmente para combater o declínio dos peixes no Kuruwitu, na costa norte do Quénia}

A Kuruwitu Conservation and Welfare Association (KCWA) foi criada em 2003 por membros da comunidade preocupados com a degradação dos seus mares. Na costa norte de Quénia, a pesca excessiva e os efeitos das alterações climáticas precisavam de ser tratados antes que o ecossistema marinho fosse danificado para além da reparação. Os pescadores e residentes preocupados que se lembravam de como o mar tinha sido saudável e produtivo no passado sentiram a necessidade de agir antes que fosse tarde demais. Em 2005, deram o passo sem precedentes de pôr de lado um MPA de 30 hectares. Esta foi a primeira zona marinha de gestão local de coral (LMMA) em Quénia. Doze anos depois, a área fez uma recuperação notável. Com a pesca proibida dentro da MPA, o peixe cresceu em abundância, tamanho e diversidade. As capturas de peixe melhoraram, e foram introduzidas empresas alternativas geradoras de rendimentos. O Kuruwitu tornou-se um modelo de conservação marinha sustentável, com a KCWA a partilhar regularmente os seus conhecimentos com outras comunidades costeiras locais e regionais.

O desenvolvimento de iniciativas sustentáveis não baseadas na pesca, tais como artesanato, fabrico de móveis, apicultura e alfaiataria, deslocou a dependência da pesca de subsistência, assumindo assim a pressão fora dos bancos de pesca.
Os recursos haliêuticos melhoraram drasticamente dentro da LMMA, e um relatório independente mostra um aumento considerável da biomassa de peixe e da biodiversidade de toda a vida marinha na área. Isto aumentou as capturas de peixe nos bancos de pesca vizinhos e melhorou os meios de subsistência. As tartarugas e os ninhos na área são protegidos através de um esquema de compensação comunitário. Comunidades ao longo da costa e de outros países vizinhos visitam o Kuruwitu para verem a nossa sala de aula viva. Pelo menos 20 outros projectos semelhantes foram iniciados por outras comunidades costeiras inspiradas na KCWA.

A KCWA demonstrou a importância do envolvimento da comunidade nos planos de gestão dos recursos naturais; um princípio que influenciou uma mudança de política longe do Estado para as comunidades locais. O Kuruwitu foi escolhido para pilotar uma iniciativa de co-gestão trabalhando com várias partes interessadas cobrindo uma área de aproximadamente 100 quilómetros quadrados. Este é um dos primeiros esquemas de gestão colaborativa do seu género na costa quéniana e criará um precedente no futuro.

Contribuido por Des Bowden (Kuruwitu Conservation and Welfare Association). 


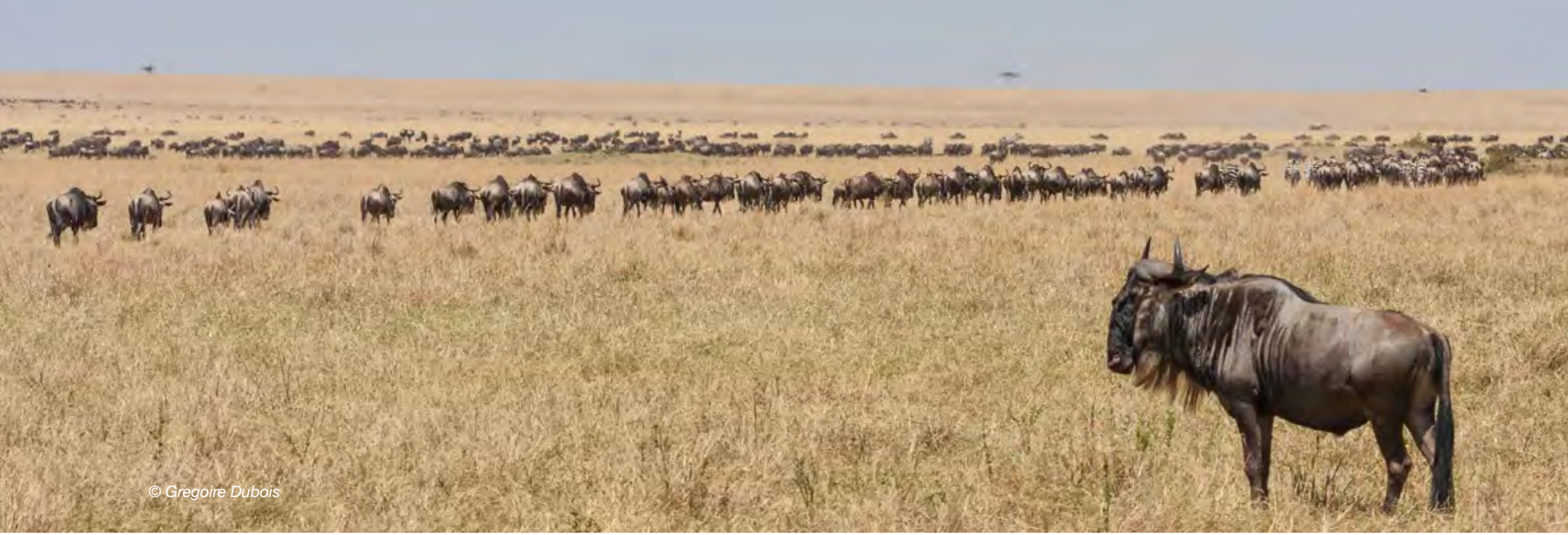

\section{Caixa 9.4 Co-gestão do Parque Nacional Gonarezhou}

O Parque Nacional Gonarezhou é o segundo maior Parque Nacional do Zimbabué, abrangendo uma área de 5,053 km². É membro do Parque Transfronteiriço do Grande Limpopo (GLTP), que inclui o Parque Nacional Kruger em África do Sul e o Parque Nacional do Limpopo em Moçambique, cobrindo uma área combinada de $36,000 \mathrm{~km}^{2}$.

Em 2007, a Autoridade de Gestão de Parques e Fauna Bravia do Zimbabué (ZPWMA) associou-se à Sociedade Zoológica de Frankfurt (FZS) para estabelecer o Projecto de Conservação Gonarezhou, que prestou assistência financeira e técnica às operações da ZPWMA no terreno. Apesar dos êxitos significativos na protecção geral e conservação do Parque, ainda se sentia que o potencial do Parque não estava a ser realizado, e que o modelo de gestão em vigor na altura não estava suficientemente orientado para agir sobre as oportunidades e ameaças específicas apresentadas por esta paisagem complexa. A sustentabilidade financeira a longo prazo não estava a ser abordada, os níveis de pessoal eram insuficientes para prosseguir projectos-chave em matéria de biodiversidade, tais como a reintrodução do Rinoceronte Negro, e as relações com as comunidades vizinhas eram fracas e conflituosas.

A situação levou a uma revisão da parceria em 2013, culminando na criação do Gonarezhou Conservation Trust em 2017, uma entidade propositadamente mandatada e modelo de co-gestão entre a ZPWMA e a FZS. O Gonarezhou Conservation Trust está encarregado da gestão e desenvolvimento quotidiano do Parque Nacional Gonarezhou durante os próximos 20 anos. A formação do Fundo baseia-se na reputação da autoridade da vida selvagem do Zimbabué de estar disposta a abraçar a mudança e a procurar soluções inovadoras, tais como a criação do CAMPFIRE na década de 1980, que envolveu directamente as comunidades na gestão da vida selvagem e introduziu a partilha de benefícios.
Os aspectos chave do Comité incluem:

- governado por um Conselho de Curadores, com representação igualitária entre ZPWMA e FZS;

- gestão descentralizada, sediada no parque;

- responsabilidade por todos os custos de gestão;

- directamente responsável por todo o pessoal;

- um enfoque declarado no emprego local e na construção de relações significativas com as comunidades; e

- retenção de todas as receitas do turismo, e no controlo do planeamento e desenvolvimento do turismo.

Um dos desafios tem sido ultrapassar alguma desconfiança tanto a nível local como nacional, que deriva da percepção de que a gestão de um bem nacional do Zimbabué tem sido externalizada. Tem exigido a criação de estruturas a nível do parque (tais como recursos humanos, gestão do turismo), que costumavam ser da responsabilidade da sede da ZPWMA, e a construção de uma base de financiamento sustentável necessária para cobrir todos os custos de gestão.

\section{O Comité tem:}

- investido fortemente na aplicação da lei, reduzindo significativamente os níveis de caça furtiva;

- sido pioneira num modelo de envolvimento comunitário 'Mphfuka' (peregrinação), baseado no facto de as comunidades serem uma parte essencial da economia centrada na conservação; e

- começada a re-desenvolver a sua oferta turística num esforço para fazer com que o turismo trabalhe para a conservação e as comunidades, e não o contrário.

Através dos ganhos obtidos, não só na aplicação da lei mas também nas relações com as comunidades, e da crescente presença de turistas no parque, as questões-chave que motivam a formação do Comité estão a ser constantemente abordadas.

Contribuido por Elsabé van der Westhuizen (Frankfurt Zoological Society). 


\section{Caixa 9.5 Trabalhar com comunidades para a conservação}

O Fundo Peregrino (TPF) iniciou o seu trabalho em Madagáscar em 1990. O programa nacional visa a conservação de espécies endémicas ameaçadas, em particular aves de rapina, aves aquáticas e outra biodiversidade, a fim de evitar a extinção destas espécies e preservar os seus habitats. O TPF concentra-se no reforço da capacidade nacional de conservação da biodiversidade para o pessoal, estudantes e comunidades locais.

Desde 1991, o TPF trabalha na zona húmida de Manambolomaty (um Sítio Ramsar) rodeado por uma típica floresta tropical seca no oeste de Madagáscar. A área abriga muitas aves aquáticas, incluindo mais de $12 \%$ da população global da espécie de ave de rapina Madagáscar (Haliaeetus vociferoides), uma espécie criticamente ameaçada de extinção, endémica de Madagáscar. A sobrepesca no local nos anos 90 ameaçou a população da águia-pescadora Madagáscar, resultando na necessidade de um processo de gestão das áreas para proteger as espécies de aves criticamente ameaçadas e outras espécies de biodiversidade, bem como para melhorar a subsistência das comunidades locais.

Desde 2001, o TPF tem trabalhado de perto com associações locais para gerir os lagos e a floresta circundante. Foram convocadas reuniões com as partes interessadas (chefes de aldeias, autoridades locais e a comunidade). A partir destas reuniões, foi elaborado um roteiro para a gestão dos recursos naturais. Este incluiu o período de abertura e encerramento do pescado, uma área central dentro dos lagos, limites ao número de pescadores e um acampamento temporário para os pescadores.
Além disso, foi desenvolvido um programa alternativo de subsistência para fornecer apoio escolar e equipamento agrícola para as actividades agrícolas. Trabalhando em estreita colaboração com agências regionais, foram organizadas actividades de desenvolvimento de capacidades em matéria de gestão de peixes e florestas para as comunidades.

O TPF trabalhou de perto com membros de associações locais para ajudar na gestão e vigilância do programa de reflorestação. Todos os anos, através do programa, os membros plantaram plântulas. O programa forneceu canoas de fibra aos pescadores com o objectivo de diminuir o abate de grandes árvores para canoas de madeira.

Hoje em dia, a comunidade local está convencida da importância dos recursos naturais para a sua futura geração. Muito poucas árvores foram removidas da área protegida e as comunidades locais estão activas na plantação de árvores. O rendimento da gestão dos peixes aumentou, os seus filhos podem ir à escola, as actividades agrícolas e agrícolas são mais lucrativas. Após 18 anos de colaboração com as comunidades locais, esta área protegida é considerada um local importante para a conservação baseada na comunidade em Madagáscar.

\section{Contribuído por Lily-Arison Rene de Roland (The Peregrine Fund, Madagáscar).}

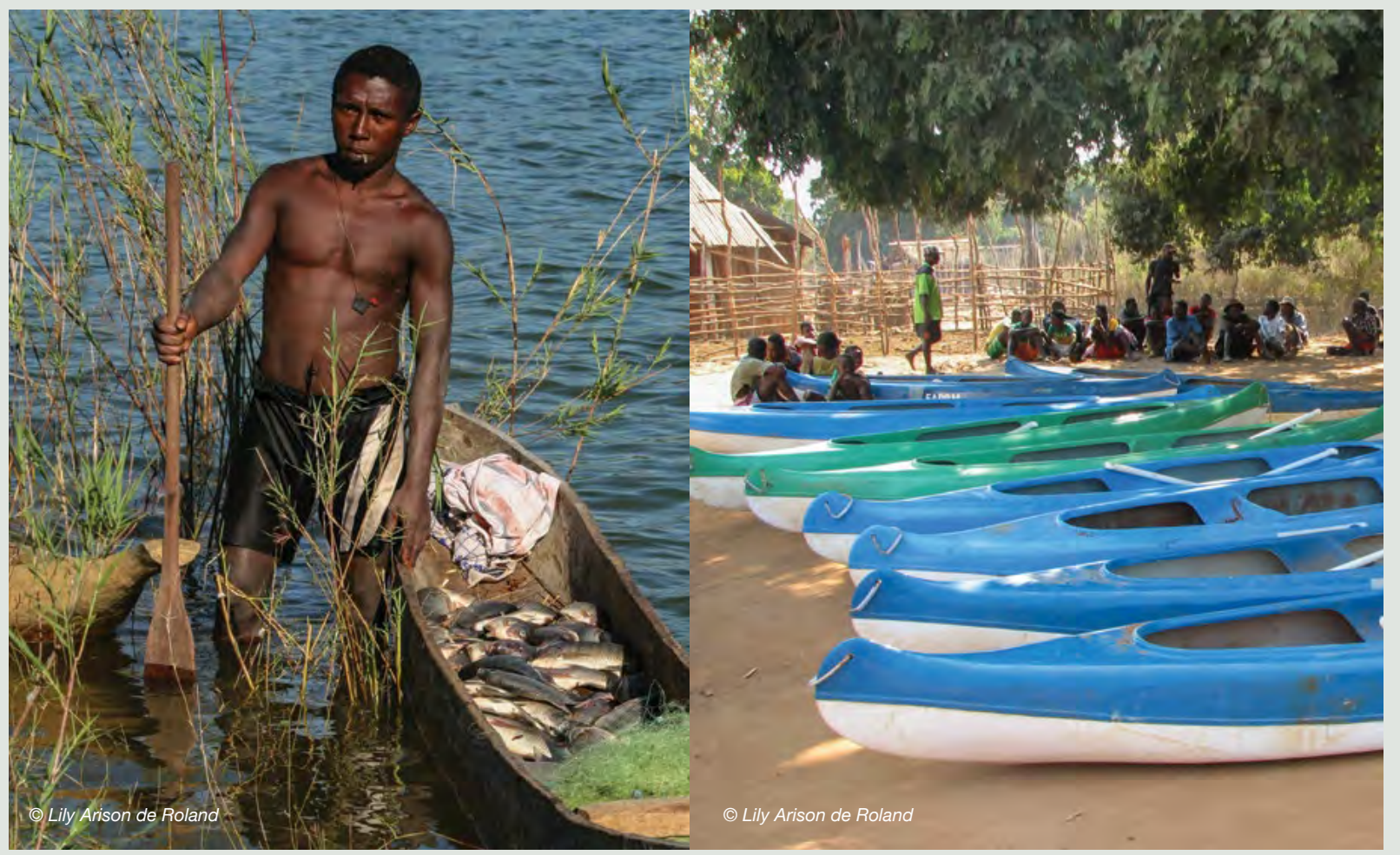




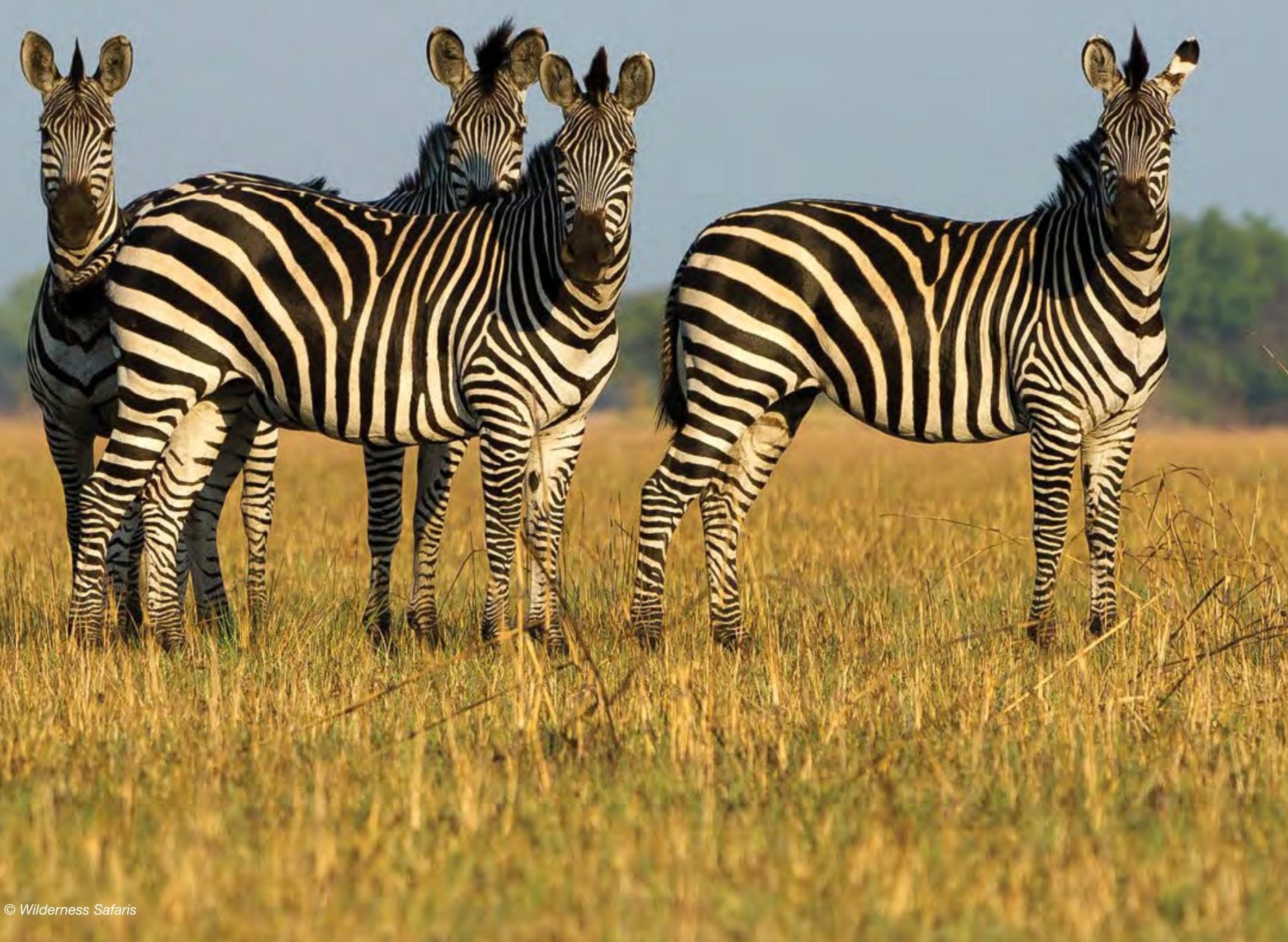




\section{Quadro 9.2 Princípios de boa governação das áreas protegidas da UICN}

\begin{tabular}{|c|c|}
\hline Princípios & Considerações relacionadas aos princípios \\
\hline $\begin{array}{l}\text { Legitimidade e } \\
\text { voz }\end{array}$ & $\begin{array}{l}\text { - } \text { - Asstabelecer e manter instituições de governação que gozem de ampla aceitação e apreciação na sociedade. } \\
\text { podem estar representado e poder ter uma palavra a dizer no aconselhamento e/ou na tomada de decisões. } \\
\text { - Fomentar o envolvimento activo dos actores sociais no apoio às áreas protegidas, defendendo a diversidade } \\
\text { - } \text { Estender o apoio especial a grupos vulneráveis, tais como povos indígenas, mulheres e jovens, e prevenir a } \\
\text { - } \text { discriminação com base na etnicidade, género, classe social, bens financeiros, etc. } \\
\text { - Preocupações e os interesses de todos. } \\
\text { - Honrar as regras acordadas, que são respeitadas porque são "propriedade" do povo e não apenas devido a } \\
\text { - } \text { medo de repressão e castigo. } \\
\text { próximaição, tanto quanto possível, de autoridade e responsabilidade de gestão às instituições capazes mais } \\
\text { precursos naturais (subsidiariedade). }\end{array}$ \\
\hline Direcção & $\begin{array}{l}\text { - Desenvolver e seguir uma visão estratégica inspiradora e consistente (perspectiva ampla e a longo prazo) } \\
\text { para as áreas protegidas e os seus objectivos de conservação, assente em valores acordados e numa } \\
\text { apreciação das complexidades ecológicas, históricas, sociais e culturais únicas a cada contexto. } \\
\text { - Assegurar que as práticas de governação e gestão das áreas protegidas sejam consistentes com os valores } \\
\text { acordados. } \\
\text { - Assegurar que as práticas de governação e gestão das áreas protegidas sejam compatíveis e bem } \\
\text { coordenadas com os planos e políticas de outros níveis e sectores na paisagem/paisagem mais ampla, e que } \\
\text { respeitem obrigações nacionais e internacionais (incluindo a CBD PoWPA). } \\
\text { - Fornecer orientações políticas claras para as principais questões de interesse para a área protegida, em } \\
\text { particular questões litigiosas (por exemplo, prioridades de conservação, relações com interesses comerciais e } \\
\text { indústrias extractivas), e assegurar que estas sejam coerentes tanto com as dotações orçamentais como com } \\
\text { as práticas de gestão. } \\
\text { Avaliar e orientar os progressos com base em resultados de monitorização regular e numa abordagem } \\
\text { consciente de gestão adaptativa. } \\
\text { Favorecer a emergência de "campeões", gerando novas ideias e permitindo/promovendo cuidadosamente o } \\
\text { teste de inovações, incluindo inovações de governação e gestão para áreas protegidas. }\end{array}$ \\
\hline Desempenho & $\begin{array}{l}\text { - Atingir os objectivos de conservação e outros, tal como planeados e monitorizados, incluindo através de uma } \\
\text { - } \text { avaliação contínua da eficácia da gestão. } \\
\text { bromoção de uma cultura de aprendizagem para a política de áreas protegidas e práticas de governação com } \\
\text { fertilização cruzada da experiência. } \\
\text { - Envolver-se na advocacia e na sensibilização para o benefício das áreas protegidas. } \\
\text { - Responder às necessidades dos detentores de direitos e das partes interessadas, nomeadamente através do } \\
\text { fornecimento atempado e eficaz de resposta a inquéritos e exigências razoáveis de mudanças na governação } \\
\text { - } \text { Assegurar que o pessoal das áreas protegidas, titulares de direitos e partes interessadas, conforme o caso, } \\
\text { tenham as capacidades necessárias para assumir as suas funções e responsabilidades de gestão e que } \\
\text { - } \text { - Fazser uma utilização eficiente dos recursos financeiros e promover a sustentabilidade financeira. } \\
\text { Promover a sustentabilidade social e a resiliência, ou seja, a capacidade de gerir riscos, superar as crises } \\
\text { inevitáveis e emergem fortalecidos da experiência. }\end{array}$ \\
\hline
\end{tabular}




\begin{tabular}{|c|c|}
\hline Princípios & Considerações relacionadas aos princípios \\
\hline & $\begin{array}{l}\text { - Defender a integridade e o empenho de todos os responsáveis por responsabilidades específicas para as } \\
\text { áreas protegidas. } \\
\text { - Garantir a transparência, com os titulares de direitos e partes interessadas a terem atempadamente para } \\
\text { informação sobre: o que está em jogo na tomada de decisões; quais os processos e instituições que podem } \\
\text { exercer influência; quem é responsável por quê; e como estas pessoas podem ser responsabilizadas. } \\
\text { - Assegurar uma partilha clara e apropriada de papéis para as áreas protegidas, bem como linhas de } \\
\text { responsabilidade e relatórios/respostas. } \\
\text { - Assegurar que os recursos financeiros e humanos atribuídos para gerir as áreas protegidas sejam } \\
\text { - Aevidamente orientado de acordo com os objectivos e planos declarados. } \\
\text { - Estar o desempenho da área protegida, dos seus decisores e pessoal, e associar a qualidade dos resultados } \\
\text { área protegida sejam acessíveis. } \\
\text { - Encorajar o feedback de desempenho de grupos da sociedade civil e dos meios de comunicação social. } \\
\text { - Assegurar que uma ou mais instituições públicas independentes (por exemplo, provedor de justiça, comissão } \\
\text { de direitos humanos, agência de auditoria) tenham autoridade e capacidade para supervisionar e questionar a } \\
\text { acção dos órgãos e do pessoal das áreas protegidas. }\end{array}$ \\
\hline $\begin{array}{l}\text { Equidade e } \\
\text { direitos }\end{array}$ & $\begin{array}{l}\text { - Esforçar-se por uma partilha equitativa dos custos e benefícios do estabelecimento e gestão de áreas } \\
\text { - } \text { protegidas e da equidade na tomada de todas as decisões relevantes. } \\
\text { áreas protegidas; as áreas protegidas não criem ou agravem a pobreza e padrões migratórios socialmente } \\
\text { perturbadores; e os custos de áreas protegidas, especialmente quando nascem de pessoas vulneráveis, não } \\
\text { vão sem uma compensação adequada. } \\
\text { - Assegurar que a conservação é feita com decência e dignidade, sem humilhar ou prejudicar as pessoas. } \\
\text { - Lidar de forma justa com o pessoal das áreas protegidas e com os empregados temporários. } \\
\text { - Aplicar as leis e regulamentos de forma imparcial, de forma consistente ao longo do tempo, sem } \\
\text { - Tiscriminação e com direito a recurso (Estado de direito). } \\
\text { individuais) sobre a terra, água e recursos naturais relacionados com áreas protegidas, e para corrigir } \\
\text { violações anteriores de tais direitos. } \\
\text { - Tomar medidas concretas para respeitar os direitos processuais sobre questões de áreas protegidas, } \\
\text { incluindo: informação e consulta adequadas dos titulares de direitos e partes interessadas; práticas justas de } \\
\text { gestão de conflitos; e recurso não discriminatório à justiça. } \\
\text { - Respeitar os direitos humanos, incluindo os direitos individuais e colectivos, e a equidade de género. } \\
\text { - Respeitar os direitos dos povos indígenas, tal como descritos na Declaração dos Direitos dos Povos } \\
\text { Indígenas das Nações Unidas. } \\
\text { - Assegurar rigorosamente o consentimento livre, prévio e informado dos povos indígenas para qualquer } \\
\text { proposta de reassentamento relacionada com áreas protegidas. } \\
\text { governação de áreas protegidas. }\end{array}$ \\
\hline
\end{tabular}

Fonte: Borrini-Feyerabend et al. (2017). 


\subsection{Medição e avaliação da governação}

As abordagens de avaliação da governação vão desde processos rápidos de avaliação até processos de avaliação participativa que podem incluir investigação, validação e discussão com uma maior variedade de actores, tais como autoridades governamentais, detentores de direitos e partes interessadas, bem como especialistas em conservação. O processo particular de avaliação da governação deve ser escolhido uma vez decidida a escala e o alcance do interesse. A avaliação da governação deve ser vista como um processo social e político que começa com uma análise diagnóstico das questões, avançando para uma componente orientada para a solução e para a acção. As avaliações podem ser realizadas em múltiplas escalas e foram desenvolvidas múltiplas ferramentas para diferentes objectivos (Campese \& Sulle, 2019).

\subsubsection{Directrizes de Melhores Práticas da UICN WCPA}

A UICN publicou um conjunto de directrizes de melhores práticas tanto para avaliações de governação a nível de sistema como de sítio (Borrini-Feyerabend et al., 2017). As directrizes oferecem conceitos e ferramentas para compreender os quatro principais tipos de governação de áreas protegidas e o conjunto de princípios de boa governação reconhecidos pela UICN, com base em exemplos de todo o mundo. Oferecem também orientações práticas para aqueles que estão dispostos a embarcar no processo de avaliação, avaliação e melhoria da governação dos seus sistemas de áreas protegidas ou de sítios de áreas protegidas individuais.

\subsubsection{Avaliação a nível do sistema}

Uma avaliação a nível do sistema é uma abordagem a longo prazo e a nível macro para avaliar e avaliar a governação das áreas protegidas. Centra-se no sistema de áreas protegidas, o que significa o sistema espacial existente de áreas protegidas, o seu quadro legal correspondente e a diversidade e alcance tanto das categorias de gestão de áreas protegidas da UICN como dos tipos de governação. Uma avaliação a nível do sistema pressupõe que nenhuma área protegida será eficaz ou equitativa, se não for considerada dentro da sua paisagem mais vasta. A maioria das ameaças às áreas protegidas provém de fora dos limites da própria área protegida (Davey, 1998), incluindo a invasão, a fraca conectividade na paisagem mais vasta e a falta de recursos (Schulze et al., 2018). As áreas protegidas não são ilhas, mas sim parte de um mosaico de usos da terra e interesses diversos. Uma avaliação a nível do sistema examina em primeiro lugar o potencial para toda a gama de tipos de governação num determinado país e faz recomendações para o reconhecimento e apoio dos acordos de governação de facto existentes. Em segundo lugar, examina toda a paisagem e, em particular, examina a coordenação destes sectores e usos do solo interligados.

A UICN oferece orientação sobre o que é um sistema de áreas protegidas e regista pelo menos cinco características-chave de um tal sistema (Davey, 1998). Estas incluem: representação, abrangência e equilíbrio; adequação; coerência e complementaridade; consistência; e eficácia e equidade. Está a ser realizada na Tanzânia uma avaliação da governação a nível do sistema, liderada pela UICN (ver Caixa 9.5).

\section{Caixa 9.6 Área de Conservação OI Kinyei e a Lista Verde da UICN}

O Rancho do Grupo OI Kinyei era uma das áreas tradicionais de pastagem para os Maasai, a norte da Reserva Nacional de Mara (MMNR). No início dos anos 90, os líderes do Group Ranch embarcaram na sub-divisão das suas terras ao norte da MMNR. A maioria das secções foram subdivididas em parcelas que variavam entre 60 e 150 acres. Com a fragmentação dos Rancho de Grupo, as áreas de dispersão da vida selvagem em redor do MMNR tornaram-se cada vez mais ameaçadas, uma vez que a serra estava a ser rapidamente convertida em pequenas explorações agrícolas e assentamentos comunitários. Em 2005, a OI Kinyei Conservancy estabeleceu uma parceria com proprietários e operadores turísticos para gerir conjuntamente a conservação e estabelecer uma área de habitat protegido para a vida selvagem. Isto visava promover a regeneração da vegetação e aumentar a biodiversidade e as populações da vida selvagem, o que, por sua vez, apoiava o ecoturismo. Os arrendamentos de terras (inicialmente cerca de 5.000 acres e actualmente com 18.500 acres) geram rendimentos e emprego para as comunidades locais. A OI Kinyei comprometeu-se com a Lista Verde da UICN e iniciou o processo de avaliação contra a Norma da Lista Verde.
Para cumprir os primeiros critérios da componente de Boa Governação, "legitimidade e voz", a estrutura de governação necessária para demonstrar como os vários grupos comunitários estão envolvidos nos processos de tomada de decisão, como os representantes são escolhidos e, em que medida estes grupos tiveram as suas opiniões tidas em conta pelo órgão executivo. Para demonstrar o segundo critério, responsabilidade e transparência, as decisões tomadas pelo órgão de decisão mais elevado precisavam de estar disponíveis ao público e a pedido. Foi também criado um mecanismo de reclamação atempado e eficaz para lidar com as queixas das partes interessadas.

A estrutura de governação partilhada criou uma plataforma estável para a conservação e assegurou uma distribuição justa dos benefícios derivados da conservação entre os membros da sua comunidade de proprietários rurais, desenvolvendo assim um maior sentido de propriedade, apreciação e compreensão da importância da conservação do património da vida selvagem de Quénia.

Contribuído por Beatrice Chataigner (UICN PAPACO, Quénia). 


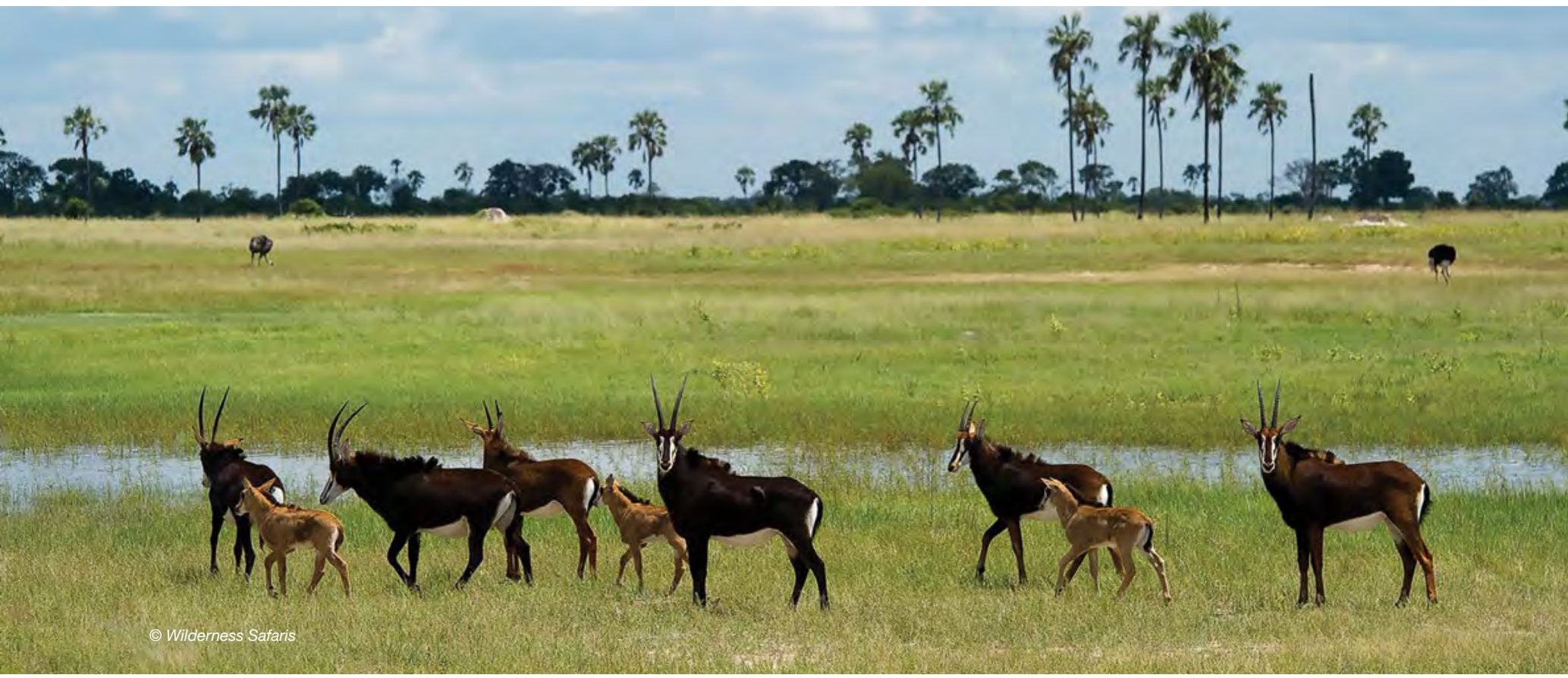

\subsubsection{Avaliação ao nível do sítio}

Uma avaliação da governação ao nível do sítio centra-se na qualidade da governação (ver Caixa 9.6 para um exemplo da Zâmbia). Ao contrário de uma avaliação a nível de sistema, não analisa a escolha do tipo de governação, mas avalia até que ponto as disposições de governação são verdadeiras para o tipo de governação, ou seja, que parte interessada tem, na realidade, autoridade decisória primária e o nível de influência na tomada de decisões de outras partes interessadas.

As avaliações de governação ao nível do local podem também examinar as componentes de diversos modelos de governação, e examinar os seus pontos fortes, desafios e factores favoráveis (ver Caixa 9.7).

\subsubsection{Governação ao nível do sítio e avaliação da equidade (SAGE)}

SAGE é uma metodologia para avaliar a qualidade da governação de uma área protegida ou conservada, incluindo a equidade, utilizando um quadro de 10 princípios de governação e equidade baseados na orientação da UICN e da CDB (IIED, 2020). É um processo rápido que permite às partes interessadas num local identificar os desafios de governação e potenciais acções para os enfrentar, e fornece aos gestores a níveis superiores uma avaliação da qualidade de governação que pode ser utilizada para a supervisão da gestão, relatórios e processo da Lista Verde da UICN.

Como em muitas metodologias PAME, SAGE gera dados de classificação utilizando um questionário com cerca de 40 perguntas (3-5 perguntas para cada princípio). O SAGE utiliza um processo multiparceiro. A actividade principal envolve um workshop de um a dois dias que começa com diferentes grupos de partes interessadas fazendo a avaliação separadamente, revelando assim diferentes perspectivas das partes interessadas. As partes interessadas discutem então as razões de quaisquer diferenças na pontuação, e identificam acções para melhorar a governação e a equidade que possam ser tomadas por uma ou mais partes interessadas.

O resultado do SAGE tem três elementos principais:

a) Perfil do sítio - da área protegida ou conservada e questões contextuais relevantes para a governação e a equidade;

b) Análise de impacto - incluindo tanto os impactos ambientais das actividades das pessoas e outros perigos (isto é, ameaças ao sítio) como os impactos sociais do sítio e a sua conservação nas pessoas; e

c) Governance and equity scorecard com as pontuações e provas de apoio de diferentes grupos de partes interessadas para cada uma das 40 perguntas, pontuações médias e intervalos de pontuação por pergunta e princípio, e sugestões de acção para reforçar a governação.

Embora o SAGE identifique os pontos fortes e fracos da governação, não é uma ferramenta de diagnóstico que possa explorar as causas profundas subjacentes aos problemas de governação. Para uma avaliação aprofundada, a Avaliação de Governação para Áreas Protegidas e de Conservação (GAPA) seria a ferramenta mais apropriada (Franks \& Booker, 2018; IIED, 2018) (ver secção seguinte).

\subsubsection{Avaliação da Governação das Áreas Protegidas e de Conservação (GAPA)}

GAPA é uma avaliação multi-partes interessadas utilização por gestores de sítios, comunidades que vivem dentro e em redor de uma área protegida ou conservada, ou outros interessados e detentores de direitos a nível local e nacional (Franks \& Booker, 2018; IIED, 2018). O principal objectivo do GAPA é melhorar a governação do sítio alvo e de quaisquer actividades de conservação e desenvolvimento relacionadas. 


\section{Caixa 9.7 Avaliação da governação ao nível do sistema na Tanzânia}

A Tanzânia é o lar de dezenas de milhões de pessoas e é um dos países mais biodiversos do mundo, ostentando milhares de espécies e ecossistemas. Inclui nove grandes bacias hidrográficas, o pico mais alto de África, terras secas, savanas e zonas costeiras e marinhas. Desde 2017, a UICN tem liderado uma avaliação participativa da governação a nível do sistema na Tanzânia, em conjunto com parceiros nacionais e partes interessadas, para examinar questões em torno da equidade no sistema de áreas protegidas (AP). O trabalho compreende uma mistura de actividades relacionadas com o ambiente de trabalho e workshops, incluindo investigação histórica, análises legais, documentação dos quatro tipos de governação da UICN/ CBD e o exame de diversos cenários de governação usando princípios de boa governação. O processo revelou a Tanzânia como um dos países mais ricos do mundo no que diz respeito ao seu património de conservação e comprometeu-se com metas nacionais ambiciosas de conservação. $O$ seu actual sistema de AA excede em muito as metas globais mínimas de cobertura. A gama de diversos tipos de governação no património de conservação é igualmente impressionante.

O sistema é vasto, abrangendo desde áreas protegidas lideradas pelo governo (Tipo A), tais como os quatro sítios naturais do Património Mundial: Área de Conservação de Ngorongoro, Kilimanjaro Parque Nacional, Selous Reserva de Caça agora Nyerere Parque Nacional e Serengeti Parque Nacional. Também inclui modelos de governação partilhada (Tipo B) tais como a Área de Gestão da Vida Selvagem de Burunge, bem como outros modelos participativos numa série de Reservas Florestais Naturais, Florestas de Aldeia e Reservas de Caça. O Parque Privado de Coral de Chumbe Island (Tipo C) serve como um exemplo de conservação voluntária da natureza dentro do sistema. A quarta categoria, ICCAs - territórios de vida - (Tipo D), áreas que estão sob governação, gestão e custódia tradicionais demonstraram a eficácia da conservação a longo prazo. Estas incluem áreas que estão actualmente a ser documentadas através dos Certificados de Direito de Ocupação Habitual (CCROs). Estão a ser realizados trabalhos para mapear e documentar estes territórios ICCAs, bem como para os registar a nível nacional e no Registo ICCA hospedado pela WDPA. Por exemplo, as instituições tradicionais para a conservação da paisagem nas Terras Altas de Matengo ilustram como o conhecimento tradicional sob o sistema Sengu habitual pode alcançar tanto uma subsistência sustentável como a conservação da paisagem. O sistema Sengu tem a sua estrutura de governação formalizada no quadro regulamentar tanzaniano. Isto revela um enraizamento impressionante da conservação, tanto nas identidades culturais nacionais tradicionais como nas modernas, o que pode servir como uma série de exemplos ilustrativos para o resto do mundo.

Contribuído por Jennifer Kelleher (UICN) e Grazia BorriniFeyerabend and Emmanuel Sulle (ICCA Consortium).
A metodologia utiliza uma combinação de: (i) entrevistas a informadores-chave e discussões de grupos focais para identificar os pontos fortes da governação e os desafios e ideias de acção; e ii) workshops de partes interessadas para discutir e validar os resultados e rever as ideias de acção para melhorar a situação. Existe um extra opcional: iii) um scorecard de governação a nível do local para fornecer uma avaliação quantitativa das questões de governação relacionadas com o local e a diversidade de pontos de vista sobre estas questões dentro e entre comunidades. A avaliação em si leva normalmente cinco a 10 dias, dependendo da dimensão da área e da logística. Após a avaliação, é uma fase de acção que compreende um conjunto de actividades para apoiar os interessados na implementação de acções-chave para melhorar a governação que foram sugeridas pela avaliação. Está disponível um manual detalhado dos utilizadores (Booker \& Franks, 2019). Para um exemplo dos resultados do GAPA, ver o estudo de caso da Zâmbia (Caixa 9.6).

\subsubsection{Indicadores}

Embora a escala de um inquérito seja uma componente importante, o desenvolvimento de indicadores reais ligados à avaliação da governação é uma característica essencial para a elaboração de relatórios eficazes sobre governação e equidade. Borrini-Feyerabend et al. (2017) fornecem uma longa lista de exemplos de indicadores de governação nos anexos da publicação. Mais recentemente, um estudo global conduziu ao desenvolvimento de tais indicadores e apresenta resultados de uma série de países (ICCA Registry, n.d.; Zafra-Calvo et al., 2017). O Manual GAPA fornece um quadro prático de princípios e indicadores (denominados temas) que constitui a base tanto das metodologias GAPA como SAGE.
Mais detalhes sobre os métodos e ferramentas de avaliação da governação mais utilizados estão disponíveis em Campese e Sulle (2019).

\subsection{Avaliações sociais}

A contribuição das áreas protegidas para a redução da pobreza, proporcionando oportunidades de emprego e meios de subsistência às pessoas que vivem dentro e à sua volta, foi notada pelo PoWPA da CBD (CBD, 2004). Na melhor das hipóteses, as áreas protegidas devem em todos os casos esforçar-se por reduzir a pobreza, e os custos e benefícios devem ser equitativamente partilhados (ligados ao elemento de distribuição do quadro de equidade da CDB). Em 2008, um estudo revelou mais de 30 métodos para avaliar os impactos sociais das áreas protegidas (Schreckenberg et al., 2010). A partir daí, uma metodologia de avaliação social foi especificamente adaptada para o contexto das áreas protegidas. A metodologia de avaliação social das áreas protegidas (SAPA) foi concebida para ajudar os gestores de áreas protegidas e outras partes interessadas a compreender e promover impactos sociais positivos, reduzindo ao mesmo tempo os impactos negativos (Franks et al., 2018; IIED, n.d.). Tal como o GAPA, utiliza uma abordagem multiparceiros para assegurar que todos os interessados e titulares de direitos estejam plenamente envolvidos na concepção da avaliação, recolha de informação, interpretação dos resultados e desenvolvimento de recomendações de acção. A Caixa 9.8 fornece um exemplo dos resultados do SAPA de Quénia. 


\section{Caixa 9.8 Avaliação da governação ao nível do sítio na GMA de Mumbwa na Zâmbia}

As Áreas de Gestão de Caça (GMAs) cobrem 22\% da área terrestre da Zâmbia. Têm um papel vital, tanto ecologicamente como áreas de dispersão e corredores que ligam os principais parques nacionais e financeiramente como fonte de grande parte das receitas que apoiam a conservação na Zâmbia (através de concessões de caça). Os GMAs são geridos ao abrigo de um acordo de governação partilhada denominado Gestão de Recursos Naturais Baseada na Comunidade (CBNRM) entre o Departamento de Parques Nacionais e Vida Selvagem (DNPW) do governo e as comunidades que vivem à volta e dentro da zona de desenvolvimento do GMA. A maioria destes arranjos CBNRM foram estabelecidos há mais de 20 anos e têm tido pouco apoio nos últimos anos. Nos últimos anos, uma série de análises tem notado fraquezas na governação como um problema importante e crescente que está a minar seriamente tanto a conservação como os resultados sociais.
Em 2018, o Fórum CBNRM da Zâmbia, com o apoio do Instituto Internacional para o Ambiente e Desenvolvimento (IIED) e a Iniciativa Global de Apoio ICCA do UNDP, ajudou as partes interessadas - comunidades, governo e operadores de caça do GMA de Mumbwa que faz fronteira com o Parque Nacional de Kafue a realizar uma avaliação de governação utilizando a metodologia GAPA do IIED. Usando esta metodologia, incluindo entrevistas de informação chave e discussões de grupos focais, as partes interessadas avaliaram os pontos fortes e fracos de governação dos GMAs e identificaram acções para melhorar a governação, centrando-se em particular em quatro princípios de boa governação. O Quadro abaixo resume algumas das principais conclusões e sugere ideias para acção.

Contribuído por Jennifer Kelleher (UICN).

\begin{tabular}{l|l|l}
\hline Princípio & Desafio & Ideias para a acção \\
\hline $\begin{array}{l}\text { Participação efectiva dos } \\
\text { actores relevantes na tomada } \\
\text { de decisões }\end{array}$ & $\begin{array}{l}\text { Os departamentos governamentais } \\
\text { dominam a tomada de decisões } \\
\text { relacionadas com o GMA e por isso as } \\
\text { comunidades têm pouca influência na } \\
\text { tomada de decisões. }\end{array}$ & $\begin{array}{l}\text { Todos os interessados precisam de se sentar e } \\
\text { reunir para reconhecer a voz da comunidade } \\
\text { na tomada de decisões. }\end{array}$ \\
\hline $\begin{array}{l}\text { Partilha justa dos benefícios de } \\
\text { acordo com uma estratégia de } \\
\text { orientação acordada pelos } \\
\text { actores relevantes }\end{array}$ & $\begin{array}{l}\text { Os líderes tradicionais partilham os } \\
\text { recursos naturais dentro da GMA com a } \\
\text { família e amigos, esquecendo-se de outros } \\
\text { membros da comunidade. }\end{array}$ & $\begin{array}{l}\text { O governo deve ajudar a sensibilizar os líderes } \\
\text { tradicionais para uma partilha justa dos } \\
\text { benefícios entre os líderes tradicionais e a } \\
\text { comunidade }\end{array}$ \\
\hline $\begin{array}{l}\text { Transparência apoiada por } \\
\text { acesso oportuno para } \\
\text { informação relevante }\end{array}$ & $\begin{array}{l}\text { A informação leva muito tempo a chegar } \\
\text { aos membros da comunidade - por } \\
\text { exemplo, informação sobre quotas de caça }\end{array}$ & $\begin{array}{l}\text { Usar diferentes métodos para partilhar } \\
\text { informação cUNDPm as comunidades - } \\
\text { folhetos, SMS, igrejas - assim como o } \\
\text { moderno era de comunicação }\end{array}$ \\
\hline $\begin{array}{l}\text { Aplicação justa e eficaz das } \\
\text { leis e regulamentos }\end{array}$ & $\begin{array}{l}\text { O governo está relutante em retirar alguns } \\
\text { intromissores do GMA por terem medo de } \\
\text { perder votos }\end{array}$ & $\begin{array}{l}\text { aumento dos salários dos oficiais da DNPW e } \\
\text { dos batedores de aldeia para ajudar a refrear } \\
\text { as ilegalidades, tais como gorjetas e subornos }\end{array}$ \\
\hline
\end{tabular}

Fonte: Lubilo (2019).

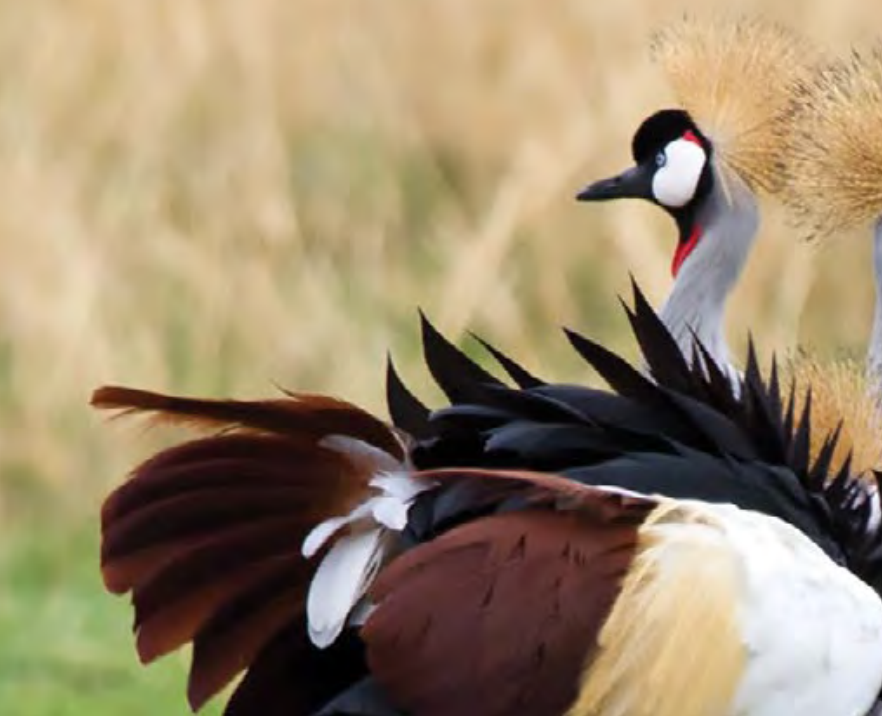




\section{Caixa 9.9 Estado das Áreas Indígenas e de conservação comunitária na Tanzânia}

A Tanzânia tem um dos sistemas de governação rural local mais bem estabelecidos da África Subsaariana. As comunidades nas zonas rurais são geridas por mais de 12.000 conselhos de aldeia, que por sua vez são responsáveis perante as assembleias de aldeia. A legislação dá poderes às aldeias para elaborarem os seus próprios estatutos, incluindo a gestão excessiva dos recursos naturais.

A importância do quadro institucional local para a gestão e conservação dos recursos naturais das comunidades locais na Tanzânia não pode ser sobrevalorizada. Os conselhos e assembleias de aldeia realizam reuniões de conselhos de aldeia, fornecendo o mecanismo estatutário para a tomada de decisões da comunidade local e a negociação colectiva relativamente à utilização da terra e dos recursos. A Lei de Terras da Aldeia permite às aldeias zonear áreas de terra comunitárias e individuais através de planos de uso da terra, e faz cumprir estas zonas com os estatutos da aldeia. Isto permite às comunidades apoiar as práticas tradicionais de uso da terra com planos e estatutos reconhecidos por lei. Centenas ou mesmo milhares de Áreas de Conservação da Comunidade Indígena da Tanzânia (ICCAs) podem existir como entidades legais a nível da aldeia ao abrigo deste sistema, tais como reservas pastoris de pastagem da estação seca. Muitas destas áreas de conservação localmente estão mal documentadas, e a aplicação a nível local depende de uma série de factores.

A política e legislação florestal da Tanzânia tamém se baseia na posse da terra e nas instituições de governação local presentes no país para proporcionar fortes condições para que as comunidades locais possam possuir e gerir as florestas. Enquanto o quadro histórico de gestão florestal da Tanzânia enfatizava as restrições legais à exploração e ao estabelecimento de reservas florestais centrais, a partir de meados dos anos 90 a Tanzânia iniciou algumas experiências formais com a gestão florestal comunitária. Em 1998 o país adoptou uma Política Florestal Nacional que visa reforçar o "quadro legal para a promoção da propriedade privada e comunitária de florestas e árvores" (República Unida da Tanzânia, 1998, p. 1). A Lei Florestal de 2002 foi subsequentemente aprovada, apelando a que as florestas fossem geridas ao nível mais baixo possível de governo e proporcionando disposições institucionais flexíveis para a gestão e propriedade florestal local. Estes incluem reservas florestais de terras de aldeia (VLFR) que são geridas por aldeias, bem como reservas florestais comunitárias (CFR) que podem ser geridas por um subgrupo de pessoas dentro da aldeia. Este quadro legal e político é altamente favorável à gestão e propriedade de florestas comunitárias, e levou à rápida expansão de reservas florestais locais reconhecidas estatutariamente (principalmente VLFRs). Consequentemente, as florestas terrestres da aldeia são reconhecidas por lei como uma parte viável e cada vez mais importante do património florestal sob protecção formal.

Tal como com a silvicultura, a Tanzânia passou por um processo de reforma do sector da vida selvagem nos anos 90 e lançou uma nova Política de Vida Selvagem em 1998 e a Lei de Conservação da Vida Selvagem № 5 de 2009 que exige a devolução das responsabilidades e direitos de gestão da vida selvagem às aldeias através de novas ICCAs estatutárias chamadas áreas de gestão da vida selvagem (WMAs).

Os objectivos das ICCAs, descritos pela Política da Vida Selvagem como áreas de conservação por e para as comunidades locais com direitos de gestão e controlo de benefícios descentralizados, estão claramente em linha com uma definição funcional das ICCAs. Contudo, os direitos efectivamente concedidos às comunidades para gerir a vida selvagem nas WMAs, de acordo com os regulamentos de 2002, são limitados. Por exemplo, as comunidades têm direitos muito limitados para gerir a caça comercial de fauna bravia nas WMAs e um controlo pouco claro sobre os rendimentos da fauna bravia nestas áreas. As preocupações em manter a posse segura da terra da aldeia nas WMAs também levaram à resistência de algumas comunidades pastoris ao conceito. Tal como estão actualmente desenvolvidas, as ADM estão limitadas a uma forma algo nebulosa de co-gestão com o governo mantendo um grau considerável de autoridade, e provavelmente não deveriam qualificar-se como ICCAs até (se) as suas disposições institucionais forem revistas.

As ICCAs estão também espalhadas pelas zonas costeiras e montanhosas da Tanzânia. Existem sistemas de conhecimento extensivo nas comunidades que vivem nestas áreas. Algumas das ICCAs são formalizadas, enquanto outras não o são, mas todas desempenham a necessidade crítica de alimentar as nossas paisagens. O Grupo Mpingo na costa oriental, o sistema tradicional Kumbi de organização ecológica política ao longo do Lago Malawi/Niassa/Nyasa e a exploração de terras Ntambo nas terras altas de Matengo na parte sul-ocidental da Tanzânia - todos retratam o significado dos sistemas de conhecimento indígena na conservação dos recursos naturais baseados na comunidade.

Contribuído por Stephen Nindi (Land Use Planning Commission, Tanzânia).

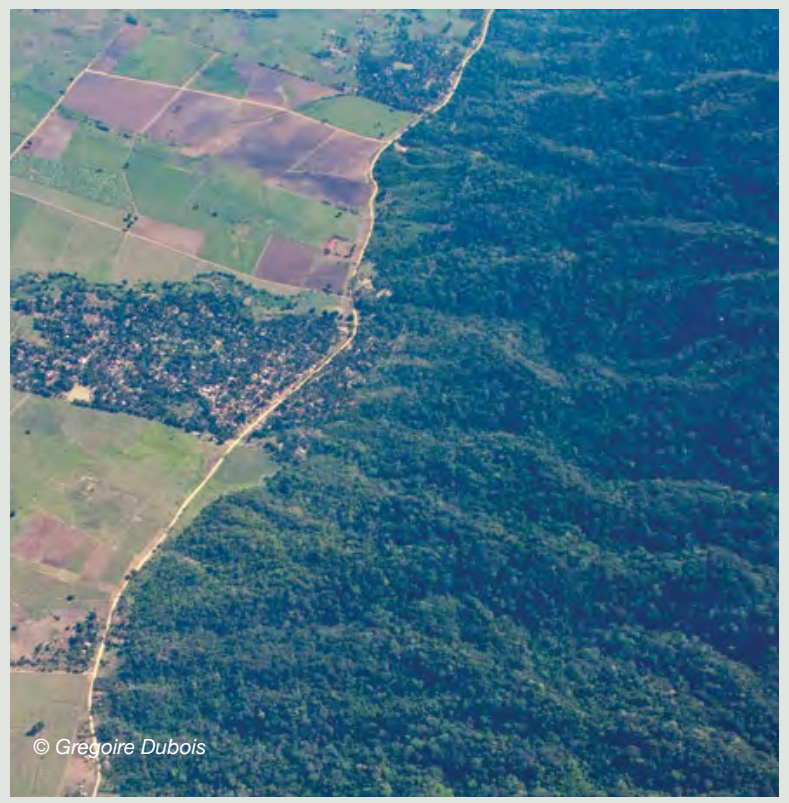




\subsection{PAGE na África Oriental e Austral}

Esta secção do relatório baseia-se na análise completada por Jessica Campese e Emmanuel Sulle no seu relatório, Eficácia da Gestão, Governação e Avaliações Sociais das Áreas Protegidas e de Conservação na África Oriental e Austral: Um rápido inventário e análise para apoiar o programa BIOPAMA e parceiros, preparado para o programa BIOPAMA (Campese \& Sulle, 2019). O relatório considerou a eficácia da gestão, governação e avaliações sociais em áreas protegidas ou de conservação terrestres e/ou marinhas na África Oriental e Austral. O foco principal foi nas metodologias desenvolvidas especificamente para avaliar uma ou uma combinação destas questões e destinadas a uma utilização replicada.

O inventário não foi exaustivo. Nem todas as avaliações inventariadas foram incluídas nas análises detalhadas porque não constituíam avaliações completas utilizando metodologias facilmente replicáveis. Estas são categorizadas como "Outras". ${ }^{107}$

\subsubsection{Avaliações da governação na África Oriental e Austral}

Trezentas e oitenta avaliações de governação foram inventariadas (ver Figuras 9.1 e 9.2). A maioria foram avaliações das florestas comunitárias ${ }^{108}$ na Tanzânia, utilizando o Painel Comunitário de Governação Florestal. Foram realizadas sete avaliações GAPA de áreas protegidas em Quénia, Uganda e Zâmbia, das quais duas análises utilizando o quadro de "escolha e reconhecimento" foram inventariadas a partir de Quénia e Uganda. Finalmente, quatro avaliações foram inventariadas utilizando um questionário de equidade protótipo em Quénia, Tanzânia, Uganda e Zimbabué. Foram inventariadas avaliações de governação para a Tanzânia, Namíbia, Quénia, Madagáscar, Uganda, Zâmbia, Zimbabué e para múltiplos países.

\subsubsection{Avaliações sociais}

Cinquenta avaliações sociais foram inventariadas, datadas de 1996 até à presente data, incluindo 19 avaliações SAPA em Etiópia, Quénia, Malawi, Moçambique, Uganda, Zâmbia, e Zimbabué (ver Figura 9.3 e Figura 9.4). Detalhes completos das metodologias utilizadas e dos países em que foram conduzidas estão disponíveis no relatório completo (ver Figura 9.1 e Figura 9.3).

A importância de se concentrar na governação e equidade das áreas protegidas é mais clara do que nunca (Bennett \& Dearden, 2014; Oldekop et al., 2015; Bennett et al., 2019;) - governação e equidade são factores chave na determinação da eficácia e eficiência da gestão em áreas protegidas. São fundamentais para assegurar que as áreas protegidas são justas e conferem benefícios ecológicos, sociais, económicos e culturais sem sobrecarregar as pessoas com custos injustos. Consequentemente, cumpre os objectivos estabelecidos na PoWPA em que as áreas protegidas são consideradas como melhor integradas nas paisagens mais vastas, mas também na sociedade como um todo.

\subsection{Resultados das avaliações sociais e de governação na África Oriental e Austral}

Na região da ESA, apenas 18 sítios no total avaliaram até agora componentes sociais e de governação utilizando o quadro de governação e equidade das ferramentas GAPA, SAPA e SAGE do IIED (ver Quadro 9.3).

Com base numa análise destas avaliações, foram destacados vários pontos fortes e desafios. Os pontos fortes observados foram a partilha equitativa de benefícios, tais como receitas derivadas de projectos de desenvolvimento comunitário e acesso a recursos nas áreas protegidas. Foram também observados canais de comunicação para envolver a comunidade e a tomada de decisões em algumas áreas foi feita em conjunto, por exemplo, a selecção de projectos a financiar.

As questões assinaladas giravam em torno da participação na tomada de decisões que, entre outras, incluíam funcionários das áreas protegidas e representantes governamentais com mais influência na tomada de decisões do que a população local. Outros desafios incluíam a transparência e o acesso à informação e particularmente na partilha de receitas e na sensibilização para os direitos. Faltava uma aplicação justa e eficaz da lei em alguns casos em que havia uma aplicação irregular da lei.

\section{Figura 9.1 Avaliações de governação inventariadas por metodologia (total 378)}
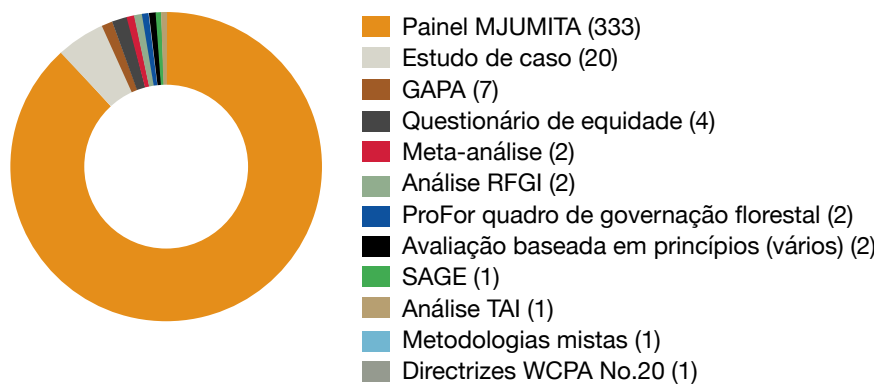

Fonte: Campese \& Sulle (2019, p. 48)
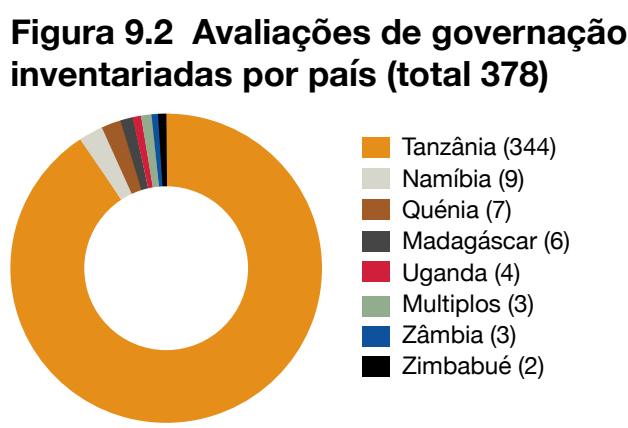

Tanzânia (344)

Namíbia (9)

Quénia (7)

Madagáscar (6)

Uganda (4)

Multiplos (3)

Zâmbia (3)

Zimbabué (2)

108 É importante notar que na Tanzânia estes são OECM, na sua maioria estabelecidos por comunidades para a gestão florestal e REDD+ em vez de conservação da biodiversidade per se. Não se encontram no WDPA. 
Figura 9.3 Avaliações sociais inventariadas por metodologia (total 50)

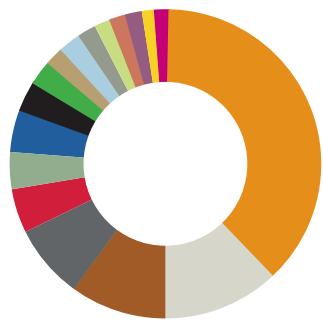

SAPA (50)

PEV (6)

RSIA (5)

Quadro dos meios de subsistência sustentáveis (4)

BNS (2)

PA-BAT (2)

Kit de ferramentas ligado a

pobreza-florestas (2)

- Avaliação do bem-estar (2)

SWIFT (1)

Avaliação do ecossistema do milénio (1)

Metodologias mistas (1)

Vídeo participativo (1)

Experiência de escolha discreta (1)

Cartografia participativa (1)

Estudo sócio-económico (1)

Fotofactura (1)

\section{Figura 9.4 Número total de avaliações sociais inventariadas por país}

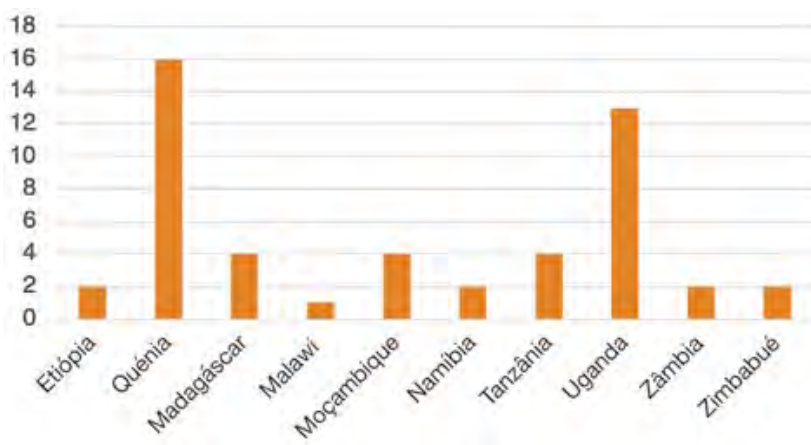

Fonte: Campese \& Sulle (2019, pg. 51).

\section{Caixa 9.10 Avaliação social no OI Pejeta Conservancy no Quénia}

Ol Pejeta Conservancy (OPC) é uma área privada protegida no Quénia que é propriedade e gerida por um trust de conservação. Desde a sua conversão de uma fazenda de gado para uma conservação no início dos anos 90 e beneficiando de apoio substancial de doadores, a OPC tornou-se um destino turístico popular, gerando receitas suficientes para cobrir os custos operacionais e fornecer anualmente montantes substanciais para o seu programa comunitário que investe na educação, saúde, extensão agrícola e abastecimento de água.

Em 2014, a OPC realizou uma avaliação dos impactos sociais positivos e negativos da conservação nas comunidades locais utilizando a metodologia SAPA, e isto foi repetido em 2019. A SAPA utiliza um método de avaliação rural participativa em comunidades seleccionadas para identificar os impactos mais significativos, um pequeno inquérito aos agregados familiares para investigar estes impactos com mais detalhe $e$ questões de governação relacionadas (mas com muito menos profundidade do que o GAPA), e finalmente um workshop de partes interessadas onde as principais partes interessadas analisam os resultados e identificam ideias para acção.

A avaliação de 2019 reiterou as conclusões de 2014 de que os benefícios mais significativos de uma perspectiva comunitária são as vedações em torno da conservação, o que reduziu o conflito entre a vida selvagem humana, e a melhoria da segurança proporcionada pela presença de pessoal de aplicação da lei da OPC numa área de outro modo insegura. Esta descoberta, de que algumas actividades de gestão de parques parecem ter mais valor para a comunidade do que as actividades de desenvolvimento do programa comunitário, foi uma verdadeira abertura de olhos em 2014. Conduziu não a um corte nas actividades de desenvolvimento, mas a uma abordagem mais focalizada que dá prioridade aos benefícios que as pessoas consideram mais valiosos, nomeadamente as bolsas escolares.
Outra descoberta chave é que estas bolsas parecem ser mais valorizadas pelas famílias mais ricas, sugerindo algum preconceito na sua atribuição que precisa de ser rectificado. Houve também uma forte mensagem de que os benefícios estavam a ser atribuídos mais às comunidades do lado sudeste mais próximas da estrada principal. Isto foi, desde então, amplamente rectificado. No entanto, continua a haver um padrão de mulheres e pessoas mais pobres mais preocupadas com esta questão. Algumas das ideias para melhorar a situação incluem uma melhor comunicação, uma vez que o problema é em parte causado pelo simples facto de as pessoas não saberem quais os benefícios que vão para os outros e suspeitarem de preconceitos que podem não estar realmente presentes.

A percepção de enviesamento na atribuição de projectos e empregos de desenvolvimento também aparece como impactos negativos significativos juntamente com os danos às culturas pelos animais (apesar das vedações). No entanto, estas preocupações parecem relativamente menores, uma vez que o quadro geral da percepção que as comunidades têm da área protegida, tendo em conta todos os benefícios e custos, tem melhorado desde 2014.

Contribuido por Jennifer Kelleher (UICN).

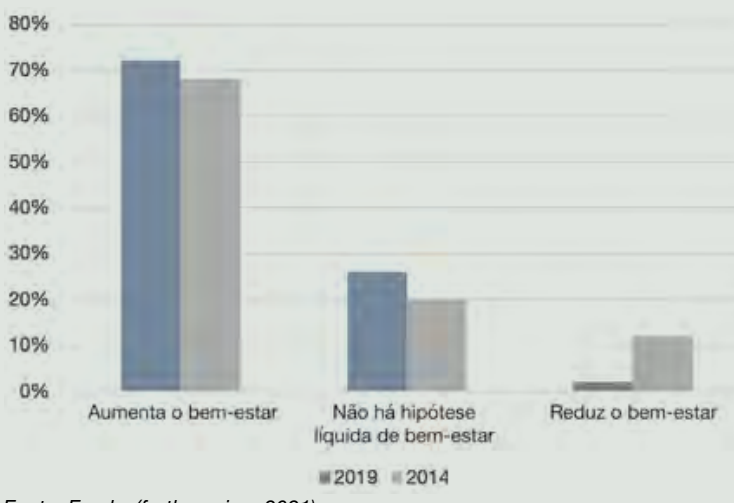

Fonte: Franks (forthcoming, 2021). 


\section{Quadro 9.3 Avaliações SAPA, GAPA e SAGE realizadas até à data}

\begin{tabular}{|c|c|c|}
\hline \multicolumn{3}{|c|}{ SAPA } \\
\hline País & Área & Versão \\
\hline Etiópia & Parque Nacional Awash & v1 \\
\hline Quénia & Parque Nacional/Reserva Marsabit & v2 \\
\hline Quénia & Conservação OI Pejeta & v2 \\
\hline Quénia & Conservação Borana & v2 \\
\hline Quénia & Conservação Loisaba & v2 \\
\hline Quénia & Área Marinha Protegida de Kisite & v2 \\
\hline Quénia & Parque Nacional de Ruma & v2 \\
\hline Moçambique & Parque Nacional de Maputo & v2 \\
\hline Uganda & Parque Nacional do Ruwenzori & $\mathrm{v} 1$ \\
\hline Uganda & Parque Nacional do Lago Mburo & $\mathrm{v} 1$ \\
\hline Uganda & Parque Nacional de Kibale & v2 \\
\hline Uganda & Parque Nacional de Mgahinga & v2 \\
\hline Uganda & Parque Nacional de Murchison & v2 \\
\hline Uganda & Parque Nacional de Bwindi & v2 \\
\hline Zâmbia & $\begin{array}{l}\text { Área de Gestão de Caça de } \\
\text { Mumbwa }\end{array}$ & $\mathrm{v} 1$ \\
\hline Zâmbia & Área de Gestão de Caça Lupande & $\mathrm{v} 1$ \\
\hline \multicolumn{3}{|c|}{ GAPA } \\
\hline País & Área & \\
\hline Quénia & Conservação Mara Norte & \\
\hline Quénia & Conservação Olderkesi & \\
\hline Quénia & Conservação Kalama & \\
\hline Zâmbia & Área de Gestão de Caça de Chiawa & \\
\hline Zâmbia & Área de Gestão de Caça de Mumbwa & \\
\hline
\end{tabular}

\begin{tabular}{l|l}
\hline \multicolumn{2}{c}{ SAGE } \\
\hline País & Área \\
\hline Zâmbia & Área de Gestão de Caça Mulobezi \\
\hline Tanzânia & Área de Gestão da Vida Selvagem de Randilen \\
\hline
\end{tabular}

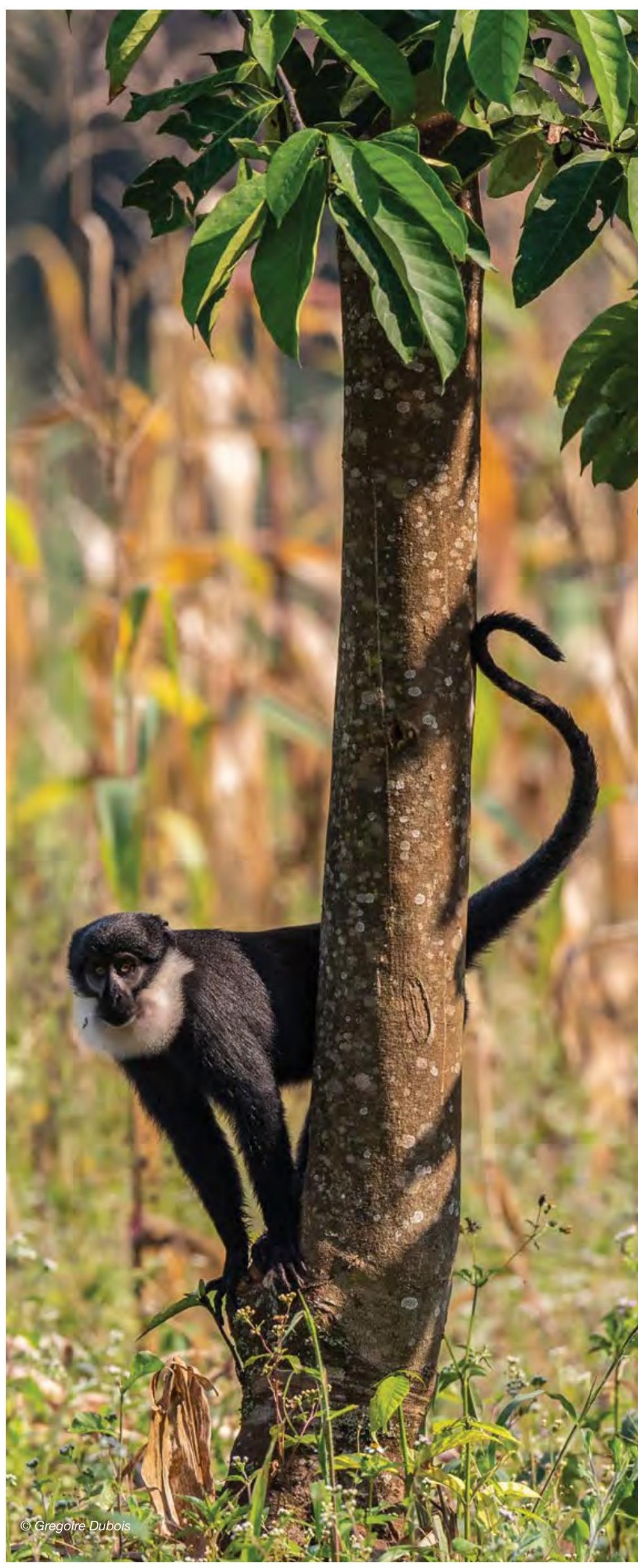




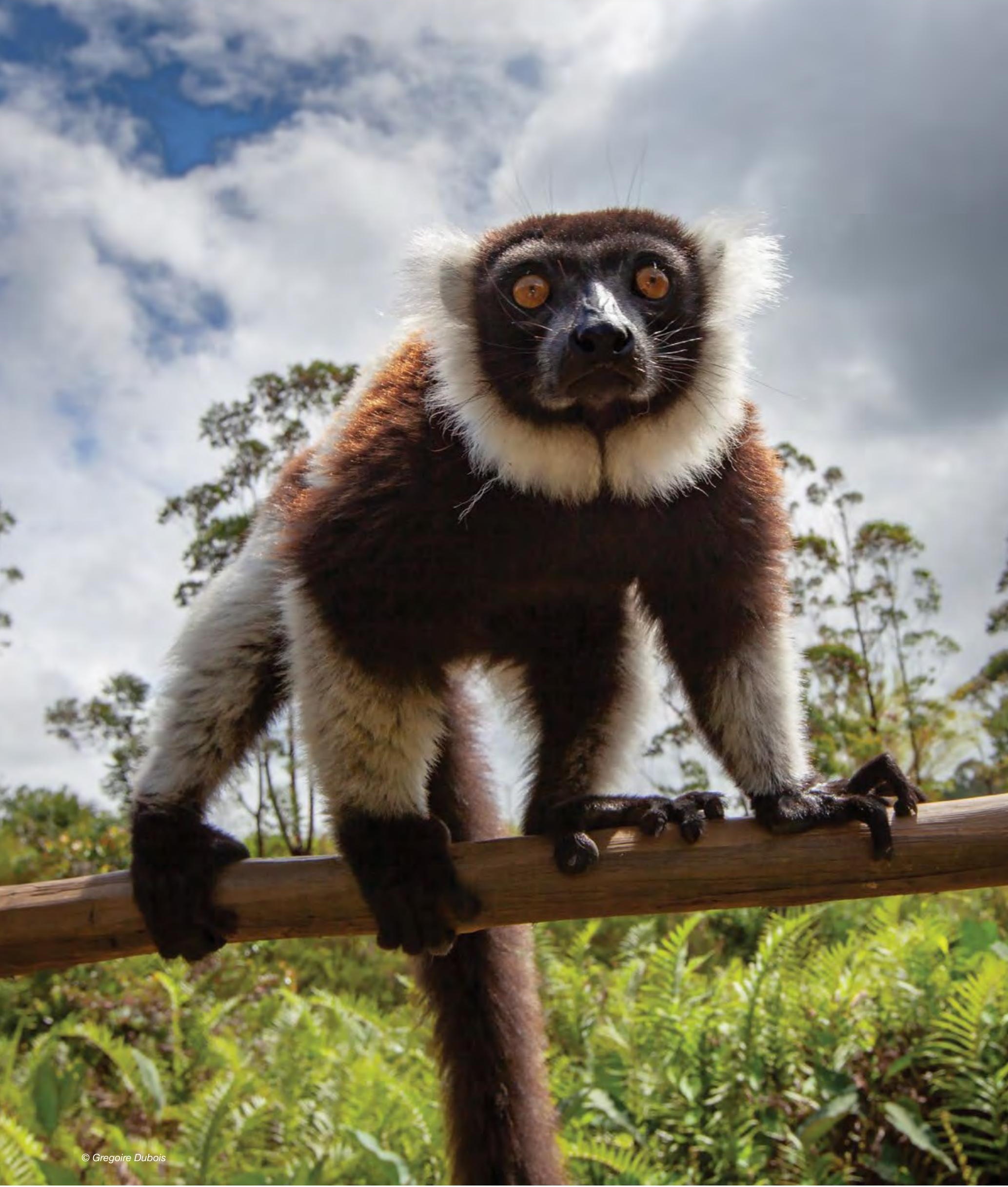




\section{Eficácia da gestão de áreas protegidas}




\subsection{O que é uma gestão eficaz?}

A eficácia da gestão está relacionada com a forma como as áreas protegidas estão a ser geridas - principalmente o grau de eficácia da gestão na conservação de valores e na consecução de metas e objectivos, tais como a protecção da biodiversidade (Hockings et al., 2006; Leverington et al., 2010). As componentes específicas da boa gestão variam com o contexto e as características de cada área protegida: por exemplo, uma área protegida remota baseada na comunidade com poucos visitantes necessita de menos pessoal e instalações recreativas do que um destino turístico icónico.

Nem todas as áreas protegidas são geridas eficazmente para proteger os valores que foram concebidas para conservar, e a qualidade da gestão da maioria das áreas protegidas é mal compreendida (Geldmann et al., 2015). Existem fortes indícios de que existem correlações positivas entre certos aspectos da gestão de áreas protegidas (tais como pessoal e orçamentos) e os resultados da conservação de espécies (Edgar et al., 2014; Geldmann et al., 2013). Tem havido muito trabalho nos últimos 30 anos para definir características gerais de áreas protegidas bem geridas, e depois para medir o quão bem as áreas individuais correspondem a estes padrões. Estas características desejáveis foram incorporadas como indicadores em metodologias, tais como a ferramenta de monitorização da eficácia de gestão, e formaram a base do "formato comum de relatórios" para a compilação global de dados sobre a eficácia de gestão (Leverington et al., 2010). Mais recentemente, o processo da Lista Verde empreendeu um exercício detalhado e robusto para desenvolver normas globais para áreas protegidas, que podem ser adaptadas e interpretadas para diferentes países.

Foram realizados alguns estudos sobre tipos específicos de áreas protegidas. Por exemplo, um estudo sobre o desempenho das áreas protegidas para leões mostrou que as áreas protegidas tendem a ser mais eficazes para a conservação de leões e/ou das suas presas onde os orçamentos de gestão são mais elevados, onde o turismo fotográfico é o principal uso do solo, e, para as presas, onde a vedação está presente. Os leões e as suas presas tiveram menos sucesso em relação à sua capacidade de carga potencial estimada nos países mais pobres, onde as pessoas se instalavam dentro de áreas protegidas e onde as áreas protegidas não eram utilizadas para turismo fotográfico nem para a caça de troféus (Lindsey et al., 2017).

\subsection{Avaliar a eficácia da gestão}

A avaliação da eficácia da gestão tem sido um tema crescente na gestão de áreas protegidas e na conservação da biodiversidade global durante muitos anos (ver Caixa 10.1). Fornece uma lente através da qual se podem analisar temas importantes na gestão de áreas protegidas, em particular:

1) Questões de concepção relacionadas com sítios individuais, bem como com sistemas de áreas protegidas;

2) Adequação e adequação dos sistemas e processos de gestão; e

3) Realização de objectivos de áreas protegidas, incluindo a conservação de valores (Hockings et al., 2006).
Em termos gerais, a avaliação da eficácia da gestão pode:

- Permitir e apoiar uma abordagem adaptativa à gestão de áreas protegidas;

- Ajudar na atribuição eficaz de recursos entre e dentro dos sítios;

- Promover a responsabilização e a transparência através de relatórios sobre a eficácia da gestão aos interessados e ao público; $\mathrm{e}$

- Ajudar a envolver a comunidade mais ampla de interessados, incluindo agências governamentais, ONG e comunidades locais, construir circunscrições eleitorais e promover os valores das áreas protegidas (Hockings et al., 2006).

Como a comunidade global de conservação prestou maior atenção à questão da eficácia da gestão e à necessidade de instrumentos para ajudar a avaliá-la, tornou-se claro que, com uma tal variedade de sistemas e contextos, a concepção de um único instrumento de avaliação não seria prática. A avaliação da eficácia da gestão deveria ser adaptada às exigências particulares do local, dado que cada área protegida tem uma variedade de características biológicas e sociais, pressões e utilizações.

Em 2000, a UICN WCPA desenvolveu um quadro para orientar o desenvolvimento de sistemas de avaliação para avaliar a eficácia da gestão. Este quadro foi actualizado em 2006, e continua a ser o quadro a que a maioria das abordagens PAME se relacionam conceitualmente (Coad et al., 2015). O quadro identifica seis componentes centrais, cada uma associada a diferentes aspectos da eficácia da gestão: contexto, planeamento, entradas, processo, saídas e resultados (ver Figura 10.1) (Hockings et al., 2006).

\section{Figura 10.1 O ciclo de gestão e avaliação da gestão das áreas protegidas}

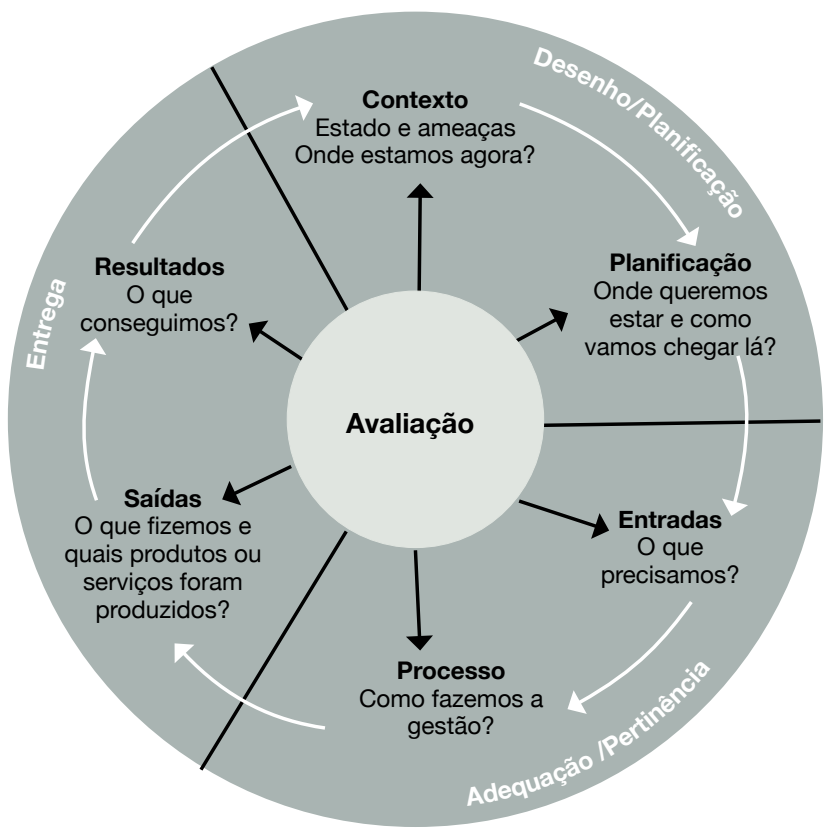

Fonte: Hockings et al. (2006, p. 12) 


\subsection{Compromissos internacionais para a avaliação da eficácia da gestão}

O Objectivo 11 da Aichi reconhece que o aumento da cobertura por si só não irá travar a perda da biodiversidade, e salienta a necessidade de uma gestão eficaz:

\begin{abstract}
Objectivo 11: Até 2020, pelo menos 17\% das áreas de águas terrestres e interiores e $10 \%$ das áreas costeiras e marinhas, especialmente as áreas de particular importância para a biodiversidade e os serviços ecossistémicos, serão conservadas através de sistemas eficazes e equitativamente geridos, ecologicamente representativos e bem conectados de áreas protegidas e outras medidas eficazes de conservação baseadas em áreas, e integradas na paisagem e paisagem marítima em geral (CDB, 2010a, p. 9)
\end{abstract}

PAME está incluído em múltiplos lugares no PoWPA da CDB. Por exemplo, o Objectivo 4.2 é "Avaliar e melhorar a eficácia da gestão das áreas protegidas” (CBD, 2004, p. 20).

\section{A Decisão COP 10 da CDB X/31 apela às Partes para}

... expandir e institucionalizar as avaliações da eficácia da gestão para trabalhar no sentido de avaliar $60 \%$ da área total de áreas protegidas até 2015 utilizando vários instrumentos nacionais e regionais, e relatar os resultados na base de dados global sobre eficácia da gestão (CDB, 2010b, p. 5).

A Resolução WCC-2012-Res-076 da UICN apela à implementação de sistemas de avaliação da eficácia da gestão de áreas marinhas protegidas (UICN, 2012), enquanto a Resolução WCC-2016-Res-036-EN da UICN apela a uma maior avaliação da eficácia das áreas privadas protegidas na conservação da biodiversidade, património natural e serviços ecossistémicos (UICN, 2016b).

\subsection{Base de dados global sobre a eficácia da gestão de áreas protegidas (GD-PAME)}

O GD-PAME foi desenvolvido através de uma colaboração de universidades, UICN e organizações não governamentais, e é agora mantido pelo UNEP-WCMC em colaboração com governos, organizações não governamentais, universidades e indústria (UNEP-WCMC \& UICN, 2019aa).

Compreende registos de muitos milhares de avaliações de PAME, recolhidos em todo o mundo, mostrando quais as metodologias que foram aplicadas onde e quando). Em 2019, mais de 240.000 áreas protegidas estavam na WDPA, com informações sobre avaliações da eficácia da gestão disponíveis para 21.743 (9\%) das mesmas. Isto equivale a $20 \%$ da área de todas as áreas protegidas na WDPA. A falta de relatórios sistemáticos, avaliações duplicadas do mesmo sítio, utilização de múltiplas ferramentas de avaliação, e por vezes uma falta de vontade política torna este elemento do Objectivo 11 de Aichi difícil de seguir (UNEP-WCMC et al., 2019). Isto pode ser utilizado, em conjunto com a análise qualitativa de relatórios de eficácia de gestão e outra literatura, para gerar análises detalhadas e relatórios de eficácia de gestão, incluindo questões-chave, pontos fortes e
Caixa 10.1 Porquê informar sobre a eficácia da gestão das áreas protegidas?

Há uma série de razões pelas quais os países podem optar por relatar as avaliações da eficácia da gestão:

- Cumprir as obrigações do país ao abrigo da CDB (PAME é um indicador oficial do Objectivo 11 de Aichi).

- O inventário dos dados nacionais armazenados de forma sistemática fornece uma imagem clara da eficácia da gestão do património da área nacional protegida e pode contribuir para uma gestão adaptativa.

- O GD-PAME permite a identificação de áreas de pontos fortes e fracos na gestão de áreas protegidas, fornecendo informação para ajudar os países a dar prioridade à atribuição de recursos e ao desenvolvimento da capacidade alvo. Fornecer também dados sobre ameaças.

- A informação no GD-PAME pode ser analisada para a região, continente e mundo para melhor compreender a relação entre a eficácia da gestão e os resultados da biodiversidade.

Para ver os dados e descarregar o Manual do Utilizador GD-PAME, por favor visite: https://pame.protectedplanet.net/.

Para enviar dados ou mais informações, por favor contacte: protectedareas@unep-wcmc.org ou rcmrd@rcmrd.org.

fracos e ameaças, em todas as regiões do mundo (Leverington et al., 2010; Nolte et al., 2010) (ver Caixa 10.1). Infelizmente, a análise não tem sido realizada desde 2010.

\subsection{Ferramentas para avaliar a eficácia da gestão}

A estrutura WCPA da UICN (ver Figura 10.1) informou o desenvolvimento de uma grande variedade de metodologias de avaliação PAME. Estas vão desde estudos detalhados ao nível do local até avaliações amplas ao nível do sistema, utilizando muitos processos diferentes, incluindo questionários e workshops, entre outros (Hockings et al., 2015; Leverington et al., 2010).

Foram desenvolvidas metodologias para diferentes tipos de áreas protegidas, desde as designadas a nível nacional até às designadas no âmbito de convenções e acordos regionais e internacionais, tais como Sítios do Património Mundial (ver Quadro 10.1).

\subsection{Princípios para avaliações PAME}

Há muitos benefícios na avaliação da eficácia da gestão de áreas protegidas e de conservação, mas também há desafios e limitações, e é imperativo que as avaliações sejam realizadas de forma apropriada paramitigar estes riscos (Hockingsetal.,2006). Afim deapoiara selecção e aplicação de metodologias, foram desenvolvidos oito princípios para avaliações da eficácia da boa gestão (Hockings et al., 2015). 
Quadro 10.1 Metodologias PAME utilizadas mais frequentemente na África Oriental e Austral

\begin{tabular}{l|l}
\hline Acrónimo & Ferramenta \\
\hline Birdlife IBA & Avifauna - Avaliaçães de Áreas Importantes para a Avifauna e Biodiversidade \\
\hline EoH & Valorização do nosso património (principalmente para sítios naturais do Património Mundial) \\
\hline IEG & (Banco Mundial) Avaliações de grupos de avaliação independentes \\
\hline METT & Ferramenta de Rastreamento da Eficácia da Gestão \\
\hline PAMETT & Adaptação METT para Madagáscar \\
\hline RAPPAM & Avaliação Rápida e Prioritização da Gestão de Áreas Protegidas \\
\hline SAPM & Avaliação da Eficácia da Gestão do Sistema de Áreas Protegidas de Madagáscar \\
\hline SGBD / SMART & Variação SMART específica de Madagáscar \\
\hline SMART & Ferramenta de Monitorização e Relatórios Espaciais \\
\hline West Indian Ocean MPA & Avaliação da Área Marítima Protegida do Oceano Índico Ocidental \\
\hline WH Outlook Report & Relatório de Perspectivas do Património Mundial \\
\hline
\end{tabular}

As avaliações da eficácia da gestão das áreas protegidas devem ser:

1) Parte de um ciclo de gestão eficaz, ligado a valores, objectivos e políticas definidos e parte de planeamento estratégico, planeamento de parques e ciclos económicos e financeiros;

2) Prático para implementar com os recursos disponíveis, dando um bom equilíbrio entre medição, relatórios e gestão;

3) Útil e relevante para melhorar a gestão de áreas protegidas, para dar explicações e mostrar padrões e para melhorar a comunicação, relações e sensibilização;

4) Lógico e sistemático, trabalhando num quadro lógico e aceite com uma abordagem equilibrada;

5) Com base em bons indicadores, que são holísticos, equilibrados e úteis;

6) Precisos - fornecendo informação verdadeira, objectiva, consistente e actualizada;

7) Cooperação e participação com boa comunicação, trabalho de equipa e participação de gestores de áreas protegidas e partes interessadas em todas as fases do projecto, sempre que possível; $\mathrm{e}$

8) Centrada na comunicação positiva e oportuna e na aplicação dos resultados.

As avaliações, embora altamente técnicas, são também processos políticos e sociais. É fundamental examinar quem participa no processo, e cujas perspectivas são incluídas nos resultados: existe o risco de pessoas que não são incluídas poderem contestar as conclusões, e os seus pontos de vista podem ser muito diferentes. A compreensão das razões subjacentes à realização de avaliações é também importante para garantir a adesão e o apoio. Não devem ser vistas como uma revisão do desempenho do pessoal, uma vez que isto terá impacto na exactidão da avaliação.

É também importante considerar cuidadosamente a comunicação dos resultados da avaliação. Sem uma comunicação eficaz, os resultados podem ser mal interpretados ou utilizados de formas inadequadas, tais como fazer comparações injustificadas (Campese \& Sulle, 2019). Os resultados da avaliação também podem ser limitados pela disponibilidade e qualidade dos dados de base. Uma vez comunicados os resultados, é também importante que as áreas identificadas para melhoria sejam postas em prática e que haja financiamento e capacidade disponíveis suficientes para assegurar uma mudança eficaz para responder às ameaças/questões/desafios identificados nas avaliações. Se este não for o caso e nada mudar, pode levar à complacência e ao desânimo dos gestores das áreas protegidas e reduzir o interesse em realizar avaliações futuras. As avaliações, e os processos para as conduzir, devem conduzir a uma gestão adaptativa positiva que resulte numa gestão mais eficaz das áreas protegidas.

\subsection{Integrar a eficácia da gestão com a governação e as avaliações sociais}

A maioria das metodologias de avaliação PAME não aborda em detalhe as questões de governação ou equidade social. Há, contudo, uma sinergia substancial entre as diferentes avaliações e muito a ganhar com a sua realização concomitante. Todas as metodologias PAME analisam o grau de envolvimento das partes interessadas, as ameaças às áreas protegidas, e algumas também exploram os benefícios e aspectos sociais relacionados com a gestão. Uma maior exploração da governação e equidade das áreas protegidas está disponível no Capítulo 4.

Foram desenvolvidas algumas normas e metodologias que integram elementos substanciais de eficácia de gestão com a governação e/ ou avaliação social (Campese \& Sulle, 2019), tais como a Lista Verde de Áreas Protegidas e de Conservação (ver secção 9.2). 


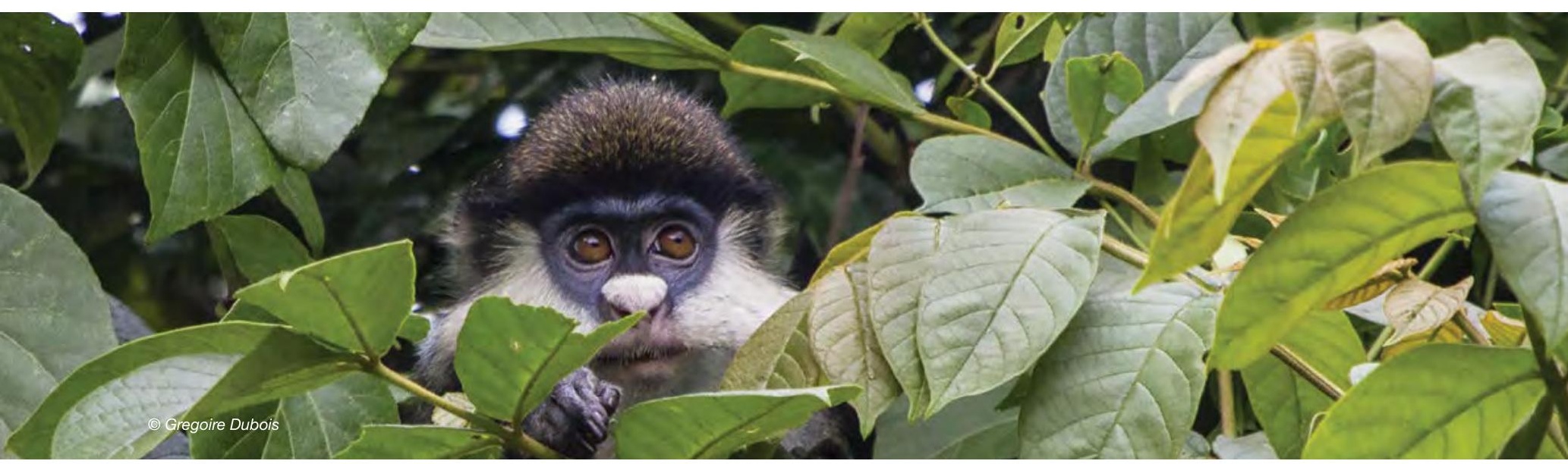

\subsection{PAME na África Oriental e Austral}

A análise da percentagem de áreas protegidas avaliadas pelo PAME no GD-PAME (Figura 10.2) mostra que a África tem feito um trabalho significativo nesta área. Inicialmente muitas avaliações estavam relacionadas com os requisitos de financiamento dos doadores, mas ao longo dos anos muitos países da região institucionalizaram avaliações e alguns, incluindo Madagáscar, África do Sul e Zâmbia, adaptaram a ferramenta METT aos seus objectivos específicos. África do Sul tem vindo a realizar avaliações METT ao longo de vários anos, utilizando objectivos METT para melhorar a gestão e como uma forma real de abordar questões.

Infelizmente, tem havido poucas análises dos resultados destas avaliações para compreender quais foram os resultados a nível regional.

Desde 1990, tem havido uma mudança global em termos de quem está a liderar as avaliações PAME. Inicialmente, a maioria das avaliações eram lideradas por ONG, mas de 2010 a 2014 houve um aumento nos esforços liderados por agências (Coad et al., 2015).

No GD-PAME, existem 681 áreas protegidas com pelo menos uma avaliação PAME na África Oriental e Austral (Quadro 10.2). Isto representa apenas $13 \%$ das áreas protegidas da região. Muitas das áreas protegidas foram avaliadas mais de uma vez, elevando o número total de avaliações para 1,510. A Figura 10.3 mostra o número de áreas protegidas com avaliações PAME no GD-PAME para a África Oriental e Austral, enquanto a Figura 10.4 mostra a percentagem de áreas protegidas com avaliações PAME no GD- PAME.

\subsubsection{Inventário das avaliações PAME na África Oriental e Austral}

This section of the report draws heavily on the analysis completed by Esta secção do relatório baseia-se fortemente na análise completada por Jessica Campese e Emmanuel Sulle no seu relatório, Eficácia da Gestão, Governação e Avaliações Sociais das Áreas Protegidas e de Conservação na África Oriental e Austral: Um inventário e análise rápidos para apoiar o programa BIOPAMA e parceiros, preparados para o programa BIOPAMA (Campese \& Sulle, 2019). O relatório considerou a eficácia da gestão, governação, e avaliações sociais em áreas protegidas ou de conservação terrestres e/ou marinhas na África Oriental e Austral. O foco principal foi nas metodologias desenvolvidas especificamente para avaliar uma ou uma combinação destas questões e destinadas a uma utilização replicada.

O inventário incluía o GD-PAME, bem como estudos académicos e avaliações totais ou parciais contidas em relatórios mais amplos. Também incluiu avaliações que foram relatadas em respostas a inquéritos e entrevistas, mas não foram relatadas no GD-PAME. Em particular, a análise incluiu 294 avaliações METT em África do Sul para 2015, 2017 e 2019 baseadas em respostas a inquéritos (e documentos publicados), juntamente com confirmações em entrevistas de acompanhamento de que África do Sul faz avaliações SA-METT pelo menos de dois em dois anos (em alguns sítios anualmente) em todas as áreas protegidas terrestres governadas pelo governo. As avaliações de impacto específicas do projecto e os relatórios de rastreio não foram incluídos. Embora o inventário seja grande, não é exaustivo. Nem todas as avaliações inventariadas foram incluídas nas análises detalhadas porque não constituíam avaliações completas utilizando metodologias facilmente replicáveis. Estas são categorizadas como 'Outras'.

Para além dos tipos de avaliação descritos abaixo [ou acima, dependendo da localização dos gráficos de inventário em relação a este texto], o inventário incluiu avaliações de governação e sociais realizadas em paisagens que acolhem áreas protegidas e de conservação, bem como processos mais amplos e inovadores envolvendo elementos de governação e avaliação social. ${ }^{109}$ Protocolos Comunitários Bioculturais (PBC), por exemplo, "articulam valores, procedimentos e prioridades determinados pela comunidade", incluindo (quando relevante) em relação as áreas protegidas e de conservação. O processo pode incluir a descrição, a reflexão e o reconhecimento dos sistemas de governação do território dos povos indígenas e das comunidades locais e dos direitos e responsabilidades relacionados. Os BCP têm sido desenvolvidos em vários países da região, incluindo Quénia, Madagáscar, Namíbia, e África do Sul. (ver website de Natural Justice)

O relatório completo está disponível online. ${ }^{110}$

109 Há também muitas experiências e recursos relacionados não incluídos no inventário porque, embora relevantes para o tópico, não envolvem uma avaliação per se. Isto inclu estudos de casos da África Oriental e Austral incluídos no registo da ICCA.

$110 \mathrm{https} / / /$ biopama.org/node/349 
Quadro 10.2 Avaliações PAME na África Oriental e Austral

\begin{tabular}{|c|c|c|c|c|c|}
\hline País & $\begin{array}{r}\text { Número de } \\
\text { áreas } \\
\text { protegidas } \\
\text { (WDPA) }\end{array}$ & $\begin{array}{r}\text { Número de áreas } \\
\text { protegidas com } \\
\text { registos de avaliação } \\
\text { PAME (GD-PAME) }\end{array}$ & $\begin{array}{r}\text { Número de registos } \\
\text { de avaliação PAME } \\
\text { (GD-PAME) }\end{array}$ & $\begin{array}{l}\text { Número de avaliações } \\
\text { PAME inventariadas por } \\
\text { Campese \& Sulle (2019) }\end{array}$ & $\begin{array}{r}\text { Número de áreas } \\
\text { protegidas com mais } \\
\text { de uma avaliação }\end{array}$ \\
\hline Angola & 14 & 4 & 4 & 4 & 0 \\
\hline Botswana & 22 & 6 & 8 & 9 & 2 \\
\hline Comores & 8 & 0 & 0 & 0 & $\begin{array}{r}\text { Nenhuma avaliação } \\
\text { sobre o GD-PAME }\end{array}$ \\
\hline Djibouti & 7 & 1 & 1 & 1 & 0 \\
\hline Eritreia & 4 & 0 & 0 & 0 & $\begin{array}{r}\text { Nenhuma avaliação } \\
\text { sobre o GD-PAME }\end{array}$ \\
\hline Eswatini & 14 & 0 & 0 & 6 & $\begin{array}{r}\text { Nenhuma avaliação } \\
\text { sobre o GD-PAME }\end{array}$ \\
\hline Etiópia & 104 & 17 & 20 & 27 & 3 \\
\hline Quénia & 411 & 41 & 70 & 112 & 18 \\
\hline Lesoto & 4 & 2 & 1 & 1 & 0 \\
\hline Madagáscar & 157 & 78 & 79 & 476 & 1 \\
\hline Malawi & 133 & 19 & 23 & 29 & 4 \\
\hline Maurícias & 44 & 13 & 19 & 13 & 4 \\
\hline Moçambique & 44 & 10 & 44 & 45 & 11 \\
\hline Namíbia & 148 & 18 & 40 & 44 & 10 \\
\hline Ruanda & 10 & 4 & 6 & 5 & 2 \\
\hline Seychelles & 40 & 6 & 10 & 12 & 2 \\
\hline Somália & 21 & 0 & 0 & 0 & $\begin{array}{r}\text { Nenhuma avaliação } \\
\text { sobre o GD-PAME }\end{array}$ \\
\hline África do Sul & 1580 & 205 & 722 & 1606 & 173 \\
\hline Sudão do Sul & 27 & 4 & 4 & 4 & $\begin{array}{r}\text { Nenhuma avaliação } \\
\text { sobre o GD-PAME }\end{array}$ \\
\hline Sudão & 23 & 2 & 2 & 2 & 0 \\
\hline Tanzânia & 840 & 183 & 329 & 340 & 80 \\
\hline Uganda & 712 & 37 & 54 & 53 & 10 \\
\hline Zâmbia & 635 & 22 & 65 & 70 & 12 \\
\hline Zimbabué & 232 & 9 & 9 & 14 & 1 \\
\hline
\end{tabular}

Fonte: Campese \& Sulle (2019); UNEP-WCMC \& UICN (2019a)

Figura 10.2 Percentagem de cobertura das avaliações da eficácia da gestão por região

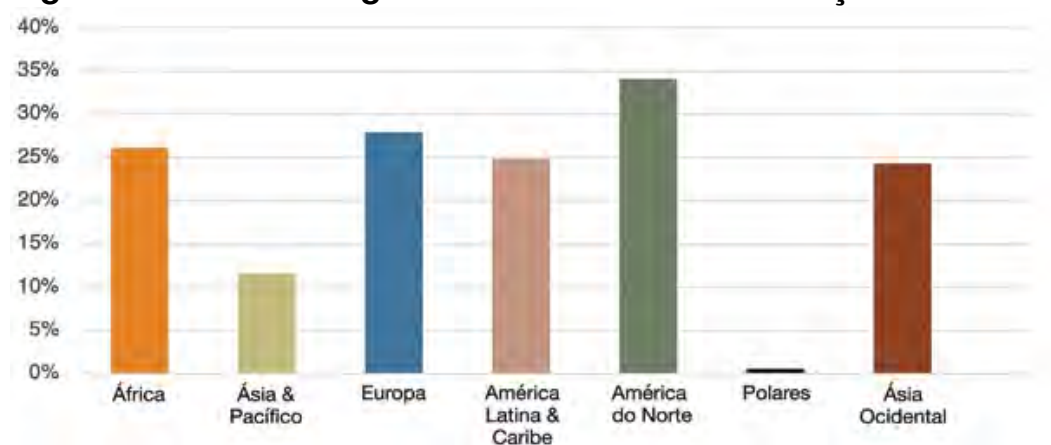

Fonte: UNEP-WCMC \& UICN (2019a).

Nota: Percentagem de cobertura de todas as áreas protegidas por região avaliadas para eficácia de gestão utilizando diferentes ferramentas de Eficácia de Gestão de Áreas Protegidas (PAME) 
Figura 10.3 Número de áreas protegidas com avaliações PAME no GD-PAME para a África Oriental e Austral

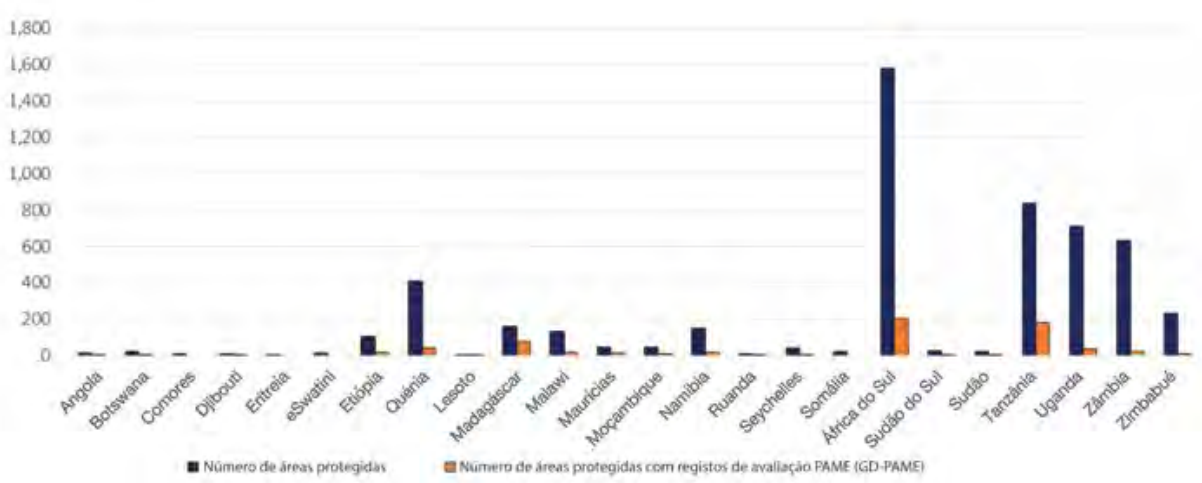

Fonte: UNEP-WCMC \& UICN (2019a).

Figura 10.4 Percentagem de área protegida com avaliações PAME no GD-PAME

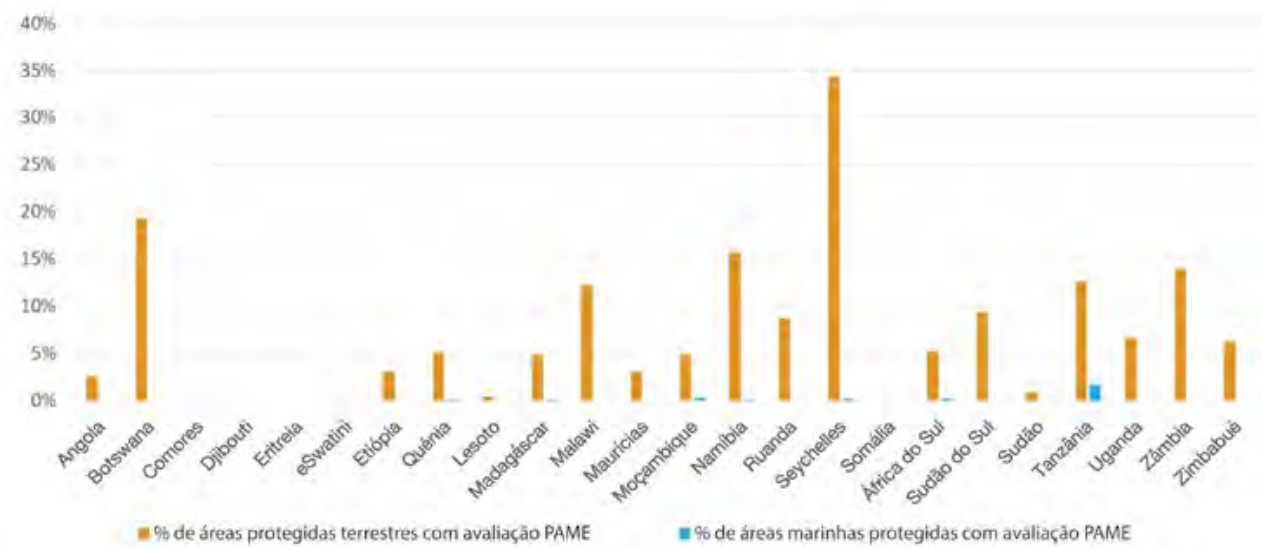

Fonte: UNEP-WCMC \& UICN (2019a)

Figura 10.5 Avaliações PAME inventariadas na África Oriental e Austral por metodologia/ferramenta (total 2 878)
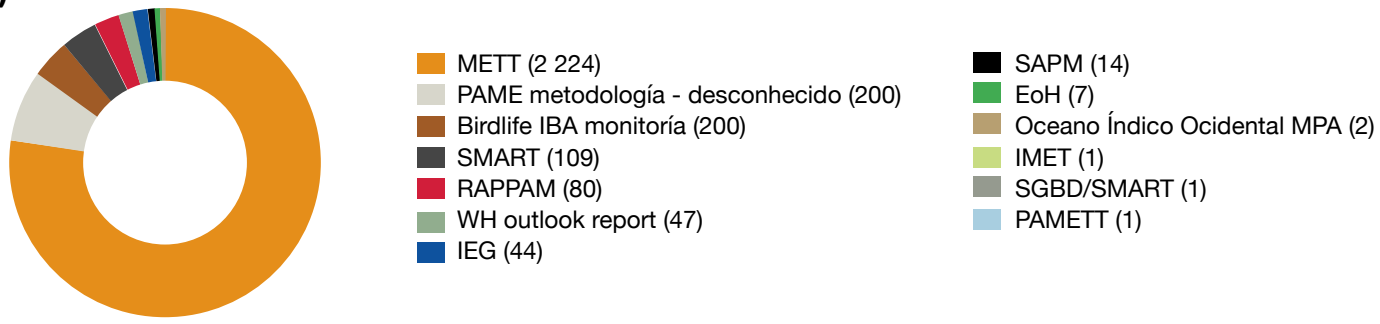

Source: Campese \& Sulle (2019, p. 44).

Figura 10.6 Distribuição das avaliações PAME inventariadas por país

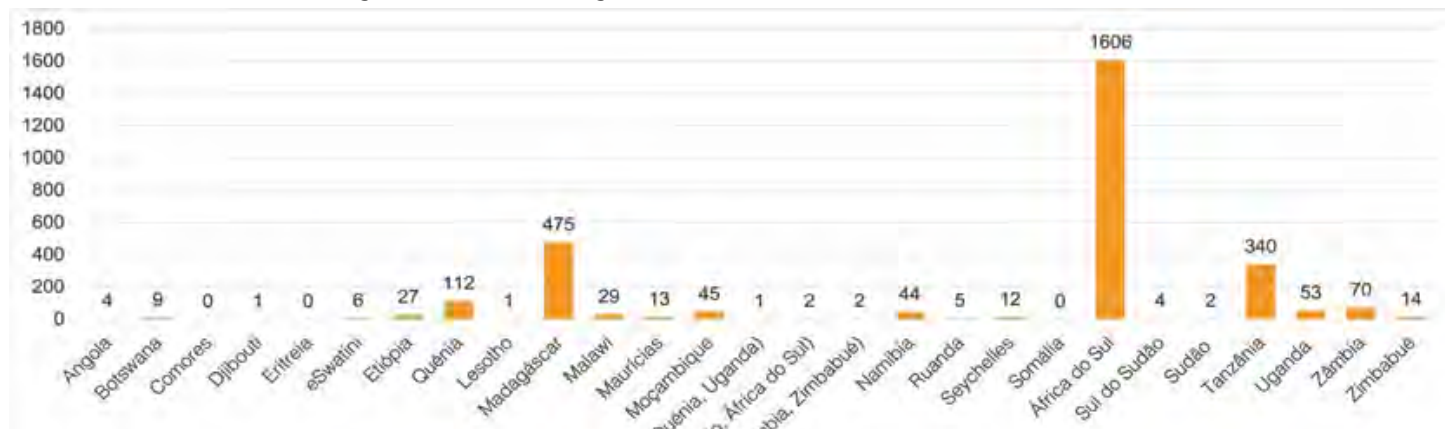


Um total de 2,686 avaliações da eficácia da gestão foram inventariadas na análise da PAME por Campese e Sulle (2019). Oitenta destas avaliações fizeram parte das avaliações RAPPAM a nível do sistema. As avaliações METT, incluindo as versões adaptadas ao país da METT, compreendem a grande maioria - 2.035 (mais de 75\%) - das avaliações PAME inventariadas (Figura 10.5).

As avaliações PAME têm sido frequentemente repetidas nos mesmos locais, em parte porque muitos doadores, incluindo o GEF e o Banco Mundial, requerem múltiplas avaliações ao longo do tempo como condição do seu financiamento. As avaliações METT, em particular, têm sido repetidas em muitos sítios e, em anos mais recentes, têm sido concluídas anualmente ou bianualmente em áreas protegidas governadas pelo Estado em África do Sul, Madagáscar, e Zâmbia. Os Relatórios de Perspectivas do Património Mundial foram concluídos em 24 sítios em 2014 e repetidos em 2017.

A informação sobre tipos de governação estava disponível para 2.046 das avaliações PAME. Mais de $95 \%$ foram conduzidos em áreas protegidas governadas pelo governo, seguidos pela governação comunitária (2\%), governação privada (2\%) e governação partilhada (menos de 1\%).

A maioria das avaliações PAME na análise foi em África do Sul (53\%), um país que adoptou o METT a nível nacional para monitorizar a eficácia da gestão e que tem repetidas avaliações para múltiplos sítios. Madagáscar representa 18\% das avaliações e Tanzânia 13\% (ver Figura 10.6). Apenas Comores, Eritreia e Somália não têm quaisquer avaliações informadas.

O número de avaliações PAME concluídas anualmente na região tem vindo a aumentar ao longo do tempo (ver Figura 10.7), com avaliações METT em particular cada vez mais anualmente (ver Figura 10.8).

\subsubsection{Inventário das avaliações combinadas na África Oriental e Austral}

O inventário incluiu uma análise de avaliações sociais e de governação para áreas protegidas, bem como para aquelas metodologias que combinam dois ou mais elementos - isto é, eficácia de gestão, impacto social, e/ou governação - de forma a dificultar a sua colocação numa única categoria. A figura 10.9 mostra as avaliações 'combinadas' inventariadas por metodologia/ferramenta.

Das 31 avaliações na categoria combinada, 20 utilizaram a abordagem de Avaliação de Risco do Forest Stewardship Council (FSC), com cinco sítios utilizando a Lista Verde da UICN (ver secção 9.2). A Lista Verde inclui uma consideração explícita da eficácia da gestão, da governação e da avaliação social. As Avaliações de Risco FSC, embora não sejam normalmente citadas entre as avaliações das áreas protegidas e de conservação, foram incluídas no inventário porque a Norma de Gestão Florestal FSC-US inclui questões sobre gestão florestal e governação, bem como alguns aspectos de impacto social, e estas avaliações têm sido relativamente amplamente realizadas em florestas de conservação na região. Isto inclui 17 reservas florestais de aldeias na Tanzânia, avaliadas sob um certificado FSC de grupo com a Iniciativa de Conservação e Desenvolvimento do Mpingo (MCDI, 2019).

\subsection{Resultados das avaliações PAME na África Oriental e Austral}

Embora tenha havido muitas avaliações PAME realizadas em toda a África Oriental e Austral (ver secção 10.8), não houve nenhuma tentativa recente e abrangente a nível regional para compilar e analisar os resultados destas avaliações. A última meta-análise global que incluiu uma análise regional para África foi conduzida em 2010 (Leverington et al., 2010). Nessa análise, foi registado um total de pouco mais de 960 avaliações de África, e foram analisados dados de 644 sítios, utilizando a avaliação mais recente disponível para cada área protegida. A pontuação global da eficácia média (média de todos os indicadores individuais) foi de $49 \%$, que foi inferior à média mundial (53\%) e inferior a qualquer outra região. Cerca de $22 \%$ das avaliações pontuaram no terço inferior da escala (claramente inaceitável), enquanto apenas $17 \%$ pontuaram no terço superior (boa gestão) (Leverington et al., 2010).

Para sítios naturais e mistos (tanto naturais como culturais) do Património Mundial, o World Heritage Outlook da UICN avalia 14 aspectos diferentes de protecção e gestão, incluindo quadro legislativo, sistema de gestão, relação com a população local, monitorização, limites do sítio, programas educativos, etc., seguido de uma avaliação global da protecção e eficácia da gestão de cada sítio. De acordo com a avaliação mais recente de 2017 (Osipova et al., 2017), as perspectivas de conservação dos sítios naturais e mistos do Património Mundial na África Oriental e Austral, ou são "boas" ou "boas com algumas preocupações" para $71 \%$ dos sítios, enquanto $21 \%$ foram avaliadas como "preocupações significativas" e $8 \%$ foram consideradas "críticas". Por exemplo, em comparação com a avaliação anterior em 2014, os resultados para Tsingy de Bemaraha Strict Nature Reserve em Madagáscar diminuíram de 'bom' para 'bom com algumas preocupações', enquanto o Parque Nacional do Serengeti na Tanzânia melhorou de 'Preocupação significativa' para 'bom com algumas preocupações'. As perspectivas de conservação de todos os outros sítios da região permaneceram as mesmas (Osipova et al. 2017). Metade dos sítios naturais e mistos do Património Mundial na África Oriental e Austral foram avaliados como tendo uma protecção e gestão "maioritariamente eficaz" ou "altamente eficaz", enquanto $29 \%$ foram avaliados como "alguma preocupação" e $21 \%$ como "séria preocupação". As classificações individuais para as Perspectivas de Conservação globais de cada um dos sítios naturais/misturados são dadas no Quadro 4.2.

Uma análise da eficácia da gestão para a África Oriental, realizada através do programa BIOPAMA em 2017, utilizou 25 indicadores principais, tal como definidos no relatório Leverington et al. (2014), representando todos os elementos do ciclo de gestão das áreas protegidas (BIOPAMA, inédito). Os resultados mostraram que $8 \%$ das áreas protegidas avaliadas têm um bom nível de gestão, enquanto que $34 \%$ têm uma gestão básica em vigor (ver Figura 10.10). Quase metade $(40 \%)$ das áreas protegidas na análise têm uma gestão básica em vigor, mas com grandes deficiências. Dezoito por cento das áreas protegidas foram consideradas como tendo uma gestão inadequada. A Figura 10.11 mostra a localização de algumas das áreas protegidas na análise, bem como o seu nível de eficácia de gestão. 
Figura 10.7 Avaliações da eficácia da gestão inventariada por ano

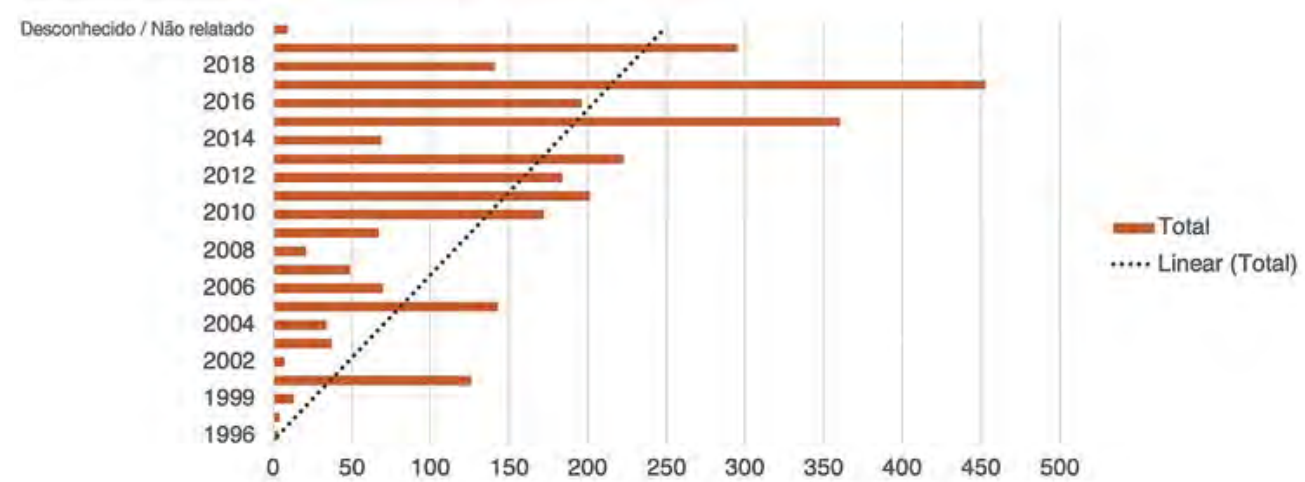

Fonte: Campese \& Sulle (2019, p. 47)

Foi descoberto um pequeno erro na atribuição de avaliações entre 2014 e 2015 desde que Campese \& Sulle (2019) foi publicada. Este número foi corrigido.

Figura 10.8 Avaliações METT inventariadas por ano

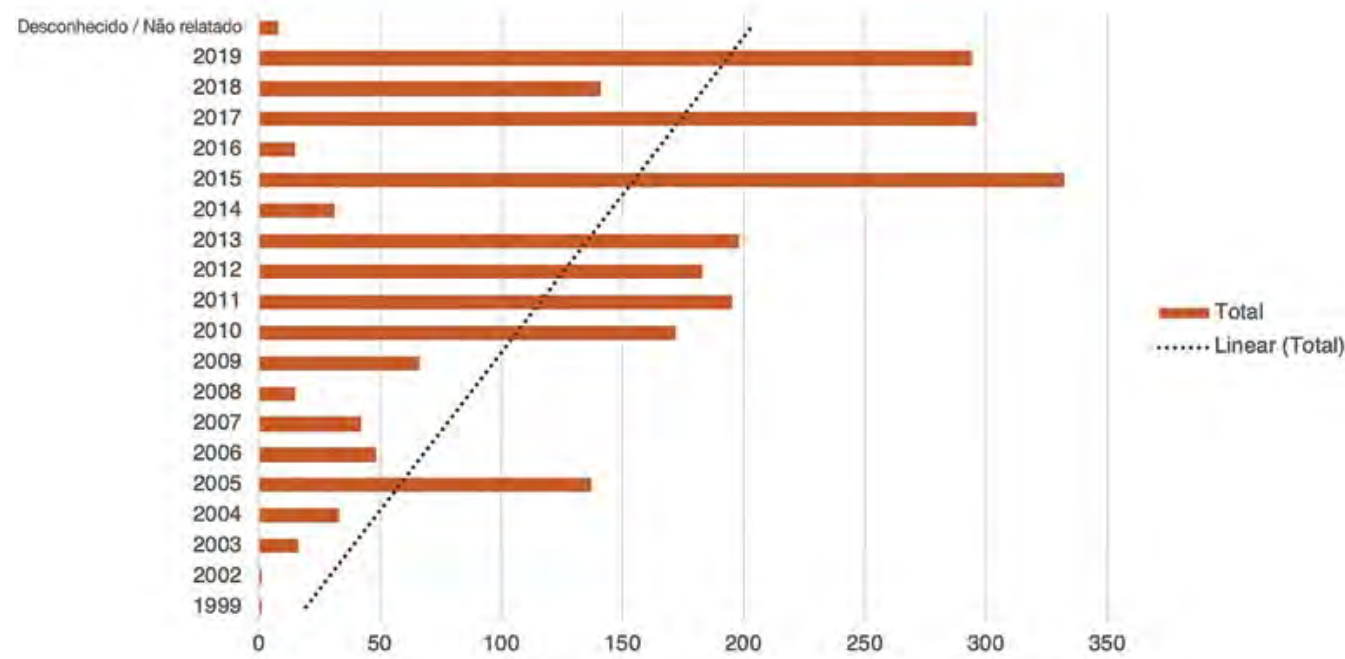

Fonte: Campese \& Sulle (2019, p. 52)

Figura 10.9 Avaliações 'combinadas' inventariadas por metodologia/ferramenta

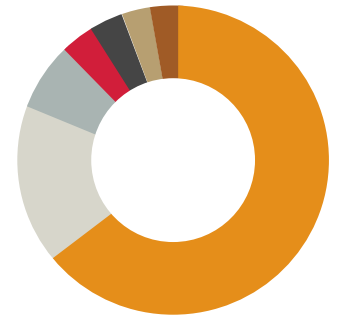

FSC Avaliação de Risco (20)

Lista Verde (5)

Sensemaker (2)

Cartografia Participativa (1)

Mecanismo Whakatane (1)

Fonte: Campese \& Sulle (2019, p. 53).

Figura 10.10 Resultados da eficácia da gestão de áreas protegidas avaliadas na África Oriental

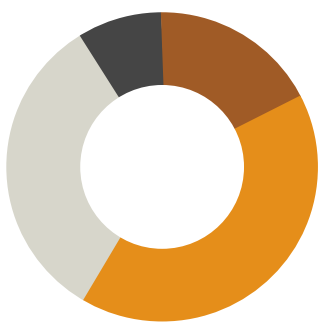

Básico (50-66\%)

Básico - principais deficiências (33.3-50\%)

Inadequado $(<33.3 \%)$

Estável (>66\%)

Nota: As áreas protegidas foram classificadas de acordo com os seus resultados médios de eficácia de gestão (entre parênteses) da avaliação mais recente. Fonte: BIOPAMA (2017). 


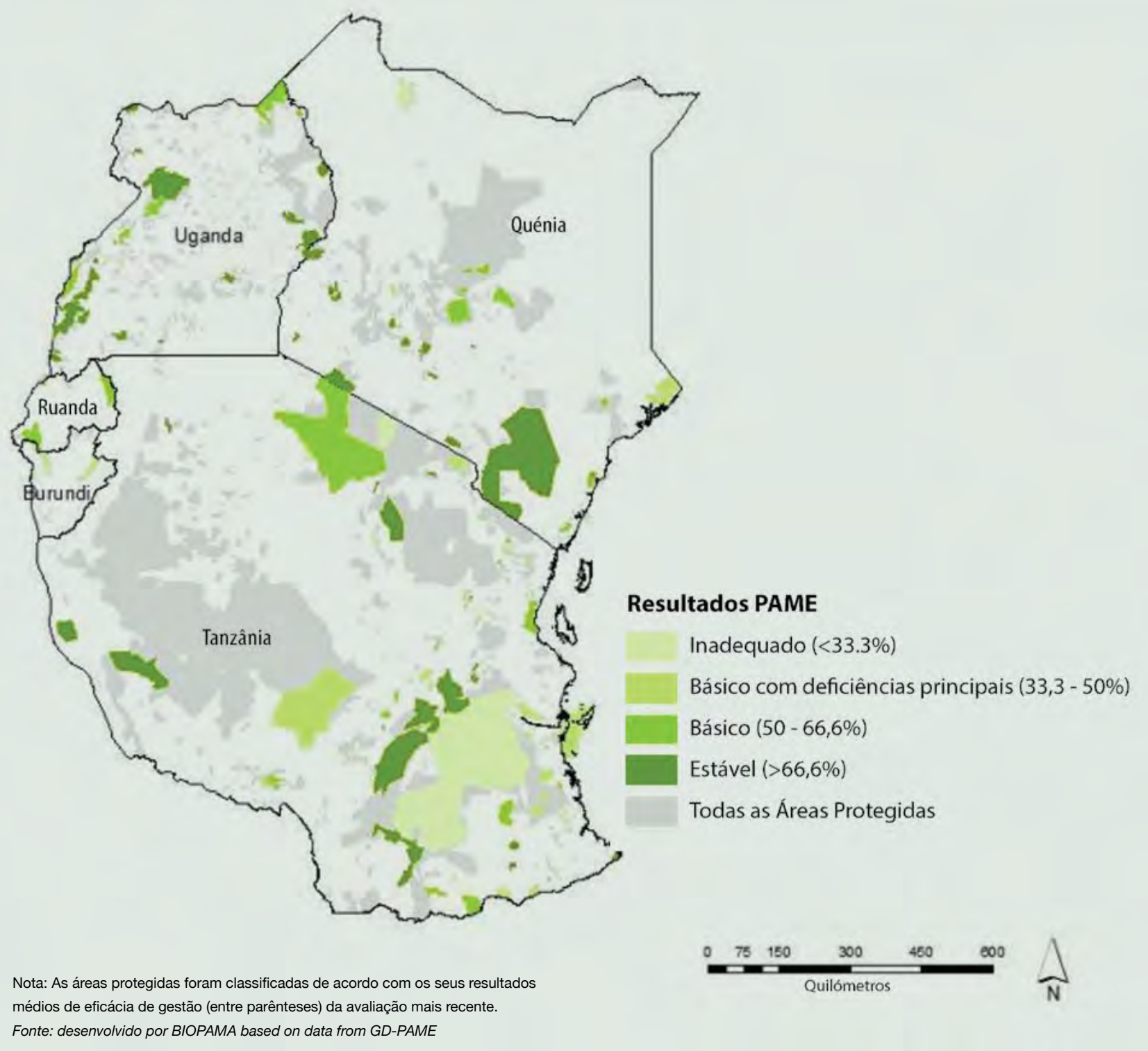

Para saber quais os aspectos da gestão de áreas protegidas que são eficazes, foi realizada uma análise mais aprofundada das avaliações para mostrar as pontuações médias dos indicadores individuais (ver Figura 10.12).

A análise é baseada na avaliação mais recente para cada área protegida. Os indicadores principais com menos de 20 amostras foram retirados da análise.

O planeamento foi o elemento mais forte da gestão em geral, especialmente no que diz respeito a aspectos de estabelecimento de sítios, enquanto que o planeamento da gestão foi um pouco mais fraco. Entre os inputs, os indicadores que reflectiam a disponibilidade de financiamento e equipamento encontravam-se entre os aspectos mais fracos da gestão.
Alguns indicadores revelaram resultados mistos - governação e liderança e o envolvimento das comunidades e partes interessadas foi avaliado como relativamente forte, mas isto não se reflectiu nos efeitos positivos da área protegida nas comunidades locais.

Houve algumas avaliações a nível nacional, por exemplo em 2014, África do Sul realizou uma análise da eficácia da gestão das áreas marinhas protegidas (Chadwick et al., 2014). A análise destacou uma série de melhorias desde a análise anterior em 2009, incluindo programas de monitorização, maior capacidade de aplicação e maior envolvimento das partes interessadas. Notou ainda limitações contínuas nos orçamentos, processos administrativos, regulamentos inadequados, disponibilidade de pessoal especializado em MPA e desenvolvimento de planos estratégicos. 


\subsection{Financiamento e recursos das áreas protegidas $^{111}$}

As áreas protegidas e de conservação desempenham um papel fundamental na protecção da diversidade biológica e dos serviços ecossistémicos dos quais dependem a economia e as populações africanas. Estas áreas necessitam de fontes de financiamento fiáveis e sustentáveis para manter as suas operações diárias de gestão, cumprir os objectivos de conservação, proporcionar experiências de qualidade aos visitantes, quando apropriado, e proporcionar benefícios às comunidades que vivem nas proximidades das áreas de conservação.

As actuais fontes de financiamento são, contudo, inadequadas. Foram concluídos vários estudos para avaliar a lacuna financeira da gestão de áreas protegidas (Credit Suisse et al., 2014; Emerton et al., 2006; Parker et al., 2012). Embora o número exacto possa variar, existe um consenso geral de que o actual montante de financiamento disponível para a protecção e gestão das áreas de conservação é totalmente inadequado. Um relatório de Credit Suisse, WWF, e McKinsey Group em 2014 estimou que são necessários 300-400 mil milhões de dólares anualmente para financiar a protecção global da biodiversidade. Mesmo que os actuais esforços governamentais e filantrópicos de conservação sejam duplicados para cerca de US\$ 100 mil milhões por ano, o relatório teorizado, a conservação global da biodiversidade ainda se depara com uma lacuna de financiamento global de 200-300 mil milhões de dólares por ano (Credit Suisse et al., 2014).

A Iniciativa de Financiamento da Biodiversidade (BIOFIN) do Programa das Nações Unidas para o Desenvolvimento (UNDP) sugere uma estimativa semelhante do défice de financiamento anual global de 150-440 mil milhões de dólares (BIOFIN, 2019).

A estimativa exacta da despesa global em biodiversidade e serviços ecossistémicos é um desafio, devido a lacunas consideráveis e inconsistências na informação e acompanhamento do financiamento da biodiversidade (OCDE, 2019). De acordo com Parker et al. (2012), as despesas globais em biodiversidade e serviços ecossistémicos atingiram 53 mil milhões de dólares por ano em 2010. A OCDE estimou que as despesas em actividades relevantes para a biodiversidade (com base nos dados disponíveis dos orçamentos governamentais) foram de 49 mil milhões de dólares em 2015 (em comparação, os sectores dos combustíveis fósseis e da agricultura receberam 500 mil milhões de dólares de subsídios e apoio governamental por ano (OCDE, 2019). Dos 53 mil milhões de dólares afectados à conservação da biodiversidade, $74 \%$ foram gastos no mundo desenvolvido, apenas 6\% em África (Parker et al., 2012) e 5\% na América Latina.

\section{Figura 10.12 Pontuações médias dos indicadores principais das avaliações mais recentes}

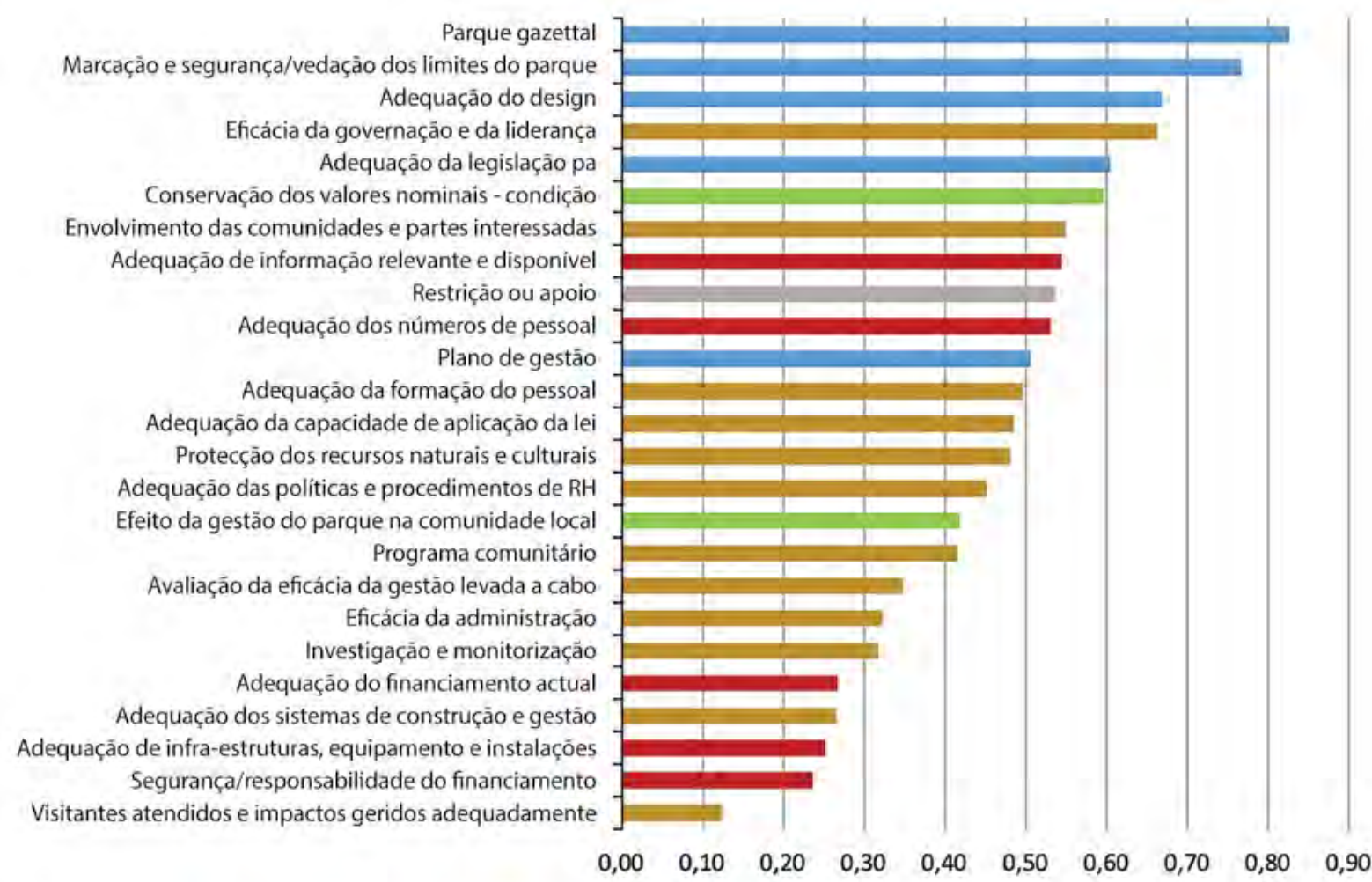

Contexto $\square$ Planeamento $\square$ Entrada $\square$ Processo $\square$ Resultado

Fonte: BIOPAMA (2017).

111 François Barnard e Kathleen Fitzgerald (Capital de Conservação) fizeram contribuições significativas para esta secção. 
Um estudo recente de 2,167 áreas protegidas, representando $23 \%$ do património global de áreas protegidas terrestres, concluiu que menos de $25 \%$ das áreas protegidas têm recursos, pessoal ou orçamento adequados (Coad et al., 2019). Nos países em desenvolvimento, este défice de financiamento das áreas protegidas foi estimado em cerca de 0.2-0.9 mil milhões de dólares por ano em 2005 (CDB, 2005), enquanto que menos de $6 \%$ dos países que apresentaram relatórios à CDB indicaram que tinham recursos adequados para a gestão das áreas protegidas (Watson et al., 2014).

\subsubsection{A lacuna de financiamento na África Oriental e Austral}

As áreas protegidas da África Oriental e Austral enfrentam um desafio significativo de financiamento e de recursos, especialmente as áreas que protegem os mamíferos de grande porte e de largo alcance, tais como rinocerontes, elefantes, leões e cães selvagens. Um estudo revelou que o custo anual da gestão de áreas protegidas que apoiam leões é de aproximadamente 2.000 dólares por $\mathrm{km}^{2}$ em áreas não vedadas e 500 dólares por $\mathrm{km}^{2}$ em áreas vedadas (UICN ESARO, 2020 , p. 16). Os resultados foram posteriormente confirmados por Lindsey et al. (2018), que estimaram que a gestão eficaz de áreas protegidas com leões requer US\$1,000 - 2,000 por km² (UICN ESARO, 2020, p. 16). No entanto, a maioria das áreas protegidas em África são geridas com menos de US $\$ 50$ por km² (Fitzgerald, 2017), o que sugere que estas áreas estão grosseiramente subfinanciadas em aproximadamente 90\% (UICN ESARO, 2020, p. 16).

Embora o financiamento, gestão e requisitos de pessoal associados de áreas protegidas individuais variem de acordo com factores tais como características geográficas locais, forma, clima, contexto cultural, espécies que vivem na área, usos da terra adjacentes e populações, existe consenso de que existe uma lacuna de financiamento significativa em toda a África Oriental e Austral.

Um estudo de 2019 avaliou os custos de gestão, receitas e subsídios de 282 áreas protegidas estatais com leões e concluiu que o financiamento disponível apenas satisfazia $10 \%$ a $20 \%$ das necessidades de gestão. No total, a lacuna de financiamento destas áreas protegidas foi estimada em aproximadamente 1,5 mil milhões de dólares por ano (UICN ESARO, 2020, p. 16).

Uma análise dos dados financeiros das áreas protegidas em 15 países da região também mostrou que 12 destes países enfrentam lacunas de financiamento significativas (ver Figura 10.13). Embora a África Oriental e Austral tenham geralmente lacunas de financiamento semelhantes (56\% e 64\%), alguns países individuais, tais como África do Sul, Quénia e Ruanda (ver Caixa 10.2), parecem ser mais bem financiados, sugerindo que os países com legislação facilitadora (tais como as políticas de propriedade da vida selvagem de África do Sul) e turismo baseado na natureza bem desenvolvido são capazes de contribuir mais para o financiamento das suas áreas protegidas.

\subsubsection{Fontes actuais de financiamento}

As opções tradicionais de financiamento para as áreas protegidas e de conservação na África Oriental e Austral estão geralmente limitadas ao financiamento governamental, apoio de doadores e financiamento auto-gerado, baseado no mercado, como por exemplo as receitas geradas pelo turismo baseado na natureza. Embora os países, as áreas protegidas e as suas necessidades de financiamento associadas sejam diferentes, existem muito poucas áreas protegidas capazes de gerar receitas suficientes através de meios internos, tornando a maioria dependente de alguma forma de apoio dos doadores ou do governo. Estas fontes externas de financiamento, no entanto, continuam a ser inadequadas.

\section{Financiamento externo}

- Apoio governamental: Globalmente, aproximadamente metade das despesas para a biodiversidade são cobertas por financiamento do governo nacional do país anfitrião (Parker et al., 2012). Na África Oriental e Austral, todas as agências de áreas protegidas recebem algum nível de financiamento dos seus governos nacionais. Por exemplo, em Quénia, 47\% do orçamento do Quénia Wildlife Service 2015 foi fornecido pelo Governo de Quénia (Quénia Wildlife Service, 2015). Contudo, os governos enfrentam frequentemente necessidades concorrentes em termos de infra-estruturas, cuidados de saúde, educação e segurança alimentar, desviando assim o financiamento da conservação para estas necessidades sociais. A diversificação das receitas, ao mesmo tempo que aumenta as receitas provenientes dos meios de auto-geração, é por isso fundamental para assegurar a sustentabilidade a longo prazo do financiamento e gestão das áreas protegidas. Do mesmo modo, o investimento na gestão de áreas protegidas é também necessário para assegurar a existência das infra-estruturas necessárias e a segurança financeira da vida selvagem ou do produto baseado na natureza.

- Apoio dos doadores e gestão colaborativa: De acordo com o estudo de Emerton et al. (2006), as subvenções externas, doações e apoio filantrópico, juntamente com o apoio governamental, continuam a ser uma das principais fontes de financiamento para a conservação e gestão de áreas protegidas na África Oriental e Austral. Em 2018, por exemplo, mais de três quartos das despesas operacionais e de capital de uma organização queniana - Northern Rangelands Trust - que apoia 30 conservas comunitárias, foram cobertos pelo apoio de doadores (The Northern Rangelands Trust, 2018). Em contrapartida, em África do Sul, $80 \%$ das receitas dos parques nacionais de África do Suln são auto-financiadas e provêm do turismo.

As organizações locais e internacionais de conservação também desempenham um papel importante no apoio, financiamento e recursos das áreas protegidas de África. Por exemplo, a Sociedade Zoológica de Frankfurt (FZS), em parceria com o Departamento de Parques Nacionais e Vida Selvagem da Zâmbia, tem apoiado a conservação no Parque Nacional de North Luangwa e GMAs circundantes há mais de 30 anos (FZS, 2019). Existem vários modelos diferentes de apoio não governamental à gestão de áreas protegidas (ver secção 11.1). Dados financeiros de 15 países da África Oriental e Austral mostram que o apoio dos doadores representa mais de $50 \%$ do financiamento (Lindsey et al., 2018).

Dada a sua compatibilidade com a conservação como uso da terra, o turismo baseado na natureza é frequentemente a principal (e em muitos casos a única) fonte de rendimento gerado pelas áreas protegidas. O turismo baseado na natureza refere-se ao turismo em 
Figura 10.13 Lacuna de financiamento e recursos financeiros disponíveis em 15 países da África Oriental e Austral
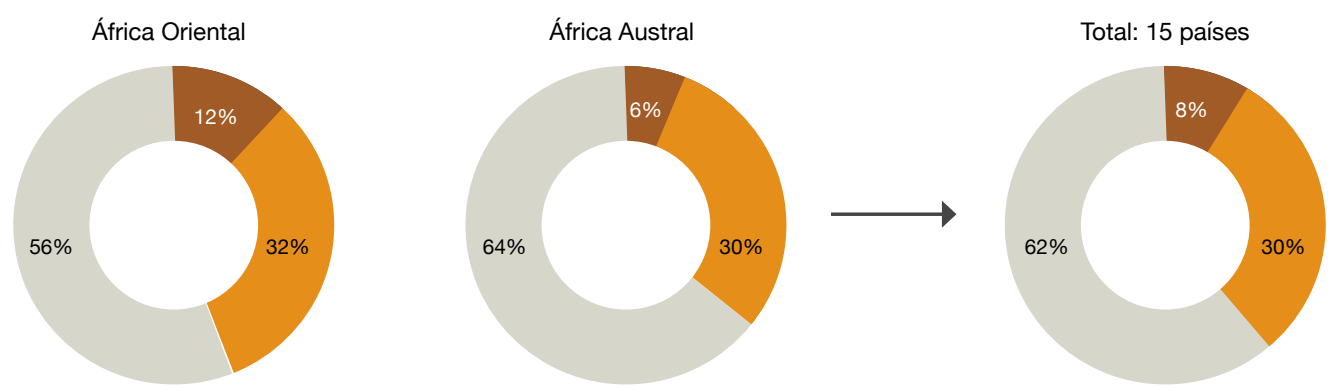

Fonte: UICN ESARO (2020, fig. 5, p. 16).

Figura 10.14 Divisão das receitas geradas internamente em sete países: Eswatini, Etiópia, Quénia, Namíbia, África do Sul, Tanzânia e Uganda
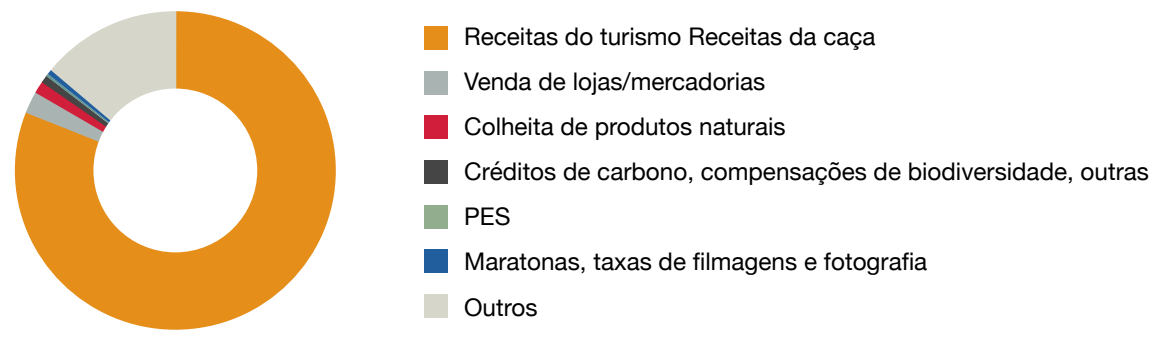

Fonte: Desenvolvido por Conservation Capital (2019) ${ }^{112}$

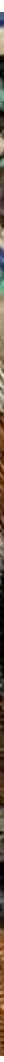

112 Este gráfico foi desenvolvido pela Conservation Capital utilizando as seguintes fontes de dados: Relatórios financeiros e anuais do Quénia Wildlife Service, Parques Nacionais da Tanzânia, Parques Nacionais de África do Sul, Comissão Fiduciária Nacional de Eswatini, Autoridade de Conservação da Vida Selvagem da Etiópia, Autoridade da Vida Selvagem do Uganda e Associação Namíbia de Gestão de Recursos Naturais Baseada na Comunidade. A categoria "Outros" inclui quando especificado: aluguer de equipamento e instalações, juros e comissões recebidas, multas de parque, taxas de garagem e de trabalho, taxas de resgate, investigação e outros rendimentos. 


\section{Caixa 10.2 A robusta economia turística do Ruanda}

Ruanda tem um mercado de viagens de lazer forte e crescente, com a maioria dos seus 1,4 milhões de visitantes provenientes dos países vizinhos (43\% vieram da Comunidade da África Oriental (EAC) e 45\% de outras partes de África) (RDB, 2017), e 80.000 visitantes vindos do estrangeiro (mais notadamente da Europa e da Índia).

O turismo de negócios e de conferências está a tornar-se cada vez mais importante e a gerar a maior quota de receitas (RDB, 2017). Por exemplo, entre as chegadas por via aérea (excluindo trânsito, residentes de regresso e visita de amigos e familiares), mais de 50\% vieram para negócios e conferências, com as férias a representar 35\% (Instituto Nacional de Estatística do Ruanda, 2017).

O turismo é a principal fonte de divisas estrangeiras do Ruanda e é impulsionado principalmente pelo ecoturismo, que tem sido uma prioridade do Governo do Ruanda ao reconhecer os benefícios sociais e económicos que o turismo proporciona. As receitas totais das viagens de lazer aumentaram de US\$390 milhões em 2016 para US $\$ 438$ milhões em 2017, representando $14 \%$ do produto interno bruto (PIB) do país (KNOEMA, 2018).

O turismo no Ruanda suporta 98,000 empregados directos (ou $5 \%$ do total de empregos fora da exploração agrícola), com um total (directo e indirecto) emprego de 250.000 pessoas (14\% de todos os empregos fora da exploração agrícola). As visitas aos Parques Nacionais aumentaram em 54\% desde 2012, de 61,000 para quase 94,000 visitas em 2017). O aumento resultou num aumento significativo das receitas - 18,6 milhões de dólares em 2017, um aumento de quase $50 \%$ a partir de 2012 (UICN ESARO, 2020, p. 28).

A maioria das receitas do ecoturismo do Ruanda é gerada através de licenças de caminhada de gorilas, que actualmente custam 1.500 dólares por licença. O Ruanda tem também o modelo mais elevado de partilha de receitas comunitárias em África, fornecendo $10 \%$ de todas as receitas do parque às comunidades e mais $5 \%$ a um fundo de Conflito Homem - Vida Selvagem (HWC) para as comunidades. Dada a dependência excessiva das receitas dos gorilas de montanha, que geraram 18,3 milhões de dólares em 2017 (RDB, 2017), o Ruanda começou a alargar e diversificar o seu turismo baseado na natureza através do desenvolvimento e atracção de investimentos para as suas outras áreas protegidas, tais como o Parque Nacional de Akagera na parte oriental do país, que oferece um produto turístico diferente, uma paisagem de savana. Ao diversificar o produto, o governo pretende manter as pessoas no país por mais tempo, aumentando assim a geração de receitas (RDB, com. pess., 2019). O Parque Nacional de Akagera é co-gerido com Parques Africanos, uma organização sem fins lucrativos com sede em África do Sul (ver secção 11.1).

\section{Contribuído por Conservation Capital.}


que o principal objectivo é ver ou desfrutar do ambiente natural, que inclui, entre outras actividades, caminhadas, observação de aves, ou condução de animais selvagens. Uma análise das sete autoridades de áreas protegidas em Eswatini, Etiópia, Quénia, Namíbia, Tanzânia, África do Sul e Uganda (totalizando mais de 240 áreas protegidas e 40 milhões de hectares sob gestão), mostra que o turismo gera aproximadamente $80 \%$ de todas as receitas geradas internamente (ver Figura 10.14).

Existe uma oportunidade significativa em vários países da África Oriental e Austral de aumentar as receitas do turismo existente e de desenvolver novas formas de geração de receitas através do turismo baseado na vida selvagem.

Outras tendências chave no financiamento de áreas protegidas na África Oriental e Austral são delineadas abaixo.

- Existem diferenças significativas entre as áreas protegidas e os países em termos de receitas. Por exemplo, de 14 parques na Tanzânia, mais de 75\% das receitas em 2012/2013 foram geradas por apenas dois parques, o Monte Kilimanjaro (42\%) e os Parques Nacionais de Serengeti (33\%). No Ruanda, o Parque Nacional dos Vulcões representa $38 \%$ de todas as visitas e gera mais de $90 \%$ de todas as receitas (RDB, 2017).

- As despesas e retenção de receitas são um aspecto chave para assegurar uma gestão eficaz da conservação. Planos de negócios para áreas protegidas (individuais e de sistema) ajudam a garantir que qualquer aumento no financiamento é gerido adequadamente, conduzindo a um melhor desempenho da conservação. A maioria das agências de áreas protegidas na região são obrigadas a remeter as suas receitas para o tesouro central e depois solicitar o seu orçamento anual, onde algumas recebem menos do que o que tinha sido gerado. Por conseguinte, mesmo que um parque seja capaz de gerar receitas suficientes para apoiar as suas operações, estes lucros são utilizados para subsidiar parques menos rentáveis. Por exemplo, na Tanzânia, a TANAPA gere 506 áreas protegidas, mas apenas dois Parques Nacionais, Kilimanjaro e Serengeti, geram 74\% das receitas em 2013 (Parques Nacionais da Tanzânia, 2013). Em África do Sul, dos 19 parques nacionais, os parques nacionais de Quadro e Kruger acolheram 77\% de todos os visitantes em 2017-2018 gerando receitas significativas a partir de taxas de conservação e concessão (SANParks, 2018). No Ruanda, o Parque Nacional dos Vulcões representa $38 \%$ de todas as visitas e gera mais de $90 \%$ de todas as receitas para a Junta de Desenvolvimento do Ruanda, o departamento responsável pela gestão das áreas protegidas e da vida selvagem do Ruanda (RDB, 2017).

- Dependência do potencial de geração de receitas da espécie emblemática. A maior parte do financiamento é direccionado para áreas emblemáticas, deixando muitas áreas protegidas efectivamente não funcionais. Por exemplo, a maioria do orçamento do Serviço de Vida Selvagem de Quénia é direccionado para os parques nacionais de Amboseli, Tsavo e Monte Quénia, deixando outros parques subfinanciados e não operacionais devido à escassez de financiamento (BIOPAMA, inédito). No Uganda, 58\% das receitas da Uganda Wildlife Authority foram geradas por licenças para gorilas de montanha em 2015 (UWA, inédito) enquanto que no Ruanda, $76 \%$ dos turistas que visitam o Parque Nacional de Volcans participaram na observação de gorilas, representando US\$15,4 milhões ou $86 \%$ de todas as receitas (UICN ESARO, 2020, p. 27). Embora estas espécies e parques emblemáticos sejam um excelente atractivo para os respectivos países, a viabilidade a longo prazo do sistema de áreas protegidas depende destes locais e espécies, o que apresenta um risco fundamental. Por exemplo, se o Ébola tem impacto numa grande população de macacos da qual depende o rendimento de um país, isto não só tem impacto na espécie como na economia de todo o sistema.

Para além de gerar receitas para áreas protegidas, a indústria do turismo, se concebida de forma apropriada e sustentável, pode ser um dissuasor da caça furtiva e de outras actividades ilegais de extracção de recursos naturais. A nível mundial, o turismo baseado na natureza estava a crescer a 10\% a 12\% por ano em 2004 (Space For Giants et al., 2019). Um estudo anterior (Balmford et al., 2009) mostrou que as visitas a áreas protegidas estavam a crescer em três quartos dos países onde os dados estavam disponíveis.

A África Ocidental e Austral é particularmente adequada para o desenvolvimento do turismo baseado na vida selvagem, dado o seu património natural e cultural único, facilidade de acesso e vida selvagem espectacular. $\mathrm{O}$ uso da terra da região é também compatível com o turismo baseado na vida selvagem: $16.54 \%$ da terra é protegida em toda a África Oriental e Austral (ver secção 4), o que significa que existem 2,1 milhões de $\mathrm{km}^{2}$ de terra com potencial para o turismo baseado na vida selvagem. Isto é mais do que alguns outros grandes destinos turísticos no mundo com paisagens muito diversas, tais como os EUA.

$\mathrm{Na}$ África Oriental e Austral, as viagens e o turismo contribuíram com 9.5\% do PIB (ou 75 mil milhões de dólares) em 2018 (WTTO, 2019). Os gastos turísticos na região representaram 50 mil milhões de dólares, dos quais o lazer foi aproximadamente 35 mil milhões de dólares e os gastos dos visitantes internacionais foram de cerca de 25 mil milhões de dólares (WTTO, 2019).

O turismo na região já desempenha um papel importante na geração de receitas para os países, proporcionando emprego, tanto directa como indirectamente, e apoiando serviços sociais vitais.

Alguns destaques do seu papel são mencionados abaixo:

- Na África do Sul, os Parques Nacionais acolheram mais de 7 milhões de turistas e geraram 109 milhões de dólares em receitas turísticas para o ano que terminou a 31 de Março de 2018 (SANParks, 2017).

- Estima-se que 2,9 milhões visitaram as áreas protegidas de Quénia em 2018 (KNBS, 2019).

- Approximately $46 \%(590,000)$ of international visitors to Tanzania visited a protected area (Spenceley et al., 2017; The World Bank Group, n.d.).

- No ano que terminou em Junho de 2018, houve 305.000 visitantes às áreas protegidas do Uganda, gerando receitas de 28 milhões de dólares para a Uganda Wildlife Authority (UWA, 2018).

- Aproximadamente $80 \%$ dos turistas que compram férias em África vêm para observar a vida selvagem, de acordo com um inquérito a 48 instituições governamentais de 31 países da África Subsaariana e 145 operadores turísticos que vendem viagens a África (OMC, 2014).

- As áreas protegidas de África atraem anualmente cerca de 69 milhões de visitantes recreativos, principalmente turistas internacionais (EC JRC, 2018). 


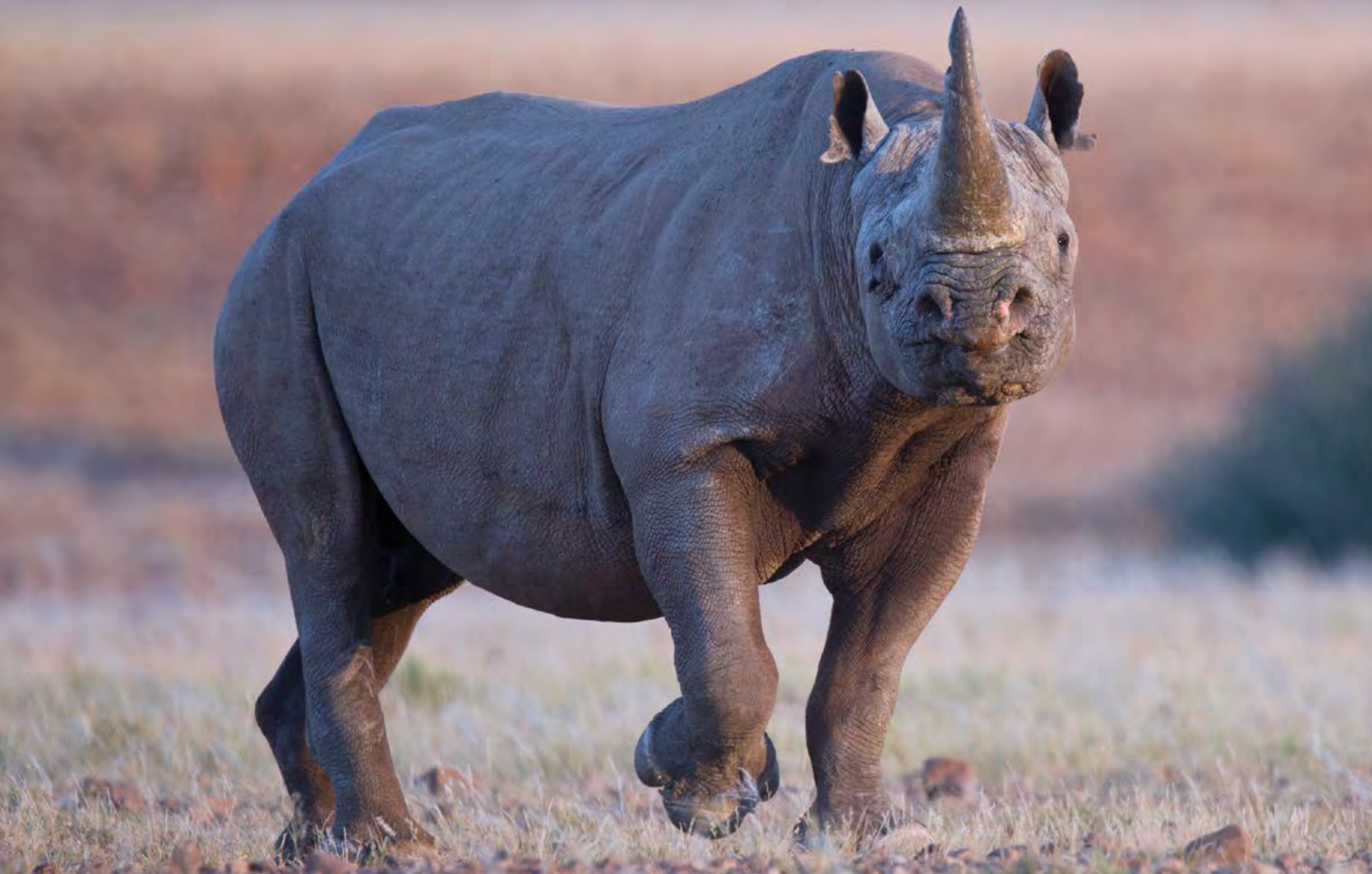

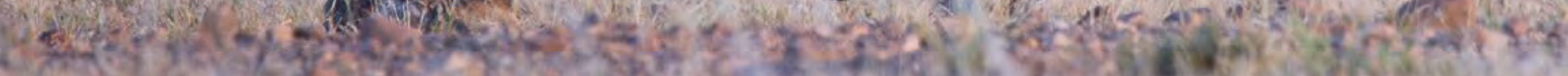

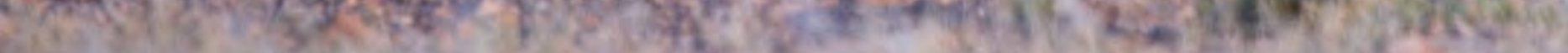


Extrapolando as estatísticas sul-africanas e ugandesas e permitindo uma margem de erro significativa, estima-se que as autoridades das áreas protegidas em toda a região poderiam gerar entre 300 milhões e mil milhões de dólares em receitas anuais através de 30 a 50 milhões de visitas por ano.

Embora o turismo baseado na vida selvagem possa não ser apropriado em vários locais, existem ainda oportunidades significativas na África Oriental e Austral para desenvolver o turismo sustentável de uma forma que aumente as receitas para a gestão das áreas protegidas. $\mathrm{O}$ mesmo ambiente favorável necessário para o turismo baseado na vida selvagem é também necessário para alguns dos mecanismos de financiamento criativos mencionados na secção seguinte. Uma abordagem diversificada é a melhor metodologia para aumentar o financiamento e a sustentabilidade do financiamento das áreas protegidas. Por exemplo, OI Pejeta Conservancy, uma conservação de 90.000 acres em Quénia que serve como um dos mais importantes refúgios de rinocerontes negros na África Oriental, gera receitas provenientes do turismo, gado compatível com a vida selvagem e agricultura zonada (OI Pejeta Conservancy, n.d.). Esta abordagem diversificada permite-lhes resistir à seca e à natureza cíclica natural das visitas turísticas. Embora estes usos do solo possam não ser permitidos em todas as áreas protegidas, mostra a importância e o potencial de uma abordagem diversificada.

\subsubsection{Fontes de financiamento novas e emergentes para as áreas protegidas}

Há um amplo reconhecimento de que o financiamento dos doadores não pode e não será capaz de preencher a lacuna de financiamento das áreas protegidas devido à natureza instável do financiamento dos doadores e aos desafios concorrentes dos países de acolhimento e das prioridades dos doadores. Foram desenvolvidos vários mecanismos de financiamento inovadores a nível mundial, tais como:

- Trocas de dívida por natureza. A troca da dívida pela natureza é um acordo que reduz o stock ou serviço da dívida de um país em desenvolvimento em troca de um compromisso de proteger a natureza do governo devedor. Trata-se de transacções voluntárias em que o(s) doador(es) cancela(m) parte ou a totalidade da dívida pertencente ao governo de um país em desenvolvimento. Em troca, o governo devedor compromete-se a investir as poupanças acumuladas na conservação da biodiversidade, mitigação do clima e conservação da paisagem. Uma delas é a Blue Bond das Seychelles (The World Bank Group, 2018), Seychelles Blue Bond (The World Bank Group, 2018).

- Incentivos fiscais, onde os proprietários de terras recebem uma dedução fiscal pelo seu compromisso de conservação ao declararem reservas naturais em terras privadas, como na África do Sul (Swart, 2019), ver Caixa 10.3.

- As compensações de biodiversidade compensam os impactos líquidos de um projecto de desenvolvimento depois de terem sido implementadas outras medidas de mitigação. As contrapartidas devem visar a não perda líquida e, de preferência, um ganho líquido de biodiversidade. As compensações podem, por exemplo, proporcionar benefícios de biodiversidade (por exemplo, reflorestação) através de uma transacção, em que os vendedores compensatórios (por exemplo, uma ONG de conservação ou governo) vendem compensações a promotores (por exemplo, uma empresa mineira ou promotor imobiliário) que procuram compensar a perda líquida de biodiversidade resultante das suas actividades (por exemplo, mineração).

- Programas de compensação de carbono, como o Projecto Kasigau REDD+ da Wildlife Works em Quénia (Wildlife Works, n.d.). Embora as compensações de carbono possam gerar financiamento para a conservação, só o podem fazer se houver um comprador disposto a compensar as suas emissões de carbono através da compra de créditos de carbono de uma área protegida ou projecto de conservação. As leis do carbono podem ultrapassar este obstáculo obrigando os poluidores a comprar créditos de carbono.

- Conservation Trust Funds, como no Uganda, o Fundo Fiduciário de Conservação da Biodiversidade (Uganda Biodiversity Fund, n.d.). Os Fundos Fiduciários de Conservação, por vezes denominados fundos ambientais, são definidos como "instituições privadas, legalmente independentes, que fornecem financiamento sustentável para a conservação da biodiversidade e muitas vezes financiam parte dos custos de gestão a longo prazo do sistema de áreas protegidas (PA) de um país" (CFA, 2008, p. 1) ou de uma área protegida específica.

- Títulos de impacto de espécies, tais como o Rhino Impact Bond (UNDP Ecosystems \& Biodiversity, 2018).

- Pagamento por Serviços Ecossistémicos, tais como o projecto PSA Kilombero Plantation Limited (Athanas, 2018).

- Os mecanismos de financiamento baseados em resultados são instrumentos de financiamento inovadores que atraem capital de investimento para abordar questões tradicionalmente financiadas pelo sector público. Títulos de espécies ou títulos de áreas protegidas são um exemplo de tais mecanismos. São instrumentos de investimento com uma maturidade definida, cujo objectivo é fazer crescer uma amostra da população de uma espécie seleccionada em sítios-chave. Os investidores na obrigação recebem um retorno financeiro apenas após a conclusão do objectivo, sendo esse retorno financiado pelos pagadores dos resultados.

- Títulos verdes podem ser utilizadas para financiar uma vasta gama de projectos, que incluem energia renovável, eficiência energética, gestão sustentável de resíduos, uso sustentável do solo, conservação da biodiversidade, transporte limpo, e água limpa (DuPont et al., 2016). Contudo, os títulos verdes ainda não foram utilizados para financiar a conservação em escala. Em 2017 , estimava-se que apenas $2 \%$ das receitas das obrigações se destinavam à conservação da terra e $4 \%$ à conservação da biodiversidade.

- Títulos azuis. Quando o governo de um país se compromete a proteger parte das suas zonas costeiras oceânicas próximas e se envolve em trabalhos de conservação (por exemplo, melhorar a gestão das pescas e reduzir a poluição), o custo de tal transição é frequentemente elevado, especialmente para os Pequenos Estados Insulares. As obrigações azuis ajudam a financiar esta transição: um governo emite uma obrigação, muitas vezes com a assistência/garantia de uma ONG e/ou de uma agência como o Banco Mundial, levando a taxas de juro potencialmente mais baixas e a períodos de reembolso mais longos. Uma parte dessas poupanças financia as novas áreas marinhas protegidas e as actividades de conservação com as quais o país se comprometeu. 
- O Financiamento de Projectos de Permanência utiliza uma técnica de financiamento de projectos para facilitar o financiamento total e antecipado de projectos ou áreas de conservação de grande escala, reunindo os financiadores num único fecho. Exemplos de tais acordos incluem um acordo de 57 milhões de dólares para proteger 2 milhões de hectares na Costa Rica e um projecto de 215 milhões de dólares para conservar 60 milhões de hectares da Amazónia brasileira (Seol, 2016). Ao abordar de forma fragmentada ou insuficiente o financiamento inicial, assegura que as intervenções de conservação sejam devidamente planeadas e permanentes e totalmente financiadas. Para serem bem sucedidos, estes projectos necessitam de empenho político, uma forte estratégia de investimento e planos financeiros rigorosos, e colaboração entre governos, ONG, e financiadores públicos e privados.

- As lotarias são populares na maioria dos países e podem gerar rendimentos substanciais, muitas vezes para fins socialmente benéficos, como a conservação da natureza (WWF, 2009). Por exemplo, na África do Sul, a Comissão Nacional de Lotarias distribui fundos a uma série de causas, incluindo instituições de caridade ambiental (NLCSA, 2019).

- Marcas. The Lion's Share (2020) é uma iniciativa financeira de conservação lançada em Setembro de 2018, onde é cobrada uma pequena taxa sobre a utilização de animais em campanhas publicitárias e distribuída a ONG de conservação através do fundo The Lion's Share, com co-financiamento do UNDP. The Lion's Share visa angariar mais de 100 milhões de dólares por ano. Exemplos de empresas privadas que aderiram incluem a Mars Inc, Nielsen, International Airline Group, JCDecaux, The Economist e Batten, Barton, Durstine \& Osborn. Na África Oriental e Austral, a Lion's Share está a financiar um Estudo de Economia do Elefante Africano para catalisar o investimento governamental na conservação do elefante e na promoção da economia baseada na natureza. Em Moçambique, a actualização do sistema de comunicação rádio digital da Reserva Nacional do Niassa fo também concluída utilizando fundos da Lion's Share.

- Outros instrumentos financeiros: BIOFIN trabalhou com nove países da região para identificar os instrumentos financeiros prioritários de conservação para cada país respectivo (UICN ESARO, 2020, p. 60).

Embora estes modelos de financiamento inovadores existam, ainda não foram adoptados ou utilizados à escala na África Oriental e Austral devido ao limitado apoio técnico, recursos e ambientes favoráveis. Além disso, embora estes modelos tenham potencial para aplicação e replicação em toda a região, fontes de financiamento mais tradicionais e comprovadas, tais como o turismo baseado na natureza, embora amplamente utilizado na África Oriental e Austral, tem ainda de ser desenvolvido em todo o seu potencial. Contudo, a situação agravou-se com a pandemia da COVID-19 que resultou no encerramento da indústria do turismo e, por conseguinte, numa diminuição significativa do financiamento relacionado com a conservação das áreas protegidas cujas principais receitas são baseadas no turismo (ver Caixa 10.4). Em toda a África, os acordos de colaboração estão a tornar-se instrumentos cada vez mais populares para aumentar o apoio financeiro e de capacidade para as áreas protegidas, dado que muitas delas estão gravemente subfinanciadas. Além disso, alguns doadores exigem acordos de colaboração para o financiamento. A gestão colaborativa ocorre quando uma organização sem fins lucrativos ou uma entidade do sector privado se associa a uma autoridade estatal para a vida selvagem, onde a autoridade ou subcontrata aspectos de gestão ou actividades específicas de conservação (por exemplo, monitorização ecológica, educação, envolvimento comunitário, restauração do ecossistema) à organização parceira ou celebra um acordo com o parceiro privado que cobre todo o espectro da gestão. Isto assume cada vez mais a forma de uma parceria público-privada (PPP) (ver secção 11.1 para mais informações).

\subsection{Conclusões}

A frequência das avaliações da eficácia da gestão tem vindo a aumentar em toda a África Oriental e Austral ao longo do tempo. Contudo, há espaço para a expansão da avaliação da eficácia da gestão em mais países da região e em áreas sob governação partilhada ou não estatal (Campese \& Sulle, 2019). Em particular, as avaliações PAME devem ser incluídas como parte do ciclo regular de gestão das áreas protegidas, com o acompanhamento necessário para implementar medidas para melhorar a eficácia da gestão.

METT é a metodologia mais comum utilizada a nível do local e é importante assegurar que seja utilizada de acordo com as melhores práticas (Stolton \& Dudley, 2016). Uma série de avaliações METT são concluídas como parte dos requisitos dos doadores, e muitas vezes não contêm comentários ou "etapas seguintes", o que limita a sua utilidade. No entanto, vários países adaptaram o METT para utilização a nível nacional, particularmente para áreas protegidas pelo Estado. O RAPPAM é a metodologia mais utilizada a nível do sistema e tem também muitas vantagens. A utilização de metodologias integradas que têm em conta a eficácia da gestão, bem como questões de governação e equidade social, poderia ser útil para assegurar que as áreas protegidas e de conservação sejam adequadamente avaliadas em os diferentes aspectos do Objectivo 11 de Aichi, para que se possam fazer melhorias para a biodiversidade e as pessoas.

Além disso, outros métodos, tais como uma nova ferramenta desenvolvida no âmbito do BIOPAMA, a Ferramenta de Eficácia de Gestão Integrada (IMET), foram concebidos para apoiar agências e gestores de áreas protegidas no planeamento, gestão e monitorização a nível do local. O IMET é um software que recolhe e organiza dados e informações sobre gestão de áreas protegidas, com análise estatística interna, fornecendo estimativas baseadas em pontuação da qualidade da gestão, bem como componentes visuais para fornecer um sistema de apoio à decisão. O IMET baseia-se num quadro da UICN para medir a eficácia da gestão de áreas protegidas, e inspirado por outras ferramentas, tais como METT, Melhorar o nosso kit de ferramentas de Património, e outras.

Os requisitos dos doadores resultaram numa maior atenção à questão da eficácia da gestão e num aumento do número de avaliações PAME a serem concluídas. Isto é de saudar, mas é também fundamental assegurar que as avaliações estejam a servir uma função de aprendizagem substantiva, bem como uma gestão melhorada, e não apenas um exercício de preencher caixas. 


\section{Caixa 10.3 O primeiro incentivo fiscal eficaz da África do Sul em matéria de biodiversidade}

A Lei do Imposto sobre o Rendimento da África do Sul ( $N^{\circ} 58$ de 1962) faz referência a um incentivo fiscal específico para a biodiversidade, secção 37D, que visa criar sustentabilidade financeira para áreas protegidas em terras privadas ou comunais, bem como motivar e recompensar o empenho dos proprietários de terras. A secção 37D permite que o valor da terra declarada como Reserva Natural ou Parque Nacional seja deduzido do rendimento tributável, reduzindo o imposto devido por um proprietário de terras. Isto assegura maior liquidez para a gestão da conservação e sustentabilidade económica do sítio. 0 incentivo fiscal é único a nível mundial e uma novidade nacional. Esta história de sucesso do financiamento da biodiversidade foi galardoada com o primeiro prémio especial Pathfinder Award Special Commendation atribuído à Sra. Candice Stevens e ao Governo da África do Sul.

Os dois principais benefícios deste incentivo fiscal específico para a biodiversidade incluem:

1) Apoio à criação de robustas áreas protegidas de propriedade privada e comunitária.

Os requisitos da Lei do Imposto sobre o Rendimento correlacionam-se especificamente com os requisitos da Lei das Áreas Protegidas da África do Sul (NEMPAA №57 de 2003) assegurando que as áreas elegíveis para esta dedução fiscal sejam declaradas áreas protegidas que se orgulham de segurança jurídica, permanência, gestão e intenção a longo prazo.

\section{2) A criação de um instrumento inovador para a} sustentabilidade das paisagens.

A secção 37D cria um benefício financeiro substancial e tangível que ajuda os proprietários de terras a cumprir as responsabilidades de gestão, reforça a motivação dos proprietários sobre a a médio e longo prazo, e facilita a eficiência fiscal essencial para o sucesso sustentado das actividades económicas compatíveis com as áreas protegidas.

\section{Contribuido por Candice Stevens (Wilderness Foundation Africa).}

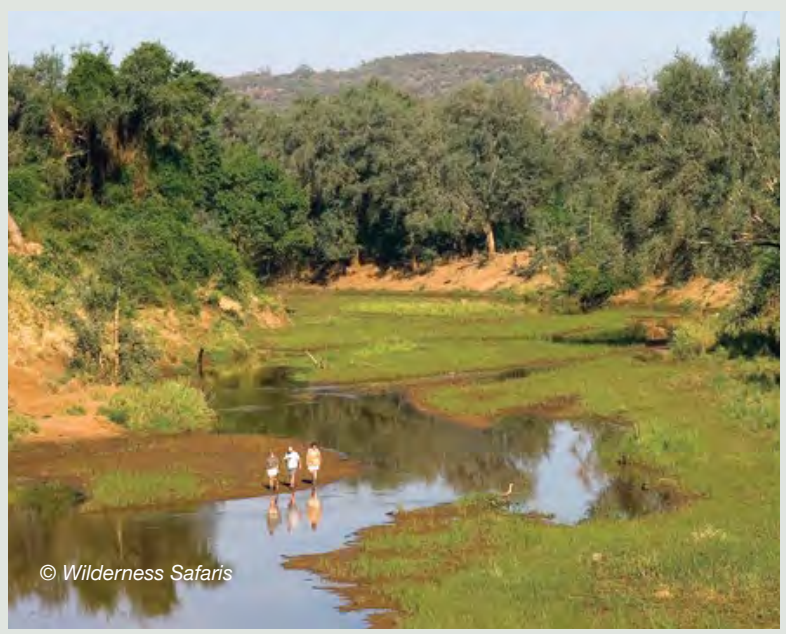

\section{Caixa 10.4 Impacto da pandemia da COVID-19 nas áreas protegidas na África Oriental e Austral}

A pandemia da COVID-19 criou uma crise urgente para a gestão de áreas protegidas em toda a África Oriental e Austral.

A pandemia já resultou numa cascata de impactos imediatos nas áreas protegidas:

- Encerramento de áreas protegidas a pessoas para turismo e recreação;

- Pessoal do parque é obrigado a isolar-se, o que resulta em níveis de pessoal mais baixos;

- Redução das patrulhas de ranger devido à redução do pessoal, levando potencialmente ao aumento de actividades prejudiciais ao ambiente;

- Possíveis impactos directos em algumas ameaças carismáticas espécies, tais como os Grandes Macacos; e

- Suspensão dos programas de gestão e restauração de rotina.

A pandemia está associada a uma crise económica global. medida que esta crise se instala, é provável que os níveis de pobreza aumentem, particularmente na África Subsaariana. Existe uma ameaça de utilização crescente e insustentável dos recursos naturais, bem como a possibilidade de um aumento da caça furtiva comercial. Estas ameaças estão a crescer ao mesmo tempo que os contributos financeiros subjacentes à conservação e gestão de áreas protegidas estão a diminuir drasticamente. É provável que o apoio financeiro seja reduzido a partir de todas as fontes actuais, incluindo os financiadores bilaterais e multilaterais, os doadores privados e os doadores com elevado valor líquido, bem como os quase encerramento completo da indústria do turismo.

Embora possa haver alguns benefícios associados ao encerramento do turismo, tais como a redução da sobrepopulação em ecossistemas delicados, a crise financeira enfrentada pelas áreas protegidas, sob todas as formas de governação, não pode ser sobrestimada. As recomendações delineadas no presente relatório relativamente à diversificação dos fluxos de receitas para a gestão das áreas protegidas são cada vez mais urgentes no contexto desta crise.

Contribuído por Leo Niskanen (UICN, ESARO). 


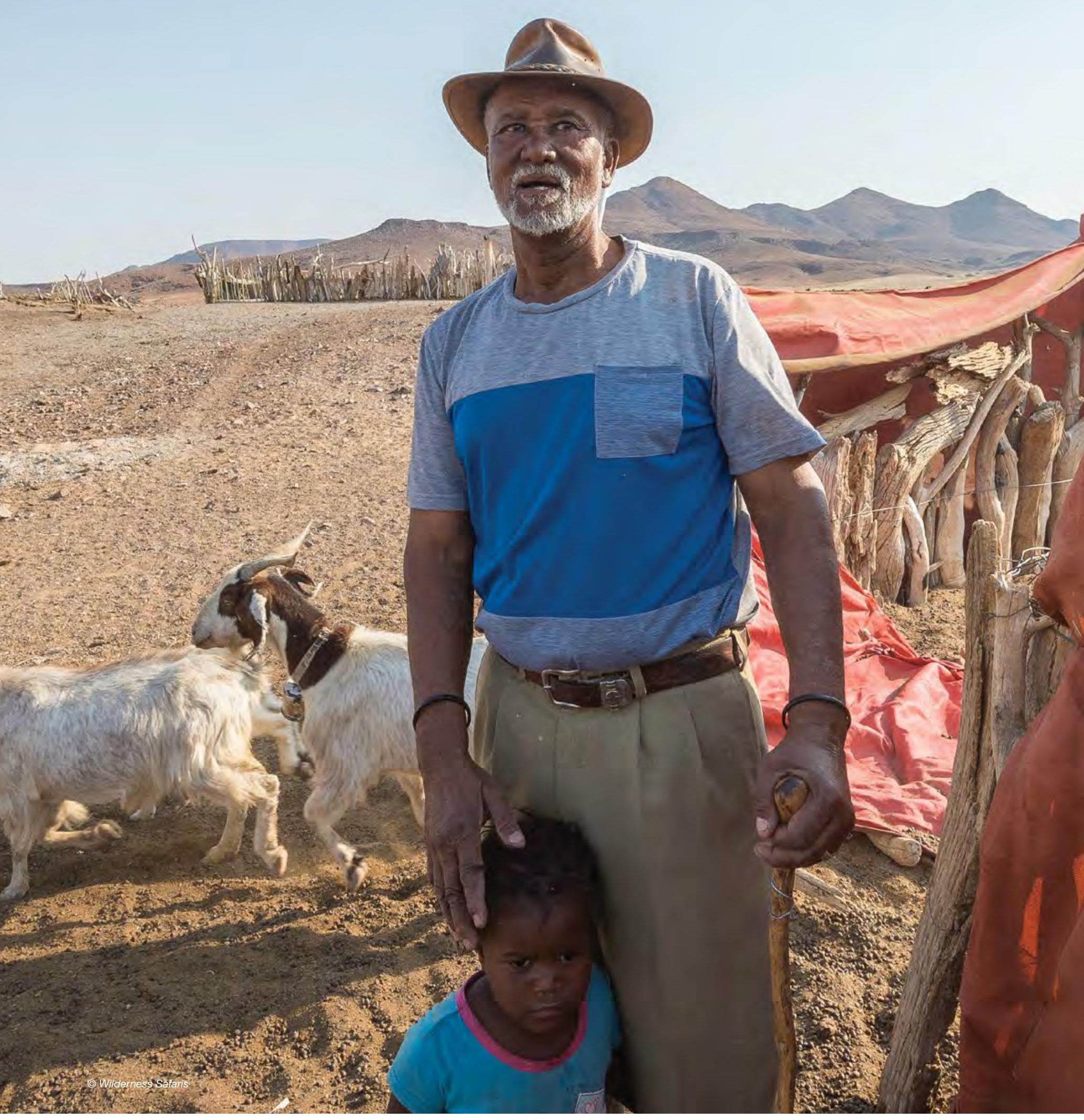




\section{Inovações e experiências regionais}


Tem havido uma série de inovações na região em termos de melhoria da eficácia da gestão, governação e equidade, especialmente à medida que a tecnologia se tem desenvolvido para apoiar este objectivo. Esta secção inclui informação sobre algumas destas inovações.

\subsection{Gestão colaborativa das áreas protegidas}

As áreas protegidas são reconhecidas globalmente como o meio mais eficaz de conservar a biodiversidade e os bens culturais associados, bem como uma forma importante de promover o desenvolvimento rural sustentável. Em toda a África Oriental e Austral, grandes áreas protegidas têm sido reservadas para conservação. Estas áreas protegidas apoiam a biodiversidade de valor global substancial, incluindo a maior abundância global de megafauna (Ripple et al., 2016). Em média, em toda a África subsariana, o financiamento estatal é muito inferior ao mínimo recomendado de 500 a 900 dólares por km2 (Lindsey et al., 2017). Existem financiamentos significativos de doadores para algumas áreas protegidas, mas em muitos casos, a capacidade para gerir eficazmente estes fundos é insuficiente para atingir os objectivos da área protegida (O'Connell et al., 2019).

O estabelecimento de parcerias de gestão em colaboração com organizações não governamentais pode ser um mecanismo importante para superar estes desafios, e tem crescido na sua importância em todo o património da área protegida na África Oriental e Austral. Existem agora muitos exemplos de parcerias de gestão colaborativa para a gestão de áreas protegidas. Surgiu uma variedade de modelos diferentes.

Uma análise recente categorizou-os em modelos distintos (Baghai et al., 2018) e duas categorias: por governação, que diz respeito a quem tem o poder de estabelecer prioridades e estratégias globais (bem como a forma como essas decisões são tomadas); e por gestão, que diz respeito às operações quotidianas e implementação no terreno (Borrini-Feyerabend et al., 2017) (ver Quadro 11.1).

A análise realizada por Baghai et al. consistiu numa série de entrevistas semi-estruturadas e num workshop para desenvolver o enquadramento e compreender o contexto em que cada modelo ocorre, bem como os pontos fortes e fracos de cada um. ${ }^{113}$

Os modelos de gestão delegados foram historicamente encontrados nas áreas protegidas com os recursos mais severamente insuficientes, em situações difíceis (tais como o extremo afastamento ou a presença de instabilidade política), onde a capacidade e os recursos das autoridades estatais responsáveis pela vida selvagem são extremamente baixos, e onde há poucos ou nenhuns rendimentos provenientes do turismo e onde as populações da vida selvagem estão severamente esgotadas ou em perigo de o se tornarem. Tais circunstâncias extremas exigem uma contribuição significativa de recursos e conhecimentos técnicos especializados, pelo que são candidatos mais aptos para uma gestão delegada. Mais recentemente, porém, os Parques Africanos foram delegados autoridade para gerir áreas protegidas de maior perfil, o que sugere a possibilidade de alguns estados estarem cada vez mais dispostos a envolver-se neste modelo de forma mais ampla. Os modelos de co-gestão oferecem uma partilha mais equitativa 8lda responsabilidade de gestão do que os acordos de gestão delegada. Podem permitir aos parceiros capitalizar os seus pontos fortes únicos, combinando a legitimidade política e o conhecimento local do Estado com a inovação, eficiência e especialização do sector não governamental. Uma tal parceria apresenta menos riscos de que a autoridade estatal em matéria de vida selvagem se sinta marginalizada ou dominada. Contudo, a partilha da autoridade de gestão entre duas entidades com estruturas organizacionais, culturas, estilos de gestão e liderança diferentes pode ser propensa a confusão, conflitos e elevados custos de transacção. Em alguns casos, os acordos de co-gestão evoluíram de parcerias de apoio técnico-financeiro que se revelaram insuficientes para alcançar os objectivos dos parceiros. Tal como o modelo delegado, o investimento adicional que vem com modelos de co-gestão leva frequentemente o parceiro não governamental a procurar uma maior autoridade na tomada de decisões, e cuja partilha torna os dois parceiros responsáveis um perante o outro.

As parcerias de apoio técnico-financeiro encontram-se na mais vasta gama de países e contextos. Este modelo tem sido de longe o modelo mais proeminente em toda a África durante muitas décadas, e vários inquiridos indicaram que a mudança para modelos mais descentralizados como a co-gestão e a gestão delegada foi o resultado de uma longa experiência com o modelo de apoio técnico-financeiro e a sua incapacidade, em muitas circunstâncias, de alcançar os resultados desejados. No entanto, continua a ser o modelo mais comum e generalizado, e quando bem implementado nos contextos apropriados, pode ser bastante eficaz.

A falta de autoridade das associações sem fins lucrativos para a tomada de decisões em matéria de governação e gestão que caracteriza estas parcerias é um produto de vários factores. Primeiro, em alguns países (tais como Botswana, Quénia, Namíbia, Tanzânia e África do Sul), existe uma significativa capacidade estatal, financiamento e empenho na gestão de áreas protegidas, e especialmente parques nacionais. Nesses países, o apoio técnico-financeiro faz sentido onde existe um sólido compromisso governamental para a gestão central da área protegida, mas existem algumas ameaças específicas - desafios, ou mesmo oportunidades - que o governo não é capaz de enfrentar sozinho e que os sem fins lucrativos podem apoiar. Em segundo lugar, como revelado por entrevistas, alguns países podem estar relutantes em se envolverem em modelos que envolvem a partilha ou delegação de autoridade devido a sensibilidades políticas e pós-coloniais.

Em terceiro lugar, algumas organizações sem fins lucrativos não dispõem de recursos ou conhecimentos adequados para assumirem uma responsabilidade de gestão significativa. Finalmente, algumas organizações sem fins lucrativos acreditam que o seu papel adequado é apoiar (e não suplantar) o Estado, que é visto como a autoridade de gestão apropriada para as áreas protegidas, mesmo onde a capacidade é baixa.

113 A informação é em grande parte proveniente de Baghai et al. (2018).. 
Quadro 11.1 Modelo de estrutura para parcerias de gestão colaborativa

\begin{tabular}{|c|c|c|}
\hline Modelo & Governação & Gestão \\
\hline Gestão delegada & $\begin{array}{l}\text { Estratégia e supervisão tipicamente } \\
\text { tratadas por uma entidade de propósito } \\
\text { especial criada por ambos os parceiros; } \\
\text { organização não governamental } \\
\text { tipicamente nomeia a gestão do parque }\end{array}$ & Gerido por uma organização não governamental \\
\hline Co-gestão & $\begin{array}{l}\text { Partilhada, em graus variáveis, entre o } \\
\text { Estado e a organização não } \\
\text { governamental (pode ou não incluir a } \\
\text { criação de uma entidade com fins } \\
\text { especiais) }\end{array}$ & $\begin{array}{l}\text { Partilhada, em graus variáveis, entre o Estado e } \\
\text { as organizações sem fins lucrativos, excepto em } \\
\text { alguns casos para a gestão da aplicação da lei } \\
\text { (gerida pelo Estado) e o emprego de pessoal (em } \\
\text { particular pessoal da aplicação da lei), que pode } \\
\text { ser gerida pelo Estado ou independentemente } \\
\text { pelos parceiros }\end{array}$ \\
\hline Co-gestão do projecto & $\begin{array}{l}\text { O Estado lidera a estratégia e supervisão, } \\
\text { com envolvimento e consenso da } \\
\text { organização não governamental em áreas } \\
\text { relacionadas com o projecto; o Comité } \\
\text { Director Conjunto nomeia a liderança do } \\
\text { projecto }\end{array}$ & $\begin{array}{l}\text { O Estado supervisiona a gestão da aplicação da } \\
\text { lei e a gestão de todo o pessoal; partilha a } \\
\text { autoridade com a organização não } \\
\text { governamental para todas as decisões } \\
\text { relacionadas com o projecto e financiadas pelo } \\
\text { projecto }\end{array}$ \\
\hline $\begin{array}{l}\text { Apoio financeiro-técnico } \\
\text { (implementação) }\end{array}$ & O Estado é a autoridade principal & $\begin{array}{l}\text { O Estado é a autoridade principal; a organização } \\
\text { não governamental desempenha papéis } \\
\text { variáveis para apoiar objectivos partilhados, } \\
\text { empregando pessoal e ajudando a implementar } \\
\text { decisões de gestão }\end{array}$ \\
\hline $\begin{array}{l}\text { Apoio financeiro-técnico } \\
\text { (consultoria) }\end{array}$ & O Estado é a autoridade principal & O Estado é a autoridade principal \\
\hline
\end{tabular}

Fonte: Baghai et al. (2018).

Alguns dos modelos de co-gestão na região são:

- Em Etiópia, o Projecto de Conservação das Montanhas dos Fardos da Sociedade Zoológica de Frankfurt (BMCP) foi criado em 2005 para fornecer todos os aspectos de apoio à gestão do Parque Nacional das Montanhas dos Fardos (abrangendo o desenvolvimento do ecoturismo, o alcance comunitário, a utilização sustentável dos recursos naturais, as operações e a gestão ecológica). Em 2007, foi ratificado pelo Presidente da região de Oromia um Plano Geral de Gestão do Parque, com a duração de 10 anos. O FZS-BMCP está actualmente a trabalhar em parceria com as autoridades no sentido de implementar este plano. (Com o novo apoio financeiro do KfW, a FZS actualizou o seu acordo de co-gestão com o governo para melhorar a gestão e governação do Parque. A African Wildlife Foundation celebrou um acordo semelhante para o apoio ao Parque Nacional da Montanha de Simien.

- Em Ruanda, a RDP celebrou um acordo de gestão delegada com Parques Africanos para a gestão do Parque Nacional de Akagera. Desde que o acordo foi celebrado, os Parques Africanos e a RDB reintroduziram a vida selvagem e desenvolveram instalações turísticas comercialmente viáveis. Ruanda espera que o desenvolvimento do Parque Nacional de Akagera ajude Ruanda a diversificar o seu produto turístico apenas do turismo de gorilas e a manter os turistas em Ruanda por mais tempo.

- Em Moçambique, foi estabelecido um acordo integrado de co-gestão após a guerra civil para a gestão da Reserva Nacional do Niassa entre o governo e uma empresa privada moçambicana, representando principalmente um indivíduo de elevado património líquido. Esta parceria, Sociedade para a Gestão e Desenvolvimento da Reserva do Niassa, foi principalmente apoiada pela Fauna \& Flora International e que chegou ao fim em 2012. A partir do final de 2019 , a Wildlife Conservation Society (WCS) estava a tentar celebrar um acordo bilateral de co-gestão para a reserva. Além disso, diferentes parceiros do sector privado e ONG têm acordos de gestão para concessões em toda a reserva. Num outro exemplo, a Carr Foundation assinou um acordo de gestão com o governo moçambicano em 2008 para restaurar e proteger o Parque Nacional da Gorongosa como uma fonte de rendimento turístico para a população local. Dois acordos foram assinados em 2019 com a Fundação Peace Parks para prestar assistência técnica e financeira na Reserva Especial de Maputo para o desenvolvimento turístico e para apoiar o Parque Nacional de Banhine na província de Gaza no combate à caça furtiva (Wright, 2018). Para além disso, a APN tem um acordo delegado sobre o Parque Nacional de Bazaruto

- No Zimbabué, o Parque Nacional Gonarezhou é governado pelo Gonarezhou Conservation Trust, cujos administradores são nomeados pela Autoridade de Gestão dos Parques e da Vida Selvagem do Zimbabué e pelo FZS, representados em partes iguais. Construído com base numa forte relação desenvolvida ao longo de nove anos de apoio do FZS para Gonarezhou, o Trust é directamente responsável pela gestão do Parque por um período de 20 anos e tornou-se plenamente responsável em 2017.

- Em toda a África. African Parks é uma organização sem fins lucrativos de conservação criada em 2000 que assume a responsabilidade total pela reabilitação e gestão a longo prazo dos parques nacionais em parceria com governos e comunidades locais. Actualmente gere 17 parques nacionais e áreas protegidas (dos quais 10 estão na África Oriental e Austral) em 11 países, cobrindo aproximadamente 14 milhões de hectares. 


\section{Caixa 11.1 Construir capacidade para combater à caça furtiva: o caso do Colégio da Vida Selvagem da África Austral}

\begin{abstract}
Como exemplo, o Southern African Wildlife College ${ }^{114}$ identificou uma necessidade prioritária de capacidade para enfrentar a crise da caça furtiva com uma inovação na implantação e gestão canina para fins de combate à caça furtiva. Esta expansão fol fortemente centrada no destacamento não tradicional de cães numa perseguição ou modo táctico, a fim de efectuar uma detenção de caçadores furtivos. Foi criada uma instalação de treino K9 para alojar, seleccionar e treinar cães de serviço e manipuladores de cães.
\end{abstract}

Durante um período de três a quatro anos foram testadas várias técnicas, com a utilização crescente do modelo de matilha de passeio livre, apoiado por um tratador de cães e uma equipa de guarda-florestal anti-caça furtiva. Os cães e os tratadores de cães foram co-treinados em conjunto com os guardas-florestais de asa aérea e anti-caça furtiva, a fim de serem utilizados através de helicópteros e veículos em operações anti-caça furtiva. A utilização de telemetria avançada, rastreio de coleiras e recolha de dados é muito eficaz.
As lições aprendidas, desafios e benefícios incluem:

1. O custo de criação da instalação de formação exigiu um apoio intensivo para a angariação de fundos;

2. A formação conjunta com a SAWC e a SANParks permitiu uma implantação eficiente e a interoperabilidade;

3. Os cães e os tratadores de cães podiam ser intercambiáveis;

4. O bem-estar e a saúde dos animais com foco contínuo era criticamente importante para o sucesso individual e das embalagens;

5. Havia falta de habilidades de treino de K9 na África do Sul, com a maioria das habilidades centradas no treino de cães para o trabalho de detecção; e

6. Dados recolhidos pelos vários sensores de rastreio K9 também representava uma área para mais inovação e investigação

O modelo desenvolvido na SAWC foi adoptado para o desenvolvimento da capacidade do K9 para operações anti-caça furtiva numa área de caça perigosa. O projecto K9 da SAWC recebeu vários prémios pela sua eficácia como agente de mudança de caça em operações de combate à caça furtiva.

Contribuido por Ashwell Glasson (Southern African Wildlife College).
Os governos que celebraram estes acordos de gestão estão a optimizar estrategicamente as relações de parceria. Ao seleccionar parceiros apropriados e capazes, as autoridades das áreas protegidas podem aumentar as receitas das áreas protegidas e do sistema como um todo, alavancando as competências, experiência e capital dos parceiros e misturando as diferentes competências trazidas por cada parceiro. Além disso, isto ajuda a diminuir o risco ao envolver outros parceiros, o que é apelativo para uma série de grandes financiadores bilaterais e multilaterais.

\subsection{Construção de capacidade para as áreas protegidas $\mathrm{e}$ de conservação}

O desenvolvimento de capacidades e o reforço institucional são fundamentais para aumentar a capacidade das autoridades das áreas protegidas em alcançar os seus objectivos (UE, 2015). Existem várias instituições na região com um mandato e foco específico no desenvolvimento de capacidades, incluindo: o Colégio de Gestão da Vida Selvagem Africana (Mweka) na Tanzânia; o Colégio da Vida Selvagem da África Austral na África do Sul (ver Caixa 11.1); a African Leadership University School of Wildlife Conservation no Ruanda; a Universidade de Ciência e Tecnologia da Namíbia, anteriormente conhecida como Politécnica da Namíbia; RCMRD Nairobi; e o Centro de Excelência em Biodiversidade e Gestão de Recursos Naturais no Ruanda, entre outros. Estas instituições estão a inovar e a expandir o seu leque de formação em resposta às necessidades expressas pelos governos e conservação organizações.

\subsection{O papel da tecnologia na gestão de áreas protegidas ${ }^{115}$}

Nos últimos 10 anos, os conservacionistas têm-se concentrado cada vez mais na utilização da tecnologia para resolver os desafios da conservação da vida selvagem. A promessa da tecnologia é a gestão orientada pelos dados, entregue à escala em (quase) tempo real $\mathrm{e}$ com um elevado nível de detalhe nos dados. A adopção de novas tecnologias pode melhorar a consciência situacional em tempo real para melhorar as capacidades de comando e controlo. O ímpeto inicial para tal veio de um requisito de protecção e aplicação, mas o foco está agora a deslocar-se para necessidades mais amplas de gestão de áreas protegidas.

Os gestores de áreas protegidas têm sido tradicionalmente lentos a adoptar a tecnologia. Isto deve-se, em grande parte, ao historial de resultados decepcionantes. A tecnologia adequada para fins comerciais ou de consumo em massa não é muitas vezes suficientemente robusta para as condições ambientais difíceis das áreas protegidas. Além disso, a tecnologia robusta está muitas vezes fora do alcance dos orçamentos disponíveis para os gestores de áreas protegidas. Tecnólogos bem intencionados doaram tecnologia adequada sem planos de manutenção e sustentabilidade a longo prazo, resultando em utilidade de curta duração.

A situação começou a mudar em África nos últimos cinco anos, à medida que os gestores de áreas protegidas avançam como consumidores de tecnologia e que surge um quadro de tecnólogos 
dedicados à missão de conservação da vida selvagem. Actualmente, os gestores fazem as perguntas certas sobre requisitos de capacidade de pessoal, custos de manutenção, planos empresariais a longo prazo, requisitos de conectividade, necessidades de formação e apoio. São melhores a afastar soluções não enraizadas nas realidades dos problemas de gestão de áreas protegidas

Os dados emergentes sobre gestão de áreas protegidas e 'ecossistema' tecnológico incluem ONG de conservação, grandes empresas tecnológicas, filantropos privados e bons empreendedores sociais. Estão a criar soluções baseadas na compreensão dos desafios enfrentados pelos gestores de áreas protegidas, resolvendo questões como a geração dos dados certos com avanços na tecnologia de sensores, entrega atempada de dados através de avanços na tecnologia de redes e análise em plataformas aplicando o mais recente em inteligência artificial e reconhecimento de imagem. O campo da "tecnologia de conservação" está a tornar-se uma realidade (ver Caixa 11.2).

É útil pensar na aplicação da tecnologia em áreas protegidas em termos de um 'quadrante mágico' com maturidade de gestão ao longo do eixo $\mathrm{Y}$, e adopção de tecnologia ao longo do eixo $\mathrm{X}$ (ver Figura 11.1). A maioria das áreas protegidas encontra-se no quadrante inferior esquerdo, com baixa maturidade de gestão e pouca infra-estrutura tecnológica. Por outras palavras, a maioria das áreas precisa de construir capacidade de gestão antes de pensar em aplicar soluções tecnológicas sofisticadas. São necessárias equipas de guardas-florestais bem treinadas e bem equipadas, bem como planos de gestão eficazes e financiamento suficiente para satisfazer essas necessidades operacionais básicas.

A parceria SMART foi pioneira na gestão orientada por dados de áreas protegidas alavancando a tecnologia com o software Spatial Monitoring and Reporting Tool (SMART). ${ }^{116} \mathrm{O}$ objectivo era mover áreas de baixa capacidade com infra-estruturas mínimas para uma gestão orientada por dados. A Parceria SMART e outros deslocaram muitos parques para o quadrante superior esquerdo.

Organizações de gestão líderes de pensamento começaram a deslocar áreas protegidas que gerem do quadrante superior esquerdo para o quadrante superior direito. Novas tecnologias de comunicação estão a ser aplicadas, e estão a ser efectuados testes de armadilhas fotográficas capazes de reconhecer imagens de alta precisão. Software sofisticado, capaz de integrar dados de fontes heterogéneas numa única imagem operacional, está também a ser utilizado. Finalmente, os dados são disponibilizados aos tecnólogos que desenvolvem algoritmos avançados de inteligência artificial que mantêm a promessa (ainda por realizar) de uma gestão preditiva e proactiva. Em cinco a 10 anos, a tecnologia promete passar a gestão de áreas protegidas de reactiva para pró-activa - mas fundamentada nas noções básicas de boa gestão e guardas-florestais bem treinados e bem equipados (ver Caixa 11.3 e 11.4).

\section{Figura 11.1 O quadrante mágico para aplicação de tecnologia em áreas protegidas em África}

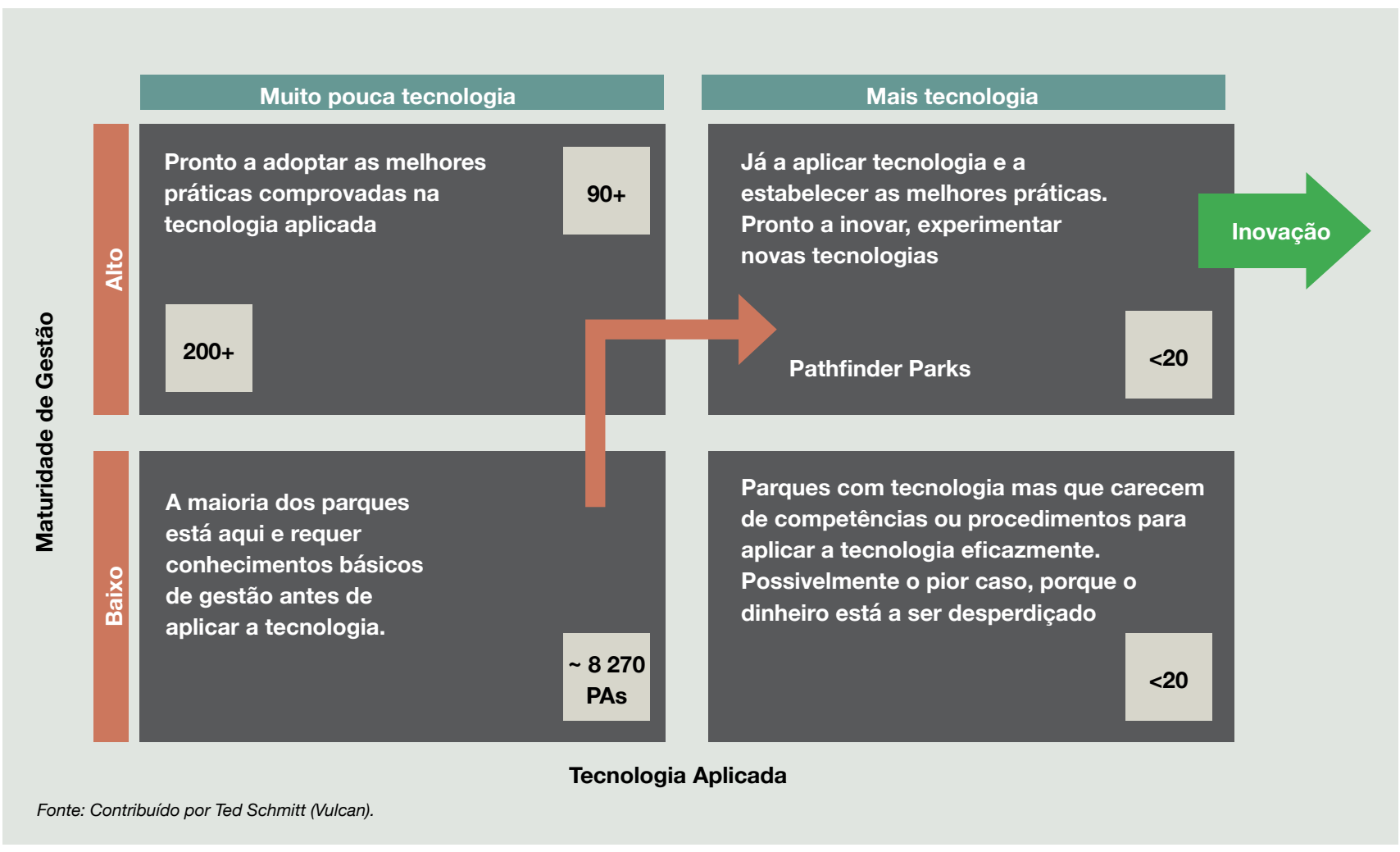

116 Para mais informações, consulte: https://smartconservationtools.org/ 


\section{Caixa 11.2 EarthRanger: consciência situacional para garantir áreas protegidas e reduzir os conflitos entre o homem e a vida selvagem}

Nos últimos anos, os gestores de parques têm vindo a introduzir cada vez mais soluções tecnológicas para melhorar a gestão de áreas protegidas através da tomada de decisões em tempo real e com base em dados. Utilizam tecnologia para recolher dados de observação de patrulhas, fornecer comunicações, localizar animais e bens como aviões e veículos, detectar intrusões, e obter uma ideia do que se está a passar na área protegida que gerem. Estes dados, alguns históricos e alguns (quase) em tempo real, viveram em silos de dados separados, cada um com a sua própria interface de utilizador.

Embora os dados em cada um destes silos possam ser úteis, os gestores ficam rapidamente sobrecarregados quando tentam sintetizar os dados nas suas cabeças, ou mesmo num mapa físico, a fim de terem uma imagem completa da situação na área protegida. O que é necessário é uma visualização única que forneça a consciência situacional necessária para tomar decisões de forma eficiente e eficaz em tempo real.

EarthRanger é uma ferramenta de software online que recolhe, integra e visualiza dados históricos e em tempo real disponíveis a partir de uma área protegida - vida selvagem, guardas florestais, informação espacial e detecção de ameaças. * EarthRanger habilita os gestores de áreas protegidas e os guardas florestais a tomar acções imediatas e proactivas para prevenir e mitigar incidentes de ameaça. A utilização de uma sala central de operações com visualização em tempo real criou raízes com EarthRanger como o sistema nervoso central das operações em áreas protegidas.

A tecnologia que produz dados sobre o que está a acontecer numa área protegida, juntamente com o EarthRanger, actua como um multiplicador de forças para operações de segurança com uma capacidade de visualização que permite aos gestores obter uma compreensão em tempo real e profunda das actividades relacionadas com a caça furtiva e outras ameaças ao habitat. $\mathrm{Na}$ Tanzânia, por exemplo, a Reserva Grumeti utiliza o EarthRanger para seguir os movimentos dos Rangers à medida que estes realizam patrulhas e respondem a incidentes de incursão. O rastreio é associado a armadilhas fotográficas que detectam incursões e outras tecnologias, dando-Ihes uma imagem completa da situação de segurança em qualquer momento e permitindo ao pessoal responder com segurança e eficácia às incursões.

Em parceria com parques africanos, a equipa de gestão do Parque Nacional de Liwonde, no Malawi, utiliza o EarthRanger para monitorizar quando os elefantes passam os limites geográficos, a fim de intervir antes de chegarem às culturas dos agricultores. Com geofences (fronteira virtual estabelecida em torno de uma localização geográfica) no local, os guardas florestais de Liwonde podem monitorizar continuamente a fronteira do parque para detectar potenciais conflitos de vida selvagem humana a partir da sua sala de operações, e responder rapidamente às quebras de geofence e intervir antes que surja uma situação de conflito. A atenuação proactiva do conflito entre vida selvagem humana através de alertas atempados e contínuos permite aos gestores reduzir os incidentes de conflito e ajudar as comunidades a coexistirem com a vida selvagem.

A monitorização do habitat - incluindo a utilização da paisagem pela fauna bravia - através de dados de rastreio e movimento, sensores e relatórios permite o planeamento e gestão do uso da terra com base em dados. Big Life, um grupo de conservação da vida selvagem baseado no ecossistema Amboseli do Quénia, criou corredores que permitem a circulação da vida selvagem entre áreas protegidas. Para assegurar autoridades que podem manter corredores e monitorizar a frequência com que a vida selvagem os utiliza, o pessoal de Amboseli utiliza o EarthRanger para consolidar dados produzidos por várias tecnologias e visualiza-os num mapa intuitivo.

Organizações de gestão de áreas protegidas em mais de 30 áreas protegidas em 13 países de África estão agora a utilizar o EarthRanger para proteger as suas áreas, mitigar os conflitos entre a vida selvagem humana e gerir os seus ecossistemas.

\section{* Para mais informações, por favor consulte: https://earthranger.com.}

Contribuído porTed Schmitt (Vulcan). 


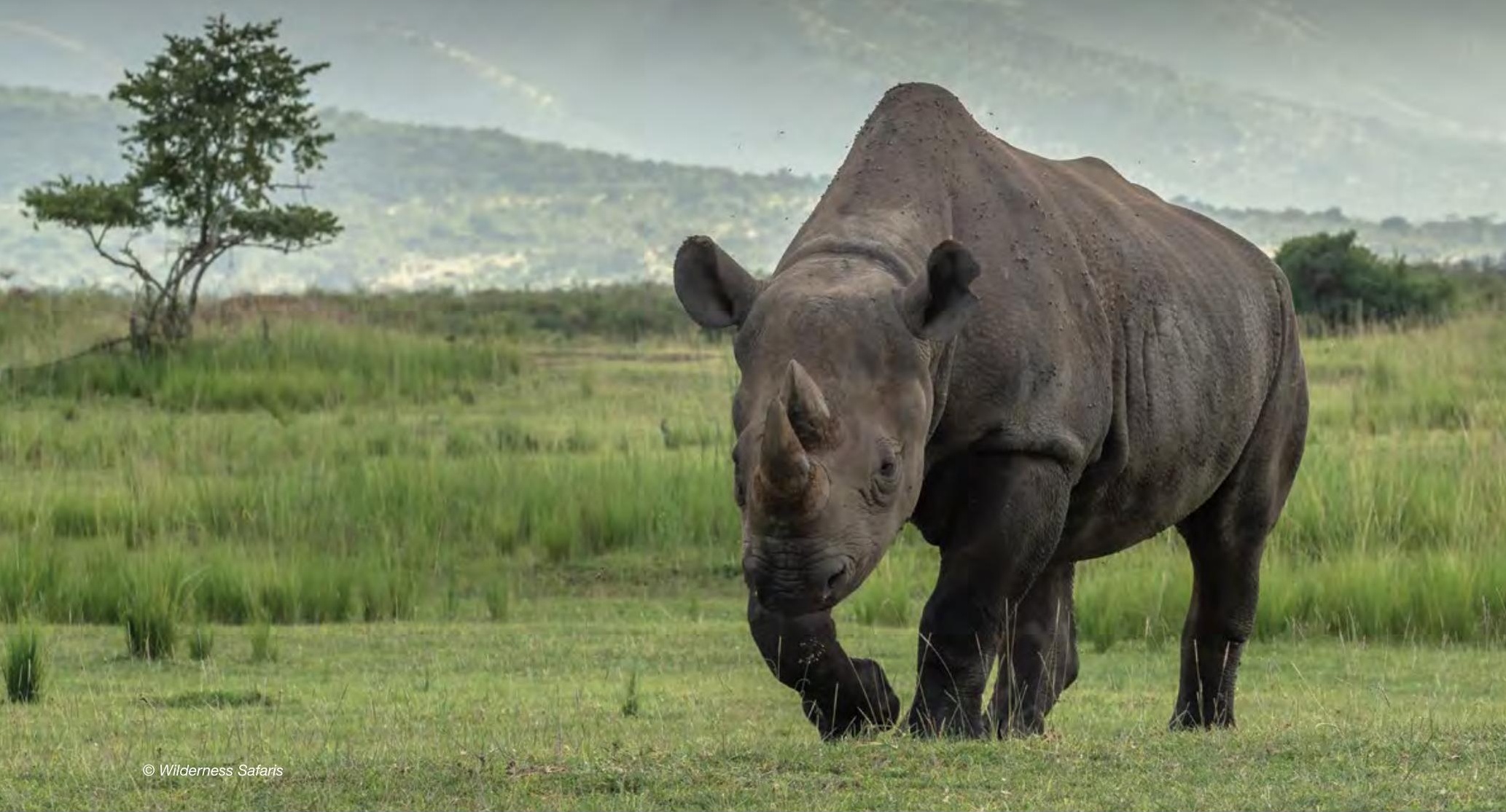

\section{Caixa 11.3 Programa de monitorização de rinocerontes após a sua reintrodução}

Os programas de re-construção de marcos exigem um acompanhamento e manutenção contínuos para garantir o sucesso. Desde a reintrodução de 17 rinocerontes negros orientais (Diceros bicornis michaeli) no Parque Nacional de Akagera, Ruanda, em Maio de 2017, foi empregue um programa de monitorização com várias vertentes para garantir a segurança da nova população e para monitorizar o estado e o comportamento. No centro do programa está uma equipa de rinocerontes de rastreio. Estes indivíduos seguem diariamente os rinocerontes para registar a condição, anotar lesões físicas, registar comportamentos e observar as interacções sociais entre os animais. A prioridade do rastreio é determinada por uma combinação de tendências recentes da condição, número de dias desde a última observação, e factores de aplicação da lei na área utilizada por um rinoceronte específico. A telemetria de frequência muito alta (VHF) é utilizada para alguns animais, enquanto que os métodos tradicionais de rastreio (rastreio de spoor) são utilizados para outros indivíduos sem transmissores nos chifres. O objectivo do programa de monitorização é avistar cada animal uma vez em cada 14 dias.

Actualmente os rinocerontes rastreadores estão a avistar cada animal de oito em oito dias, e a ver quase três animais por dia, excedendo largamente os objectivos de observação. Altas taxas de observação são auxiliadas por rastreio aéreo e armadilhas fotográficas. Os voos de helicóptero voados de duas em duas semanas utilizam a telemetria VHF para se concentrarem em indivíduos com transmissores. $\mathrm{O}$ aumento da velocidade de detecção do helicóptero permite que muitos mais animais sejam vistos num curto espaço de tempo; chegam a ser $10 \mathrm{em}$ duas horas. Os voos são utilizados para pontuações rápidas de condições e verificações de segurança, mas falta a capacidade de controlar o comportamento. $A$ armadilhagem com câmara preenche frequentemente as lacunas nos dados de comportamento. Câmaras bem colocadas ao longo das paredes de lama e dos poços de água, ou trilhos de caça comummente utilizados, permitem a detecção de interacções sociais e comportamentos mais naturais sem perturbar os animais. As armadilhas fotográficas também recolhem imagens durante a noite, iluminando a actividade nocturna e as interacções entre os rinocerontes.

Até à data, não se perderam animais para a caça furtiva, e foram recolhidos dados úteis sobre as gamas domésticas, interacções sociais e composição dietética. Os programas de monitorização íntima permitem a compreensão detalhada da população e o desenvolvimento da capacidade de resposta rápida a situações de segurança, caso estas surjam. A monitorização continuará a tornar-se mais avançada, com melhorias tecnológicas a serem constantemente testadas e ensaiadas. No entanto, nada substituirá a abordagem da monitorização no terreno. Rastreadores dedicados, motivados e com bons recursos, guardas-florestais e pessoal fazem toda a diferença para garantir o sucesso de tais projectos de reintrodução.

Contribuido por Drew Bantlin (African Parks). 


\section{Caixa 11.4 Armadilhas fotográficas para monitorização ecológica e segurança}

As armadilhas de movimento e as câmaras remotas acionadas por calor permitem uma monitorização que de outra forma seria impossível. Em áreas protegidas com poucas estradas e topografia desafiante como o Parque Nacional de Akagera, Ruanda, as armadilhas fotográficas podem preencher lacunas na compreensão das espécies e da ecologia do parque. São utilizadas múltiplas formas de utilização de armadilhas fotográficas. As armadilhas fotográficas de infravermelhos com o mínimo de perturbação para os animais são colocadas sistematicamente em padrões de grelha de $1 \mathrm{~km}$ em todo o parque. Isto permite uma melhor compreensão da composição das espécies no parque e da sua distribuição por toda a paisagem. Os movimentos sazonais e a utilização do habitat podem ser examinados. Dados comportamentais e interacções inter-espécies e intra-espécies podem ser obtidos a partir de fotografias.

Várias câmaras estão também reservadas para uso especial fora das grelhas. As câmaras dedicadas à monitorização de rinocerontes são movidas frequentemente dentro de áreas utilizadas com maior frequência para monitorizar o comportamento, o estado e as interacções sociais. Outras câmaras são utilizadas para monitorizar itens especiais como covas de hienas, limpeza e decomposição de carcaças, $e$ conflitos entre homem e vida selvagem ao longo da fronteira do parque. As armadilhas de câmaras de flash branco proporcionam imagens de espécies com casacos remendados, como os leopardos, para identificação individual.
As câmaras permitem a observação de comportamentos que muitas vezes não seriam visíveis durante os avistamentos mais perturbadores em pessoa. Do mesmo modo, espécies raras, difíceis de ver e nocturnas são frequentemente capturadas por câmaras.

As câmaras servem também uma importante função de aplicação da lei. Após a entrada das equipas de guarda-florestal no terreno, as câmaras são colocadas ao longo de caminhos normalmente utilizados pelos caçadores furtivos e ao longo da linha da vedação onde se sabe que os caçadores furtivos atravessam para o parque. A vigilância silenciosa e invisível das actividades dos caçadores furtivos informa as patrulhas, as patrulhas reactivas e as actividades de aplicação da lei nas comunidades circundantes. Na maioria das vezes despercebidas, as câmaras fornecem frequentemente imagens que podem ser utilizadas para identificar os caçadores furtivos. Isto levou a numerosas detenções e serviu como prova crítica em tribunal durante os julgamentos. Mais importante ainda, as câmaras apoiam equipas de guardas-florestais no terreno, fornecendo informações de inteligência e reforçando as operações de aplicação da lei no parque.

Contribuido por Drew Bantlin (African Parks).

\subsection{Adaptação às mudanças climáticas}

O planeta está actualmente a sofrer uma das transformações climáticas mais rápidas da história da Terra. As alterações climáticas antropogénicas já afectaram a maioria dos processos ecológicos, desde genes a comunidades, através de sistemas terrestres, de água doce e marinhos. Estas alterações estão a causar mudanças ecológicas em grande escala, à medida que as espécies são forçadas a deslocar-se para encontrar um novo habitat adequado. As áreas protegidas e de conservação são uma das ferramentas mais eficazes para a protecção da biodiversidade. No entanto, a maioria destas áreas foi escolhida sem considerar os impactos climáticos futuros. O planeamento adequado para futuras redistribuições de espécies e habitats pode ajudar a manter e melhorar as salvaguardas da biodiversidade para preservar os serviços ecossistémicos e reduzir a ameaça de extinção. O projecto Spatial Planning for Área-Based Conservation in Response to Climate Change (SPARC), por exemplo, identificou áreas terrestres prioritárias para a redução do risco climático na África Subsaariana (ver Caixa 11.5)

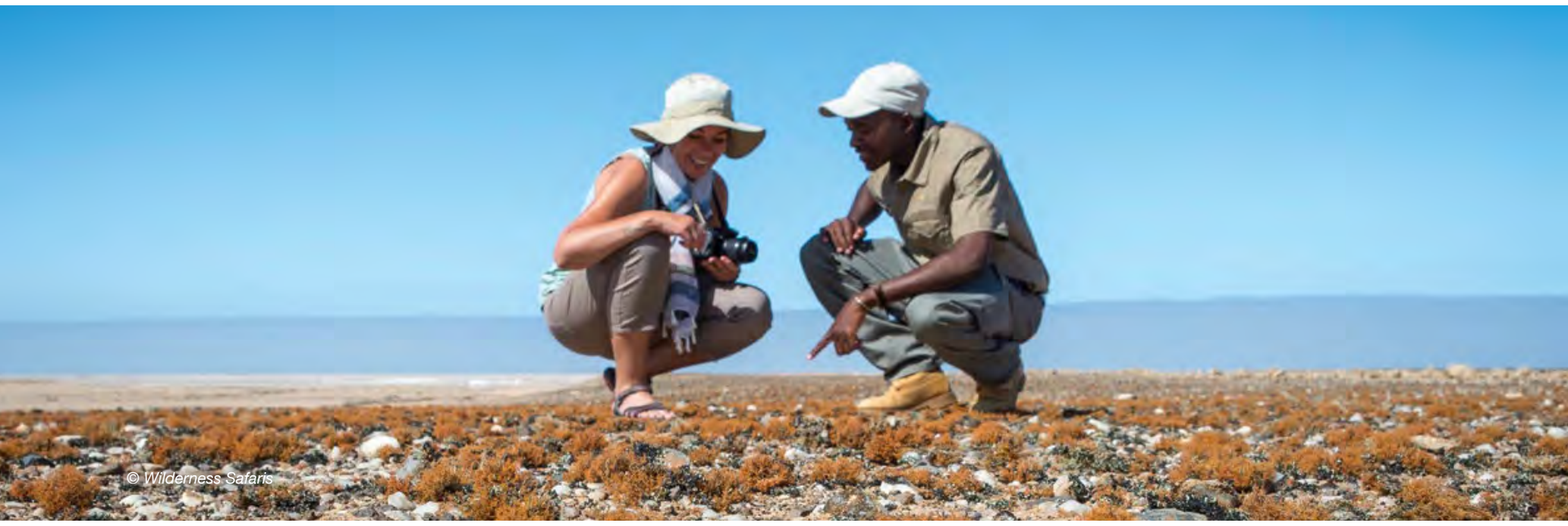




\section{Caixa 11.5 SPARC: Redução do risco climático para as redes de conservação}

O planeta está actualmente a sofrer uma das transformações climáticas mais rápidas da história da Terra (Diffenbaugh \& Field, 2013). As alterações climáticas antropogénicas já afectaram a maioria dos processos ecológicos, desde genes a comunidades, através de sistemas terrestres, de água doce e marinhos (Scheffers et al., 2016). Estas alterações estão a causar mudanças ecológicas em grande escala, uma vez que as espécies são forçadas a deslocar-se para encontrar novos habitats adequados (Parmesan \& Yohe, 2003). As áreas de conservação são uma das ferramentas mais eficazes para proteger a biodiversidade, contudo a maioria destas áreas foi escolhida sem considerar os impactos climáticos futuros. O planeamento adequado para futuras redistribuições de espécies e habitats pode ajudar a manter e melhorar as salvaguardas da biodiversidade para preservar os serviços dos ecossistemas e reduzir a ameaça de extinção.

O projecto Planeamento Espacial Para A Conservação Baseada $\mathrm{Na}$ Área Em Resposta Às Alterações Climáticas (SPARC) utilizou a velocidade das alterações climáticas (Loarie et al., 2009), mapas de estratificação ambiental (Metzger et al., 2013), 10 modelos climáticos globais, e as distribuições futuras de mais de 28.000 espécies para determinar as áreas de maior prioridade para a redução do risco climático na África Subsaariana (Figura a). (Para mais informações ver sparc- website.org).

Angola, por exemplo, possui uma biodiversidade excepcional. Possui a maior diversidade de biomas em África, formando uma zona crucial de transição do mosaico florestal congolês, através das florestas, savanas e prados da escarpa angolana, para os prados inundados do Zambeze e o deserto de Kaokoveld (Huntley, 2019). Se as emissões globais continuarem a aumentar, Angola poderá assistir a uma transição quase completa das zonas climáticas a nível nacional dentro dos próximos 50 anos (SPARC).

A maioria dos parques nacionais de Angola estão localizados em áreas de alta velocidade climática, onde as espécies terão de percorrer longas distâncias para seguir o seu clima preferido. O oeste, contudo, com a sua elevada diversidade altitudinal e baixa velocidade climática, oferece oportunidades significativas para maximizar a protecção de espécies e habitats dentro da menor área possível. Aumentar os esforços de conservação, ou proteger formalmente, as áreas de maior prioridade para a resiliência climática (Figura b) ajudará as espécies angolanas a evitar os piores impactos das alterações climáticas. De facto, manter um corredor de habitat ocidental bem ligado é uma das maiores prioridades de conservação no continente (Figura a), formando a espinha dorsal de um corredor de movimento de espécies topograficamente diversificado que se estende desde a República do Congo até à África do Sul. Este corredor protegerá as espécies ao longo das actuais rotas de migração, que se prevê que se tornem cada vez mais importantes à medida que um número crescente de espécies se disperse para sul, acompanhando temperaturas mais frias.
Figura a: Dar prioridade aos esforços de conservação, ou proteger formalmente, estas áreas resistentes ao clima ajudará a reduzir a ameaça de extinção em toda a África (com base em projecções até 2070 ao abrigo do RCP 8.5

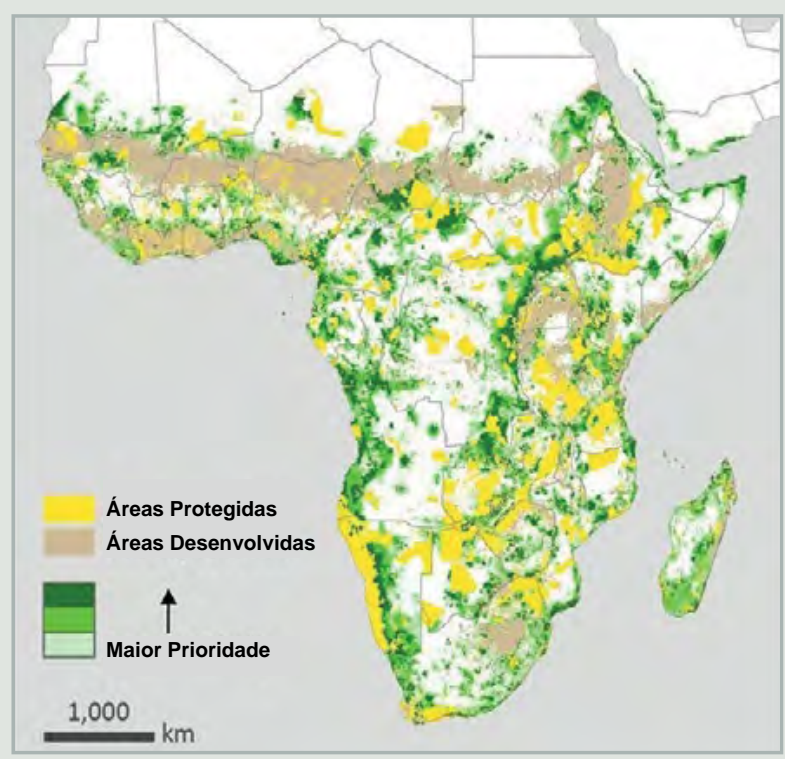

Figura b: Um olhar mais atento às prioridades de resistência climática para Angola revela a importância de proteger um corredor de habitat ocidental interligado (com base em projecções até 2070 ao abrigo do RCP 8.5).

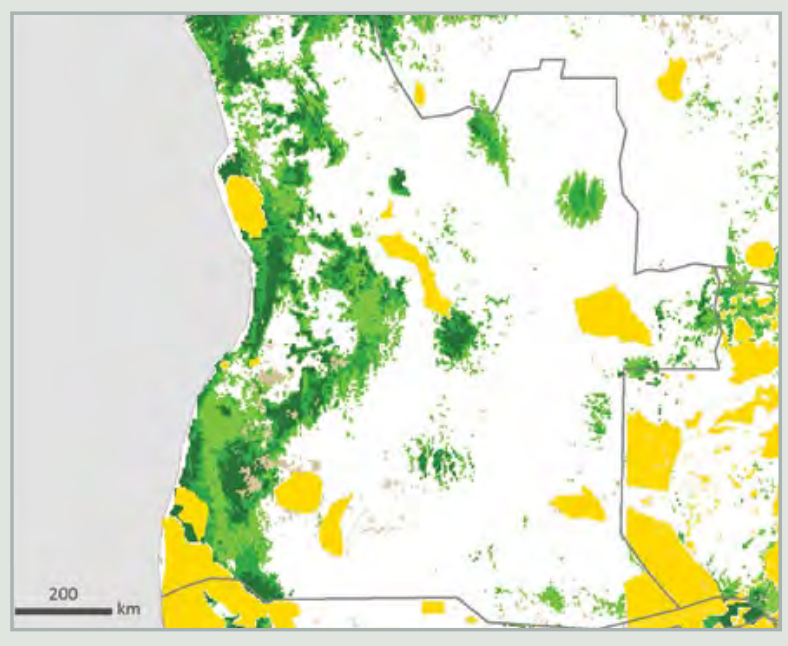

Fonte para figuras a e b: Hannah et al. (2020).

Texto e mapa contribuídos por Caitlin Kelly (Planeamento Espacial Para A Conservação Baseada Na Área Em Resposta Às Alterações Climáticas). 

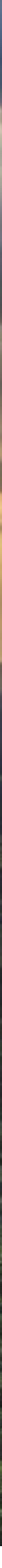
Parte IV

\section{Recomendações}


As áreas protegidas continuarão a ser um elemento essencial dos esforços globais de conservação da biodiversidade na era pós-2020, protegendo a preciosa biodiversidade, mantendo processos naturais na paisagem e fornecendo habitats e refúgios chave para espécies numa era de mudança rápida e sem precedentes (Ceballos et al., 2015). As áreas protegidas também proporcionam benefícios de subsistência para as pessoas, desde água potável limpa à segurança alimentar, para além de uma miríade de outros benefícios culturais, espirituais e sócio-económicos, mas as medidas de conservação também podem ter impactos sociais negativos.

Os desafios ameaçam a existência e a eficiência das áreas protegidas, uma vez que a biodiversidade global continua a deteriorar-se (Secretariado da CDB, 2014; Thomas \& Gillingham, 2015). As questões-chave das alterações climáticas e da perda de biodiversidade significam que um sistema alargado e eficazmente gerido de áreas protegidas e outras áreas de conservação não só é cada vez mais vital, como também necessita de um nível mais elevado de investimento bem direccionado e coordenado.

A seguinte lista de recomendações é prioritária para as autoridades das áreas protegidas, doadores, ONG e parceiros em toda a África Oriental e Austral, a fim de cumprir os objectivos globais, bem como para assegurar que as áreas protegidas sejam capazes de conservar a biodiversidade e contribuir para uma melhor subsistência em toda a região.

O plano de trabalho BIOPAMA, que foi desenvolvido através de consultas e avaliações nacionais e regionais das necessidades nacionais e regionais, alinha-se com as recomendações abaixo delineadas. Inclui o desenvolvimento de capacidades e outras actividades relacionadas com cada uma das recomendações para apoiar uma melhoria na eficácia da gestão, governação e equidade.

\subsection{Aumentar o financiamento sustentável e o apoio político das áreas protegidas e de conservação}

Um financiamento adequado e sustentável é essencial para a gestão das áreas protegidas e de conservação. Embora a região esteja actualmente longe de atingir este objectivo, existem novos mecanismos empolgantes de financiamento inovador de áreas protegidas, e é necessário mais trabalho para pilotar e ampliar as abordagens em diversos contextos em toda a África Oriental e Austral. Além disso, é necessário mais trabalho para demonstrar a importância das áreas protegidas e de conservação na prestação de serviços ecossistémicos e no apoio aos meios de subsistência rurais. Isto pode ajudar a aumentar a vontade política e os compromissos dos governos e, espera-se, levar a um aumento das dotações orçamentais para o sector da conservação que são necessárias para assegurar um apoio sustentável a longo prazo a estas redes. A importância da economia da vida selvagem e o importante papel da conservação da biodiversidade estão a ser cada vez mais reconhecidos pelas partes interessadas como uma chave para o desenvolvimento sustentável na região.

\subsection{Aumentar as capacidades de gestão das áreas protegidas e de conservação}

O desenvolvimento de capacidades em todo o sector da gestão de áreas protegidas e da conservação da biodiversidade é urgentemente necessário em toda a região. Isto inclui apoio ao pessoal da linha de frente, como guardas-florestais, mas também se estende ao pessoal da "sede", bem como a organizações de apoio comunitário, ONG e doadores. A capacitação de gestores intermédios do sector também é crítica, uma vez que muitos destes gestores abandonam posições no terreno e carecem das competências administrativas, financeiras e de negociação necessárias ao sucesso na sua nova posição de gestores intermédios das áreas protegidas e de conservação. O reforço de capacidades é necessário, não só na gestão tradicional de áreas protegidas e anti-população, mas também em tecnologia de conservação, envolvimento comunitário, mercados e negócios, financiamento inovador (por exemplo, mercados de carbono), e parcerias, incluindo parcerias público-privadas.

\subsection{Diversificar a governação das áreas protegidas e reconhecer iniciativas eficazes de governação local, comunitária e de co-gestão}

A África Oriental e Austral alberga uma grande diversidade de disposições de governação para a protecção e conservação da biodiversidade. $O$ apoio contínuo e a melhoria dos ambientes políticos favoráveis irão reforçar este sector em crescimento. A identificação de OECMs é fundamental para compreender e maximizar toda a gama de oportunidades de inovação na conservação da biodiversidade em toda a região. $O$ estabelecimento de parcerias de gestão em colaboração com organizações não governamentais pode ser um mecanismo importante para superar estes desafios, e tem crescido na sua importância em toda a área protegida na África Oriental e Austral. As parcerias público-privadas representam uma oportunidade significativa para aumentar o financiamento e melhorar a gestão das áreas protegidas na região. Políticas, estruturas e pessoal precisam de estar em vigor para facilitar e supervisionar tais acordos inovadores.

\subsection{Abordar as lacunas na cobertura de ecossistemas marinhos e terrestres em áreas protegidas e de conservação}

Tem havido, e continuará a haver, um aumento das ferramentas tecnológicas disponíveis para analisar a conectividade e representatividade das áreas protegidas e de conservação. É necessário utilizar estes instrumentos para identificar lacunas críticas na cobertura, permitindo o início do processo para assegurar a sua protecção, bem como para que as partes interessadas se concentrem mais numa abordagem paisagística, em vez de áreas isoladas a serem conservadas. Os benefícios da conservação da paisagem estão a ser cada vez mais realçados e as análises da 
sobreposição de espécies importantes (fauna e flora) e áreas de conservação precisam de ser uma área de enfoque fundamental para os decisores políticos e os responsáveis pelo ordenamento do território.

\subsection{Melhorar a colaboração além fronteiras e sectores para responder às ameaças existentes e emergentes}

Nestes tempos de mudanças climáticas dramáticas, de aceleração da perda de biodiversidade, de crescimento do comércio ilegal de animais selvagens e de rápidas mudanças demográficas, a África Oriental e Austral enfrenta um desafio monumental na sua busca de manter uma rede de áreas protegidas robusta e interligada. O "business as usual" não tem provado ser bem sucedido, e é necessário reforçar a colaboração além fronteiras e sectores para responder a ameaças emergentes, através de uma maior utilização de mecanismos de partilha de informação. O Centro Regional de Recursos BIOPAMA fornece uma importante plataforma para a partilha de informação e troca de conhecimentos.

\subsection{Melhorar a conservação transfronteiriça}

A África Oriental e Austral alberga 30 áreas de conservação transfronteiriças estabelecidas e potenciais. Estas áreas têm potencial para apoiar acções à escala ecológica e economicamente significativa, e são de interesse para os financiadores bilaterais e multilaterais. A SADC estabeleceu um forte programa TFCA, que pode servir como um modelo útil para a África Oriental, uma vez que trabalha para melhorar a conservação transfronteiriça na sub-região. Várias áreas importantes de conservação na África Oriental são transfronteiriças e é necessária uma maior colaboração na conservação dessas áreas. Além disso, as áreas marinhas e costeiras de conservação estão geralmente sub-representadas na propriedade da TFCA.

\subsection{Melhorar a cobertura das avaliações da eficácia da gestão, governação e equidade}

Actualmente, apenas $13 \%$ das áreas protegidas na região tiveram pelo menos uma avaliação da eficácia da gestão, e uma proporção muito menor avaliou a governação e a equidade. Além disso, não foi realizada recentemente nenhuma análise regional dos resultados destas avaliações. O Objectivo 11 de Aichi afirma claramente que o objectivo é ter áreas protegidas geridas de forma eficaz e equitativa. $\mathrm{Na}$ ausência de dados, é impossível saber até que ponto a região está a cumprir este importante objectivo. A melhoria da capacidade para levar a cabo a eficácia da gestão, a governação e a equidade a nível local e nacional é, portanto, uma prioridade. Ao mesmo tempo, é também importante sensibilizar e aumentar a orientação sobre como elaborar relatórios através de plataformas globais para monitorizar o cumprimento dos objectivos. Estes são importantes para assegurar a sustentabilidade e uma institucionalização reforçada das avaliações. É necessária uma análise aprofundada dos resultados das recentes avaliações realizadas na região da África Oriental e Austral para ajudar a construir uma imagem regional do estado da eficácia da gestão e da governação equitativa, e para orientar futuras intervenções.

\subsection{Aumentar a frequência e a abrangência dos relatórios à Base de Dados Mundial de Áreas Protegidas}

A região da África Oriental e Austral quase atingiu o Objectivo 11 de Aichi para áreas protegidas terrestres, quase atingindo a meta de $17 \%$ da área terrestre coberta por áreas protegidas. Para a protecção marinha e costeira, a região atingiu pouco mais de metade da meta de $10 \%$, com $5,6 \%$ da área costeira e marinha coberta por protecção. Com a expansão da meta para incluir OECMs, os países são encorajados a reportar ao WDPA todas as áreas protegidas e de conservação. Uma vez que existe uma elevada proporção de "não comunicados" nas categorias de governação e gestão da UICN, os países são encorajados a clarificar as categorias em que se enquadram as áreas protegidas e de conservação existentes. Os dados da WDPA são utilizados para estabelecer e medir muitas metas globais e regionais, o que torna crucial que os países assegurem que os dados estejam actualizados e precisos. 


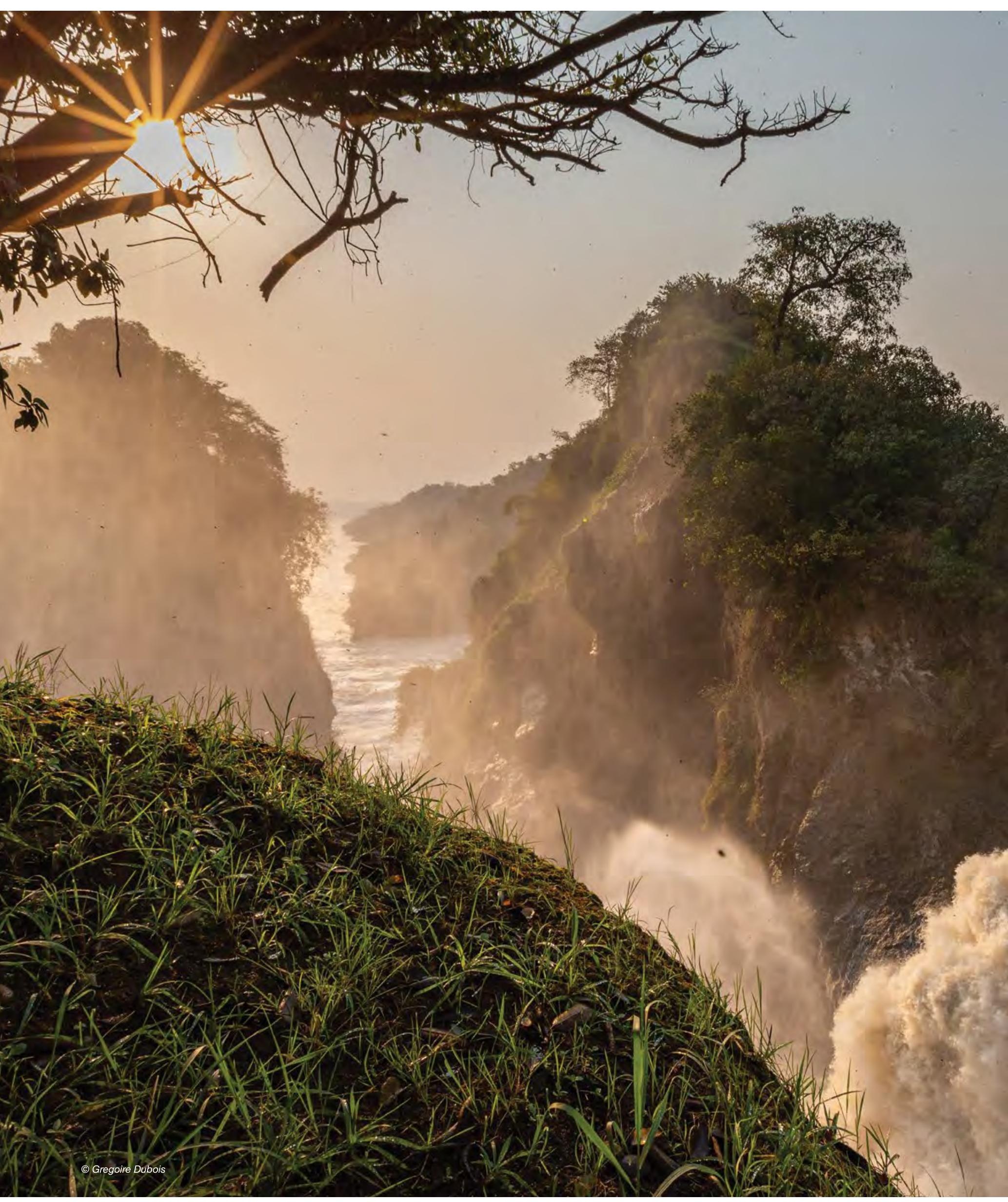




\section{Referências}

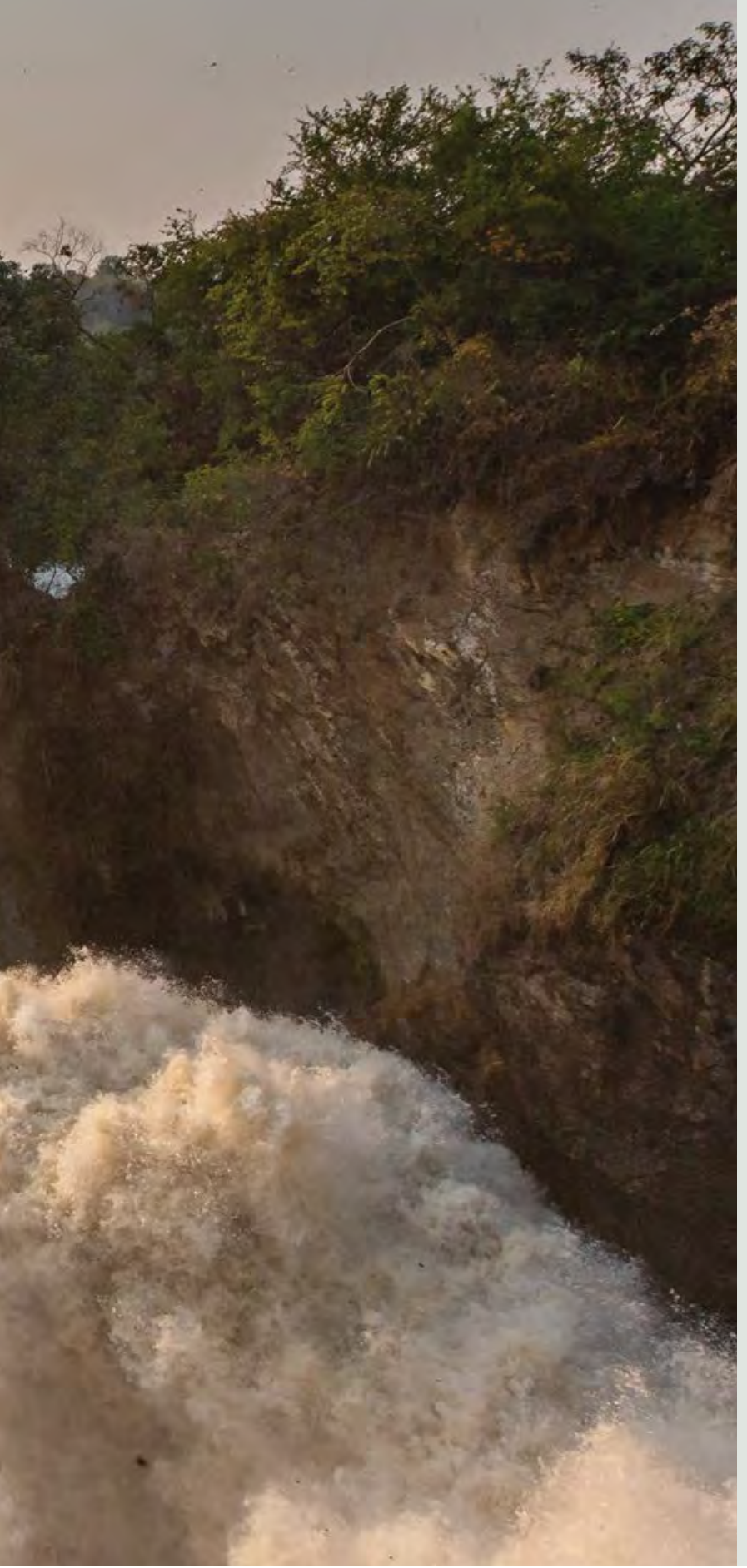


Athanas, A. (2018). 'Engaging business to boost sustainability in African agriculture'. Panorama [website], (22 November 2018). https:// panorama.solutions/en/solution/engaging-business-boost-sustainability-african-agriculture.

Alliance for Zero Extinction (AZE) Secretariat (n.d.). AZE [website] . http://zeroextinction.org/.

Baghai, M., Miller, J.R.B., Blanken, L.J., Dublin, H.T., Fitzgerald, K.H., Gandiwa, P., Laurenson, K., Milanzi, J. Nelson, A., Lindsey, P. (2018). 'Models for the collaborative management of Africa's protected areas'. Biological Conservation 218: 73-82. https://doi. org/10.1016/j.biocon.2017.11.025

Balmford, A., Beresford, J., Green, J., Naidoo, R., Walpole, M. and Manica, A. (2009). 'A Global Perspective on Trends in Nature-Based Tourism'. PLoS Biology 7(6): e100014. https://doi.org/10.1371/journal.pbio.1000144

Bastin, L., Mandrici, A., Battistella, L. and Dubois, G. (2017). 'Processing Conservation Indicators with Open Source Tools: Lessons Learned from the Digital Observatory for Protected Areas'. Free and Open Source Software for Geospatial (FOSS4G) Conference Proceedings 17(6): 101-111. https://doi.org/10.7275/R5XK8CQS

Belle, E., Wicander, S., Bingham, H. and Shi, Y. (2015). Governance of protected areas in Africa: A global review. Cambridge, UK: UNEP-WCMC. https://papaco.org/wp-content/uploads/2015/04/PAPACO-study-17_GOVERNANCE-STUDY-0-FINAL_REPORTCONTEXT.pdf

Bennett, N.J. and Dearden, P. (2014). 'Why local people do not support conservation: Community perceptions of marine protected area livelihood impacts, governance and management in Thailand'. Marine Policy 44: 107-116. https://doi.org/10.1016/j.marpol.2013.08.017

Bennett, N.J., Franco, A.D., Calò, A., Nethery, E., Niccolini, F., Milazzo, M. and Guidetti, P. (2019). 'Local support for conservation is associated with perceptions of good governance, social impacts, and ecological effectiveness'. Conservation Letters 12(4). https://doi. org/10.1111/conl.12640

Biodiversity Finance Initiative (BIOFIN) (2017). Biodiversity Finance Initiative [website]. https://www.biodiversityfinance.net/

(2019). 'Finance for nature, a commitment of the whole society to the sustainability of the planet'. BIOFIN [website], (1 July 2019). https://www.biodiversityfinance.net/news-and-media/finance-nature-commitment-whole-society-sustainability-planet.

Biodiversity and Protected Areas Programme (BIOPAMA) (Unpublished). State of Protected Areas Report for East Africap. Nairobi, Kenya: EAC, UICN ESARO, JRC.

BIOPAMA and International Union for Conservation of Nature (UICN) (2016). IMET (Integrated Management Effectiveness Tool) training summary report. Mbale, Uganda: IMET Training Workshop. Unpublished.

BirdLife International (2019a). 'Sites and Habitats (IBAs and KBAs)'. BirdLife International [website]. http://www.birdlife.org/worldwide/ programmes/sites-habitats-ibas-and-kbas

(2019b). World Database of Key Biodiversity Areas. Developed by the KBA Partnership: BirdLife International, International Union for the Conservation of Nature, Amphibian Survival Alliance, Conservation International, Critical Ecosystem Partnership Fund, Global Environment Facility, Global Wildlife Conservation, NatureServe, Rainforest Trust, Royal Society for the Protection of Birds, Wildlife Conservation Society and World Wildlife Fund. Available at: www.keybiodiversityareas.org. [Accessed (please insert date of download 20/10/2019)].

(2019c). 'Important Bird and Biodiversity Areas'. World Database of Key Biodiversity Areas. Developed by the KBA Partnership: BirdLife International, International Union for the Conservation of Nature, Amphibian Survival Alliance, Conservation International, Critical Ecosystem Partnership Fund, Global Environment Facility, Global Wildlife Conservation, NatureServe, Rainforest Trust, Royal Society for the Protection of Birds, Wildlife Conservation Society and World Wildlife Fund. Available at: www.keybiodiversityareas.org. [Accessed (please insert date of download 20/10/2019)].

Booker, F. and Franks, P. (2019). Governance Assessment for Protected and Conserved Areas (GAPA): Methodology manual for GAPA facilitators. London: IIED. https://www.sprep.org/attachments/Publications/articles/governance-assessment-protected-conservedareas.pdf

Borrini-Feyerabend, G., Dudley, N., Jaeger, T., Lassen, B., Pathak Broome, N., Phillips, A. and Sandwith, T. (2017). Governança de áreas protegidas: da compreensão à ação. Série Diretrizes para melhores Práticas para Áreas Protegidas, No. 20, Gland, Suiça: UICN.https:// portals.iucn.org/library/node/46934 (Também disponível em francês, inglês e espanhol)

Burgess, N.D., Malugu, I., Sumbi, P., Kashindye, A., Kijazi, A., Tabor, K., Mblinyi, B., Kashaigili, J., Wright, T.M., Gereau, R.E. et al. (2017). 'Two decades of change in state, pressure and conservation responses in the coastal forest biodiversity hotspot of Tanzania'. Oryx 51(1): 77-86. https://doi.org/10.1017/S003060531500099X

Campese, J. and Sulle, E. (2019). Management Effectiveness, Governance, and Social Assessments of Protected and Conserved Areas in Eastern and Southern Africa: A rapid inventory and analysis to support the BIOPAMA programme and partners. A report prepared for BIOPAMA Eastern and Southern Africa. BIOPAMA, UICN ESARO. https://biopama.org/wp-content/uploads/2019/11/inline-files_ BIOPAMA_Sept_2019_MEGSA-of-PCA-in-ESA_0.pdf 
Ceballos, G., Ehrlich, P.R., Barnosky, A.D., García, A., Pringle, R.M. and Palmer, T.M. (2015). Accelerated modern human-induced species losses: 'Entering the sixth mass extinction'. Science Advances 1(5). https://doi.org/10.1126/sciadv.1400253

Chadwick, P., Duncan, J. and Tunley, K. (2014). State of Management of South Africa's Marine Protected Areas. WWF South Africa No. 2014/Marine/001. South Africa: WWF. http://awsassets.wwf.org.za/downloads/final_wwf_marine_report_02_dec_2014_web_1.pdf

Coad, L., et al. (2015). 'Measuring impact of protected area management interventions: current and future use of the Global Database of Protected Area Management Effectiveness'. Philosophical Transactions of the Royal Society B: Biological Sciences 370(1681). https:// doi.org/10.1098/rstb.2014.0281

Coad, L., Watson, J.E., Geldmann, J., Burgess, N.D., Leverington, F., Hockings, M., Knights, K., Marco, M.D. (2019). 'Widespread shortfalls in protected area resourcing undermine efforts to conserve biodiversity'. Frontiers in Ecology and the Environment 17(5): 259-264. https://doi.org/10.1002/fee.2042

Conservation Finance Alliance (CFA) 2008. Rapid Review of Conservation Trust Funds. Second Edition. Prepared for the CFA Working Group on Environmental Funds by Barry Spergel and Philippe Taïeb. https://www.cbd.int/financial/trustfunds/g-rapidassess.pdf

Conservation International (Cl) and World Wildlife Fund (WWF) (n.d.). PADDDtracker.org Data Release Version 2.0 (May 2019). Arlington, VA and Washington, DD: $\mathrm{Cl}$ and WWF. DOI: 10.5281/zenodo.3371733 (accessed 13 August 2019).

Convention on Biological Diversity (CBD) (2004). Decision adopted by the Conference of Parties to the Convention on Biological Diversity at its seventh meeting VII/28. Protected areas (Articles 8 (a) to (e)). No. UNEP/CBD/COP/DEC/VII/28. Kuala Lumpur, Malaysia: Convention on Biological Diversity. https://www.cbd.int/decisions/cop/7/28 https://www.cbd.int/decisions/cop/7/28 (online); https://www.cbd.int/ doc/decisions/cop-07/cop-07-dec-28-en.pdf (PDF)

(2005). Options for Mobilizing Financial Resources for the Implementation of The Programme of Work by Developing Countries and Countries with Economies in Transition. No. UNEP/CBD/WG-PA/1/6. https://www.cbd.int/decision/cop/?id=11038 (online) and https:// www.cbd.int/meetings/PAWG-01 (links to six UN languages in Word and PDF).

(2010a). Decision adopted by the Conference of the Parties to the Convention on Biological Diversity at its tenth meeting X/2. The Strategic Plan for Biodiversity 2011-2020 and the Aichi Biodiversity Targets. No. UNEP/CBD/COP/DEC/X/2. Nagoya, Japan: Convention on Biological Diversity. https://www.cbd.int/doc/decisions/cop-10/cop-10-dec-02-en.pdf

(2010b). Decision adopted by the Conference of Parties to Convention on Biological Diversity at its tenth meeting: X/31. Protected areas. No. UNEP/CBD/COP/DEC/X/31. Nagoya, Japan: Convention on Biological Diversity. https://www.cbd.int/doc/decisions/cop-10/ cop-10-dec-31-en.pdf

(2018). Decision adopted by the Conference of the Parties to the Convention on Biological Diversity at its fourteenth meeting 14/8. Protected areas and other effective area-based conservation measures. No. CBD/COP/DEC/14/8. Sharm El-Sheikh, Egypt: Convention on Biological Diversity. https://www.cbd.int/doc/decisions/cop-14/cop-14-dec-08-en.pdf

Credit Suisse, WWF and McKinsey (2014). Conservation Finance: Moving beyond donor funding toward an investor-driven approach. https://www.cbd.int/financial/privatesector/g-private-wwf.pdf

Davey, A.G. (1998). National system planning for protected areas. Best Practice Protected Area Guidelines Series No. 1. Gland, Switzerland and Cambridge, UK: IUCN World Commission on Protected Areas. https://portals.iucn.org/library/node/7394 (also available in Arabic, Chinese and Russian)

Deguignet, M., Arnell, A., Juffe-Bignoli, D., Shi, Y., Bingham, H., MacSharry, B. and Kingston, N. (2017). 'Measuring the extent of overlaps in protected area designations'. PLOS ONE 12(11): e0188681. https://doi.org/10.1371/journal.pone.0188681

de Koning, M., Parr, J.W.K., Sengchanthavong, S. and Phommasane, S. (2016). 'Collaborative governance improves management effectiveness of Hin Nam No National Protected Area in Central Lao PDR'. Parks 22(2): 27-40. https://doi.org/10.2305/IUCN.CH.2016. PARKS-22-2MdK.en

Diffenbaugh, N.S. and Field, C.B. (2013). 'Changes in ecologically critical terrestrial climate conditions'. Science 341: 6145. https://doi. org/10.1126/science.1237123

Donald, P.F. et al. (2019). 'The prevalence, characteristics and effectiveness of Aichi Target 11's "other effective area-based conservation measures" (OECMs) in Key Biodiversity Areas'. Conservation Letters 12(5): e12659. https://doi.org/10.1111/conl.12659

Dubois, G. et al. (2016). 'Integrating Multiple Spatial Datasets to Assess Protected Areas: Lessons Learnt from the Digital Observatory for Protected Areas (DOPA)'. ISPRS International Journal of Geo-Information 5(12). https://doi.org/10.3390/ijgi5120242

Dudley, N. (ed.) (2008). Guidelines for applying protected area management categories. Gland, Switzerland: UICN.https://doi. org/10.2305/IUCN.CH.2008.PAPS.2.en

DuPont, C.M., Levitt, J. and Bilmes, L. (2016). Green bonds and land conservation: The evolution of a new financing tool. Harvard Environmental Economics Program (Discussion Paper 16-67). https://doi.org/10.2139/ssrn.2700311

East African Community (EAC) (2010). East African Community Transboundary Ecosystems Management Bill, 2010. http://www.eala.org/ uploads/Transboundary_Bill.pdf 
(2018). Strategy to Combat Poaching, Illegal Trade and Trafficking of Wildlife and Wildlife Products 2017/18-2021/22. https://www. eac.int/documents/category/tourism-wildlife-management

Edgar, G.J., et al. (2014). 'Global conservation outcomes depend on marine protected areas with five key features'. Nature 506(7487): 216-220. https://doi.org/10.1038/nature13022

Eklund, J. and Cabeza, M. (2017). 'Quality of governance and effectiveness of protected areas: crucial concepts for conservation planning'. Annals of the New York Academy of Sciences 1399(1): 27-41. https://doi.org/10.1111/nyas.13284

Emerton, L., Bishop, J. and Thomas, L. (2006). Sustainable Financing of Protected Areas. A global review of challenges and options. Best Practice Protected Area Guidelines series No. 13. Gland, Switzerland: UICN. https://doi.org/10.2305/IUCN.CH.2005.PAG.13.en

Eswatini (2014). Swaziland's Fifth National Report to the Convention of Biological Diversity. Eswatini Environment Authority. https://www. cbd.int/doc/world/sz/sz-nr-05-en.pdf

Eswatini Environment Authority (2016). Eswatini's Second National Biodiversity and Action Plan. National Biodiversity Strategy and Action Plan (NBSAP) No. 2. Ministry of Tourism and Environmental Affairs. https://www.cbd.int/doc/world/sz/sz-nbsap-v2-en.pdf

European Commission (EC) (2015). Larger than elephants: Inputs for the design of an EU strategic approach to Wildlife Conservation in Africa. Brussels, Belgium: EC. doi:10.2841/123569 EC Joint Research Centre (2018). Science for the AU-EU Partnership - Building knowledge for sustainable development. https://ec.europa.eu/jrc/en/publication/eur-scientific-and-technical-research-reports/ science-au-eu-partnership (provides link to main report and summary in six languages)

EC Joint Research Centre (JRC)/Digital Observatory for Protected Areas (DOPA) (2019a). An introduction to DOPA Explorer 4.0. DOPA Factsheet No. A.1. EC and DOPA. https://dopa.jrc.ec.europa.eu/sites/default/files/DOPA\%20Factsheet\%20A1\%20EN\%20An\%20 introduction\%20to\%20DOPA\%20Explorer_0.pdf. Accessed: 8/7/2019

(2019b). Regional factsheet 201910 Africa (Eastern) and (Southern). EC JRC /DOPA [website]. https://dopa.jrc.ec.europa.eu/en/ regional-factsheet. Accessed: 15/11/2019

(2019c). Connectivity of terrestrial protected areas. DOPA Factsheet C.1. https://dopa.jrc.ec.europa.eu/sites/default/files/ DOPA\%20Factsheet\%20C1\%20EN\%20Connectivity.pdf. Accessed: 8/7/2019

Federal Republic of Somalia (2014). Fifth national report on the implementation of the Convention on Biological Diversity of Somalia. National Report on Biodiversity No. 5. Mogadishu, Somalia: Ministry of Fisheries and Marine Resource. https://www.cbd.int/doc/world/ so/so-nr-05-en.pdf

(2019). Sixth National Report to the Convention of Biological Diversity. The Clearing-House Mechanism of the Convention on Biological Diversity. https://chm.cbd.int/pdf/documents/nationalReport6/248495/1 (PDF) or https://chm.cbd.int/database/ record?documentID=248495 (online)

Fitzgerald, K.H. (2017). 'The challenge of funding Africa's protected area system'. Swara (July-September): 59-61. https://swara.co.ke/ making-africa-s-protected-area-system-financially-viable/

Frankfurt Zoological Society (FZS) (2019). 'North Luangwa conservation programme'. FZS [website]. https://fzs.org/en/projects/ north-luangwa/

Franks, P. and Booker, F. (2018). Governance Assessment for Protected and Conserved Areas (GAPA): Early experience of a multistakeholder methodology for enhancing equity and effectiveness. IIED Working Paper. London: IIED. https://pubs.iied.org/ pdfs/17632IIED.pdf

Franks, P., Small, R. and Booker, F. (2018). Social Assessment for Protected and Conserved Areas (SAPA). Methodology manual for SAPA facilitators. Second edition. IIED, London. https://pubs.iied.org/pdfs/14659IIED.pdf

Franks, P., Booker, F. and Small, R. (eds.). (forthcoming 2021). Social Assessment for Protected Areas and Conserved Areas. IIED Results Report. London, UK: International Institute for Environment and Development.

Gannon, P., Dubois, G., Dudley, N., Ervin, J., Ferrier, S., Gidda, S., MacKinnon, K., Richardson, K., Schmidt, M., Seyoum-Edjigu, E. et al. (2019). 'An update on progress towards Aichi Biodiversity Target 11'. Parks 25.2 November 2019. http://dx.doi.org/10.2305/IUCN. CH.2019.PARKS-25-2PG.en

Geldmann, J., Barnes, M., Coad, L., Craigie, I.D., Hockings, M. and Burgess, N.D. (2013). 'Effectiveness of terrestrial protected areas in reducing habitat loss and population declines'. Biological Conservation 161: 230-238. https://doi.org/10.1016/j.biocon.2013.02.018

Geldmann, J., Coad, L., Barnes, M., Craigie, I.D., Hockings, M., Knights, K., Leverington, F., Cuadros, I.C., Zamora, C., Woodley, S. et al. (2015). 'Changes in protected area management effectiveness over time: A global analysis'. Biological Conservation 191: 692-699. https://doi.org/10.1016/j.biocon.2015.08.029 
Golden Kroner, R.E., Qin, S., Cook, C.N., Krithivasan, R., Pack, S.M., Bonilla, O.D., Cort-Kansinally, K.A., Coutinho, B., Feng, M., Martínez Garcia, M.I. et al. (2019). 'The uncertain future of protected lands and waters'. Science 364(6443): 881-886. https://doi.org/10.1126/ science.aau5525

Godoy, F., Tabor, K., Burgess, N., Mbilinyi, B., Kashaigili, J. and Steininger, M. (2012). 'Deforestation and CO2 emissions in coastal Tanzania from 1990 to 2007'. Environmental Conservation 39(1): 62-71. https://doi.org/10.1017/S037689291100035X

Gorenflo, L.J., Corson, C., Chomitz, K.M., Harper, G., Honzák, M. and Özler, B. (2011). 'Exploring the Association Between People and Deforestation in Madagascar'. In: Cincotta, R.P. and L.J. Gorenflo (eds.). Human Population: Its Influences on Biological Diversity, pp. 197-221. Berlin, Heidelberg: Springer. https://doi.org/10.1007/978-3-642-16707-2_11

Government of Malawi (2014). Fifth National Report To The Convention on Biological Diversity. Lilongwe, Malawi: Environmental Affairs Department. https://www.cbd.int/doc/world/mw/mw-nr-05-en.pdf

(2015). National Biodiversity Strategy and Action Plan II (2015-2025). Lilongwe, Malawi: Environmental Affairs Department. https://www.cbd.int/doc/world/mw/mw-nbsap-v2-en.pdf

(2019). Sixth National Report to the Convention on Biological Diversity.Ministry of Natural Resources, Energy and Mining. https://www.cbd.int/doc/nr/nr-06/mw-nr-06-en.pdf

Government of Seychelles (2014a). Fifth National Report to the Convention on Biological Diversity. Victoria. https://www.cbd.int/ doc/world/sc/sc-nr-05-en.pdf

(2014b). Seychelles National Biodiversity Strategy and Action Plan 2015-2020. National Biodiversity Strategy and Action Plan No. 2. https://www.cbd.int/doc/world/sc/sc-nbsap-v2-en.pdf

Graham, J., Bruce, A. and Plumptre, T. (2003). Governance principles for protected areas in the 21st century. The Fifth World Parks Congress in September 2003. Durban, South Africa: Institute On Governance. https://www.files.ethz.ch/isn/122197/pa governance2.pdf

Gutiérrez, N.L., Hilborn, R. and Defeo, O. (2011). 'Leadership, social capital and incentives promote successful fisheries'. Nature 470(7334): 386-389. https://doi.org/10.1038/nature09689

Hannah, L., Roehrdanz, P.R., Marquet, P.A., Enquist, B.J., Midgley, G., Foden, W., Lovett, J.C., Corlett, R.T., Corcoran, D., Butchart, S.H.M. et al. (2020). '30\% land conservation and climate action reduces tropical extinction risk by more than $50 \%$ '. Ecography 43: 943-953. https://doi.org/10.1111/ecog.05166

Hockings, M. et al. (2019). 'The IUCN green list of protected and conserved areas: Setting the standard for effective conservation'. PARKS 25(2): 57-66. https://doi.org/10.2305/IUCN.CH.2019.PARKS-25-2MH.en

Hockings, M., Leverington, F. and Cook, C. (2015). 'Protected Area Management Effectiveness'. In: Worboys, G.L., M. Lockwood, A. Kothari, S. Feary, and Pulsford, I. (eds.). Protected Area Governance and Management, pp. 889-928. ANU Press, Canberra. http://press-files.anu.edu.au/downloads/press/p312491/pdf/CHAPTER28.pdf

Hockings, M., Stolton, S., Leverington, F., Dudley, N. and Courrau, J. (2006). Evaluating effectiveness: A framework for assessing management effectiveness of protected areas. 2nd edition. Best Practice Protected Area Guidelines Series No. 14. Gland, Switzerland and Cambridge, UK: IUCN. https://portals.iucn.org/library/node/8932

Howard, P. and Bertzky, B. (2019). Natural world heritage in Africa: Progress and prospects. BIOPAMA Programme. Nairobi, Kenya and Ouagadougou, Burkina Faso: IUCN ESARO and IUCN PACO. https://portals.iucn.org/library/node/49029

Hummel, C., , Poursanidis, D., Orenstein, D., Elliott, M., Adamescu, M.C., Cazacu, C., Chrysoulakis, N., van der Meer, J., Hummel, H. (2019). 'Protected Area management: Fusion and confusion with the ecosystem services approach'. Science of The Total Environment 651: 2432-2443. https://doi.org/10.1016/j.scitotenv.2018.10.033

Huntley, B.J. (2019). 'Angola in outline: Physiography, climate and patterns of biodiversity'. In: B. Huntley, V. Russo, F. Lages, N. Ferrand (eds.), Biodiversity of Angola. Cham, Switzerland: Springer. https://doi.org/10.1007/978-3-030-03083-4_2

Huntley, B.J., Russo, V., Lages, F. and Ferrand, N. (eds.) (2019). Biodiversity of Angola: Science and conservation: A modern synthesis. Springer. https://doi.org/10.1007/978-3-030-03083-4

Indigenous and Community Conserved Areas (ICCA) Registry (n.d.). ICCA Registry [website]. http://www.iccaregistry.org/ Intergovernmental Science-Policy Platform on Biodiversity and Ecosystem Services (IPBES) (2018). IPBES regional assessment report on biodiversity and ecosystem services for Africa. Bonn, Germany: Secretariat of the Intergovernmental Science-Policy Platform on Biodiversity and Ecosystem Services. https://ipbes.net/sites/default/files/africa_assessment_report_20181219_0. pdf and https://ipbes.net/assessment-reports/africa (provides direct links to summary and other material and commentaries).

International Institute for Environment and Development (IIED) (2018). 'Assessing governance at protected and conserved areas (GAPA)'. International Institute for Environment and Development. https://www.iied.org/assessing-governance-protectedconserved-areas-gapa 
(2020). Assessing governance and equity at protected and conserved areas (SAGE). International Institute for Environment and Development. https://www.iied.org/assessing-governance-equity-protected-conserved-areas-sage accessed 23 January 2020.

(n.d.). 'Assessing social impacts of protected and conserved areas (SAPA)'. IIED [website]. https://www.iied.org/assessingsocial-impacts-protected-conserved-areas-sapa

International Union for Conservation of Nature (IUCN) (2005a). 'Governance of Protected Areas - New Ways of Working Together'. In: Benefits Beyond Boundaries. Proceedings of the Vth IUCN World Parks Congress, pp. 64-75. Gland, Switzerland and Cambridge, UK: IUCN. https://portals.iucn.org/library/node/8662. Also available in French: https://portals.iucn.org/library/ node/8755; and Spanish:https://portals.iucn.org/library/node/8756

(2005b). 'The Durban Accord'. In: Benefits Beyond Boundaries. Proceedings of the Vth IUCN World Parks Congress, pp. 219-223. IUCN, Gland, Switzerland and Cambridge, UK. https://portals.iucn.org/library/node/8662. Also available in French: https://portals.iucn.org/library/node/8755; and Spanish:https://portals.iucn.org/library/node/8756

(2012). Accelerating the global pace of establishing marine protected areas and the certification of their effective management. WCC-2012-Res-076-EN. IUCN. https://portals.iucn.org/library/node/44043 (link to English, French and Spanish versions)

(2016a). A global standard for the identification of Key Biodiversity Areas, Version 1.0. Gland, Switzerland: IUCN. https:// portals.iucn.org/library/node/46259

(2016b). Supporting privately protected areas. WCC-2016-Res-036-EN. IUCN. https://portals.iucn.org/library/node/46453 (link to English, French and Spanish versions)

IUCN Eastern and Southern Africa Region (ESARO) (2020). Closing the gap. The financing and resourcing of protected and conserved areas in Eastern and Southern Africa. Nairobi, Kenya: IUCN ESARO; BIOPAMA. https://portals.iucn.org/library/ node/49045

IUCN and World Commission on Protected Areas (WCPA) (2017). IUCN Green List of Protected and Conserved Areas: Standard, Version 1.1. Gland, Switzerland: IUCN. https://www.iucn.org/theme/protected-areas/our-work/iucn-green-list-protected-andconserved-areas/global-standard

IUCN-WCPA Task Force on Other Effective Area-based Conservation Measures (OECMs) (2019). Recognising and reporting other effective area-based conservation measures. Gland, Switzerland: IUCN. https://doi.org/10.2305/IUCN.CH.2019.PATRS.3.en

Jonas, H. and Sandwith, T. (eds.) (2019). Towards Recognising, Reporting and Supporting OECMs: Report of the Fourth Expert Meeting of the IUCN-WCPA Task Force on Other Effective Area-based Conservation Mesaures. Gland, Switzerland: IUCN. https:// www.bfn.de/fileadmin/BfN/ina/Dokumente/Tagungsdoku/2019/towards_recognising_reporting_and_supporting_oecms_-report_of_4th_meeting_of_the_task_force_on_oecms_-_june_2019bf.pdf

Key Biodiversity Area (KBA) Secretariat (2019). Key biodiversity areas proposal process: Guidance on proposing, reviewing, nominating and confirming sites. Version 1.0. Cambridge, UK: KBA Secretariat and KBA Committee of the KBA Partnership. http://www.keybiodiversityareas.org/userfiles/files/KBA\%20Proposal\%20Process-v1.0.pdf

KBA Standards and Appeals Committee (2019). Guidelines for using A global standard for the identification of Key Biodiversity Areas: Version 1.0. Prepared by the KBA Standards and Appeals Committee of the IUCN Species Survival Commission and IUCN World Commission on Protected Areas. Gland, Switzerland: IUCN. https://portals.iucn.org/library/node/47982

Kenya National Bureau of Statistics (KNBS) (2019). Economic survey 2019. Nairobi, Kenya: Kenya National Bureau of Statistics. https://www.knbs.or.ke/?wpdmpro=economic-survey-2019

Kenya Wildlife Service (KWS) (2015). Annual Report. Nairobi, Kenya: KWS. http://www.kws.go.ke/file/2559/ download?token=skN48S4I

Kingdom of Eswatini (2019). Sixth National Report to the United Nations Convention on Biological Diversity Project. Ministry of Tourism and Environmental Affairs. https://www.cbd.int/doc/nr/nr-06/sz-nr-06-en.pdf

Kingdom of Lesotho (2019). Sixth national report: Lesotho vision 2020. National Report on Biodiversity (draft) No. 6. https://www. cbd.int/doc/nr/nr-06/ls-nr-06-en.pdf

Knoema (n.d.). 'Rwanda - Contribution of travel and tourism to GDP as a share of GDP'. Knoema [website] https://knoema.com// atlas/Rwanda/topics/Tourism/Travel-and-Tourism-Total-Contribution-to-GDP/Contribution-of-travel-and-tourism-to-GDPpercent-of-GDP?origin=knoema.fr. Accessed: 27 March 2020.

Leverington, F., Lemos Costa, K., Courrau, J., Pavese, H., Nolte, C., Marr, M., Coad, L., Burgess, L.N., Bomhard, B. and Hockings, M. (2010). Management effectiveness evaluation in protected areas - A global study. Second edition - 2010. Brisbane, Australia: The University of Queensland. https://www.eci.ox.ac.uk/publications/downloads/coad11-protected-areas.pdf

Lewis, E., MacSharry, B., Juffe-Bignoli, D., Harris, N., Burrows, G., Kingston, N. and Burgess, N.D. (2017). 'Dynamics in the global protected-area estate since 2004'. Conservation Biology 33(3): 570-579. https://doi.org/10.1111/cobi.13056 
Lindsey, P.A. et al. (2017). 'The performance of African protected areas for lions and their prey'. Biological Conservation 209: 137-149. https://doi.org/10.1016/j.biocon.2017.01.011

Lindsey, P.A. et al. (2018). 'More than $\$ 1$ billion needed annually to secure Africa's protected areas with lions'. Proceedings of the National Academy of Sciences 115(45): E10788-E10796. https://doi.org/10.1073/pnas.1805048115

Loarie, S.R., Duffy, P.B., Hamilton, B., Asner, G.P., Field, C.B., and Ackerly, D.D. (2009). 'The velocity of climate change'. Nature 462: 1052-1055. https://doi.org/10.1038/nature08649

Long, S.A. (2002). Disentangling benefits: Livelihoods, natural resource management and managing revenue from tourism: The experience of the Torra Conservancy, Namibia. Directorate of Environmental Affairs, Ministry of Environment and Tourism. http:// www.met.gov.na/services/research-discussion-papers-rdp/158/

Lubilo R, Sitai N, Daka D, Kalaluka N, Booker F and Franks P (2019). 'Governance Assessment for Protected Areas and Conserved Areas (GAPA) '. Case study report. International Institute for Environment and Development. https://www.iied.org/assessing-governanceprotected-conserved-areas-gapa

Mascia, M.B. and Pailler, S. (2011). 'Protected area downgrading, downsizing, and degazettement (PADDD) and its conservation implications'. Conservation Letters 4(1): 9-20. https://doi.org/10.1111/j.1755-263X.2010.00147.x

Mascia, M.B., Pailler, S., Krithivasan, R., Roshchanka, V., Burns, D., Mlotha, M.J., Murray, D.R., Peng, N. (2014). 'Protected area downgrading, downsizing, and degazettement (PADDD) in Africa, Asia, and Latin America and the Caribbean, 1900-2010'. Biological Conservation 169: 355-361. https://doi.org/10.1016/j.biocon.2013.11.021

Mayaux, P., Pekel, J.-F., Desclée, B., Donnay, F., Lupi, A., Achard, F., Clerici, M., Bodart, C., Brink, A., Nasi, R. and Belward, A. (2013). 'State and evolution of the African rainforests between 1990 and 2010'. Philosophical Transactions of the Royal Society B: Biological Sciences 368: 20120300. https://doi.org/10.1098/rstb.2012.0300

McDermott, M., Mahanty, S. and Schreckenberg, K. (2013). 'Examining equity: A multidimensional framework for assessing equity in payments for ecosystem services'. Environmental Science and Policy 33: 416-427. https://doi.org/10.1016/j.envsci.2012.10.006

McNeely, J.A. and Miller, K. (1984). 'The role of protected areas in sustaining society'. In: National Parks, Conservation and Development. The role of protected areas in sustaining society. Proceedings of the World Congress on National Parks, Bali, Indonesia, 11-22 October 1982. Washington, DC, USA: Smithsonian Institute Press. https://portals.iucn.org/library/node/5846

Metzger, M.J., Bunce, R.G.H., Jongman, R.H.G., Sayre, R., Trabucco, A. and Zomer, R. (2013). 'A high-resolution bioclimate map of the world: a unifying framework for global biodiversity research and monitoring'. Global Ecology and Biogeography 22: 630-638. https://doi. org/10.1111/geb.12022

Millennium Ecosystem Assessment (MEA) (2005). Ecosystems and Human Well-Being: Synthesis. Washington, DC, USA: Island Press. https://www.millenniumassessment.org/documents/document.356.aspx.pdf

Mpingo Conservation and Development Initiative (MCDI) (2019). 'Group Certificate Members'. Mpingo Conservation and Development Initiative [website] http://www.mpingoconservation.org/what-we-do/forest-certification/certificate-members/?L=378

Namibian Association of CBNRM Support Organisations (NACSO) (n.d.). 'Regional Communal Conservancies'. NACSO [website]. http:// www.nacso.org.na/conservancies. Accessed 9/9/2019.

National Institute of Statistics of Rwanda (2017). Statistical year book 2017. Kigali, Rwanda. https://www.statistics.gov.rw/file/6157/ download?token=UErS25hP

Nolte, C., Leverington, F., Kettner, A., Marr, M., Nielsen, G., Bomhard, B., Stolton, S., Stoll-Kleemann, S. and Hockings, M. (2010). Protected area management effectiveness assessments in Europe: A review of applications, methods and results. BfN- Scripten No. 271a. Vilm, Germany: BfN. https://www.bfn.de/fileadmin/BfN/service/Dokumente/skripten/Skript_271a.pdf

O’Connell, M.J., Nasirwa, O., Carter, M., Farmer, K.H., Appleton, M., Arinaitwe, J., Bhanderi, P., Chimwaza, G., Copsey, J., Dodoo, J. et al. (2019). 'Capacity building for conservation: problems and potential solutions for sub-Saharan Africa'. Oryx 53(2): 273-283. https:// doi.org/10.1017/S0030605317000291

Oldekop, J.A., Holmes, G., Harris, W.E. and Evans, K.L. (2015). 'A global assessment of the social and conservation outcomes of protected areas'. Conservation Biology 30(1): 133-141. https://doi.org/10.1111/cobi.12568

OI Pejeta Conservancy (n.d.). OI Pejeta Conservancy [website]. https://www.olpejetaconservancy.org/about-us/our-story/. Accessed 5 January 2020.

Olson, D.M., Dinerstein, E., Wikramanayake, E.D., Burgess, N.D., Powell, G.V.N., Underwood, E.C., D’amico, J.A., Itoua, I. Strand, H.E., Morrison, J.C. et al. (2001). 'Terrestrial ecoregions of the world: A new map of life on earth: A new global map of terrestrial ecoregions provides an innovative tool for conserving biodiversity'. BioScience 51(11): 933-938. https://doi.org/10.1641/00063568(2001)051[0933:TEOTWA]2.0.CO;2 
Organisation for Economic Cooperation and Development (OECD) (2019). Biodiversity: Finance and the economic and business case for action, report prepared for the G7 environment ministers' meeting. https://www.oecd.org/env/resources/biodiversity/biodiversityfinance-and-the-economic-and-business-case-for-action.htm (link to report, summary and annexes; and French version)

Osipova, E. et al. (2017). IUCN World Heritage Outlook 2: A conservation assessment of all natural World Heritage sites. Gland, Switzerland: IUCN. https://doi.org/10.2305/IUCN.CH.2017.17.en

Packer, C., Loveridge, A., Canney, S., Caro, T., Garnett, S.T., Pfeifer, M., Zander, K.K., Swanson, A., MacNulty, D., Balme, G. et al. (2013). 'Conserving large carnivores: dollars and fence'. Ecology Letters 16(5): 635-641. https://doi.org/10.1111/ele.12091

Parker, C., Cranford, M., Oakes, N. and Leggett, M. (eds.) (2012). The little biodiversity finance book: A guide to proactive investment in natural capital - 3rd ed. Oxford: Global Canopy Programme. https://www.globalcanopy.org/sites/default/files/documents/resources/ LittleBiodiversityFinanceBook_3rd\%20edition.pdf

Parmesan, C. and Yohe, G. (2003). 'A globally coherent footprint of climate change impacts across natural systems'. Nature 421: $37-42$. https://doi.org/10.1038/nature01286

Qin, S., Golden Kroner, R.E., Cook, C., Tesfaw, A.T., Braybrook, R., Rodriguez, C.M., Poelking, C., Mascia, M.B. (2019). 'Protected area downgrading, downsizing, and degazettement as a threat to iconic protected areas'. Conservation Biology 33(6): 1275- 285. https://doi. org/10.1111/cobi.13365

Ramsar Convention on Wetlands (n.d.). 'Sites \& Countries'. Ramsar [website]. https://www.ramsar.org/sites-countries/the-ramsar-sites accessed 12 September 2019. https://www.ramsar.org/sites-countries

Republic of Angola (2014). 5th National Report on Biodiversity in Angola 2007-2012. Luanda, Angola. https://www.cbd.int/doc/world/ao/ ao-nr-05-en.pdf (in English); https://www.cbd.int/doc/world/ao/ao-nr-05-fr.pdf (in French);

Republic of Botswana (2015). Fifth National Report to the Convention of Biological Diversity 2015. Gabarone, Botswana: Department of Environmental Affairs. https://www.cbd.int/doc/world/bw/bw-nr-05-en.pdf

(2016). National Biodiversity Strategy and Action Plan. Gaborone, Botswana: Department of Environmental Affairs. https://www. cbd.int/doc/world/bw/bw-nbsap-v3-en.pdf

(2019). The Sixth National Report for the Convention of Biological Diversity. https://chm.cbd.int/pdf/documents/ nationalReport6/246394/1 (pdf) or https://chm.cbd.int/database/record?documentID=246394 (online)

République de Djibouti (2014). 5ème Rapport Convention sur la Diversité Biologique. National Report on Biodiversity No. 5. Ministère de l'Habitat, de l'Urbanisme et de l'Environnement. https://www.cbd.int/doc/world/dj/dj-nr-05-fr.pdf

(2017). Stratégie et Programme d'Action Nationaux pour la Biodiversite. (National Biodiversity Strategy and Action Plan). Ministère de l'Habitat, Urbanisme et l'Environnement, Direction de l'Aménagement du territoire et de l'environnement. https://www.cbd.int/doc/ world/dj/dj-nbsap-v2-fr.pdf

(2019). Gème Rapport. Convention sur la Diversité Biologique 2011-2020. National Report on Biodiversity No. 6. Ministère de l'Urbanisme, de l'Environnement et du Tourisme (MUET), Direction de l'Environnement et du Développement Durable. https://www.cbd. int/doc/nr/nr-06/dj-nr-06-fr.pdf

Republic of Ethiopia and Ethiopian Biodiversity Institute (2014). Ethiopia's Fifth National Report to the Convention on Biological Diversity. Addis Ababa. https://www.cbd.int/doc/world/et/et-nr-05-en.pdf

(2015). Ethiopia's National Biodiversity Strategy and Action Plan 2015-2020. Addis Ababa. https://www.cbd.int/doc/world/et/ et-nbsap-v2-en.pdf

(2019). Sixth National Report (2014-2018) to the Convention on Biological Diversity. https://chm.cbd.int/pdf/documents/ nationalReport6/245702/3 (PDF) or https://chm.cbd.int/database/record?documentID=245702 (online)

Republic of Kenya (2015). Fifth National Report to the Conference of Parties to the Convention on Biological Diversity 2015. Nairobi, Kenya: Ministry of Environment, Natural Resources and Regional Development Authorities. https://www.cbd.int/doc/world/ke/ke-nr-05en.pdf

Republic of Madagascar (2014). Cinquième rapport national de la Convention sur la Diversité Biologique de Madagascar Antananarivo, Madagascar: Ministère de l'Environnement et des Forêts. https://www.cbd.int/doc/world/mg/mg-nr-05-fr.pdf

(2016). National Biodiversity and Action Plan 2015-2025. National Biodiversity Strategy and Action Plan. Antananarivo, Madagascar: Ministère de l'environnement, de l'écologie, de la mer et des forêts. https://www.cbd.int/doc/world/mg/mg-nbsap-v2-en. pdf (English) and https://www.cbd.int/doc/world/mg/mg-nbsap-v2-fr.pdf (French)

(2019). Gème Rapport national sur la diversité biologique de Madagascar. Ministère de l'Environnement et du Développement Durable. https://www.cbd.int/doc/nr/nr-06/mg-nr-06-fr.pdf

Republic of Mauritius (2015). Fifth National Report on the Convention on Biological Diversity. Ministry of Agro-Industry and Food Security. https://www.cbd.int/doc/world/mu/mu-nr-05-en.pdf 
(2017). National Biodiversity Strategy and Action Plan 2017 - 2025. Ministry of Agro-Industry and Food Security. https://www.cbd. int/doc/world/mu/mu-nbsap-v2-en.pdf

Republic of Mozambique (2014). Fifth National report on the implementation of Convention on Biological Diversity in Mozambique. Maputo: Ministry for the Coordination of Environmental Affairs. https://www.cbd.int/doc/world/mz/mz-nr-05-en.pdf

(2015). National Strategy and Action Plan of Biological Diversity of Mozambique (2015-2035). Maputo: Ministério da Terra, Ambiente e Desenvolvimento Rural. https://www.cbd.int/doc/world/mz/mz-nbsap-v3-en.pdf

Republic of Namibia (2014). Fifth National report to the Convention on Biological Diversity (2010-2014). National Report on Biodiversity No. 5. Windhoek, Namibia: Ministry of Environment and Tourism. https://www.cbd.int/doc/world/na/na-nr-05-en.pdf

(2018). Sixth National Report to the Convention on Biological Diversity (2014-2018). Ministry of Environment and Tourism. https:// www.cbd.int/doc/nr/nr-06/na-nr-06-en.pdf

Republic of Rwanda (2009). Fourth national report to the Convention on Biological Diversity. National Report on Biodiversity No. 4. Kigali: Rwanda Environment Management Authority, Ministry of Natural Resources. https://www.cbd.int/doc/world/rw/rw-nr-04-en.pdf

(2014). Fifth National Report to the Convention on Biological Diversity. https://www.cbd.int/doc/world/rw/rw-nr-05-en.pdf

Republic of South Africa (2014). South Africa's Fifth National Report to the Convention on Biological Diversity. Pretoria: Department of Environmental Affairs. https://www.cbd.int/doc/world/za/za-nr-05-en.pdf

(2019). The Sixth National Report for the Convention of Biological Diversity. National Report on Biodiversity No. 6. https://chm.cbd. int/pdf/documents/nationalReport6/241240/2 (PDF) or https://chm.cbd.int/database/record?documentID=241240 (online)

Republic of South Sudan (2015). Fifth national report to the Convention of Biological Diversity. Ministry of Environment. https://www.cbd. int/doc/world/ss/ss-nr-05-en.pdf

(2019). National Biodiversity Strategy and Action Plan (2018-2027). Ministry of Environment and Forestry. https://www.cbd.int/doc/ world/ug/ug-nr-05-en.pdf

(2019). Sixth National Report to the Convention on Biological Diversity (6th NR) (Draft). Ministry of Environment and Forestry. https://www.cbd.int/doc/nr/nr-06/ss-nr-06-en.pdf

Republic of Sudan (2014). Sudan Fifth National Report to the Convention on Biological Diversity (CBD). Khartoum, Sudan: Ministry of Environment, Forestry and Physical Development, Higher Council for Environment and Natural Resources. https://www.cbd.int/doc/ world/sd/sd-nr-05-en.pdf

(2019). Sixth National Report for the Convention of Biological Diversity. https://chm.cbd.int/pdf/documents/ nationalReport6/241358/2 (PDF) and https://chm.cbd.int/database/record?documentID=241358 (online)

Republic of Uganda (2016). National Biodiversity Strategy and Action Plan II (2015-2025). Theme: Supporting Transition to a Middle Income Status and Delivery of Sustainable Development Goals. Kampala, Uganda: National Environment Management Authority (NEMA). https://chm.cbd.int/api/v2013/documents/13784B07-8850-A5BE-8960-90D65EAC1211/attachments/Uganda\%20-NBSAP-Resigned. pdf

Republic of Zambia (2015). Fifth National Report on Biodiversity. Lusaka: Ministry of Lands Natural Resources and Environmental Protection. https://www.cbd.int/doc/world/zm/zm-nr-05-en.pdf

(2019). Sixth National Report for the Convention of Biological Diversity. https://chm.cbd.int/pdf/documents/ nationalReport6/241363/3 PDF) or https://chm.cbd.int/database/record?documentID=241363 (online)

Republic of Zimbabwe (2014). National Biodiversity Strategy and Action Plan 2014. National Biodiversity Strategy and Action Plan No. 2. Harare: Ministry of Environment, Water and Climate. https://www.cbd.int/doc/world/zw/zw-nbsap-v2-en.pdf

(2015). Fifth National Report to the Convention on Biological Diversity. Harare: Ministry of Environment, Water and Climate. https:// www.cbd.int/doc/world/zw/zw-nr-05-en.pdf

(2019). Zimbabwe's Sixth National Report to the Convention on Biodiversity. Ministry of Environment, Tourism and Hospitality Industry. https://www.cbd.int/doc/nr/nr-06/zw-nr-06-en.pdf

Ripple, W.J., Chapron, G., López-Bao, J.V., Durant, S.M., Macdonald, D.W., Lindsey, P.A., Bennett, E.L., Beschta, R.L., Bruskotter, J.T., Campos-Arceiz, A. et al. (2016). 'Saving the World's Terrestrial Megafauna'. BioScience 66(10): 807-812. https://doi.org/10.1093/biosci/ biw092

Rwanda Development Board (RDB) (2017). 2017 Annual Report. Kigali, Rwanda: Rwanda Development Board. https://rdb.rw/wpcontent/uploads/2018/08/RDB-Annual-Report-2017-Final.pdf

Saura, S., Bastin, L., Battistella, L., Mandrici, A. and Dubois, G. (2017). 'Protected areas in the world's ecoregions: How well connected are they'? Ecological Indicators 76: 144-158. https://doi.org/10.1016/j.ecolind.2016.12.047

Saura, S., Bertzky, B., Bastin, L., Battistella, L., Mandrici, A. and Dubois, G. (2018). 'Protected area connectivity: Shortfalls in global targets and country-level priorities'. Biological Conservation 219: 53-67. https://doi.org/10.1016/j.biocon.2017.12.020 
(2019). 'Global trends in protected area connectivity from 2010 to 2018'. Biological Conservation 238(108183). https://doi. org/10.1016/j.biocon.2019.07.028

Scheffers, B.R., De Meester, L., Bridge, T.C.L., Hoffmann, A.A., Pandolfi, J.M., Corlett, R.T., Butchart, S.H.M., Pearce-Kelly, P., Kovacs, K.M., Dudgeon, D., et al. (2016). 'The broad footprint of climate change from genes to biomes to people'. Science 354: 6313. https://doi. org/10.1126/science.aaf7671

South African National Parks (SANParks) (2017). South African National Parks Annual Performance Plan Financial Year 2018/19. Pretoria, South Africa: SANParks. https://www.sanparks.org/assets/docs/about/annual_performance_plan_2018-2019.pdf

(2018). Annual Report 2017/2018. Pretoria, South Africa. https://www.sanparks.org/assets/docs/general/annual-report-2018.pdf

Southern African Development Community (SADC) Secretariat (2013). SADC Programme for Transfrontier Conservation Areas. Gaborone, Botswana: SADC. https://www.sadc.int/files/4614/2122/3338/SADC_TFCA_Programme_FINAL_doc_Oct_2013.pdf

(2018). Guidelines for Community Engagement in Southern African Development Community Transfrontier Conservation Areas - Final Draft. Gaborone, Botswana: SADC. https://tfcaportal.org/sites/default/files/public-docs/SADC\%20TFCA\%20Guideline \%20for\%20 Community\%20Engagement \%20\%20in\%20TFCAs\%20-\%20\%20Nov\%202018-\%20English\%20-\%20not\%20yet $\% 20$ endorsed.pdf

SADC Transfrontier Conservation Areas (TFCA) (2019). SADC TFCA Portal [website] https://tfcaportal.org/sadc-tfcas. Accessed 13 August 2019.

Schreckenberg, K., Camargo, I., Withnall, K., Corrigan, C., Franks, P., Roe, D., Scherl, L. M. and Richardson, V. (2010). Social assessment of conservation initiatives: A review of rapid methodologies. Natural Resources Issues No. 22. London: IIED. https://pubs.iied.org/ pdfs/14589IIED.pdf?

Schreckenberg, K., Franks, P., Martin, A. and Lang, B. (2016). 'Unpacking equity for protected area conservation'. Parks 22(2): 11-26. https://doi.org/10.2305/IUCN.CH.2016.PARKS-22-2KS.en

Schultz, L., Folke, C., Österblom, H. and Olsson, P. (2015). 'Adaptive governance, ecosystem management, and natural capital'. Proceedings of the National Academy of Sciences 112(24): 7369-7374. https://doi.org/10.1073/pnas.1406493112

Schulze, K., Knights, K., Coad, L., Geldmann, J., Leverington, F., Eassom, A., Marr, M., Butchart, S.H.M., Hockings, M., Burgess, N.D. (2018). 'An assessment of threats to terrestrial protected areas'. Conservation Letters 11(3): e12435. https://doi.org/10.1111/conl.12435

Secretariat of the Convention on Biological Diversity (CBD) (2014). Global Biodiversity Outlook 4 - Summary and Conclusions. Montreal, Canada: Secretariat of the CBD. https://www.cbd.int/gbo/gbo4/gbo4-summary-en.pdf

Seol, M. (2016). 'New finance model brings extraordinary conservation measures to life'. Harvard Government Innovators Network [blogpost], 13 September 2016. https://www.innovations.harvard.edu/blog/new-finance-model-brings-extraordinary-conservationmeasures-life

Snyman, S. (2012). 'Ecotourism joint ventures between the private sector and communities: An updated analysis of the Torra Conservancy and Damaraland Camp partnership, Namibia'. Tourism Management Perspectives 4: 127-135. https://doi.org/10.1016/j. tmp.2012.07.004

South African National Lotteries Commission (NLCSA) (2019). National Lotteries Commission [website]. http://www.nlcsa.org.za/ wp-content/uploads/2019/02/National-Lotteries-Commision-54X10-Light-Blue-Final.pdf

Space For Giants, UN Environment and Conservation Capital (2019). Building a wildlife economy. Working Paper 1: Developing NatureBased Tourism in African State Protected Areas. https://spaceforgiants.org/wp-content/uploads/2019/06/Building-Africas-WildlifeEconomy-Space-for-Giants-Working-Paper-1.pdf

Spalding, M.D., Agostini, V.N., Rice, J. and Grant, S.M. (2012). 'Pelagic provinces of the world: A biogeographic classification of the world's surface pelagic waters'. Ocean and Coastal Management 60: 19-30. https://doi.org/10.1016/j.ocecoaman.2011.12.016

Spalding, M.D. et al. (2007). 'Marine Ecoregions of the World: A Bioregionalization of Coastal and Shelf Areas'. BioScience 57(7): 573-583. https://doi.org/10.1641/B570707

Spenceley, A. (2018). Development of a SADC Guideline on cross border tourism products in TFCAs. SADC Guideline for cross-border tourism products. https://www.tfcaportal.org/sites/default/files/public-docs/SADC\%20Guideline\%20on \%20Cross-border\%20 tourism\%20products\%20in\%20TFCAs_2\%20August\%202018\%20Final\%20Draft_\%20not\%20yet\%20endorsed.pdf

Spenceley, A., Rylance, A. and Laiser, S.L. (2017). 'Protected area entrance fees in Tanzania: The search for competitiveness and value for money'. Koedoe - African Protected Area Conservation and Science 59(1): a1442. https://doi.org/10.4102/koedoe.v59i1.1442

State of Eritrea (2014). The 5th National Report on the Implementation of the UNCBD.. Asmara, Eritrea. https://www.cbd.int/doc/world/er/ er-nr-05-en.pdf

(2015). Revised National Biodiversity Strategy and Action Plan for Eritrea (2014-2020). National Biodiversity Strategy and Action Plan (NBSAP) No. 2. Asmara, Eritrea: Ministry of Land, Water and Environment, Department of Environment. https://www.cbd.int/doc/ world/er/er-nbsap-v2-en.pdf 
Stattersfield, A.J., Crosby, M.J., Long, A.J. and Wege, D.C. (1998). Endemic Bird Areas of the World. Priorities for biodiversity conservation. BirdLife Conservation Series No. 7. Cambridge: BirdLife International. http://datazone.birdlife.org/info/pubEBAs

Stoll-Kleeman, S., Bender, S., Berghöfer, A., Bertzky, M., Fritz-Vietta, N., Schliep, R. and Thierfelder, B. (2006). Linking governance and management perspectives with conservation success in protected areas and Biosphere Reserves. Perspectives on Biodiversity Governance and Management No. Discussion Paper 01. Berlin: GoBi Research Group. https://citeseerx.ist.psu.edu/viewdoc/ download?doi=10.1.1.474.1324\&rep=rep1\&type=pdf

Stolton, S. and Dudley, N. (2016). METT Handbook: A guide to using the Management Effectiveness Tracking Tool (METT). WWF-UK, Woking. https://www.protectedplanet.net/system/comfy/cms/files/files/000/000/208/original/WWF_METT_Handbook_2016_FINAL_0. pdf

Subsidiary Body on Scientific, Technical and Technological Advice (SBSTTA) (2010). In-depth review of the implementation of the Programme of Work on Protected Areas. No. UNEP/CBD/SBSTTA/14/5. Nairobi: Convention on Biological Diversity. http://www.cbd.int/ doc/meetings/sbstta/sbstta-14/official/sbstta-14-05-en.pdf (English) and https://www.cbd.int/kb/record/ meetingDocument/67344?RecordType=meetingDocument (for links to Word formats and other languages)

Swart, I. (2019). 'Carbon tax effective from 1 June 2019 following Presidential assent'. Deloitte South Africa [online article]. https://www2. deloitte.com/za/en/pages/tax/articles/carbon_tax_2019.html. Accessed: 21 January 2020.

Symes, W.S., Rao, M., Mascia, M.B. and Carrasco, L.R. (2016). 'Why do we lose protected areas? Factors influencing protected area downgrading, downsizing and degazettement in the tropics and subtropics'. Global Change Biology 22(2): 656-665. https://doi. org/10.1111/gcb.13089

Tanzania National Parks (Unpublished). Annual report 2013.

Tessema, Y. (Unpublished). A review of policy and legislation related to protected area management, governance and equity in the Eastern and Southern Africa region. A report prepared for BIOPAMA Eastern and Southern Africa. BIOPAMA, IUCN ESARO.

The Lion's Share (2020). The Lion's Share [website]. https://thelionssharefund.com/

The Nature Conservancy (n.d.). 'IUCN-CMP Unified Classifications of Direct Threats and Conservation Actions'. Conservation Gateway [website]. https://www.conservationgateway.org/ExternalLinks/Pages/iucn-cmp-unified-classifi.aspx (accessed 20 November 2019).

The Northern Rangelands Trust (2018). State of Conservancies Report 2018. Kenya: The Northern Rangelands Trust. https://static1. squarespace.com/static/5af1629f12b13f5ce97ca0b5/t/5c9df55b71c10b45cbb2c862/1553856154045/SOCR2018

The World Bank Group (2018). 'Sovereign blue bond issuance: Frequently Asked Questions'. World Bank [online feature story], 29 October 2018. https://www.worldbank.org/en/news/feature/2018/10/29/sovereign-blue-bond-issuance-frequently-asked-questions.

Thomas, C.D. and Gillingham, P.K. (2015). 'The performance of protected areas for biodiversity under climate change'. Biological Journal of the Linnean Society 115(3): 718-730. https://doi.org/10.1111/bij.12510

Uganda Biodiversity Fund (n.d.). Uganda Biodiversity Fund. https://ugandabiodiversityfund.org/. Accessed 21 January 2020.

Uganda National Environment Management Agency (2014). Fifth National Report to the Convention on Biological Diversity. Kampala, Uganda: National Environment Management Authority, Ministry of Water and Development. https://www.cbd.int/doc/world/ug/ ug-nr-05-en.pdf

Uganda Wildlife Authority (UWA) (Unpublished). Annual Report 2015.

(2018). Uganda Wildlife Authority Corporate Report 2018. https://www.ugandawildlife.org/download/category/12-annualreports?download=39:corporate-annual-report-2018

United Nations (UN) (2016). Report of the Special Rapporteur on the Rights of Indigenous Peoples: Conservation Measures and Their Impact on Indigenous People's Rights. United Nations General Assembly, Seventy-first Session, A/71/229. New York: United Nations. https://www.un.org/en/ga/search/view_doc.asp?symbol=A/71/229

UNDP Ecosystems and Biodiversity (2018). 'Results for rhinos. Using innovative financing to achieve conservation outcomes'. Exposure [online article], 2 March 2018. https://undp-biodiversity.exposure.co/results-for-rhinos

United Nations Educational, Scientific and Cultural Organization (UNESCO) (1971). The Convention on Wetlands of International Importance especially as Waterfowl Habitat. Paris. https://treaties.un.org/doc/Publication/UNTS/Volume\%20996/volume-996-I-14583English.pdf

(1972). Convenção para a Protecção do Património Mundial, Cultural e Natural. Adotado pela Conferência Geral em sua décima sétima sessão, 16 de novembro de 1972. Paris: UNESCO. https://whc.unesco.org/archive/convention-pt.pdf

(n.d.a). 'Biosphere Reserves'. UNESCO [website] http://www.unesco.org/new/en/natural-sciences/environment/ecologicalsciences/biosphere-reserves/ 
(n.d.b). 'World Heritage List'. UNESCO World Heritage Centre [website]. https://whc.unesco.org/en/list/

United Nations Environment Programme Wildlife Conservation Management Centre (UNEP-WCMC) and IUCN (2016). Protected Planet Report 2016: How protected areas contribute to achieving global targets for biodiversity. Cambridge, UK and Gland, Switzerland: UNEP-WCMC and IUCN. https://www.iucn.org/theme/protected-areas/publications/protected-planet-report

(2019a). Protected Planet: World Database on Protected Areas (WDPA) [On-line], September 2019. Cambridge, UK: UNEP-WCMC and IUCN. https://www.protectedplanet.net/

(2019b). Protected Planet: User Manual for the World Database on Protected Areas and world database on other effective areabased conservation measures: 1.6. Cambridge, UK: UNEP-WCMC. https://www.protectedplanet.net/c/wdpa-manual/wdpamanual-v16.

(2019c). 'Protected Planet: Protected area dataset for Angola'; The World Database on Protected Areas (WDPA)/The Global Database on Protected Areas Management Effectiveness (GD-PAME)] [On-line], September 2019. Cambridge, UK: UNEP-WCMC and IUCN. https://www.protectedplanet.net/country/AO.

(2019d). 'Protected Planet: Protected area dataset for Botswana'; The World Database on Protected Areas (WDPA)/The Global Database on Protected Areas Management Effectiveness (GD-PAME)] [On-line], September 2019. https://www.protectedplanet.net/ country/BW

(2019e). 'Protected Planet: Protected area dataset for Comoros'; The World Database on Protected Areas (WDPA)/The Global Database on Protected Areas Management Effectiveness (GD-PAME)] [On-line], September 2019. https://www.protectedplanet.net/ country/KM.

(2019f). 'Protected Planet: Protected area dataset for Djibouti'; The World Database on Protected Areas (WDPA)/The Global Database on Protected Areas Management Effectiveness (GD-PAME)] [On-line], September 2019. https://www.protectedplanet.net/ country/DJ.

(2019g). 'Protected Planet: Protected area dataset for Eritrea'; The World Database on Protected Areas (WDPA)/The Global Database on Protected Areas Management Effectiveness (GD-PAME)] [On-line], September 2019. https://www.protectedplanet.net/ country/ER

(2019h). 'Protected Planet: Protected area dataset for eSwatini'; The World Database on Protected Areas (WDPA)/The Global Database on Protected Areas Management Effectiveness (GD-PAME)] [On-line], September 2019. https://www.protectedplanet.net/ country/SZ

(2019i). 'Protected Planet: Protected area dataset for Ethiopia'; The World Database on Protected Areas (WDPA)/The Global Database on Protected Areas Management Effectiveness (GD-PAME)] [On-line], September 2019. https://www.protectedplanet.net/ country/ET.

(2019j). 'Protected Planet: Protected area dataset for Kenya'; The World Database on Protected Areas (WDPA)/The Global Database on Protected Areas Management Effectiveness (GD-PAME)] [online], September 2019. https://www.protectedplanet.net/country/KE.

(2019k). 'Protected Planet: Protected area dataset for Lesotho'; The World Database on Protected Areas (WDPA)/The Global Database on Protected Areas Management Effectiveness (GD-PAME)] [online], September 2019. https://www.protectedplanet.net/ country/LS.

(2019l). 'Protected Planet: Protected area dataset for Madagascar'; The World Database on Protected Areas (WDPA)/The Global Database on Protected Areas Management Effectiveness (GD-PAME)] [online], September 2019. https://www.protectedplanet.net/ country/MG

(2019m). 'Protected Planet: Protected area dataset for Malawi'; The World Database on Protected Areas (WDPA)/The Global Database on Protected Areas Management Effectiveness (GD-PAME)] [online], September 2019. https://www.protectedplanet.net/ country/MW

(2019n). 'Protected Planet: Protected area dataset for Mauritius'; The World Database on Protected Areas (WDPA)/The Global Database on Protected Areas Management Effectiveness (GD-PAME)] [online], September 2019. https://www.protectedplanet.net/ country/MU.

(2019o). 'Protected Planet: Protected area dataset for Mozambique; The World Database on Protected Areas (WDPA)/The Global Database on Protected Areas Management Effectiveness (GD-PAME)] [Online], September 2019. https://www.protectedplanet.net/ country/MZ.

(2019p). 'Protected Planet: Protected area dataset for Namibia'; The World Database on Protected Areas (WDPA)/The Global Database on Protected Areas Management Effectiveness (GD-PAME)] [online], September 2019. https://www.protectedplanet.net/ country/NA.

(2019q). 'Protected Planet: Protected area dataset for Rwanda'; The World Database on Protected Areas (WDPA)/The Global Database on Protected Areas Management Effectiveness (GD-PAME)] [online], September 2019. https://www.protectedplanet.net/ country/RW. 
(2019r). 'Protected Planet: Protected area dataset for Seychelles'; The World Database on Protected Areas (WDPA)/The Global Database on Protected Areas Management Effectiveness (GD-PAME)] [online], September 2019. https://www.protectedplanet.net/ country/SC.

(2019s). 'Protected Planet: Protected area dataset for Somalia'; The World Database on Protected Areas (WDPA)/The Global Database on Protected Areas Management Effectiveness (GD-PAME)] [Online], September 2019. https://www.protectedplanet.net/ country/SO.

(2019t). 'Protected Planet: Protected area dataset for South Africa'; The World Database on Protected Areas (WDPA)/The Global Database on Protected Areas Management Effectiveness (GD-PAME)] [Online], September 2019. https://www.protectedplanet.net/ country/ZA.

(2019u). 'Protected Planet: Protected area dataset for South Sudan'; The World Database on Protected Areas (WDPA)/The Global Database on Protected Areas Management Effectiveness (GD-PAME)] [online], September 2019. https://www.protectedplanet.net/ country/SS.

(2019v). 'Protected Planet: Protected area dataset for Sudan'; The World Database on Protected Areas (WDPA)/The Global Database on Protected Areas Management Effectiveness (GD-PAME)] [online], September 2019. https://www.protectedplanet.net/ country/SD.

(2019w). 'Protected Planet: Protected area dataset for Tanzania'; The World Database on Protected Areas (WDPA)/The Global Database on Protected Areas Management Effectiveness (GD-PAME)] [online], September 2019. https://www.protectedplanet.net/ country/TZ.

(2019x).'Protected Planet: Protected area dataset for Uganda'; The World Database on Protected Areas (WDPA)/The Global Database on Protected Areas Management Effectiveness (GD-PAME)] [online], September 2019. https://www.protectedplanet.net/ country/UG.

(2019y). 'Protected Planet: Protected area dataset for Zambia'; The World Database on Protected Areas (WDPA)/The Global Database on Protected Areas Management Effectiveness (GD-PAME)] [online], September 2019. https://www.protectedplanet.net/ country/ZM.

(2019z). 'Protected Planet: Protected area dataset for Zimbabwe'; The World Database on Protected Areas (WDPA)/The Global Database on Protected Areas Management Effectiveness (GD-PAME)] [online], September 2019. https://www.protectedplanet.net/ search?q=zimbabwe.

(2019aa). 'Protected Planet: Protected Area Management Effectiveness (PAME)'. The World Database on Protected Areas (WDPA)/ The Global Database on Protected Areas Management Effectiveness (GD-PAME)] [On-line], 10 August 2019. Cambridge, UK: UNEPWCMC and IUCN. https://www.protectedplanet.net/c/protected-areas-management-effectiveness-pame. Accessed: 10 August 2019.

UNEP-WCMC, IUCN and National Geographic Society (NGS) (2018). Protected Planet Report 2018: Tracking progress towards global targets for protected areas. Cambridge UK; Gland, Switzerland; and Washington, DC, USA: UNEP-WCMC, IUCN and NGS. https:// livereport.protectedplanet.net/pdf/Protected_Planet_Report_2018.pdf

(2019). Protected Planet Live Report 2019. Cambridge UK; Gland, Switzerland; and Washington, DC, USA: UNEP-WCMC, IUCN and NGS. Accessed in September 2019.

United Nations Global Compact (UNGC) and IUCN (2012). A framework for corporate action on biodiversity and ecosystem services. https://portals.iucn.org/library/node/10174

Union des Comores (2014). 5ème Rapport national sur la diversité biologique (Fifth National Report on Biodiversity of Comoros). https:// www.cbd.int/doc/world/km/km-nr-05-fr.pdf

(2016). Stratégie nationale et Plan d'Action Actualisés pour la Diversité Biologique V2.2 (Updated National Strategy and Action Plan for Biological Diversity V2.2). https://www.cbd.int/doc/world/km/km-nbsap-v2-fr.pdf

(2017). Stratégie d'expansion du système national des aires protégées aux Comores, 2017-2021 (Strategy to expand the system of national protected areas of Comoros, 2017-2021). Directorate General for Environment and Forestry (DGEF). PNUD/GEF Comores: DGEF, VP-MAPEATU.

(2019). Gème Rapport national sur la biodiversité de l'Union des Comores (Sixth National Report on Biodiversity of Comoros). Ministère de l'Agriculture, de la Pêche et de l'Environnement. https://www.cbd.int/doc/nr/nr-06/km-nr-06-fr.pdf

United Republic of Tanzania (1998). National Forestry Policy. Dar es Salaam, Tanzania: Tanzania: Ministry of Natural Resources and Tourism. http://www.fao.org/forestry/15159-06c36bd31a5b3877ae3168cc5bedadd18.pdf

(2014). Fifth National Report on the Implementation of the Convention on Biological Diversity. Dar es Salaam, Tanzania: Division of Environment, Vice President's Office. http://www.cbd.int/doc/world/tz/tz-nr-05-en.pdf

(2019). The Sixth National Report for the Convention of Biological Diversity. https://chm.cbd.int/pdf/documents/ nationalReport6/245938/1 (PDF) or https://chm.cbd.int/database/record?documentID=245938 (online) 
Visconti, P., Marco, M.D., Álvarez-Romero, J.G., Januchowski-Hartley, S.R., Pressey, R.L., Weeks, R. and Rondinini, C. (2013). 'Effects of Errors and Gaps in Spatial Data Sets on Assessment of Conservation Progress'. Conservation Biology 27(5): 1000-1010. https://doi. org/10.1111/cobi.12095

Watson, J.E.M., Dudley, N., Segan, D.B. and Hockings, M. (2014). 'The performance and potential of protected areas'. Nature 515(7525): 67-73. https://doi.org/10.1038/nature13947

Wildlife Works (n.d.). Wildlife works. REDD+ conservation programme [website]. https://www.wildlifeworks.com Accessed: 21 January 2020.

World Bank Group (n.d.). 'International tourism, number of arrivals'. World Bank DataBank [website], https://data.worldbank.org/ indicator/st.int.arvl. Accessed: 15 October 2019

Worldometer (n.d.). 'Africa Population'. Worldometer [website]. https://www.worldometers.info/world-population/africa-population/. Accessed: 17 December 2019.

World Tourism Organization (WTO) (2014). Towards measuring the economic value of wildlife watching tourism in Africa. Briefing Paper. Madrid: UNWTO. https://doi.org/10.18111/9789284416752

World Travel and Tourism Council (WTTO) (2019). 'Country reports'. WTTO [website]. https://www.wttc.org/economic-impact/countryanalysis/country-reports/

Wright, E. (2018). 'Leveraging PPPs in Mozambique to scale conservation and promote economic development'. World Bank [blogpost], 18 July 2018. https://blogs.worldbank.org/ppps/leveraging-ppps-mozambique-scale-conservation-and-promote-economicdevelopment. Accessed 27 March 2020.

World Wildlife Fund (WWF) (2009). Guide to Conservation Finance: Sustainable Financing for the Planet. Washington DC, USA: World Wildlife Fund (WWF). http://awsassets.panda.org/downloads/wwf_guide_to_conservation_finance.pdf

(2017). 'Southern Africa: Northwestern Madagascar'. The Global Ecoregions [website]. https://www.worldwildlife.org/ecoregions/ at0202 Zafra-Calvo, N., Pascual, U., Brockington, D., Coolsaet, B., Cortes-Vazquez, J.A., Gross-Camp, N., Palomo, I., Burgess, N.D. (2017). 'Towards an indicator system to assess equitable management in protected areas'. Biological Conservation 211(Part A): $134-141$. https://doi.org/10.1016/j.biocon.2017.05.014

Zunckel, K. (2014). Southern African Development Community Transfrontier Conservation Guidelines: The establishment and development of TFCA initiatives between SADC member states. Gaborone, Botswana: SADC. https://www.academia.edu/12527362/SOUTHERN AFRICAN_DEVELOPMENT_COMMUNITY_TRANSFRONTIER_CONSERVATION_GUIDELINES_The_establishment_and_development_ of_TFCA_initiatives_between_SADC_Member_States 



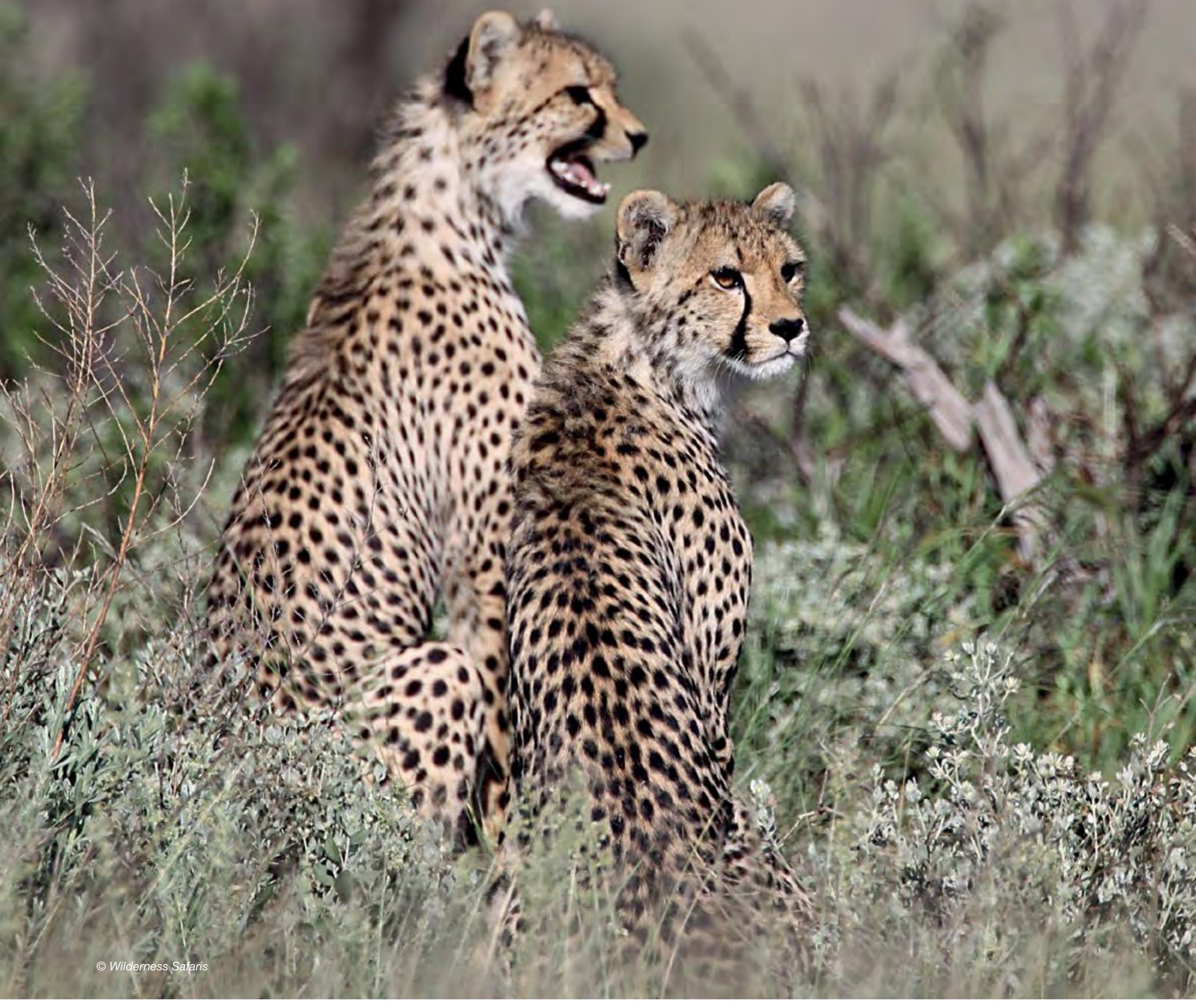




\section{Apêndices}




\section{Índice}

Apêndice 1. Pontos Focais BIOPAMA 219

Apêndice 2. Estatísticas regionais sobre áreas protegidas e de conservação na África Oriental e Austral ...... .220

A2-Quadro 1. Áreas terrestres protegidas e de conservação na África Oriental e Austral ......................................................220

A2-Quadro 2. Áreas costeiras e marinhas protegidas e de conservação na África Oriental e Austral.....................................221

A2-Quadro 3. Categorias de gestão de áreas protegidas e de conservação da UICN na África Oriental e Austral ...................221

A2-Quadro 4. Tipos de governação das áreas protegidas e de conservação da UICN na África Oriental e Austral...................222

Apêndice 3. Sítios globais de importância na África Oriental e Austral ..............................................................................222

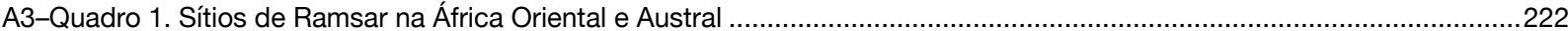

A3-Quadro 2. Reservas de Homem e da Biosfera na África Oriental e Austral ................................................................226

Apêndice 4. Representatividade ecológica na África Oriental e Austral .............................................................................227

A4-Quadro 1. Representatividade ecológica nas áreas protegidas da África Oriental e Austral...........................................227

Apêndice 5. Instrumentos legais de apoio à equidade e governação não estatal de áreas protegidas............................................228

Apêndice 6. Áreas protegidas e de conservação nas Categorias de Gestão da UICN por país ....................................................230

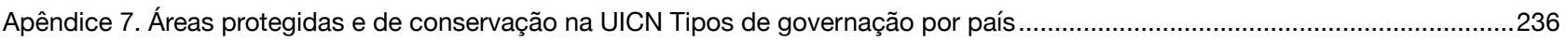




\section{Apêndice 1. Pontos Focais BIOPAMA}

\begin{tabular}{|c|c|c|}
\hline País & Nome do ponto focal & Instituição \\
\hline Angola & Marta Zumbo & Ministério do Ambiente, Chefe das Áreas Protegidas \\
\hline Botswana & Bakang Mokime & $\begin{array}{l}\text { Departamento de Vida Selvagem e Parques Nacionais, Ministério do Ambiente, } \\
\text { Vida Selvagem e Turismo }\end{array}$ \\
\hline Comores & Moina Hali & Direcção Geral do Ambiente e Silvicultura \\
\hline Djibouti & Mohamed Elmni Obsieh & Ministério do Ambiente \\
\hline Eritreia & Estefanios Bein & Ministério da Terra, Água e Ambiente \\
\hline Eritreia & Fatsum Hagos & Autoridade Florestal e da Vida Selvagem \\
\hline Eswatini & Thulani Methula & Comissão Nacional do Fundo Eswatini \\
\hline Etiópia & Gebremeskel Gizaw Kassa & Autoridade Etíope para a Conservação da Vida Selvagem \\
\hline Quénia & Arthur Tuda for MPA & Serviço de Vida Selvagem do Quénia (KWS) \\
\hline Lesoto & Mamasheane Motabotabo & Departamento do Ambiente, Ministério do Turismo Ambiente e Cultura \\
\hline Malawi & Davis Kalima & Departamento de Parques Nacionais e Vida Selvagem \\
\hline Madagáscar & Ramanantsoa Seheno & Ministério do Ambiente, Ecologia e Florestas \\
\hline Madagáscar & Rakotobe Domoina & Sociedade de Conservação da Vida Selvagem \\
\hline Maurícias & Kevin Ruhomaun & Parque Nacional e Serviço de Conservação \\
\hline Moçambique & Raimundo Vasco Matusse & Administração Nacional de Áreas de Conservação \\
\hline Namíbia & Shayne Kotting & Ministério do Ambiente e Turismo \\
\hline Ruanda & Eugene Mutangana & Conselho de Desenvolvimento do Ruanda \\
\hline Seychelles & Selby Remy & Autoridade dos Parques Nacionais das Seychelles \\
\hline Somália & Mohamed Moallim Osman & $\begin{array}{l}\text { Director de Sensibilização Ambiental, Gabinete de Assuntos Ambientais do } \\
\text { Gabinete do Primeiro Ministro }\end{array}$ \\
\hline África do Sul & Karl Naude & Departamento de Assuntos Ambientais \\
\hline África do Sul & Thivhulawi Nethononda & Departamento de Assuntos Ambientais \\
\hline Sudão do Sul & Malik Doka Morgan & Ministério da Conservação da Vida Selvagem e Turismo \\
\hline Sudão do Sul & Lona Nalurit Darius & Ministério da Conservação da Vida Selvagem e Turismo \\
\hline Sudão & Noureldin Ahmed Abdalla & Conselho Superior do Ambiente e Recursos Naturais \\
\hline Sudão & Khidir Elsadig Jabir Arin & Administração Geral de Conservação da Vida Selvagem \\
\hline Tanzânia & Paul Banga & Autoridade dos Parques Nacionais da Tanzânia \\
\hline Tanzânia & Dr James Wakibara & Autoridade de Gestão da Vida Selvagem da Tanzânia \\
\hline Tanzânia & Asanterabi Lowassa & Instituto de Investigação da Vida Selvagem da Tanzânia \\
\hline Tanzânia & Prof. Dos Santos (CEO) & Serviço Florestal da Tanzânia \\
\hline Uganda & John Makombo & Autoridade da Vida Selvagem do Uganda \\
\hline Zâmbia & Chisha Moseni & Departamento de Parques Nacionais e Vida Selvagem \\
\hline Zâmbia & Sydney Tembo & Departamento de Parques Nacionais e Vida Selvagem \\
\hline Zimbabué & Geoffreys Matipano & Autoridade de Gestão de Parques e Fauna Bravia do Zimbabué \\
\hline
\end{tabular}




\section{Apêndice 2. Estatísticas regionais sobre áreas protegidas e de conservação na África Oriental e Austral}

A2-Quadro 1. Áreas terrestres protegidas e de conservação na África Oriental e Austral

\begin{tabular}{|c|c|c|c|c|c|}
\hline Pais & $\begin{array}{l}\text { Numero de áreas } \\
\text { protegidas* }\end{array}$ & $\begin{array}{r}\text { Área terrestre } \\
\text { coberta em áreas } \\
\text { protegidas }\left(\mathrm{km}^{2 \star}\right)\end{array}$ & $\begin{array}{r}\% \text { de área } \\
\text { terrestre coberta } \\
\text { em áreas } \\
\text { protegidas }^{\star}\end{array}$ & $\begin{array}{r}\% \text { de área } \\
\text { terrestre coberta } \\
\text { em áreas } \\
\text { protegidas e de } \\
\text { conservação** }\end{array}$ & $\begin{array}{r}\% \text { de área } \\
\text { terrestre } \\
\text { protegida e } \\
\text { ligada }^{\star * \star}\end{array}$ \\
\hline Angola & 13 & 87507 & $6.97 \%$ & $12.50 \%$ & $2.56 \%$ \\
\hline Botswana & 22 & 169370 & $29.14 \%$ & $29.10 \%$ & $18.37 \%$ \\
\hline Comores & 5 & 173 & $10.15 \%$ & $22.00 \%$ & $10.21 \%$ \\
\hline Djibouti & 3 & 344 & $1.57 \%$ & $1.34 \%$ & $1.34 \%$ \\
\hline Eritreia & 4 & 5936 & $4.87 \%$ & Not found & $3.21 \%$ \\
\hline Eswatini & 14 & 738 & 4.26 & $3.90 \%$ & $2.7 \%$ \\
\hline Etiópia & 104 & 200074 & $17.62 \%$ & $14.00 \%$ & $8.28 \%$ \\
\hline Quénia & 391 & 72545 & $12.36 \%$ & $8 \%$ & $5.55 \%$ \\
\hline Lesoto & 4 & 80 & $0.26 \%$ & $0.50 \%$ & $0.24 \%$ \\
\hline Madagáscar & 109 & 33242 & $5.59 \%$ & Not found & $1.7 \%$ \\
\hline Malawi & 133 & 27190 & $22.88 \%$ & $15.12 \%$ & $11.39 \%$ \\
\hline Maurícias & 15 & 97 & $4.73 \%$ & $4.00 \%$ & $3.41 \%$ \\
\hline Moçambique & 42 & 170662 & $21.57 \%$ & $26.00 \%$ & $8.87 \%$ \\
\hline Namíbia & 146 & 313534 & $37.89 \%$ & $17.00 \%$ & $28.08 \%$ \\
\hline Ruanda & 10 & 2320 & $9.11 \%$ & $10.10 \%$ & $5.75 \%$ \\
\hline Seychelles & 10 & 242 & $49.64 \%$ & $46.60 \%$ & $36.96 \%$ \\
\hline Somália & 20 & $0^{117}$ & $0.00 \%$ & $0.80 \%$ & N/A \\
\hline África do Sul & 1444 & 102060 & $8.34 \%$ & $12.96 \%$ & $2.47 \%$ \\
\hline Sul do Sudão & 27 & 98214 & $15.50 \%$ & $13.00 \%$ & $6.65 \%$ \\
\hline Sudão & 19 & 42698 & $2.28 \%$ & $5.80 \%$ & $1.17 \%$ \\
\hline Tanzânia & 709 & 361594 & $38.17 \%$ & $54.60 \%$ & $21.55 \%$ \\
\hline Uganda & 712 & 39059 & $16.06 \%$ & $18.00 \%$ & $6.66 \%$ \\
\hline Zâmbia & 635 & 286161 & $37.87 \%$ & $37.80 \%$ & $16.28 \%$ \\
\hline Zimbabué & 232 & 106837 & $27.21 \%$ & $28.00 \%$ & $19.76 \%$ \\
\hline TOTAL & $4821^{118}$ & $2120112^{119}$ & $16.54 \%$ & N/A & $\mathrm{N} / \mathrm{A}$ \\
\hline
\end{tabular}

Fontes: *World Database on Protected Areas (UNEP-WCMC \& IUCN, 2019a); ** National Reports to the Convention on Biological Diversity. *** EC JRC/DOPA (2019).

118 Há duas áreas protegidas transfronteiriças dentro deste Quadro, que se enquadram em quatro países (Lesoto/África do Sul e Zâmbia/Zimbabué). Cada sítio é contado uma vez no total de cada país; contudo, cada sítio é contado apenas uma vez no número total para a região.

119 Calculado directamente da Base de Dados Mundial sobre Áreas Protegidas, em vez de uma simples soma de todas as áreas do país. 
A2-Quadro 2. Áreas costeiras e marinhas protegidas e de conservação na África Oriental e Austral

\begin{tabular}{|c|c|c|c|c|}
\hline Nome & $\begin{array}{r}\text { Número } \\
\text { (WDPA) }\end{array}$ & $\begin{array}{r}\text { Área costeira e marinha } \\
\text { coberta em áreas } \\
\text { protegidas } \mathrm{km}^{2 *}\end{array}$ & $\begin{array}{r}\% \text { da área costeira e } \\
\text { marinha coberta em áreas } \\
\text { protegidas }^{\star \star}\end{array}$ & $\begin{array}{r}\% \text { da área costeira e } \\
\text { marinha coberta em áreas } \\
\text { protegidas }^{*}\end{array}$ \\
\hline Angola & 1 & 24 & 0 & $0.0 \%$ \\
\hline Comores & 3 & 37 & 0 & $0.02 \%$ \\
\hline Djibouti & 4 & 12 & $0.46 \%$ & $0.17 \%$ \\
\hline Eritreia & 0 & 0 & 0 & $0.0 \%$ \\
\hline Quénia & 20 & 904 & 0 & $0.8 \%$ \\
\hline Madagáscar & 48 & 8998 & 0 & $0.75 \%$ \\
\hline Maurícias & 29 & 50 & 0 & $0.0 \%$ \\
\hline Moçambique & 2 & 12821 & 0 & $2.23 \%$ \\
\hline Namíbia & 2 & 9646 & $0.01 \%$ & $1.71 \%$ \\
\hline Seychelles & 30 & 209930 & $0.03 \%$ & $15.66 \%$ \\
\hline Somália & 1 & 0 & 0 & 0 \\
\hline África do Sul & 136 & 224640 & $10 \%$ & $14.56 \%$ \\
\hline Sudão & 4 & 10662 & $0.03 \%$ & $15.96 \%$ \\
\hline Tanzânia & 131 & 7330 & $6.50 \%$ & $3.02 \%$ \\
\hline TOTAL & 411 & 473815 & N/A & $5.60 \%$ \\
\hline
\end{tabular}

Fontes: *World Database on Protected Areas (UNEP-WCMC \& UICN, 2019a); ** National Reports to the Convention on Biological Diversity.

Nota: Ver Capítulo 8 para informações detalhadas sobre os relatórios nacionais para a CDB, de 2014 a 2019.

A2-Quadro 3. Categorias de gestão da UICN de áreas protegidas e de conservação na África Oriental e Austral

\begin{tabular}{|c|c|c|}
\hline Categoria de Gestão da UICN & Número & Área $\left(\mathrm{km}^{2}\right)^{120}$ \\
\hline la. Reserva natural estrita & 9 & 3788 \\
\hline Ib. Zona silvestre & 17 & 103882 \\
\hline II. Parque nacional & 209 & 522053 \\
\hline III. Monumento natural & 32 & 8388 \\
\hline IV. Gestão do habitat/espécie & 164 & 147821 \\
\hline V. Paisagem protegida/paisagem costeira & 49 & 19918 \\
\hline VI. Área protegida com utilização sustentável dos recursos naturais & 155 & 384507 \\
\hline Não Reportado & 4538 & 1498805 \\
\hline Não aplicável & 56 & 158898 \\
\hline Não atribuído & 3 & 4019 \\
\hline
\end{tabular}

Fonte: (UNEP-WCMC \& UICN, 2019a).

120 Esta não é uma nova cobertura por categoria de gestão. Algumas das áreas protegidas sobrepõem-se, e poderiam ter diferentes categorias de gestão da UICN. Se duas áreas protegidas cobrem a mesma localização mas têm categorias de gestão diferentes, ambas as categorias são contadas, 
A2-Quadro 4. Tipos de governação da UICN de áreas protegidas e de conservação na África Oriental e Austral

\begin{tabular}{l|r|r}
\hline Tipo de governação da UICN & Número & Área (km²) \\
\hline A. Governação pelo governo & 2468 & 1424849 \\
\hline B. Governação partilhada & 18 & 5214 \\
\hline C. Governação privada & 959 & 33271 \\
\hline $\begin{array}{l}\text { D. Governação pelos Povos Indígenas e } \\
\text { Comunidades Locais }\end{array}$ & 238 & 199957 \\
\hline Não Reportado & 1549 & 1131803 \\
\hline
\end{tabular}

Fonte: (UNEP-WCMC \& UICN, 2019a).

\section{Apêndice 3. Sítios de importância global na África Oriental e Austral ${ }^{122}$}

A3-Quadro 1. Sítios de Ramsar na África Oriental e Austral

\begin{tabular}{|c|c|c|c|c|}
\hline Pais & $\begin{array}{l}\text { Data de entrada em } \\
\text { vigor da convenção }\end{array}$ & No. de sítios & Sítios & Área coberta (ha) \\
\hline Botswana & 9 de abril de 1997 & 1 & Sistema Delta do Okavango & 5537400 \\
\hline \multirow[t]{3}{*}{ Comores } & \multirow[t]{3}{*}{9 de junho de 1995} & \multirow[t]{3}{*}{3} & Lago Dziani Boundouni & \multirow[t]{3}{*}{16030} \\
\hline & & & Le Karthala & \\
\hline & & & Le Mont Ntringui & \\
\hline Djibouti & 22 de março de 2003 & 1 & Haramous-Loyada & 3000 \\
\hline \multirow[t]{3}{*}{ Eswatini } & \multirow[t]{3}{*}{15 de junho de 2013} & \multirow[t]{3}{*}{3} & Barragem de Hawane e Reserva Natural & \multirow[t]{3}{*}{1183} \\
\hline & & & Barragem do Rio de Areia & \\
\hline & & & Barragem Van Eck & \\
\hline \multirow[t]{6}{*}{ Quénia } & \multirow[t]{6}{*}{5 de outubro de 1990} & \multirow[t]{6}{*}{6} & Lago Baringo & \multirow[t]{6}{*}{265449} \\
\hline & & & Lago Bogoria & \\
\hline & & & Lago Elmenteita & \\
\hline & & & Lago Naivasha & \\
\hline & & & Lago Nakuru & \\
\hline & & & Sítio Ramsar Delta do Rio Tana & \\
\hline Lesoto & 1 de novembro de 2004 & 1 & Lets'eng-la-Letsie & 434 \\
\hline
\end{tabular}




\begin{tabular}{|c|c|c|c|c|}
\hline Pais & $\begin{array}{l}\text { Data de entrada em } \\
\text { vigor da convenção }\end{array}$ & No. de sítios & Sítios & Área coberta (ha) \\
\hline \multirow[t]{20}{*}{ Madagáscar } & \multirow[t]{20}{*}{25 de janeiro de 1999} & \multirow[t]{20}{*}{20} & Barreira de Corais Nosy Ve Androka & \multirow[t]{20}{*}{2094911} \\
\hline & & & Complexo dos Lagos Ambondro e Sirave (CLAS) & \\
\hline & & & Complexo dos Lagos de Manambolomaty & \\
\hline & & & Complexo das Terras Húmidas de Bemanevika & \\
\hline & & & Illhas Áridas & \\
\hline & & & Lago Kinkony & \\
\hline & & & Lago de Sófia & \\
\hline & & & $\begin{array}{l}\text { Lago Alaotra: Zonas húmidas e bacias } \\
\text { hidrográficas }\end{array}$ & \\
\hline & & & Mangues de Tsiribihina & \\
\hline & & & $\begin{array}{l}\text { Pântanos de Torotorofotsy com as suas bacias } \\
\text { hidrográficas }\end{array}$ & \\
\hline & & & Parque Tsarasaotra & \\
\hline & & & Parque Nacional Tsimanampesotse & \\
\hline & & & Rio Nosivolo e afluentes & \\
\hline & & & Sítio Biocultural de Antrema & \\
\hline & & & Pântano Mandrozo & \\
\hline & & & Zonas Húmidas Ankarafantsika (CLSA) & \\
\hline & & & Zonas Húmidas de Ambondrobe & \\
\hline & & & Zonas húmidas de Bedo & \\
\hline & & & Zonas Húmidas Onilahy & \\
\hline & & & Pântanos de Sahamalaza & \\
\hline \multirow[t]{2}{*}{ Malawi } & \multirow[t]{2}{*}{14 de março de 1997} & \multirow[t]{2}{*}{2} & Pântano do Elefante & \multirow[t]{2}{*}{286356} \\
\hline & & & Lago Chilwa & \\
\hline \multirow[t]{3}{*}{ Maurícias } & \multirow{3}{*}{$\begin{array}{l}30 \text { de setembro de } \\
2001\end{array}$} & \multirow[t]{3}{*}{3} & Parque Marinho Blue Bay & \multirow[t]{3}{*}{401} \\
\hline & & & Pointe d'Esny Wetland & \\
\hline & & & Santuário de Aves do Estuário Rivulet Terre Rouge & \\
\hline \multirow[t]{2}{*}{ Moçambique } & \multirow[t]{2}{*}{3 de dezembro de 2004} & \multirow[t]{2}{*}{2} & Lago Niassa e a sua Zona Costeira & \multirow[t]{2}{*}{4534872} \\
\hline & & & Delta do Zambeze & \\
\hline \multirow[t]{5}{*}{ Namíbia } & \multirow{5}{*}{$\begin{array}{l}23 \text { de dezembro de } \\
1995\end{array}$} & \multirow[t]{5}{*}{5} & Sítio Ramsar Bwabwata-Okavango & \multirow[t]{5}{*}{676564} \\
\hline & & & Etosha Pan & \\
\hline & & & Boca do Rio Orange & \\
\hline & & & Porto Sandwich & \\
\hline & & & Baía de Walvis & \\
\hline Ruanda & 1 de abril de 2006 & 1 & Rugezi-Burera-Ruhondo & 6736 \\
\hline \multirow[t]{3}{*}{ Seychelles } & \multirow[t]{3}{*}{22 de março de 2005} & \multirow[t]{3}{*}{3} & Aldabra Atoll & \multirow[t]{3}{*}{44025} \\
\hline & & & $\begin{array}{l}\text { Pântanos de água doce em altitude } \\
\text { Mare Aux Cochons }\end{array}$ & \\
\hline & & & Zonas Húmidas Costeiras Porto Launay & \\
\hline
\end{tabular}




\begin{tabular}{|c|c|c|c|c|}
\hline Pais & $\begin{array}{l}\text { Data de entrada em } \\
\text { vigor da convenção }\end{array}$ & No. de sítios & Sítios & Área coberta (ha) \\
\hline \multirow[t]{27}{*}{ África do Sul } & \multirow[t]{27}{*}{21 dezembro 1975} & \multirow[t]{27}{*}{27} & Barberspan & \multirow[t]{27}{*}{557028} \\
\hline & & & Blesbokspruit & \\
\hline & & & Sistema Estaurino Bot - Kleinmond & \\
\hline & & & Reserva Natural da llha Dassen & \\
\hline & & & De Hoop Vlei & \\
\hline & & & De Mond & \\
\hline & & & $\begin{array}{l}\text { Reserva Natural Provincial Ilha Dyer e } \\
\text { Reserva Natural Provincial Ilha Geyser }\end{array}$ & \\
\hline & & & Reserva & \\
\hline & & & Reserva Natural False Bay & \\
\hline & & & Reserva de Montanha Kgaswane & \\
\hline & & & Baía Kosi & \\
\hline & & & Lago Sibaya & \\
\hline & & & Langebaan & \\
\hline & & & Zonas Húmidas Makuleke & \\
\hline & & & Parque Natal Drakensberg & \\
\hline & & & Reserva de Caça Ndumo & \\
\hline & & & Parque Natural Ntsikeni & \\
\hline & & & Nylsvley & \\
\hline & & & Orange River Mouth & \\
\hline & & & Ilhas Prince Edward & \\
\hline & & & Reserva Natural Seekoeivlei & \\
\hline & & & Sistema de St. Lucia & \\
\hline & & & $\begin{array}{l}\text { Praia das Tartarugas Marinhas / Recifes Corais } \\
\text { de Tongaland }\end{array}$ & \\
\hline & & & Reserva Natural uMgeni Vlei & \\
\hline & & & Reserva Natural Verloren Valei & \\
\hline & & & Verlorenvlei & \\
\hline & & & Lagos Wilderness & \\
\hline Sudão do Sul & 10 de outubro de 2013 & 1 & Sudd & 5700000 \\
\hline \multirow[t]{3}{*}{ Sudão } & \multirow[t]{3}{*}{7 de maio 2 de 005} & \multirow[t]{3}{*}{3} & Parque Nacional Dinder & \multirow[t]{3}{*}{2489600} \\
\hline & & & Baía Dongonab -Marsa Waiai & \\
\hline & & & Golfo -Suakin de Agig & \\
\hline
\end{tabular}




\begin{tabular}{|c|c|c|c|c|}
\hline Pais & $\begin{array}{l}\text { Data de entrada em } \\
\text { vigor da convenção }\end{array}$ & No. de sítios & Sítios & Área coberta (ha) \\
\hline \multirow[t]{12}{*}{ Uganda } & \multirow[t]{12}{*}{4 de julho de 1988} & \multirow[t]{12}{*}{12} & Sistema de zonas húmidas Lago Bisina & \multirow[t]{12}{*}{454303} \\
\hline & & & Lago George & \\
\hline & & & $\begin{array}{l}\text { Sistema de zonas húmidas do Lago } \\
\text { Mburo-Nakivali }\end{array}$ & \\
\hline & & & Sistema de Zonas Húmidas do Lago Nabugabo & \\
\hline & & & Sistema de Zonas Húmidas do Lago Nakuwa & \\
\hline & & & Sistema de Zonas Húmidas do Lago Opeta & \\
\hline & & & Sistema de Zonas Húmidas da Baia Lutembe & \\
\hline & & & Sistema de Zonas Húmidas da Baía Mabamba & \\
\hline & & & $\begin{array}{l}\text { Sistema de Zonas Húmidas do Delta Murchison } \\
\text { Falls-Albert }\end{array}$ & \\
\hline & & & Sistema de Zonas Húmidas Nabajjuzi & \\
\hline & & & Sítio Ramsar Montanhas Rwenzori & \\
\hline & & & $\begin{array}{l}\text { Sistema de Zonas Húmidas Sango } \\
\text { Bay-Musambwa Island-Kagera (SAMUKA) }\end{array}$ & \\
\hline \multirow[t]{4}{*}{ Tanzânia } & \multirow[t]{4}{*}{13 de agosto de 2000} & \multirow[t]{4}{*}{4} & Planície do vale Kilombero & \multirow[t]{4}{*}{4868424} \\
\hline & & & Bacia da Lago Natron & \\
\hline & & & Zonas Húmidas Malagarasi-Muyovozi & \\
\hline & & & Sítio Ramsar Marinho Rufiji-Mafia-Kilwa & \\
\hline \multirow[t]{6}{*}{ Zâmbia } & \multirow[t]{6}{*}{28 de dezembro de 1991} & \multirow[t]{6}{*}{6} & Pântanos Bangweulu & \multirow[t]{6}{*}{4030500} \\
\hline & & & Pântanos Busanga & \\
\hline & & & Planícies Kafue & \\
\hline & & & Planícies de inundação Luangwa & \\
\hline & & & Pântanos Lukanga & \\
\hline & & & Mweru wa Ntipa & \\
\hline \multirow[t]{7}{*}{ Zimbabué } & \multirow[t]{7}{*}{3 de maio de 2013} & \multirow[t]{7}{*}{6} & Parque Recreativo das Caves Chinhoyi & \multirow[t]{7}{*}{453828} \\
\hline & & & Represa Cleveland & \\
\hline & & & Prados Driefontein & \\
\hline & & & Lago Chivero e Manyame & \\
\hline & & & Parque Nacional Mana Pools & \\
\hline & & & Monavale Wetland & \\
\hline & & & Parque Nacional Cataratas Vitória & \\
\hline \multicolumn{4}{|c|}{ TOTAL ÁREA } & 32021044 \\
\hline
\end{tabular}

Fonte: (Ramsar Convention on Wetlands, 2019). 
A3-Quadro 2. Reservas Humanas e da Biosfera na África Oriental e Austral

\begin{tabular}{|c|c|c|c|}
\hline País & $\mathbf{N}^{\circ}$ de sítios & Reserva da Biosfera & Ano de designação \\
\hline \multirow[t]{5}{*}{ Etiópia } & \multirow[t]{5}{*}{5} & Kafa & 2010 \\
\hline & & Yayu & 2010 \\
\hline & & Sheka & 2012 \\
\hline & & Lago Tana & 2015 \\
\hline & & Floresta Majang & 2017 \\
\hline \multirow[t]{6}{*}{ Quénia } & \multirow[t]{6}{*}{6} & Monte Quénia & 1978 \\
\hline & & Monte Kulal & 1978 \\
\hline & & Malindi-Watamu & 1979 \\
\hline & & Kiunga & 1980 \\
\hline & & Amboseli & 1991 \\
\hline & & Monte Elgon & 2003 \\
\hline \multirow[t]{5}{*}{ Madagáscar } & \multirow[t]{5}{*}{5} & Mananara Nord & 1990 \\
\hline & & Sahamalaza-Iles Radama & 2001 \\
\hline & & Littoral de Toliara & 2003 \\
\hline & & Belo-sur-Mer - Kirindy-Mite & 2016 \\
\hline & & Tsimanampesotse - Nosy Ve Androka & 2018 \\
\hline Maurícias & 1 & Macchabee/Bel Ombre & 1977 \\
\hline \multirow[t]{2}{*}{ Malawi } & \multirow[t]{2}{*}{2} & Monte Mulanje & 2000 \\
\hline & & Pântano do Lago Chilwa & 2006 \\
\hline Moçambique & 1 & Quirimbas & 2018 \\
\hline Ruanda & 1 & Volcans & 1983 \\
\hline \multirow[t]{5}{*}{ Tanzânia } & \multirow[t]{5}{*}{5} & Lago Manyara & 1981 \\
\hline & & Serengeti-Ngorongoro & 1981 \\
\hline & & Usambara Oriental & 2000 \\
\hline & & Baía de Jozani-Chwaka & 2016 \\
\hline & & Gombe Masito Ugalla & 2018 \\
\hline \multirow[t]{2}{*}{ Uganda } & \multirow[t]{2}{*}{2} & Queen Elizabeth & 1979 \\
\hline & & Monte Elgon & 2005 \\
\hline \multirow[t]{10}{*}{ África do Sul } & \multirow[t]{10}{*}{10} & Kogelberg & 1998 \\
\hline & & Costa Oeste do Cabo & 2000 \\
\hline & & Waterberg & 2001 \\
\hline & & Kruger to Canyons & 2001 \\
\hline & & Winelands do Cabo & 2007 \\
\hline & & Vhembe & 2009 \\
\hline & & Aglomerado Gouritz & 2015 \\
\hline & & Magaliesberg & 2015 \\
\hline & & Rota do Jardim & 2017 \\
\hline & & Marico & 2018 \\
\hline Zimbabué & 1 & Zambeze Médio & 2010 \\
\hline
\end{tabular}

Fonte: UNESCO (2019). 


\section{Apêndice 4. Representatividade ecológica na África Oriental e Austral}

A4-Quadro 1. Níveis de protecção para as ecorregiões terrestres representadas na região

\begin{tabular}{r|r|r|r|r}
\hline Protecção & $\begin{array}{r}\text { Contagem de } \\
\text { ecorregióes }\end{array}$ & $\begin{array}{r}\text { Ecorregiões com } \\
<75 \% \text { de área na } \\
\text { região }\end{array}$ & $\begin{array}{r}\text { Ecorregiões com } \\
\mathbf{7 5 - 9 9} \% \text { de área na } \\
\text { região }\end{array}$ & $\begin{array}{r}\text { Ecorregiões } \\
\text { exclusivas da } \\
\text { região }\end{array}$ \\
\hline 0 & 5 & 5 & 0 & 4 \\
\hline 0.01 to $4 \%$ & 7 & 3 & 0 & 4 \\
\hline 4 to $8 \%$ & 14 & 2 & 1 & 10 \\
\hline 8 to $12 \%$ & 8 & 0 & 1 & 7 \\
\hline 12 to $17 \%$ & 11 & 4 & 6 & 6 \\
\hline$>17 \%$ & 37 & 4 & & 27 \\
\hline
\end{tabular}

Fonte: EC JRC/DOPA (2019).

A4-Quadro 2. Níveis de protecção das ecorregiões marinhas e das províncias pelágicas representadas na região

\begin{tabular}{r|r|r|r|r}
\hline Protecção & $\begin{array}{r}\text { Contagem de } \\
\text { ecorregiões }\end{array}$ & $\begin{array}{r}\text { Ecorregiões com } \\
<75 \% \text { de área na } \\
\text { região }\end{array}$ & $\begin{array}{r}\text { Ecorregiões com } \\
75-99 \% \text { de área na } \\
\text { região }\end{array}$ & $\begin{array}{r}\text { Ecorregiões } \\
\text { exclusivas da } \\
\text { região }\end{array}$ \\
\hline 0 & 9 & 0 & 7 & 3 \\
\hline 0.01 to $5 \%$ & 10 & 2 & 1 & 5 \\
\hline 5 to $10 \%$ & 5 & 1 & 3 & 3 \\
\hline$>10 \%$ & 6 & 0 & & 3 \\
\hline
\end{tabular}

Fonte: EC JRC/DOPA (2019). 


\section{Apêndice 5. Instrumentos legais de apoio à equidade e governação não estatal de áreas protegidas}

\begin{tabular}{|c|c|}
\hline País & Lei, secção e artigo relevantes \\
\hline Quénia & $\begin{array}{l}\text { A Lei de Conservação e Gestão da Vida Selvagem de } 20137 \\
\text { Secção } 4 \text {. A aplicação da presente lei deve ser orientada pelos seguintes princípios } \\
\text { (a) A conservação e gestão da vida selvagem será descentralizada, sempre que possível e apropriado para os } \\
\text { proprietários e gestores de terras onde a vida selvagem ocorre; } \\
\text { (b) A conservação e gestão da vida selvagem implicará a participação efectiva do público; } \\
\text { (c) Sempre que possível, a conservação e gestão da vida selvagem será encorajada através de uma } \\
\text { abordagem ecossistémica; } \\
\text { (d) A conservação e gestão da vida selvagem deve ser encorajada e reconhecida como uma forma de } \\
\text { utilização da terra em terras públicas, comunitárias e privadas; e } \\
\text { (e) Os benefícios da conservação da vida selvagem serão obtidos pelo utilizador da terra a fim de compensar } \\
\text { os custos e assegurar que o valor e a gestão da vida selvagem não diminuam; (pp. 1250-1251). } \\
\text { A Lei de Gestão e Coordenação Ambiental (1999, revista em 2012) e a Lei de Conservação e Gestão da Vida } \\
\text { Selvagem (WCMA) } 2013 \text { permitem a conservação de terras de servidão. }\end{array}$ \\
\hline ibique & $\begin{array}{l}\text { A Lei de Terras (Lei 19/97) } \\
\text { Artigo } 24 \text { (p. 1301) reconhece o papel das comunidades locais na gestão dos recursos naturais, na resolução de } \\
\text { conflitos, entre outros; a lei também permite a caça sob uma licença simples. } \\
\text { A Lei sobre Floresta e Vida Selvagem cobre a protecção das normas e práticas consuetudinárias: valor histórico-cultural } \\
\text { e uso da terra; exploração sob licença. } \\
\text { Lei de Conservação da Biodiversidade, Lei N 16/2014, } 20 \text { de Junho } \\
\text { Artigo } 4 \text { (p. 1297) aborda sete princípios: património ecológico; soberania, igualdade; participação dos cidadãos na } \\
\text { gestão e benefícios; responsabilidade ambiental; desenvolvimento; parcerias público-privadas; precaução e decisão } \\
\text { informada; e cooperação internacional. } \\
\text { Artigo 7, No. } 1 \text { (p. 1298) refere-se à criação do Conselho de Gestão da Área de Conservação, composto por } \\
\text { representantes das comunidades locais, do sector privado, das associações e dos organismos locais do Estado. } \\
\text { Artigo } 9 \text {, Nos. } 1 \text { e } 2 \text { (p. 1298) estipula que o Estado pode estabelecer parcerias com vista a criar sinergias a favor } \\
\text { da conservação da diversidade biológica. }\end{array}$ \\
\hline Namíbia & $\begin{array}{l}\text { Política Nacional de Gestão de Recursos Naturais Baseada na Comunidade, Março de } 2013, \text { Secção } 4.4 \text { (p. } 9 \text { ) } \\
\text { O governo está empenhado, em conformidade com as suas próprias leis sobre acesso e partilha de benefícios } \\
\text { e políticas e convenções globais, em proteger os direitos de propriedade intelectual das comunidades no que } \\
\text { respeita aos recursos naturais e à gestão desses recursos naturais, e em ter uma distribuição justa e equitativa dos } \\
\text { benefícios derivados da utilização dos recursos naturais. }\end{array}$ \\
\hline África do Sul & $\begin{array}{l}\text { Política Nacional de Biodiversidade e Plano de Acção } \\
\text { A Secção } 2 \text { (f) (p. 12) firma que a NEMPAA "deve promover a participação das comunidades locais na gestão das } \\
\text { áreas protegidas, quando apropriado ("). } \\
\text { A Secção } 42 \text { (p. 34) prevê que "um acordo de co-gestão pode prever" uma série de assuntos, incluindo (entre } \\
\text { outros): } \\
\text { • A delegação de poderes pela autoridade de gestão à outra parte no acordo; } \\
\text { • A repartição de quaisquer rendimentos gerados pela gestão da área protegida ou qualquer outra forma de } \\
\text { partilha de benefícios entre as partes; } \\
\text { - A utilização de recursos biológicos na área; } \\
\text { - O acesso à área; } \\
\text { - A ocupação da área protegida ou de partes da mesma; e } \\
\text { - Desenvolvimento de oportunidades económicas dentro e adjacente à área protegida. }\end{array}$ \\
\hline
\end{tabular}




\begin{tabular}{|c|c|}
\hline País & Lei, secção e artigo relevantes \\
\hline Uganda & $\begin{array}{l}\text { Política Nacional de Vida Selvagem do Uganda, Secção } 26 \text { (p. 22) } \\
\text { Direitos históricos dos indivíduos em áreas de conservação } \\
\text { (1) As disposições da presente parte não afectam as pessoas cujos direitos, até à entrada em vigor do presente } \\
\text { Acto, tenham sido preservados por:- } \\
\text { (a) a Lei da Caça (Preservação e Controlo), nomeadamente:- } \\
\text { (i) pessoas, suas esposas e filhos efectivamente residentes em reservas de caça no dia } 1 \text { de Julho de 1959; } \\
\text { (ii) quaisquer pessoas efectivamente residentes em reservas de caça na data da sua declaração, para as } \\
\text { reservas de caça declaradas após } 1 \text { de Setembro de 1959; } \\
\text { (b) a Lei dos Parques Nacionais, nomeadamente, as pessoas que adquiriram legalmente direitos nos parques } \\
\text { nacionais antes de } 3 \text { de Abril de 1952; } \\
\text { (c) a Lei dos Parques Nacionais, nomeadamente, as pessoas residentes em florestas que o Ministro possa ter } \\
\text { isentado das disposições dessa lei e que, desde então, tenham sido declaradas parques nacionais ao } \\
\text { abrigo da Lei dos Parques Nacionais. } \\
\text { (2) A autoridade pode estabelecer directrizes para o acesso das comunidades vizinhas de áreas de conservação } \\
\text { aos recursos que são cruciais para a sobrevivência dessas comunidades. }\end{array}$ \\
\hline Zimbabué & $\begin{array}{l}\text { Lei de Parques e Vida Selvagem (Capítulo 20:14) } 1996 \\
\text { Secção } 2 \text { confere privilégios aos proprietários ou ocupantes de terras alienadas como guardiães da vida selvagem } \\
\text { e oferece o estatuto de "Autoridade Apropriada" aos Conselhos Distritais Rurais sobre a vida selvagem nas suas } \\
\text { respectivas Terras Comunais, em nome das suas comunidades locais rurais, referidas como "comunidades } \\
\text { de produtores". } \\
\text { Política para a Vida Selvagem Zimbabué } 1999 \\
\text { A política visa capacitar os proprietários de terras para conservarem e retirarem benefícios dos recursos da vida } \\
\text { selvagem existentes nas suas terras, incluindo as terras comunitárias e privadas. } \\
\text { Política de Reforma Agrária Baseada na Vida Selvagem } 2004 \text {. } \\
\text { Secção 3: "para facilitar a indigenização do sector da vida selvagem e assegurar um acesso mais equitativo da } \\
\text { maioria dos zimbabueanos à terra e aos recursos da vida selvagem e às oportunidades de negócio que advêm } \\
\text { destes recursos". }\end{array}$ \\
\hline
\end{tabular}

Fonte: Tessema (n.d.)"issued":\{“date-parts":[["2019"]]\}\}]],"schema":"https://github.com/citation-style-language/schema/raw/master/csl-citation.json"\} . 


\section{Apêndice 6. Áreas protegidas e de conservação nas Categorias de Gestão da UICN por país}

Áreas protegidas e de conservação em Angola em Categorias de Gestão da UICN

\begin{tabular}{|c|c|c|}
\hline Categoria de Gestão da UICN & No. & $\%$ Cobertura \\
\hline II. Parque Nacional & 8 & 77.49 \\
\hline IV. Gestão de Habitat / Espécies & 4 & 16.42 \\
\hline V. Paisagem Protegida / Paisagem Marítima & 1 & 0.24 \\
\hline Não Reportado & 1 & 5.26 \\
\hline
\end{tabular}

Fonte: UNEP-WCMC \& UICN (2019C).

Áreas protegidas e de conservação em Botswana em Categorias de Gestão da UICN

\begin{tabular}{|c|c|c|}
\hline Categoria de Gestão da UICN & No. & $\%$ Cobertura \\
\hline lb. Área Selvagem & 7 & 61.12 \\
\hline II. Parque Nacional & 6 & 2.40 \\
\hline IV. Gestão de Habitat / Espécies & 7 & 1.08 \\
\hline Não Reportado & 1 & 37.78 \\
\hline Não Aplicável & 1 & 12.07 \\
\hline
\end{tabular}

Fonte: UNEP-WCMC \& UICN (2019c).

Áreas protegidas e de conservação em Comores em Categorias de Gestão da UICN

\begin{tabular}{l|r|r}
\hline Categoria de Gestão da UICN & No. & \% Cobertura \\
\hline II. Parque Nacional & 1 & 17.74 \\
\hline Não Reportado & 7 & 81.75 \\
\hline
\end{tabular}

Fonte: UNEP-WCMC \& UICN (2019d).

Áreas protegidas e de conservação em Djibouti em Categorias de Gestão da UICN

\begin{tabular}{|c|c|c|}
\hline Categoria de Gestão da UICN & No. & $\%$ Cobertura \\
\hline IV. Gestão de Habitat / Espécies & 1 & $0.00 \%$ \\
\hline V. Paisagem Protegida / Paisagem Marítima & 2 & $0.00 \%$ \\
\hline VI. Área Protegida com Utilização Sustentável dos Recursos Naturais & 1 & $0.00 \%$ \\
\hline Não Reportado & 3 & $100 \%$ \\
\hline
\end{tabular}

Fonte: UNEP-WCMC \& UICN (2019e). 
Áreas protegidas e de conservação em Eritreia em Categorias de Gestão da UICN

\begin{tabular}{l|r|r}
\hline Categoria de Gestão da UICN & No. & \% Cobertura \\
\hline IV. Gestão de Habitat / Espécies & 3 & 100.00 \\
\hline Não Reportado & 1 & \\
\hline
\end{tabular}

Fonte: UNEP-WCMC \& UICN (2019f).

Áreas protegidas e de conservação em Eswatini em Categorias de Gestão da UICN

\begin{tabular}{|c|c|c|}
\hline Categoria de Gestão da UICN & No. & $\%$ Cobertura \\
\hline II. Parque Nacional & 6 & 94.20 \\
\hline IV. Habitat / Gestão de Espécies & 2 & 0.19 \\
\hline V. Paisagem Protegida / Paisagem Marítima & 1 & 2.14 \\
\hline Não Reportado & 5 & 3.09 \\
\hline
\end{tabular}

Fonte: UNEP-WCMC \& UICN (2019g).

Áreas protegidas e de conservação em Etiópia em Categorias de Gestão da UICN

\begin{tabular}{|c|c|c|}
\hline Categoria de Gestão da UICN & No. & $\%$ Cobertura \\
\hline II. Parque Nacional & 17 & 17.35 \\
\hline IV. Gestão de Habitat / Espécies & 8 & 11.69 \\
\hline VI. Área Protegida com Utilização Sustentável dos Recursos Naturais & 18 & 75.76 \\
\hline Não Reportado & 58 & 0.02 \\
\hline Não Aplicável & 3 & 0.07 \\
\hline
\end{tabular}

Fonte: UNEP-WCMC \& UICN (2019h).

Áreas protegidas e de conservação em Quénia em Categorias de Gestão da UICN

\begin{tabular}{|c|c|c|}
\hline Categoria de Gestão da UICN & No. & $\%$ Cobertura \\
\hline II. Parque Nacional & 36 & 46.15 \\
\hline IV. Gestão de Habitat / Espécies & 5 & 0.65 \\
\hline VI. Área Protegida com Utilização Sustentável dos Recursos Naturais & 16 & 10.91 \\
\hline Não Reportado & 345 & 46.19 \\
\hline Não Aplicável & 9 & 5.23 \\
\hline
\end{tabular}

Fonte: UNEP-WCMC \& UICN (2019i).

Áreas protegidas e de conservação em Lesoto em Categorias de Gestão da UICN

\begin{tabular}{l|r|r}
\hline Categoria de Gestão da UICN & No. & \% Cobertura \\
\hline IV. Gestão de Habitat / Espécies & 1 & 86.89 \\
\hline Não Reportado & 2 & 5.43 \\
\hline Não Aplicável & 1 & 7.00 \\
\hline
\end{tabular}

Fonte: UNEP-WCMC \& UICN (2019j). 
Áreas protegidas e de conservação em Madagáscar em Categorias de Gestão da UICN

\begin{tabular}{|c|c|c|}
\hline Categoria de Gestão da UICN & No. & $\%$ Cobertura \\
\hline la. Reserva Natural Estrita & 3 & 2.00 \\
\hline II. Parque Nacional & 30 & 19.00 \\
\hline IV. Gestão de Habitat / Espécies & 22 & 14.00 \\
\hline VI. Área Protegida com Utilização Sustentável dos Recursos Naturais & 7 & 4.00 \\
\hline V Paisagem / Paisagem marítima protegida & 29 & 18.00 \\
\hline Não Reportado & 61 & 39.00 \\
\hline Não Aplicável & 5 & 3.00 \\
\hline
\end{tabular}

Fonte: UNEP-WCMC \& UICN (2019k).

\section{Áreas protegidas e de conservação em Malawi em Categorias de Gestão da UICN}

\begin{tabular}{l|r|r}
\hline Categoria de Gestão da UICN & No. & \% Cobertura \\
\hline II. Parque Nacional & 5 & 25.60 \\
\hline IV. Gestão de Habitat / Espécies & 4 & 14.03 \\
\hline Não Reportado & 121 & 64.73 \\
\hline Não Aplicável & 3 & 0.27 \\
\hline
\end{tabular}

Fonte: UNEP-WCMC \& UICN (2019)).

Áreas protegidas e de conservação em Maurícias em Categorias de Gestão da UICN

\begin{tabular}{l|r|r}
\hline Categoria de Gestão da UICN & No. & \% Cobertura \\
\hline la. Reserva Natural Estrita & 1 & 0.21 \\
\hline II. Parque Nacional & 10 & 42.74 \\
\hline IV. Gestão de Habitat / Espécies & 21 & 42.47 \\
\hline Não Reportado & 10 & 0.32 \\
\hline Não Atribuído & 1 & 0.01 \\
\hline
\end{tabular}

Fonte: UNEP-WCMC \& UICN (2019m).

Áreas protegidas e de conservação em Moçambique em Categorias de Gestão da UICN

\begin{tabular}{l|r|r}
\hline Categoria de Gestão da UICN & No. & \% Cobertura \\
\hline II. Parque Nacional & 6 & 24.62 \\
\hline IV. Gestão de Habitat / Espécies & 4 & 9.82 \\
\hline VI. Área Protegida com Utilização Sustentável dos Recursos Naturais & 3 & 0.71 \\
\hline Não Reportado & 29 & 63.70 \\
\hline Não Atribuído & 2 & 2.19 \\
\hline
\end{tabular}

Fonte: UNEP-WCMC \& UICN (2019n). 
Áreas protegidas e de conservação em Namíbia em Categorias de Gestão da UICN

\begin{tabular}{|c|c|c|}
\hline Categoria de Gestão da UICN & No. & $\%$ Cobertura \\
\hline II. Parque Nacional & 9 & 31.01 \\
\hline III. Monumento Natural & 2 & 0.00 \\
\hline IV. Gestão de Habitat / Espécies & 1 & 0.00 \\
\hline V. Paisagem Protegida / Paisagem Marítima & 3 & 0.16 \\
\hline VI. Área Protegida com Utilização Sustentável dos Recursos Naturais & 1 & 2.94 \\
\hline Não Reportado & 131 & 72.49 \\
\hline Não Aplicável & 1 & 9.52 \\
\hline
\end{tabular}

Fonte: UNEP-WCMC \& UICN (20190).

Áreas protegidas e de conservação em Ruanda em Categorias de Gestão da UICN

\begin{tabular}{|c|c|c|}
\hline Categoria de Gestão da UICN & No. & $\%$ Cobertura \\
\hline II. Parque Nacional & 2 & 50.98 \\
\hline IV. Gestão de Habitat / Espécies & 3 & 45.38 \\
\hline Não Reportado & 4 & 2.96 \\
\hline
\end{tabular}

Fonte: UNEP-WCMC \& UICN (2019p).

Áreas protegidas e de conservação em Seychelles em Categorias de Gestão da UICN

\begin{tabular}{|c|c|c|}
\hline Categoria de Gestão da UICN & No. & $\%$ Cobertura \\
\hline la. Reserva Natural Estrita & 5 & 1.16 \\
\hline Ib. Área Selvagem & 1 & 0.00 \\
\hline II. Parque Nacional & 8 & 0.04 \\
\hline VI. Área Protegida com Utilização Sustentável dos Recursos Naturais & 6 & 0.00 \\
\hline Não Reportado & 18 & 98.36 \\
\hline Não Aplicável & 2 & 0.21 \\
\hline
\end{tabular}

Fonte: UNEP-WCMC \& UICN (2019q).

Áreas protegidas e de conservação em Somália em Categorias de Gestão da UICN

\begin{tabular}{l|r|r}
\hline Categoria de Gestão da UICN & No. & \% Cobertura \\
\hline Não Reportado & 21 & 0.00 \\
\hline
\end{tabular}

Fonte: UNEP-WCMC \& UICN (2019r).

Áreas protegidas e de conservação em África do Sul em Categorias de Gestão da UICN

\begin{tabular}{l|r|r}
\hline Categoria de Gestão da UICN & No. & \% Cobertura \\
\hline Não Reportado & 1567 & 97.75 \\
\hline Não Aplicável & 13 & 5.15 \\
\hline
\end{tabular}

Fonte: UNEP-WCMC \& UICN (2019s). 
Áreas protegidas e de conservação em Sudão do Sul em Categorias de Gestão da UICN

\begin{tabular}{|c|c|c|}
\hline Categoria de Gestão da UICN & No. & $\%$ Cobertura \\
\hline II. Parque Nacional & 9 & 52.35 \\
\hline IV. Gestão de Habitat / Espécies & 3 & - \\
\hline V. Paisagem Protegida / Paisagem Marítima & 1 & 1.18 \\
\hline VI. Área Protegida com Utilização Sustentável dos Recursos Naturais & 13 & 30.33 \\
\hline Não Reportado & 1 & 24.66 \\
\hline
\end{tabular}

Fonte: UNEP-WCMC \& UICN (2019t).

\section{Áreas protegidas e de conservação em Sudão em Categorias de Gestão da UICN}

\begin{tabular}{|c|c|c|}
\hline Categoria de Gestão da UICN & No. & $\%$ Cobertura \\
\hline II. Parque Nacional & 3 & 39.19 \\
\hline IV. Gestão de Habitat / Espécies & 1 & 2.17 \\
\hline VI. Área Protegida com Utilização Sustentável dos Recursos Naturais & 3 & 13.57 \\
\hline Não Reportado & 13 & 46.66 \\
\hline Não Aplicável & 3 & 4.84 \\
\hline
\end{tabular}

Fonte: UNEP-WCMC \& UICN (2019u).

\section{Áreas protegidas e de conservação em Tanzânia em Categorias de Gestão da UICN}

\begin{tabular}{|c|c|c|}
\hline Categoria de Gestão da UICN & No. & $\%$ Cobertura \\
\hline Ib. Área Selvagem & 8 & 0.10 \\
\hline II. Parque Nacional & 14 & 11.77 \\
\hline III. Monumento Natural & 1 & 0.00 \\
\hline IV. Gestão de Habitat / Espécies & 53 & 19.95 \\
\hline VI. Área Protegida com Utilização Sustentável dos Recursos Naturais & 19 & 3.02 \\
\hline Não Reportado & 738 & 70.98 \\
\hline Não Aplicável & 7 & 18.76 \\
\hline
\end{tabular}

Fonte: UNEP-WCMC \& UICN (2019v).

Áreas protegidas e de conservação em Uganda em Categorias de Gestão da UICN

\begin{tabular}{l|r|r}
\hline Categoria de Gestão da UICN & No. & \% Cobertura \\
\hline II. Parque Nacional & 10 & 28.80 \\
\hline III. Monumento Natural & 11 & 21.19 \\
\hline IV. Gestão de Habitat / Espécies & 1 & 0.48 \\
\hline VI. Área Protegida com Utilização Sustentável dos Recursos Naturais & 13 & 12.74 \\
\hline Não Reportado & 673 & 44.24 \\
\hline Não Aplicável & 4 & 3.38 \\
\hline
\end{tabular}

Fonte: UNEP-WCMC \& UICN (2019W). 
Áreas protegidas e de conservação em Zâmbia em Categorias de Gestão da UICN

\begin{tabular}{|c|c|c|}
\hline Categoria de Gestão da UICN & No. & $\%$ Cobertura \\
\hline II. Parque Nacional & 19 & 21.13 \\
\hline III. Monumento Natural & 16 & 0.03 \\
\hline IV. Gestão de Habitat / Espécies & 1 & 0.04 \\
\hline VI. Área Protegida com Utilização Sustentável dos Recursos Naturais & 36 & 49.11 \\
\hline Não Reportado & 562 & 38.15 \\
\hline Não Aplicável & 1 & 0.01 \\
\hline
\end{tabular}

Fonte: UNEP-WCMC \& UICN (2019x).

Áreas protegidas e de conservação em Zimbabué em Categorias de Gestão da UICN

\begin{tabular}{|c|c|c|}
\hline Categoria de Gestão da UICN & No. & $\%$ Cobertura \\
\hline lb. Área Selvagem & 1 & 0.01 \\
\hline II. Parque Nacional & 10 & 25.15 \\
\hline III. Monumento Natural & 2 & 0.02 \\
\hline IV. Gestão de Habitat / Espécies & 19 & 0.12 \\
\hline V. Paisagem Protegida / Paisagem Marítima & 12 & 3.41 \\
\hline VI. Área Protegida com Utilização Sustentável dos Recursos Naturais & 19 & 17.79 \\
\hline Não Reportado & 166 & 54.84 \\
\hline Não Aplicável & 3 & 6.33 \\
\hline
\end{tabular}

Fonte: UNEP-WCMC \& UICN (2019y). 


\section{Apêndice 7. Áreas protegidas e de conservação nos tipos de governação da UICN por país}

Áreas protegidas e de conservação em Angola nos tipos de governação da UICN

\begin{tabular}{l|r|r}
\hline Categoria de governação da UICN & No. & \% Cobertura \\
\hline Não Reportado & 14 & 100.00 \\
\hline
\end{tabular}

Fonte: UNEP-WCMC \& UICN (2019C).

Áreas protegidas e de conservação em Botswana nos tipos de governação da UICN

\begin{tabular}{|c|c|c|}
\hline UICN Governance Category & No. & $\%$ Cobertura \\
\hline A. Governação pelo Governo & 18 & 63.58 \\
\hline C. Governação Privada & 1 & 0.44 \\
\hline D. Governação pelos povos indígenas e comunidades locais & 1 & 0.57 \\
\hline Não Reportado & 2 & 37.80 \\
\hline
\end{tabular}

Fonte: UNEP-WCMC \& UICN )2019d).

Áreas protegidas e de conservação em Comores nos tipos de governação da UICN

\begin{tabular}{l|r|r}
\hline Categoria de governação da UICN & No. & \% Cobertura \\
\hline B. Governação Partilhada & 6 & 23.29 \\
\hline Não Reportado & 2 & 76.19 \\
\hline
\end{tabular}

Fonte: UNEP-WCMC \& UICN (2019d).

Áreas protegidas e de conservação em Djibouti nos tipos de governação da UICN

\begin{tabular}{l|r|r}
\hline Categoria de governação da UICN & No. & \% Cobertura \\
\hline Governação pelo Governo & 3 & 90.84 \\
\hline Não Reportado & 1 & 8.43 \\
\hline
\end{tabular}

Fonte: UNEP-WCMC \& UICN (2019e).

Áreas protegidas e de conservação em Eritreia nos tipos de governação da UICN

\begin{tabular}{l|r|r}
\hline Categoria de governação da UICN & No. & \% Cobertura \\
\hline Não Reportado & 4 & 100.00 \\
\hline
\end{tabular}

Fonte: UNEP-WCMC \& UICN (2019f).

Áreas protegidas e de conservação em Eswatini nos tipos de governação da UICN

\begin{tabular}{l|r|r}
\hline Categoria de governação da UICN & No. & \% Cobertura \\
\hline B. Privado & 3 & 2.33 \\
\hline Não Reportado & 11 & 97.29 \\
\hline
\end{tabular}

Fonte: UNEP-WCMC \& UICN (2019g).

* Eswatini relata informações adicionais que ainda não constam da WDPA. Nem todos os países foram actualizados na WDPA antes da publicação deste relatório. Os países são encorajados a actualizar os seus dados SIG e tabulares no WDPA em qualquer caso em que os seus dados não coincidam com os que constam neste relatório. 
Áreas protegidas e de conservação em Etiópia nos tipos de governação da UICN

\begin{tabular}{l|r|r}
\hline Categoria de governação da UICN & No. & \% Cobertura \\
\hline Não Reportado & 104 & 100.00 \\
\hline
\end{tabular}

Fonte: UNEP-WCMC \& UICN (2019h).

Áreas protegidas e de conservação em Quénia nos tipos de governação da UICN

\begin{tabular}{l|r|r}
\hline Categoria de governação da UICN & No. & \% Cobertura \\
\hline Governação pelo Governo & 76 & 67.68 \\
\hline B. Governação Partilhada & 1 & 0.45 \\
\hline C. Governação Privada & 16 & 2.59 \\
\hline D. Governação pelos povos indígenas e comunidades locais & 51 & 1.97 \\
\hline Não Reportado & 267 & 36.37 \\
\hline
\end{tabular}

Fonte: UNEP-WCMC \& UICN (2019i).

Áreas protegidas e de conservação em Lesoto nos tipos de governação da UICN

\begin{tabular}{l|r|r}
\hline Categoria de governação da UICN & No. & \% Cobertura \\
\hline Governação pelo Governo & 3 & 92.32 \\
\hline Não Reportado & 1 & 7.00 \\
\hline
\end{tabular}

Fonte: UNEP-WCMC \& UICN (2019j)

Áreas protegidas e de conservação em Madagáscar nos tipos de governação da UICN

\begin{tabular}{l|r|r}
\hline Categoria de governação da UICN & No. & \% Cobertura \\
\hline Governação pelo Governo & 8 & 3.50 \\
\hline B. Governação Partilhada & 2 & 0.05 \\
\hline C. Governação Privada & 2 & 4.97 \\
\hline D. Governação pelos povos indígenas e comunidades locais & 34 & 11.12 \\
\hline Não Reportado & 111 & 89.83 \\
\hline
\end{tabular}

Fonte: UNEP-WCMC \& UICN (2019k).

Áreas protegidas e de conservação em Malawi nos tipos de governação da UICN

\begin{tabular}{l|r|r}
\hline Categoria de governação da UICN & No. & \% Cobertura \\
\hline Governação pelo Governo & 10 & 41.87 \\
\hline Não Reportado & 123 & 62.76 \\
\hline
\end{tabular}

Fonte: UNEP-WCMC \& UICN (2019I). 
Áreas protegidas e de conservação nas Maurícias nos tipos de governação da UICN

\begin{tabular}{l|r|r}
\hline Categoria de governação da UICN & No. & \% Cobertura \\
\hline A. Governação pelo Governo & 42 & $82.74 \%$ \\
\hline C. Governação Privada & 2 & $1.67 \%$ \\
\hline
\end{tabular}

Fonte: UNEP-WCMC \& UICN (2019m).

Áreas protegidas e de conservação em Moçambique nos tipos de governação da UICN

\begin{tabular}{l|r|r}
\hline Categoria de governação da UICN & No. & \% Cobertura \\
\hline A. Governação pelo Governo & 28 & 69.94 \\
\hline B. Governação Partilhada & 1 & 2.00 \\
\hline D. Governação pelos povos indígenas e comunidades locais & 1 & 0.00 \\
\hline Não Reportado & 14 & 33.31 \\
\hline
\end{tabular}

Fonte: UNEP-WCMC \& UICN (2019n).

* Outros sítios relatados por Moçambique ainda não se encontram no WDPA. Nem todos os países foram actualizados no WDPA antes desta publicação do presente relatório. Os países são encorajados a actualizar os seus dados SIG e tabulares no WDPA em qualquer caso em que os seus dados nãa coincidam com os que constam deste relatório.

Áreas protegidas e de conservação em Namíbia nos tipos de governação da UICN

\begin{tabular}{l|r|r}
\hline Categoria de governação da UICN & No. & \% Cobertura \\
\hline A. Governação pelo Governo & 31 & 47.58 \\
\hline C. Governação Privada & 2 & 0.89 \\
\hline D. Governação pelos Povos Indígenas e Comunidades Locais & 112 & 50.60 \\
\hline Não Reportado & 3 & 10.12 \\
\hline
\end{tabular}

Fonte: UNEP-WCMC \& UICN (20190).

Áreas protegidas e de conservação em Ruanda nos tipos de governação da UICN

\begin{tabular}{l|r|r}
\hline Categoria de governação da UICN & No. & \% Cobertura \\
\hline Governação pelo Governo & 3 & 94.88 \\
\hline Não Reportado & 7 & 4.44 \\
\hline
\end{tabular}

Fonte: UNEP-WCMC \& UICN (2019p).

Áreas protegidas e de conservação em Seychelles nos tipos de governação da UICN

\begin{tabular}{l|r|r}
\hline Categoria de governação da UICN & No. & \% Cobertura \\
\hline Governação pelo Governo & 20 & 1.20 \\
\hline Não Reportado & 20 & 100.00 \\
\hline
\end{tabular}

Fonte: UNEP-WCMC \& UICN (2019q).

\section{Áreas protegidas e de conservação em Somália nos tipos de governação da UICN}

\begin{tabular}{l|r|r}
\hline Categoria de governação da UICN & No. & \% Cobertura \\
\hline Governação pelo Governo & 21 & 0.00 \\
\hline
\end{tabular}

Fonte: UNEP-WCMC \& UICN (2019r). 
Áreas protegidas e de conservação em África do Sul nos tipos de governação da UICN

\begin{tabular}{l|r|r}
\hline Categoria de governação da UICN & No. & \% Cobertura \\
\hline Governação pelo Governo & 645 & 92.29 \\
\hline B. Governação Partilhada & 1 & 0.18 \\
\hline C. Governação Privada & 932 & 7.84 \\
\hline Não Reportado & 2 & 0.81 \\
\hline
\end{tabular}

Fonte: UNEP-WCMC \& UICN (2019s).

Áreas protegidas e de conservação em Sudão do Sul nos tipos de governação da UICN

\begin{tabular}{l|r|r}
\hline Categoria de governação da UICN & No. & \% Cobertura \\
\hline Governação pelo Governo & 26 & 83.87 \\
\hline Não Reportado & 1 & 24.66 \\
\hline
\end{tabular}

Fonte: UNEP-WCMC \& UICN (2019t).

Áreas protegidas e de conservação em Sudão nos tipos de governação da UICN

\begin{tabular}{l|r|r}
\hline Categoria de governação da UICN & No. & \% Cobertura \\
\hline Governação pelo Governo & 9 & 73.50 \\
\hline Não Reportado & 14 & 32.93 \\
\hline
\end{tabular}

Fonte: UNEP-WCMC \& UICN (2019u).

Áreas protegidas e de conservação em Tanzânia nos tipos de governação da UICN

\begin{tabular}{l|r|r}
\hline Categoria de governação da UICN & No. & \% Cobertura \\
\hline Governação pelo Governo & 777 & 87.24 \\
\hline B. Governação Partilhada & 4 & 0.15 \\
\hline C. Governação Privada & 1 & 0.00 \\
\hline D. Governação pelos povos indígenas e comunidades locais & 39 & 7.98 \\
\hline Não Reportado & 19 & 33.54 \\
\hline
\end{tabular}

Fonte: UNEP-WCMC \& UICN (2019v).

Áreas protegidas e de conservação em Uganda nos tipos de governação da UICN

\begin{tabular}{l|r|r}
\hline Categoria de governação da UICN & No. & \% Cobertura \\
\hline Governação pelo Governo & 699 & 98.00 \\
\hline Não Reportado & 13 & 2.00 \\
\hline
\end{tabular}

Fonte: UNEP-WCMC \& UICN ((2019w)

Áreas protegidas e de conservação em Zâmbia nos tipos de governação da UICN

\begin{tabular}{l|r|r}
\hline Categoria de governação da UICN & No. & \% Cobertura \\
\hline Governação pelo Governo & 49 & 66.35 \\
\hline Não Reportado & 586 & 41.50 \\
\hline
\end{tabular}

Fonte: UNEP-WCMC \& UICN (2019x).

Áreas protegidas e de conservação em Zimbabué nos tipos de governação da UICN

\begin{tabular}{l|r|r}
\hline Categoria de governação da UICN & No. & \% Cobertura \\
\hline Não Reportado & 232 & 100.00 \\
\hline
\end{tabular}

Fonte: UNEP-WCMC \& UICN (2019y). 


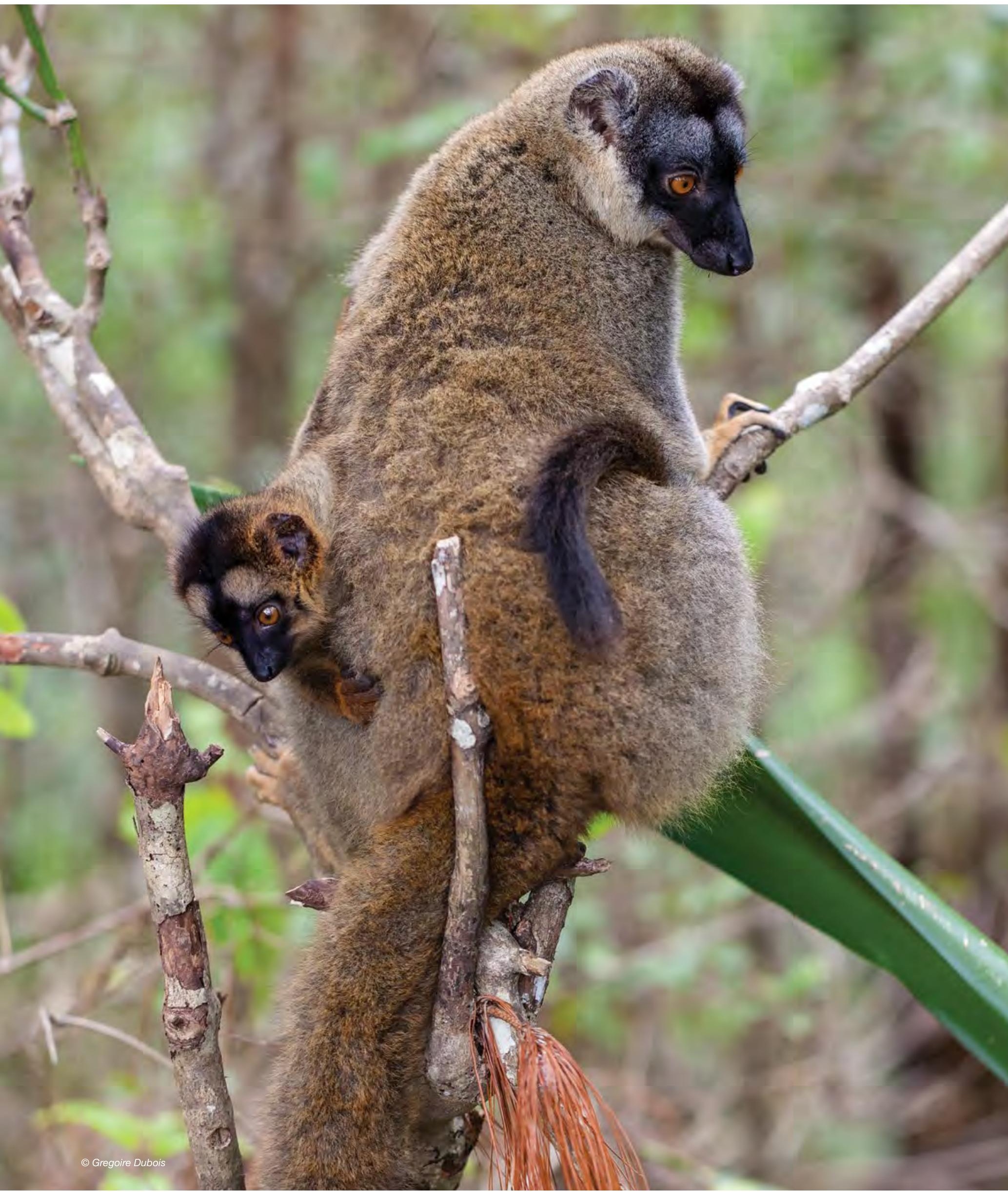





\section{UICN}

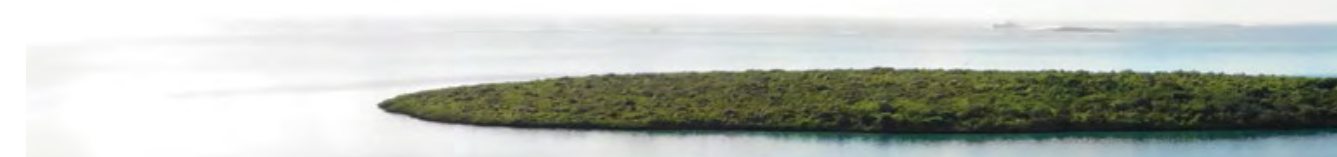

UNIÃO INTERNACIONAL

PARA A CONSERVAÇÃO DA NATUREZA

Escritório Regional da África Oriental e Austral

Centro de Conservação de Wasaa, Mukoma Road (ao largo de Magadi Road, City Square)

P. O Box 68200, 200

Nairobi, Quénia

Linha fixa: +254 20 2493561/65/70

Email: info.esaro@iucn.org

Website: https://www.iucn.org/esaro 